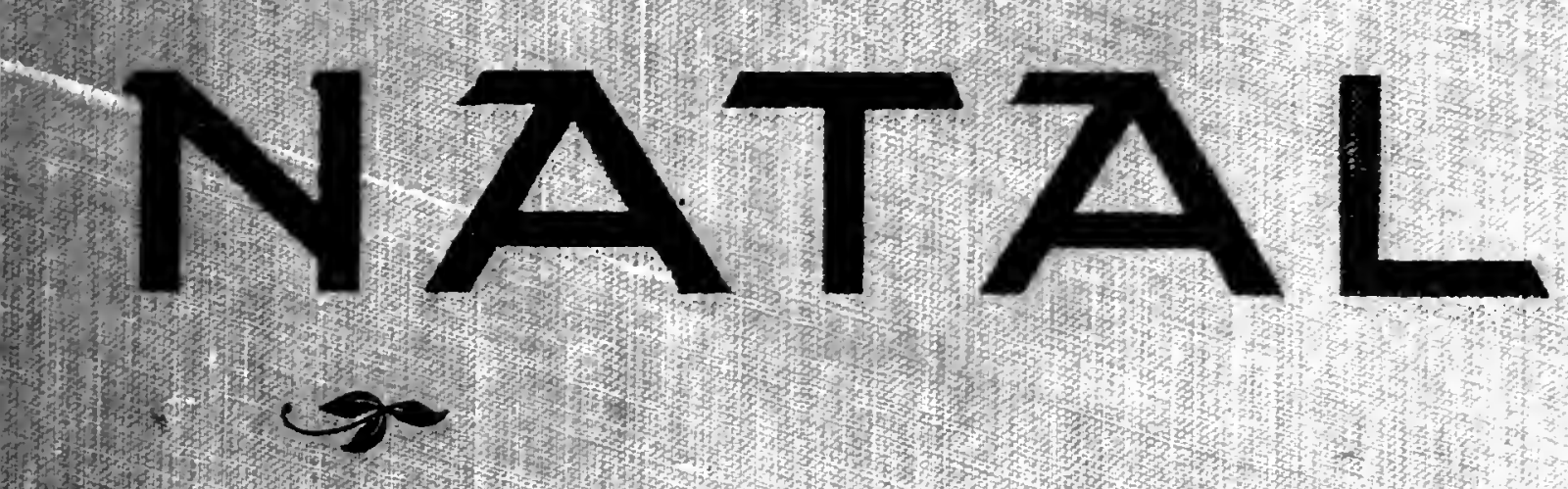

1 4 ,

ILLUSTRATED

OFFICIAL
RAILWAY

GUIDE'AND

GENERAL

HAND'BOOK

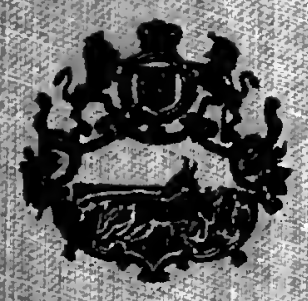


13 
$x-160+7$

JCSB LIBRAKY

NATAL:

OFFICIAL ILLLSTRATED RAILWAI GLIJE ANI)

GENERAL HANDBOOK. 


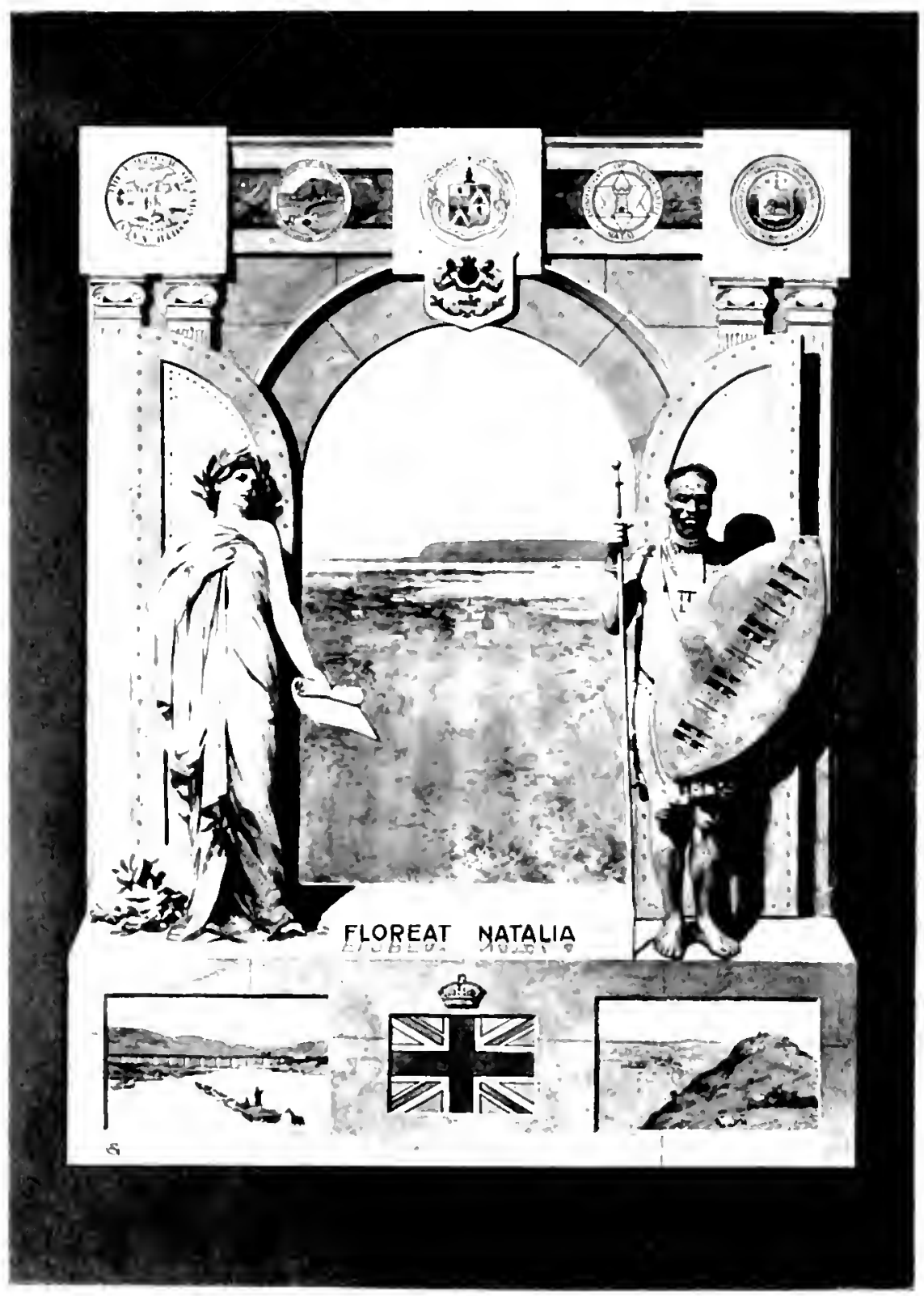




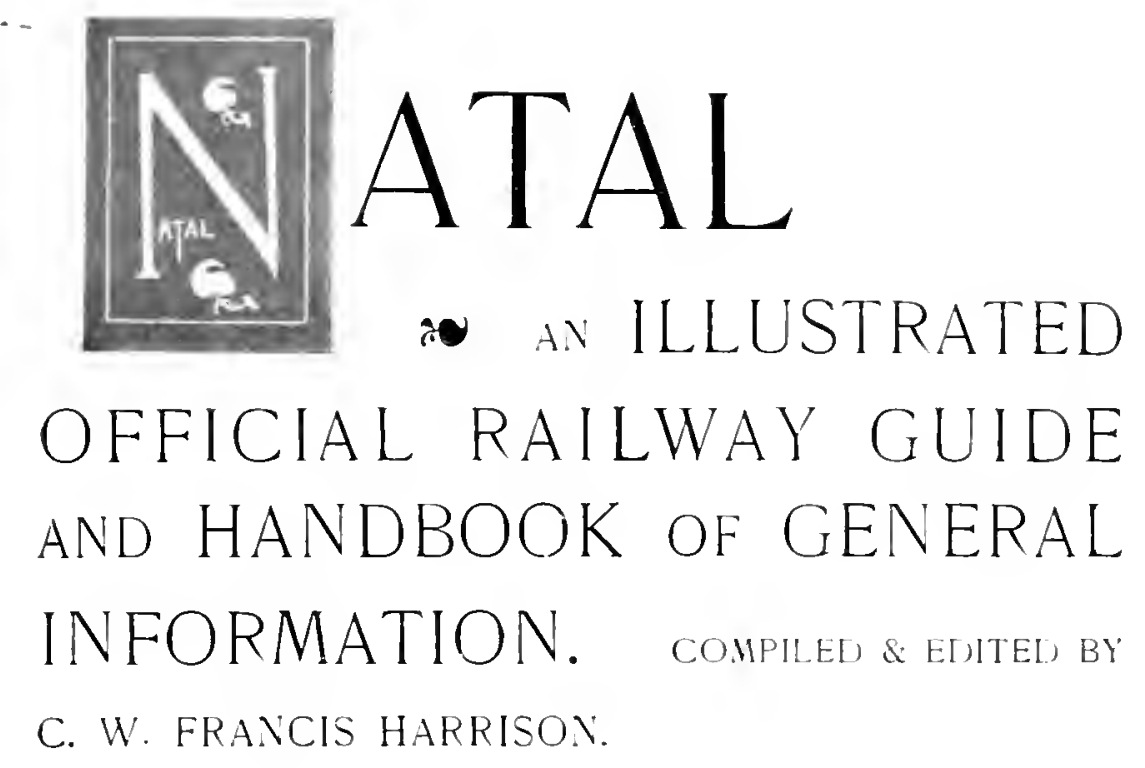

PL'BLISHEE BY AL'THORITY.

LONDON: * PAYNE JENNINGS, REGENT HOUSE, REGENT ST., W. HDCCCCIII. 



\section{PREFACE.}

W

ITr the establishment of a firm and honourable Peace. there dawns on the Sub. Continent of Africa an era of prosperity more resplendent than any it has ever known; and in the conception and realisation of the rast developments which will surely rise from the ashes of the past Catal may be relied upon to contribute her portion as cheerfully as she shared the sorrows. labours. and mistortunes of the late inevitable war.

Some years anterior to the struggle, tle South Atrican States were but little heeded by the outside world, and in this neglect and disregard. Natul, with its delightful scenery, its great farming advantages and mineral wealth, its varied peoples and inmense possibilities, was perhaps the greatest sufferer. Now the reil of obscurity has vanished: it is no longer erroneuusly regarded as a shire of Cape Cokny, but is well known to he a large self-goveming State. and is universally renowner as one of the most desirable and interesting portions of south Africa.

Numbers of emigrants are proceeding to Natal, and to meet the requirements of these and other colonists. tourists, and travellers, this manual. containing the most recent information anent the Colong has been compiled.

The volume is composed of two Books. The FIRST BOOk is a complete Guide to the Port, Railways. Battlefields. Towns. Villages. Industries. and Attractions of Catal, embodying also brief articles upon the adjacent States. the Natal railways aftording the quickest and prettiest route to the Transvaal and other Colonies.

The SECOND BOOK. which is also an official work of reference. sives in Hancl-book torm full and accurate information of a wide range and general character, useful to one and all.

An endeavour has been made to give a faithful picture of Natal, its teatures and many attractions as they stand at the present juncture. In this earnest task the former official guide (I895), an excellent compilation by Mr. J. Forsyth Ingram, I.R.G.s... has been of the most valuable assistance. But the Colony has advanced so exceedingly within the last eight years. that the material of the First Book is almost wholly new, while that of the Hand-book has been re-arranged. augmented and rerised.

lt may be as well to point out, however. that while Natal realises the desirability of attracting to her shores farmers, traters, manutacturers, miners. mechanics. and other suitable emigrants, none but the best fitted and most energetic should seek to open up "fresh woods and pastures new." for, as it has heen truly said, although the 


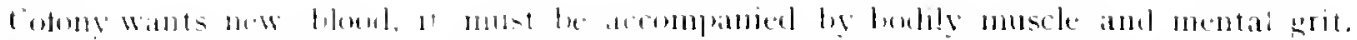

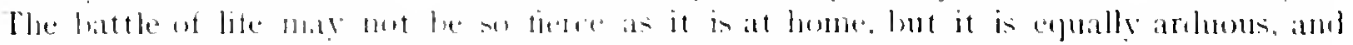

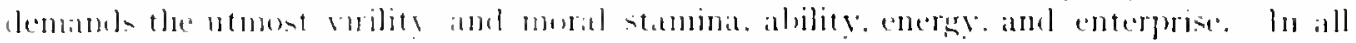

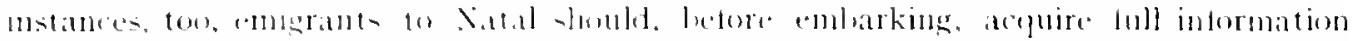

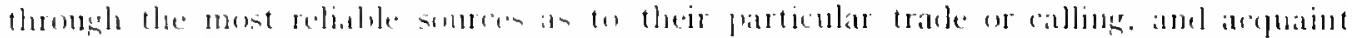

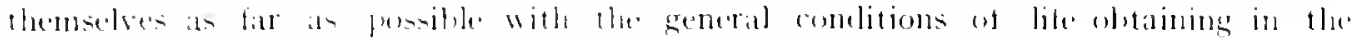
coloms. The latter is espertalls merestry in the case of invalids.

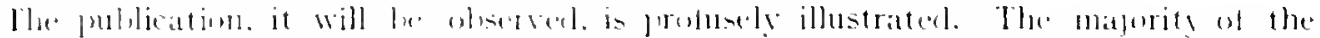

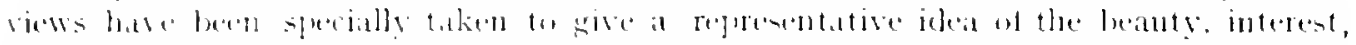

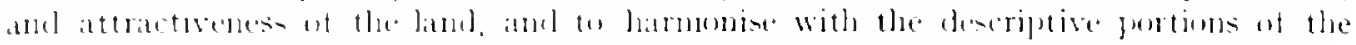

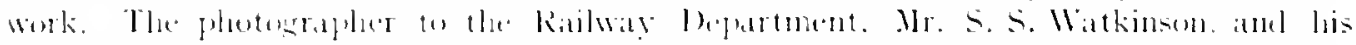

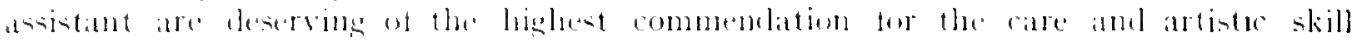

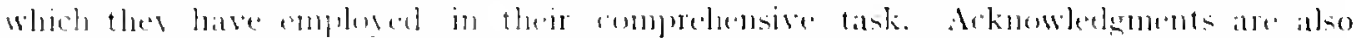

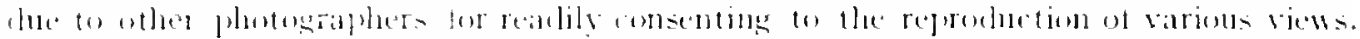
In adelition. the solume contame reveral other serverable and interesting batures,

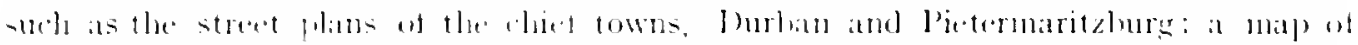

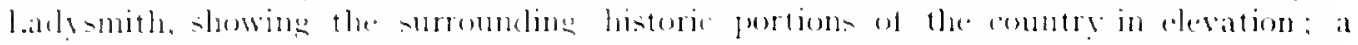

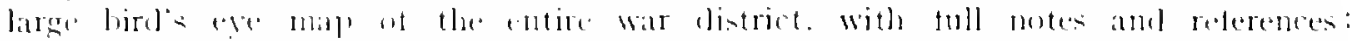

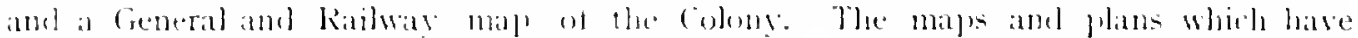

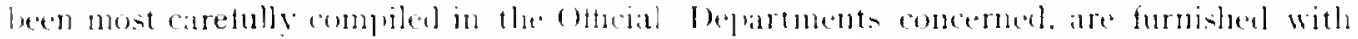

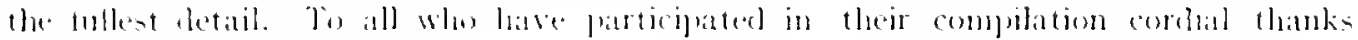
are herehs temlerel.

In conclusion, the compiler also desire to experes his gratitule to the conrteous offices of the several Government and Municipal lepartments. the experts on various

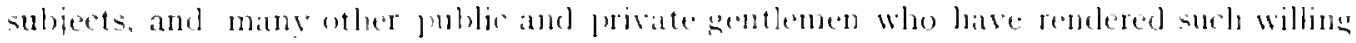

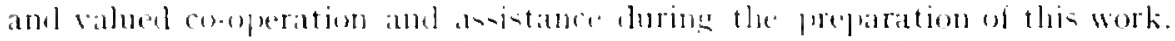

C.W.F.H.

D1'Rは.1\%,

S.IT.1. 


\section{CONTENTS.}

\section{FIRST BOOK.}

A GLILE TO THE

PORT, RAILWAYS, BATTLEFIELLS, TOWNS, VILLAGES, INDUSTRIES, AND ATTRACTIONS OF

NATAL,

INCLUDING ALSO USEFUL INFORMATION ANENT THE ORANGE RIVER COLONY, AND THE TRANSVAAL.

PART ONE: THE PORT ANI) TOTIX OI DLRBAX.

Chapter l. Fron RoAdim. To Qtay

. II. THE POINT AXI ITS WURK

.. III. THI SEAPOKT TOMY OI Derbas

PART TWO: THE MAN IINE OF RAIIUAY.

EN ROUTE TO THE TRANSVAAL THROUGH THE

PRINCIPAL TOWNS AND BATTLEFIELDS OF NATAL.

CHATER I. FrOU DURBA IU PINETAW:

. II. . PISETOWX TO INCHANGA

.. III. .. IXCHAXGA TO PIEIERMARIT/RERQ

. IV. THE CITY OF PJETERMARTTZBCRG

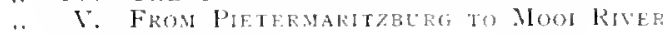

PART THREE: THE MAIN IALE OF R.ALWH CONASED

THROUGH THE WAR DISTKICT.

CHAPER I. IXTEODECTHEY

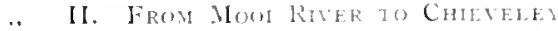

. IJI. COLESSO ITS HatTLEFIEIJS

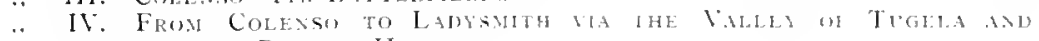
PiEThes Hejghts

,. V. Historic LaDisitith

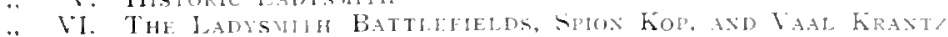

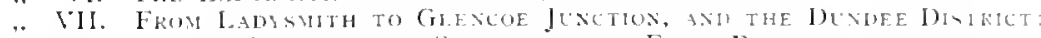
THROLOH THF SCINES OH I HE FIESI BATTLES

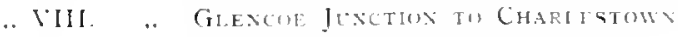

790

$10 \quad-6$

, $6 \quad 46$

$0_{-10}^{-1030}$

iil II:

IOF 1 id

110125

I 21 I 35

PART FOLR: TOWARIS THE RAXI).

CHAPTFR I. FROM CHAKLESTMWX TO JOHANESRERG

.. II. JOHANXESELKE

.. III. PRETORLA

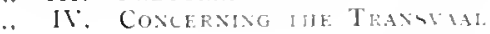

I 31$\} 1+2$

II I I i :

$1+7+1+9$

$1+1,15$

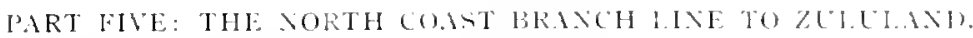

CHAPTER I. A NOTE

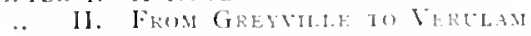

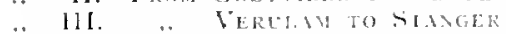

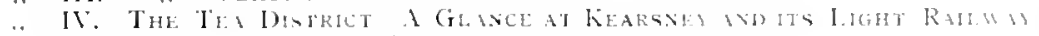

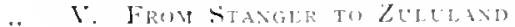

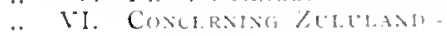

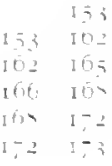

vii. 


\section{CONTLNTS continutd).}

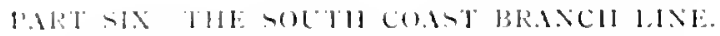

CHU1+R I. HASIS

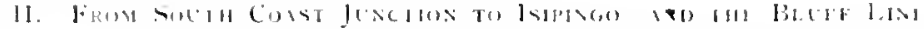

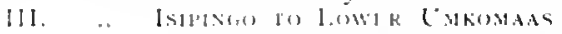

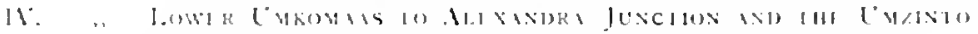
BRANe11

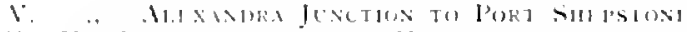

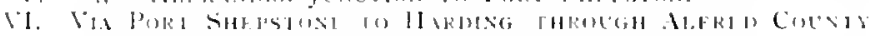

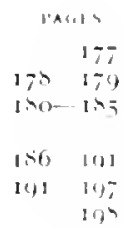

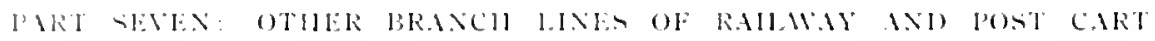
SlEKICI: TO BLI,MER.

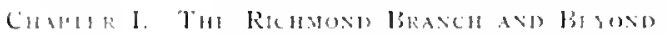

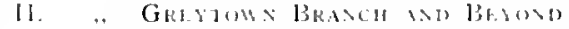

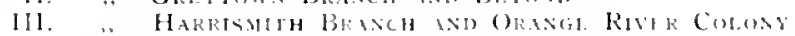

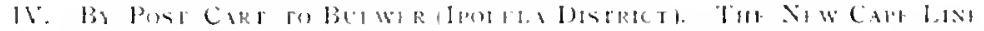

$\therefore 1125$

$215 \quad 212$

31250

21221

\section{SECOND BOOK.}

\section{HAXIUBOOK OF CIENERAL INFORMATION}

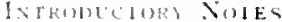

J'P

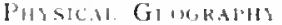

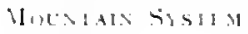

RTIRE -

(i) (1).06)

l一iRISI

FoRA, FRU1'S, CHRABS, AC.

lind de de

linionerented

(j.) U1: I. AW

Cinatic Conntmess dic.

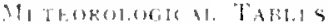

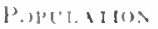

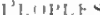

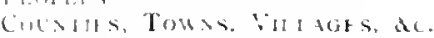

(1)

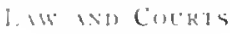

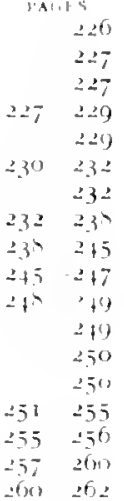

linctures

Ruthwis

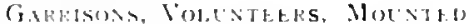
folice

Mevichas. Sistris

POSIAR AND THILGKAHH S'STEMS

PRESS

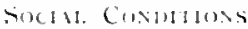

Jixinel

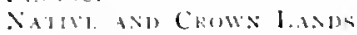

Convalled

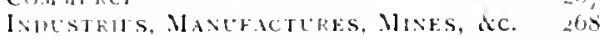

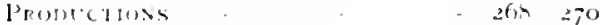

Ilokb

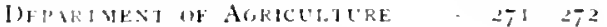

T)FARI YENT UF MINRS.

ZCi.1.1.1) $27=$

Useful Information for Emigrants 27,3

\section{THE RAILWAYS OF NATAL: A SHORT REVIEW.}

PAST, PRESENT, AND FUTURE

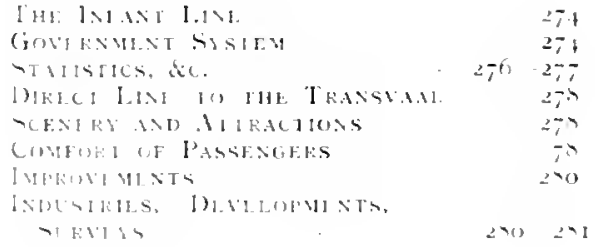

\section{PRACTICAL WORKING}

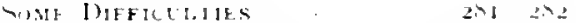

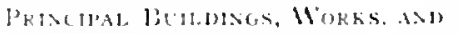
B) lakTMISIS

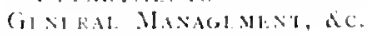

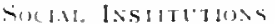

\section{THE WAR PERIOD}

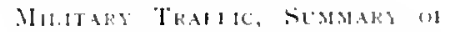

THE EARLHR STACIS OH IHE WAK SFFules of III DI IRTMENT

$$
\text { .. STati }
$$

263

263

14

265

205

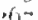

267

$\div$ 


\section{LIST OF ILLUSTRATIONS}

Floreat Natalia

River Scene, Natal

Durban from the Berea

Liner Entering the Harbour, Port Natal

Entrance to Harbour

Lighthouse and Signalling Station. Durban

Cave Rock, Bluft Main Wharf, Point

Bayside-Durban

Paul's Wharf.

Sailing Ships, Durban

Coaling a Liner-The Jetty, Joint

Quayside Road, Point-Suction Dredger, Newquay Wall-Paul's Wharf-Durban

"The Victorian" at Pauls Wharf: 1 anding Troops-Departure of Royal Dublin Fusiliers from Durban, 1002 - Nain Wharf-Durban

Bird's Eye View of Durban, East

Bird's Eye View of The Point

Market Hall, Durban -

Wesleyan Church and Standard Bank, West Street, Durban

Cricket on the Oval, Albert l'ark

Government Hospital, Addington Roman Catholic Church--Durban

Jinricksha Boys

Point

Vasco Da Gama Monument. Point

The Back Beach, Durban

Court House, West sitreet, Durban

Town Hall and P'ublic Baths, Durban

West Street-st. Paul's Church-The Town Hall-Interior of Museum

Town Gardens and Queen Victoria Statue, Durban

South African Mutual Buildings, Durban

The Esplanade, Gardiner Street Turning

R. $\mathcal{N}$. Yacht Club, Durhan

Bayside Villa, St. Andrew Street-Banyan Tree, Albert Park-1)urban

Girls' IIodel Government Sichool-West Street, Durban

Observatory, Durban

On the lierea. Durban

Naris Stella Convent - Presbyterian Church Berea

Race Course, Durban

Railway Street: Lintrance to Railway Station

- Post Ofince-Durban

Electric Trams

Johannesburg Mail, 1)urban Station

Durban: West End and Berea

The Bay

Train Ascending "Jacob's Ladder" - Sugar Refinery, South Coast Junction - - 35

Fruit Farms, Naliern.

Among the Pineapples

Katir Girls Getting Water

At the Waterworks: Pinetown Reserwoirs

Umbilo Falls (Pinetown Waterworks)

Marianohill Monastery

Palmiet Falls, near Pinetown.

The Gorge, Krantz Kloof

On the N.G.R., near Botha's Hill
PAGE
Group of Natives

13y Rail and Road, near Botha's Hill

Cato Ridge Station

River Unsindusi

Source of the $\mathrm{L}^{\mathrm{m}} \mathrm{m}$ sindusi

Pietermaritzburg from Town Hill

Railway Station. Pietermaritzbury

llarket Square - Church Stret Scott's Bride 1)orp Spruit-Maritzburg

Cathedral Bell.

Colonial Offices, Maritzburc Opening of "lown Hall, Maritzburg by T.R.1l. the Duke and Duchess of York, August, rgor.

Town Hall: Interior-Gosernment House Legislative Buildings Post Office and Court House - Maritzburg

Presentation of War Medals and Reviell of Colonial Troops, Alexandra Park. Ausunt. 1901

Picnic Party Crossing a Drift

In the Park, Maritzburg

Entrance to the Park Sir Theophilus shepstonte Monument-- The College in the Botanical Gardens-Maritzburg

Interior of Theatre, Maritzburg

Umsindusi River Falls.

Lovers' Walk, Alexandra Park, Maritzbure

Fidendale lialls

Civalized Wedding, Edendale Mission Station

Camp Drift, Maritzburg

Kafir Chief Teteleku

Sweet Waters

On the N.G.R., near Boshoff"s Road

llowick Falls

L'moeni River, Howich

Falls near Howick

The levil"s Pyramid, Impendhla

Lmgeni River

An [" p. Country Orchard

River Scene, Nid!ands, Natal

Michael House College, Balgowan

Drakensberg

Drakensberg, Basutoland Border

Eagle's Nest Peak, Drakensberg

Recollections of the Mar: 1899-1900

Highlands Station

Brynbella Hill-Beacon Hill

Estcuurt

Railway Bridge, litere-Railway bridge oter Bushman's Kiver, Estcourt

Site of Armoured Train Disaster, lirere - s

Chieveley vilitary Cemetery-Graves at Colenso

Graves at Colenso

Colenso ishewing the Boer Positions, Dec. 1 ith, rs sogl

british Position at Colenso, viewed from lort Wrielie

Where Lieut. Roberts fell at Colenso- Mlonumernt to 2 th Battery

Colenso and River Tugela from Hlangwane Hill

Tugela River at Colenso 


\section{I.ISI OH II.L.LSTRATIONS-continued}

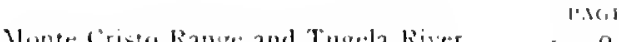

General Buller's lorces C'rosing l'ontoon Bridge

boer Frenches at Colemso

Where the dublun Croned the Tugela, Cinlenio

'I of of Railway IIill, Colenso

Tugela lleights, Colenso

Sew Kailway Bridge at Colenso ifrom fort Wvile!

" Poim.pom" Bridge. Colenso

lingela l*alls, Colenso.

IJart's I Iill, Grobelaar's. \& "Sheba"s Breasts"

Irish Brigade Monument, Jlart's lfill Mom ment to kuval d)ublin liusiliers at l'om pom Bridee Graves, Railway lli!l, near l'ieters Graves of Jrish Jigigade. IJart's llill

Aasvogel's kloof, near Pieters

Pieter's Hill and IIonte Cristo

klip liver, ladymith.

Railway Station Railway Crossing lown IJall l.adysmith

Jadysmith

Siteet Sicene, 1,adynsth

Biggarberg

Surprist Hill and Nicholson's Nek

Tinta Invoni Battlefield-Xicholson's Xek Wonumient and Graves of the ciloucester liegt. Grave of the lrish liusiliers . Yonu ment Obecration llill J.adysusth.

Jndomba Cemeters, near Ladyinith

"l.ong Tom" Sangar. Lmbulwana Breastworks, L'mhulwana Gunllilland lombard's kop, I,adsimith

Where l.ient. Col. Dick Cumnghan fell Nomument to Manchester Regt. on C:esar's Camp and Battalion Rifle Brigade: Monument on Ciesar's Camp-Imperial l.ight Horse Monument, lVaron llill

ladvsmitl from Wayon Ilill

Wagon l lill

Spion kop

Devonshire Regt. Nonument, Wagon llill Cairn to Roval lingineers. Wagon IIill Spion Kop Intabammymal

Top of Spion liop shewing Monuments and Graves Honument to Imperial l.jght Infantry-king's lioyal litles Nonumems Sipion kiop

The Peaks, Sipion kop

Ladymith Town Cemetery

Collierie, at Elands I aagte

Graves, Elands laagte Battleficed

Main Street, Jundee

Coal Hine, bundee

Rortic:s Drift

lsandhlwana Mountain, Yululand

scene of the loirst Battle in Natal

Where General sir William Penn-sivmons fell

Katir Corn

Native kraal

Main sireet, Newcastie

Majuba and Lang's leh

Military Cemetery at Iount Prospect
Ilorse shoe Curve. Jngogu

PACB:

O'Veil's liam, where the Treaty of ras was signed

Farn at the Bace of Hajuba

Johamesburg Wail at Foot of Majuba

Heidelberg

Interior Parh station, Johannenurg

Commissioner sitreet Pritchard Sitreet lo. hanresburg .

1he Nitwatersand coldfield

Battery of Gold Wine on the kand

Joubert's Park Jobannesburg llospital

Warch Jast loord loberts of $\$ 5,000$ liritish Troops: ()ccupation of l'retoria. June 5,1900

Churchstreet (iosernment Buildings putch Reformed Church l'retoria

On the L'mentir lioad.

llindoo 'lemple near L"meneni.

Sugar Nill. Mlount Edgeconbe $\quad 156$

Vesleyan Church, Verulam - . 157

Indian linuit fillers, Verulam. $\quad 158$

Tobacco Plantation near Verulan . I $15 \%$

Native in Nar Costume . . . I60

Native Drinkin! Latir Beer _ 161

Cucting Sugar Cane . - $\quad 163$

River [mblali - 16.

Katir with Head-dress of lieathers of the "siakabula" Burd

picking lea, kearsney

Kearmey 'Jea Jintates The liactory- 'lbe Residence light Railway

I.ower 'lugela Rapids and Railway Bridgelower Tugela Railway Station Crossing the Jugela

Fishowe

Jishowe l'ont Cart

Puhlic School, Eshowe Chief Dinizulus House. Eshowe

Natives Travelling

Zebras

A l.agoon on the South Coast

The Beach. Limblali

Viests Station, Bluff. Durban

Sugar Nill and Cane lifields

The Beach, ] sipingo

On the South Coast Branch line

Amanzimtoti

A Kafir Girl

IVoodland Sicener.

L'mlomaas

1.agoon, Imanyimtoti.

Celson's 1)rift, L'mkomas

On the L'mkomas:

South Coast ],ine

Scottslyurg Beach-Scottsburg lighthouse

l.auroon, Slevandra Junction

On the I'mzinto Branch

Sugar Nill, Esperanza

['mzinto Church

Bridge over the L'mzuni

C'mtwalumi: River and Railway Bridge

Railway Bridge, South Coast fine . 192

Port Shepstone 193

Port Shepstone: looking up the River 


\section{LIST OF ILLUSTRATIONS continued}

On the Unzimkulu, Port Shepstone Pagk

it. Helen's Rock, Umzimbulu River, Port

\section{Shepstone}

Narble Quarries, Port Shepstone

"Place of Death," Port Shepstone

Indians Crossing a Drift

Kafir Nilking

Dairy, Nel's Rust

Richmond

Aloes

Native Huts

Albert lialls, Umgeni River

New Hanover Railway Station-Sterk Spruit,

New llanover

kafir Kraal and Cattle

Stretet Sicene - Oftices of Local board-Wutch

Reformed Church-Greytown

Ostriches and Iivers, Jatal

The loakensberg $\quad 213$

Rerersing Stations, Harrimeth Branch it

Van Reenen's Pass, X.G.R. Harrismith Branch 245

Bushmen's Drawings

Kloofs, near Van Reenen

Harrismith

Source of the Tugela

The Bulwer Post Cart.

An lnduna, or llead Man

Wife of a Kafir Chief

Mont Aux Sources

River Limzisskulu

Granite Outcrop. Inchanga

Native studien

Encephalartos Altensteni

Giant l)ate Palms.

A Pawpaw Tree

Sub-Tropical Foliage

The Black Rhinoceros with Cali
$19+$

195

197

19t'

201

202

202

203

204

$20+$

206

206

209

I0

I I

216

216

217

2 IS

221

222

223

221

229

230

234

235

$23^{6}$

237

239

339
Horns of the South African Intelope $2+1,2+2$

Natal Butterties - 2+1244

Praying .Jantids (IJottentot Gods) - 245

Queen Moth - 2.15

Natal Coast Hoth

A 'lypical Kafir Kraal-Kafir Weddune l)ance 24'

An Indian Girl. 25

Indian Fruit Siellers, Durban 252

Natives - $\quad 252$

Natives at lood 253

A Kafir Witch Doctor

Interior of hatir llut - 255

A Pair of Lovers - .

Sir Henry Edward McCallum, R.E., A.D.C..

K.C.M.G. Governor of Xatal

The

Sir Walter Peace, K.C.M.G. - 266

Sir Henry Bale. K.C. - - 262

lirigadier-General. wir John G. Fartmeil, K.C.B. 264

lea Plantation. . $\quad 265$

Sugar Cane Field. 265

Banana dienue - 2,0

Principal Ofticers. Natal Governnent Kailways 275

X.G.R. Station Map - - 2,79

N.G.R.. Diagram of Gradient: 2hI

Lang's Nek Tunnel - - abs

The Station lard - Reid Engine and LoadCentral Railway Station--New Loco. Erect. ting Shops-Interior Xew Loco. Erecting Shops- Durban

Botha's Hill Cutting . 204

Pietermarit/burg station Yard-1,ower l' lugela Bridge Lmbilo Bridge . - 285 lang:s Xek (damaged) Tunnel-Colen-o Bridge

Carriage of $100-1 b$ ciun

Ladresnith rard:

\section{MAPS AND PLANS}

Stret Plan of Durban

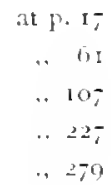

(Net Puchet Bach Cover.) 


\section{FIRST BOOK. \\ GUIDE TO THE RAILWAYS OF NATAL, \\ ETC.}

\section{INTRODUCTORY NOTES}

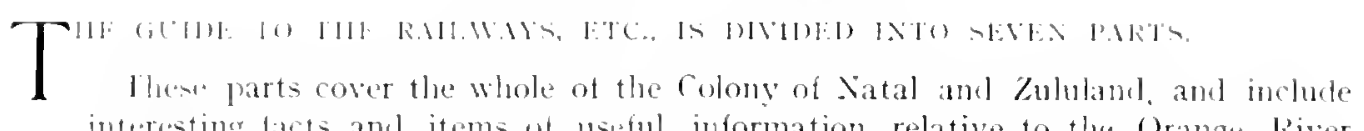
interesting tacts and jtems ut useful information relative to the orange liver and Transwal colonies, and the important town- of llarrisuith in the formes, and

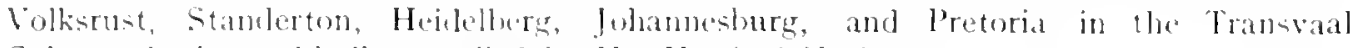
Colong, the latter hindly supplied ly Mr. Manfred Xathan.

The FlKST TWO PARTS are writen in a narrative stre, directing the attention of the reader to the many seenes of interest and attraction as he procueds througla the port and the tuws of lorban. and dones the most picturesque portion of the Main line ol kitilway ats tar as the Mar lojetriet.

l'ART TIlRE is a sontinuation of the trunk romte. and trabrsos the heart of the ared insaled by the boers to the nuthernmost point of the Colony, where the liailway passes in to the Transwal keritury. This portion, besides rmbulying all necessary details conceming tle agricultural industrial. scenic, and otber atractions of the comtry, has heen treated in a listinctive fashion, and comprises in itself a complete and

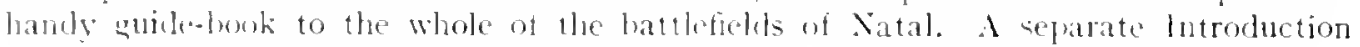
bas lien provided to this section (ser page zo).

P.ART linlli takes the traveller over the Railway System of the Transvaal to the great gold-mining centre, JOHANNESBURG, where ends the quickest and best route to that world-famed town and other places in the Transvaal, and one that affords the unique opportunity of a passing survey of the principal towns, immortal battlefields, and splendid scenerv of Natal.

PART liVle returns to Xatal, and discusses the lovely South Coast Pranch line.

l'ART sld deals with the more "industrial" Branch. the Nortl coast Line, and Zululand: and the PART SIETEX contains the Richmond, Greytown, and Harrismith Pranches, and the Post-Cart route to the lpolela District.

The Raiway Stations, both on the Nain Line and on the rarious branches, are placed in sequence, and the distance trom I Jurlan, the fares in operation therewith, as well as the altiturle atove the sea level. are plainly shewn.

.Il partinalars as to the times of trains, accommodation, tickets, rates and fares, and other inciulental dotails will he reallily given on application to the Railway Officials in

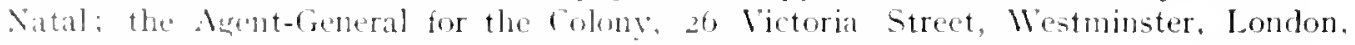
Vessrs. T. Cixk and Sons, Ludgate Circus, lonton: and other agencies.

It should te noted. that while every endeavour has been made to collect and -upply the mut acrurate particulars in Loth Books, the autlorities fo not hold them-elves responsible for any errors through varying conditions or other fircumstances. 
PART ONE.

\section{THE PORT AND TOWN OF DURBAN.}




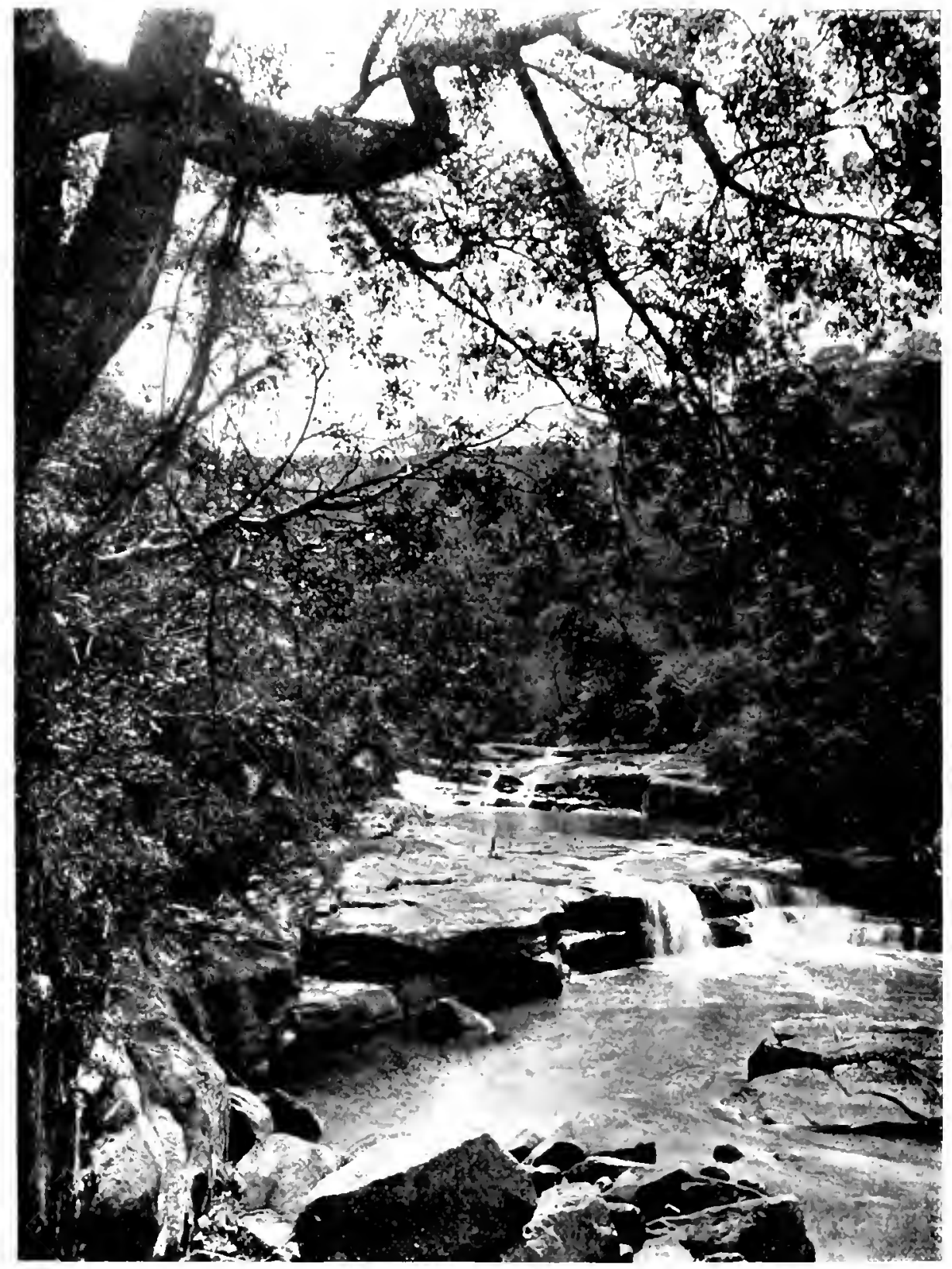




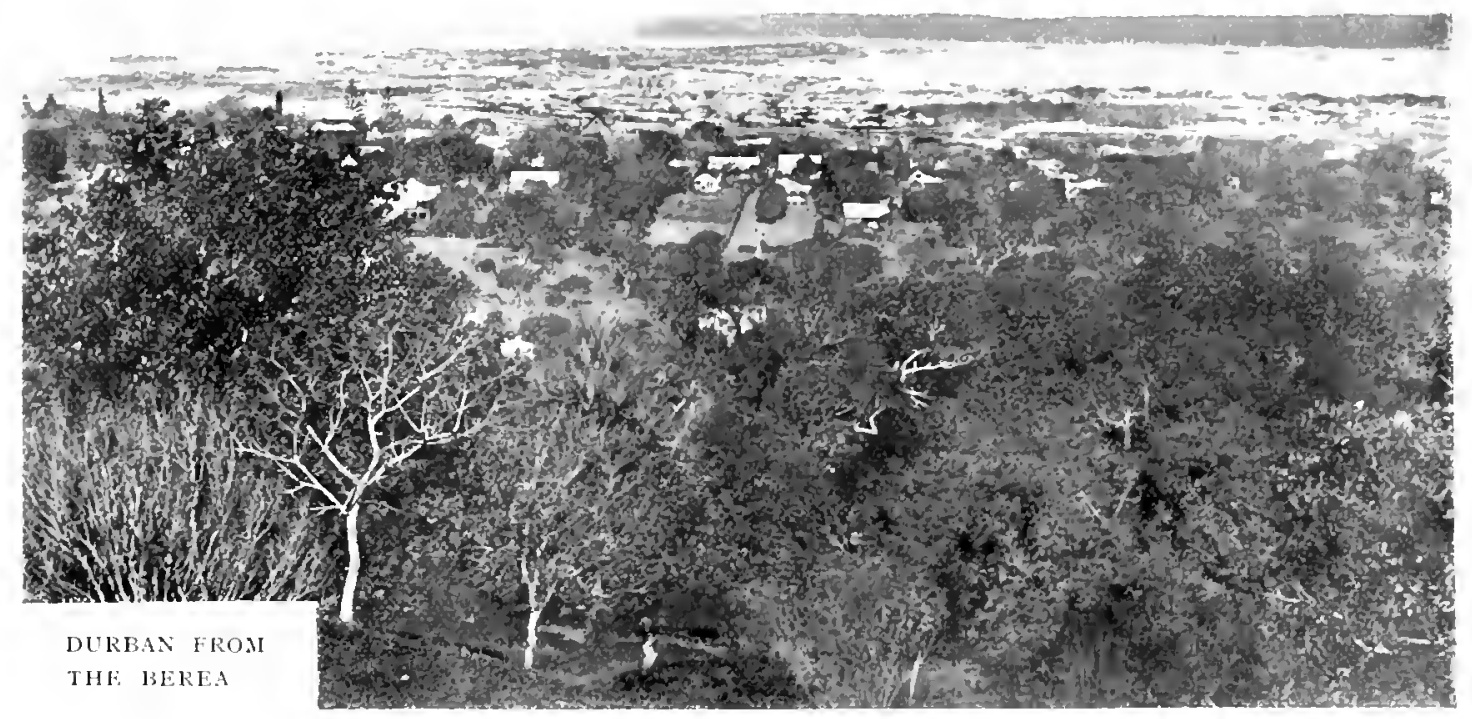

\title{
PART ONE.
}

\author{
CHAPTER I.
}

\section{FROA ROADSTEAI 'TO QUAY.}

$\mathrm{T}$ HERE are few more impressive scenes than the captivating panorama which is revealed when crossixg the BAR on the way to the Quay. There. crowned by a lighthouse and signal station, stands the majestic bush-clad Bluff: immediately before us is a waterway formed by two long stone piers; beyond is the circular sweep of the Bay, embraced by wary tiers of foliaged hills, and dottel with mumerous villas: below lies the town; near to on the right are the ship-thronged wharves: and awar to the North, backed by low undulatung lills, is the coast line which trends towards Zululand. Delagoa Bay, Beira, and other East African ports and possessions.

As we enter the Harhour, the chief features of the Port are passed in closer vicw, and may be described as they occur:-

This submerged bett of sand is not permitted to impede navigation. Owing to the THE BAR of powerful dredsers, a depth more than sufficient to admit to the wharves the largest ressels is now secured. As an illustration of the great improvement effected in recent years, the average low-water depth on the Bar in the year InoI was $I 9$ feet $I \frac{1}{2}$ inches, and the maximum draught of ressels across same 23 fret (steamers), and 2 I feet II inches (sailers). In I89I the average depth was but Io feet 9 inches, and the maximum draught is feet (steamers), and I feet (sailers). 


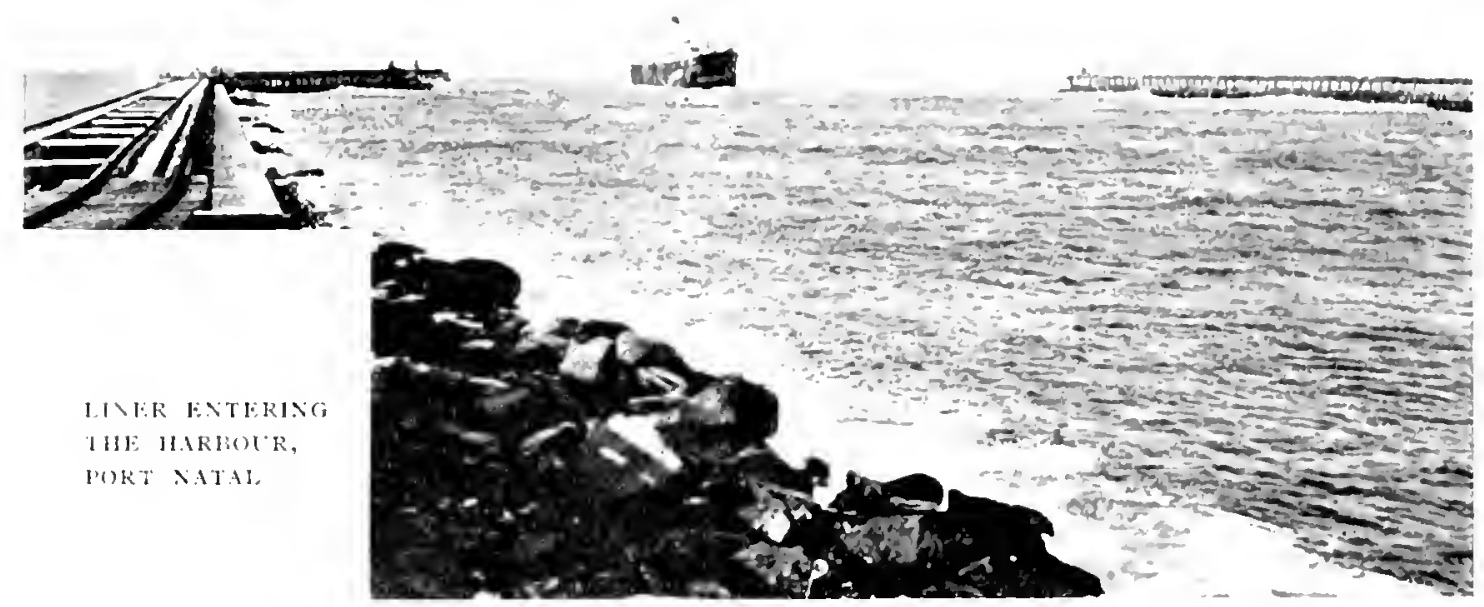

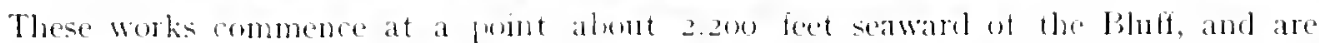
paralles for a consicterable portion of their length. being

THE NORTH PIER ANI) SOUTH BIREAKWATER
Son feet apdart. except at the head of the piers, where the width is exes leet. The clinmel between the Bluff wharfage and the repringing jetty on the Point side attains a brearlth of $\mathrm{I}$. I w teet te

The summit of the Bluti proper is 21 I teet abose the seal. Fhe lighthouse, which is huilt on iron, is s s teet in levight, and gires a

THE BLUFF, LIGHTHOUSE. ANI) SIGNAL STATION White resolving light (dioptric). at an altitule of 2 z z leet above high-water level. It reaches its greatest hrilliancy once erery minute, and is

risible in clear weatler for twentr-four miles at sea

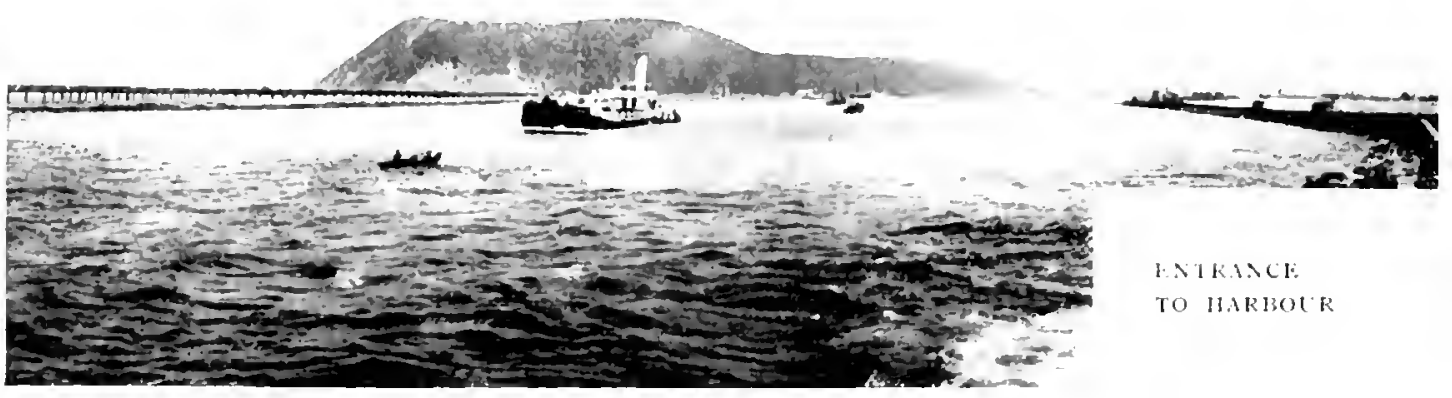




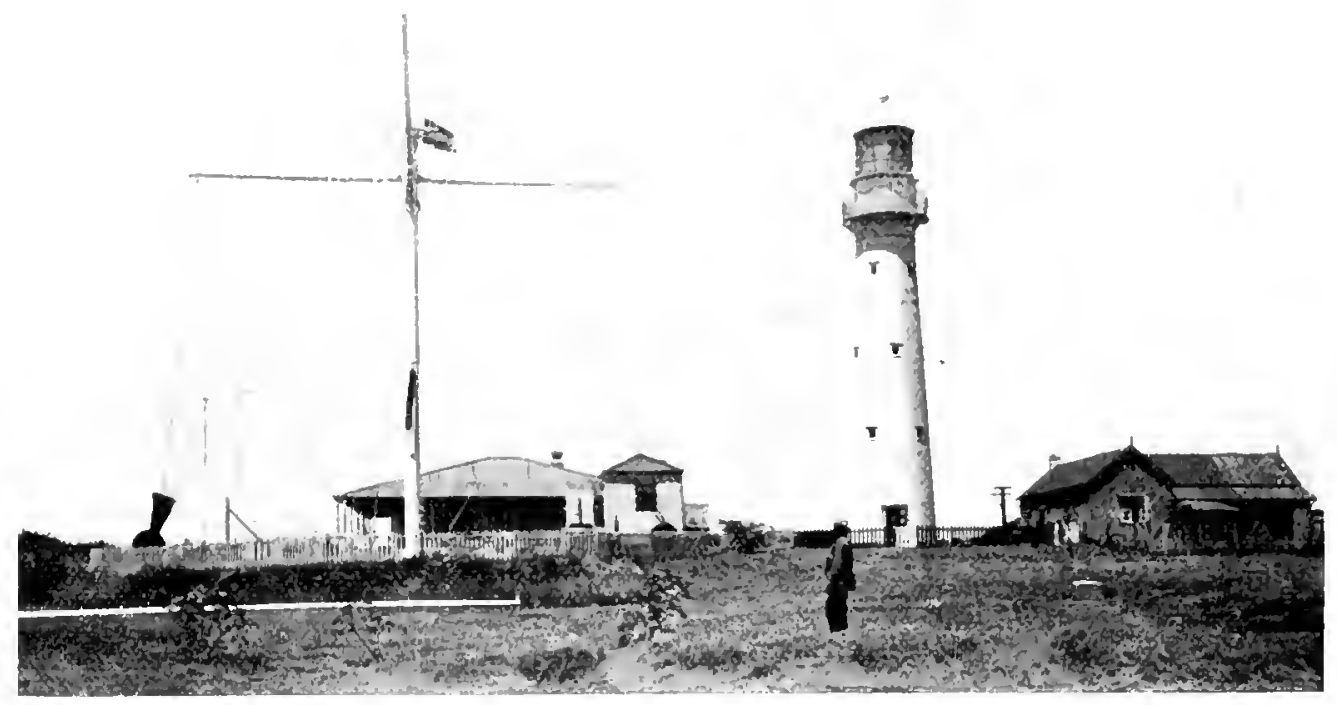

LIGHTHOLSE AND SIGXILING STATION, DLRBAN

The Signal Station is fully equilped for day and uight service. and all communications by signal from ressels fying at the outer anchorage are made through this asency. whence they are transmitted to the Port Office Look-out Signal Station on the other side of the Harlour channel, and vice verat.

It is not until we reach the end of the Channel that a comprehensive view of Durban is secured. Then its size, compactness, and charming situation are beheld, while the near prospect of the bluft and the Wentworth hills, green with virginal forests, the broad expanse of the heautiful hay, and the refreshing life and movement on terra firma. produce an effect wholly surprisins and agreeable.

Turning for a monent to the burFF SIDE. a railway station is seen. This is "Wests," Well known to pleasure seekers, who reach it either hy crossing the Channel or hy the Bluff trains from the Durban Central Station. Wharfage and other improvenent works are noticed in active progress on this side. and denote the growing importance of the Harbour.

THE BAY magnificent sheet of water has an area of wer six miles. Naturally it is the tarourite resort for vachting, hoating, swimming. and fishing, while its island also attracts many visitors. Running townwards from the end of the wharves, on the north side of the Bay, is the victoria EsfLAxide. nearly a mile and a quarter in length, and built at a cost of $\$ 77.000$.

In a few minutes more we have gained the Quay, and alight at THE (rATE OF THE GAKDEX COIOXY.

It may be said in passing, that whether the passenger land at the Public Whart, or Patl's Wharf, of at the Landing Jetty-all comprised in the one word "Point," the projecting tongue of land on which the docks are built-he may be assured of the existence of equal if not superior facilaties to those of any other port in South Africa. 


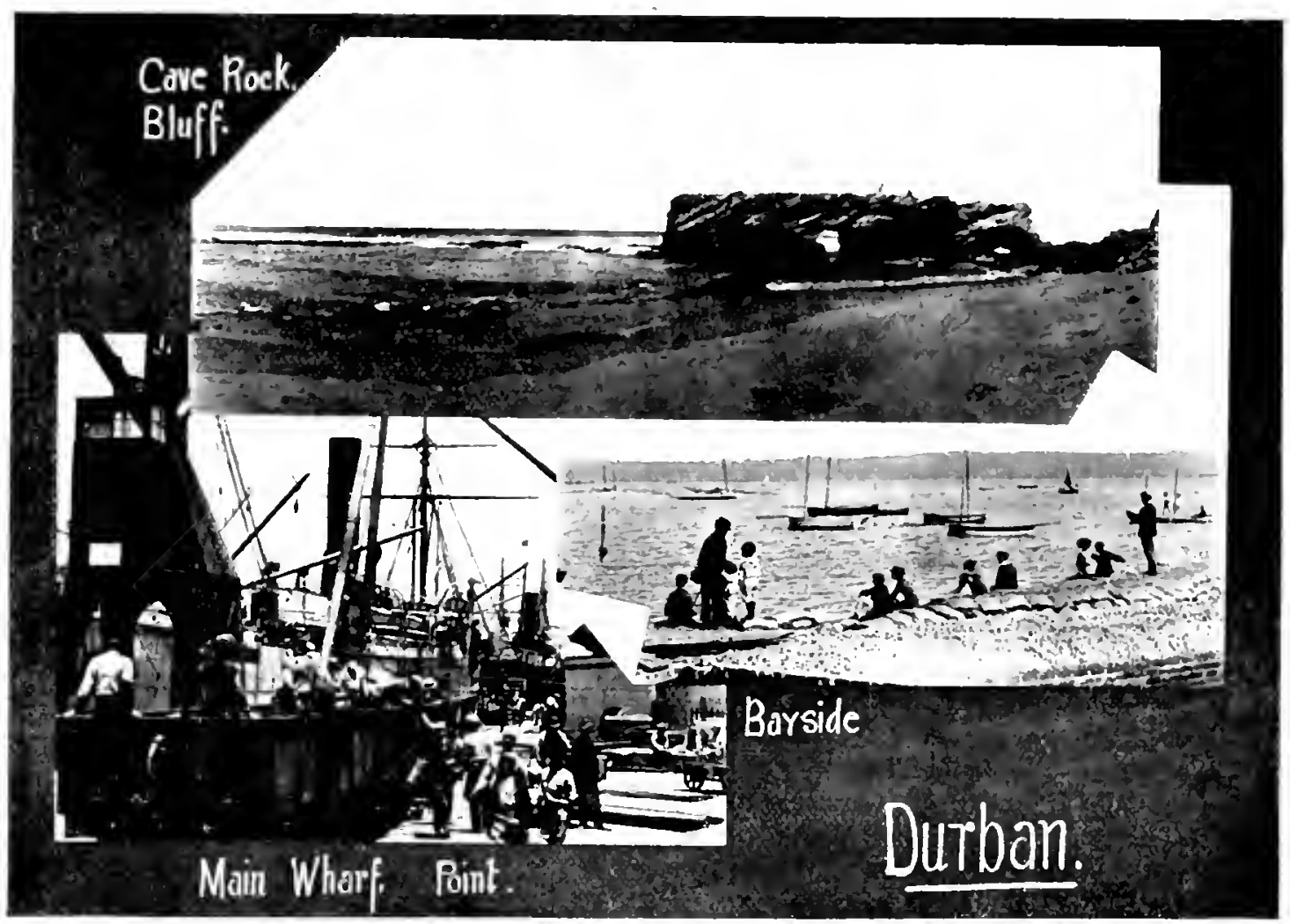

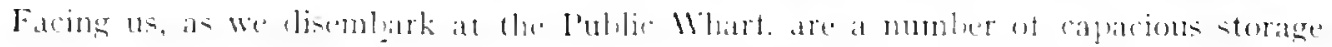
THE DOChS W

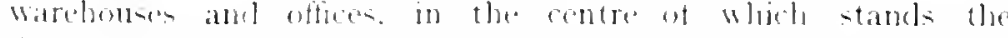

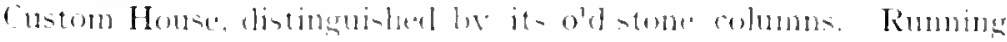

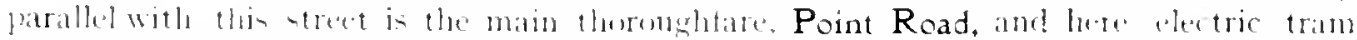

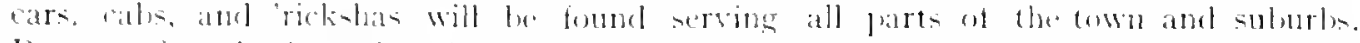

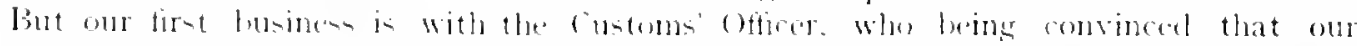

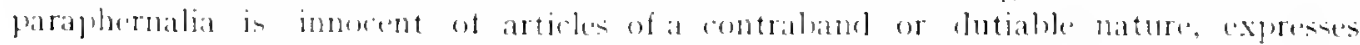

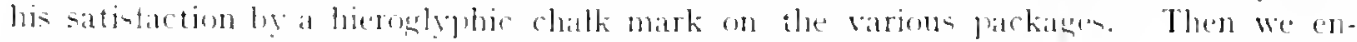
trust them to the belivery Agent, and atterwards. having an hour at our disposal, jast the time in rambling romal the doeks.

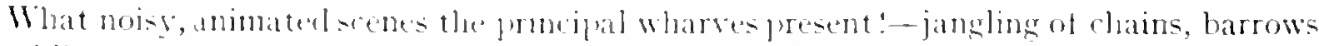

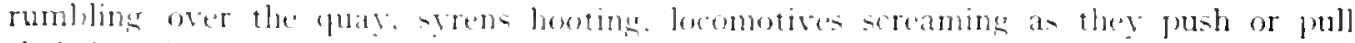

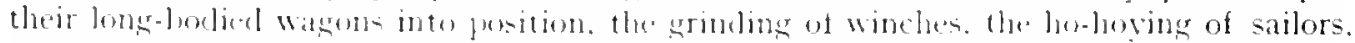
and natives chanting some momotonous retram. It is one ceaseless rattle and commotion.

looking down the hung quays, blocked with gingways, clutes ropes, and all manner of merchandioe, the conntless spars and tunnets of shifs from all guarters of the globe dwindle away in the distance. Iabourers pass to and fro the long lines of sleds: pyramids of stores rise in the anljoining areas; railway trucks are everywlere, some lisporging fuel for the mumerous vessels, others beiner luten with weighty cargoes. It is a pretty sight, 
Secting the jetty, the scene is somewhat queter. Passengers are wating to be ferried across the channol. or for a tug to hear them to a vesed hejond the liar. Dredgers are

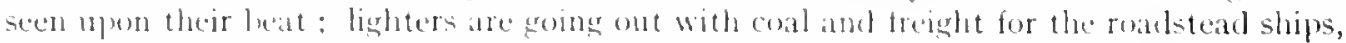

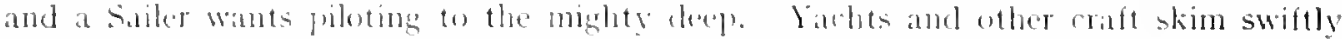

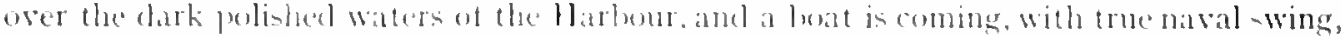
trom a man ot war. Al coery turn the tis some excitement, some new happening. The docks ate indeed intensely interesting.

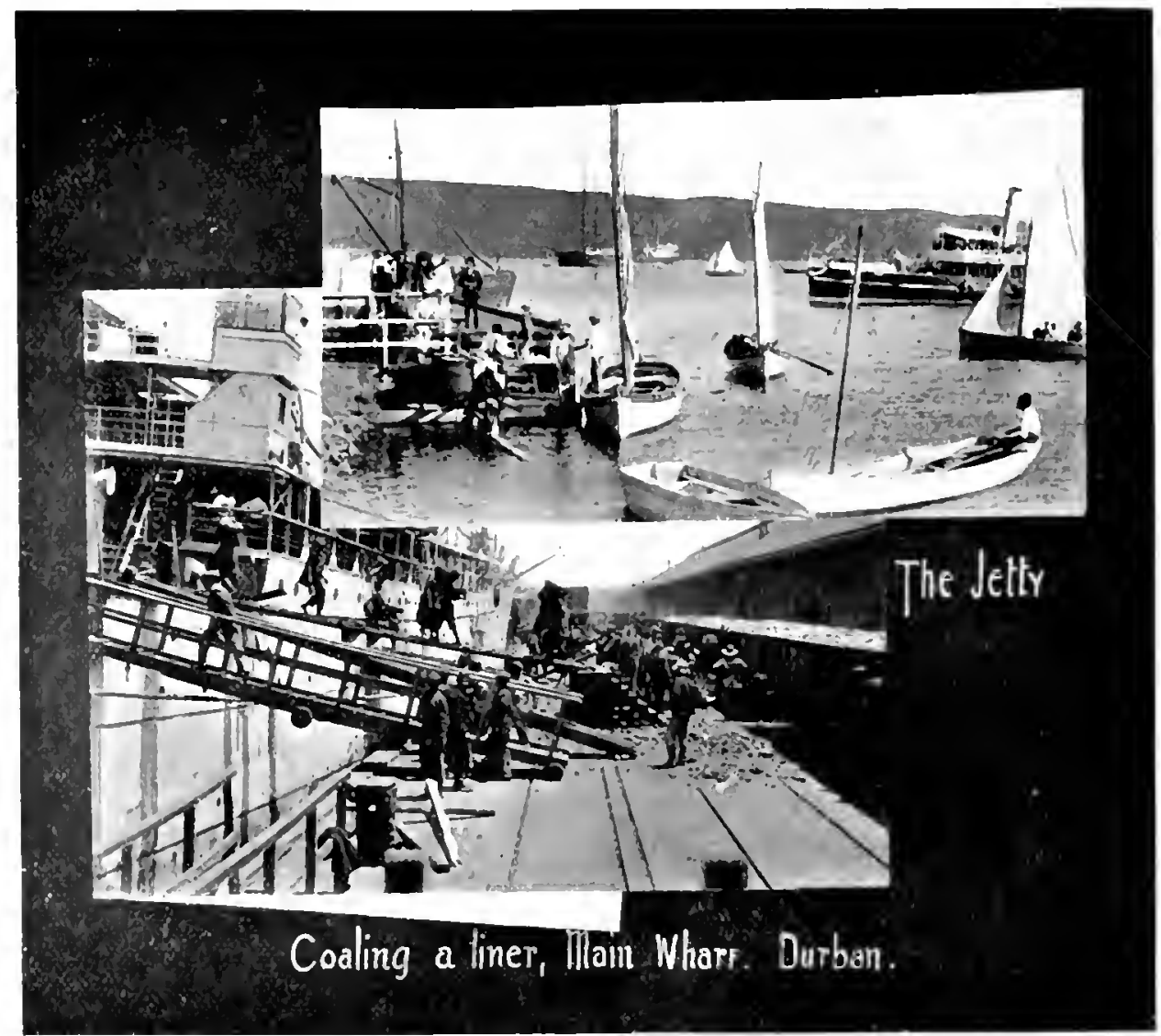




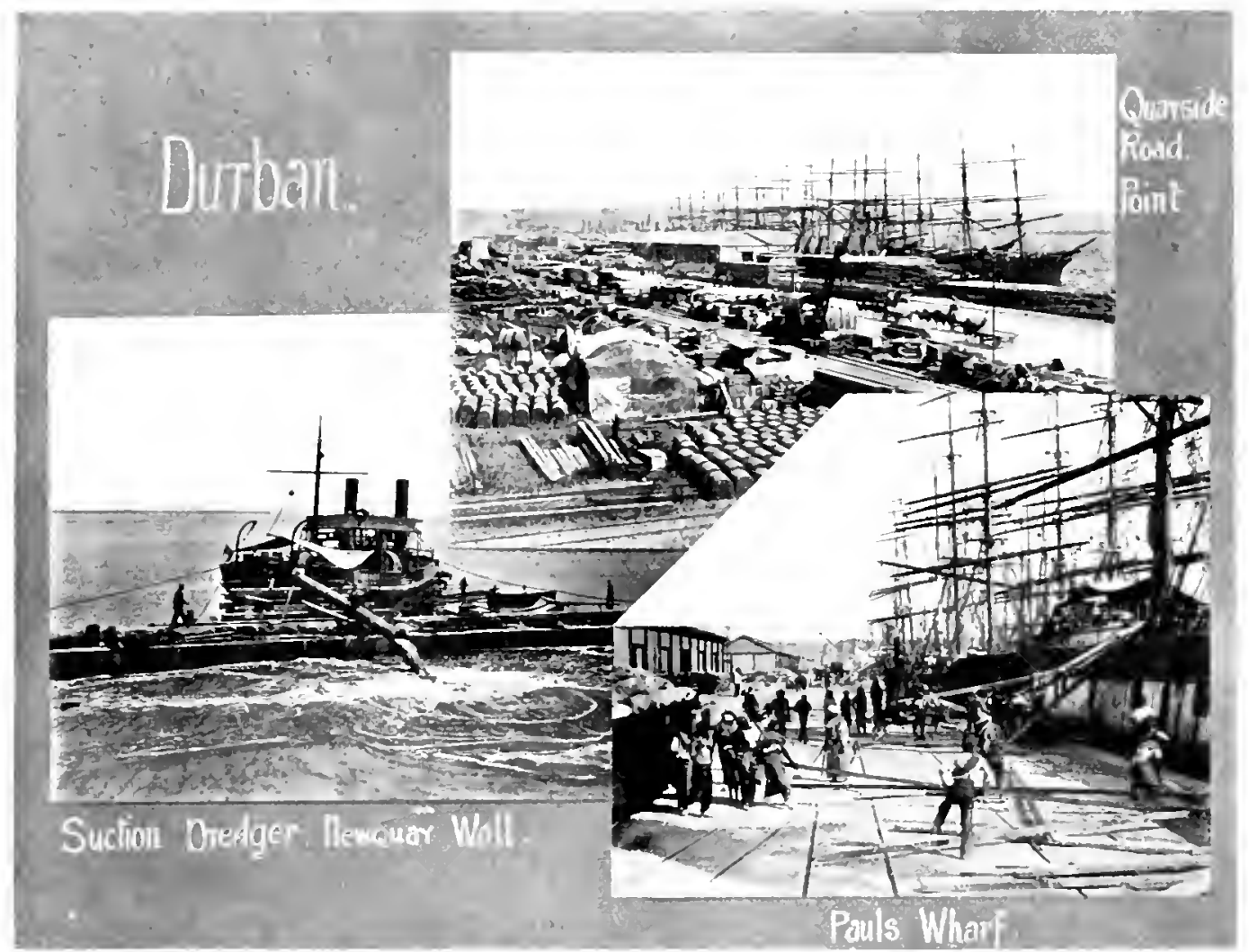

CHAPTER H

THE POINT' AND ITS WORK.

The Harbour is furnished with 2.856 lineal teet of concrete quay-wall, with a depth of 23 feet ilongside at low water (ordinary Spring tides). and a further I,000 feet, with 27 leet at low water. is well in hand. In addition there are 2.300 feet of timber wharfage, with a dejeth of from It to 20 feet at low water, as well as

WHARFAGE AND

DEPTH ALONGSILE I,050 leet on the opposite (Bluff) side. with 25 leet alongside. Ten vears ago there were but 2,500 feet all told. with an average depth of only ahout is feet.

The accommodation is divided amonest the several whartes known as "The Public (Main) Wharf," "Paul's Wharf," "Bell's Quar." and "Bluff Whall." The first three flank the Northerm side of the harhour, and stretch from near the root end of the Forth pier to a point 200 feet townards of the Wharf shed, the I.anding Stage or "Jetty," as it is called, being in the centre. The lourth wharl, as its name indicates, is on the Bluff side of the Channel. 


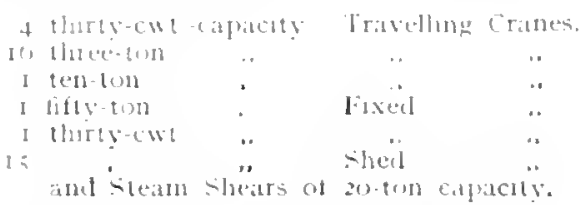

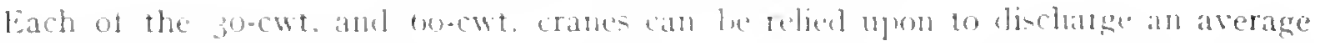

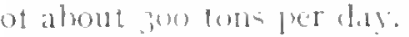

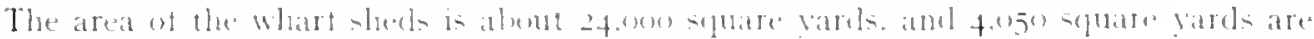

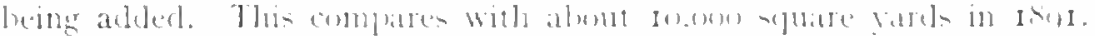

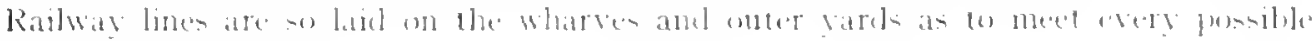
redpuirement.

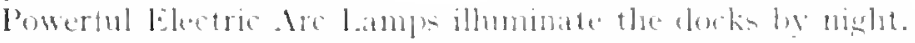

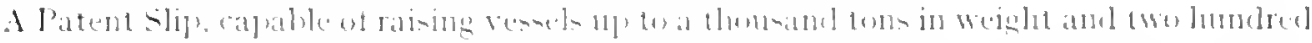
leet in lengish, in in une.

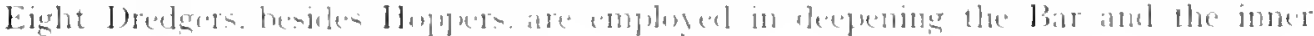

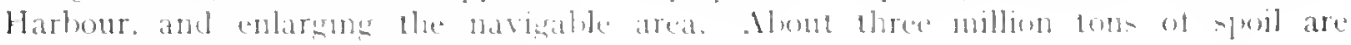
removed vearly he this meins.

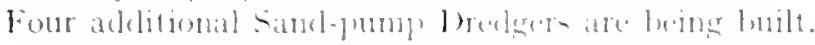

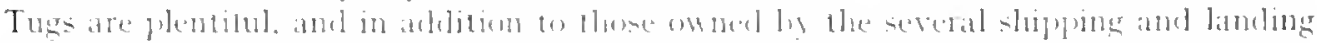

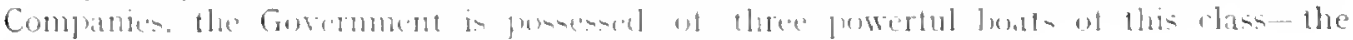

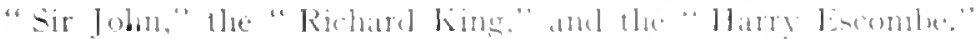

Ligliters are alon mumerom.

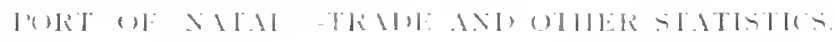

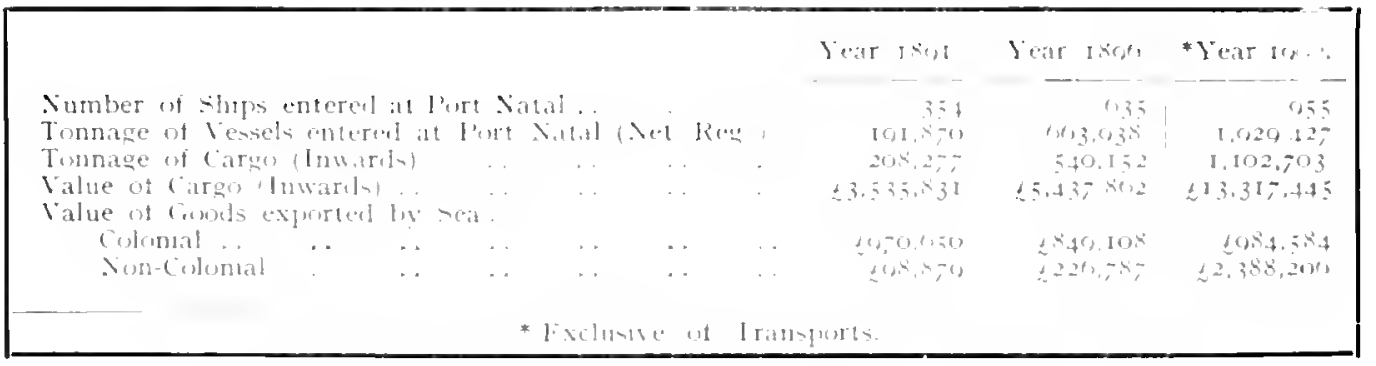

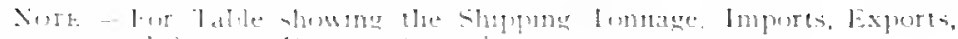

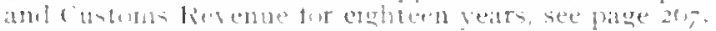

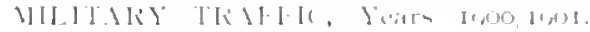

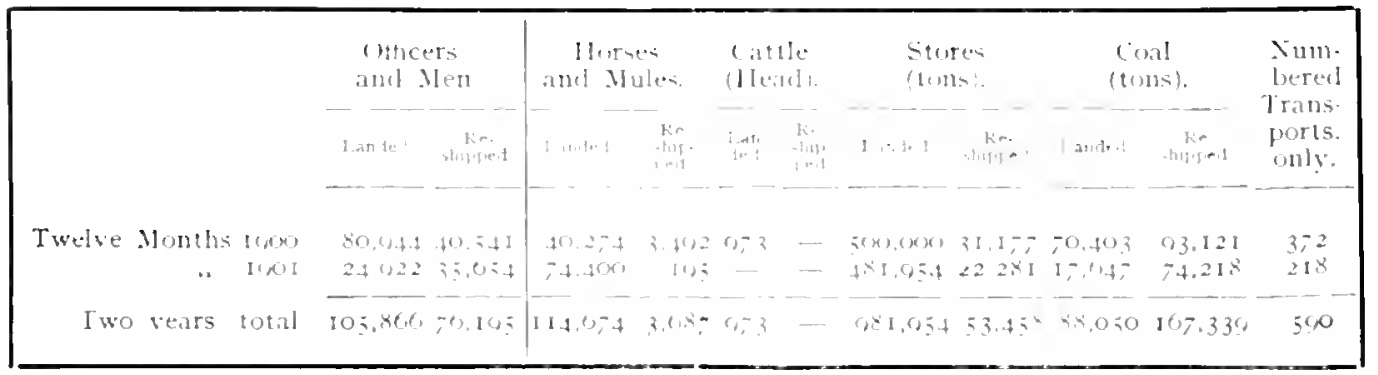


LARCIE VESSELS PERTHET I000-I90I.

\begin{tabular}{|c|c|c|c|c|c|c|c|c|}
\hline S. S. & Minnefrelian. & 10,405 & grons & $\operatorname{magt}$ & 5,70 & feet & OVET & all. \\
\hline .. & Baverian. & $10.3-i 1$ & ,. & ., & $\therefore 20$ & ., & ,. & ., \\
\hline . & Atlantian. & $0,35:$ & . & .. & 500 & . & .. & . \\
\hline .. & Custollan. & $r_{1} 2 I t$ & .. & .. & $=00$ & .. & . & .. \\
\hline , & Armeman & $\therefore 23$ &. & .. & 530 & .. & .. & .. \\
\hline$\therefore$ & Victorian. & $\therefore \therefore$ &. & .. & 530 & .. & .. & \\
\hline & Intran. & 13,12 & .. & . & $\therefore 5$ & .. & . & .. \\
\hline .. & Mechanicın. & $1.0+4$ & & $\therefore$ & $\because \%$ & .. & $\therefore$ & .. \\
\hline
\end{tabular}

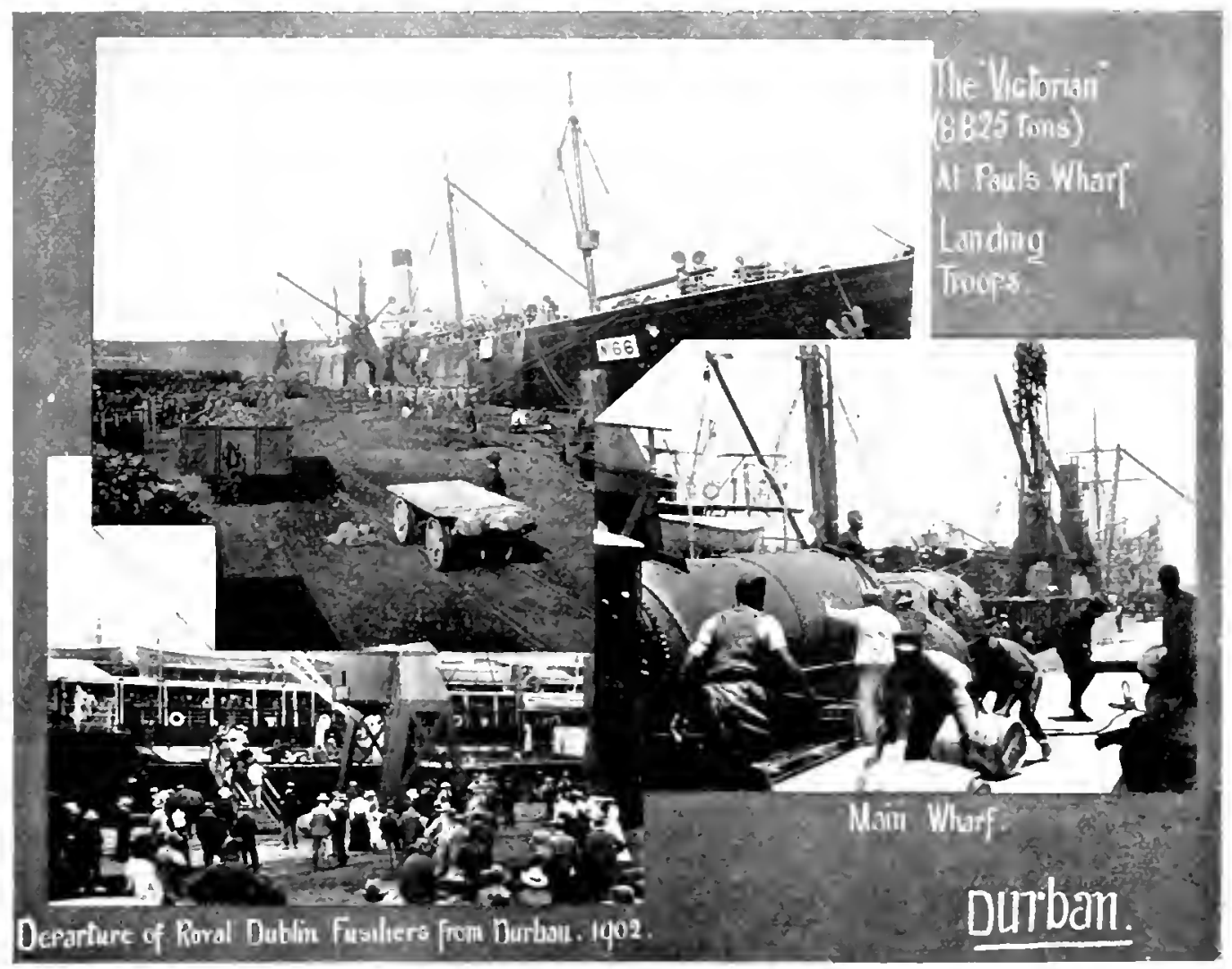

The war and its many exigencies need not be minutely entered into here. It may. however, be casually remarked that the conflict has not been without its henefits and lessons in a commercial sense, tor it has proved. more potently than any peaceahle event could have done, the unique arlvantages of Xatal in relation to the New Colonies. and the tact that she is capable of meeting any contingency. As with the railways, her maritime resources were taxed to the uttermost, hut she neither waved nor failed, and there can 
be no misgivnge that her acherements wall have ther meet reward in the certain adrance. ment and prospersty of the country.

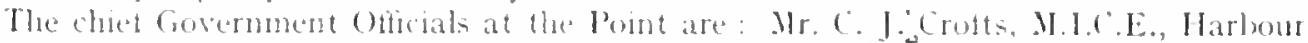
Engineer: Mr. Mayston, Collectur of Customs: and Mr. Henry Ballarel, C.M.Cs., Port (ajtain: all most able men. assisted by competent staffis.

The flan of Dorban at page 17 gires an excellent idea of the extent and capacity of the llarlour.

The phenomenat increase on commeree in the past. the lasge additional military tratic

l HEVIOPMENTS

AT THE PORT at the present, and the inevitable acession of trate in the future. hatre riused the consiteratson of rery costly schemes for improsing and angmenting the facilities and capahilities

of the Pont. Some of the works have alreaty heen completed. and the development

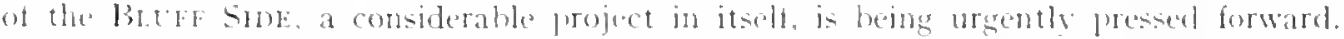
This work involves the redamation of no fewer than one hundred aces of land at the lowest estimate worth 2.000 per acrel: the erection of one mile and a halt of tene-water what lage, and the complete equipment of the hatter with the hest appliances and mathinery, mot only for loading export coal in bulk. Lor which purpose the accommolation will princi-

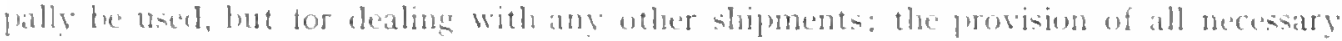

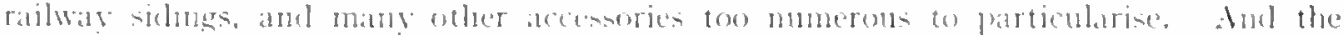

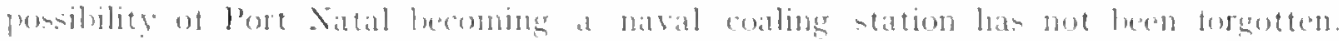

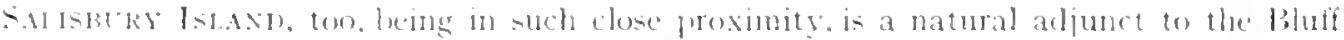
side workis, It is proposed to raise the surtace of the lstand. to provide whartage slides,

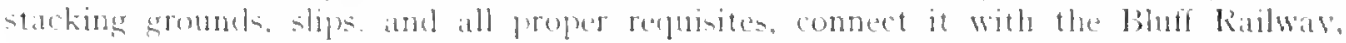
and utiliae it for dealing witle the emormous import timber traltir. This will alford

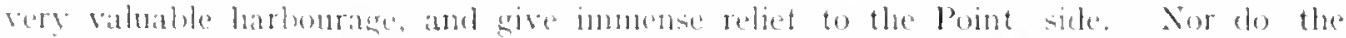

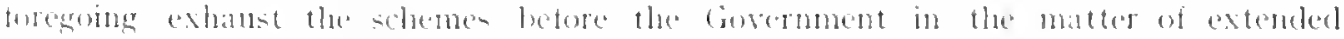

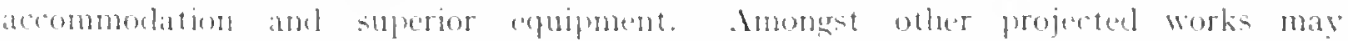
he mentionet: the purision of adtitional mhartage, with shedeling amel al! neces-

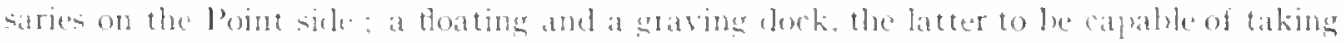

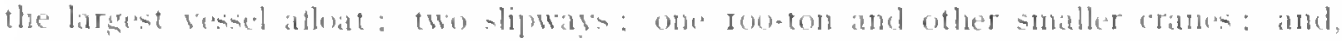

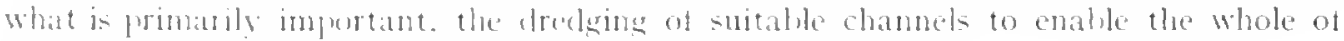

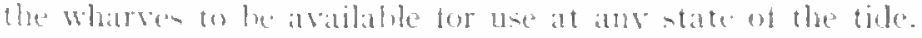

surely. when all these improverment have heen carried out. Port Natal will become one

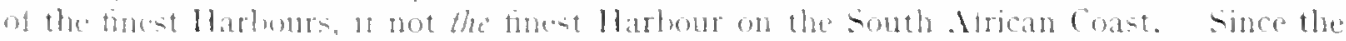

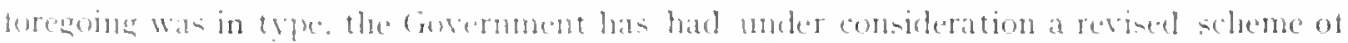
hathenr improvemeat. The outlines of the proposed new sheme are shown in the plan of Durtan.

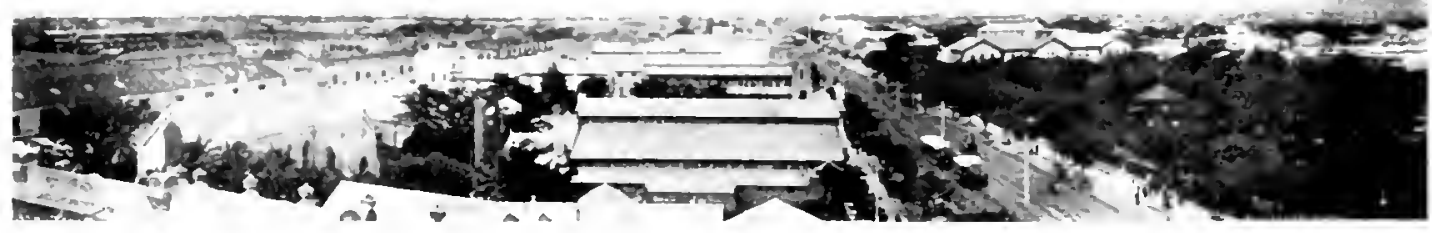




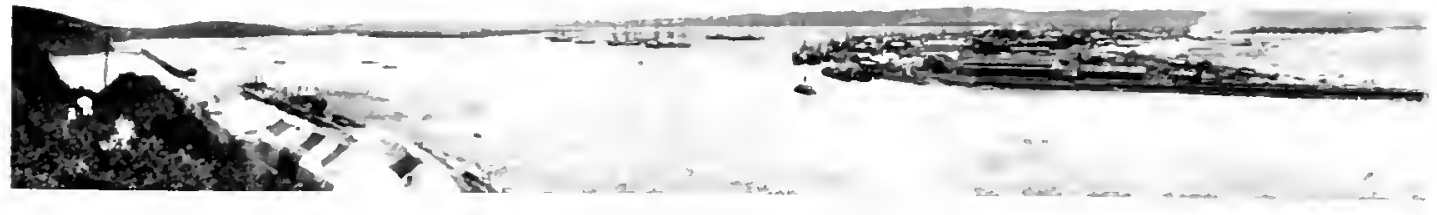

CHAPTIER III.

THE SEAPORT TOWN OF DL'RBAX.

A NOTE.-Appended to the undermentioned particulars of the sea-port town of Durban, is the description of a TOUR FROM THE POINT TO THE CENTRAL RAILWAY STATION via POINT ROAD, WEST STREET, THE BAY EMBANKMENT, ALBERT PARK, AND THE BEREA. This tour is given more particularly for the information of those whose soiourn in Durban is brief, but who, before proceeding further on their travels, desire to obtain a passing glimpse of the many attractive features of the town.

The JINRICKSHA might be employed as the means of locomotion for the first part of the excursion because of its novelty to the newcomer, and also that it enables a detour to be made at the Town Hall for the inspection of the Esplanade and the Albert Park. Omitting these two items, however, the ELECTRIC TRAM.CARS would be found to traverse the whole circuit with greater celerity and comfort, and at a much cheaper rate. The route of the teur as arranged can be traced on the street plan of Durban.

$\mathrm{N}$

ATAL's largest and prettiest town embraces ithree parts-Addington; the town proper: and the Berea. The first is the centre of maritime interests, alrearly described - the Point; the second, the venue of conmercial and general actirit ; the third, the fashionable, residential hills which semi-gird and beautify the whole.

Durban was founded on the 23 rd June, I835, and named after the

DURBAN. then Governor of the Cape, Sir Benjamin D'C'rban. At that time it THE was mere sand and bush, the haunt of elephants. and the abode of TOWN serpents: now there is not a fairer or more progressive town in all South Africa.

The area of the Borough, including town lands, is ten square miles. The population (according to the census taken in July, Igo2) stands at 60,4 40 , composed of 28.049 Europeans, I 2,460 Indians. I9, Iqo natires, and 747 halt-castes. The European birth rate in 1902 was 27.7 per thousand, and the death rate I 4.I per thousand, but the latter is to some extent swollen by invalids from the ferer-stricken regions on the East Coast, and other aliens.

The climate during the wmter months is superb, and entices a goodly army of health and pleasure seekers trom all parts. During the summer months, however, the heat is frequently oppressive. 


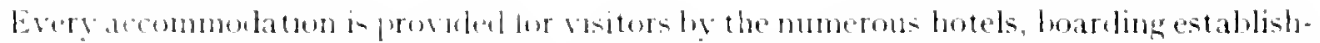

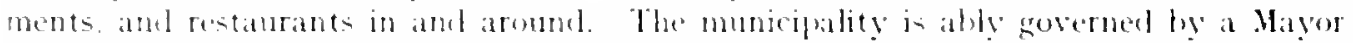

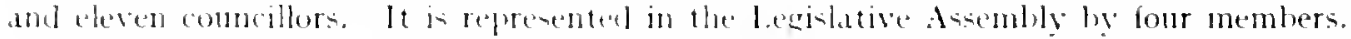

In the gear rew2. the rateahle vahe ot the burengh was is.553.255. Which compares

MUNICIPAL FACIS

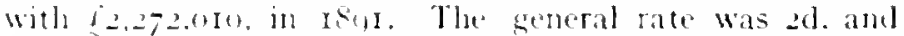
the Water rate sol in the found. The Municipal Rerenue

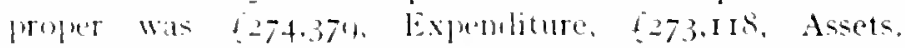

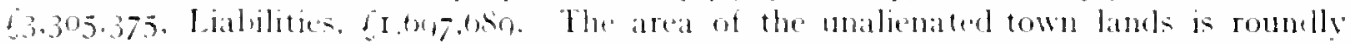

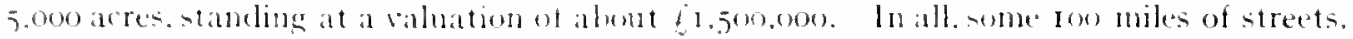

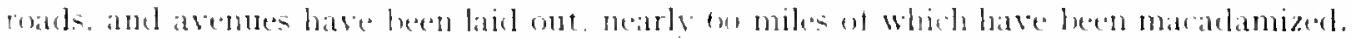

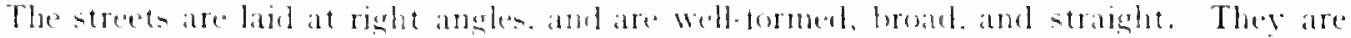
maintanes in mexceptenable condition, lighted by electricits and prosided with an

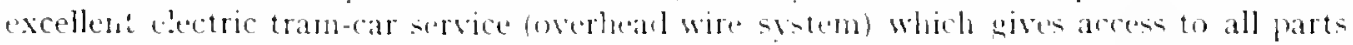
of the town and the linera. representines some 22 miles of linte. There is alen a plentiful suply of cates and rickshas.

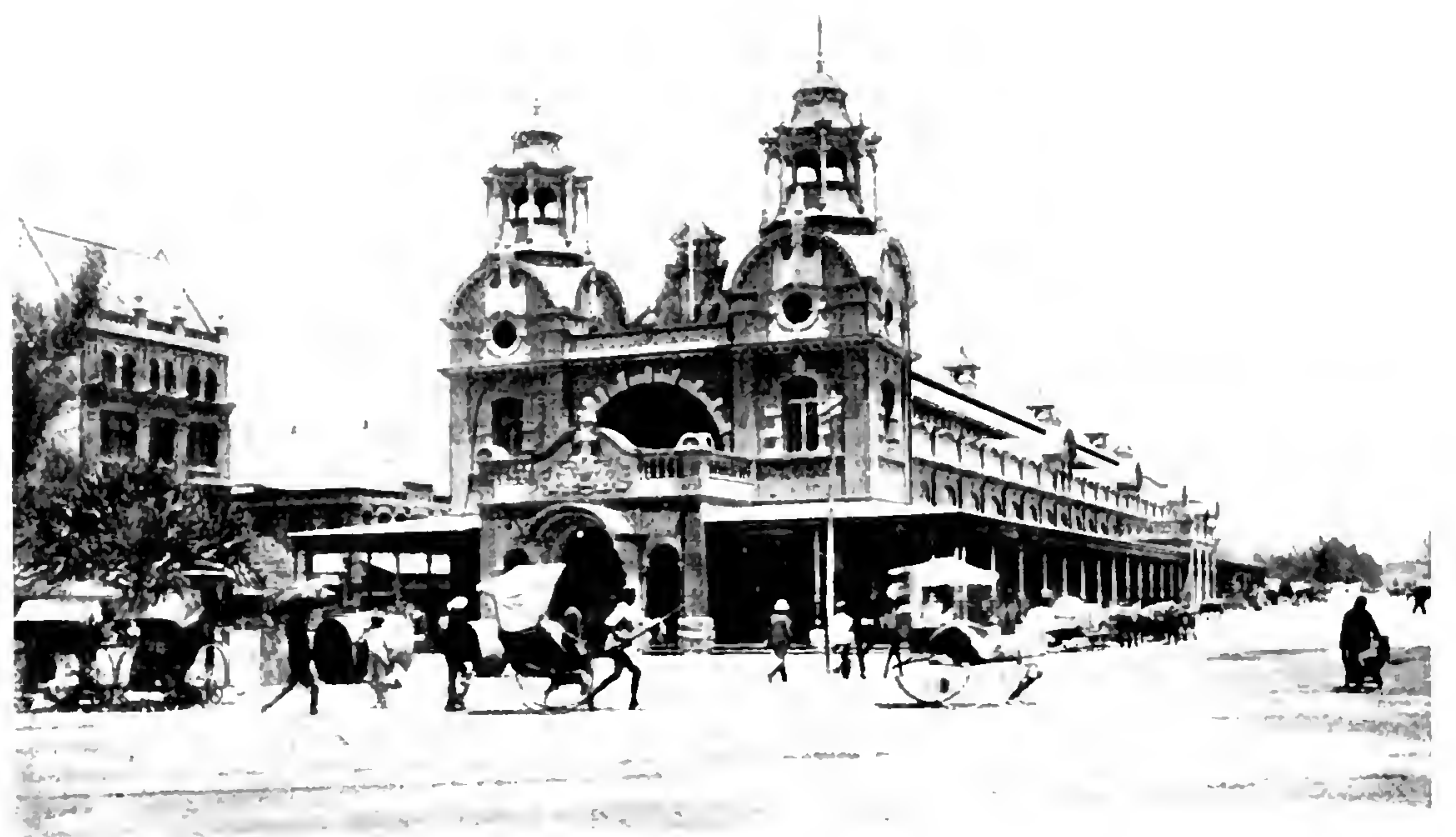

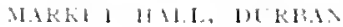

The frimipal thoronghtares are adornet hy many handsome blocks of buldings, which comply with the various necessities of thin rising town. Notwithstanding the high price of husines sites. quite a number of new erections of a bright and imposing character are going up. Corporation lanels are also being wontinually thrown open tor building and wher purposes, on accesible terms to the thritty man. The electric-lighting and tram installations are worked and maintaineel ly the Municipality. 
The water consumption is at jresent three million and a quarter gallons per diem. This supply is gained from two independent sources, and is practically inexhaustible. In addition to the natural sources of suply, however, a reservoir has been constructed. with a capacity of 500 million gallons of water, to meet any case of emergency. The clear water storage reservoirs. situated at a convenient distance from the town, will have a capacity of over r 20 million gallons.

Durban's sewerage srstem is particularly good.

The town is possessed of a very efficient Police Force and Fire Brigarle.

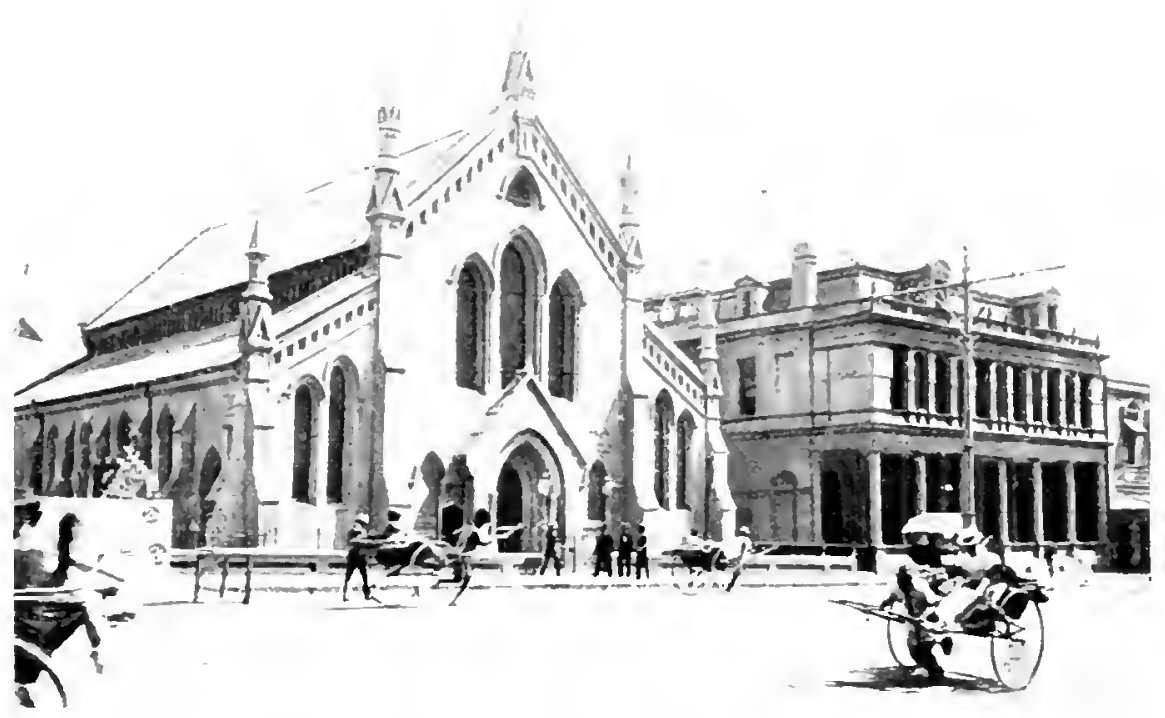

WESLEYAX CHLRCH AYD STAYDARD PAYK, WEST STREET, DLRBAX

Churches and Chapels of every denomination are represented. There is a large number of Schools of various grades, and

PLACES OF WORSHIP, SCHOOLS, NEWSPAPERS, INSTITUTIONS. SOCIETIES, CLUBS the scholastic training in Durban is excellent. Two well-conducted Journals of long standing and extensive circulation, are issued daily, the "Natal Mercury" in the

morning, and the "Natal Advertiser" in the afternoon.

There are the usual Benerolent and Political Institutions: the Durban Home for the unemplored; Orchestral. Musical. Theatrical, Literars, and other Associations.

A well-stocked Library and Reałing Room. Museum. Art Gallers, and other arenues of intellectual advancement and pleasure are open to the public.

Several private Hospitals and Sanatoria are in existence, besides the Natal Government Hospital at Addington. Masonic, Odfellows, and similar Lodges are established. There are numerous Social, Sporting. and Athletic Clubs.

Entertainments, histrionic, musical, and the like, for which the best talent is secured. are provicled all the year round. 


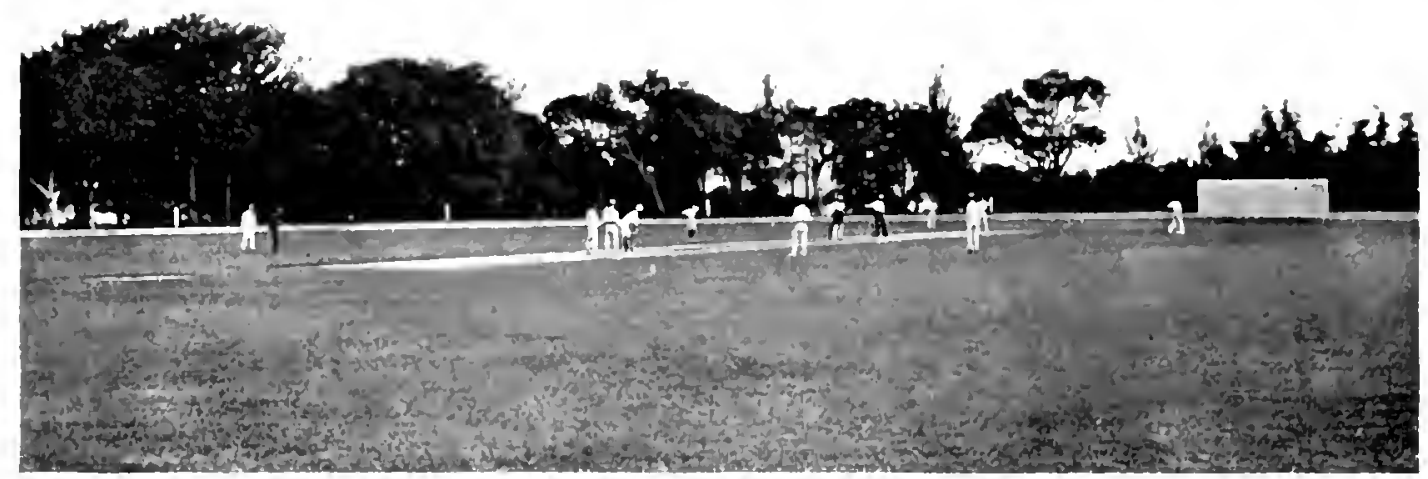

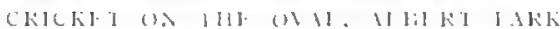

ENTERTANMENTS AND RECREATIONS
The tomb 1- erramed be tome puldic parks, the "Mllert." "Mlexamelra." "Nitchell." amel "Pereat."

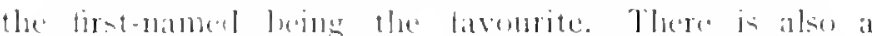

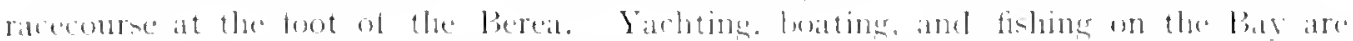

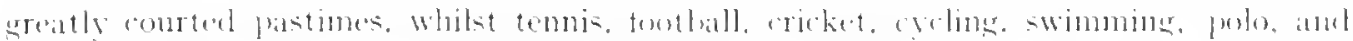

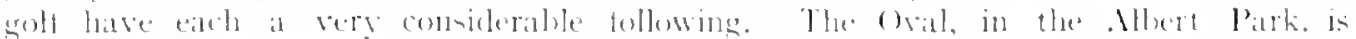

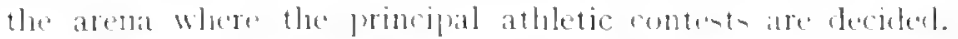

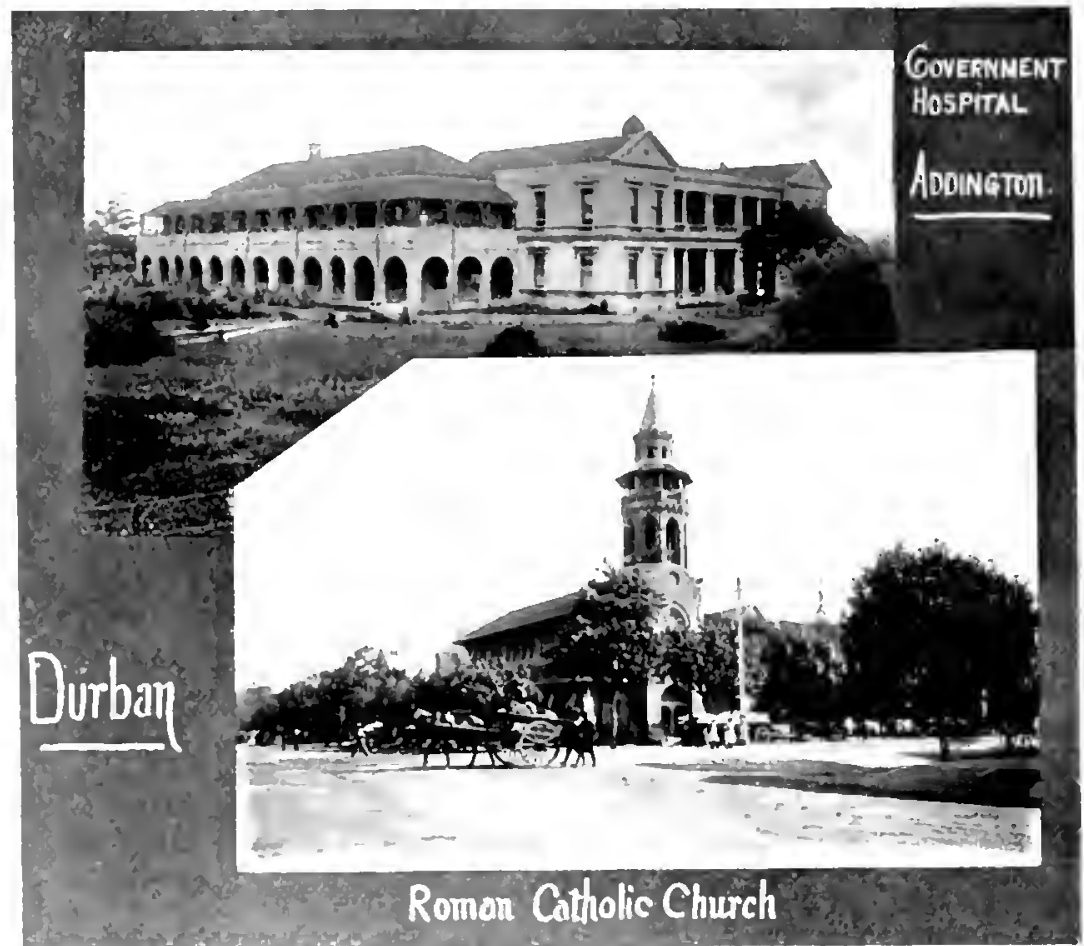





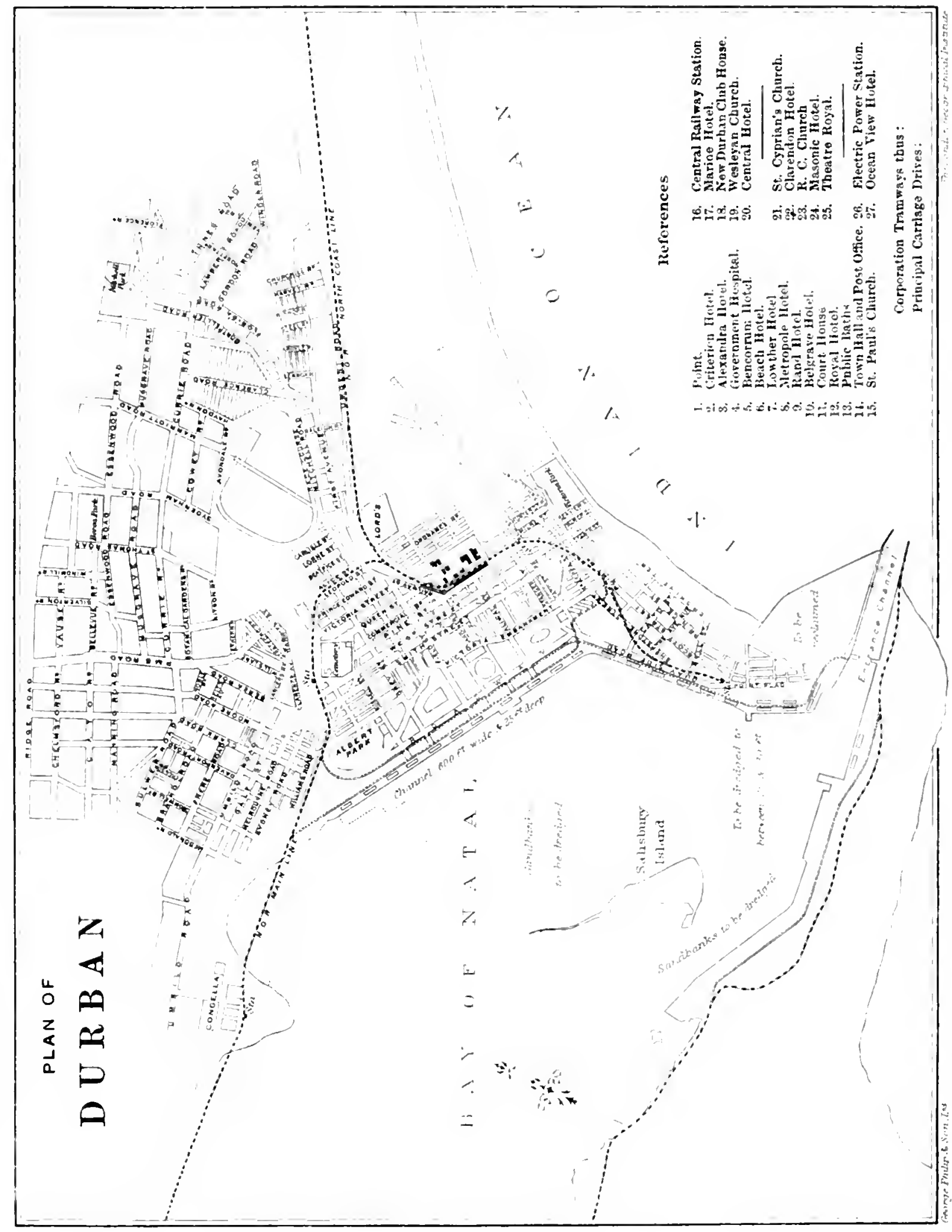


Of the Commercial. Industrial and Banking houses represented in I)urban, the follown: may be mentioned: The Eastern Telegraph and

COMMERCIAL,

INDUSTRIAL, BANKING HOUSES, ETC., ETC. Sulmarine Cable, Lloxd's Agent and Surveyor, Bureau Veritas. Reuter's Telegraph Company, I.td., Life and Insurance Companies: Ucean and Coast Lines of Steamers, Carting and Coal Companies, Landing and Shipping Agencies, Stock Exclange, Natal Land and Colonization Co., Sugar, Tea and Coffee Companies. the Standard Bank of South Africa L.td., Natal Bank. I.td., The Bank of Africa, Ltd.. National Bank, and the African Banking Corporation; also numerous other mercantile, and general business establishments.

A comprehensive plan of the Porough. upon which is indicated the situation of the PLAN OF LURBAN etc.. as well as the tram routes, will he found facing page I 7

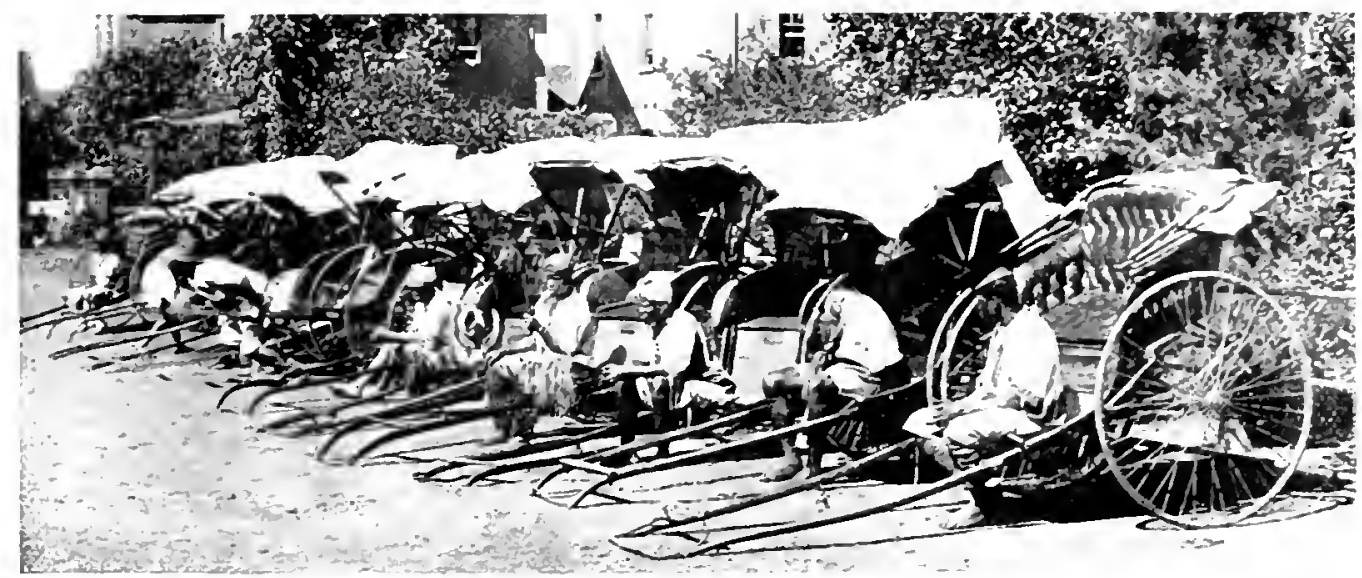

IINRICKSHA DUM:

\section{$\therefore$ TOLR.}

FRON THE POINT TO THE RALLIA S'TATIOA

I.1.

POINT ROAD, WEST STREET (EAST, BAY EMBANKAE.NT,

ALBERT PARK, AND THE BEREA.

Taking a farewell glance at the Point and its lively wharves, the immense Alexamlrat Square, the bonded stores, shipping offices, hotels, and the numerous other huildng: which are the boast of a good port. We pass an ornamental Drinking Fountain surmounted by a clock. This was erected in honour of Vasco da Crama, the Portuguese Admiral who discovered Natal on Christmas Day, 1497. At the back of this memorial are the Railway Station premises, and to the left of these, the square-towered Electric Lighting Works. Immediately afterwards we observe the quarters of the Water Police, while behind, fon the right, is a long row of restaurants, shops. institutes for sailors and private 


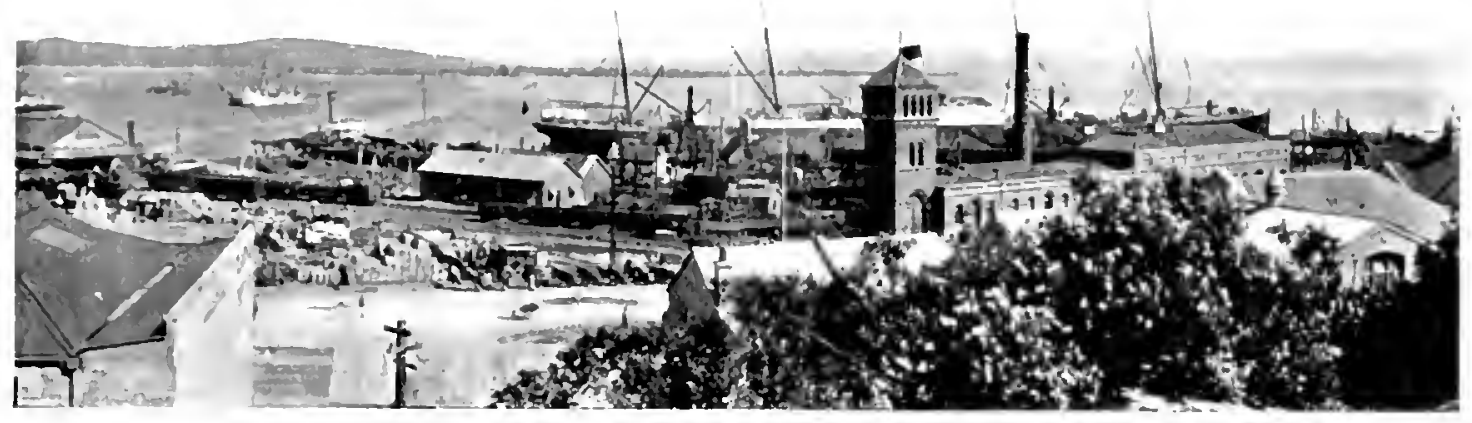

I'OI I

residences. This part of the Point Road throbs withexcitement.-. Electric trams speed by in both directions; trollies. facked with all descriptions of gooks driven lyy the light hand of the kithr, roll towards the town, atod a procession of similar velicles, rodieved of their burdens. ane refurning for turther bads. Pedestrians are hurrying to

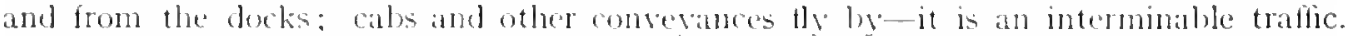

Now we tmm to the maze of masts at l'alul's Whart: now to the right atrain, noticing

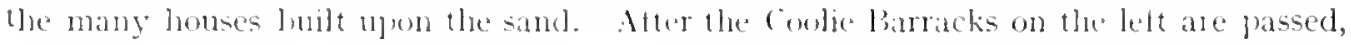

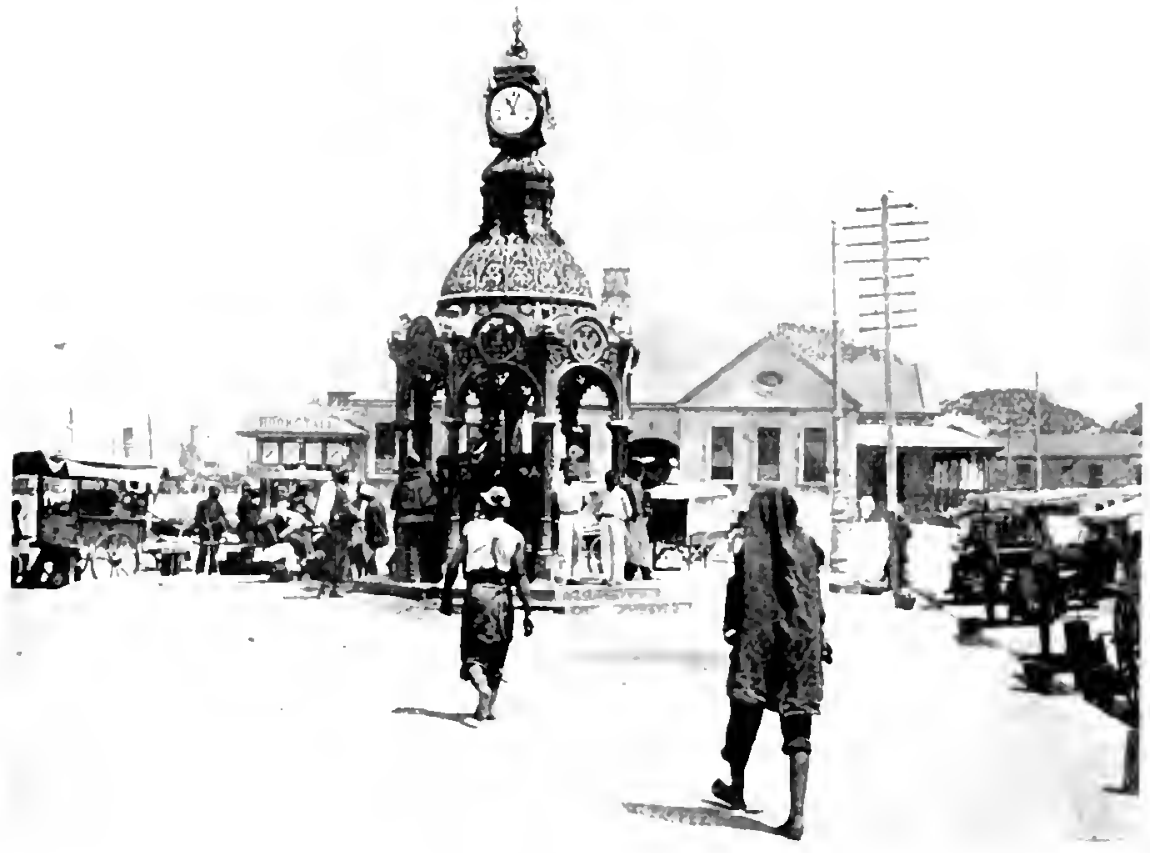

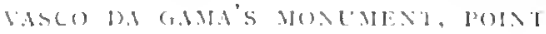


there is little of new interest to engage our attention, save a Masonic Hall, severa churches, and a statuesque native policeman on the look-out for the delinquencies of his brethren. This dark limb of the law does not carry a truncheon, but is allowed his own equally effective weapon called a knob-kerrie. which he disports with considerable satisfaction and can use, if need he, with telling accuracy, eitler in throwing or at close quarters.

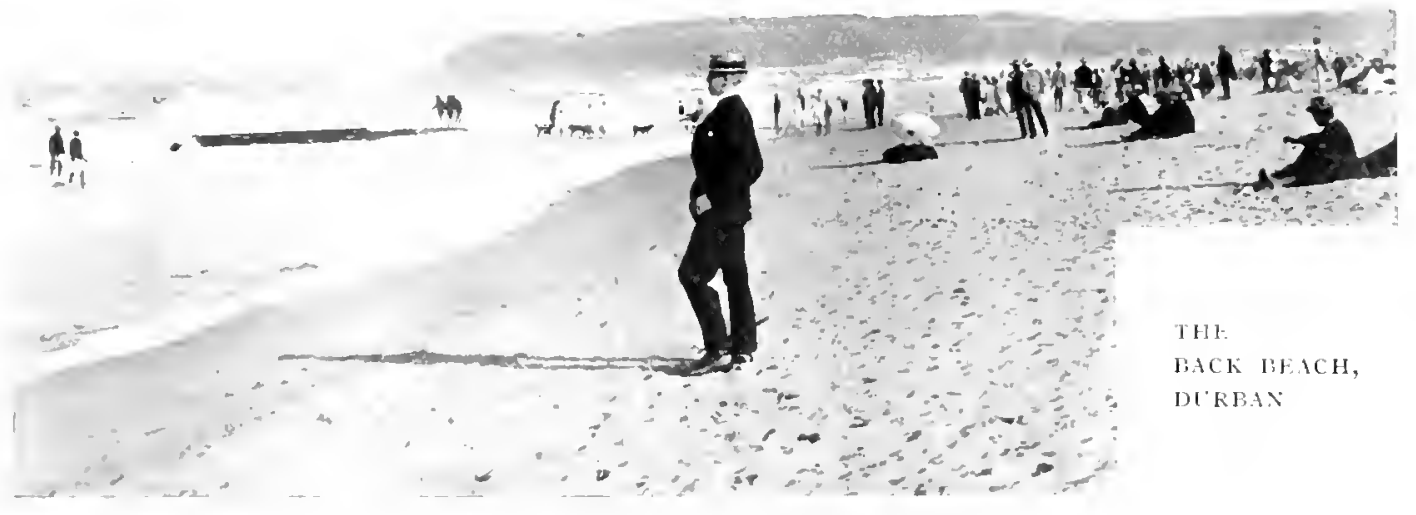

For some distance, hefore reaching the junction with West Street, we are flanked by the Railway lin leading to the Point, and are passed by a long train of coal bound for the docks. This piece of line, it might be mentioned, was the first railway constructed in Africa. We are now at the turning into West Street, the principal thoroughfare of the town. (The short sandy roal on the right leads to the Sea beach.) l'assing onwards, over the railway crossing, and proceding for some distance by shops, cafes. and hotels, we notice a large mercantile house on our right. Looking sharply in the

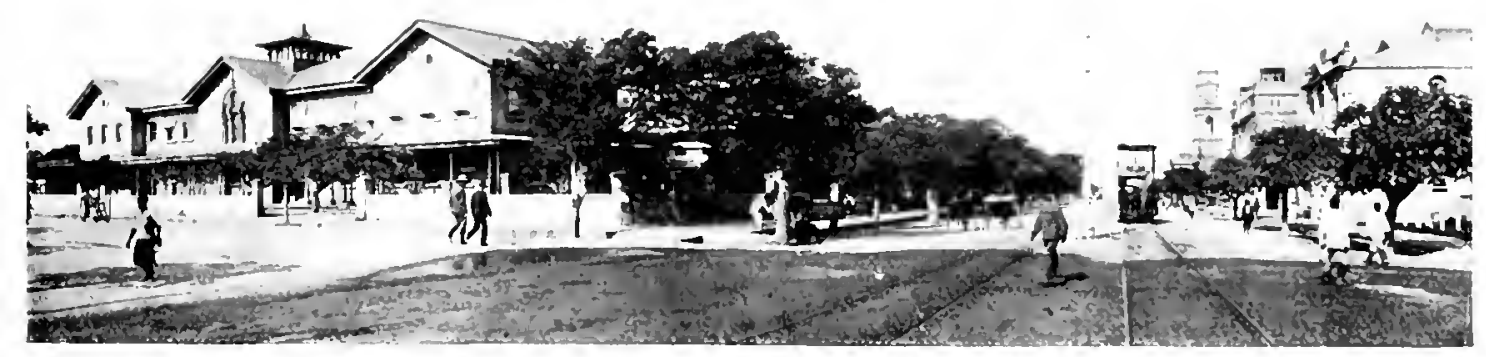

COURT HOUSE, WHST STRFET, DULH.IN 


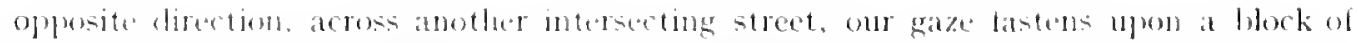

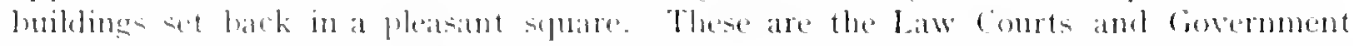
Buildings, Mljoinger this square are the loblic Gordens. Immediately on the other

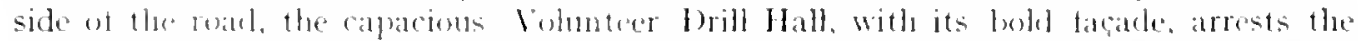
eve. This in innet tretween the stome-built Regmental offices and the solid-hooking

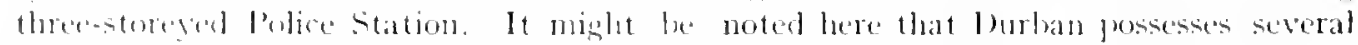

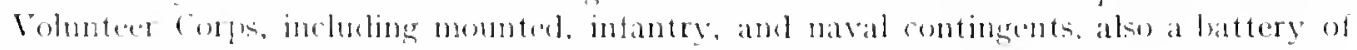

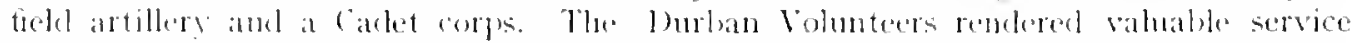
during the War. and lost a mumber of Olticess and men. inclueling the gallant Commanter of the Xatal Vounted Rittes and the Vohmeder Composite Corps the late

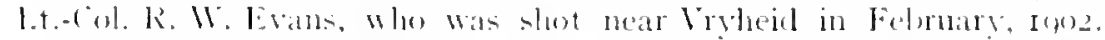

Resuning our observations: abutting on the Police station is a valunt space, which is

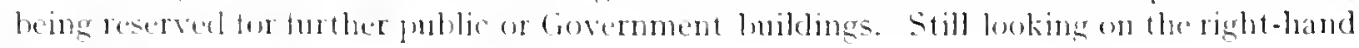

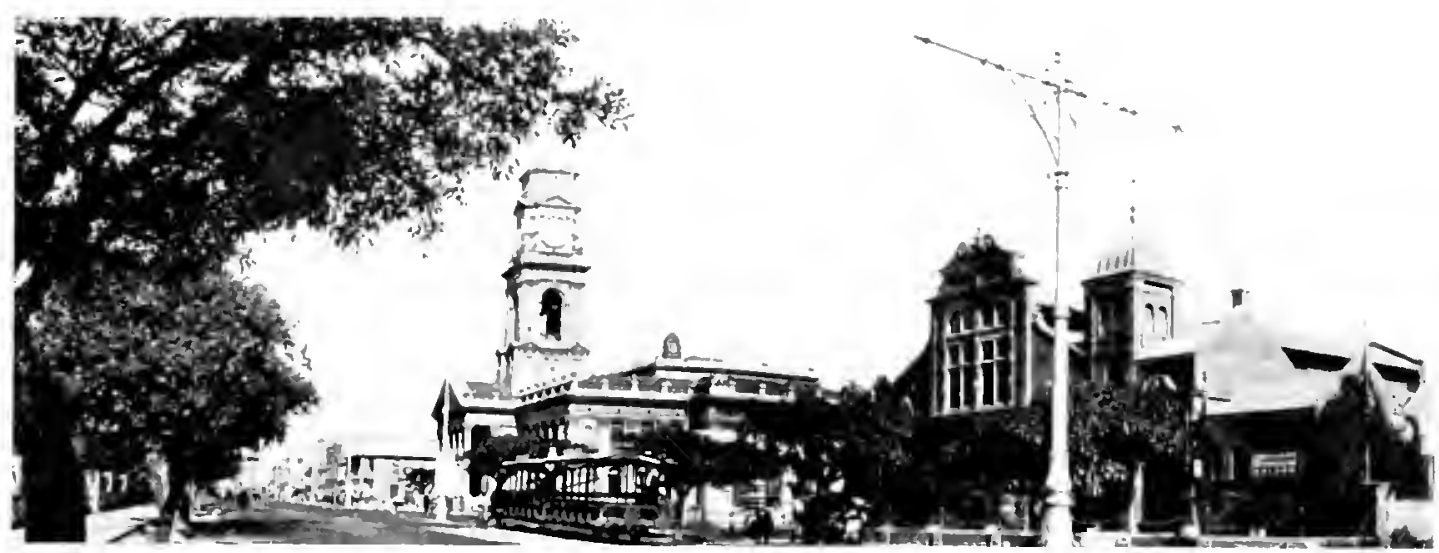

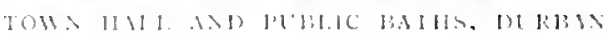

side of the rovel. We see the creper-covered exterior of the Public swimming Baths. These are the poperty of the (orpuration and are largely patronised. Now directing our attention to the ledt, we gather a prettier aspect of the fown Gardens. am note the short,

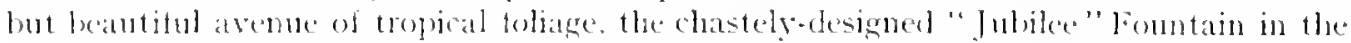
midelle view, and in the backgromel-insmith Street-the clegant pile of huildingserect

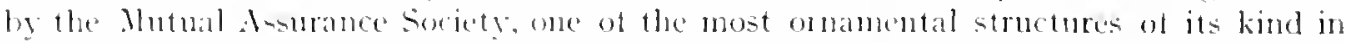
Natal. Turning our eres again to the right. the Public Library ank Reading Room manifest themsetres. Poth are mull appreciated. The present conplement of books in the library execeds 12,000 , and the yeirly issue approximates to some fo, oos volumes. Passing an oft-etret, at the fottom ot which is situated the Anglican Clureh of $\mathrm{St}$. Paul's. We come face to face with th. Town Hall. This imposing Corinthian edifice

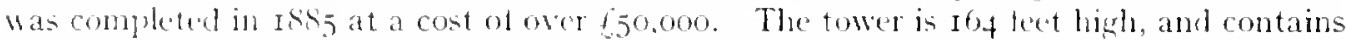
a masive clock. The main Hall, which is used for all impurtant concerts, dances, and other entedtainnents, is capacions and tastefully deorated. A very fine three-manual organ, upon which pulsic recitals are trequently given, was erected hy the Corporation in Istaf. The Durban Public Mlusum and Art Gallery are each located in the uper portion of the fmilding. They are open to visiturs on certain week-dils, and a bery pleasant and 
mstructive hour may be spent therein. The Vuseum is devoted to tle exhibition of rare and extensive collections of zoological, botanical, geological, ethoological, and mineralogical specimens, as well as insects and reptiles, coins and medals, relics of the ditferent ages, savage implements of war, and many other interesting acquisitions, not only from Sonth Africa, but other countries. The Art Gallery contain a 13 mmler of valuable paintings, including canvases la such celebrated artists as Val Prinsep, NacWhirter, Herkoner, and the late T. Sydney Cooper. The Postal, Telegrapll, and Cable

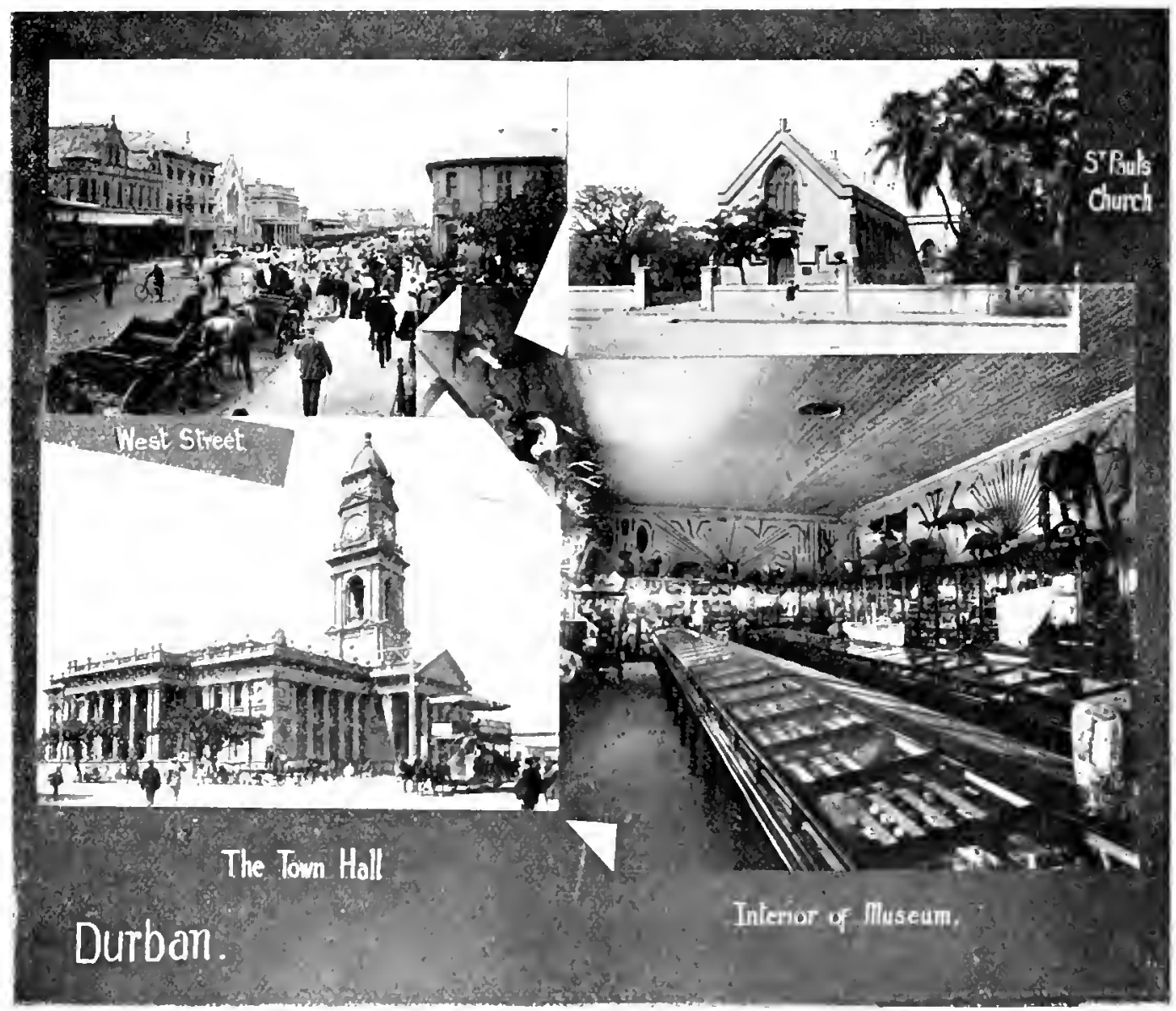

Dejurtments occupls a portion of the Hall. While the various Corporation (uffices and Chambers are of course, inclueled in the building. A lew reirs lack thin llunicipal edifice was sufficient tor all purposes. Junt the town has progresenel so rapidly in recent years and shows such signs of greater and continuous derelomment in the future. that the corporation have under contemplation the erection of a still more commodions Hall, and the proxision of new and more atequate accommolation lor the Public Library and Realing Romms. Musem and An Gallery, resigning the pestent Town Habl for Government use. I.ooking over to the ornamental Gandens, we abserve the beatufully- 


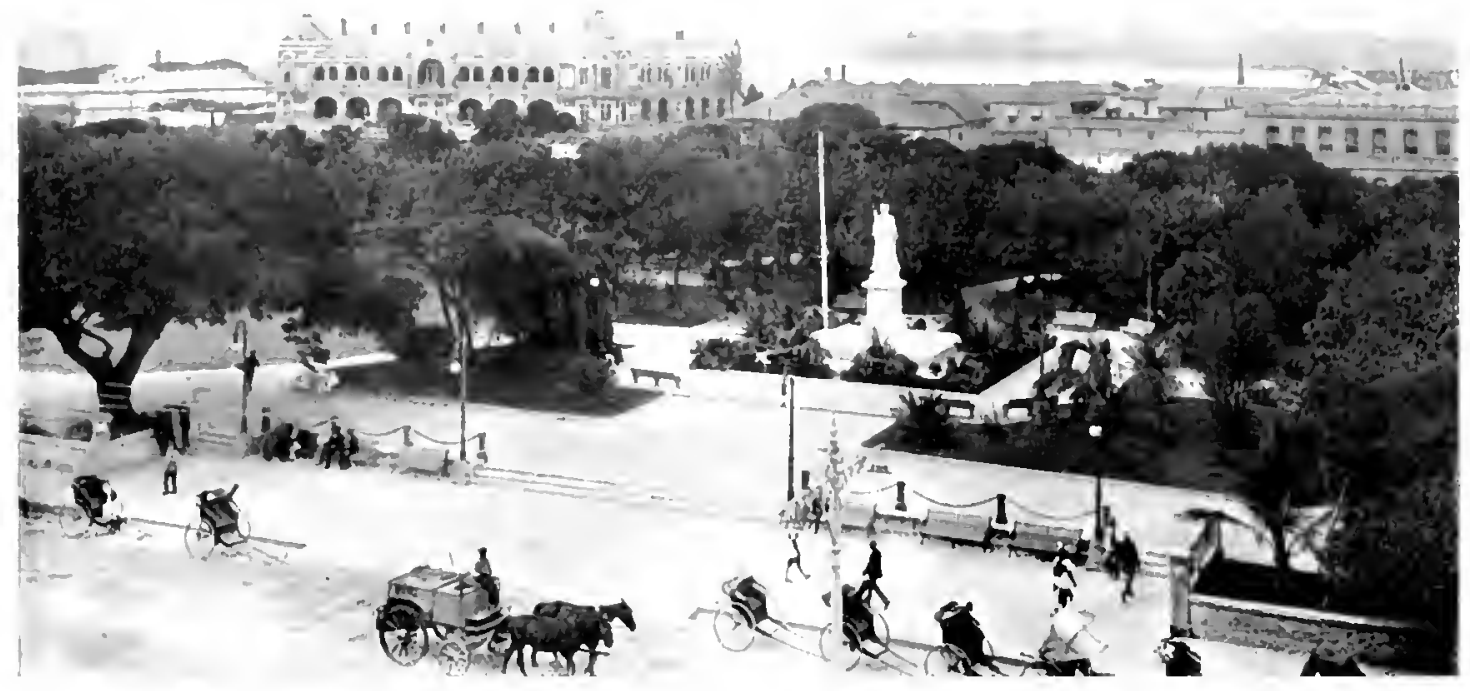

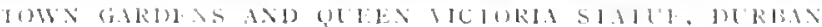

enshrined statue of the late Queen Vintoria. This was arected in Ison in commemoratun of her glerions reign. The statue. which is executed in white marble and of exquisite treatment and finish, is hy the celetrated sculptor Hano Thurneverolt.

We have now arrivel at the busy pivot of the town. In front, West street still exterds for about a mile until it merges into the bereal llatu Roarl. The cross roal is Gardiner Street, the right pertion of wheh leats to the lost ()flece (ientral hatway Station, and Market Hall, and the left to the bay Embankment, and the second principal thoronghtare, Smith street. This circus is a moving pjeture of electric trams, carriages, cals and carts, rickshas and bicycles, newspaper loys and other loys, knots of mero gossipers, chmps of cagereyed business men, smart and observant policemen, and an incessant stream of ladies, tastetully apparlleel. Funing from this entertaining sight, which give the stamp and character of the town with much more loree and directness than mere description, we proceed to the lett and passing along Gardiner Street, tlanked by a row of shops and offices on the one sile, and the Pulyic Gardens on the other. fuickly cut through. Sunth street and catch a better glimpse of the highly-ornate dutual Buildings. We are now almost within a stone's throw of the bay, and are greeted by an acceptalle hrege. The Esplanale being reached, we stay a moment to review the Point and the bay trom this quarter. The latter makes excedingly pretty scenery at bull tike. with its islanel and encasment of wouded hills and the life on its rippling waters. Lonking towards the lead of the bay, we descry the sulurbs of Congelat, l'mbilo, and south coast Junction, set pleasantly upon the slopes of the hills.

Pursung onr journey along the Embankment in the latter direction, we appreciate this substantial addition to the attractiveness of Durlan. It is formed of a wide asplualted promenade presided with seits. a nanow grass-plot bordererl with galms and trees, and 


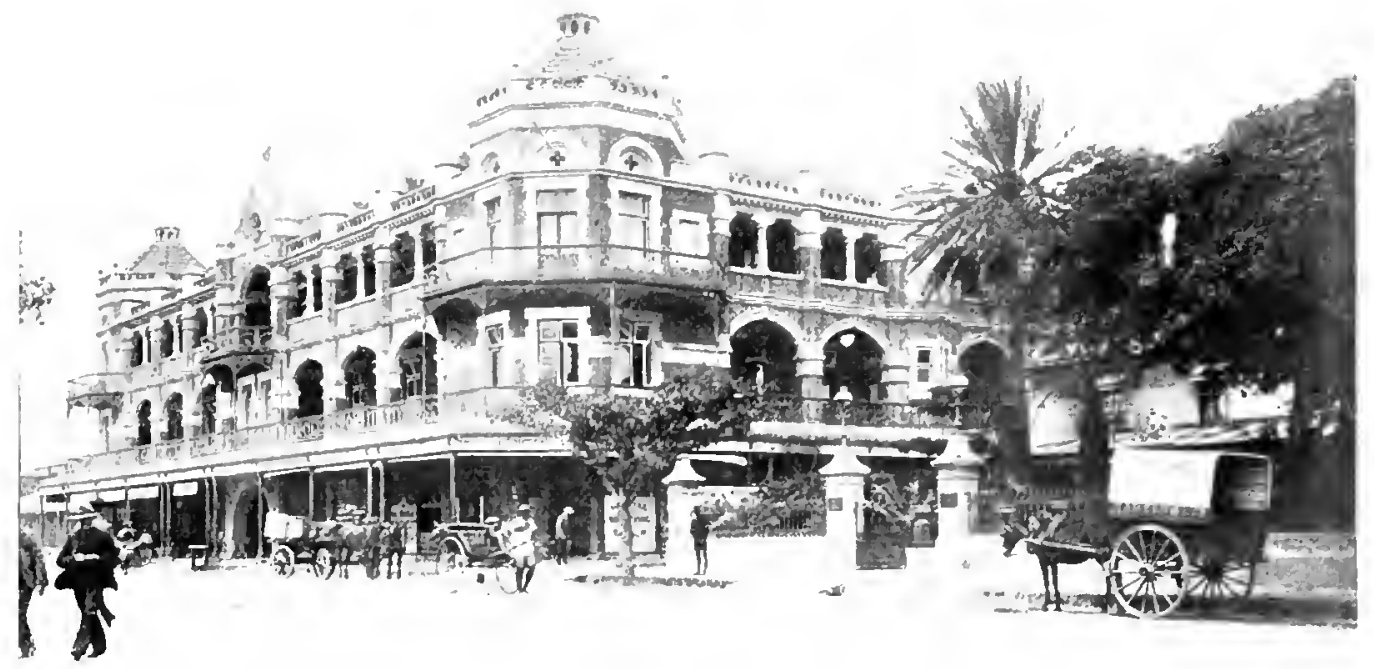

SOLTH AFICAN MUTULL JULLINGS, DURBAN

a broad carriage drive, overlooked by handsome villas and clubs. The embankment stretches in graceful curves for over 2.000 yards trom end to end. Resting, as it does, on a once fetid swamp, the work is a monument, not only to the foresight and progressiveness of the Corporation, hut also to that "great statesman and famous citizen " the late Right Honourable Harry Escombe, a marble statue of whom has been erected in the Town Gardens. in recognition of his devoted and inestimable labours towards the advancement of the Port, and the general welfare of the Colony. Passing by the magnificent new buidlings of the Durban Club, and the less pretentious but good-looking Roral Naval Yacht Club, situated opposite the jetty, we take the first turning to the right, and then almost at once seek the road that soes to the left. This is St. Andrew's Street, and we find ourselves in the midst of sedate and tashionable residences. Albert Park being reached, we enter by the first gateway, and traverse an averue delicionsly cool

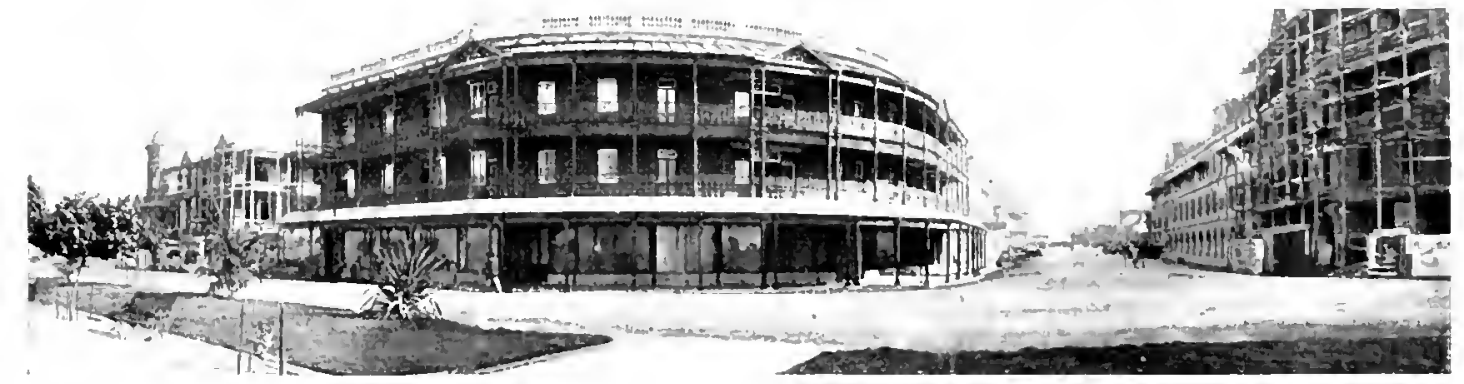

THE ISHIANAL, GIRIINIR SIRIFI TLRXIXG 


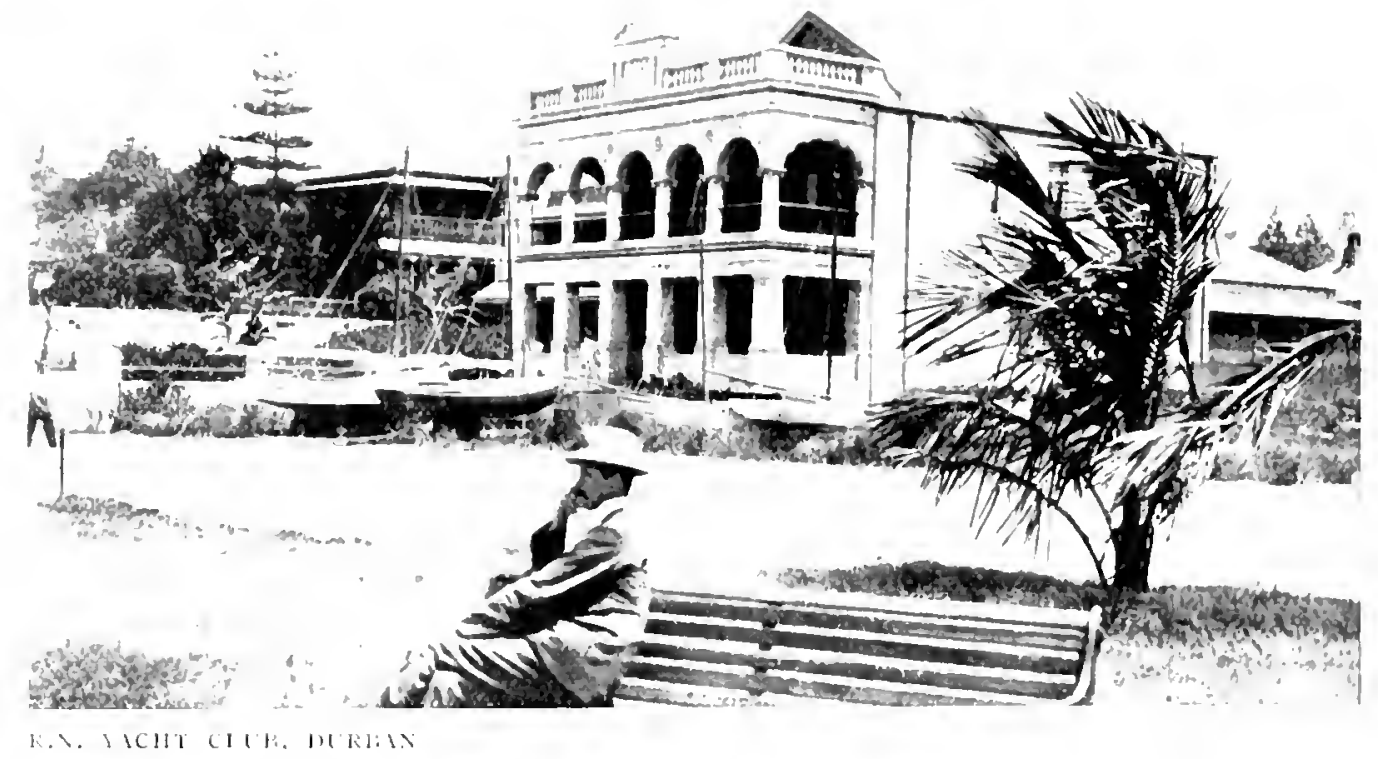

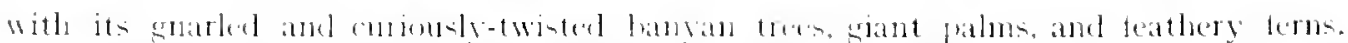

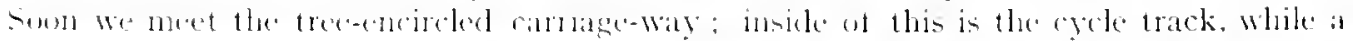

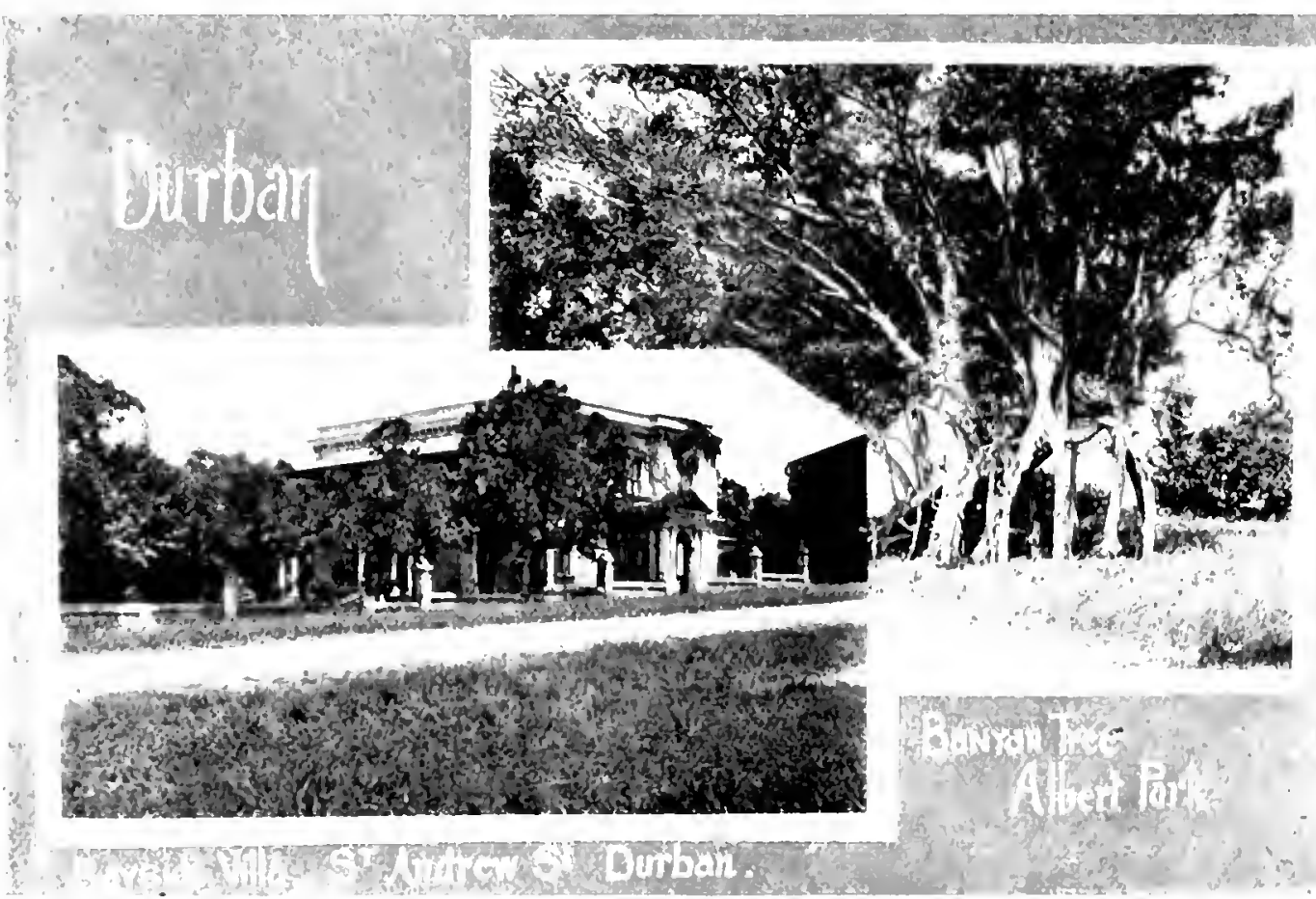


large oval grass-plot lies in the centre, the whole being presided over by a capacious Grand Stand. Proceeding round the "Oval"-by which name the park popularly goes-we are given lovely vistas of the Bay, with yachts ghiding gracefully witl windpuffed sails over the glistening waters. Seats are everywere for the tired or contemplative, and the cycle track and recreation ground are at the service of whosoever may lesire their use. This beautiful retreat is kejt in very creditable order, and is cuite a pleasurable feature of the town. Completing our run round the ovil, we leave by the main gates and pass into Park Street ahead. which leads direct to the Berea-znd of West Street. On reaching this point, we see immediately opposite, the commodious Theatre koyal, with its long balcony promenade. Looking along the same sirle of the street, we observe a thick patch of foliage. This is the corner of the cemetery. Further on is the lrightest and busiest portion of West Street.

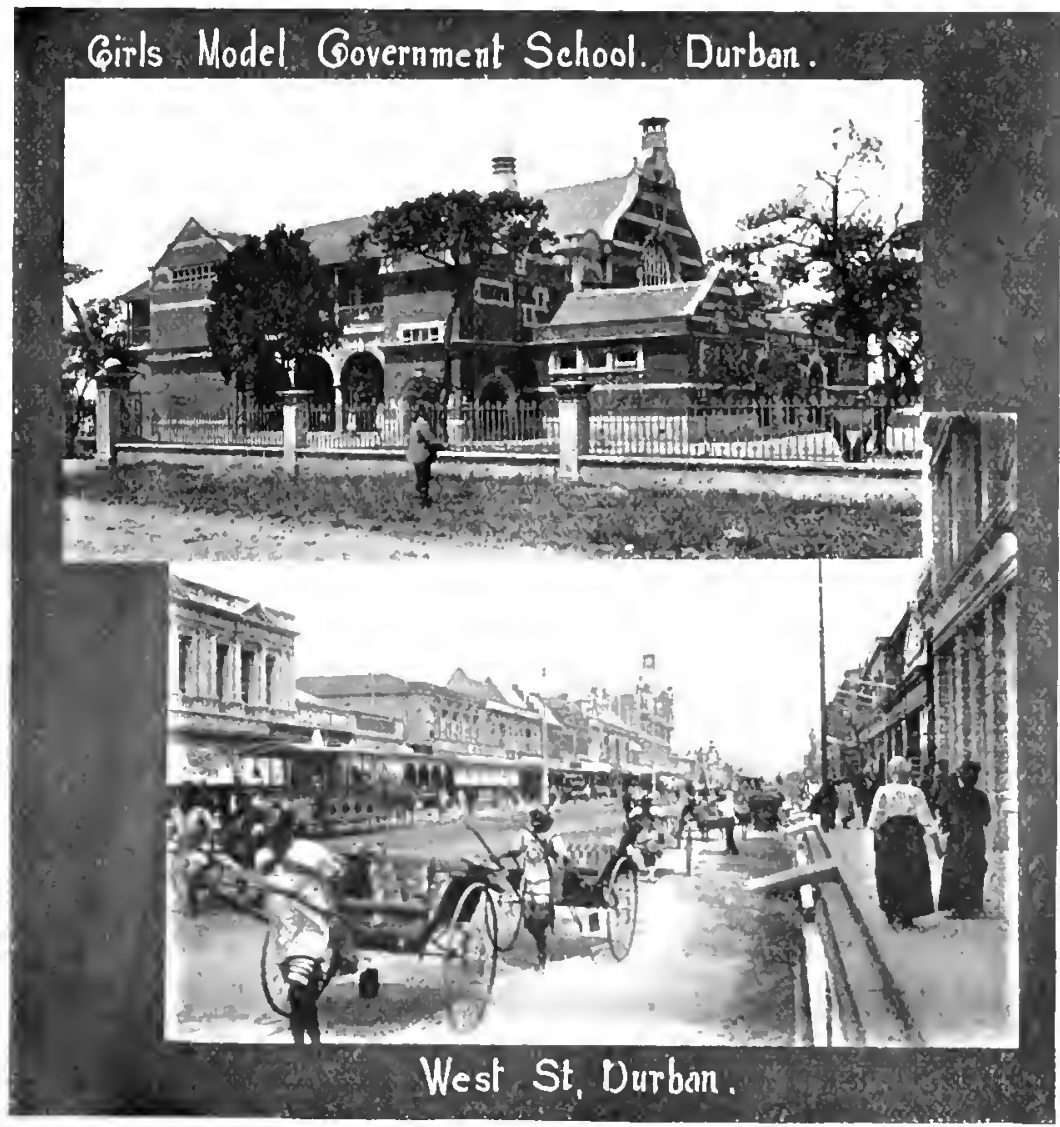

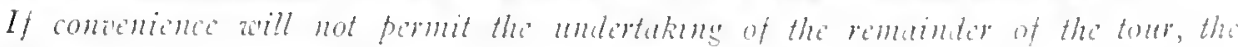

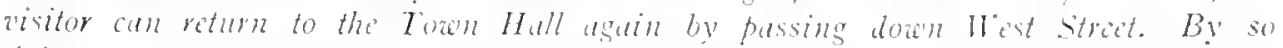
doing he will sether an evellent ids of the stubitity of the toring as reflected by its handsome well-stocked shops, and its well-alressed and animated crowets, and

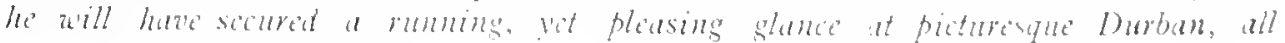
in the space of an hour. 
bischargng our 'rickisha-lauler, we hail a Berea Car and seat omsetres to enjoy the ascent. The first ohject of attraction is the castellatel mill opposite the BIERE ROAD Sration. Rumbing over the brikge, past a long fringe of hamboos, we observe the redbrick fovernment School, and immerliately pass the junction of the Umburo koan, which gives access to congella. Cintrilo. South roast Junction. and Isipingo-a charming route for a separate tour. As we megotiate the almupt slope of the berea, we lave ample time to note the combortable residences which line the whe road and stretch upwarks to the right amb lett as tar as the ere can reach. Sheltered as they are by trees, and aldoned by towers and plants. it is suburlia indeed. In a little white we

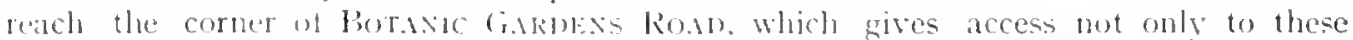
gardens, hut alse to the ohservatory and labotatories. As these would repay a

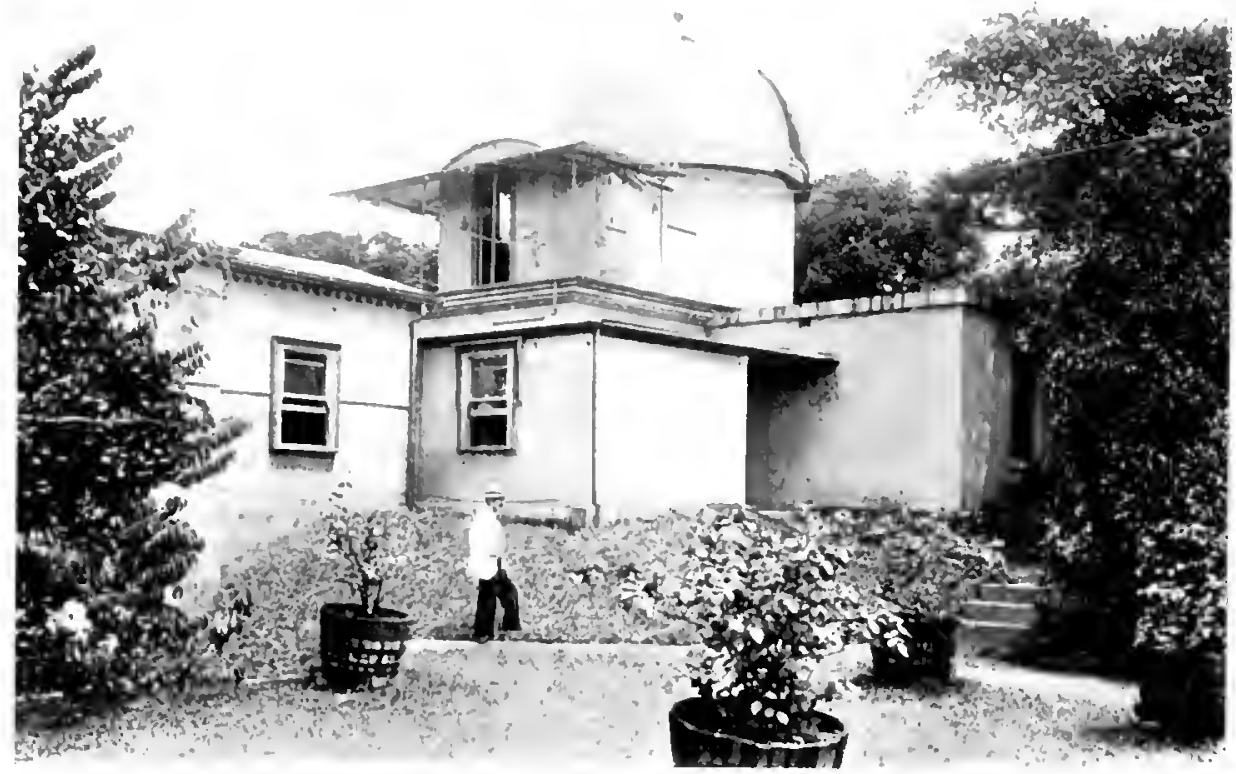

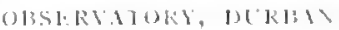

lengthened star. the can be made the objetives of another vicit, for which the undermentioned particulars concerning them may be nsetul :- -

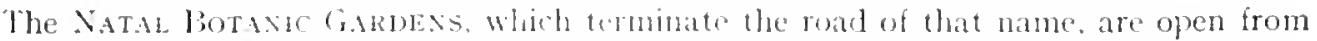
sumrise to sunset all the vear rombl, hat on Sundass the Conservatory is not accessible until 2 p.m. The Gardens have leen in existence for many yous, and receive the full

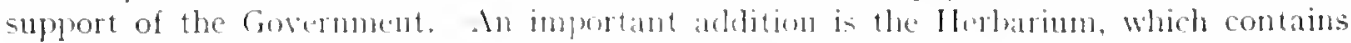
some 27,500 monnteri syecinems. and several thombands of unmounted ones for distribution and exchange with other simitir institutions. This Horlurium was formerl hy the present

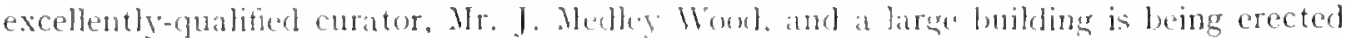
for its accommodition. One of the clued atractions of the Ciarelens is the Jubibe Conservatory, or l'alm Honse, as it is callud. Tlutein will be fomul many kinds of ferns and palns, the most dainty and the most pisantic. Nany lewitching suote will be discovered in rambling round the cartens, and tempting seats will be ecpied umber the shady 


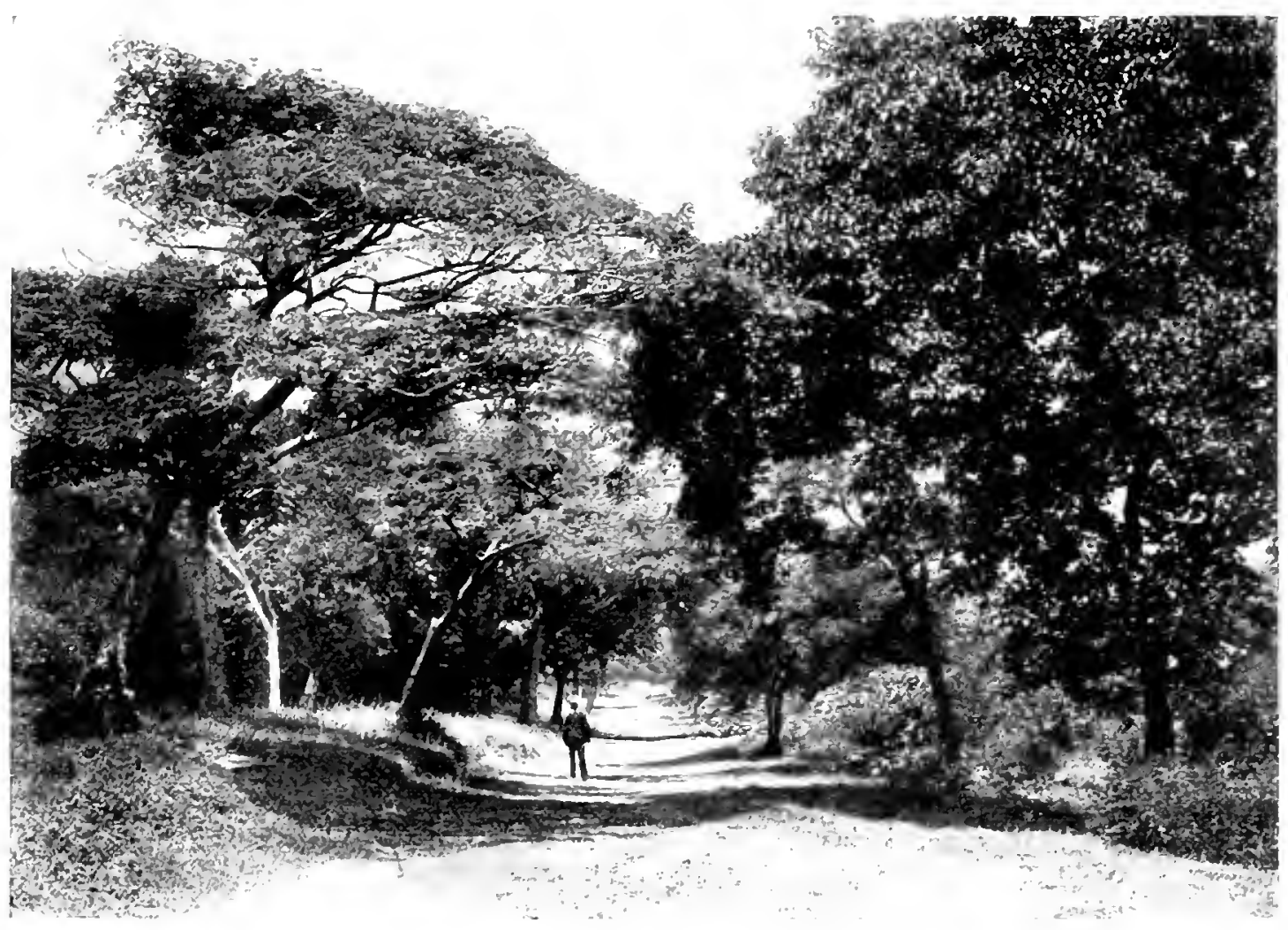

ON THE BERIA, ITRBAN

trees. Some of the flower-beds amit the most delicious pertumes. While the oft-timen quoted fallacy, that the land is without teatherel song. will he retuted hy the cheerful notes of birds in a perfect forest of trees, many of which. the vicitor will observe, latre been imported from foreign lands.

On leaving the Crardens, a steep roal will be seen running to a higher level of the berea. This road leads to the Government Observatory and laboratorien. THE OnsERratory. which is situated 260 feet above the sea, las been in operation since issz. It is in z hours, 4 minutes I. I8 see. East l.ongitude from Greenwich. ant in $2050^{\prime}+7^{\prime \prime}$ South Latitude. The time kept all orer the Colony is Durban ()herratory mean time. which is two hours in advance of Creenwich time. The Observatory consisti of a simple rectangular lorick building. carrying at dome $\mathrm{I}+\mathrm{f}$ teet in diameter. sheltering a fine eighteinch equatorial refractor, and a small transit room containing a three-inch transit instrument. Each of these instruments is supported on substantial concrete piers, whicle raise them twelve feet above the surrounding surface. Attached is a rom for the use of the Astronomer, a temporary computing room, and a room tor the cheki and electrical fittings. There is a first-class mean time clock hy Victor kullbers, and an excellent sidereal clock by Dent, besides chronometers and other accessories. On the lawn to the North East is a magnetic room, carrying a small magnetic instrument for letermining the rariation of the compass, whilst a similar small detached room on the East contains the principal 


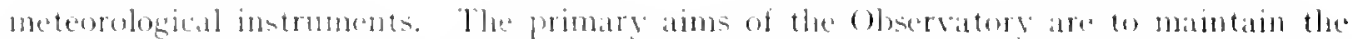

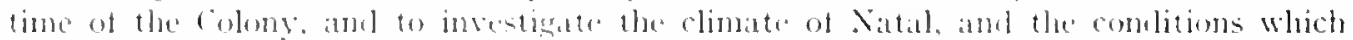
affect anel regulate the changes of the elimales but at the same time it is desired that there shoulal be utilised such opportunities which present themsetres for contributing to the achancement of the sience of Astronomy, lig making those sperial researches which

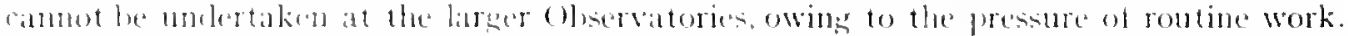

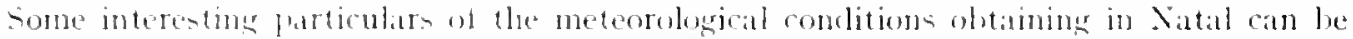

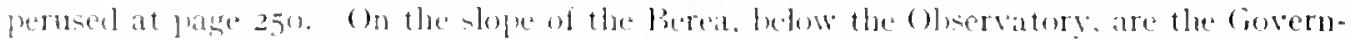

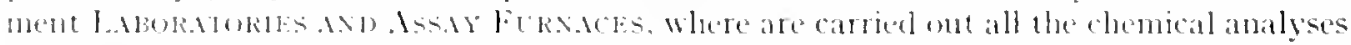
and ascays recpuired for 11 se in the various fovermment Departments, the mest important

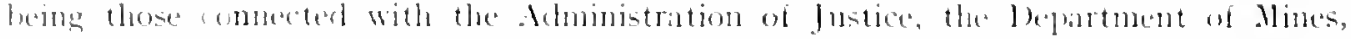

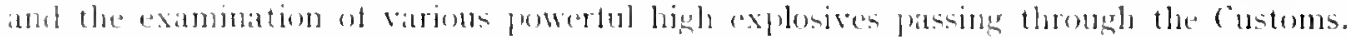

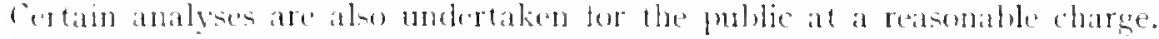

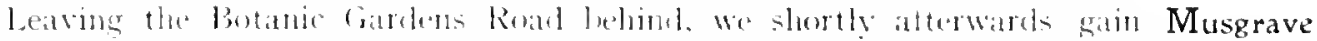

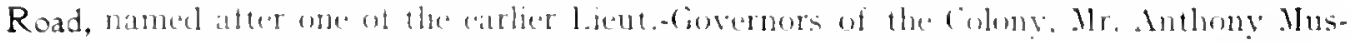

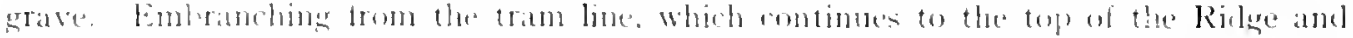

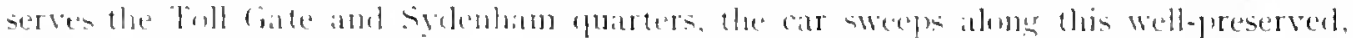

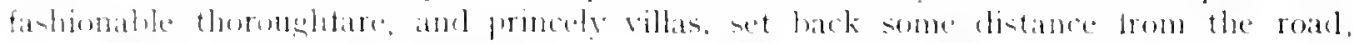

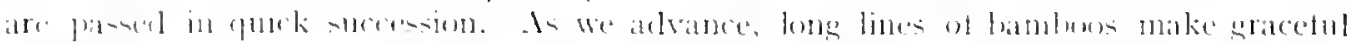

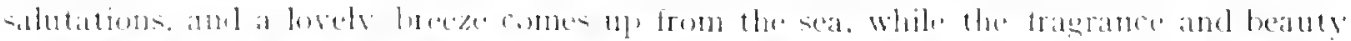

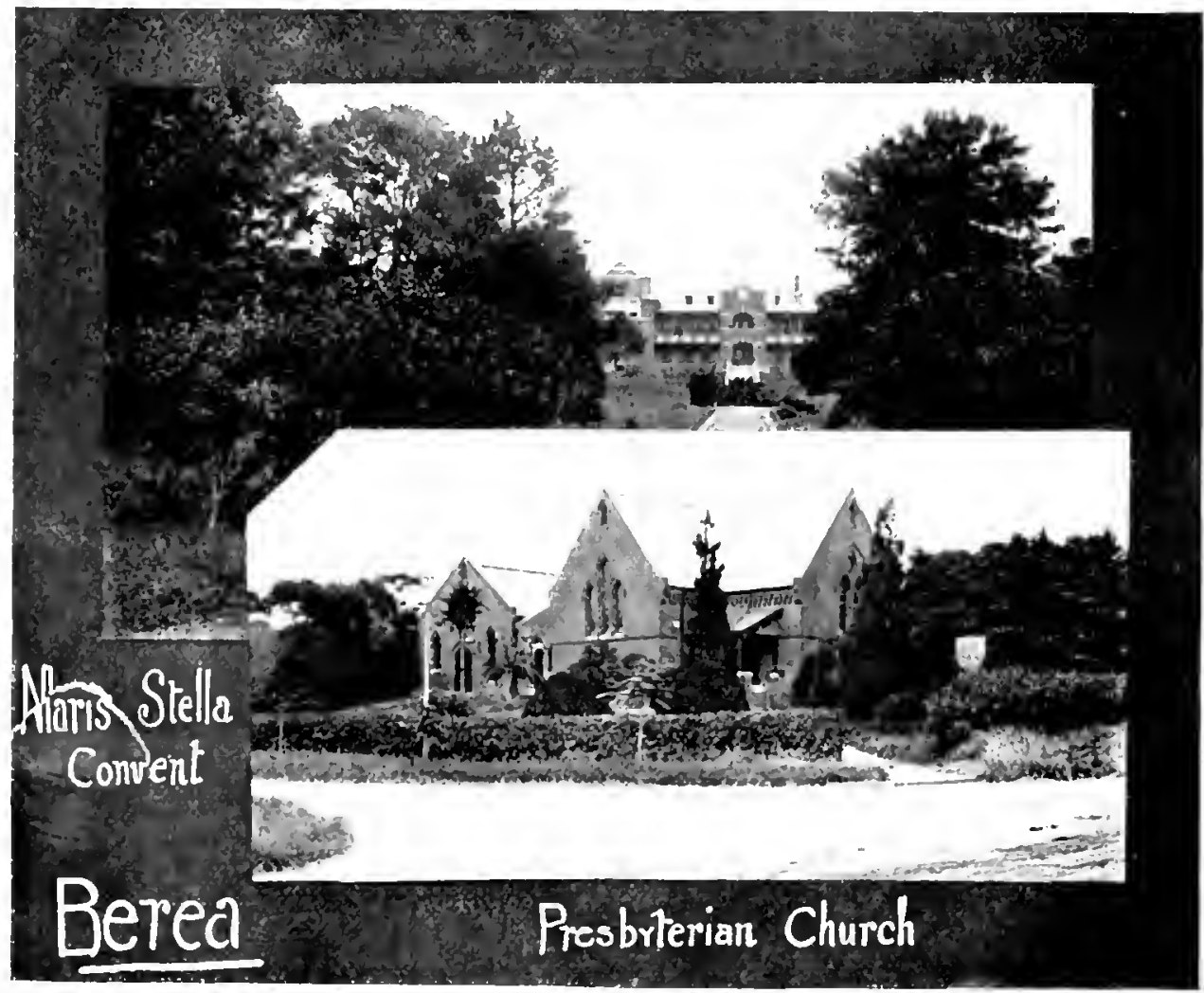




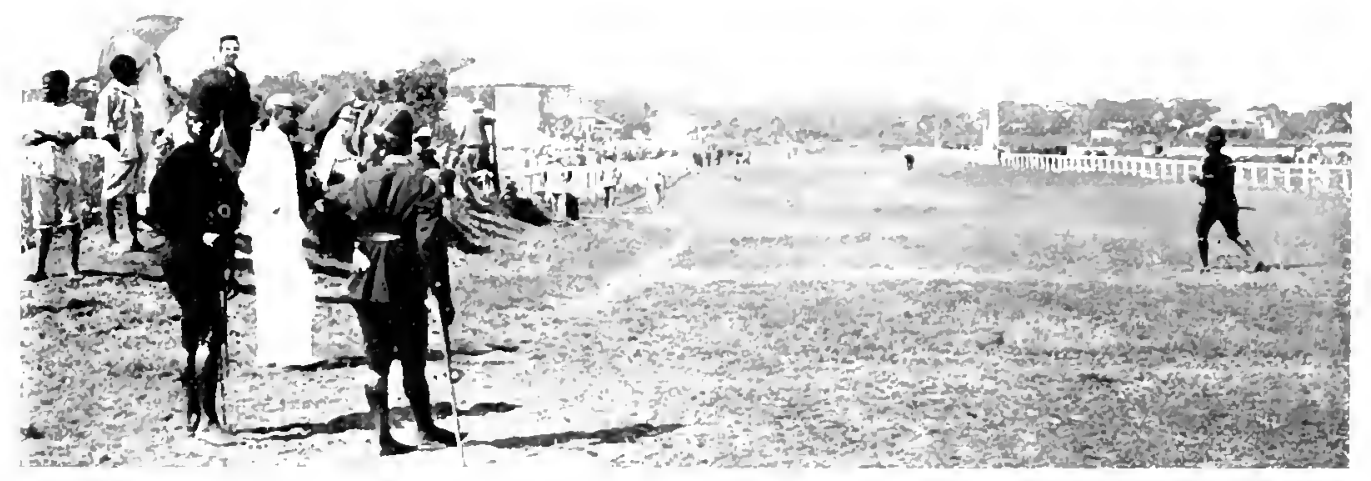

IACECOEKSF IIRPAX

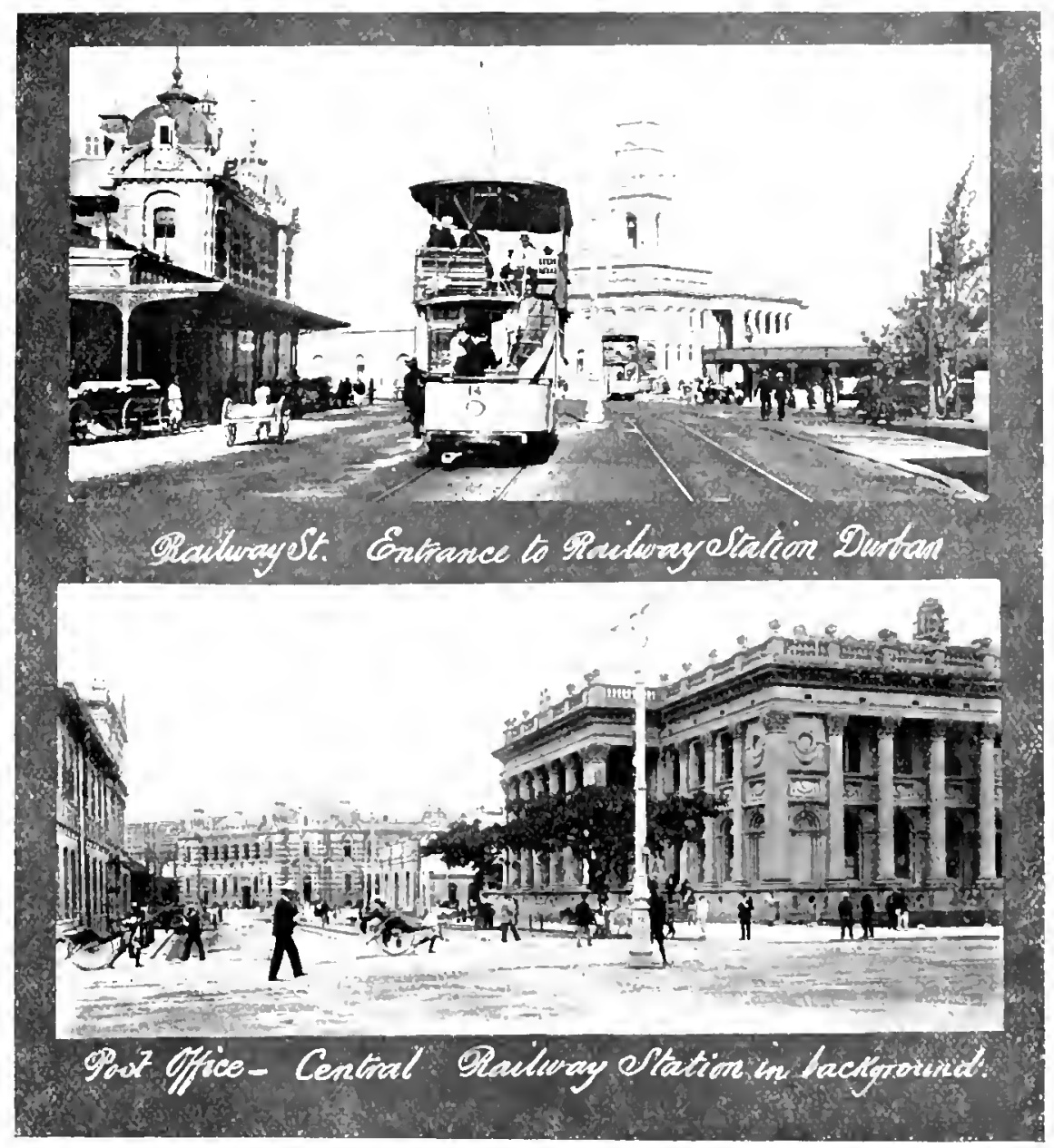




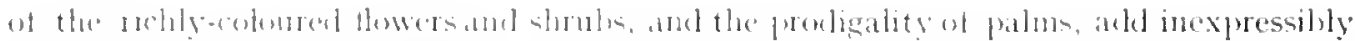

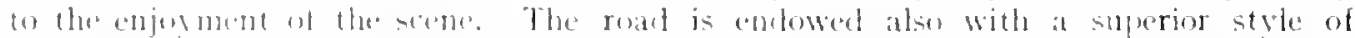

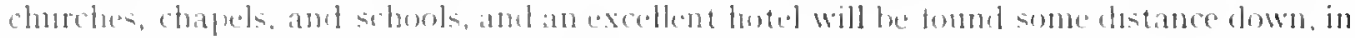
the vicinty of which pesildy the finest and most complete hirelsege viell of burlan can the shaneal. A little Way heond this spot we notice llarrott Roal which crosses at

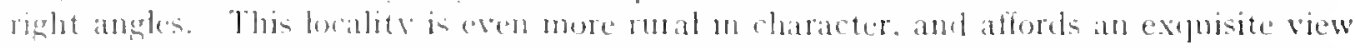

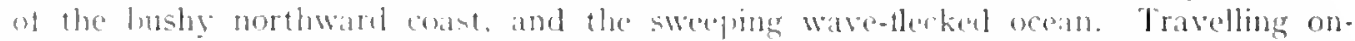

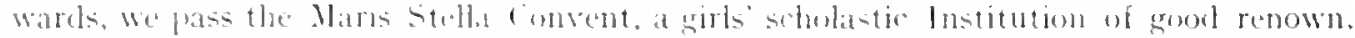

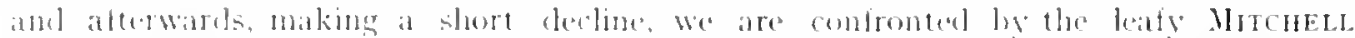

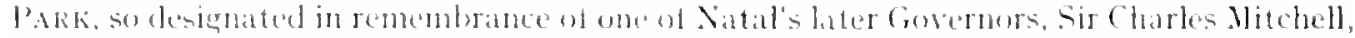
and near which a site has lecen seledent for the marine resilene of the present

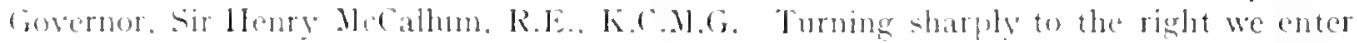
Florida Road, and jumrney monwards once more. The descent is enpally as agreeable as the ascent, for we have the Town, the bats and the ocran at our feet. We whisk by roakls on the ledt and avenues on the right. which serve the numerons villas

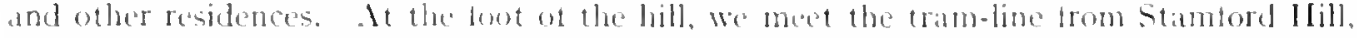
and procerel down the long First Avenue at the end of whith, lowking to the right. we catch a glimpse of the Racecourse and the Golf links. In a lew seconds more we emerge untw the Umgeni Road, and notice the Railway sidings and the corpuration stone-

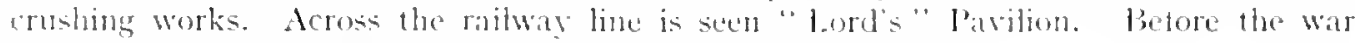
lord's was the most popular Athletic Ground.

We are now nearing the end of our tom. Railway Street is in front of us. To the left. on the other side of the linomel Prince Eatwarel serent ralilwats hritge, is the Okl Cometers. The sacted spot contains the dust at mans hrave men, forth soldiers and pioners, who perished in the "arly strugegles with the l)utcle a lull account of which is griven in Mr. J. li. Ingram's "Story of at South Atrican Seaport." Still thanking the railway. we slortly reach the hamelsome Central Sta. tion, where all is hustle and exritement.

Here our tou is ended-truly. wne of the most interesting and beatitiful that ran be afforded by any town or city in the southern portion of the African Contincentand wealight to pursneour journey by train through the heart of Natal.

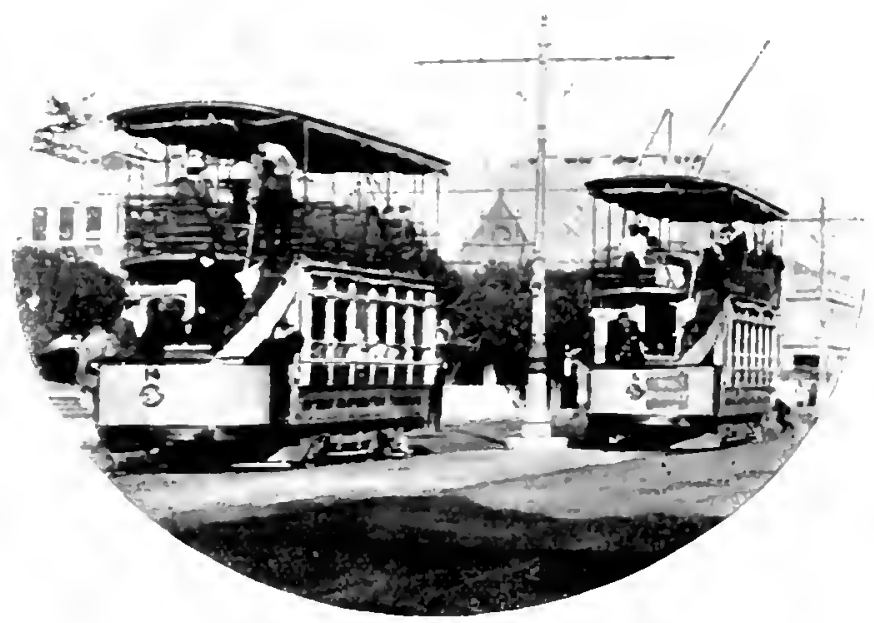

NOTE.-In order to complete the circuit, the tram-car crosses over PINE STREET in the centre of this street and opposite the Railway Station, will be observed the new Market House, a commodious erection costing some $£_{35,000}$ then passes along the northern part of Gardiner Street by the General Post Office, and, turning the corner, pauses at the steps of the Town Hall, prior to its return to the Point. 


\section{PART TWO.}

\section{THE MAIN LINE OF RAILWAY.}

EN ROUTE TO THE TRANSVAAL

THROUGH THE

PRINCIPAL TOWNS AND BATTLEFIELDS

UF

NATAL. 



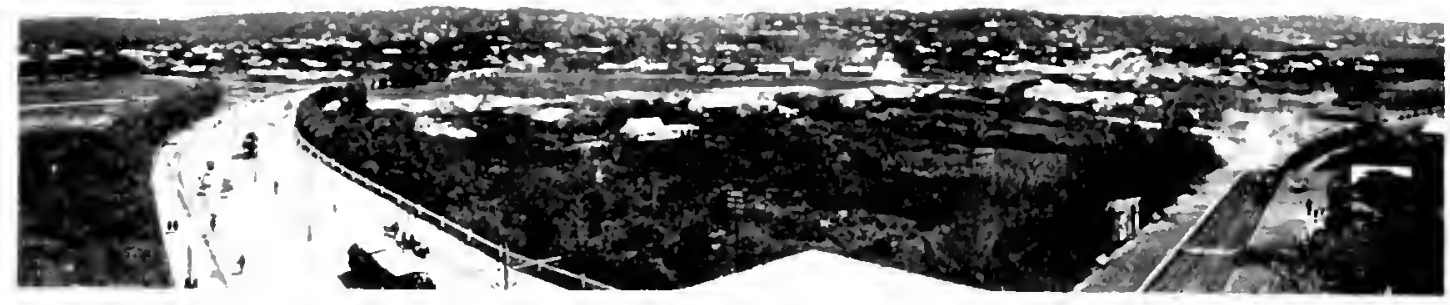

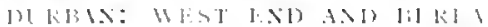

articles of their personal impedimeme. With a hrict respite, the train move on atgan past solid evidences of the town's progressirenes and activity-there a larere, red-hrick Government School, liere a stone-laced grist mill, ober the way colel-storage premines, as well as various sheds, shops, brick-works, and extenswe wagon-works, where fong lines of railway trucks are seren in sereral stages of ereetion.

Now sweeping along the arm of the bay, ored at shghty elevated well-hat doulde track, we survey a scene particularly picturesque-the dark dear waters of the bay shimmering

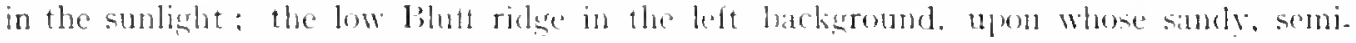

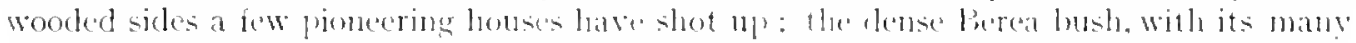
mansions on the right: and in between. a longe wide, stretele of land. bordered by erer-green grass and tropical shruls. Pexomel. tuming again to the lelt. We see, on the edge of the bay, sereral white-mathed, shell-lime kilns, and the spats of small sabling cratl

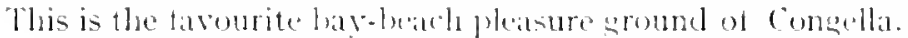

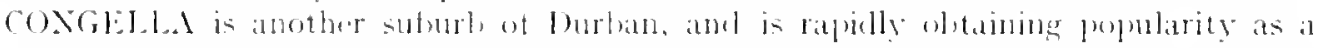

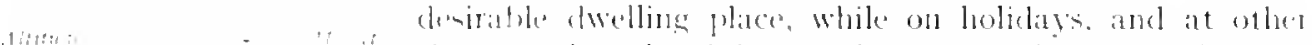

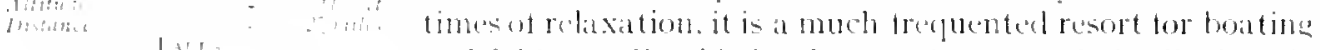
and fishing. Should the Corporation exteme the Esplanade thas tar. the attractions ot the place will tre comsiderably.

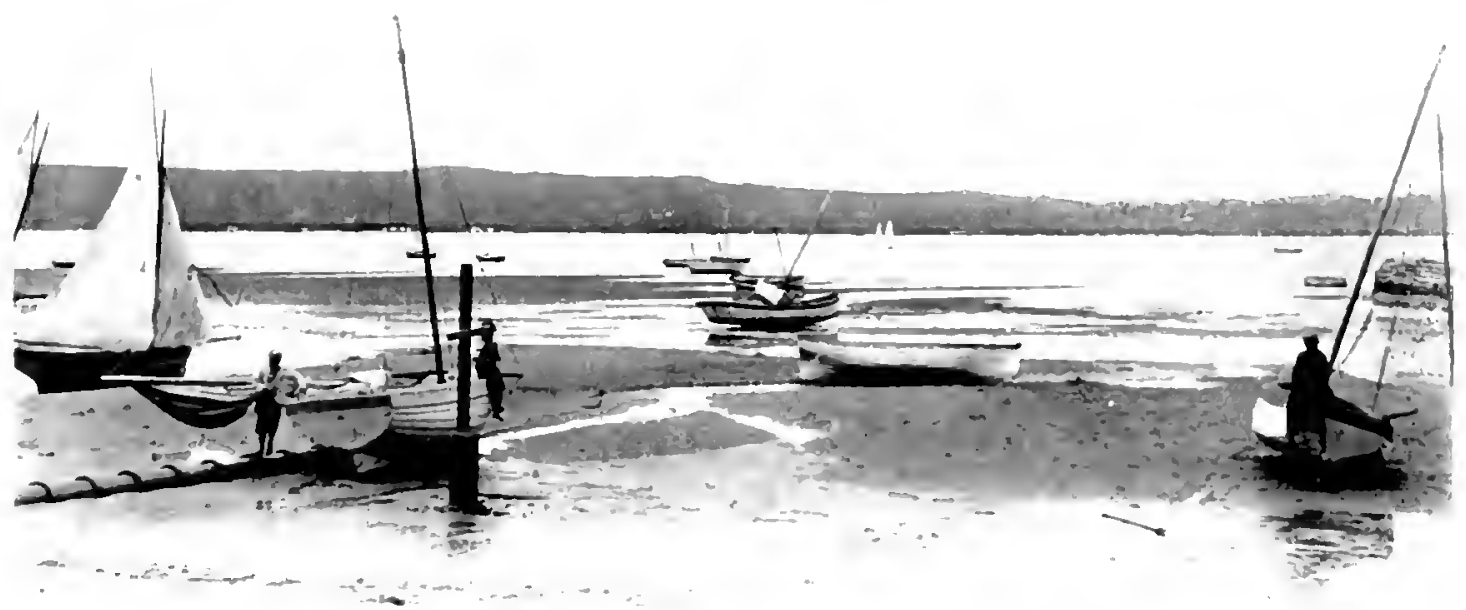

111: 1311 
enhanced. Historically, Congella is famed as the scene of the first hattle with the Dutch for supremacy in Natal, for it was at this spot. on the $23 \mathrm{rd}$.llay, I842, that the British lost nearly half their men in a michiglst attack upon the Boer Emigrants, resulting in Richurd King's memorable ride to the Cape Colony for reinforcements. Fvery Colonial boy has ingrained in his heart the incident of this hero's terrible ride through tempest. jungle, and flood, spurred lravely on hy the knowledge of his countrymen's perilous situation. Space permits only a passing reference to those eventful days, which are exhaustively" treated in other works.

Leaving Congella behind, another pretty, senti-circular panorama of bay, bush. and landscape greets the eje. It is lost all too soon, tor we have gained another station,

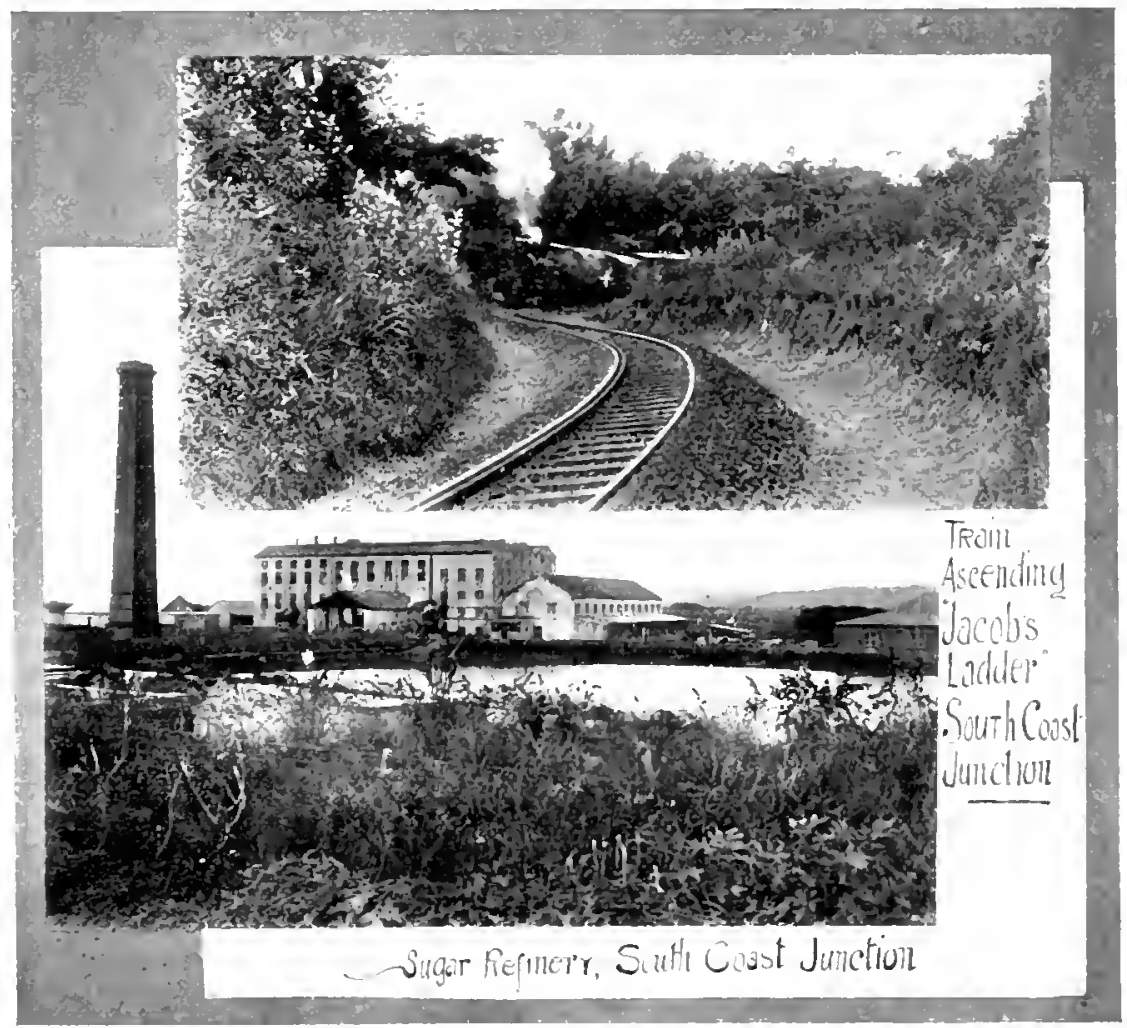

UMBILO, at which point the inuit-producing portion of the country may be said to thate - an commence. Passing over a sturdy iron hridge, under which Distume - imins the river that gives its name to the station sleepily flows,

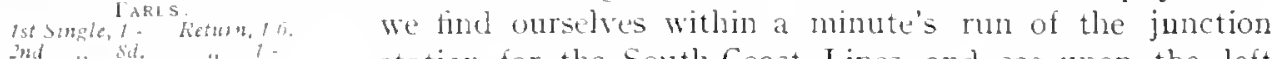
Ind " station for the Soutlu Coast Lines, and see upon the left a large flat, patched with the vegetable gardens and fruit plantations of the industrious Indian. Looking to the right, we discover our passage contested by a platform of hills, with houses dotted on the sloping tiers. This is the suburb of 


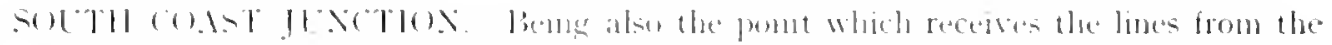

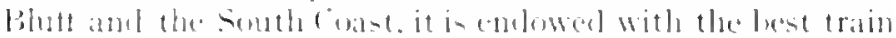

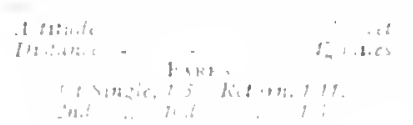

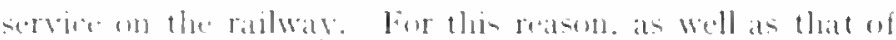

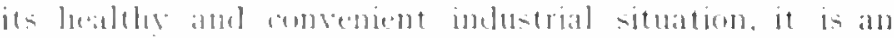

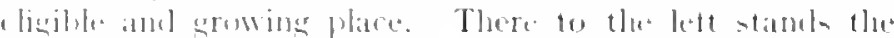

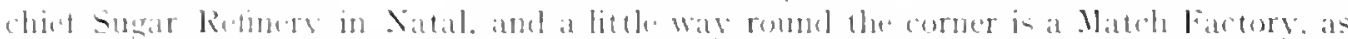

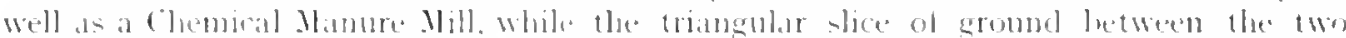

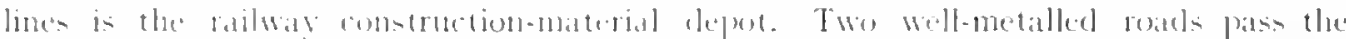

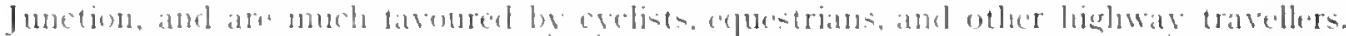

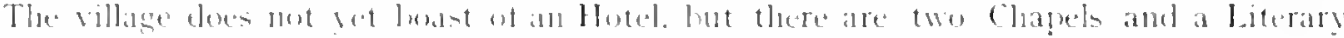

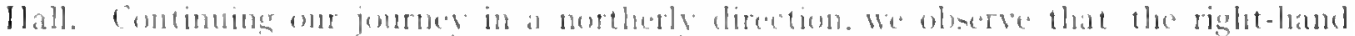

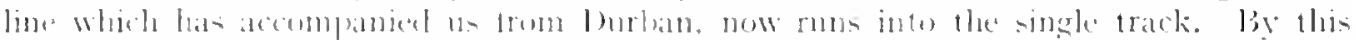

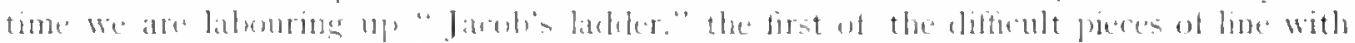

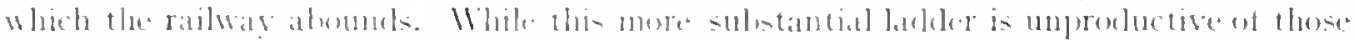

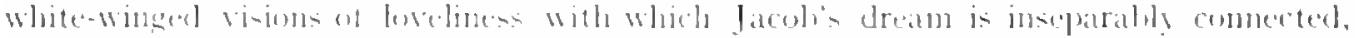

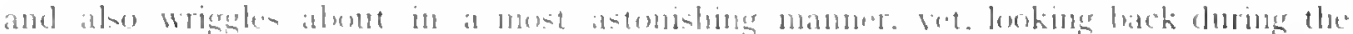

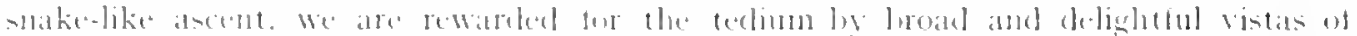

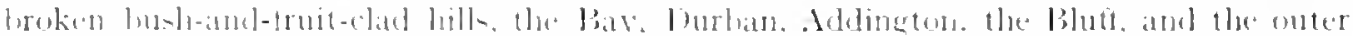

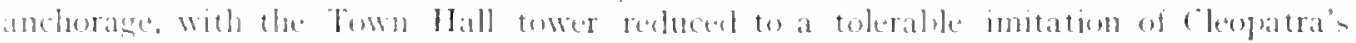

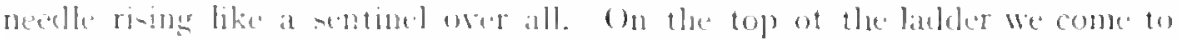

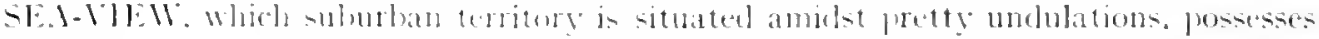

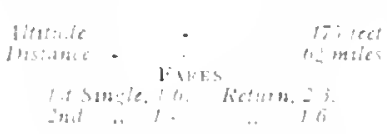

more preposesaing alprearance than ather themselses or their habitations.

BELA.AlK is another attrative suburl), clining a population of oxer foo souls. Inis-

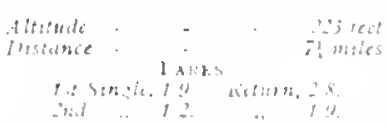
tributed on the womed elevations are superior dwellings. set in trim ant ixtensive grounds. The price of lanel in the vicinty is high, and what twenty vears ago could have leen secured for a ten-pound note. now realises i200 to $\$ 300$ per ace. The lesure of the resilents is cmplesed in a diversity of ways. There are a Church and two (halpets, an Hotel, a troop of Hounted Voluntecrs, a Rifle Association,

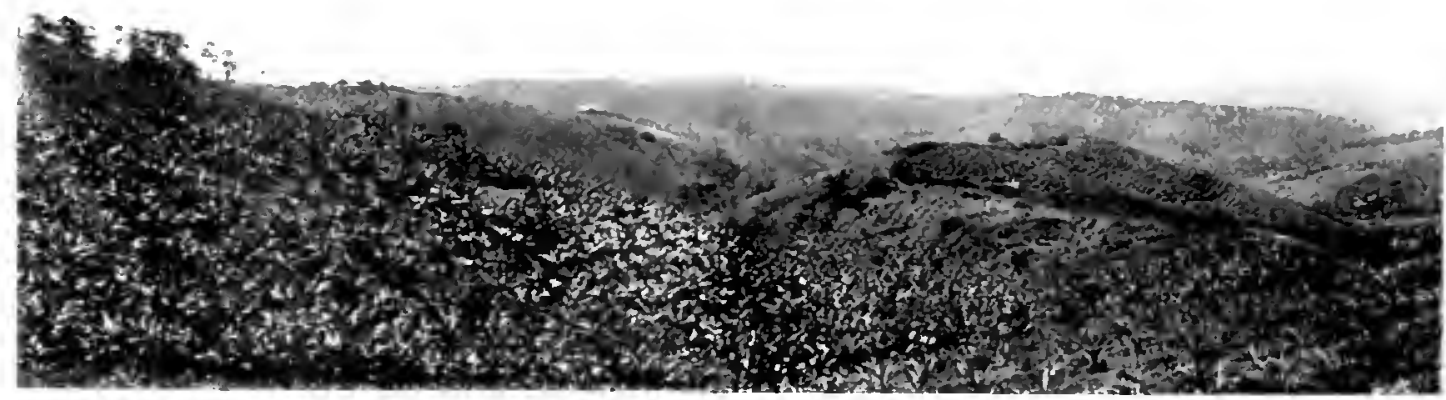

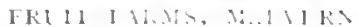




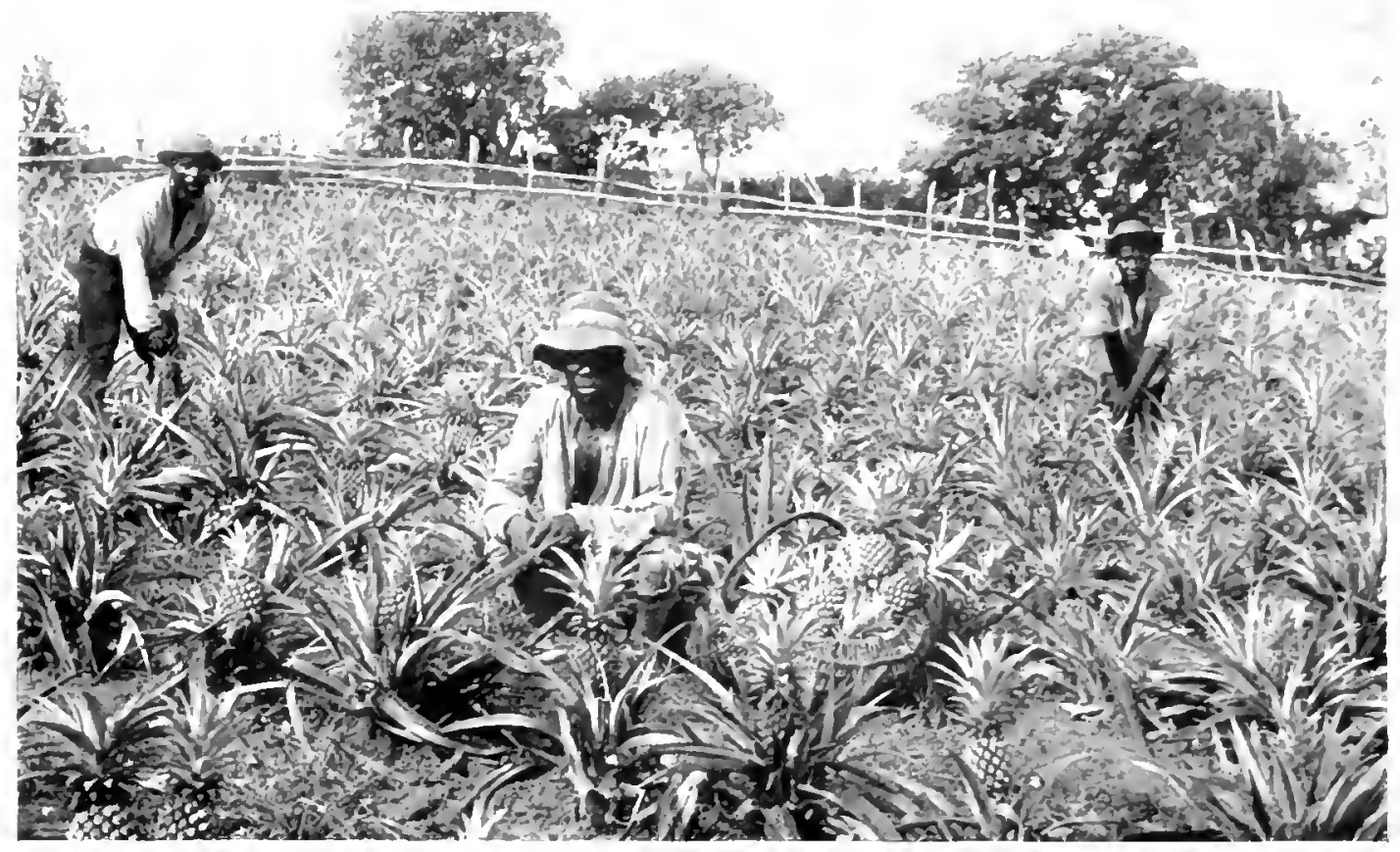

AMONG THE I'INF BPPIES

Political and Sporting Clubs. Literary and bebatine Societies, and a Concert and Volunteer I) rill Hall. The scenery around is undeniably beantitul, and, despite the suly-tropical foliage. remind one exceedingly of Deron. The soil is rich and prolific, especially favourable th fruit culture, and exotics of all kinds also flourisin. Before quitting the station we hestow a glance upon its handsome red-brick buildings. This taking and contenient -tyle of station premises is gradually supplanting the usty wood and iron strurtures of early days.

As we advane tomare the next station pasing an equi-distant Stopping Place called Hillary's situated in the milet of truit plantations, the country hecomes more billowy. with hills tossed ahunt in all manner of thapes. There is an unasoming charm about the district of

MALERX, and the tuture should witness it rise to the front rank of suburhan retire.

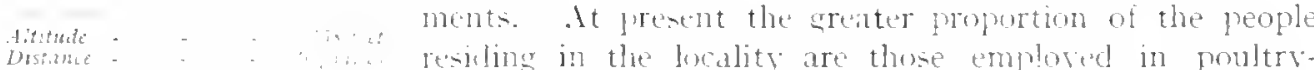

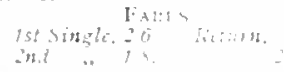
taming and floral. and suis-tropical fruit cultivations. The ne-iglohourhom is reputedly one of the best and most largely monopulised in these pursuits in Natal, especially the last-named. The rivers Lmhlatumn and [molio are within walking listance of the station, and upon their invitine bunkic many at pleasunt pionic occurs. botanical and kindred students will also fincl mucl matcrial tor their fascinatime resarehes in the district.

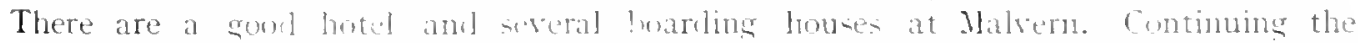
upward trend ot enr jumer. We resel on the one hand in an exquiste siew of both sea and landscale, and on the ofler. In loroul hills and kloots and rales. whtil we sight 


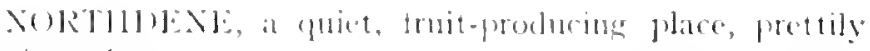
anviroment.

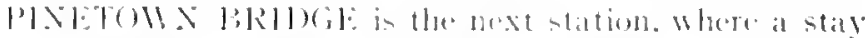
of a tew minutes in mate lon wattr. Immellately on the tight of the line, anel scarped

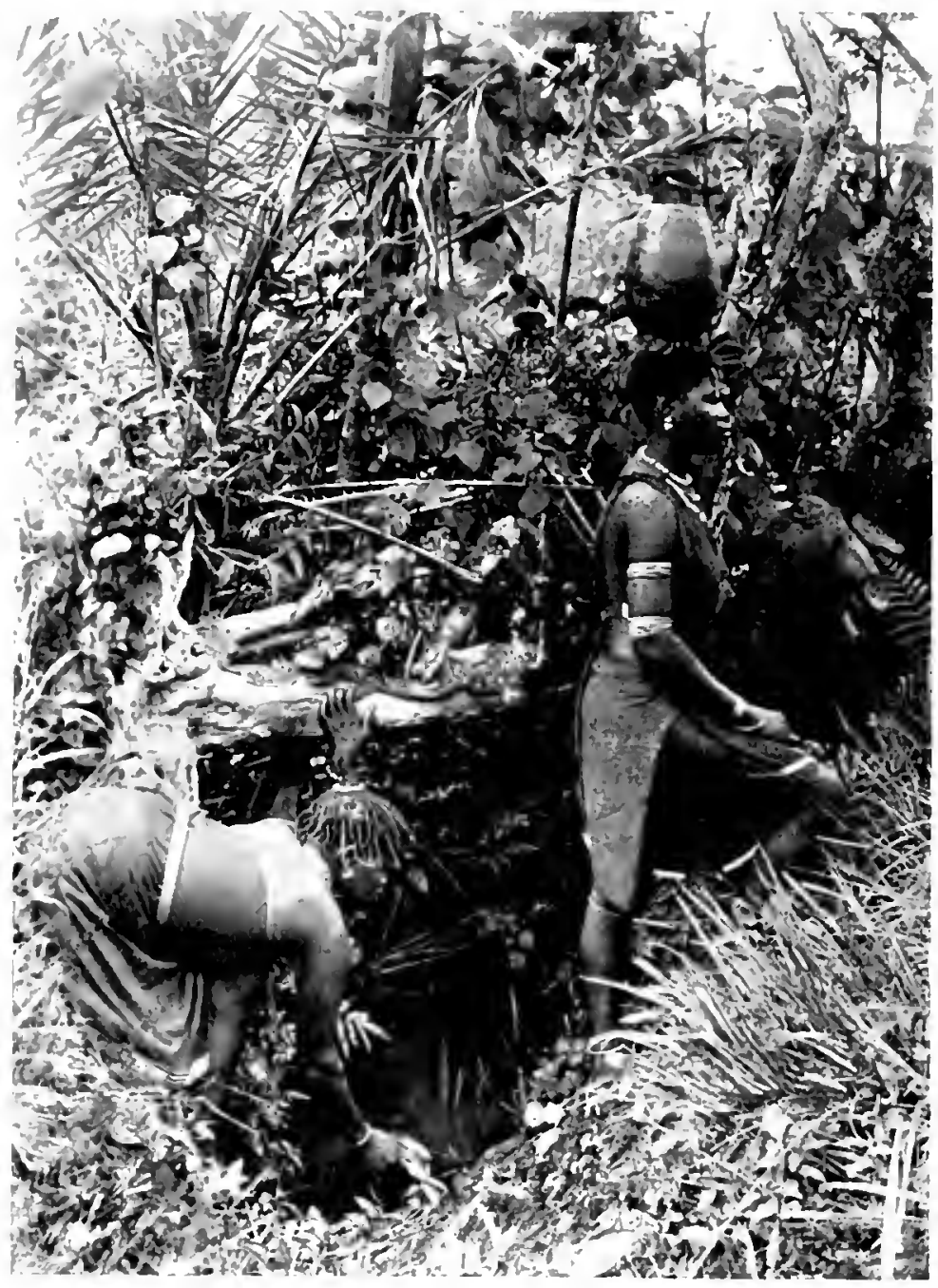

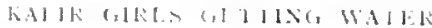

tititid $1+1: 1$

also a grood tome guarry in working, but this

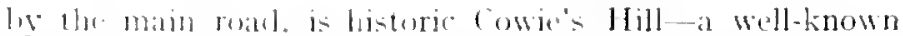
lanklmark. Lonking lark trom the train. We discern the "Samb" Inick, tile, pije and pottery works, one of the larrest induntrics of its kind in south Atrica. There is 


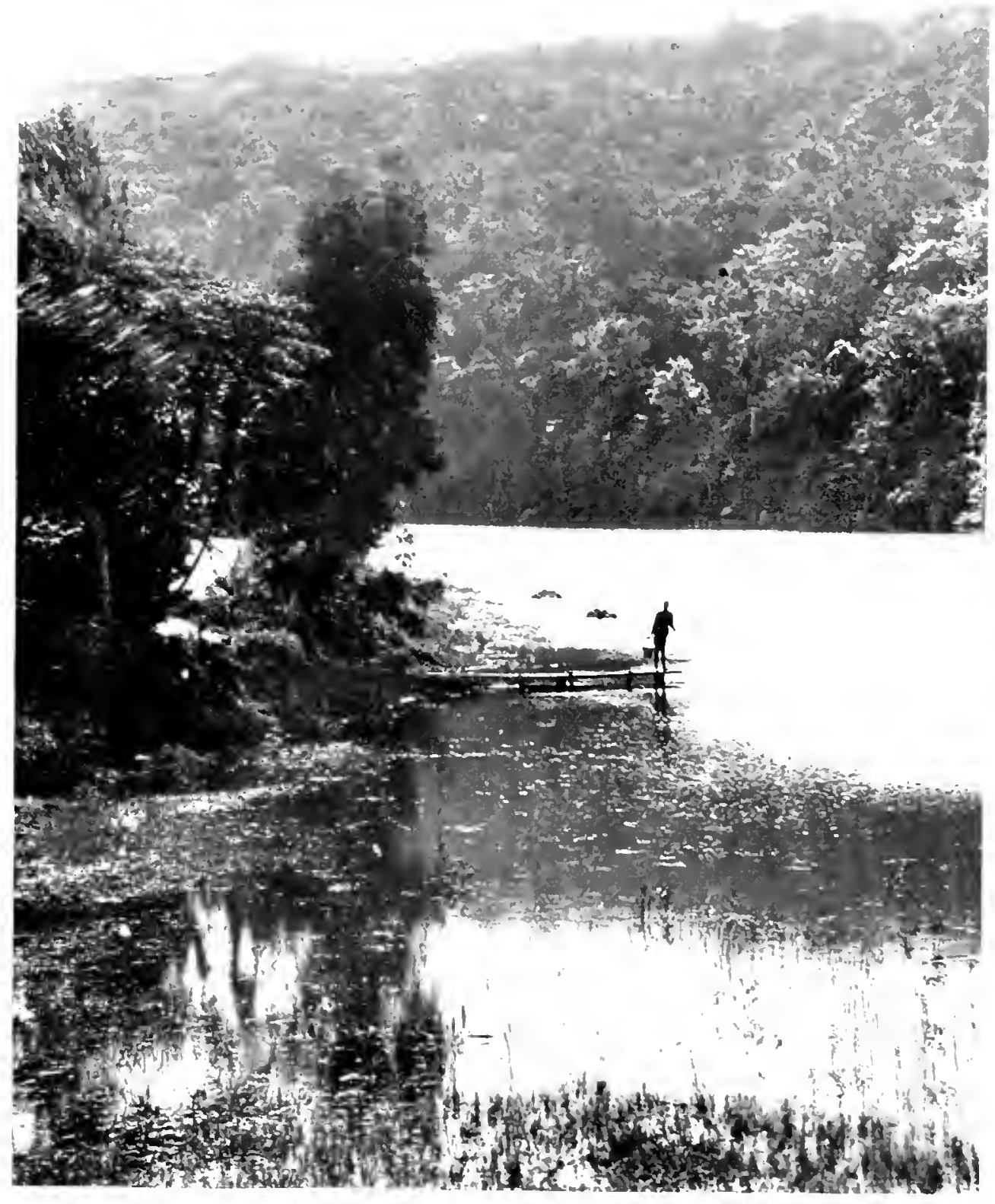

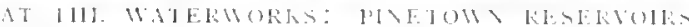


opplosite side of the line. We view the site of the fambus Priness Christian Military

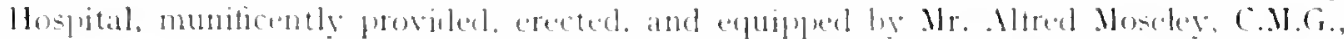

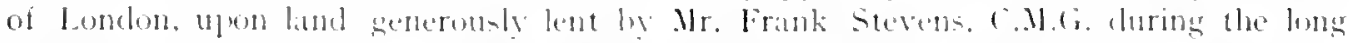

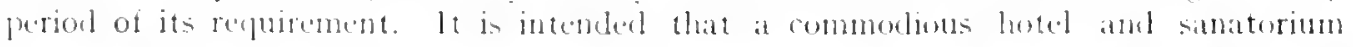

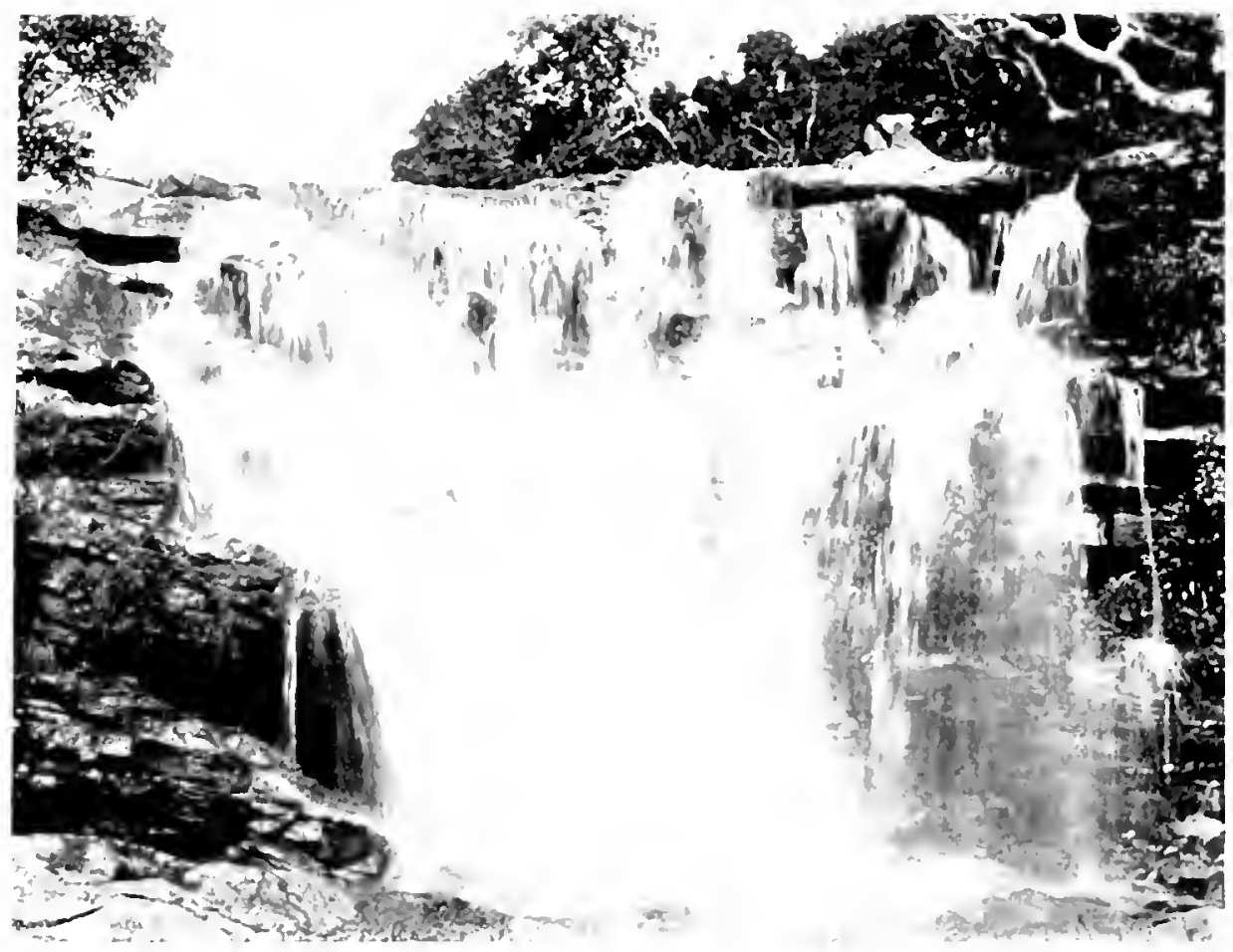

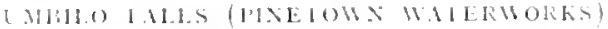

shall prergetuate its memory. and l'inctown Bridge will some day blosom as an inviger ating boliday resort. It is alreaty remowned as the centre for that farourite picnicking spot "The Waterworks" - two capbleinu reservoirs sustained hy the Lubi s River for the supply of Durlan. These are situated some two miles awaty in a lovely valler. the more direct route to which is ain the lorick fields. with the ever-geady permision

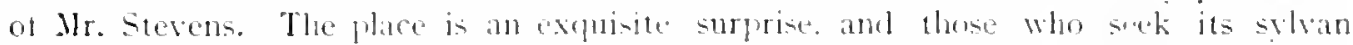
slades and pieturespueness. will he delighted. It is not neressary to stay the whole time in tle valley with its river, liketets. and watertalls; one may roim for many a mile higl up on hilly, whllekep roats, and gaze trom end to con orer the immeasurable crescent of the silent, restul seat, and back agian ore: the sen-port tomn, and the topsy-

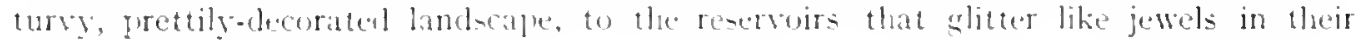
sombre, timbered mounts.

Setting off at a sharp, ascenling pace over a river bridese past thick, arching lines of elegant bamboos, tall gracetul palmo, and tangles of the wikl banana. we quichly reach the one-time Alderslat of Natal, 
PINETOIVN. This is really the boundary of the suburban district proper, and enjoys

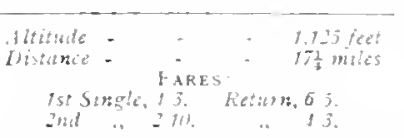
a most equable climate. On this account I'inetom is fairly well peopled. It has a population of over 300, two Churches, a Covernment School. Pullic Jibrary and Hall, various Societies and Cluts, several boarding-houses, and a very comfortable hotel, the "Imperial," where converances can be hired for the Waterworks, and other attractions in the vicinity. The country around is highly suitable for the cultivation of marketable fruits. Two jam factorics hate also been started within recent years, and the production of maize and roots is undertaken. Situated a few miles to the East is the farming settlement of New Germany.

During the few minutes' detention at this station, we remark. by his very singularity of garb-a coarse gown, broad black scapular. and leathern girdle-the thoughtful figure of a monk. There, over the harren hills to the left, will be found a road which leads to Mariaximl, the monastery of the Trappists. and one of the greatest missionary institu. tions in South Africa for the education and the development of the industrial sinews of the native. The establishment is not old-barely twenty vears-hut from its inception it has flourished commendably, and from this. the parent house, havesprung twenty-five different stations throughout the southern portion of the continent. At Mariannhill alone there are 320 monks and 275 sisters. The number of coloured pupils maintained, educated. and instructed, is 220 boys. and I bo girls. while in addition. 2I European orphan boys find a friendly asylum.

The Pinctown monastical cstate embraces some I2,000 acres, and the total African possessions of the Order number I00.000 acres. The Monastery, to a certain cxtent, is self-supporting. chietly from the products of its land and industries. Most of the monks and nums are of German extraction. and are wedded to silence, only those who are engaged in various works being permitted to speak, and then only when absolutely necessary. The present Abbot is the Right Reverend Father Gerard. and the institution is under Catholic dominion. Among the monks are many of great learning. and professed in arts, sciences, and industries. In the sisterhood. too, there are those of superior accomplishments. The monastic day commences at two o'clock in the morning, and closes at seven in the evening. The Fathers are most hospitable, and a visit to the settlement would prove one of much profit and pleasure. Thousands of people trom all parts of the world have journeged hither. and many number amongst their valued mementoes some small article manufactured at Hariannhill.

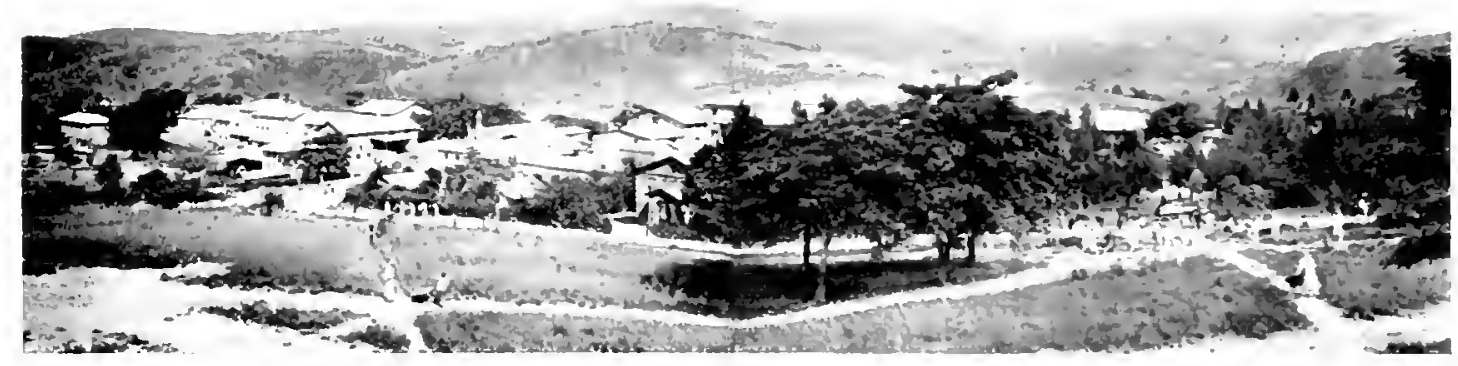

MARIANXUII. M(IXISIERI 


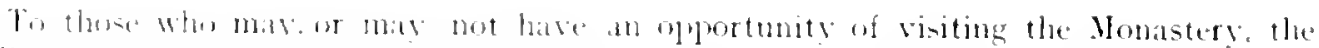

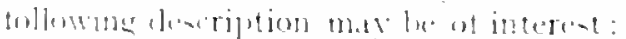

$$
\text { -.. }-11:-11,1:-111, \cdots
$$

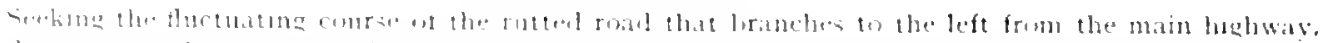

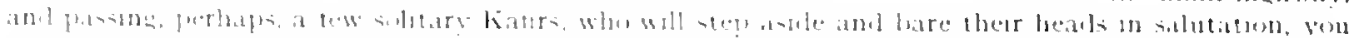

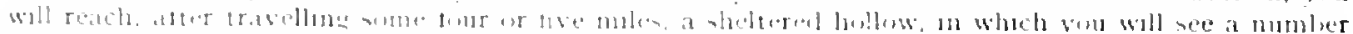

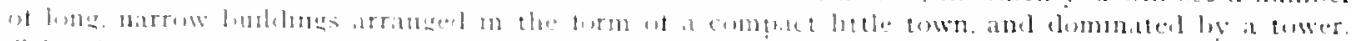

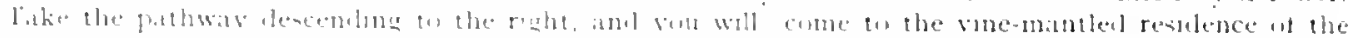

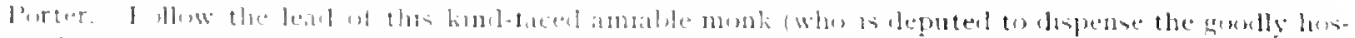

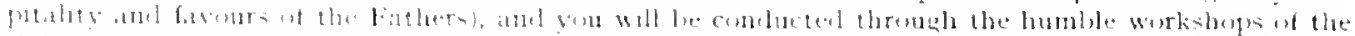

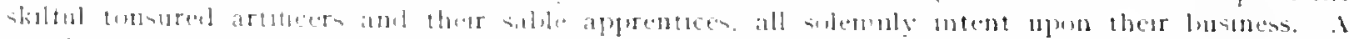

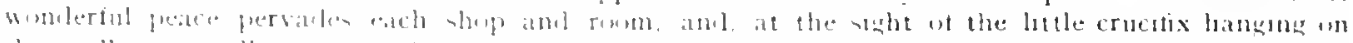

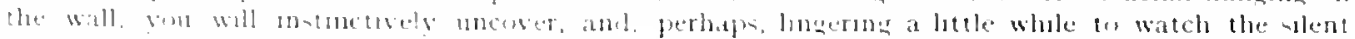

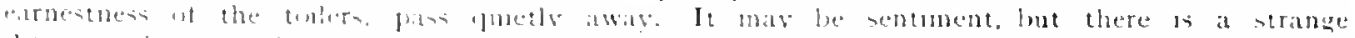

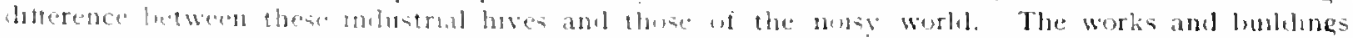

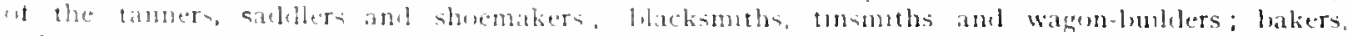

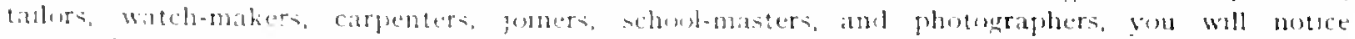

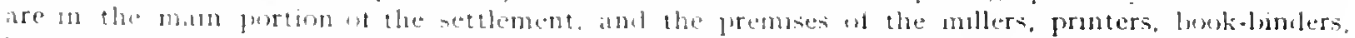

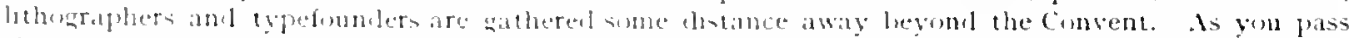

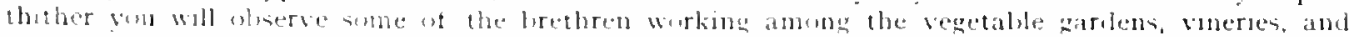

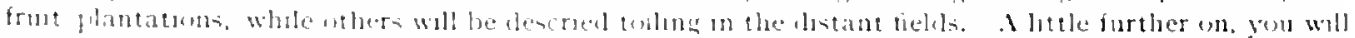
mberve the monate cemetery. where, under a tall amb exulerant tree, repuse the remans of the

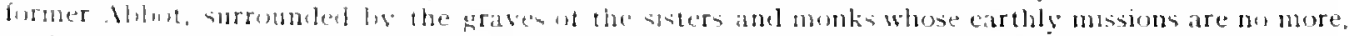

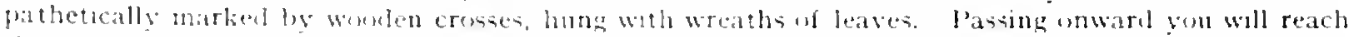

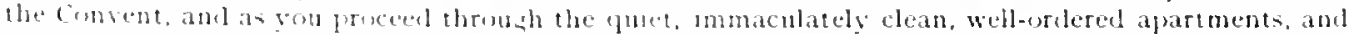

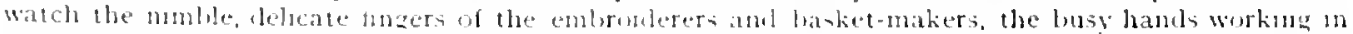

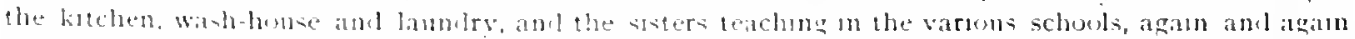

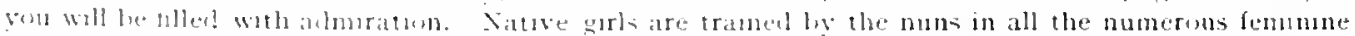

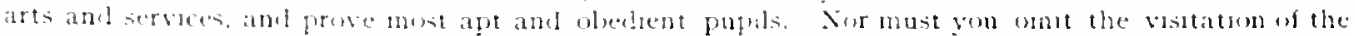
churches. Thrumbunt eat hom of the day, and in the stoll dirkness of the unawakencel morn. the

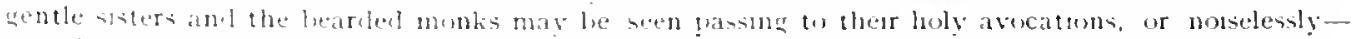

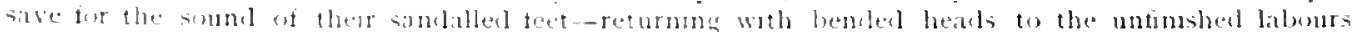

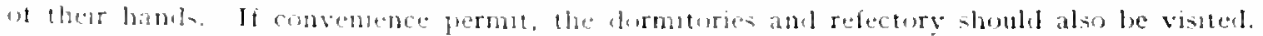

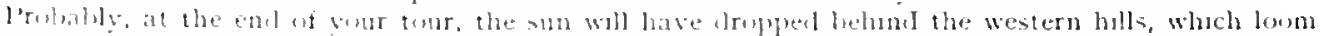

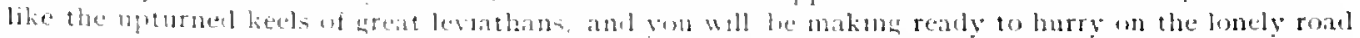

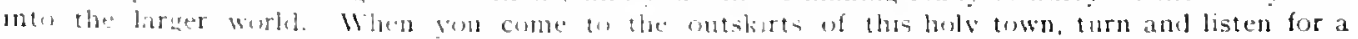

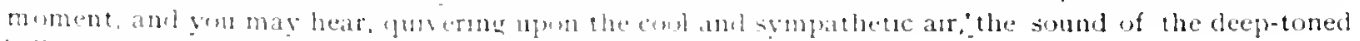

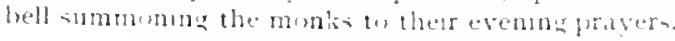

$$
\text { The methe withe orrite. }
$$

\section{CHAPTEK II.}

\section{FROAT PINETOWX TO INCH.KGA.}

$\mathrm{S}^{\mathrm{n}}$ HOKII after quiting Pinctown, we commence the aseent of one of the longest and most exhansting "pulls" on the line-lrelel"s Hill-and as we rise higher and higher to the next terrace, we look down upon long, folding hills, emerald excres. cences, narrow, foliaged valleys, an expanding hush-strewn plain, and at the back of all the delicate luke of the ambient sea. The prospect is delightful, and relreshing bresze flow alout our ears. Passing P'sl.met Staft station, just bejond which on the left we sight some heautiful cascacles. we rise towarels MreBAxk, another similar station, and an impressive sight lursts into view when the massive hill immediately on the right is overtaken-a vast rujuture of the earth. blackened with forests, aucl long, levelopperl momtains soarine mourntuly over it. Alter twisting to a bigher altitude. 


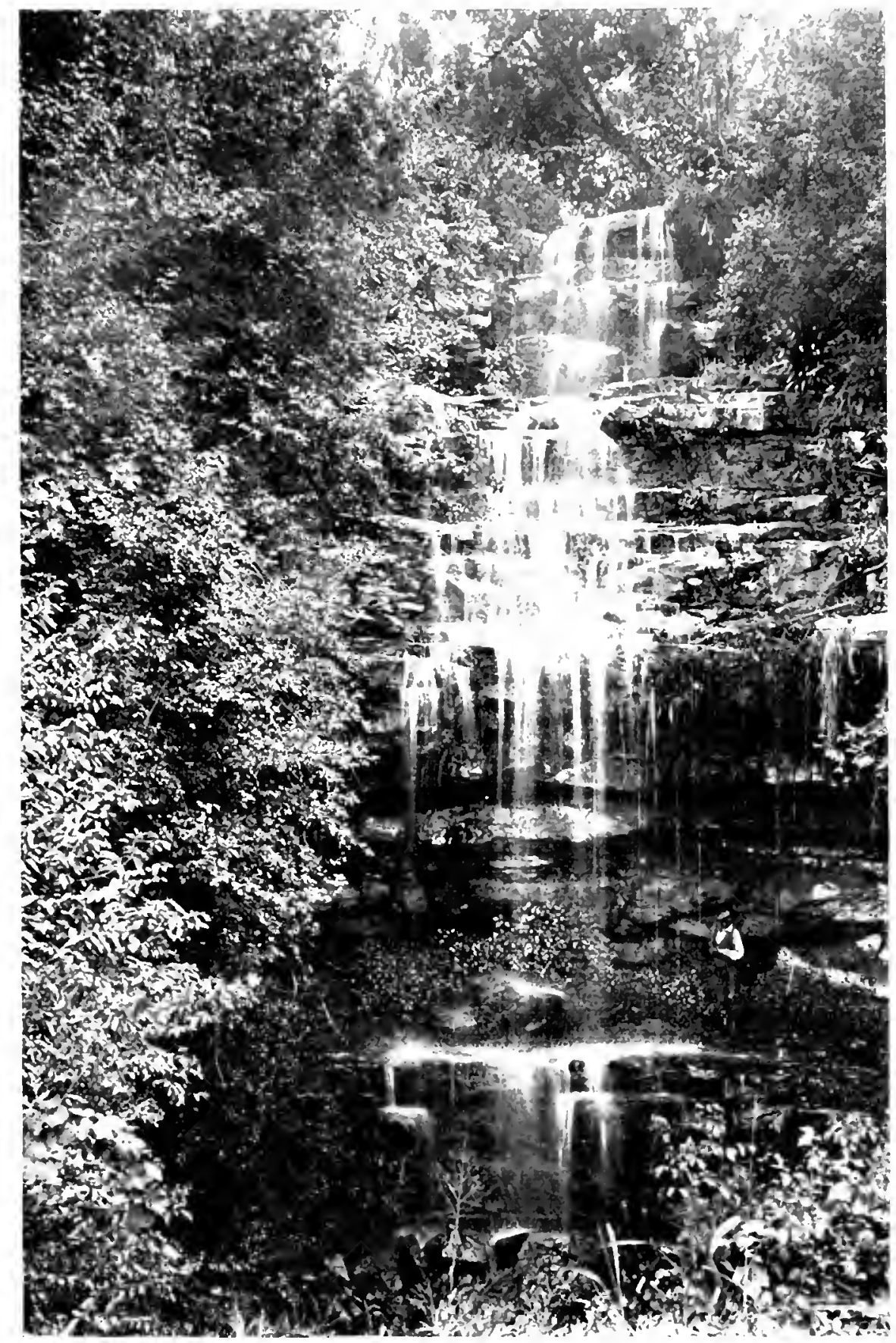

PALMLT IAILS, NIAK IFNE $10 W \mathrm{~W}$ 


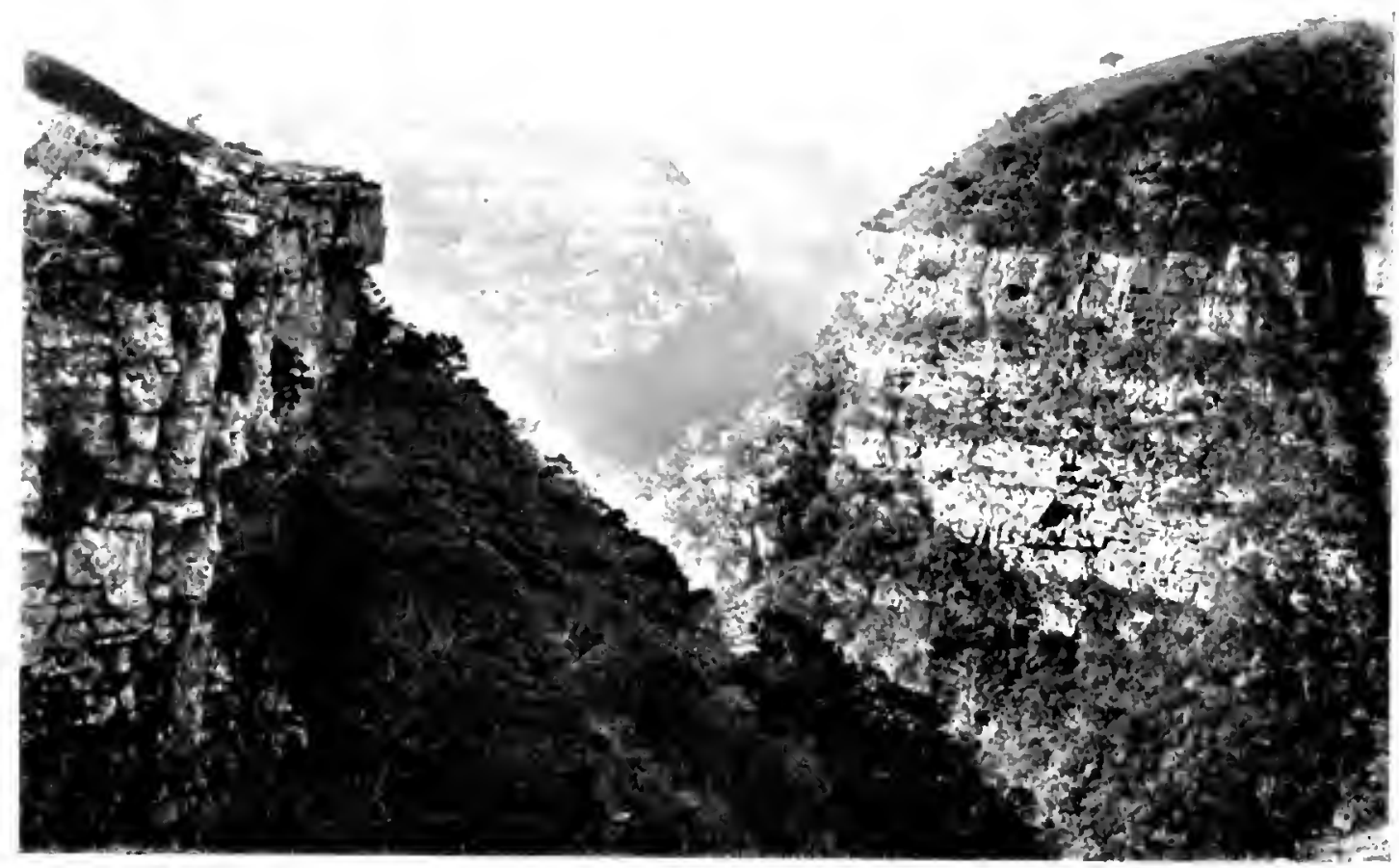

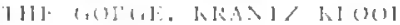

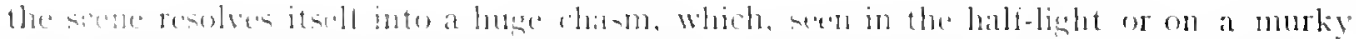

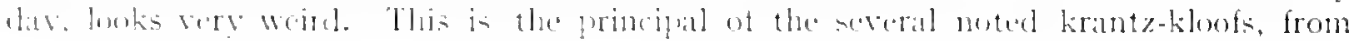

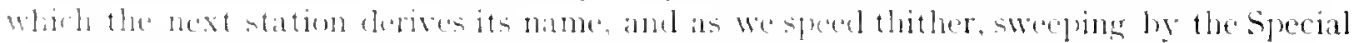

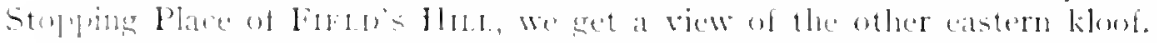

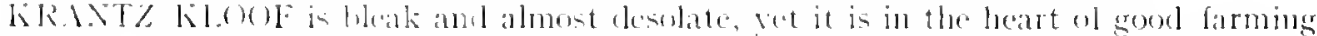

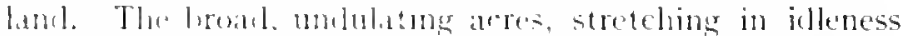
$\operatorname{lilli}_{\text {Ilithe }}$ Iusth, south, atit. and west, conlal be turned to excellent account in reots, cereisls, amd forage, and latirying could le protitathe followerl. The climate is superd and would alone inclue lealtis and fleasure seckers. It is saif that upon a clear day,

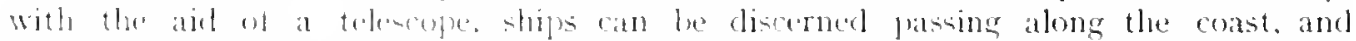

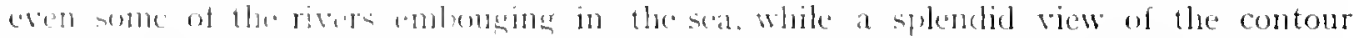

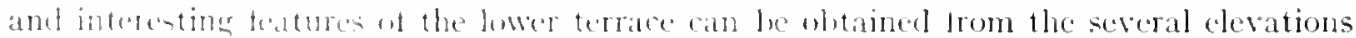
remel. Lint the attracturn of the klonts is supreme, and they must be visited before an

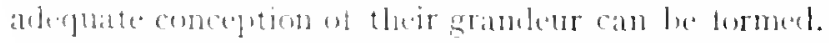

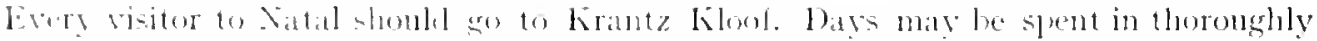

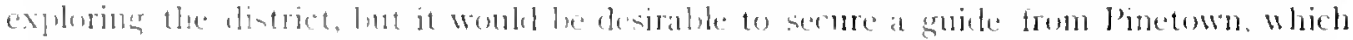
place inted might he mate the leathluarters.

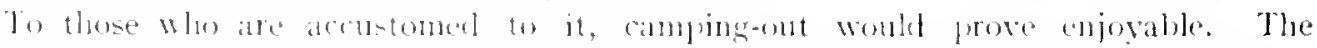

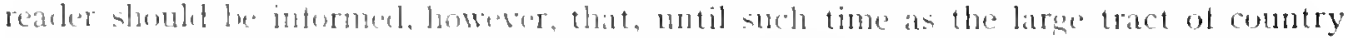

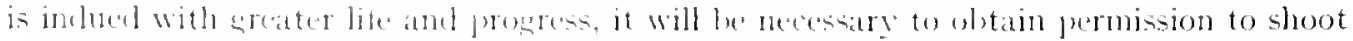

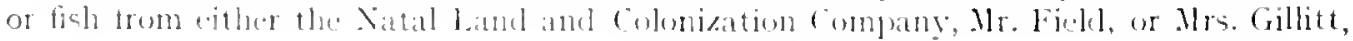


who are the owners of practically the whole ot the land around. From Krantz Klonte GILLITT'S (the S.A. Constabulary Remount bepot) is a sloort run through a pastorial

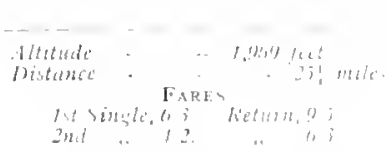
conntrs relieved be a few blantations of black wattle and laskycucalyptus. Passing this station and another stoppingplare which lwars the legend "E.rBertos." we get a glimpse of the estate-owner's house, pleasantly set on a wooked slope (far behind our trail we maty still take occasional peejs at the ocean) and ascent towarls

HHLL CREST, A few years ago this plare was almost unknown. Sow it is a goor sized suburban settlement, and the sahubrionsness of its Wlithinde climate is drawing turther residents. The scene des-

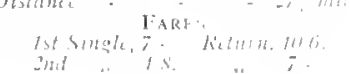
cribed below is within walking distance, and there are also some fine waterlalls five miles away. The Inanda Hills ancl the sea are plainly visible in clear weather.

Passing sintomsly onwards we observe the acte groovings in atrance and the track vanishing sharply round the jorjecting hills. and wonder how long the winding and climbing will continue, and what the ascent hetokens. We are lete hut briety in suslense, for, cutting through a clett in the rocks, there. involuntarily turning nur gaze towards it, lies an enchanting sight. Imatrine a wind-tormented sei, the nearer waters rocking in countless pyrmits of fury, tar off great liflows tosing momtains high. Next concerve a Power having commanded the pramich and the billows to remain immovable, and the greenest grass to clothe them, and you will gather something of the magnificent spectacle. As we proceed, this wonderful scene broadens and decpens until

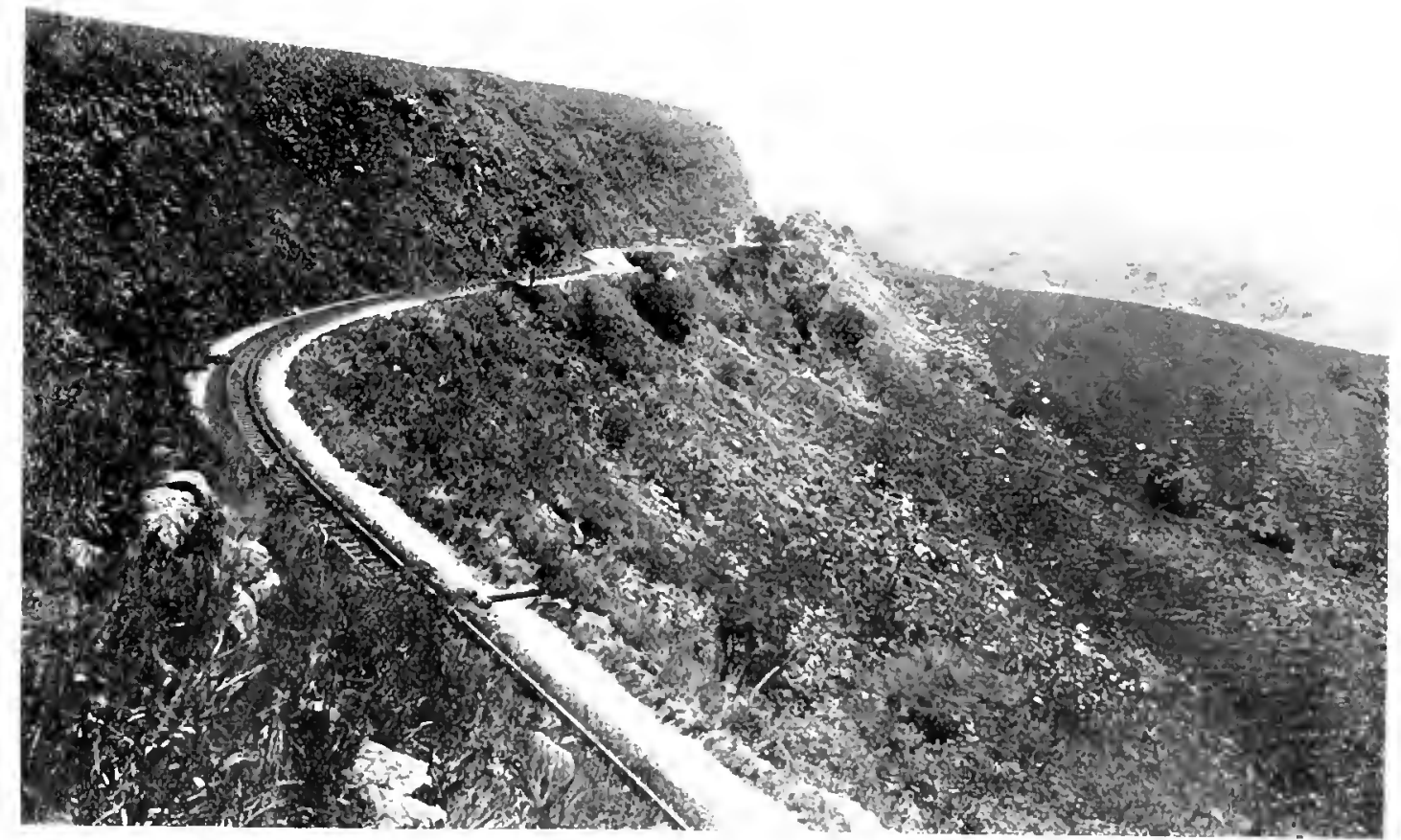

(1) THL X.G.R., NIAR BOTHL"S IIIL. 


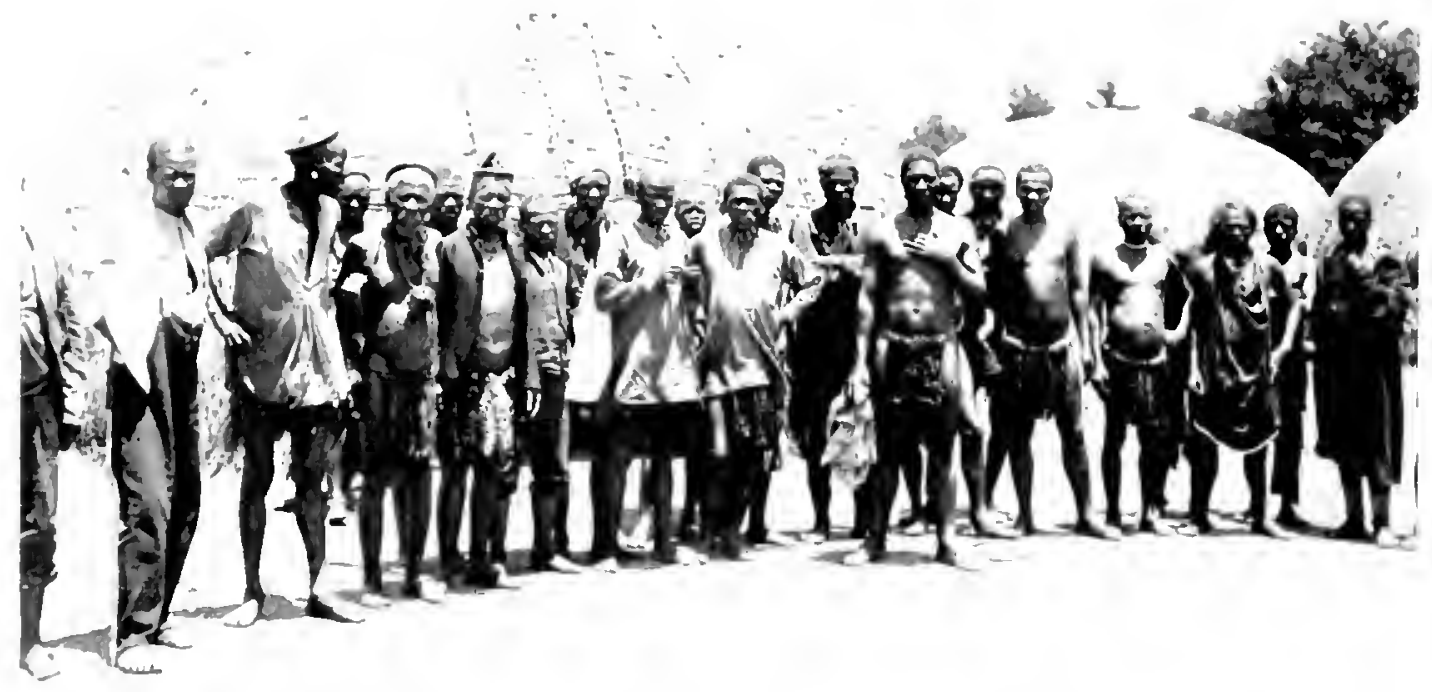

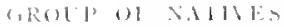

BOTHA'S HI1. je reached, where a mumber of natives detrain. They are going home. ()1 all the races on the carth it is questionalule whether there is one more irresistibly allured to his "family learth"

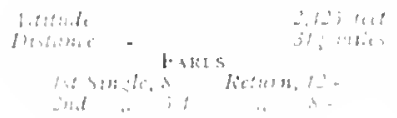
than the Kitfr. Within easy distance of this station several trihes have their villages, and a visit to the kraals accompanied hy a grood guide and a kolak would afford considerable fleasure to anvone interested in the customs and characteristics of the native.

Journeying now towads luchanga, which may be styled the half-way house to the Capital, we olserve several huts sprouting on the sides and summits of the humpbacked dills, looking strangely like inserted pudeling-basins, and round about we mark the small mealie plots of the none too provident native. As we proceed, the western view gives us a wikl and hroken country, with great halls of good workable granite clinging like tungi to the mountain sides, and in between the gaps we get a final glimpse of the filmy sea. The momentum of the train plainly inclicates that we are descending a heary gracke, and we soon dart into a tunnel-iso feet in length, and a splendiel bit of work-then we tum on eves eastwards. take a long last look at the "beantiful valley of a theusand hills," and in a little while pass through

DRUMMOND (Traflic llotel), renowned for its braciner climate and hily picturesque.

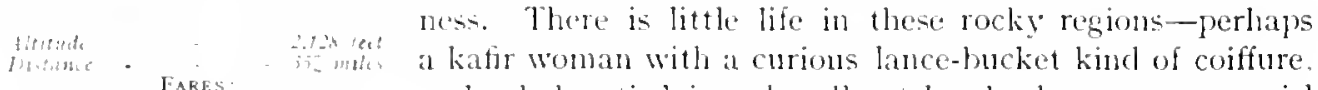

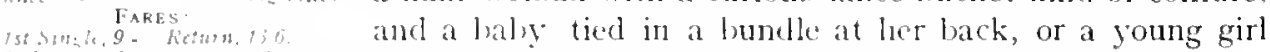
sh. attired in an excedingly light and inexpensive costume, balancing on her head, as she swings along, a calibasle of utgwala (a large onionshaped ressel of native beer). In a few minutes we are at 
INCHANGA, where a wait of twenty minutes for refreshments is announced. A large

\begin{tabular}{|c|c|c|c|}
\hline Altilude & - & - & $=z^{3}(1)+1$ let \\
\hline I)isturnce & $\cdot$ & - & - 3y milts \\
\hline
\end{tabular}
and claborately-appointed hotel has recently becn erected, and is sure to be well patronised by persons desirous of deriving health and pleasure from this invigorating neighliourhood.

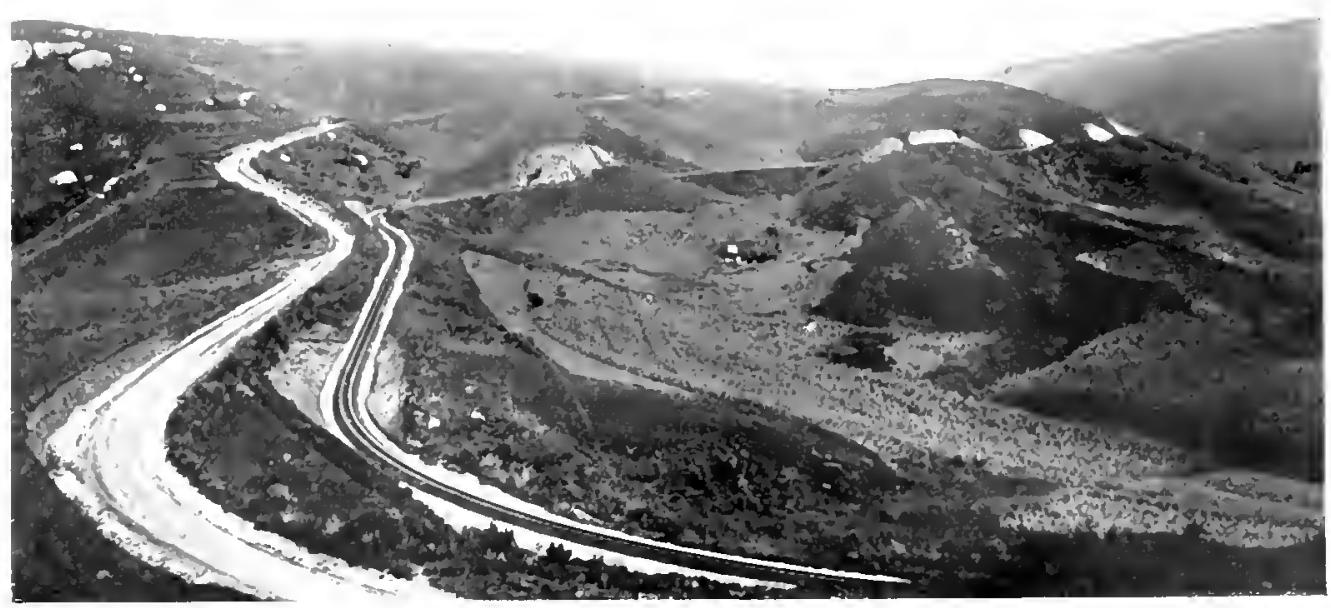

BY RAIL AND ROAD, YEAR HOTHA'S HILI

CHAPTER III.

\section{FROA INCHANGA TO PIETERMARITZILLR.}

$\mathrm{R}^{\mathrm{n}}$ Esuming our tratels, we observe a decided difference in the configuration of the country. What were angry-looking mountains at

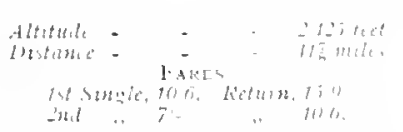
while ago. is now undulating pasturage. cultirated land, and a freshening air, in the mildle of which is the small station of HARRISUN, dividing the long section to

CATO RIDGE. Arriving at this centre we see a number of storage sidings running in all directions, and connecting in an evidently con-

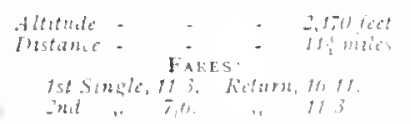
venient manner with the main line. This district does not, as the stranger might suppose. contain a flourishing tornship as yet, hut it is an excellent one for stock, dairy and poultry farming, and for the cultivation of com, potatoes, and mealies. The farming community has increased considerably during recent years, and, as there is good land still available, it will no doubt attract further cultivators. An hotel is contemplated. as well as a sanatorium. but at present. visitors find accommodation at several of the neighhouring farms. The Lmgeni, Lmlaas, and Lmsindusi Rivers-in which devotees of the rod will find good sport-are only a few miles away, and some exceedingly pretty falls, turned like a loorst-shoe, are to be found in the L'mlans and well deserve a visit. A striking range of flat-topped and conical mountains is scen some ten 


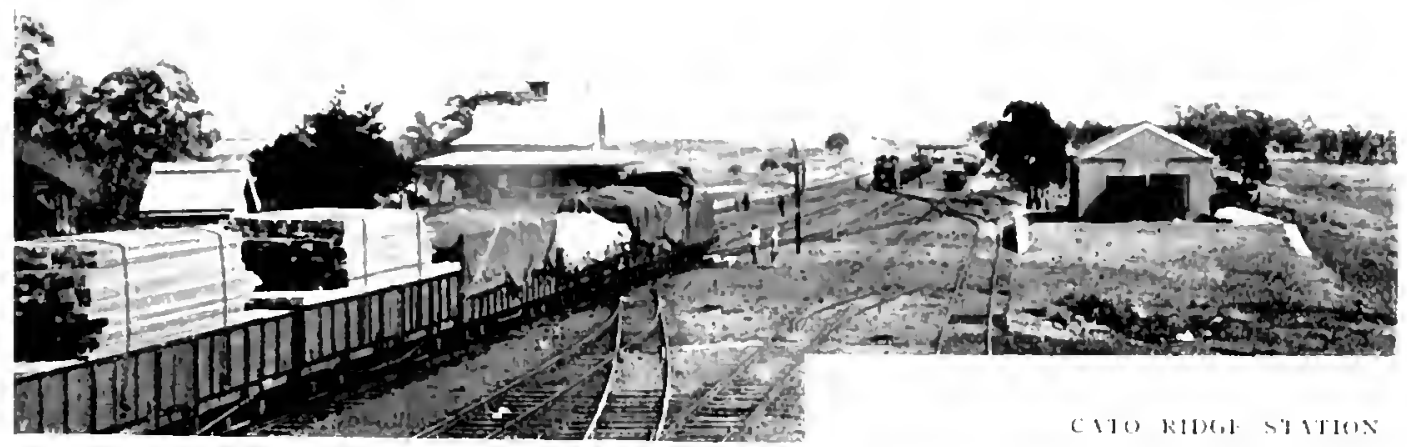

miles distant. and leve the first glimpse is catusht of the noted Talue Mountain dominating its companions. To those whose hotanical, geologionl, or other seientitic

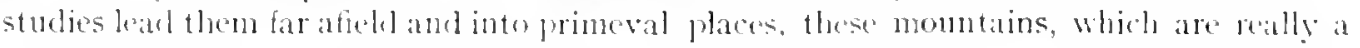
continuation of those at lirantz kikof, can he commended.

The district between Cato Ridere and Thermville Junction may be at once described as one of the oldest, laggest, and most prosperous agricultural divicions in the Colong. Dary-tarming is also surcestully pursued. though the locality is not particularly adajed to stock-loreding. The principal articles of produce are oats, forage, mealies, potatoes, and leans. Maritzlurg. being the nearest town, is a large market, hut the cultivations also find readr buvers in other centres of Natal and in the Transial. Land is valualle and in ereat demanol.

Returning, howerer, to Cato Rirge. leaving this station in the rear, we still enjoy, looking to the cast. the magnificent "xpanse of lookl nugged conntry. Som we sight

CAMPJRh)(IX, which, heing within easy reach of both Pietermaritzhurg and lurban,

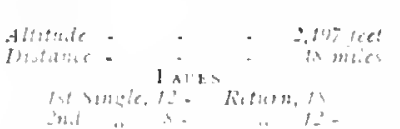
is a spot freely recommended to convalescents and those requiring clange and rest at a bracing elevation. It is said to lw most agrecable for those suffering from chest complaints. There is a well-appointed brick hotel close to the station and in the vicinity a number of houses open to paying guests. lhotographers and sportsmen will be accorded hair "hags" in their respective operations, and many other ways will be tound for phasantly whiling away the time. Eight miles away, in a pretty situation, will be found the largest hody of fresh water in Natal,-the new emergency dam constructed for the lourban Corporation. It is two miles long, at tinins a width of over suo yards, and has a capacity of tive humedred million gallons of water... lt shonld prove of considerable attraction to Camperdown visitors. l'assing on, we take in our way the little station of
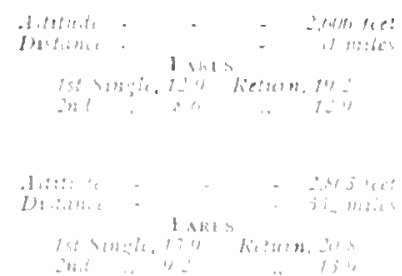

(XIAAS ROAD), trom which coign of vantage we are afforderl a grand prospect of the mountain range in the distince.

MANDERSTOA. our next station, has no special charms and we lead tor 
THORNVILIE JUNCTHON. This place is but santily turmaluel with buillings-

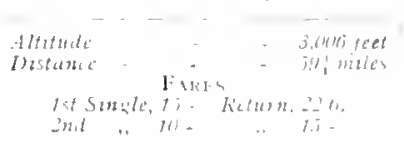
an hotel, at hacon and ham factory and a trew honses and tarms compose its structural weilth. It is. however, a railway centre of no mean activity and imyortance, being the junction for the kirhmencl Branch. A ronvenient morning and afternoon service of trains is arranged between Richmond amel Maritzhurg. making connection at the latter station with the trains from the uplands, and at the junction with those from the coast. For a description of the Richmond district and its facilities, see pages 201-205. After Thomville Junction the next main line stition is

FOX HILI. This surburban territory is within seven miles of l'ietermaritzburg,

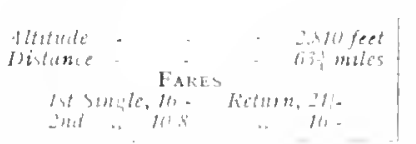
and enjoys a very healthy situation. In the east distance our rocky guide, Table Hountain, again appears, and as we pace down the hill we jerceive an unequal country to the right, enlivened with mushroom-like bushes of the

mimosa class. Now, setting our eyes on the north-east. We cateh the first faint glimpse of the Capital, becomingly dressed in toliage and nestling under the protecting wing of the massive Zwartkop hills. With occasional interruptions we keep the city in sight, and, after overtaking Motxit Rle, an internediate staff station, the scene becomes more animated and picturesque, and our attention is withlawn from the dimpled cheeks of the rounded hills to the bortering view of pretty villas and straggling people on the abutting road which strutches citywards, while from this nearer quarter we secure a larger panorama of the Capital. Fort Napier is detected on the lett elevation, embracing quite a little town in itself, and down below is the City proper.

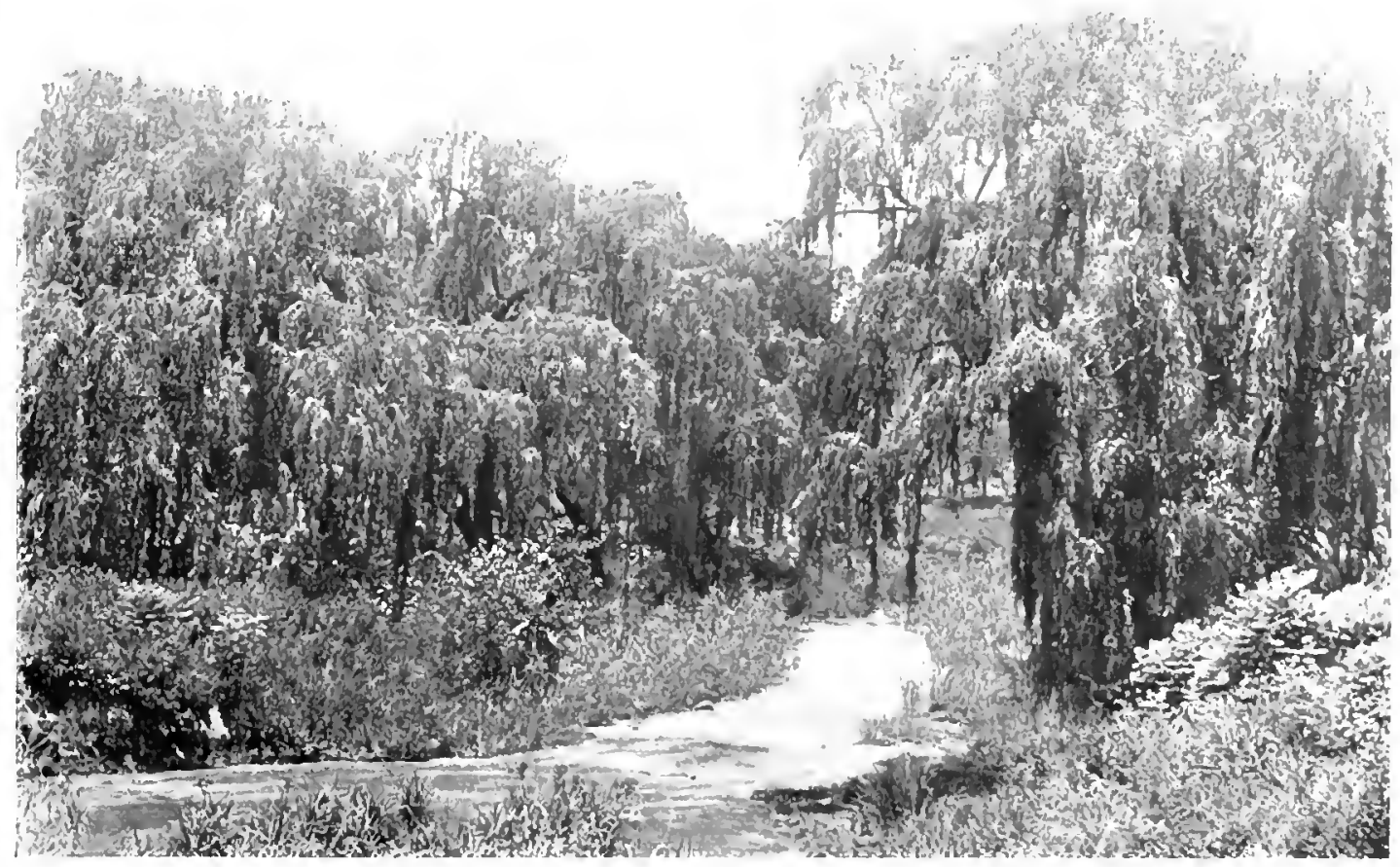

RIYKR ITMSINIUSI 


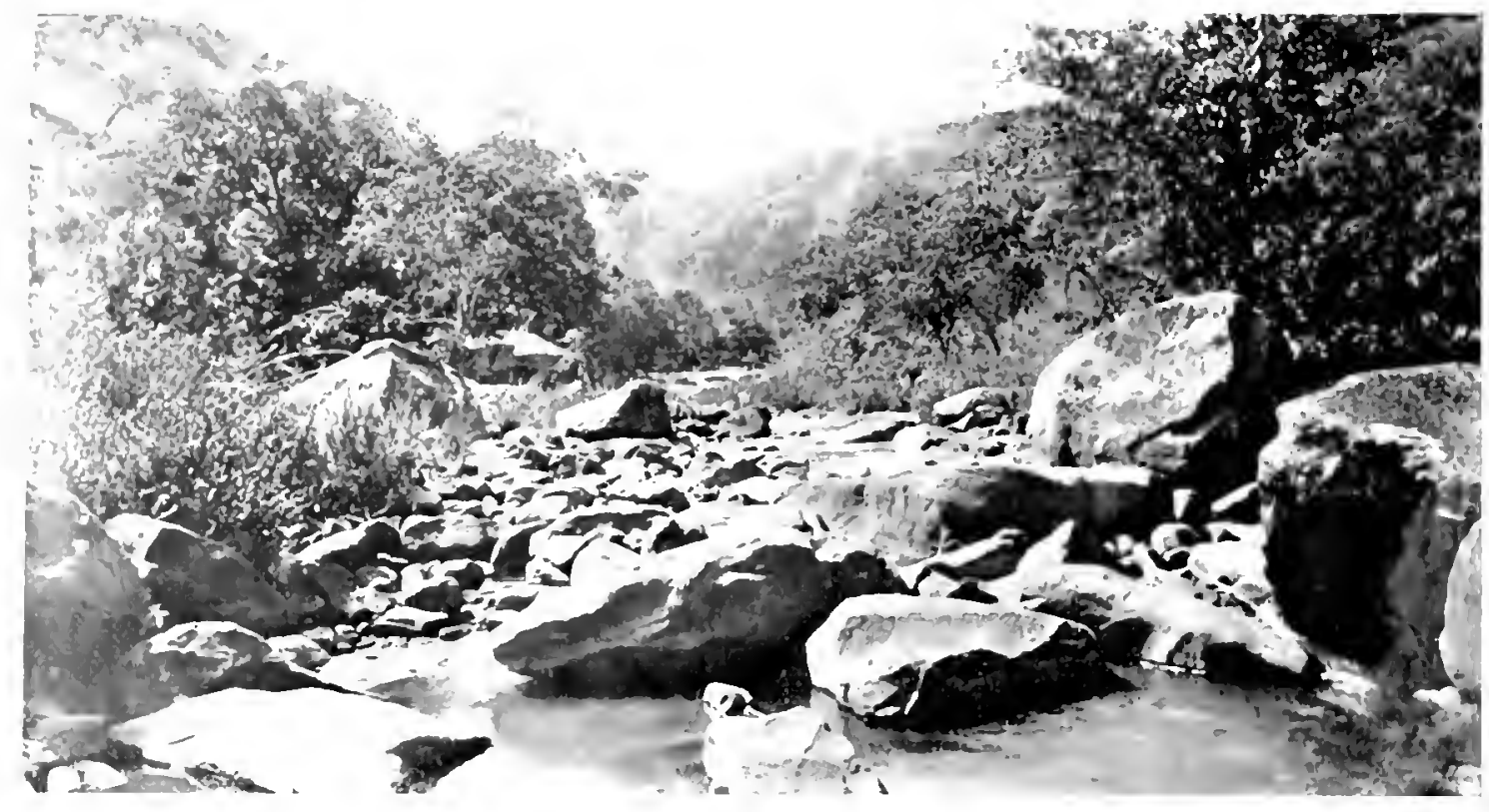

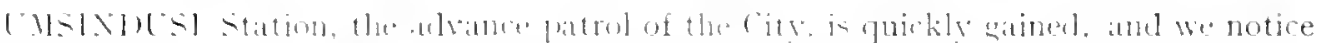

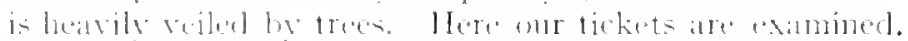

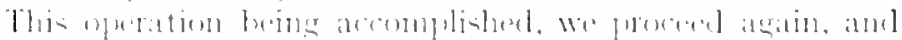

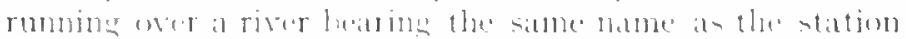

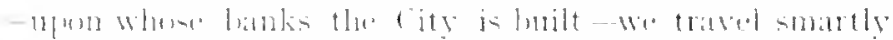

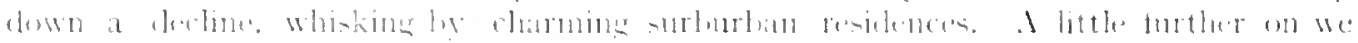

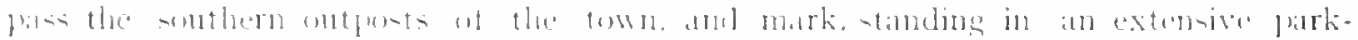

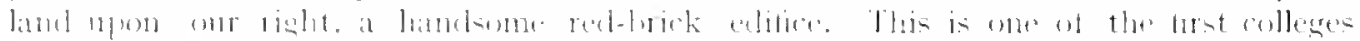

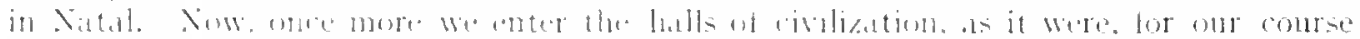

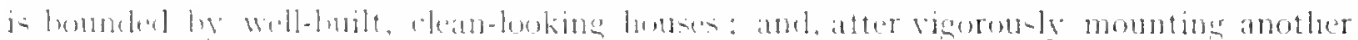

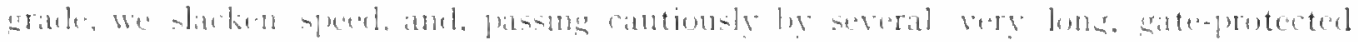

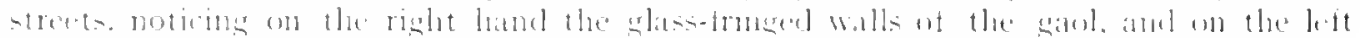
hand the gatrison church, we stean inte the second largest station on the line and

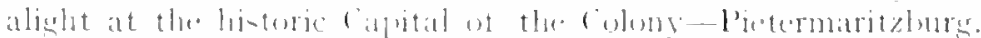

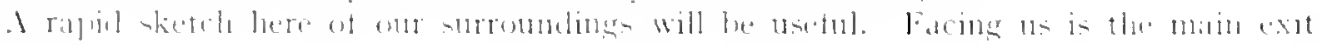

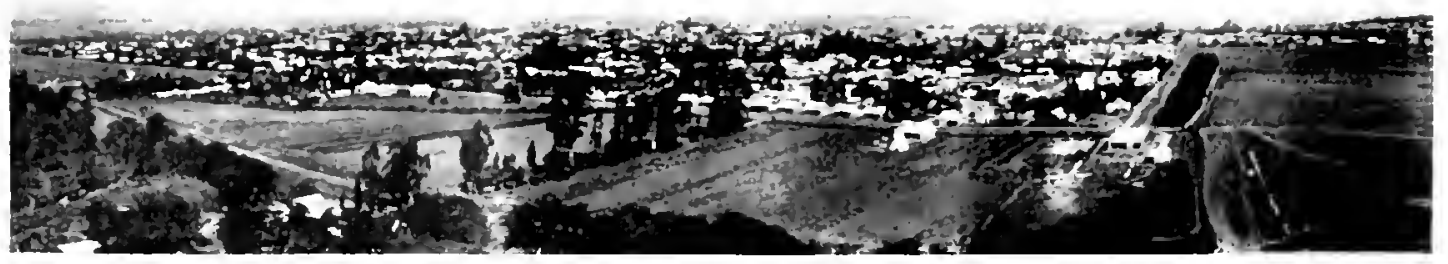

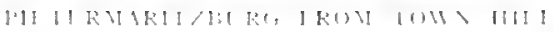


leading through a wirle hooking-hall. in which are the Booking and Telegraph offices and Cloakroom. To our right are the Refreshment and Dining Roons. and a "hay" from which the Richmond branch trains depart. To our left are the Irookstall, the various Station officisls" and Iarcels (Iffeces, Waiting Rooms. and the "bay" set aside for the Greytown ban trains.

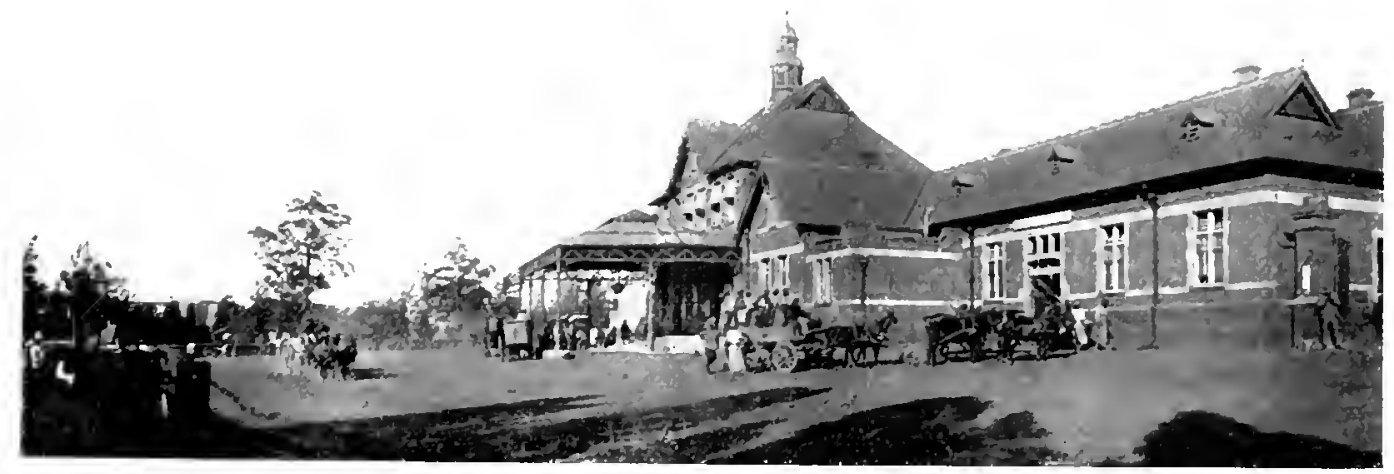

RAILWAY STATION, IPETERMIRIT/BURC

CHAPTER IV.

'THE CITY OF PIETERAIRITZBL'RG.

The Capital ot the Colony was lail out in the year Is.9 by the Dutch voortrekkers from the Calke. and was named from two of their leaders. Pieter Retief and Gert Mlaritz. The sturdy pioneers hat suffered much since thes had brought their wagons down the pases of the lere into "the meadow of Natat." Seventr of FOUNDATION onsly murdered at Lmgungunhlow. on the IThite Cmiolosi. the Creat Liral of Dingaan. the Zulu king, to whom they had gone to sue for territorial rishts. Following that massacre. Dingain's impis attacked in the night the Dutch camps scattered along the Tugela ant Bushman Rivers and within a week murdered il wut 6 on men. women, and childen. Warfare continued until Anlries Pretorius defeated l)ingan at the blood River on the Ibth December. I8j8_- Dingan's Day"-ind so securerl peice for his countrymen.

From "The Story of a South Arican City" (J. F. Ingram), -which volume it might he mentioner is a complete hiography of the Capital-we gather that after the events indicated above. the Settlement of Maritzburg consisterl of sis small hovels and many. Wagons and tents; that in the beginning of 1839 a Volksrad. or Council of the people. was elected. and that on the $5^{\text {th }}$ of February of the same vear the town was officially named Pietermaritzhurg. The natives name it " Lmgungunhlovu" trom the ancient seat of government of the Zulus on the White L'mfolosi River.

Such then, was the founding of the Capital of Natal.

MARITZBLRr. as it is usually called. enjoys an altitude of 2.2 Is teet above the sea

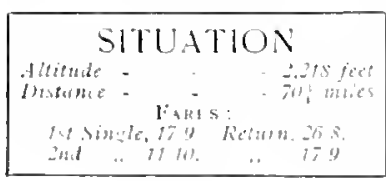
level. It is $70_{4}^{3}$ miles by rail from Durban. and 55 hs road. It lies in a leaty hollow. and is commanted by hills on every side. Two small but pretty rivers, the Cinsinelusi, and borp spruit, embrace the tomn, and ar strongly bridged. 


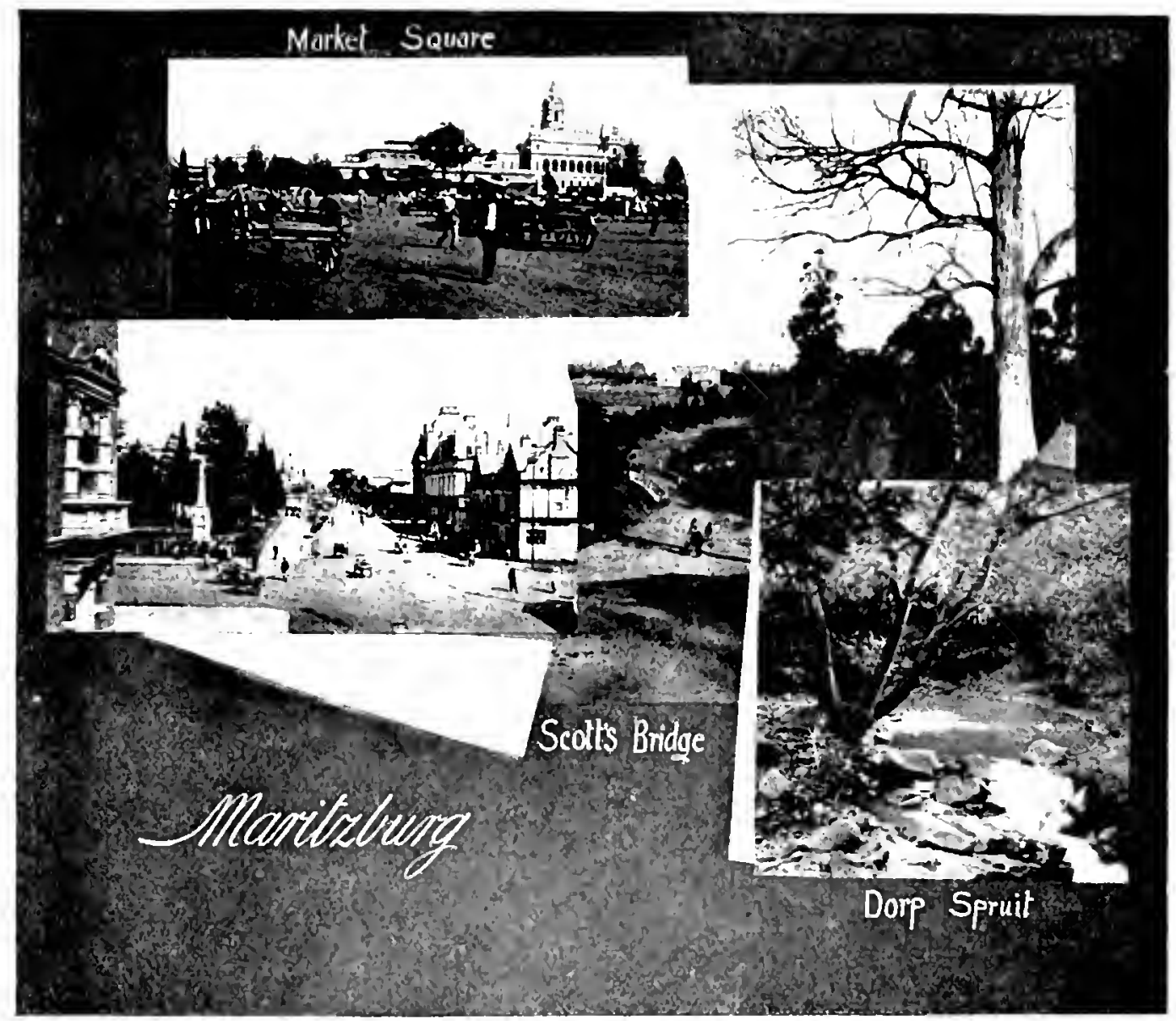

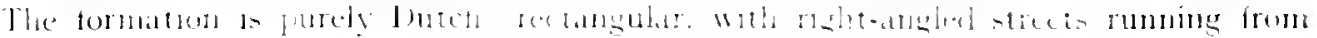

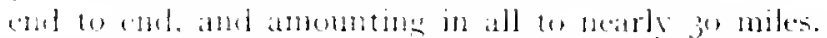

F(M)MATHON. E.TENT.

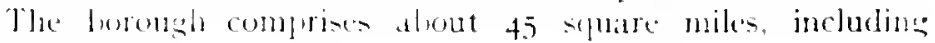
town lithelis.

POPULATION

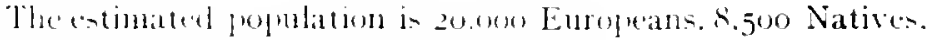
and $0.5(1)$ Indians. or at total ot j.7.000.

The Municipalitg is diveled inte eisht wards. and its aftar are well administered

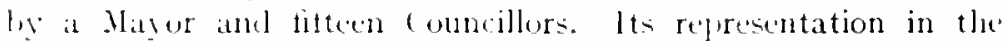
11.tTTERS legislative Asomuly is three members. The rateable amount

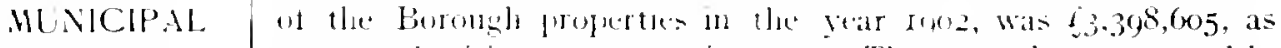

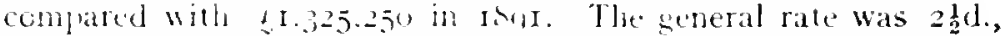

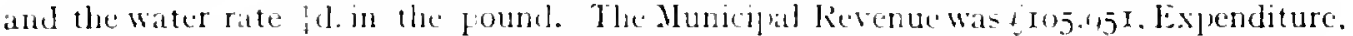

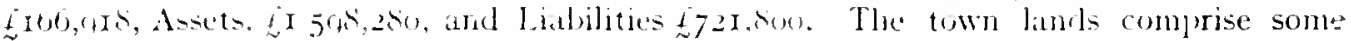
I 5 , fue atres. valued at iftoz.000

The matn theroughtares alle well-mate and lighted by electreity. 
The houses, especially those erected during the last few years, are substantia ly built, mostly of red brick, commodious, and conveniently arranged. In the suburls there are many very handsome villa residences.

The water is good, and the supply; which had fallen short of the greatly increased demand, has now been met from additional sunres at considerable cost.

The sanitary arrangements are fairly efficient.

The European birth rate is $25^{\circ} \mathrm{O}$, and the death rate $13^{-3}$ per thousand.

There is a well-disciglined European and Coloured Town Police Force : also a Folunteer Fire Brigade, under a permanent Fire Master. fully equipped with steam engine, manuals. escape, and all necossary modern appliances.

There are a laree number of public buildinges some of which are of pretentious proportions anr excellent design. notably the Sew Town

PRINCIPAL BUILIMING Hall. which was opened hy H.R.H. The Duke of Cornwall and York. in Anmust. Inn (one of the finest edifices in South Atrica. and posse-ing the fourth largest organ in the world). the

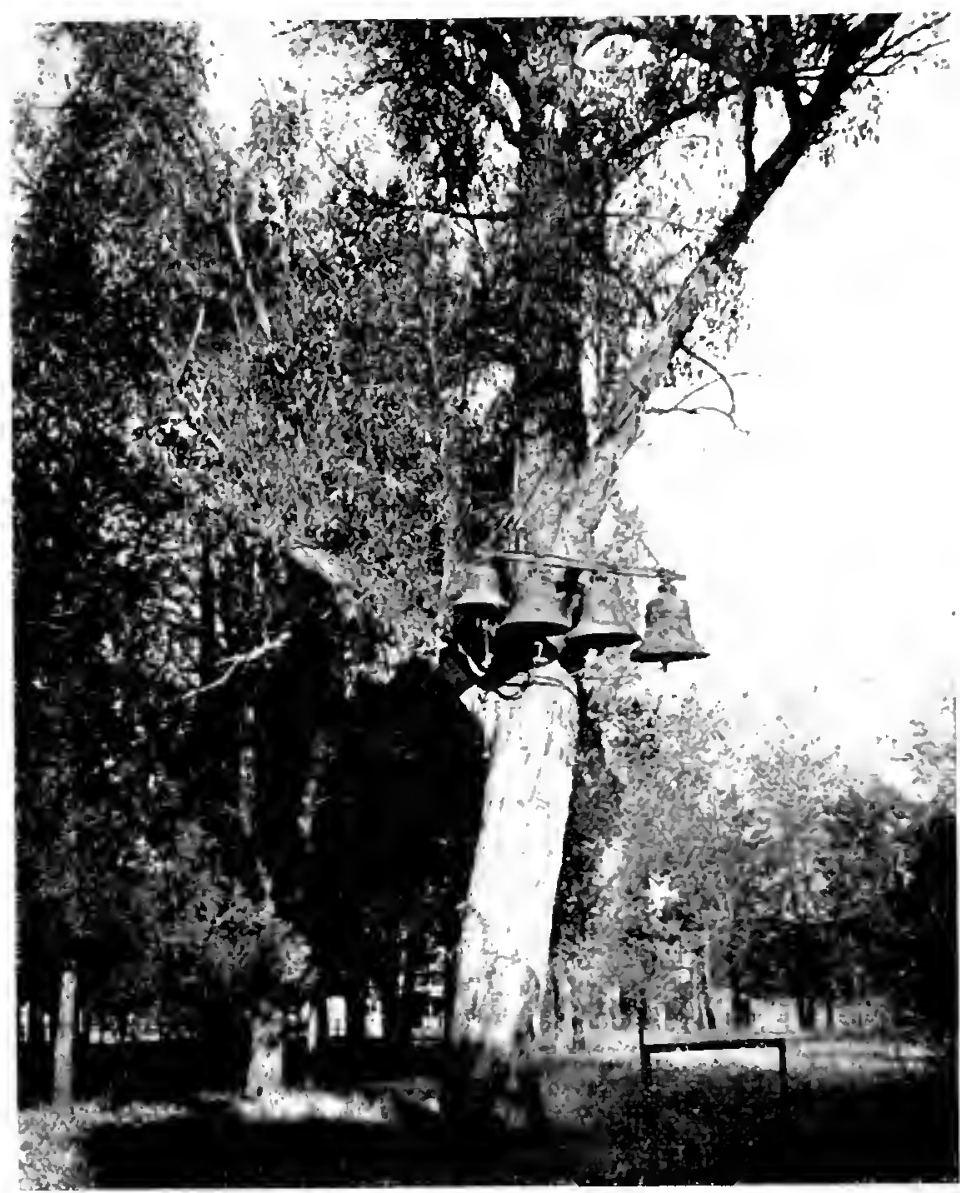
iolonial Offices. Honses (1) Parliament, Government House. Marjizhine College. Natal Police Barachs, Lunatic Asylum, and Central Station. There are also many other structures. cajacious and attractive. clice amongst whichare the Post Office and sulreme Court. Victoria Club, "Xatal Mitnes:" Office, Police station. Market Hall I.iluars, and Reading Romm. Ilasonic Hall. Theaire. and several lianks.

Building operations are everwhere appalent. anil in a little while new Postal and Telegraply Otfices. new premles for the Engineer ot Railwas' Deprotment, and possibly it Drill Hall and a Ifreeum will be erected. The active prosecution ol structural worlis, 


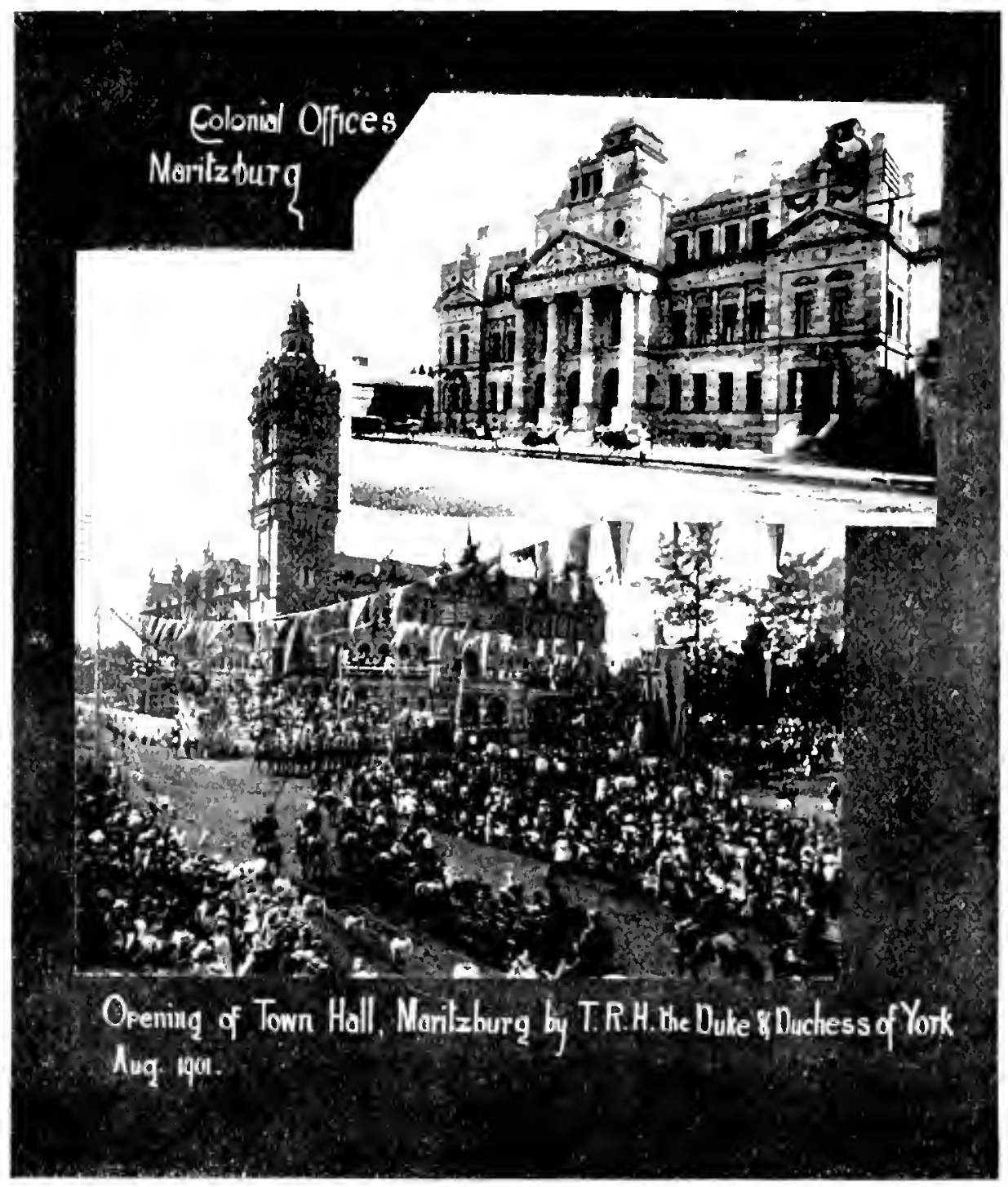

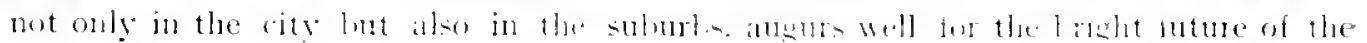
Capital.

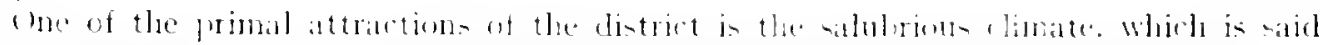

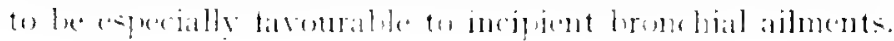

C.ENERAI.

ATTRACTICNS

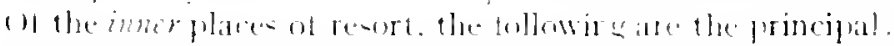

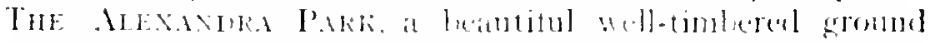

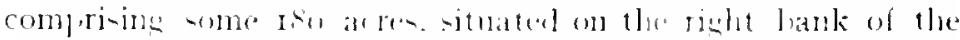

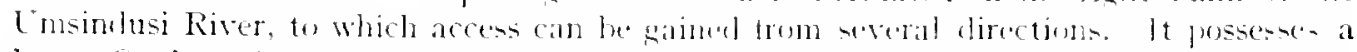

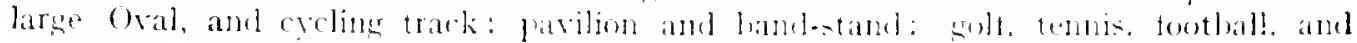

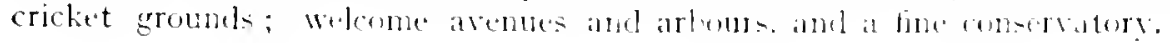


The Botanfal Gakdens. Which lie on the we-t side of the City, are a good example of their kind. They afford lorely walks and are larsely visited. The charminely-atuated Waterworks are also in the vicinity.

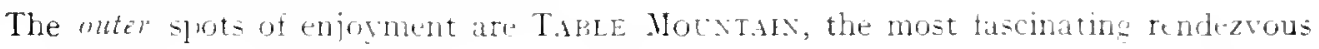
for picnickers. Thotographers, and scientists:

The Tow Brsh Axp Chase Villeys, where nature has been most lountulu wath her waterfalls and sweet wondland gifts; and

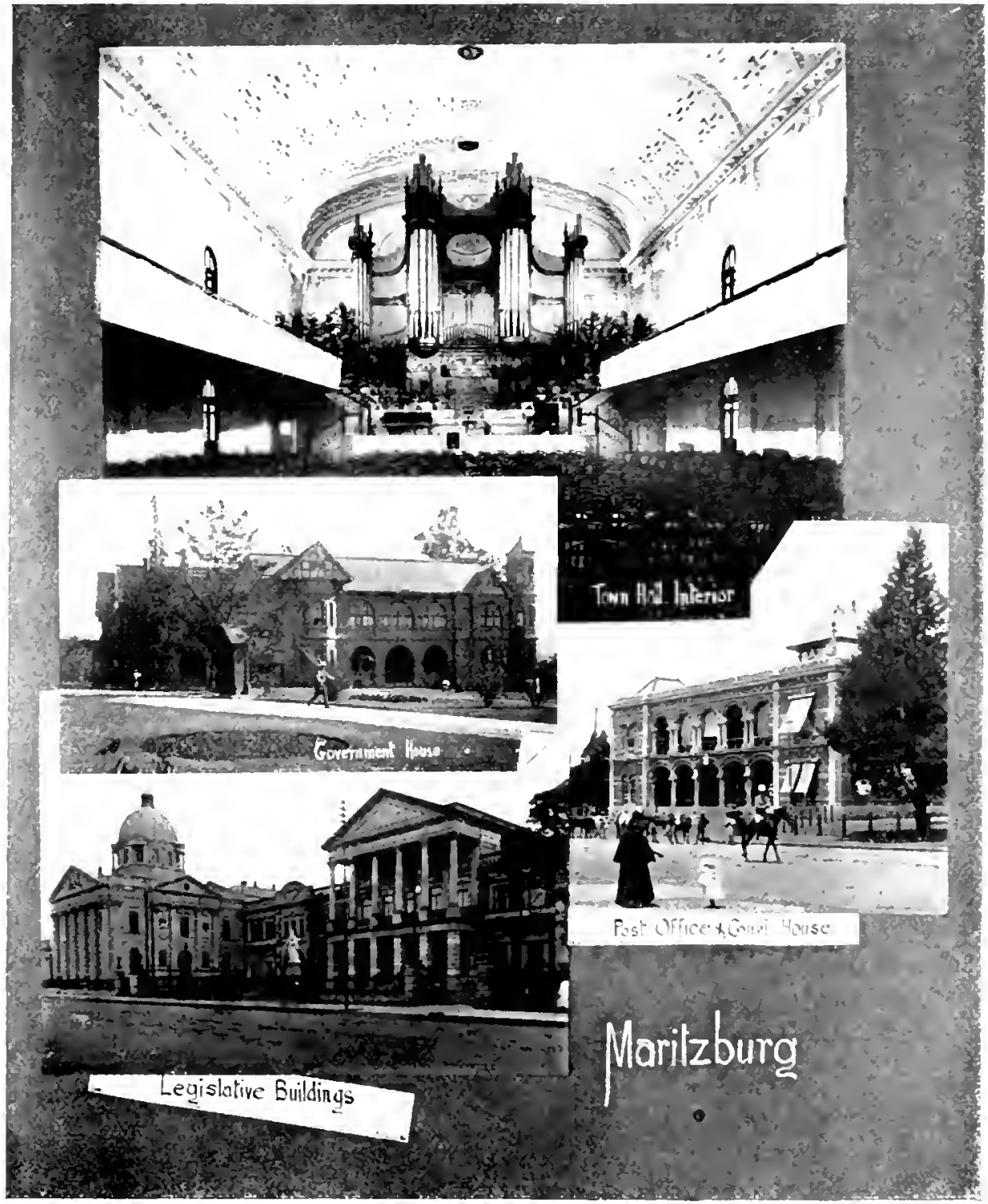




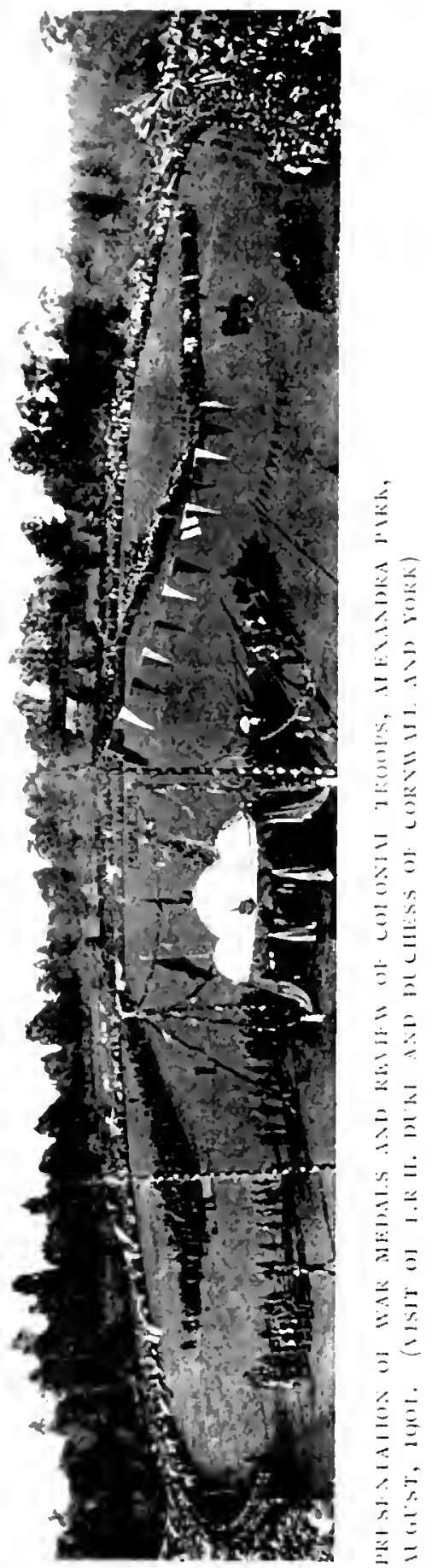

THE rahol's HOLWAY CENRES, ach withm easy reach of the city, namely, Camperdown, lidendale, Zwaartkop, Sweetwaters, Hilton Road, luwick and Albert. These ate rescribed in their appropriate places.

The following hambone monuments, the handiwork of eminent souptors, adorn the City: A

\section{STATUARY. ETC.}

white marble statue of the late Qneen Victoria. al statue of Sir "lieophilus Shepstone, two

striking momuments, one comnemorating the brave who tell in the Zulu war of 1879 , and the other, a column, erected in remembrance of the volunteers whoted in suppressing the Langalibalele Kafir Relellion in 1873 . The lobly of the House of Asembly ontains the lust of the late Sir Henry binns. as well as two tablets, one erected to the memory of the latter and the other to that of the late Rislit Honourable Harry Escombe. also at one time I'remier of the Colong.

In the restibule of the new Town Hall is a large thoscely-designed talslet, moviled hy H.R.H. the 1)uches of cornwall anel York, in remembrance of the Natal Volunteers who lost their lives in the recont Boer llar and, fittingly enough, opposite this tablet has heen placed the bust of that able amel prescient statesman, the late sir Edward Bartle lirere.

In the various churches will he seen many taliets in homour of those beloved and worthy pioneers and citizens who have joined the great majority.

These are many and sundrs, and applied to the

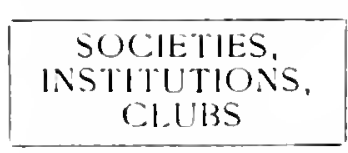
adrancement of com merce, agriculture. horti. culture learning, music, law, hotany, photo. staphr, moral and plissical development, angling, shooting, sociability, thrift, etc. There are also a number of henevolent institutions, while Grey's llospital and the Sanatorium do splendid work.

The Natal Society is the oldest of all local Institutions, and counts anongst its members the colony's most learned, eminent, and influential men. It maintains a commodions lonilding, which includes Musenm, Subscription Library, and free Reading Room. The circulation of looks is about f),000, and magazines 15.000 per annum. 


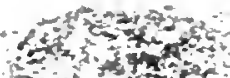

s.t.

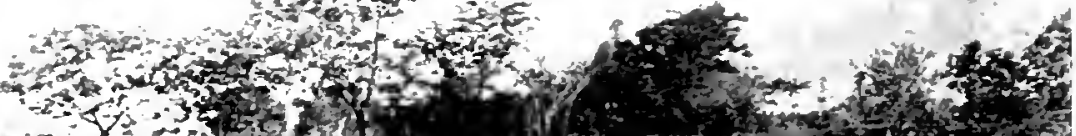

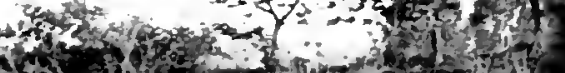
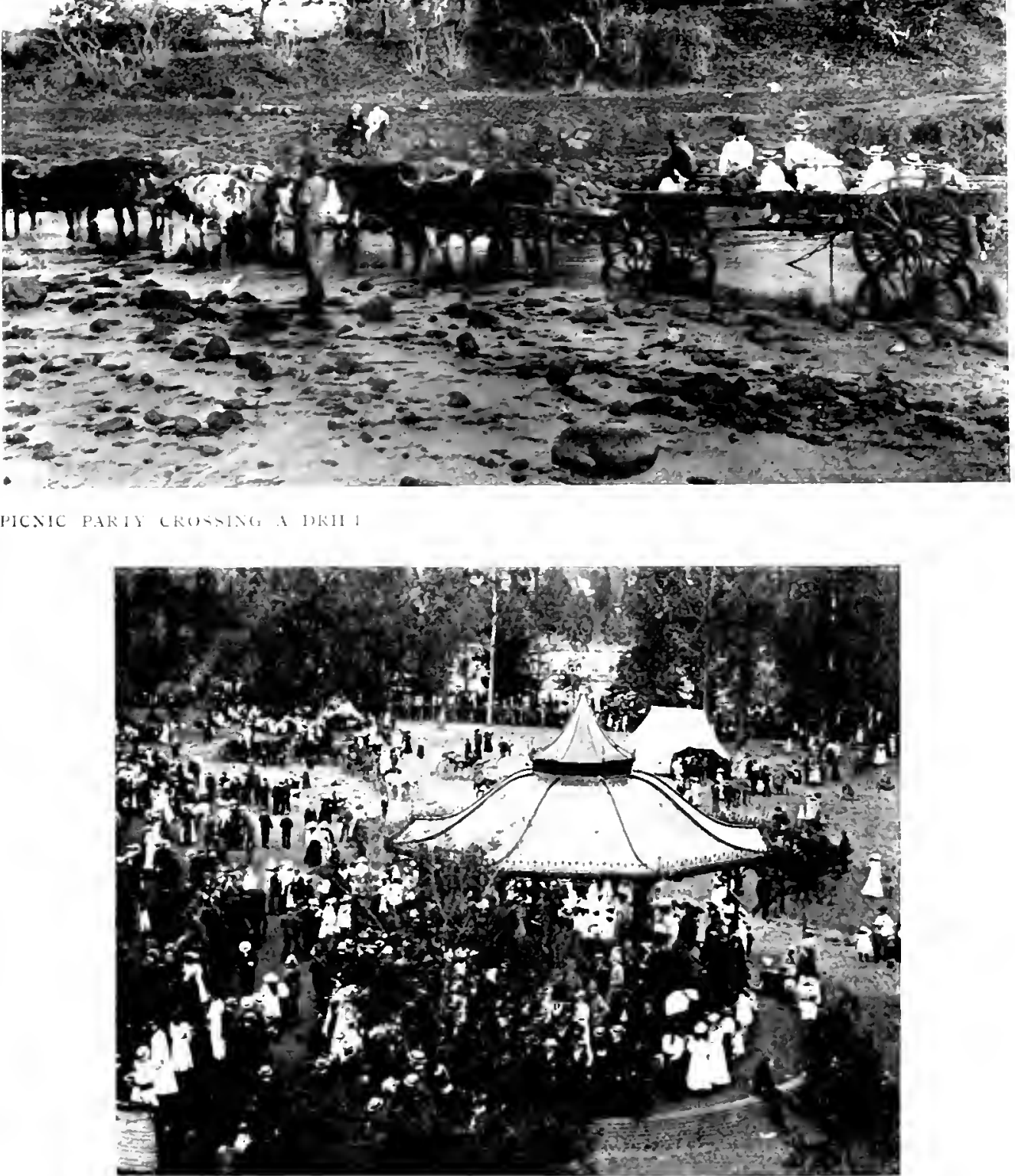

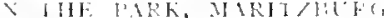


The principal clubs ate the "Victorid." and the "Xatal."

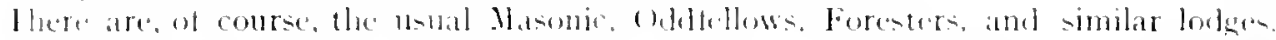

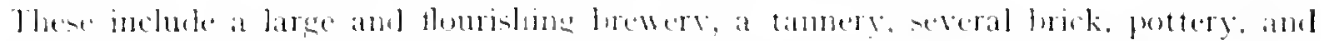
INUSTRIES

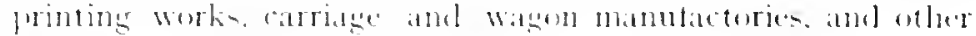
mailler (mtaphises.

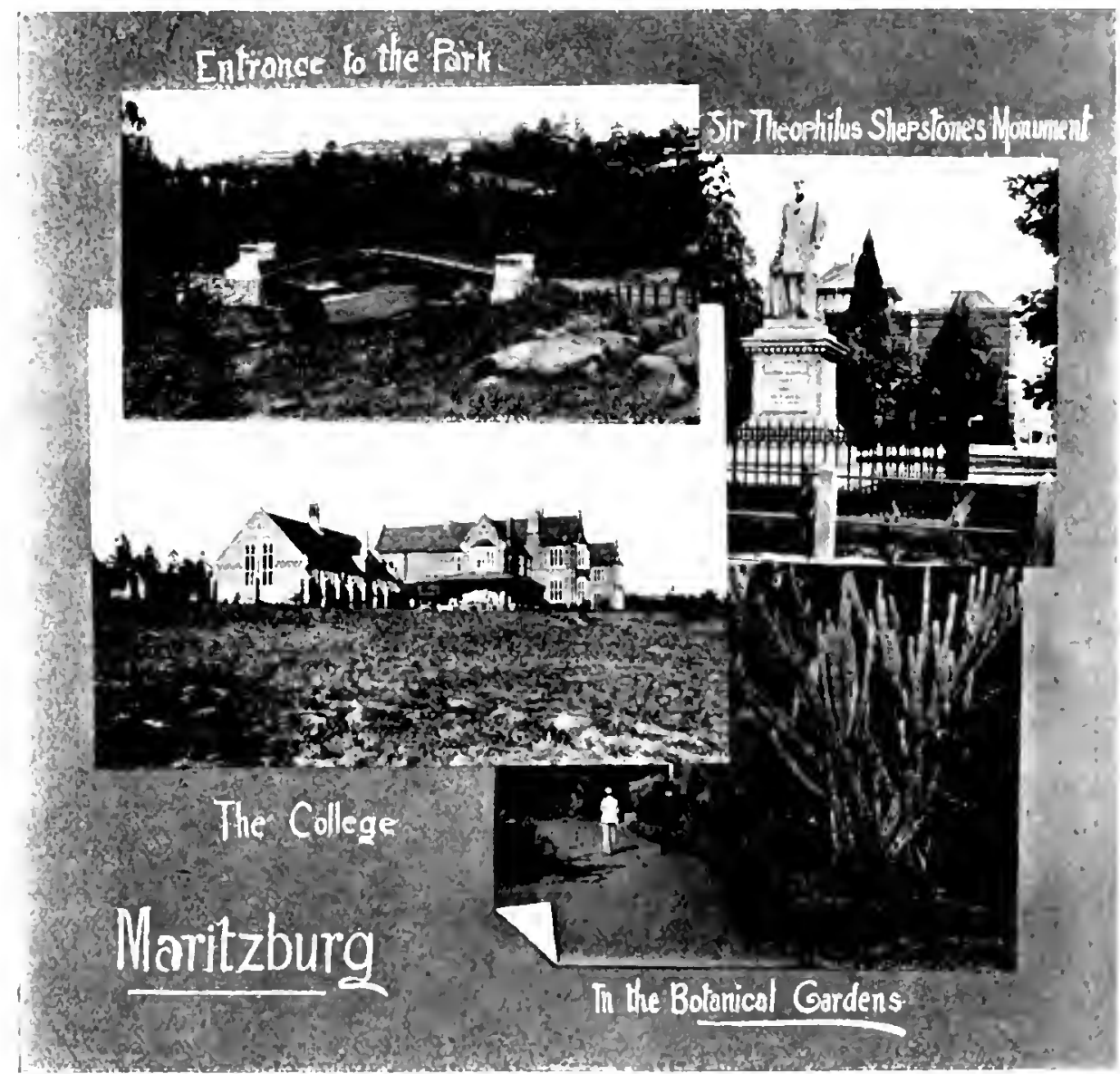

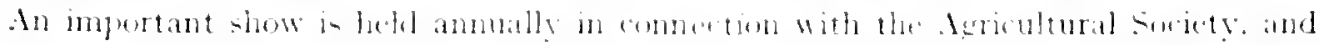

E.HIB!TICNS

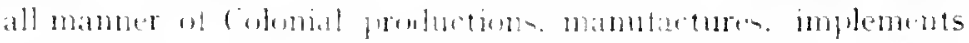

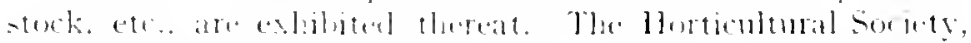
Satal Foulug (hoh, ame Maritzhure kenmed club, are other well-reputed Jostitutions that give gearly exhilitions.

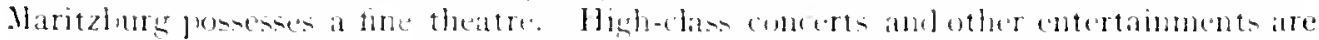
ENTERTAINHEXTS

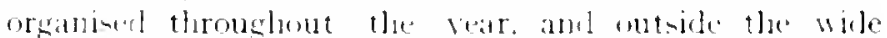
array of local telent. distingumbel artistes nom every part ot the slobe vist the Cits. Sacrel concert andorgan

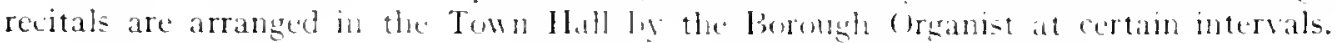


Quite a number of acred edifices are to be found. There are two cathedral-churehen-

RELIGION St. Peter's ard St. Sariour's. The remains of that great ecclezidst and scholar. I)r. Colenso, first Lord Pishopl of Natah, regnose he-ide the altar in St. Peter's. To indicate the relisions tervour of the citizens, a former writer may be quoted: "Every denomination is strongly represented. and the strle of bulding together with the interior fittings, are sufficient evidence ot the religiotis vitality."

Maritzbure is an educational centre of considerable importance. and its scholistic SCHOOLS Vasters are Lniversity men. and the curriculum embraces classics. Funglish I.iterature. Science, liathematic. Irocem Languages. etc.. as well as elementary subjects. The Nerchiston School for hors and the Girls Collegiate school. are also important educational institutions. There are. in addition, the Government Boys' líndel Primary school. ant] two Girls' Irimary Schools, beside denominational and private scholiatic estallishment.

LXI1:KLR OR $1 \mathrm{HL} . \mathrm{IIRE}$.

M.IRIT/I:LRG

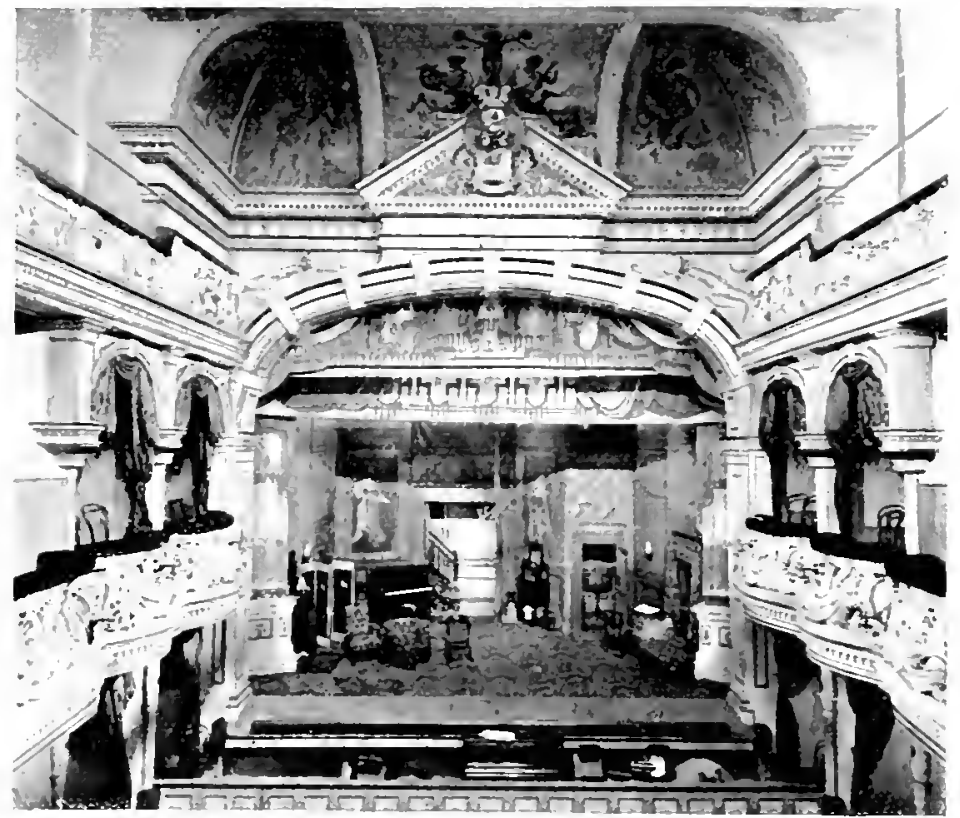

The coloured children alou lave their schools. The Colleges tor hos at Hiltom kuat and Balgowan, and the Girls private school at Zwaartkop. are mentioned turther un.

Two dailies are published in Maritzhurg, viz.: the "Xatal Witness" in the murning. NEWSPAPEKS and the "Times of Natal" in the atternom. Bon are in ahle hinds, and enjos a larse circulation all ore There are also the "Covemment Gazette" and "Catal Atrikaner" issued weekly and bi-metily respectively.

Branches of three Banking Corporations are in the City: The Catal Bank. 1.tu.. The BANkS Standart Bank of South Africa. Ltd.. 


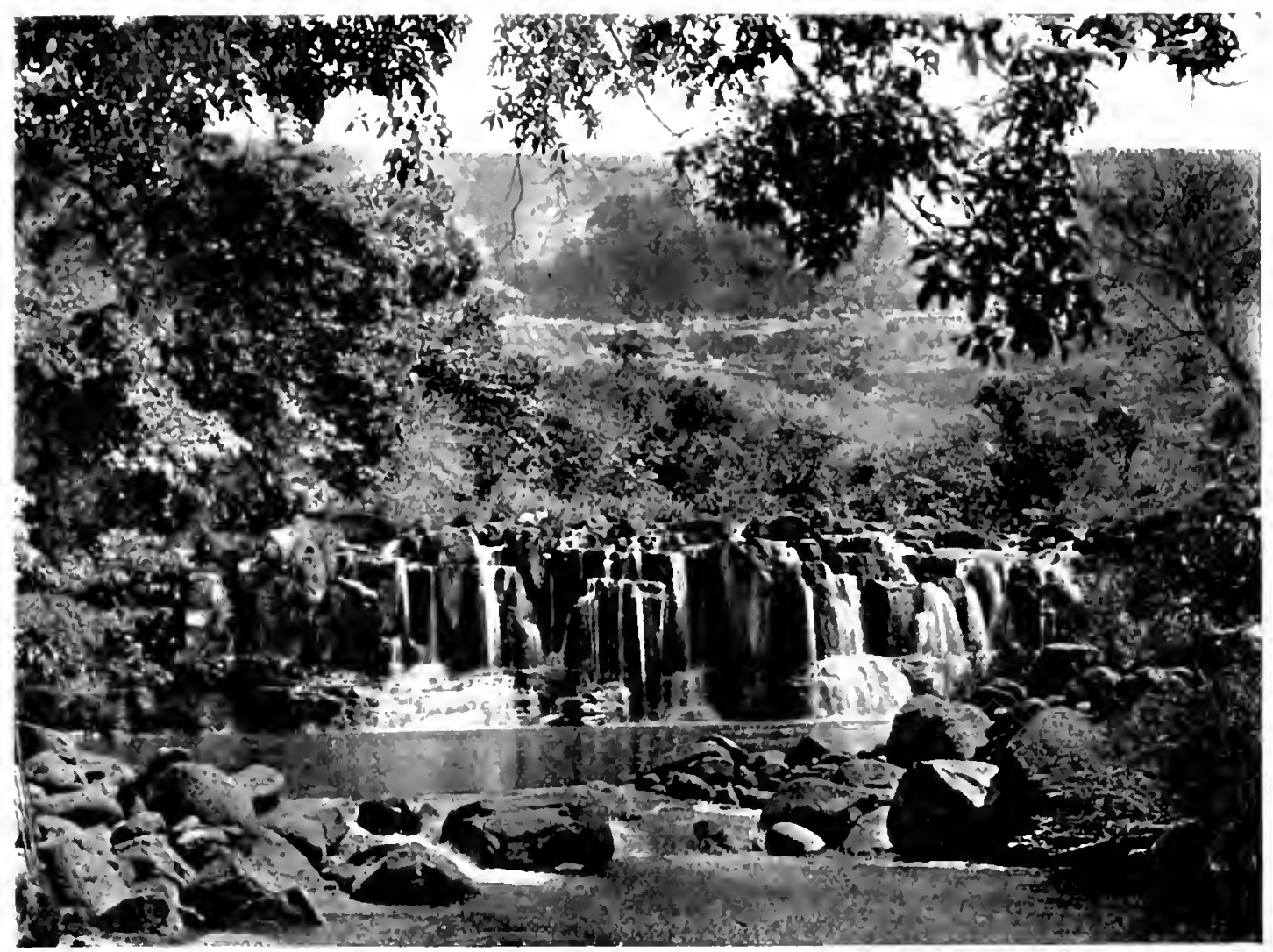

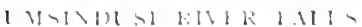

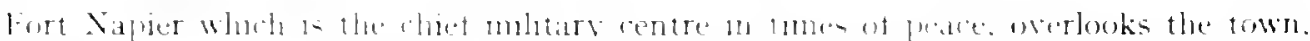

riARRISOX.

IOLINTEERS.

NITAL POLICL

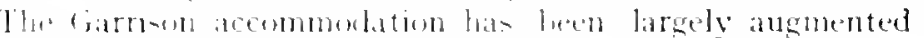
smee the II it

There are two Volunter regments - the Natal Carbineers. and Xatal kosal Rifles, as well as a Hotclikiss gun section.

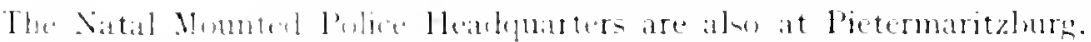

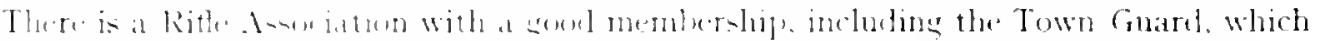

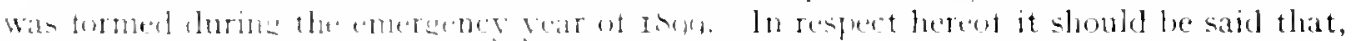

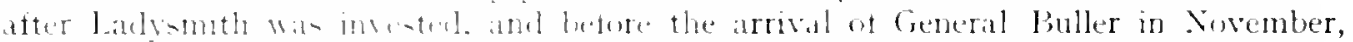

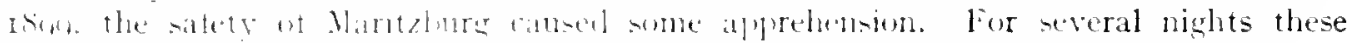

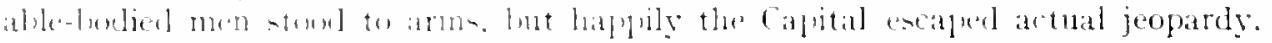

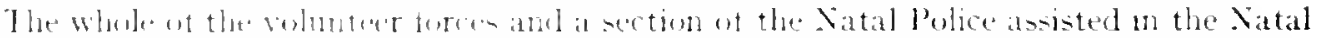

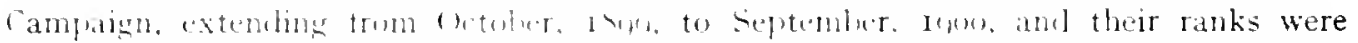

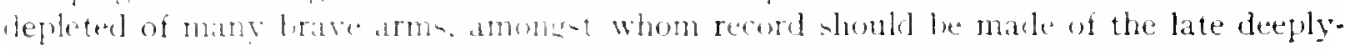

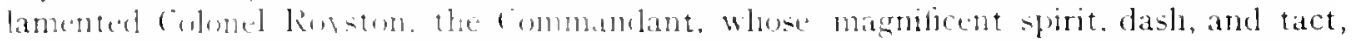

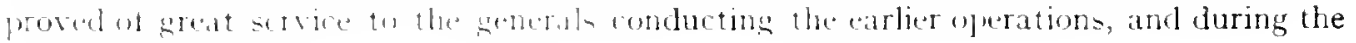
l.advinith Siteren. 


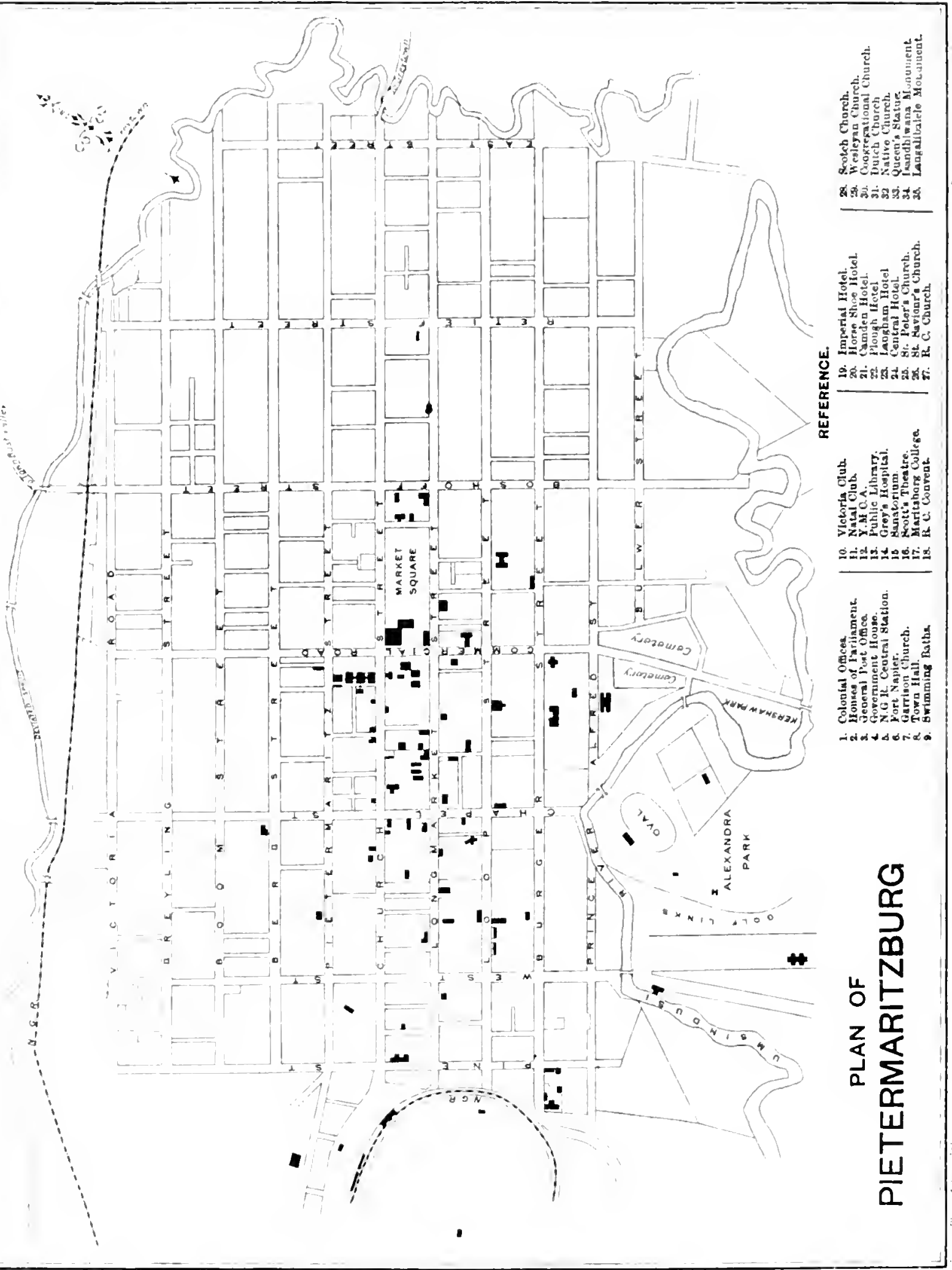


THE MAIN RAILWAY LINE gives actess Soth to the fort of Durban, and to Richmonel (via Tlornville function): Sorth, to Howick, Mooi RAILWAY, POST Kiver. Estcourt, Iadysmith, Harrismith, Glencor, Dundee, CART, HOTEL, Newastle, Charlestowil. and the Transvaal, while a branch ETC., FACILITIES line radiates from llaritzbure, running to breytown in Lmvoti county (see pages 205-2I2). The ricw route to the Cale will, when constructed. also have its junction with the Natal trunk line at Maritzhurg.

THE SUBLRPS of the lapital reathed by rail are Lmeindusi. Fox Hill. Zwaarthop, and Hitton Road, on the Main line ; and Victoria Roul. on the Greytown Branch Line.

A POST CART SERVhe runs daily from the City to Edendale. Bostun, and Buber - (sec page 22I).

HOTELS and boarding Hownes are plentitul. catering for all clatane.

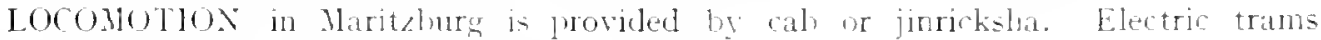
will prolably he introluod in the near future.

The street plan of Pietermaritzhurg has becn specially prepared hy the Borough PLAN OF PIETERMARITZBURG Engineer, and will be

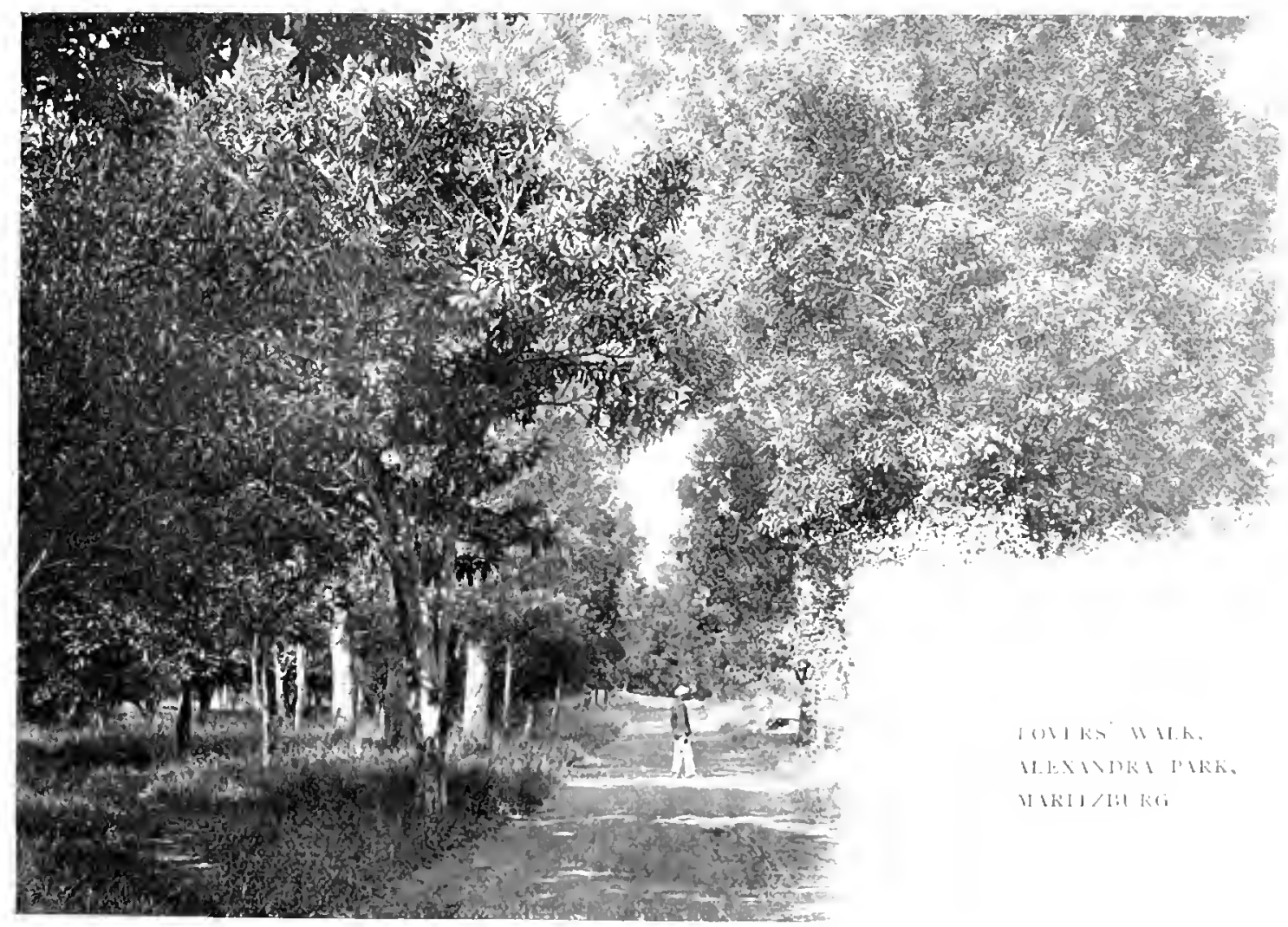




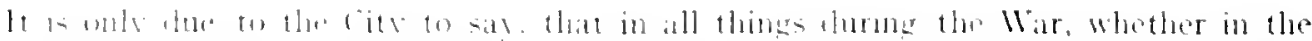

$C .10 .1310 \times$

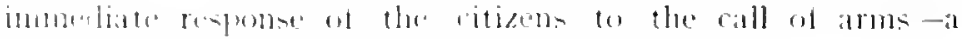

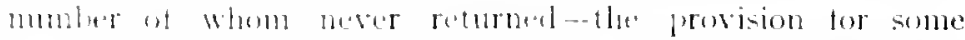

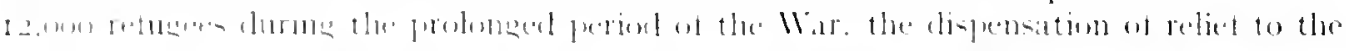

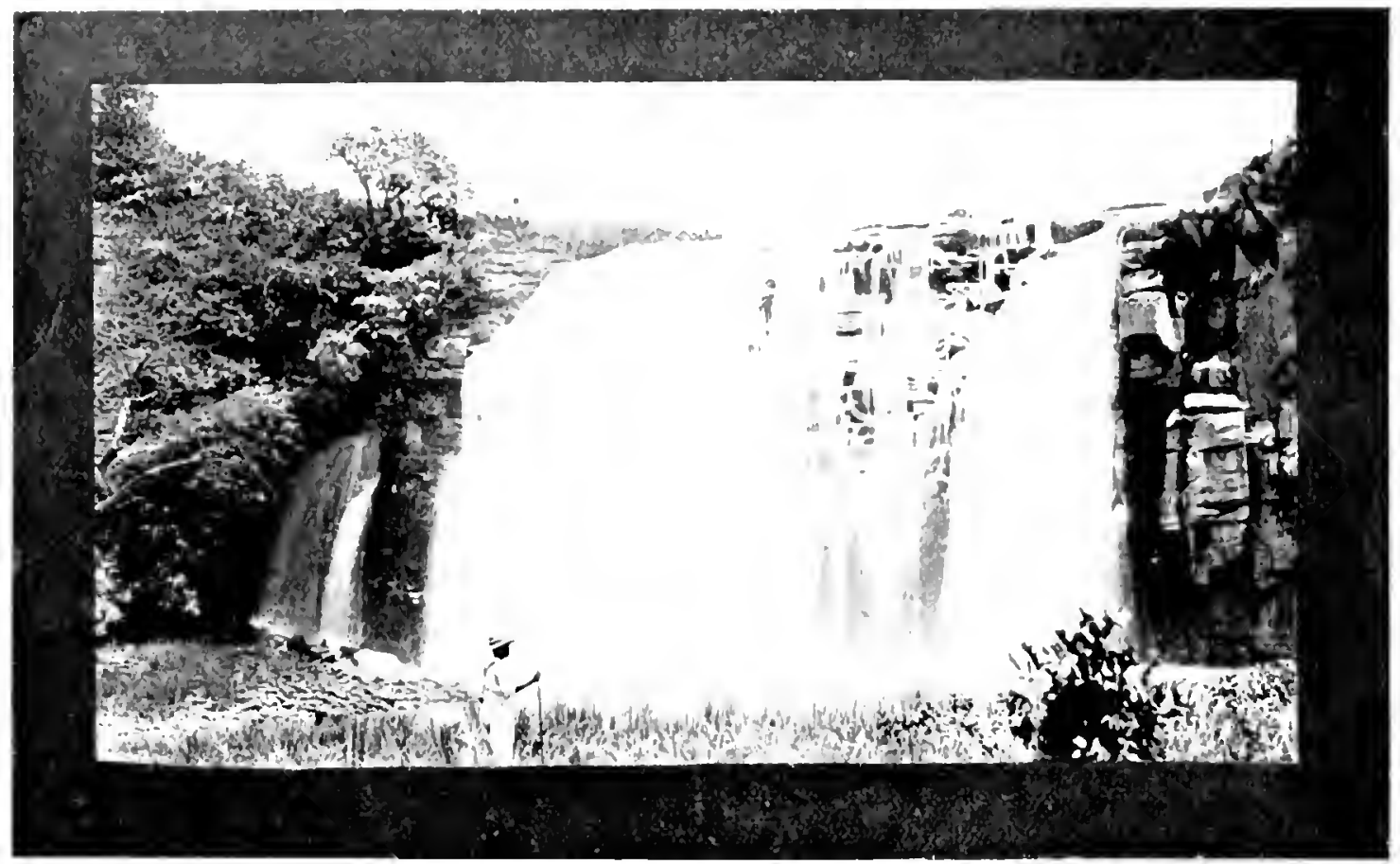

$111 \times 1111111$

intigent anmenget them. of the surcomring of the sick and wounded in their lospitals,

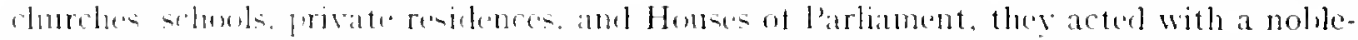

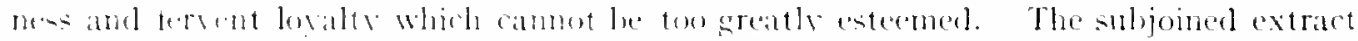

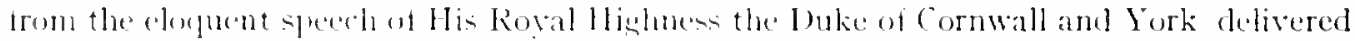
at the ofening of the $\mathrm{X}$ (w) Town Hall in Sugust, Inor, will be kejet long in honourable. remembrance:

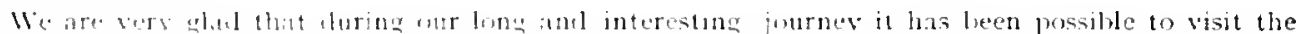

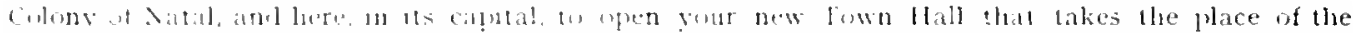

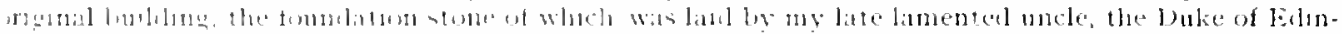

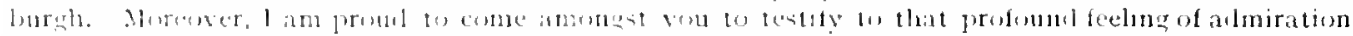

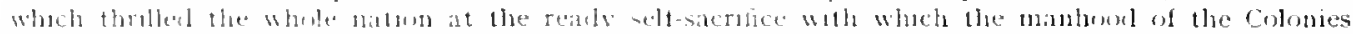

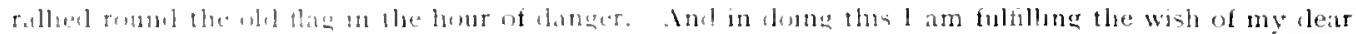

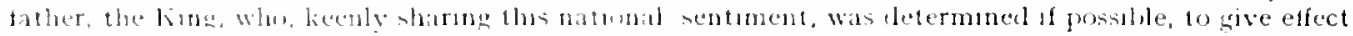

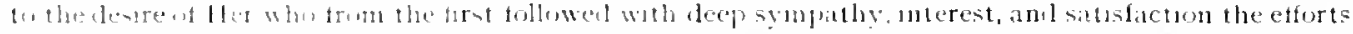

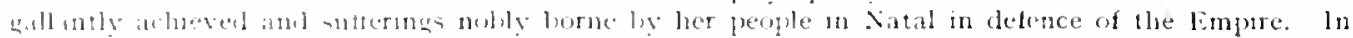

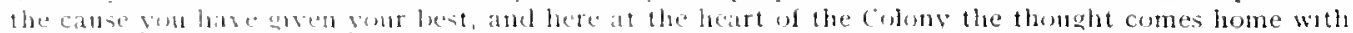

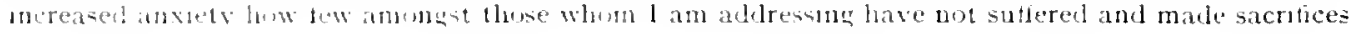


on account of the Mar. We cifer nur leepest stomathy with all who sent then dear ones to the froms never lo return. These sacrifices have nut luen in valn. Never in our hstory dul the pulse of the

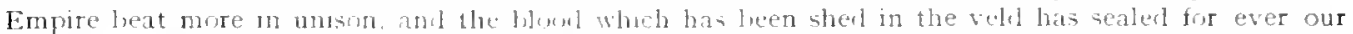

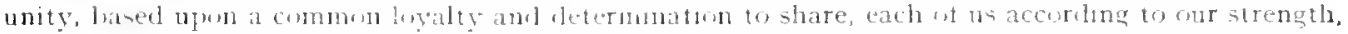

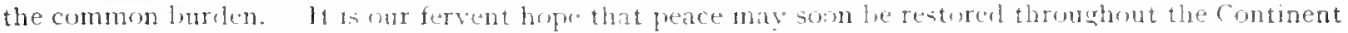

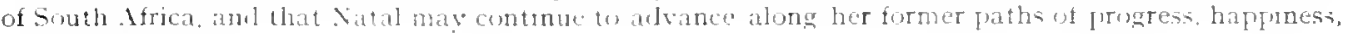
and prosperity."

\section{CH.APTER Y.}

\section{IRROA IPETERMARITZBURG TOO MOOI RIVER.}

$\mathrm{R}^{\mathrm{r}}$

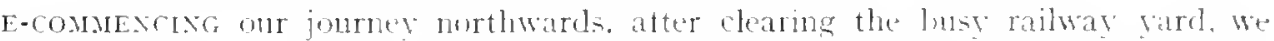
have upon our right a wide-spreating plain with a lofty range of libls ir the backgromel. Fiving our eres upon the predominating peak - the Zwaurthop-

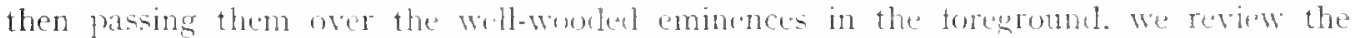
pleasant sitnation of the botaniral Garkens. the Waterworks and the leantiful Town Bush, and Chase Valleg alrearly namest. It the lase of the hills is the suhurban station

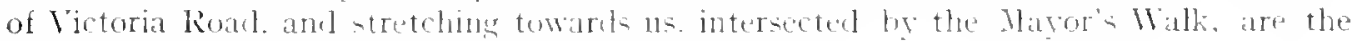
Dilitary Parade, Pole, and Recreation Cirounds.

The Electric lighting Horks, we notice. skirt the line, and the large Inick sheds, located some distance (o) the nonth-east. are the stables of the railway loromotives. Jielow the latter the Grevtown birinch Line runs.

We are now toilines up the Tuwn Hill. On the right we pass the site of the boer Refugee

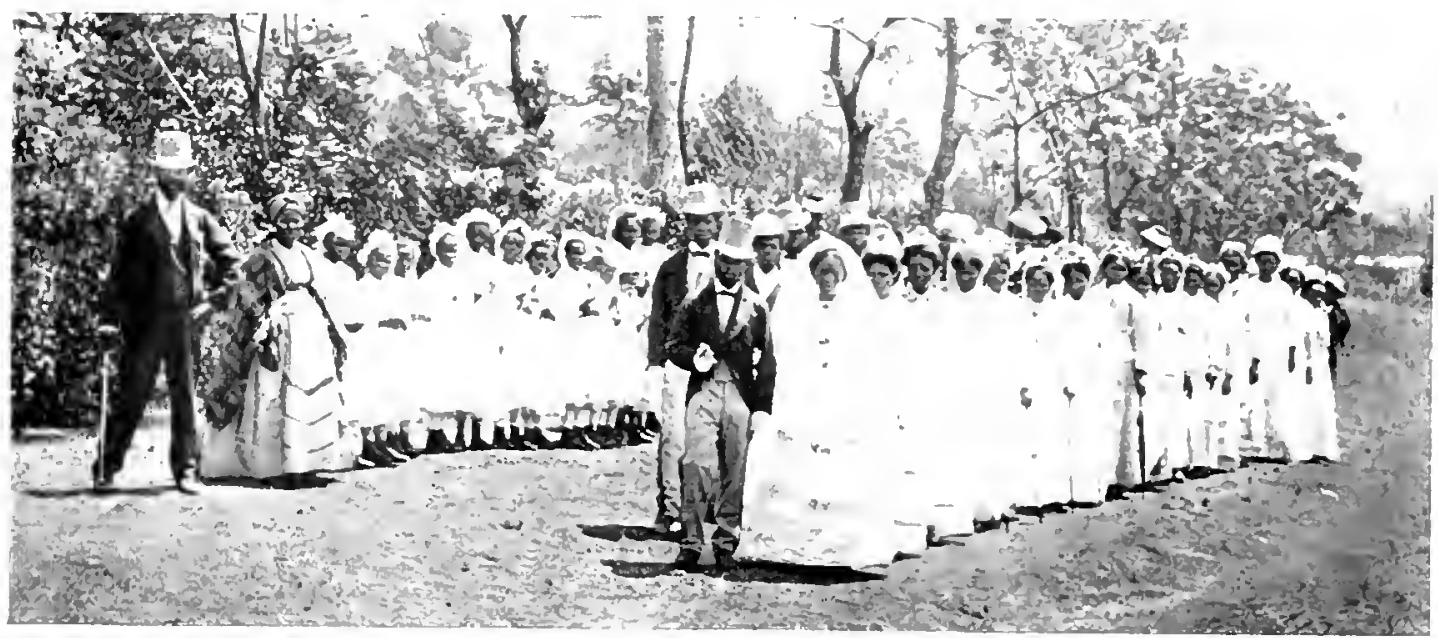

CIVIIIZED WI:1)

Ii II. Cane:

Camp, on the left is Fort Napher, with its numerous buildings and works. In a moment the Military Cemetery appears in sight.

Passing the sacreal field where offecr and man are lronght to the same nohle level, demanding one equal. reverent rexard. We wind slowly up the diffentt steeps. past the Military Camp Siding, and sex, hir below our feet, an inmense farm-and-hut-spected 


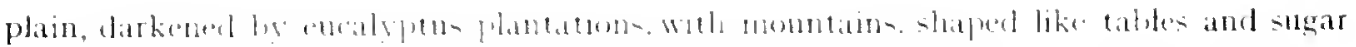

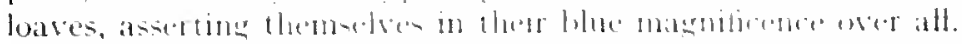

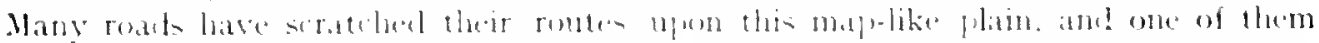

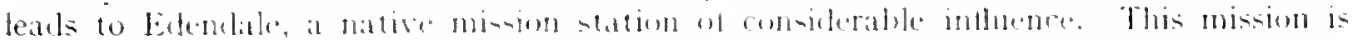

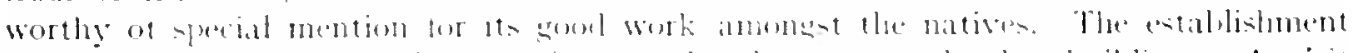

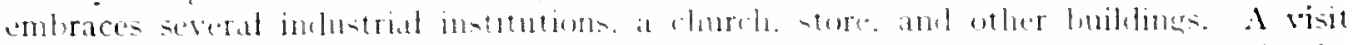

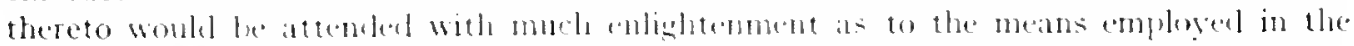

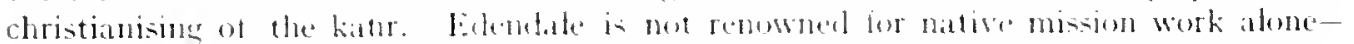

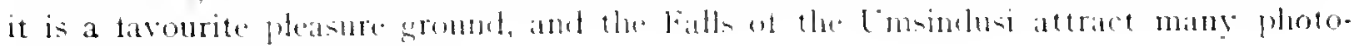
graphers amel otler visitors.

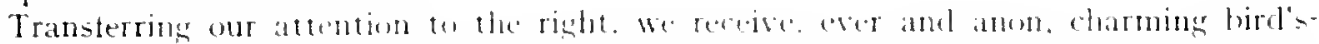

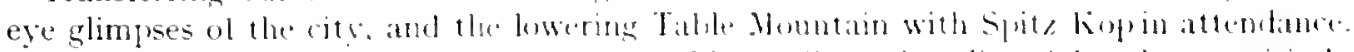

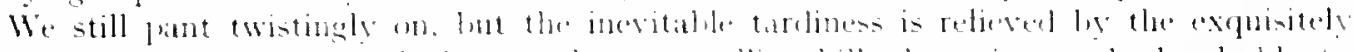

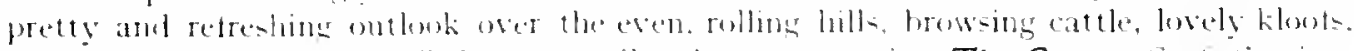

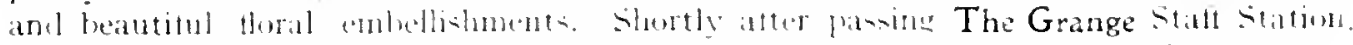

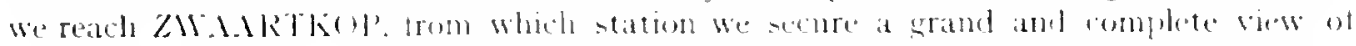

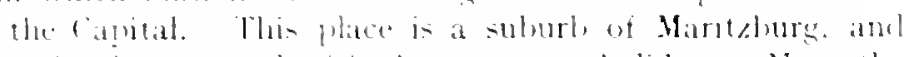

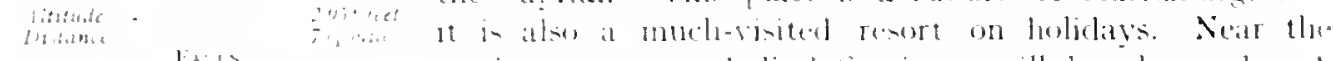

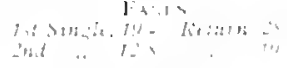
station a somne latlies" seminary witt he observerl. A

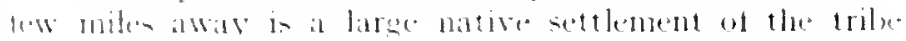
which hat lor its a heet

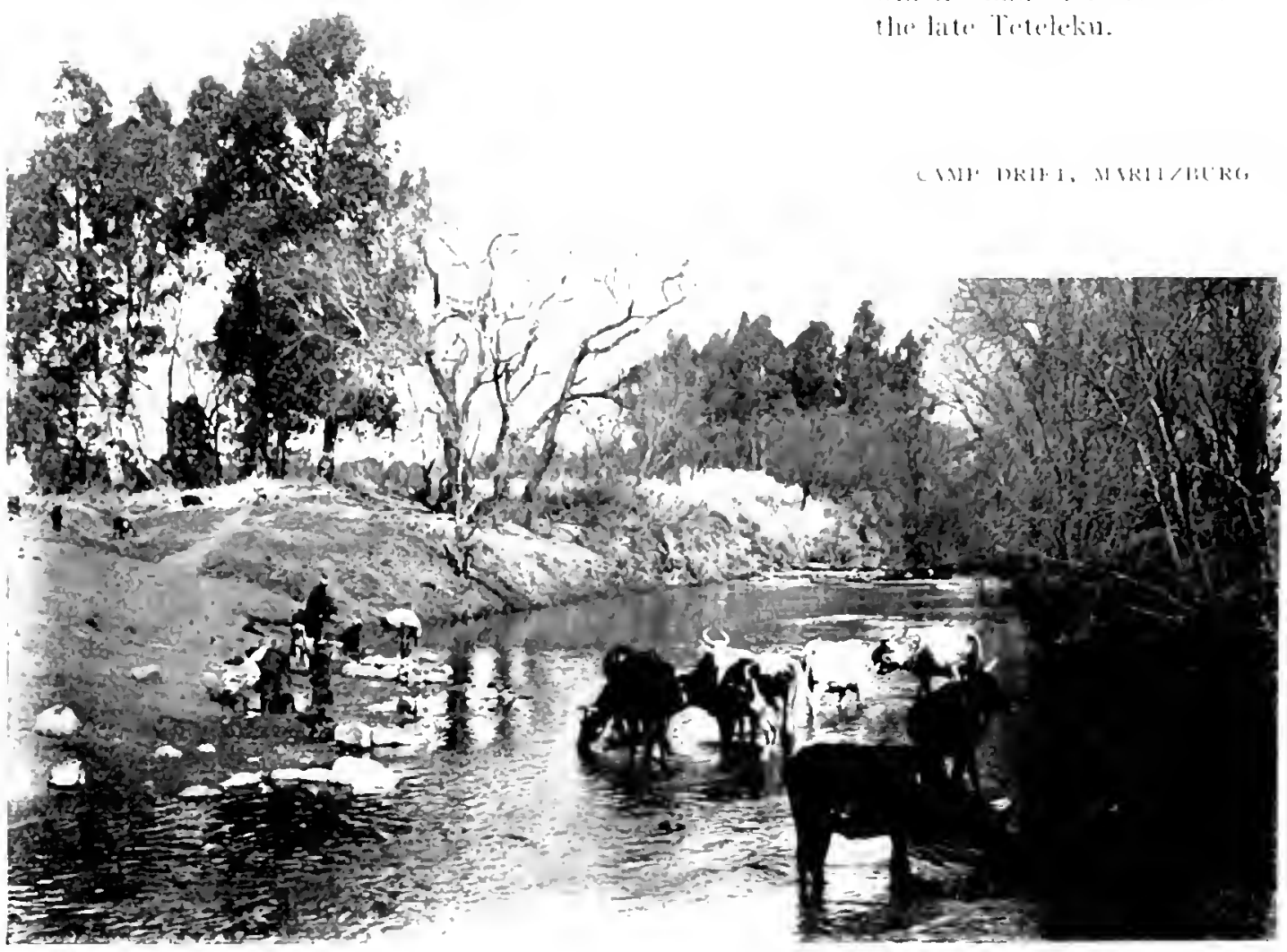


Leaving Zwaart kop, we advance to a still higher altiturle, and traverse one of the most charming pieces of country imaginable. The risht hand gives us a view of two score miles of undu. latine land. and the left presents us at intervals with evergreen hush and creejer. covered kloots. So near are they that we may aimost truch the trees and fernfrilled rocks. and hear the ripple of the Sweet Waters, as this spot is called. Winding through the cuttings to a greaterelevition. ve gain another of Nature's similar lavishments, Winter's Kloof, where a station has been established. Needless to remark. hoth Sweet llatersand Winter's Kloof are favourite pic. nicking haunts.

The end of our ascent is not ret.

although we have risen mearly. 1.200 tert sinco leaving Pietermaritzhure-and it is necessary to pause for a tew minutes at Bo-HOFF's RoAD for locomotive watering purposes. After accomplishing this. We make for one of the most important wattlegrowing centres in the Colmy. Hilton koakl. ()n the hill to the right we descry at

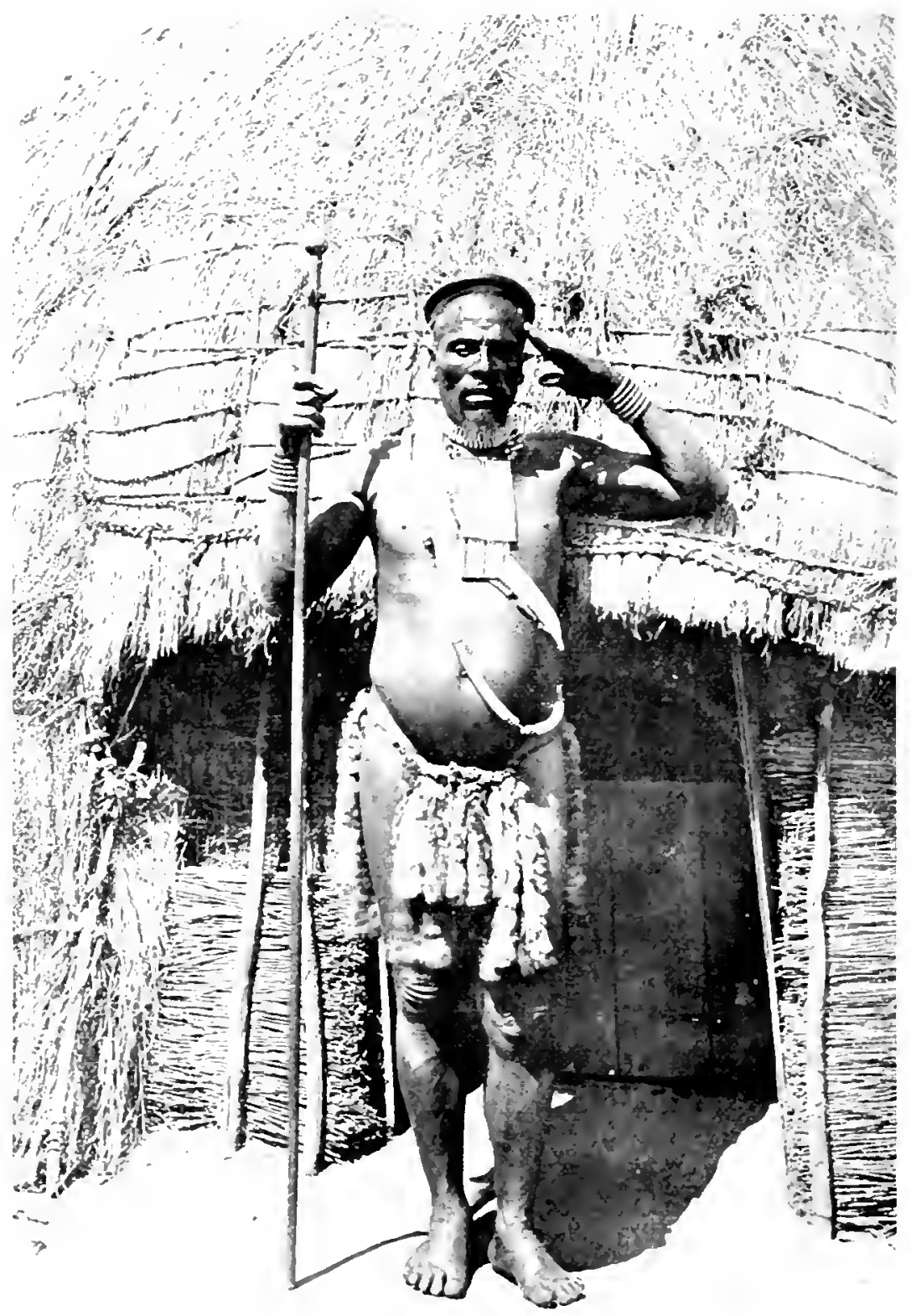

kill cill $1111.11 \mathrm{ki}$ 


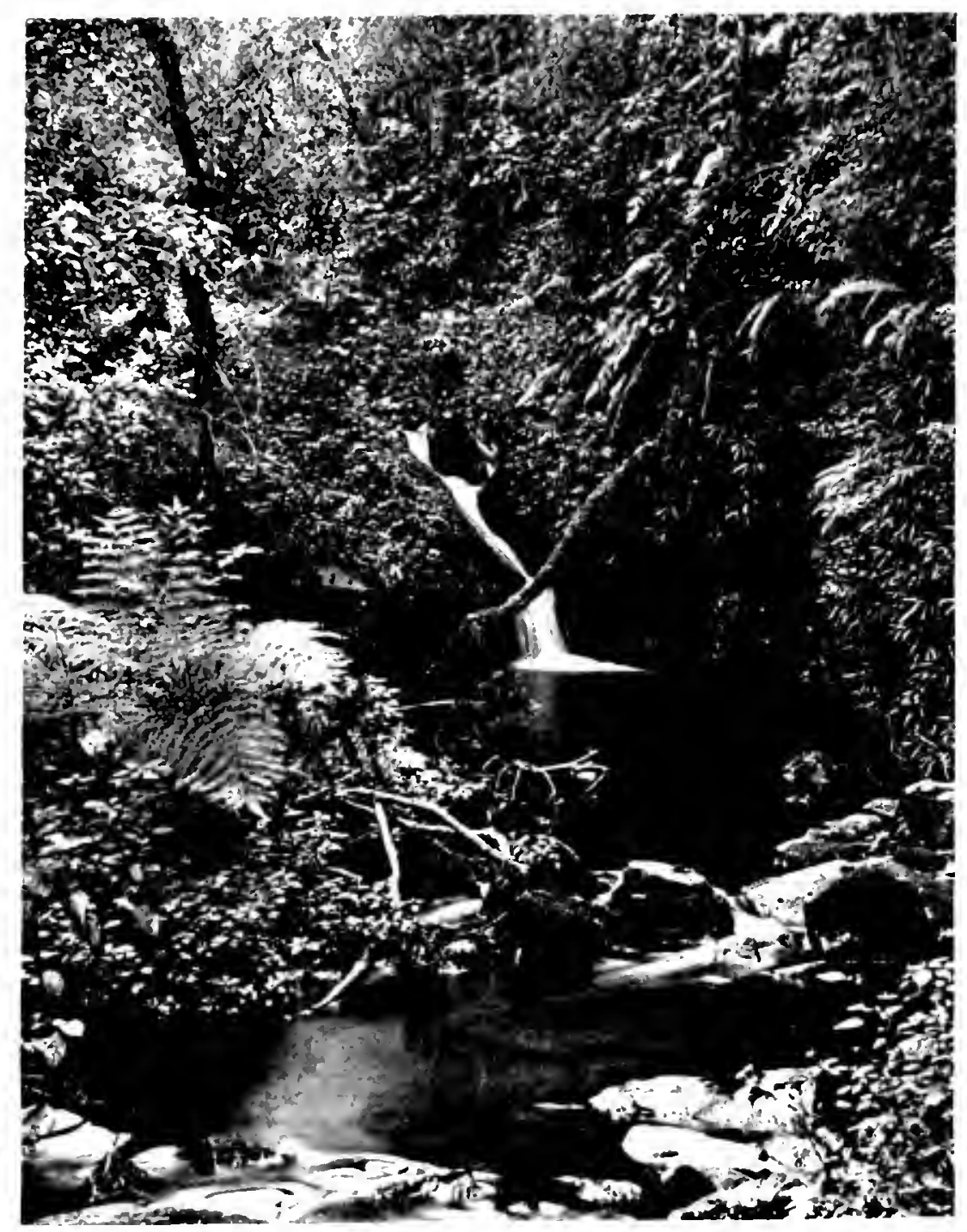

$\checkmark 111$ I $11.11: 2$

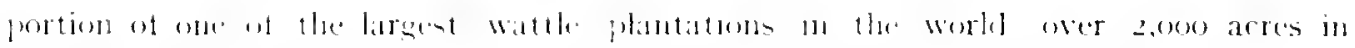

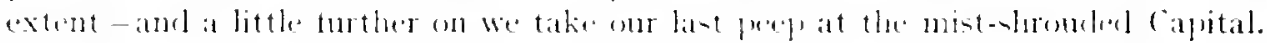

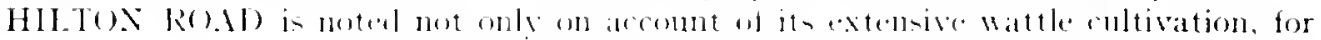
it herats at boys' collenen: it is an increasingly popular

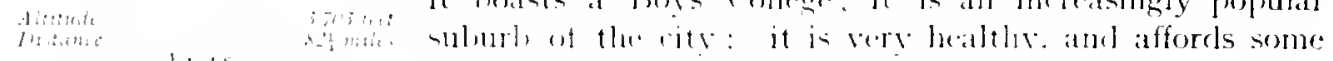

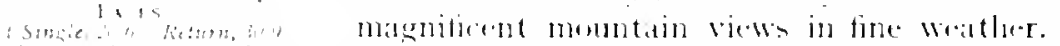

After Hilton lioal. We winl combrtably through a

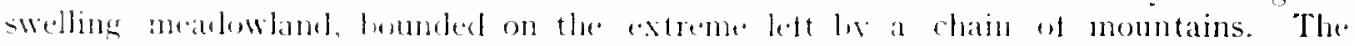

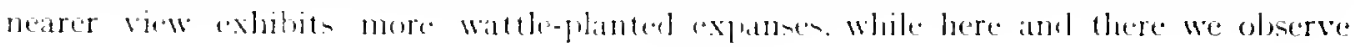




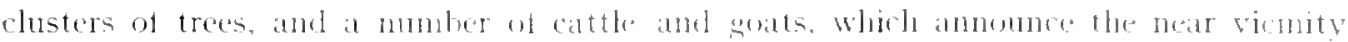
of farms. Presently the kiver Lmeni and the luxuriantly situated village of llowick conse in sight.

HOWlCK needs scant introcluetion. It is iustly tamed as one of the chich bealth and

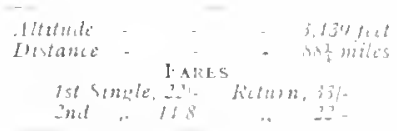

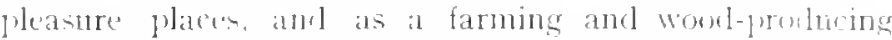
district it is also of some account. The rheot attraction lies, of courso in the celedrated Limgeni Falls. The river at this proint dashes over a precipice sto teet in luesht. In the rainy season, especially, the sight of this sheet of water, stretchine sheer from top to the of the mighty rock, is thrilling and magnifuent. The kar klorf Falls. sume eight to ter miles higher up the C'mgeni, are in no somse interior in splendour. Ther are formed by tiers of heantitul cascarles having an agregegate descent of over 35 foet.

The village is situated abont two miles trom the station, and carriages trom the "F fulls and "Castle" Hotels, meet all passenger trains. There is also an hotel locater near the station. Accommorlation is much in chemand at all three. There are three eluneles, a Public Lilorary, and various clubs in the villige, while gond fishing may le secured above the lalls.

Passing on, and orer tle iron structure which hrieluges the river, we kerp the Emgeni in sirht. and may discem disciples of the immortal Izaak busy nith rocl. line, and $\mathrm{H} r$, teasing the timid tront. Almost as we watch, we run throngh Hos. pital Siding which markstle location of two larece camps during the war, those of the Hospital and the Poer retu gees. At the latter some 3.500 men, women and chil. dren were provided lor. As we proceed, the comntry maintains its leantibul wattle-timbered character. and mealie and rengetiale fields break the sanemes of the grass lands. Fern Hill (Swan's Crossing) is now quite near, and as we spreal by, we catch a glimpse of the prettily-set Sanatorimmhotel, which is the resort of many visitors during the summer months. We soon make another stopling place, rejoicing in the name

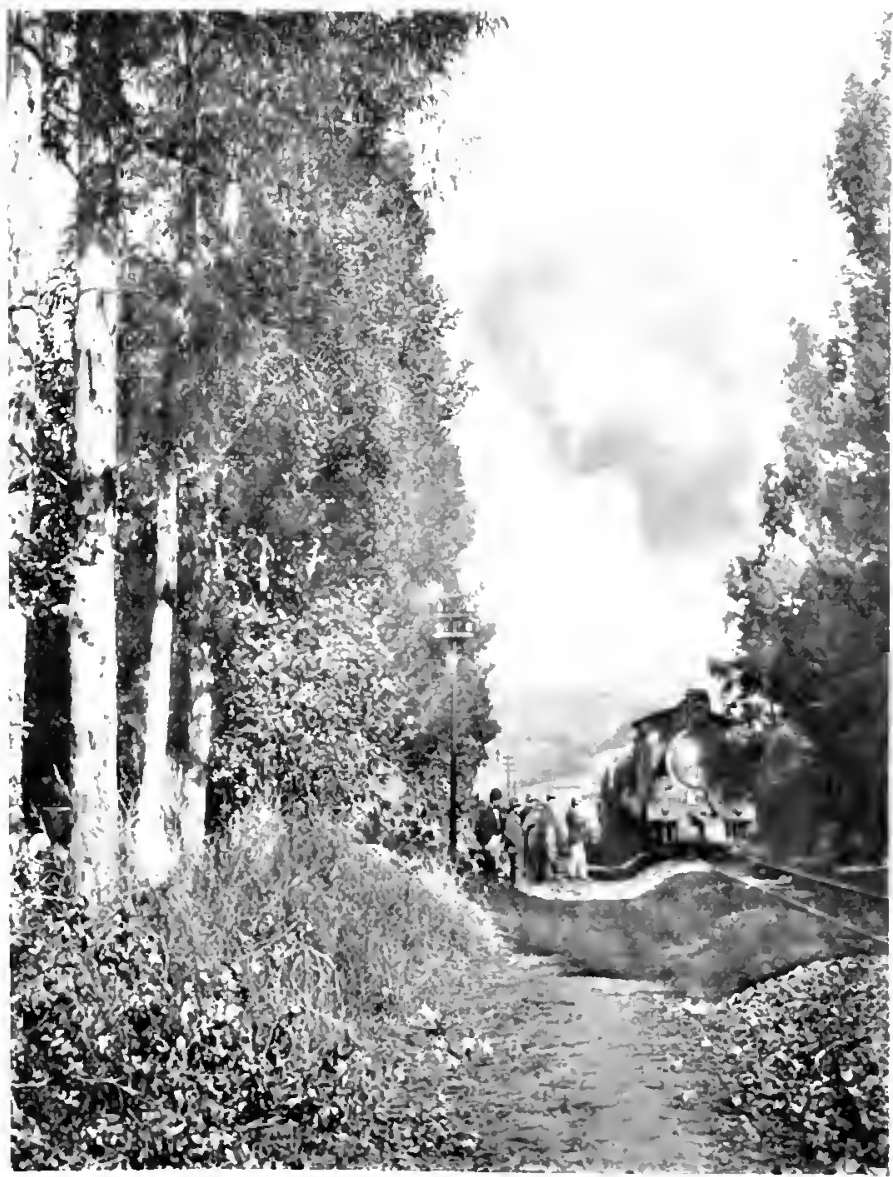

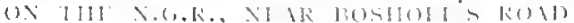




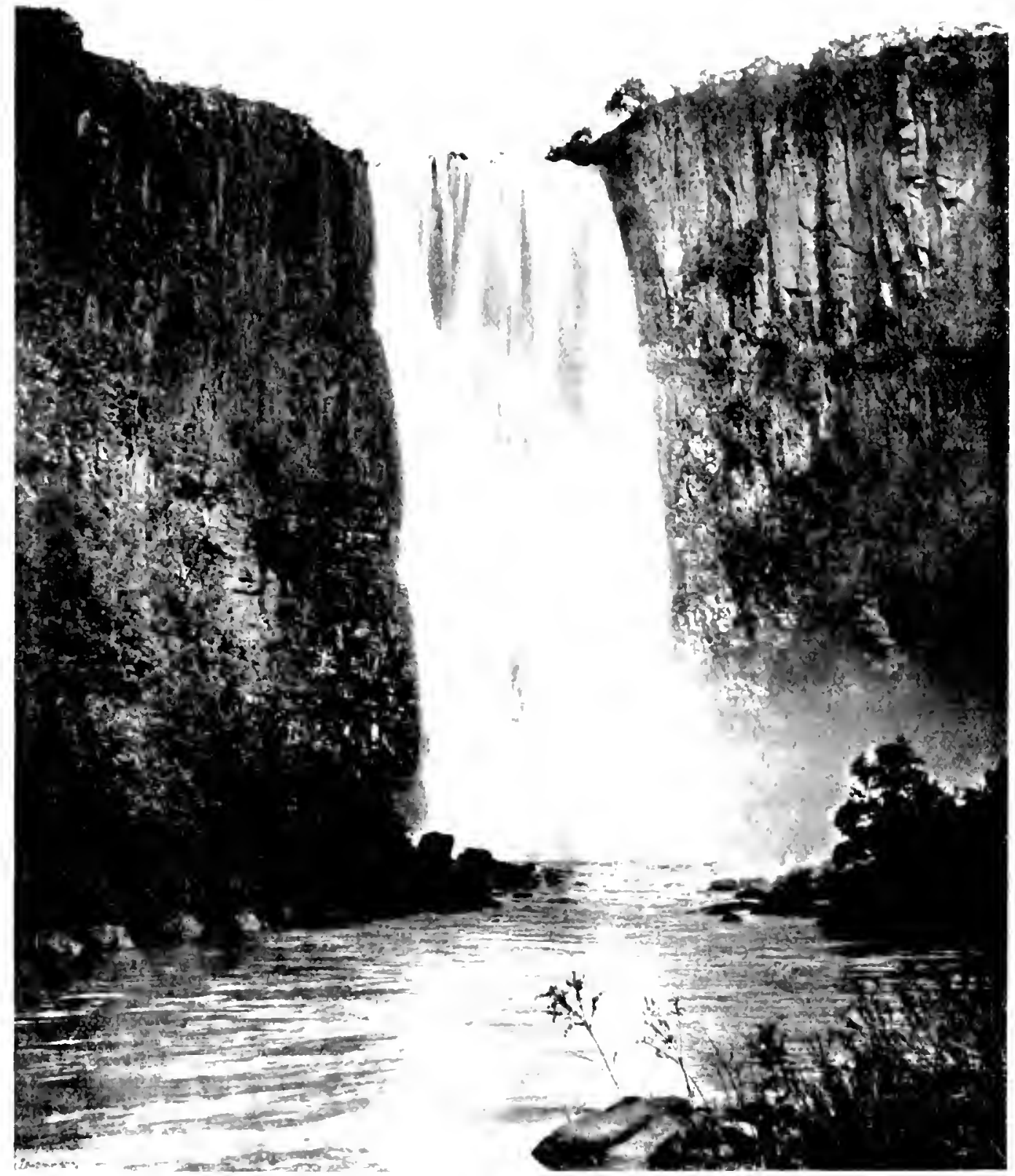

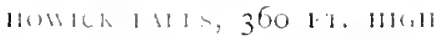


of "Tweedie Hall," a station serving a flourialning wattle and dairv-tarming distret. Now we make for the gateway of the Dargle and Impendhla settlements, particularly noted for their horse and stock-hreeding, as well as agricultural pursuits. Indeed. not only these jortions of the Colony. lout those all along the raiway from here to Hooi River are especially adapted for these occupations. as well as for wattle-erciving and dairylarming. Good clay is also obtamable. and the brick-maling industry has been started at several points within the area. As we apleroach

DARGLE ROAD. we notice that the steep contry to the left is wertopled ly marquee-
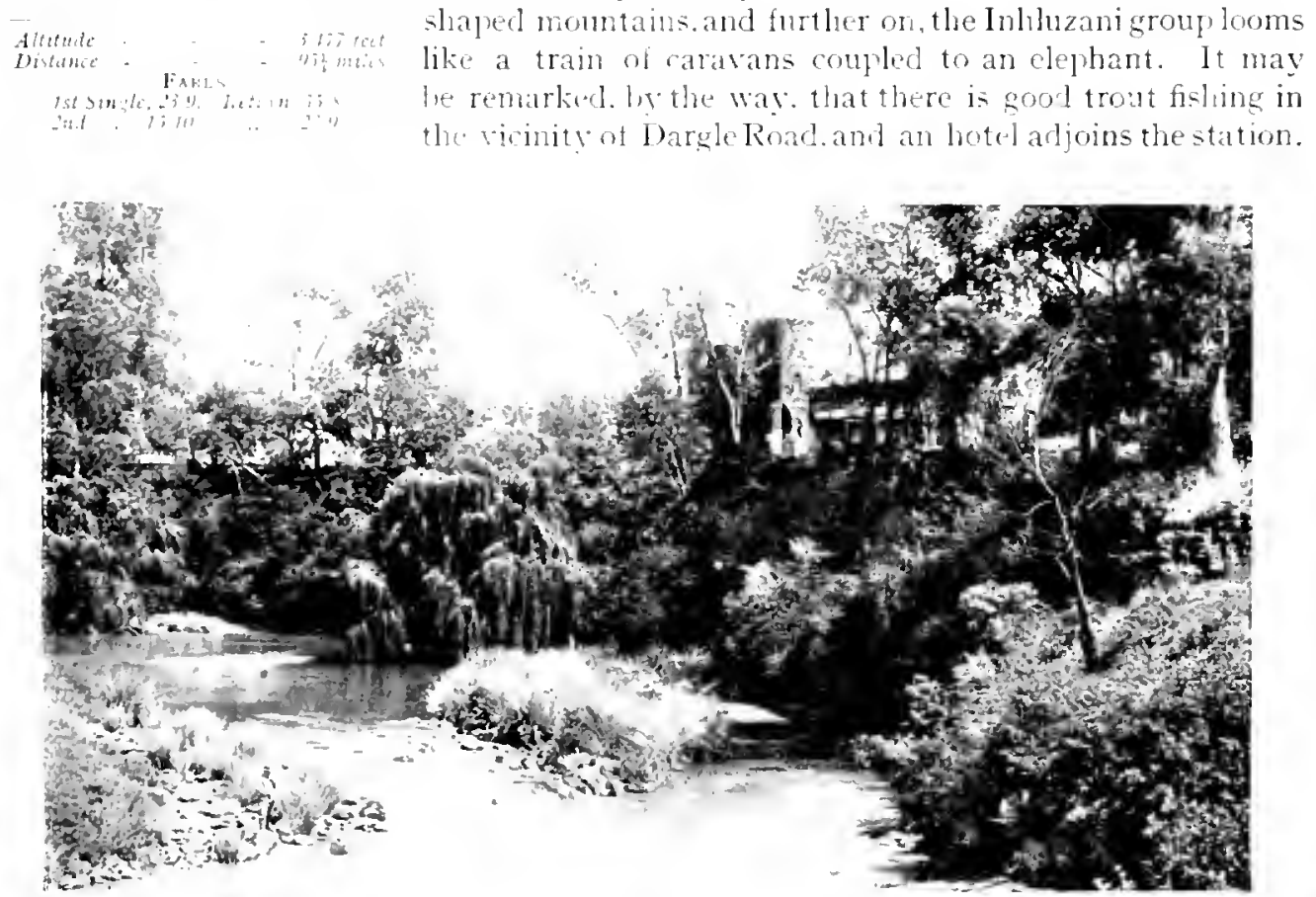

L"MGIYI RITR, HOWLA

There is little to rivet our attention atter jansmg barele. sate the rustic wooden bridge over the Lion's River-lowing oll and decrepit compred witl the iron span orer which the railway passes-and perhap's an ox-wagon with several slothful Kafirs in command. It is a striking picture of the old style and the new. In a little while we comimence the negotiation of another stiff serpentining climh. At the top of this ascent we receive an extremely fine panoramic view of the country to the lett. and notice that the former swollen lands are now reduced to sightly motnds, the pleated hills are streaked with dark brown foliage. while scattered promiscnonsly ahout are a number of lian lints looking no bigger than ant heaps.

LIDGFTTON is soon afterwards reached. This is a vers arreente hamlet. where a

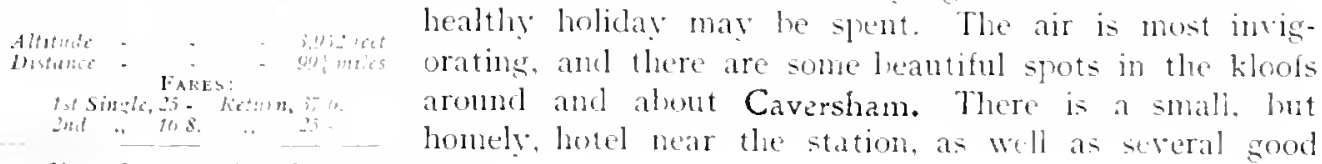
loarding houses in the vicinity. 


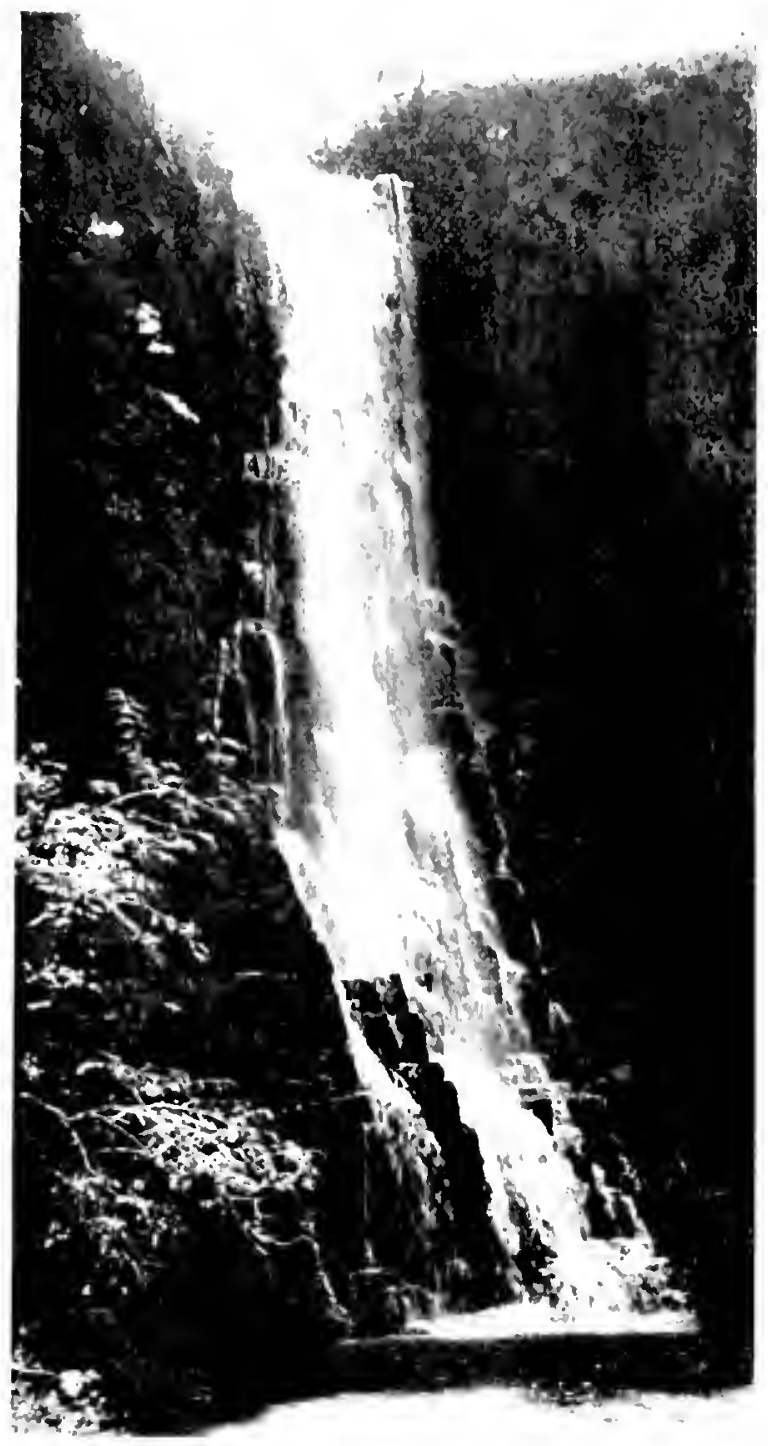

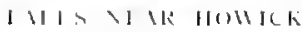

station and"school hetore pasing lla two staff Stations of Lynedoch and Kingston,

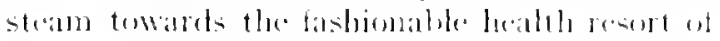

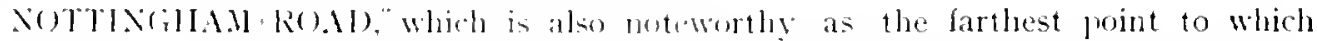

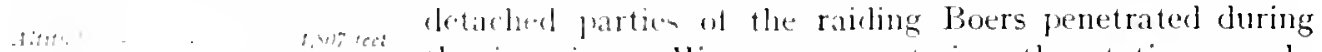

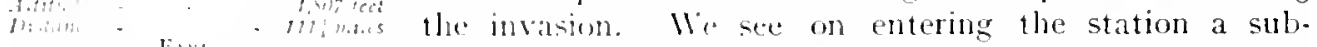
, sn stantial two-storeged hotel and several other buildings,

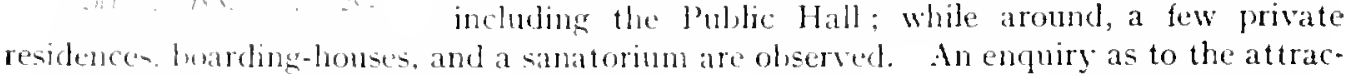

Parting trom this station, we cross a second liridgeover the Lion's liver. This stream, it might be said, is neither remarkable for its roar, nor for any other leonine jeculiarity. but It gives some pretty falls abont a mile from the station, which we view in passing. A little beyond the falls will ha olserved a delightinl picce of pastoral and woodland scenery. Immediately afterwards we enter 11] wh the rougher-surfaced country, "ith hig boulders and stones strewn in all directions.

BALGONAX is the next patssenerer station. and here, while the emgine is refreshing itself, we may

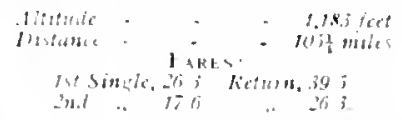

do the same with the light lare provikled at a moderate clarge. Taking a forward view of the comntry, we sore, standing a little way lack from the railway line, a red bick erection, with a srpuare tower surmounting an archwaly. This is the new Mlichacl Jouse Collexge. It was huilt with the latudable object of providing a imblic school conducted on precisely. the sime lines as those in England, with houses and house-masters. all, of course. 'Varsity men.

There is no hotel at Balgowan, but at least one farm is open to paying zulcists.

l'roceeding, we make a long curve, atwd taking a farewell view of the 
tions of the locality would elicit the answer-fishing. shootnge, nding, tennis, health, with an unmistakable emphilsis upon the last-named.

The air is unexceptionalle for reculerative purposw. The Drakensherg Mountains lie about thirty miles away and atter leaving the stition, its two famous castles. "Giant" and "Champagne," are disernilile on the lett, l"rom an agrienltural and stock-raising point of view, especially the latter, the district is prosperous. Farms have been largely. taken up under the berg during recent vears, and the importation of valuatile thoroughbred stock from home has greatly improved the herds. In the luck-shooting season, a visit to the Drakensherg from Suttinglam Road would not only prove an exceedingly enjoyable and profitable excursion trons a sportsman's standpoint, hut other persons undertakine it - of course provinger for their absence from civilisation tor a week or two-

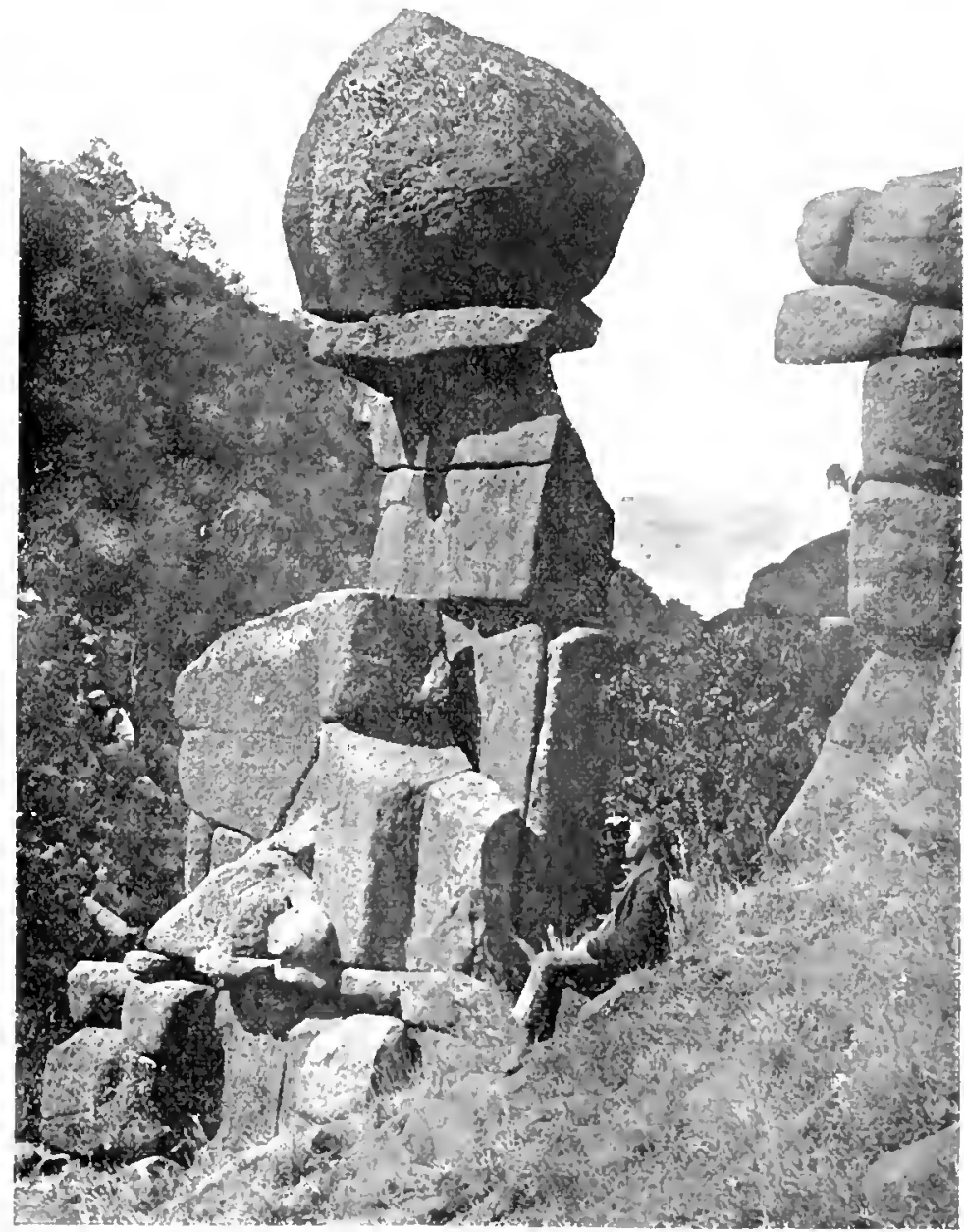

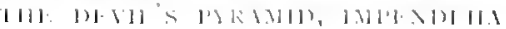

1: 1/2,itichon: 


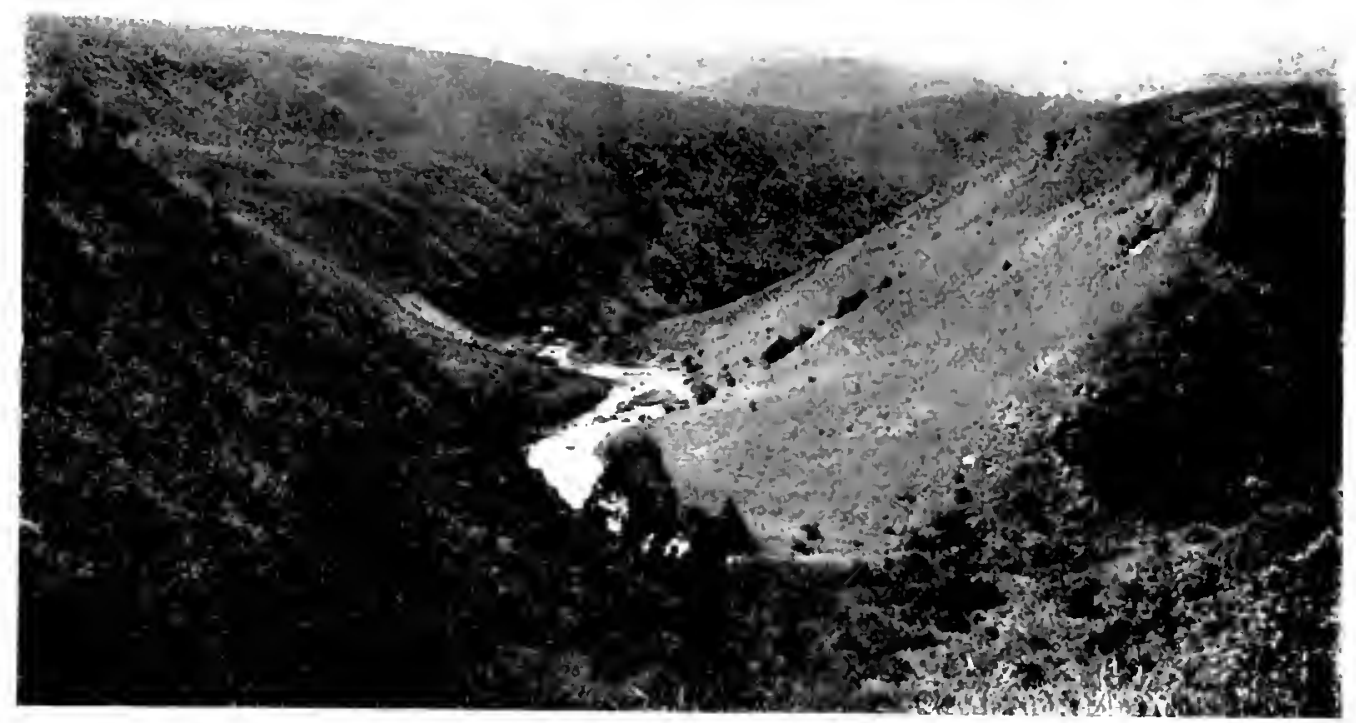

Uagk KI KISK

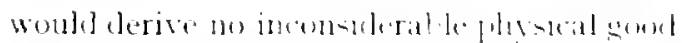
from the exhilaratiner solomm ammenget lhe

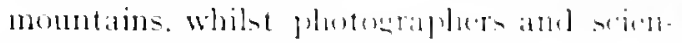

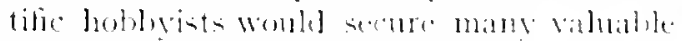

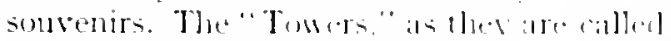
a seritalide lusur nuture, wombl in themselves repay the jommer. There they-tamel.

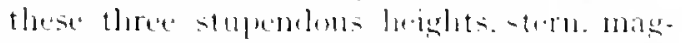

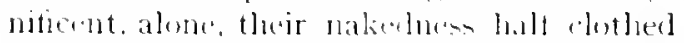
by tresase of long sillinn pram, while rugesent precijices gaze in awe. ame thithm kerep theme each inviolate mishty monument of

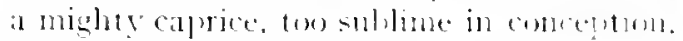

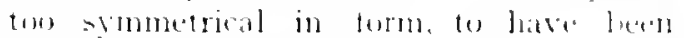
cliselled ly mortal hamels.

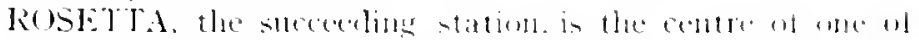

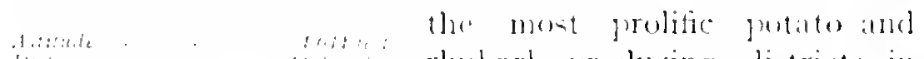

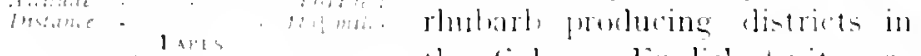

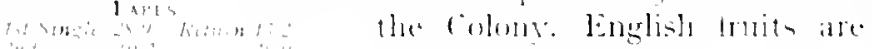
alon larendy gromin.

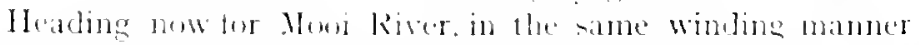
as the cand-hke stram whe?l we have as comprany ler

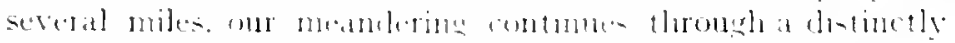

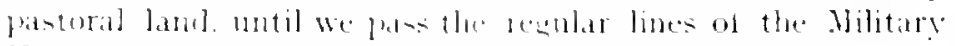

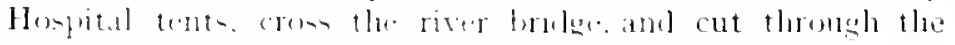

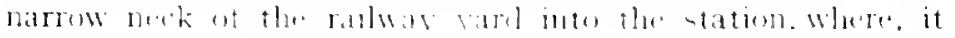




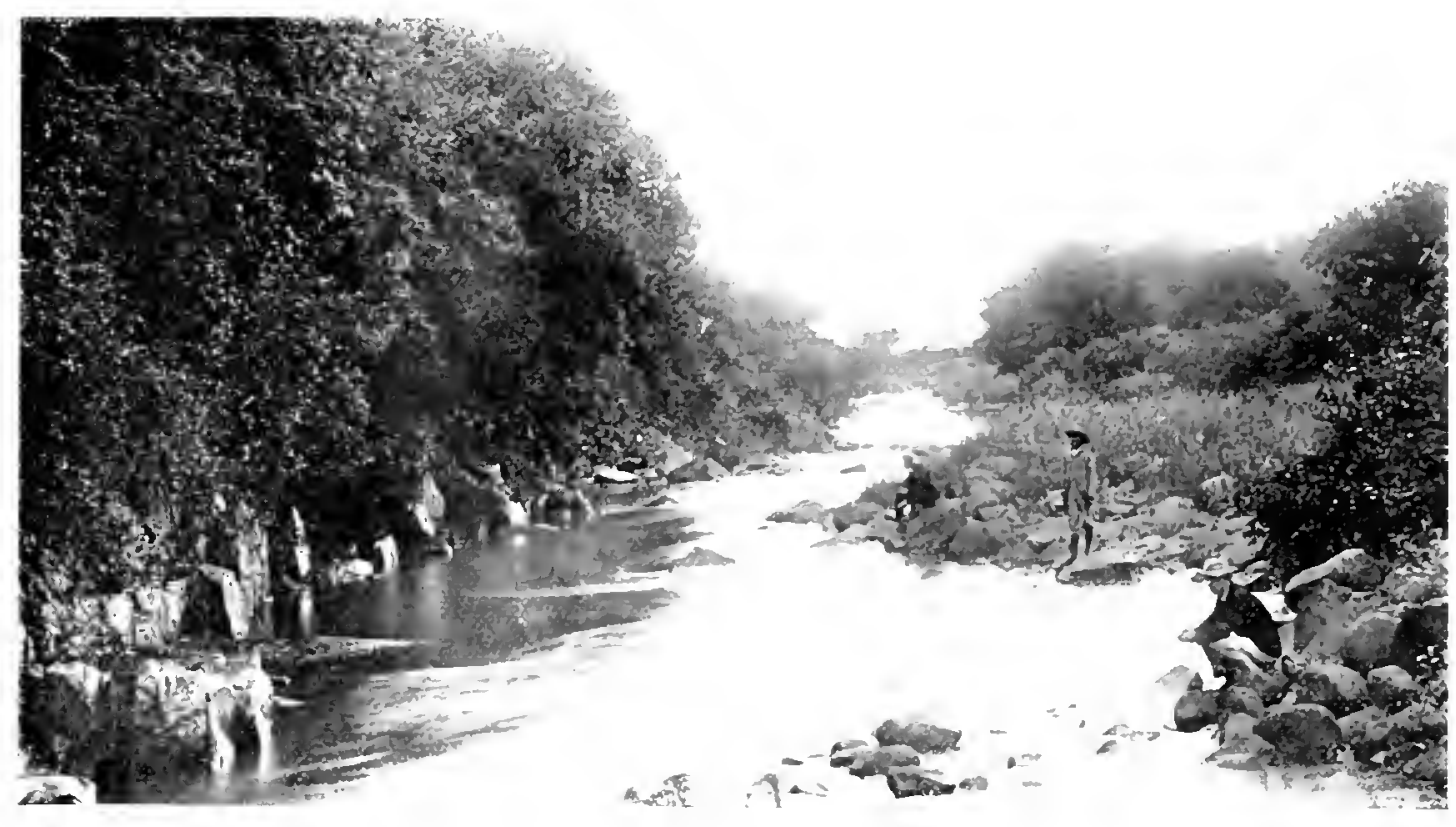

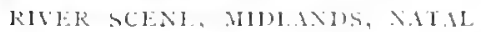

should he noted, a sufficiently lons stat is made tor retreshments.

IIOO) RIVER is not honest to its name. It cannot. by any posible stretch of

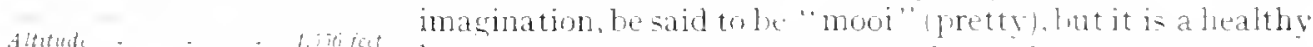

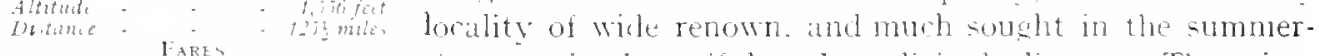

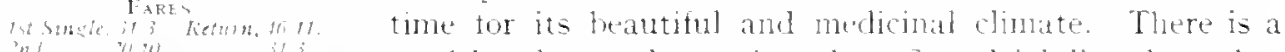

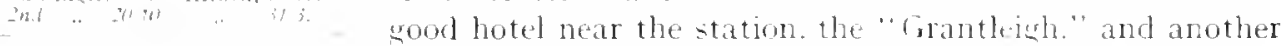
ahout a mile away at Weston. the "Lake," a very commotious and picturesque hostelry. some fine talls recur in the Hooi River, about fifteen miles awa.

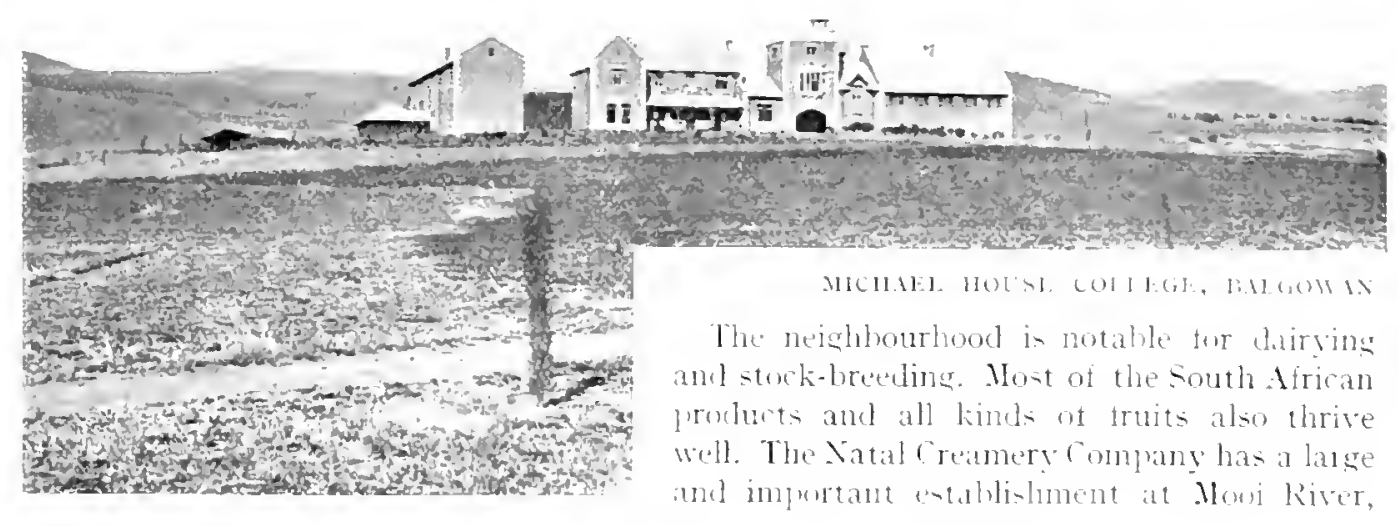




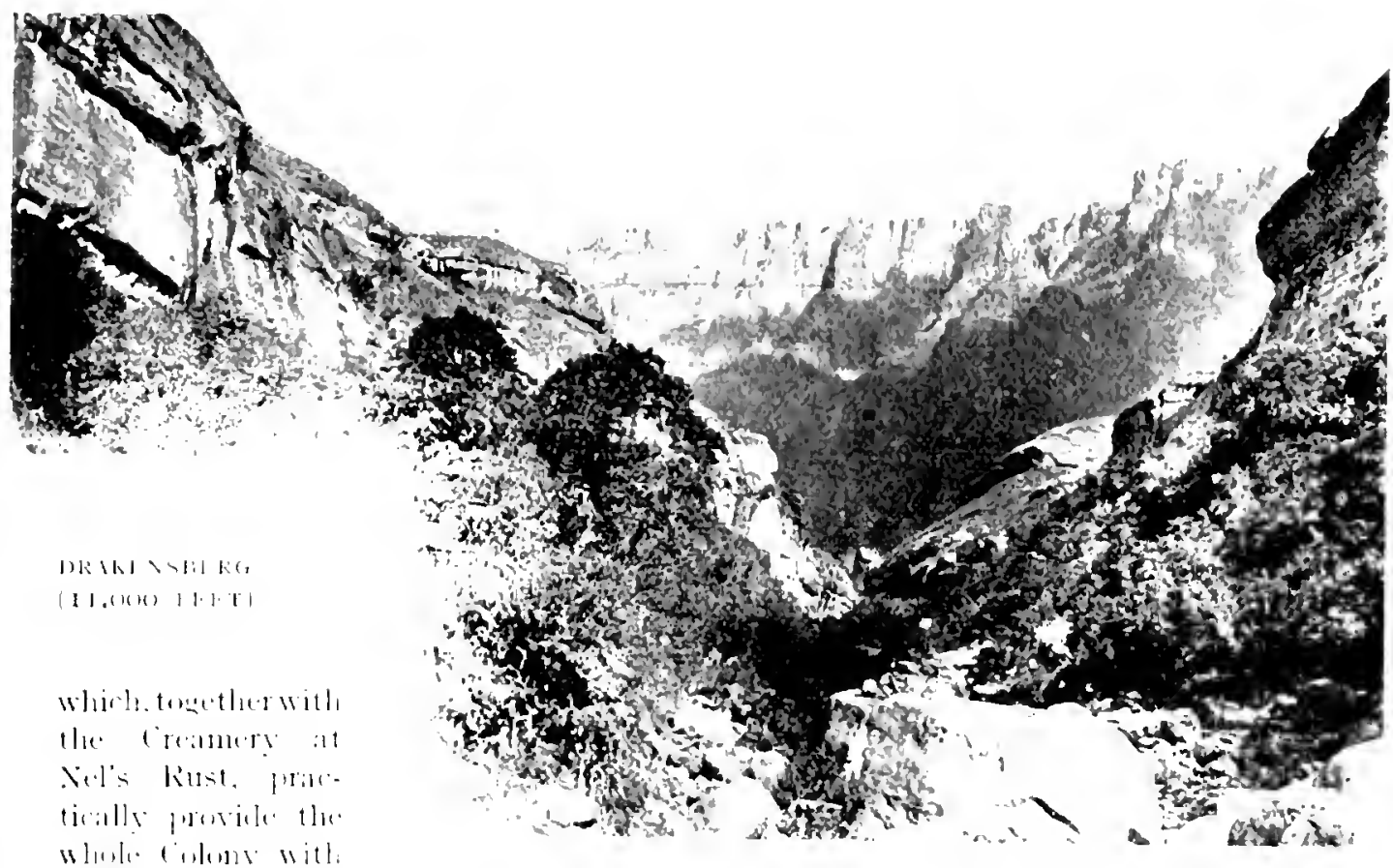

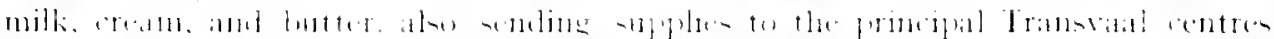

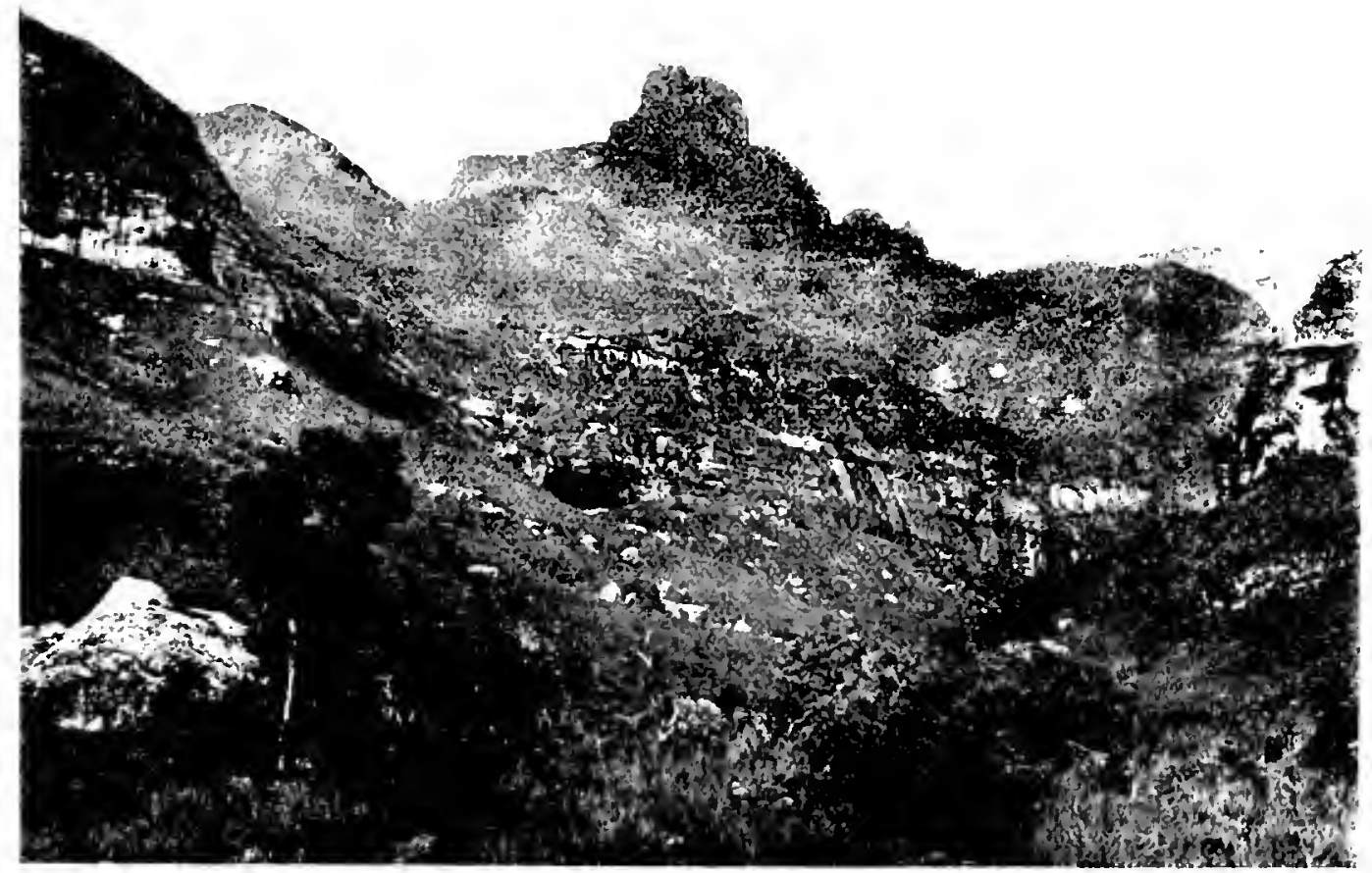

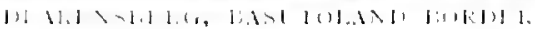




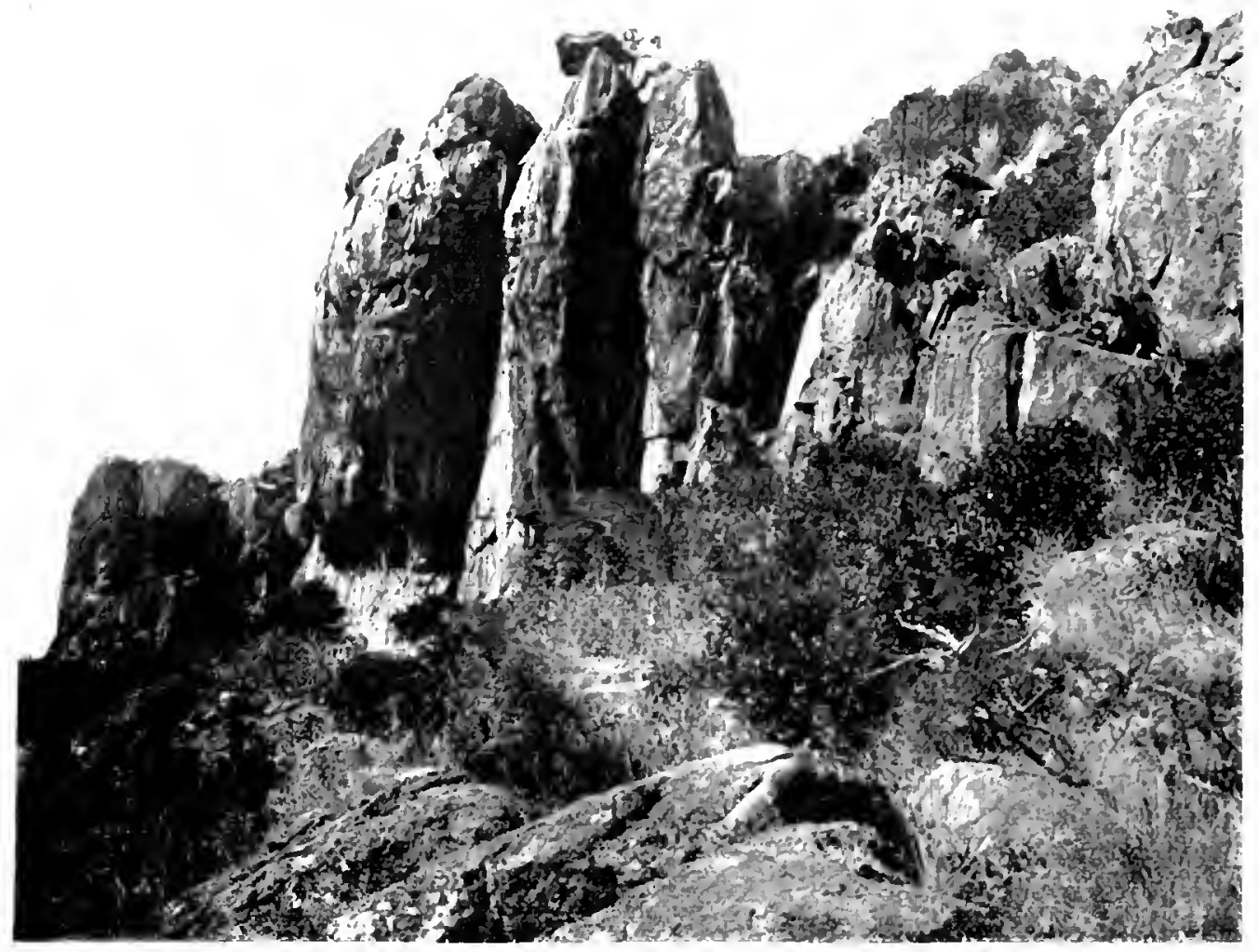

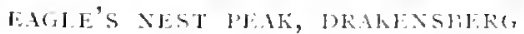

REIT VLEl, a considerable larming and stock district in Lmoti Counts, is reacled by post-cart, which runs from Mooi kiver station every Tuesday and Friday ahout I. 30 F.m., fare I2s. $6 d$.

Mooi River is historic as marking the termination of the Boer invasion under responsible leaders. The enemy was certamly observed farther south, kut, as previously stated, in disconnected bands. The operations in Natal may therefore be said to have commented from this point, and are distnctively treated in the following pages, which, in addition to encompassing the attractive seenes observable from the tran in passing through the War district, will, it is hoped, present a reliable atale meitum for the guidance of visitors to th: various battle grounds and interesting spots incidental to the Natal Campargn. 


\section{PART THREE.}

\section{THE MAIN LINE OF RAILWAY \\ Continues.}

THROUGH THE WAR DISTRICT. 


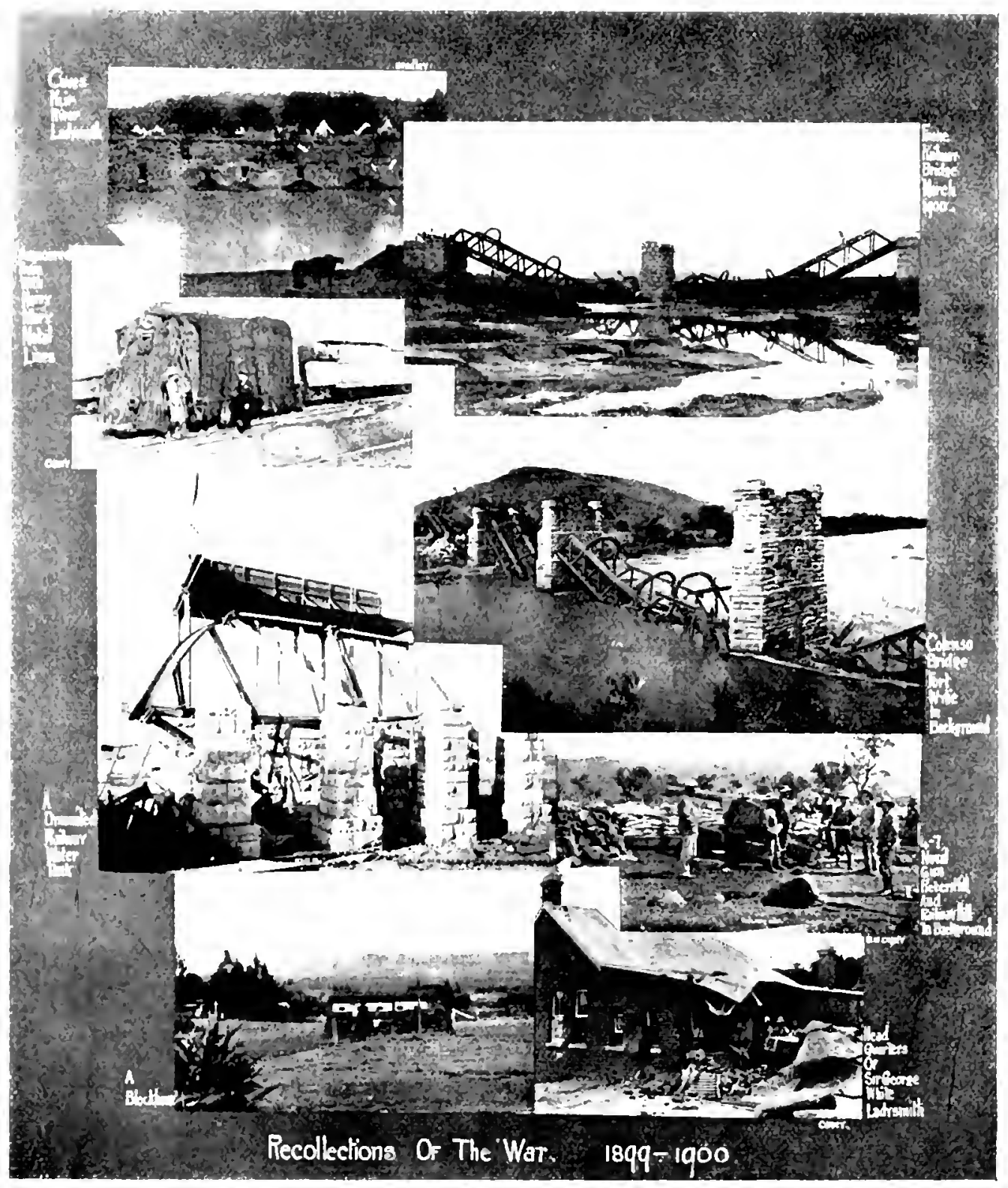




\title{
PART THREE.
}

\section{THE WAR DISTRICT.}

\author{
CHAPTER 1. \\ INTRODCCTORY.
}

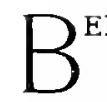

EFORE passing into that district wherein were enacted those noble deeds, and where occurred those grim and stirring episodes which have photographed themselves upon the imagination of the world, it is desirable to mention that except in a few instances, notably about Estcourt, between Colenso and Ladysmith, and Eurther on between Waschbank and Glencoe Junction, there is nothing exceptionally picturesque in the LANDSCAPE visible from the train, although a deeper search would be rewarded with seenes both bold and romantically beautiful. The visitor will review many notatle and historic hills, the nuagniticent Drakensberg and Biggarsberg Mountain ranges; broad alluvial valleys: important rivers; and a number of kafir kraals; but the verdure and loveliness of the Jower portions of the land will not be so evident. Nevertheless this area is the most lascinatng part of all the Colony to the tourist, and attractive likewise to the agricultural and stock-farming settier.

As regards INDUSTRIAL CAPABILITIES, the northern districts are essentially pastoral, as will be gathered from the flocks of sheep, herds of cattle, and droves of horses which may be encountered. All kinds of South Alrican Produce-roots, cereals, fruit, etco, are also extensively cultivated, whilst dairy farming is a considerable pursuit. The mmense coal mining operations in the latutude north of Ladysmith, and especially in the Dundee district, are well known to constitute one of the largest industries in the Colony. New mines are being contunually opened up in different parts of the country, which says much for the abundance of the "black diamond" deposits.

Touching the matter of CLIMATE, it may be said at once that every place enjoys a bracing atmosphere, but during the winter months the uplands are occasionally very cold.

CONCERNING THE WAR. The country between Mooi River and the border of the Transval has been made the subject of an moependent part, divided into EIGHT CHAPTERS, as follows: Chapter I. is assigned to these Introductory observations; II. deals with the events before Colenso: III. with the battlefields and interesting points around that place; IV. describes the historic spots in wute between Colenso and Ladysmith; V. is devoted to the town of Ladvsmith and the Siege; VI. reviews all its battlefields and attractions, including Spion Kop and Vaal Krantz: VIl, is concerned with the country between Ladysmith and Dundee, embracing the Elands Laagte and Dundee engagements, together with a resume of the cause of the quarrel: while VIII. covers the district between Glencoe Junction and the Transvaal border, summarizing General Buller's sweeping movement beyond Lady. smith, and detailing the battle-grounds in the vicinity of Ingogo and Charlestown.

Each station within the War territory is given in exact order, and the numerous incidents and seenes have been described and arranged to suit the convenient reference of the tourist. Nearly all the battles were fought within easy access of the Rallway line.

Great care has been exercised to give a lathful account of the various scenes, conflicts, and casualites, and to combine the descriptive with the practical. The exhaustive details and data have been collected from the most reliable sources, and the following excellent works, of which the writer has consulted several to verify or supplement his own impressions, and to the authors of which lie tenders his grateful obligations, can be recommended for full and engrossing details of all the incidents connected with the Natal campaign, viz.: "The "Times' History of the War," "The Great Boer War," by Sir A. Conan Doyle; "The Natal Campaign," by Bennet Burleigh; "From London to Ladysmith, via Pretoria," by Winston Churchill; "With the Flag to Pretoria," by H. W. Wilson: "South Africa and the Transval War," by Louis Creswicke, as well as "The Battlefrelds of Natal Revisited," published by John Singleton \& Sons, Durban.

The stupendousness of the task which Sir Redvers Buller and his army at last so magnificently accomplished, and the obvious difficulties, dangers, hardships, and Imperial responsibilities with which Sir George White and the heroes at Ladysmith were confronted, can only be fully realised by a visitation 
of the mmortal fields. At everyturn mumerable mouths in sid, mute, cloquence proclam "the purple estament of bleedng wa" monuments and grives; emmon emp!acements, redoubts, sangars and schanzes; wire entanglements, lyddate-blasted trees and rocks: as well as the cleverly concenved Boer cmernchments, deep and marrow, whl overhanging sand bag ledges to protect from shrapmel and tme fuse shells and to conceal the ocupants, some woth covered acommodation at the end not only sulficent for stormg inmense quntutes of lood and ammunution, but for housing large numbers of Boers them. selves. These trenches are particulariy well desggned at Colenso, on the Ladysnath Hulls, and on L.ung's Nek. In somi places, Time, the elements, and the tourist, have inevitably damaged the orignal Jormation, but many are untact, whle some of the coher evidences of the gigante struggle will remant for genaratons. Ta those whe may not be able to secure shells, empty cartridges, or other relies from the varous frelds and hills, and who are not photographers, wowld perhaps be a pretty alteruative to prek Howers from each and kexp them as remembrancers. By the means the vistor will become possessed of some speimins of Hor 1 ndigenous to the Colony, as well as emblematral mementoes of peace plucked from Naial's battelields.

The BIRD'S EYE MAP of the War Distriet ancluded with this work forms a speenl addituon. The country is shown in elevation, and it is hoped that the idea which prompted its compilation, that of provding a unique, and at the same ume, complete, servieable, and acurate roference map of lhe enurs War Area, sn one sheet, whll be found of interest and assistance not enly m tracug the varaus seenes narrated in the following pages, kut also as a ecmpendrous and undependent souvenur of the memorable Campaign.

('II.MITIER II.

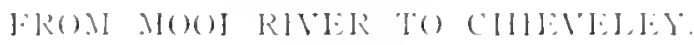

\section{BEFORE COLENSO.}

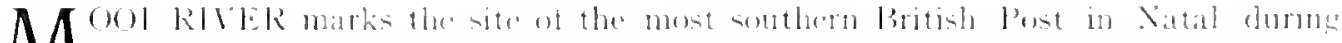

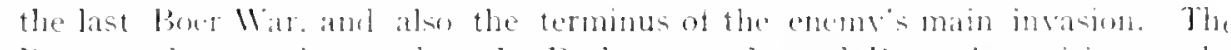

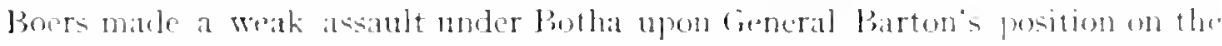

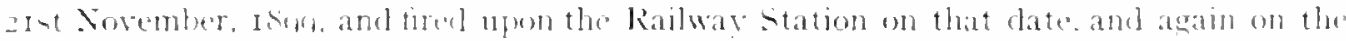
z2nd. lut wete afterwards whtulrawn at the commanel of Joubert. In this elfore they

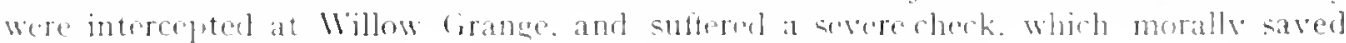
Fistourt iromorilution.

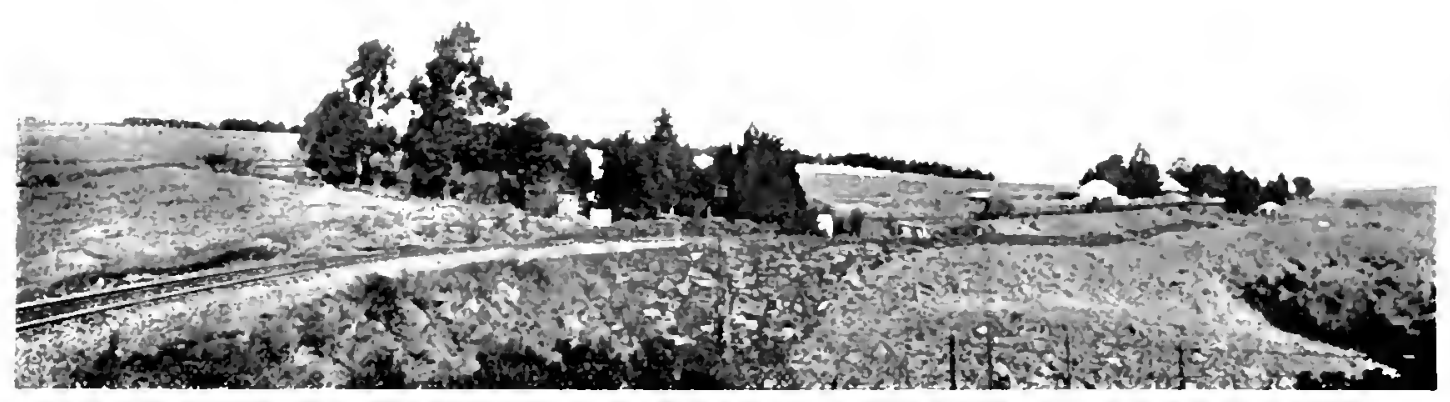

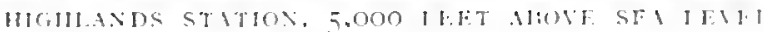


HIGHLANIS is the highest station above the Alutude - bust seat bea letween the

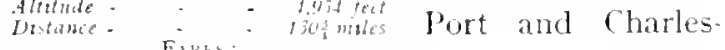

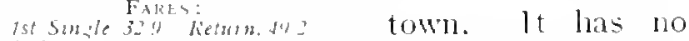
ind if iw. special attractions,

but is noteworthy as the last Railway Station vacated upon the approach of the invader. Glen is a Staff station, and

BRYXBELLA a small passenger station be-

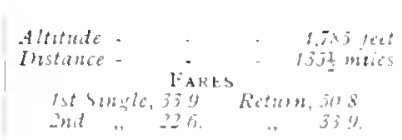
tween Highlands and Willow Grange. Brynbella is of some little notoriety, as

recorded below.

WILLOIV GRANGE. As already mentioned,

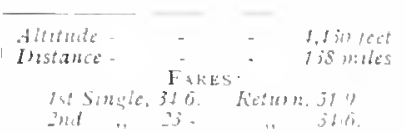
the Boers retired from llooi River, and in this move. ment were accele. rated by General Hildvard, who held the next British Post at Estcourt. To force this limb of the enemy in front of our main body was absolutely essential, and with that object, in the early hours of the morning of the $23 \mathrm{rt}$ November, I809, a small army, covered by a naval gun on Beacon Hill, attacked the Boers on Bryubella Hill, and after a severe encounter took the position. Our losses were I 3 killed and $7 t$ wounded and missing. The enemy then retreated to their stronghold on the Tugela, wrecking the Railway bridges as they passed.

There is no hotel at Willow Grange, but several farms in the vicinity accommorlate paying guests.

Beaco.r Hill and Mimosa are Staff Stations between Willow Grange and

ESTCOURT. The Railway approach to this

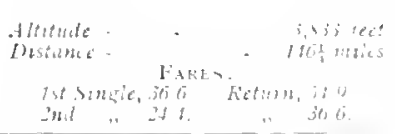
town is thoroumlily agreealile. The rug. ged mountainous countrr, mimosa ralleys, and the winding Bushman's River invite more than a hasty glance. Estcourt, being the chief trading centre for the surrounding district, is of some importance. It lias a population of over 400 , and possesses a tair number of substantially-erected stone buildings. There are several

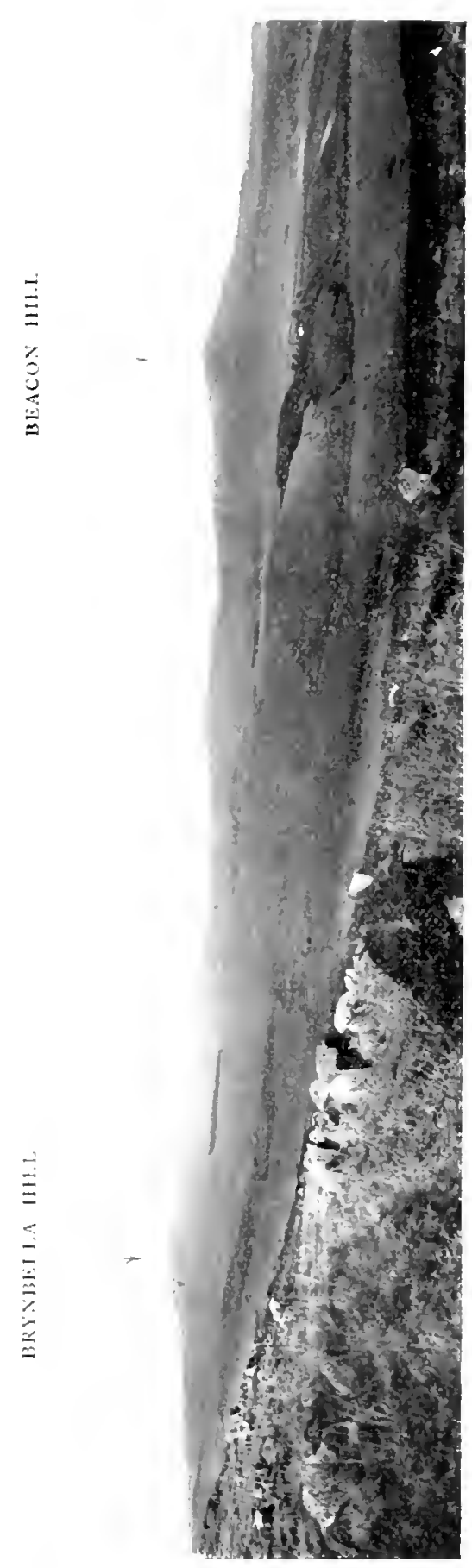




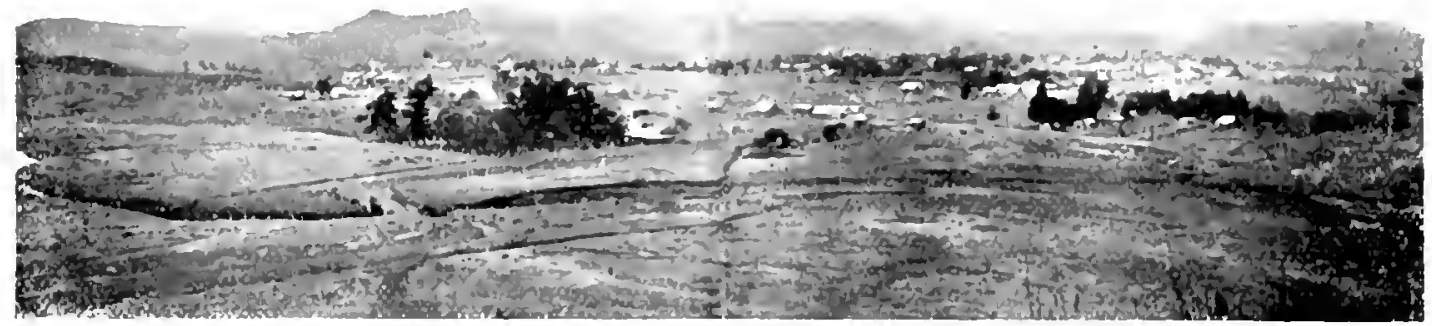

ESICUKI

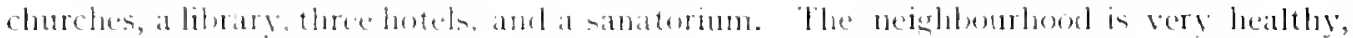
ant inferesting. The district is a fers gond one for steck and tiary taming, as well

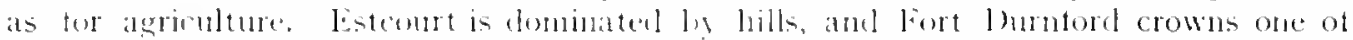
the sonthern eminemes. The rivers bis ame Litte bishman converge at the north end of the town. forming some pretty lalls. The long five-span briclge across the larger river, and the one arer the klip River at Lielysmith, were the only wo structures

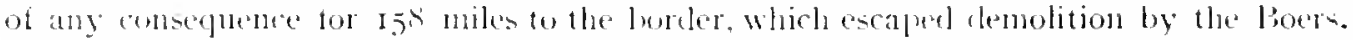

Estcourt played an important part doring the war. It was a large British post for some time after the investment of ladysmith. and a portion of the relieving army was concentrated lere prior to General libller's atvance. lieacon Ifill, previously referred to, and (imn llill, on which the Xaval guns were plued when the fown was theatened, are within easy reach.

The important and historic village of Weenen is siluated alumt zo miles to the northeast of listcont. With which place it is connected ly a tri-weekly Post Cart service. It is pleasmely set in a de'p), warm, well-woorled hollow, and has a popmlation nearly that of Esteonrt itself, the larger proportion of the inbalitants being the descendants of the early Huteh pioncers. This agricultural settlensent is an excellent one for the thrifty and industrious farmet. The soil is rery prolific, and grain, roots, tobaceo, and truits of gool prality are produced in lirege guantities.

There are alse crielenes of limestone deposits in the valley, and coal is known to exist

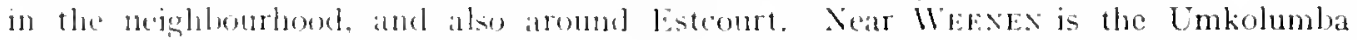
Momtan, which was usel as our lediographic statum throughout the Jarlysmith siege.

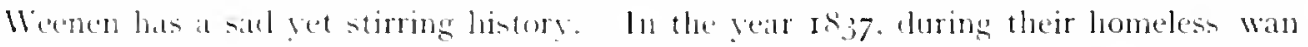

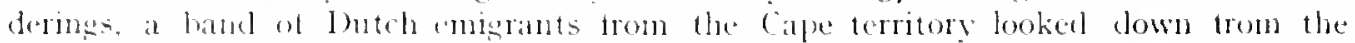

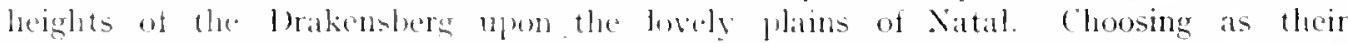
leaders bet Retiet and fiert llaritz. they came through the wild passes of the monntains to this then savage lant. pitcleed the ir tents along the hanks of the Tugeta an! Bushman's Rivers, and treated thromgh the Zulu king Dingaan for a grant of land. The assissination of Retiet and his party immediately after the cession was concluded in known. This, however, was lut the beginning of greater bloodshed, for lingain. intent upon externinating the remaining emigrants, at once despatcled 


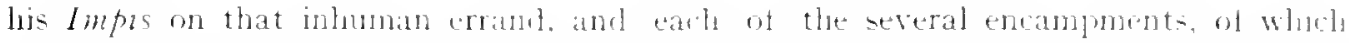
"Weenen" was one. Was attacked almost simultareously in the midrle of the night,

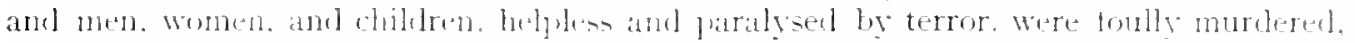
only the catte leebg spared. In all wne boo were killed, and the boer wept greatly for the masiacred. and in remembrance named their lager on the lowshman's river. "Weenen." which is "weepher." Ther then waged war against theje harbaric foes.

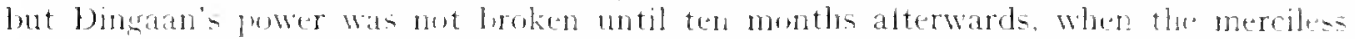
and treacherous king wan utturly deteated and three thousand of hin follewere wert

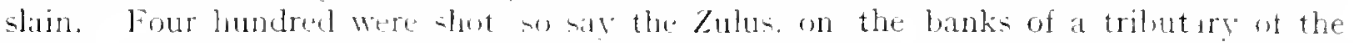
Bufiah. whose wates ran rel with their bloul. and Blood River it is callerd to this dity. This singumary battle ocommed on the Itoth December. Iszs. which date in religinu-ly.

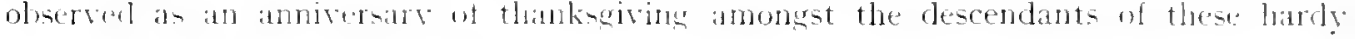

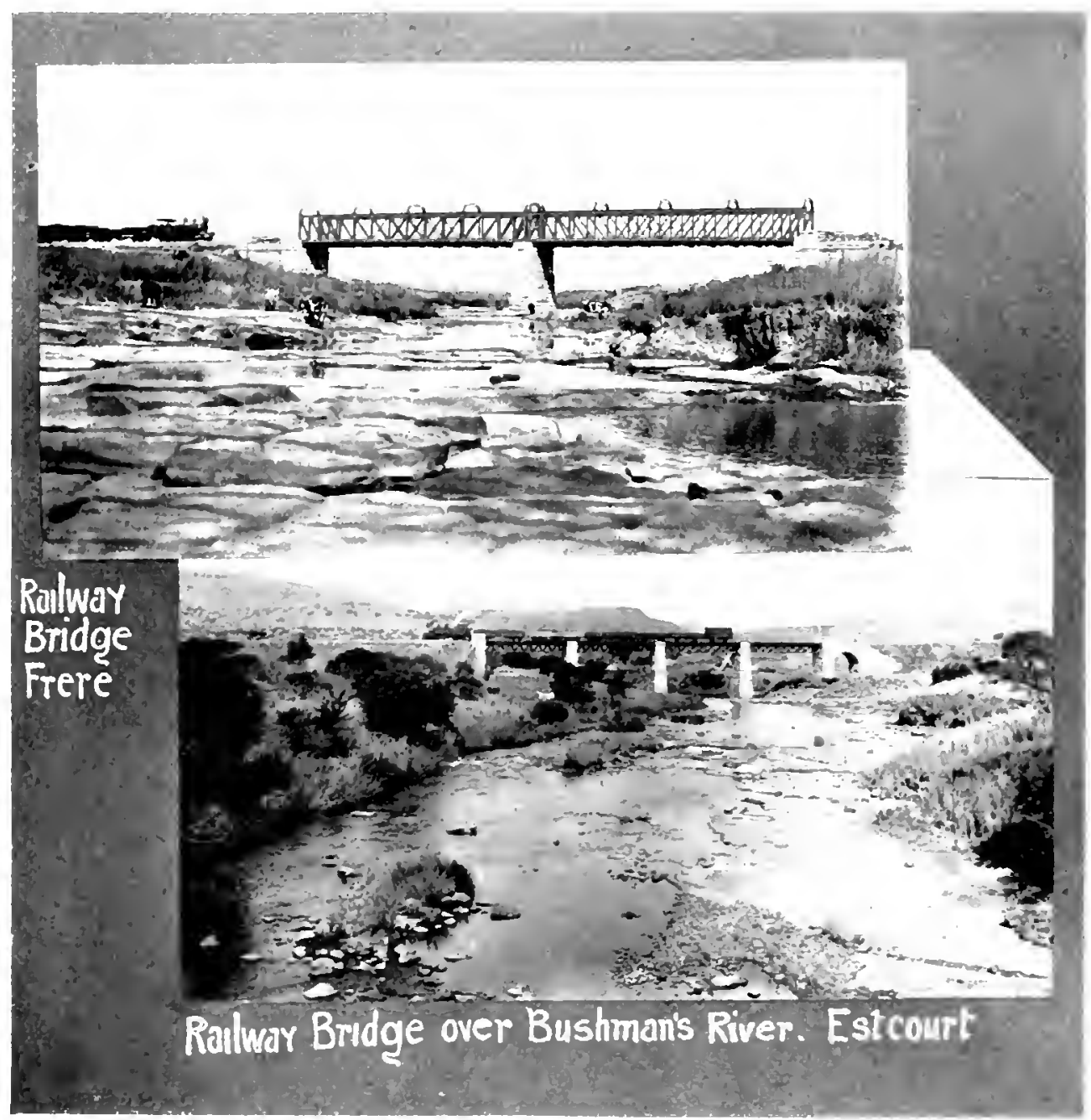


and adventurems roetreklers. It is interestug to note that at Blaauw krantz drift. alvent four miles to the east of chievelep station, a cairn, enclosing the bones of some of the massated emigrants. Was erected in $\mathrm{s}$ sig on the site of one of the unhappy encampments.

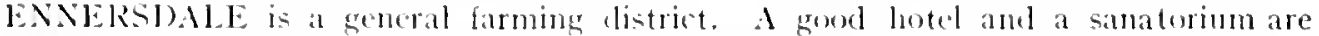

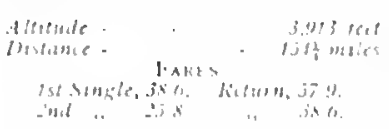
in evitlence. The Drakinsherg with its long, hazy, bluish tiers, imposing and serere, is over thirty miles away, but looks nearer. Some tourists make this their starting point for visiting the caves once inhabited he those quant human pigmies, the bushmen, an aboriginal race now almost extinct. Tabamblope, or white mountain, 6.500 deet high, is accessible from this station, or from Estcourt.

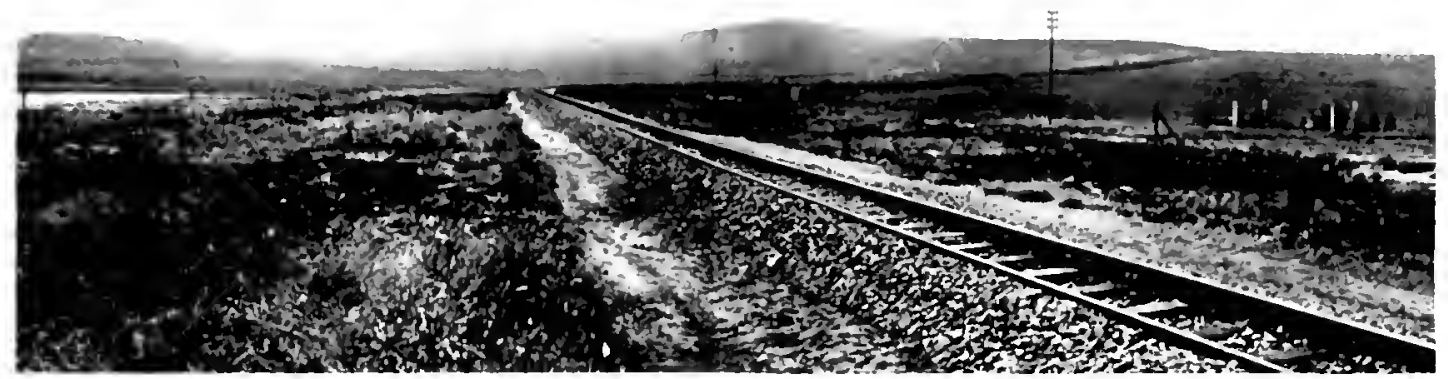

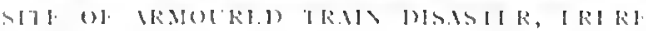

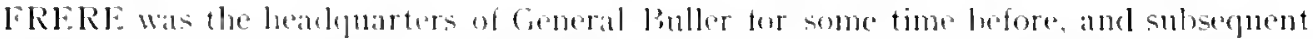

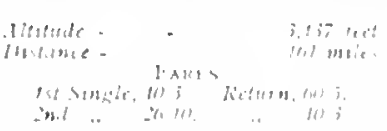
to. the disistrous battle of Colensis. From this point the tlank movement was made atong the Springfickl koat to spearman's (camp, culminating in the unsuccessul attacks upon Spion liop and Vaal lirantz in the Jamury and Fely. ruary following. Some of the offeces anel men wouneled in the former engagement, and who died in the Mititary. Hospital then stationed at Frere. he huried in the same gravevard with those who fell at the armoured train disaster on the Isth Novemher, ston. The cemetery marking the site of the latter mishap, will be fomm close to a hend in the line on the right hand sicle, ahout a mile and a half north of the station. The circumstances of this unfortunate affair may be briefly recomnted: An armoured train, containing in all some $\mathrm{z} 20$ officers. men, and railway staff was tespatchert on a scouting experlition from Fstourt. The enemy cunningly allowed it to pass this particular spot, in the vicinity of which are several hills, then placed an obstruction on the line where it talics a curve. back came the cumbrous. steaming scout all at once it was vigorously chellel, tull steam was put on, the train reached the tatal curve, stumbled, and the three front trueks foppled over, shooting the occupants on to the gromnd, only the engince and two hinder vehicles feeping the rails. The enemy rained shot and sheli upon the unturtunate men, and althoush they retaliated with anmirable spirit while the engine was cutting a way through the wrectiage, the little force 
was out-numbered and out-gunned. The locomotive ferced a passage back to Estcourt during the time the fight was proceeding. hearing some of the killed and wounded, but after a gallant stand against orerwhelming odds, in which Mr. Winston Churchill took a consincuous part, the men surtendered. The casualties were one hundred killed, wounded, and taken prisoners.

For the information of those wishing to visit this graveyard, or the Springfield District, it might be stated that a roomy hotel is situated within a few minutes' walk of Frere.

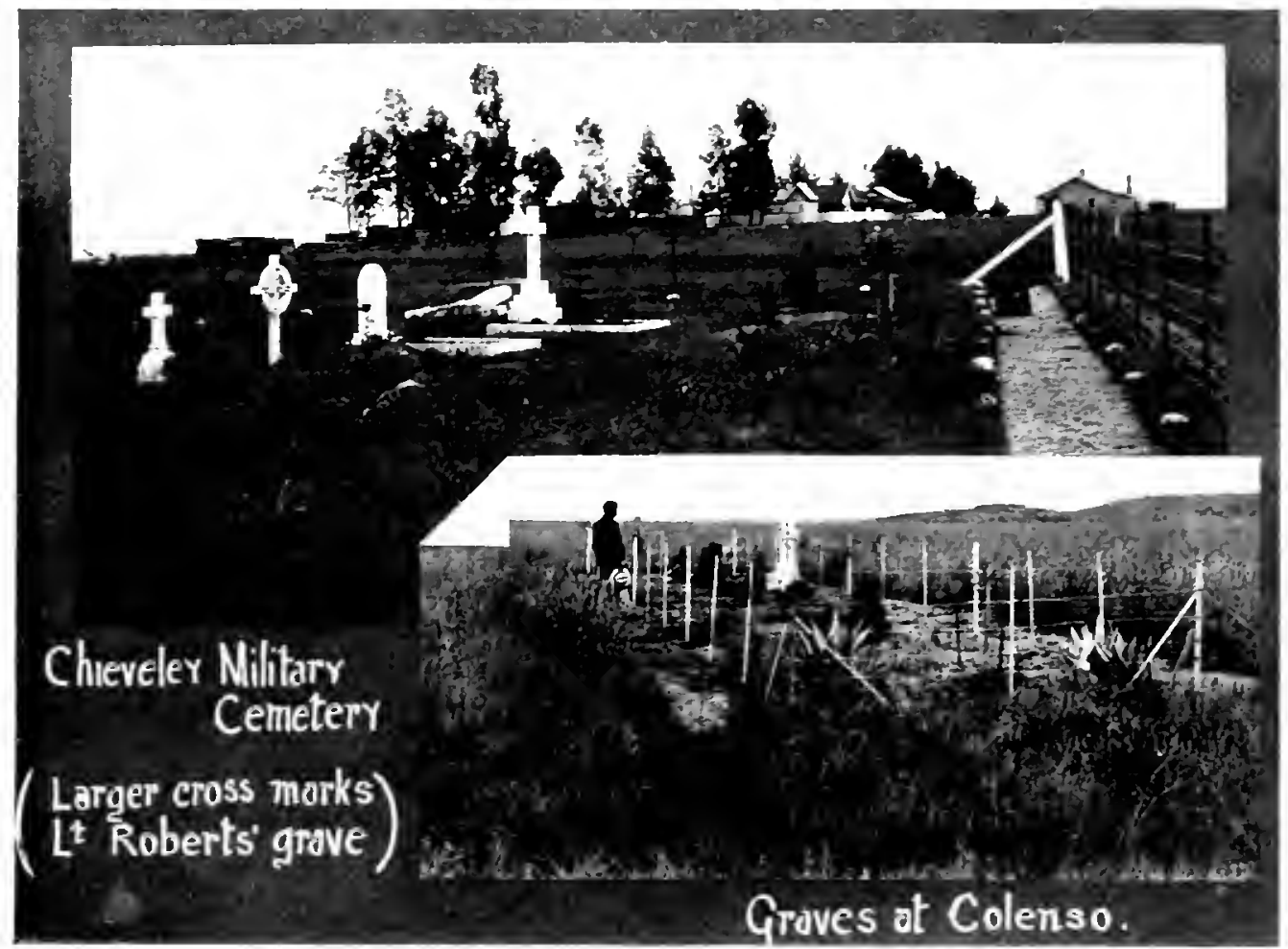

The Blaaw Krantz River flows near the station, and is strongly bridged by a new erection in place of the one destroved by the Boers. The station-master's and platelarer's houses were the respective headquarters of General Buller and Commandant General Joubert during one period of the war.

CHIEVELEY is five and a half miles trom Frere. and is set in the midst of an enormous Artmite - 3.51 rect tableland. It is noted as the camping ground of General Distume - Vofinitit Buller's army of 20.000 men, which he mored into action

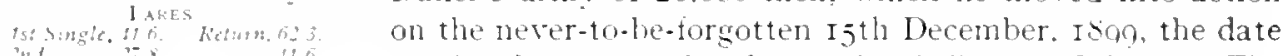
Ind ." of the first great battle of the Relieving Column. The actual fighting ground is at Colenso. but the greater number of our soldiers who suffered death on this occasion (together with I.ieut. the Hon. F. H. S. Roberts.V.C.) are buried in the military cemetery about 200 yarks south of Chieveley station. Gun Hill and Slooter's Hill which hore our large Aaval camon. are alsosituated not far from the station. 




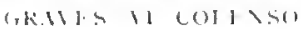

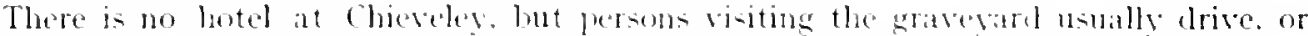
take train from Colenso." Four miles to the risht of Chieveley station. on the hanks of the Blatuw lirantz River, mas be seren the monument raised in commemoration of

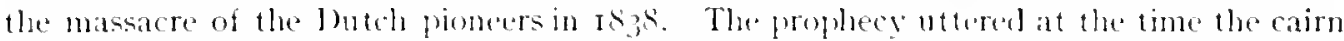
Was creeted, that the bomes it contains would remain "a monument of buteh supromacy till they wasted away or a greater heap of homes took their place." is passing strangethe great colenso battles were fought three gears afterwards within sumshot of the very place.

The next famous station is seren miles from Chieveley. In the West the Perer looms massively, and in the east distance as the tratin preceeds. the rarth is seen to be diafigured lig luge lomps and that-topped swellins-. Nearer the line are tiny molnds and crosses. This is the tatal fiekl of Colenise!

(HAPTIR III.

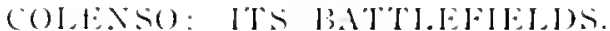

T

He traveler on nearing this historic village will note a semi-circle of hills stretching from east to the tar west, where they seem to he swathwel up he the Drakenglerg.

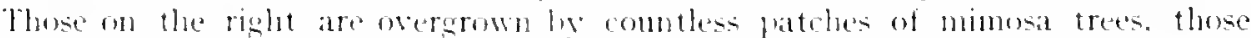
on the left are mostly stons. rugged and bate. At the base of these heights winds the longest, Imoallest. swittest river in the colons, and in tront

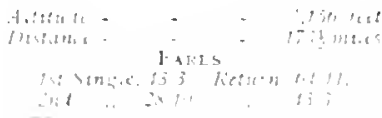
is an immense dongiteracked plain. Prelind the litls are whers. tier upon ticr. rolling and on tracting like an agitated sea, and in the bollow at the back of all is-Ladysmith. 

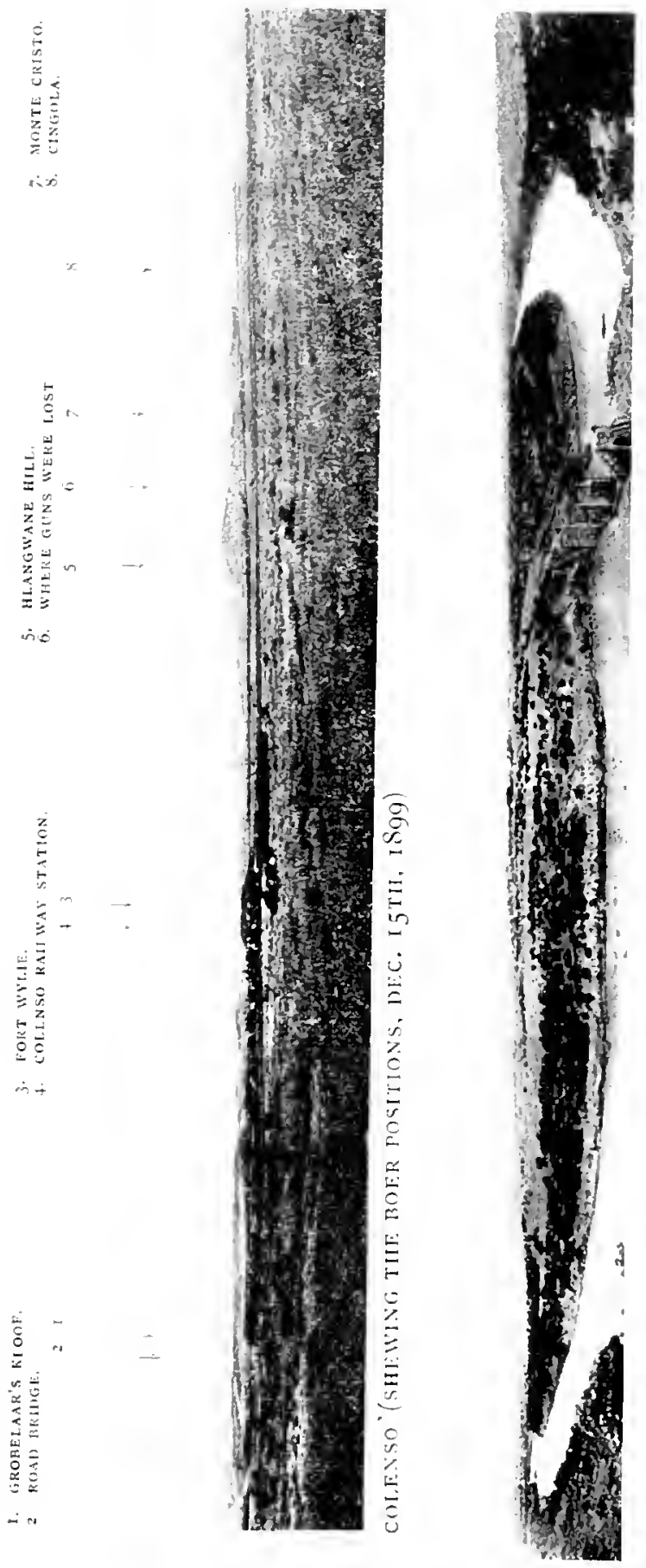

Standing on the plattorm of the Colenso station and looking across the railway line, sou wi]] see a Jow-backed nonnd. inolated from the broken range. This is Hussar Hill. The hide eminences behind are the noted Cingola. Green Hill. and Hlangwane, white Monte Cristo runs back letween the two last-named hills. By walking a little distance upon the field in front, on a clear day can be seen the distant summits of "Hart's," "Railway," and "Pieter's" Hills. all of which are drawn in blood on the map of fame. A few hundred yards to the north-east of the station, immediately on the far side of the new hridge orer the Tugela, stands Fort Wylic, hut neither the bridge nor the river are perceptible from the station. To the left of these again is a hlock of hills, all bearing traces of the Struggles of ring and 19oo. In the distance the Grobelaar's Kloof and Doorn Kloot ranges are descried, while. far off. with its deceptive proximity. is the Drakenshers.

THE GREAT FIELD OF COLEXSO bristles with mournful memories; graves are everywhere. almost every rood has borne the tread of death-dealing armies. But it seems peaceful enough to-day with oxen and goats scattered orer the widesweeping flat. birds twittering in the squat thorn lushes. the dusky lafir lightly carolling as he swings along towards his kraal, and the level-crowned Hlangwane and lis companions looking down in surly silence. the trench rents in their hodies nearly' 


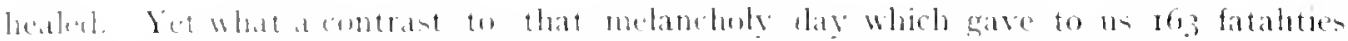

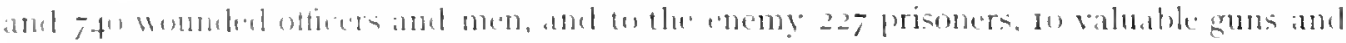

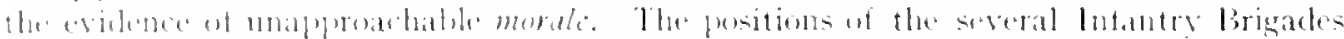

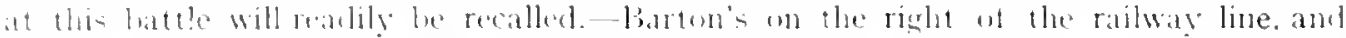

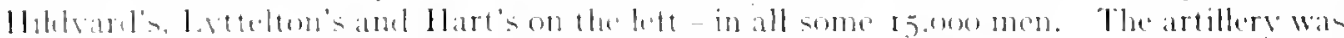

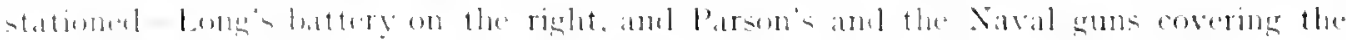

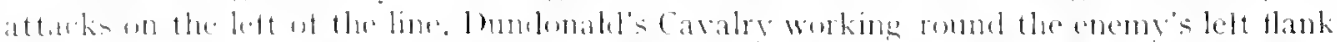

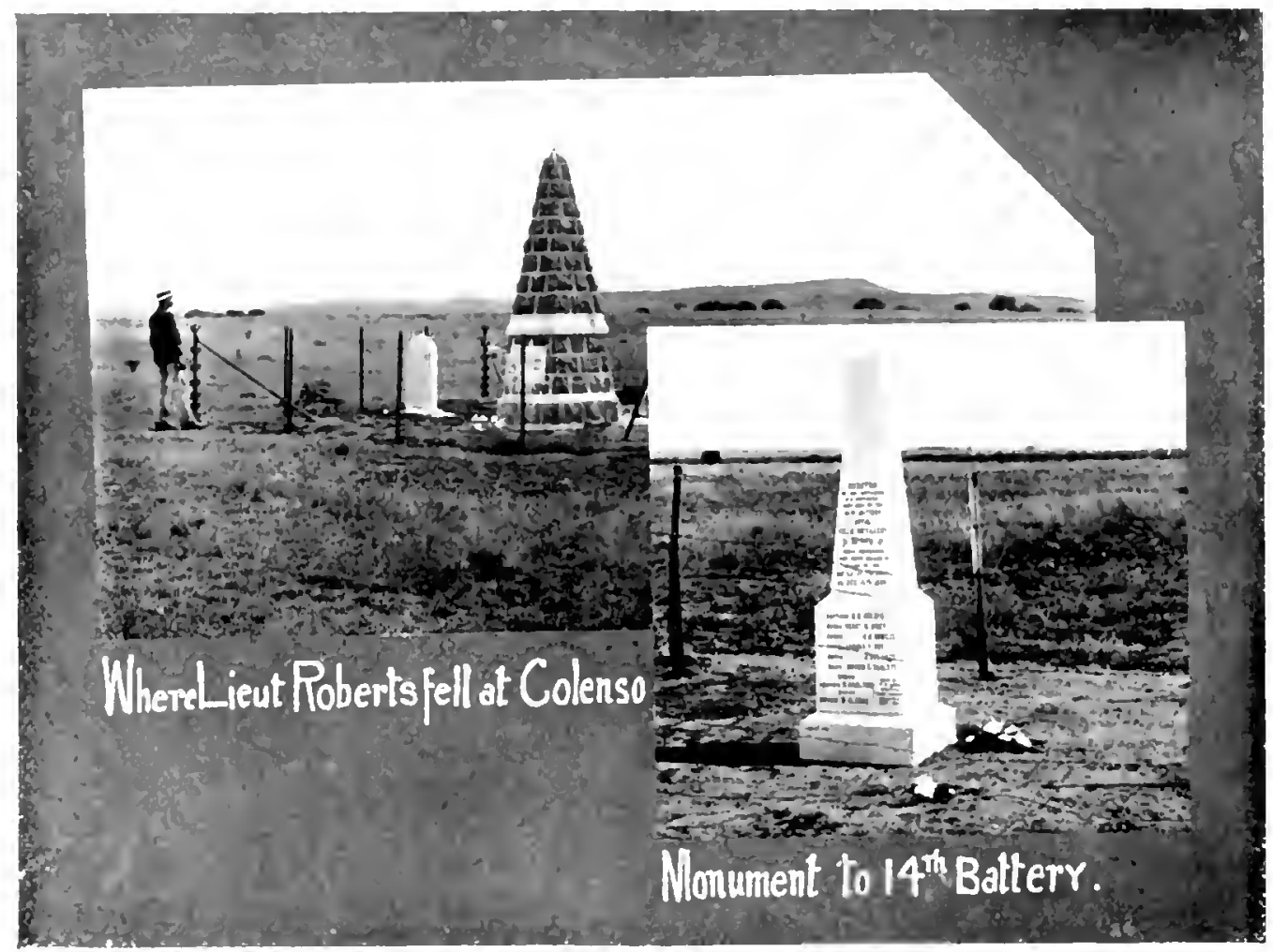

The VILLAGE OF COLENSO is about 300 yards from the station, where a commodious hotel will be found. Guldes have therr headquarters there, and excursions, either by converanee or on horseback, are organtsed daily to the many PLACES AND SCENES OF INTEREST DESCRIBED.

It may be useful to know that some teursts visit Ladysmith first, and Colenso on their return fourney, while others do the reverse. The arrangement of tours must necessarily depend upon the tume at the visitor's disposal, but a week or more can easily be spent at either place. Of course, the more prominent features of attraction can be seen in a couple of days

Colenso is not alone magnetic by reason of its battle recollections: it is a most invigoraing spot, and has a distinct charm of seenery in the unsurpassable Drakensberg, whose soft green early mornmg rament is most beautuful, and whose deep blue evening mantling, fruged and piereed by a golden luminance, and backed by mingling crimsens, gress, and greens, is indescribably grand. 
Witlin a quarter of a mite of the railwa station platiorm, and plump in the centre of the historic arena, is the spot where Col. Long's guns (rqth ant of th Batteries) were captured and the donga to which the wounded were remorerl. Two monuments have been erected near by, one to the memory of lieut. F. H. = kolerts. the gallant son of the honoured Commander-in-Chief, who was shot whilst endeabouring to save the guns; and the other to the officers anil non-commissioned ofticers and men of the Ifth Battery who tell to the homour and glory of British tradition on the I 5 th December, Inom. It will be marvelled how terribly near to the deadly shell and riffe fire of the enemy the Batteries were unlimbered, and what an unequalled tareet they prentent for the boer Artillery, from the amphitheatre in which it was locaterl. How truly magnificent must have been the behaviour of the gunners. Can we conjure anvthing worther of adniration than the following incident told by Conan Dorle:

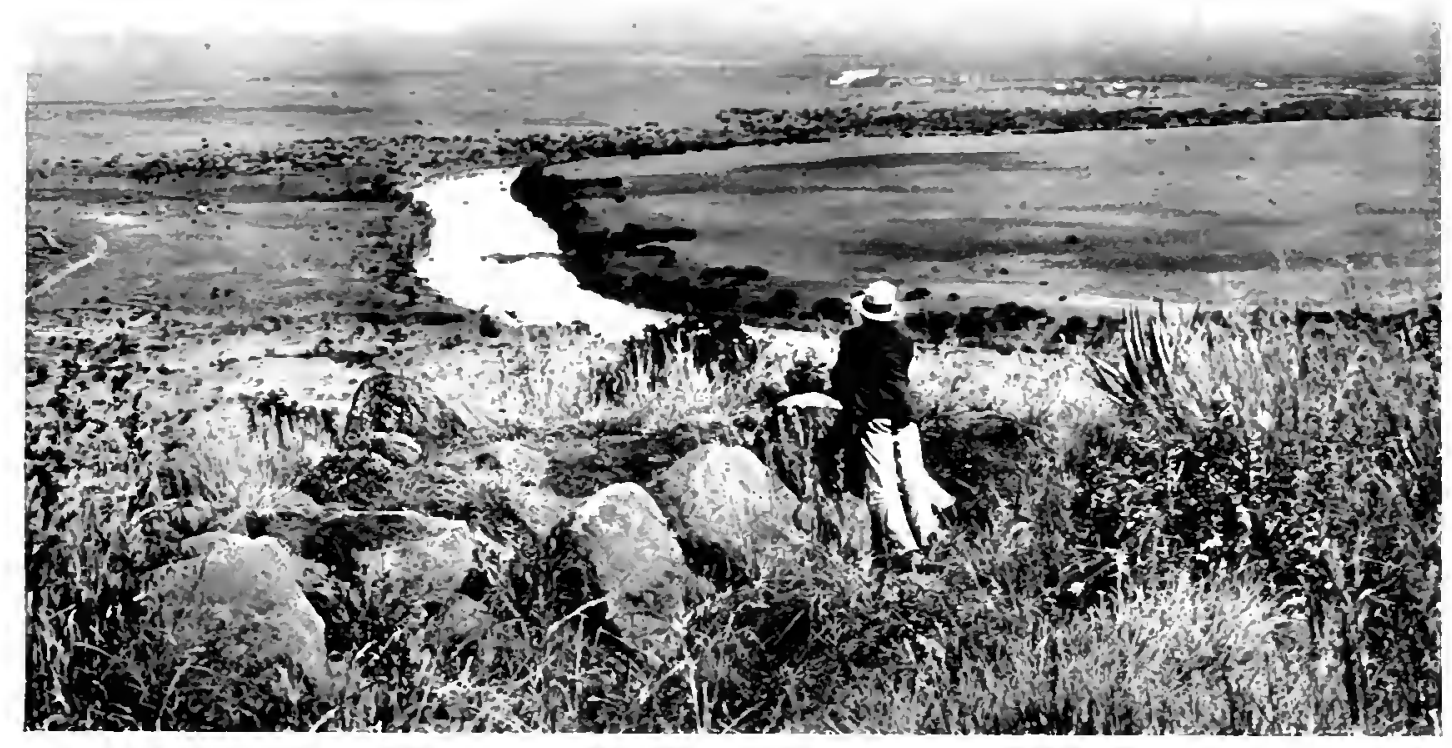

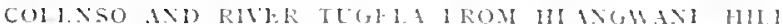

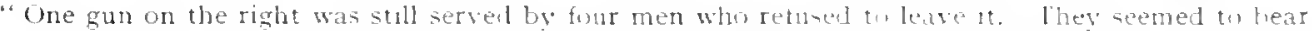

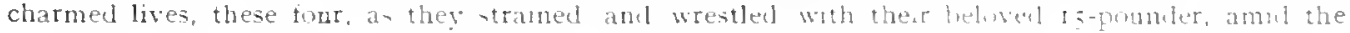

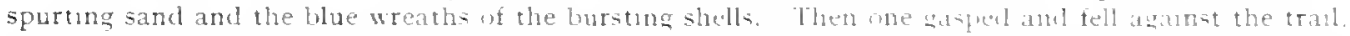

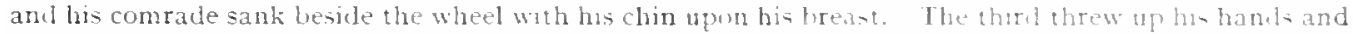

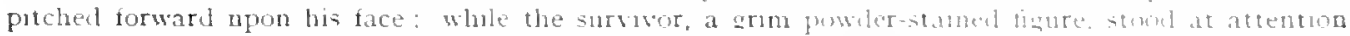

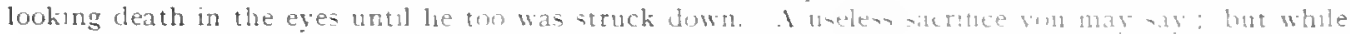
the men who saw them die can tell such a stury round the camp ine the eximple ht weh deathe as

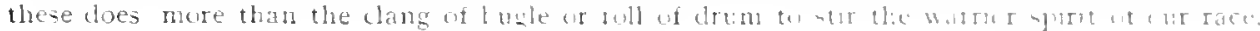




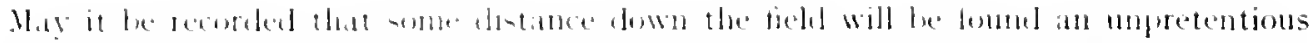

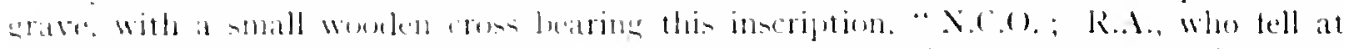

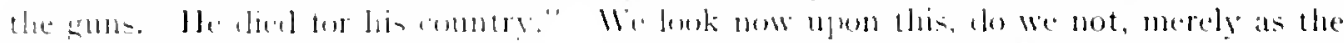

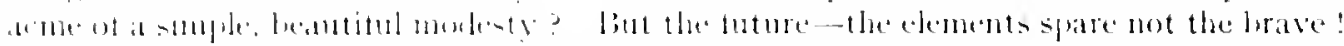

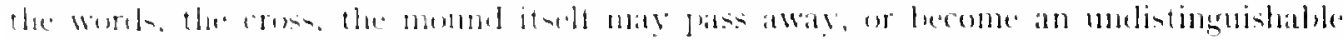

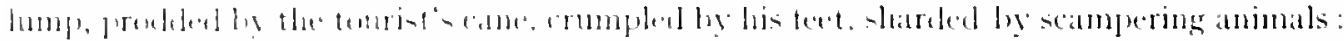

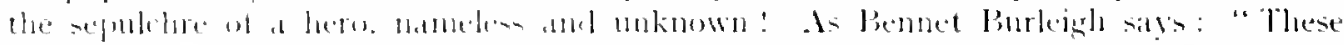

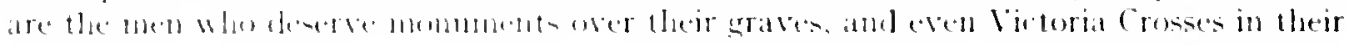
cutfins."

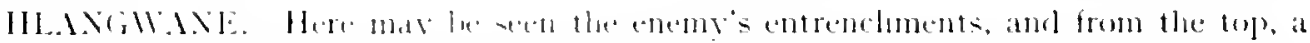

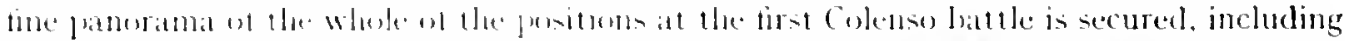

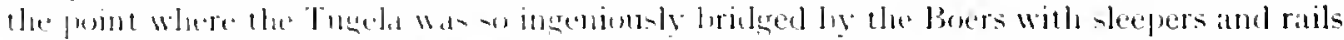

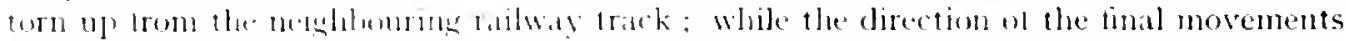

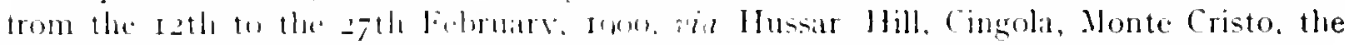

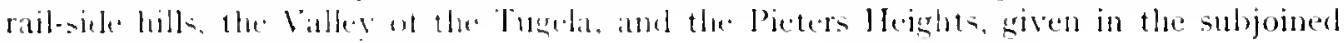

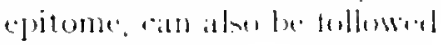

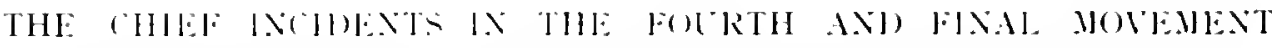

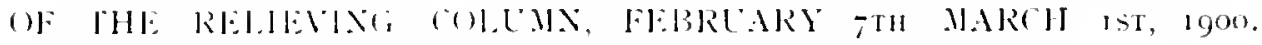 (Extrated trom liemeral Sir Redrers Buller's Despateh.)}

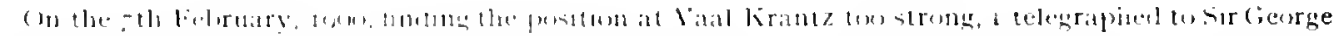

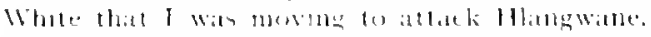

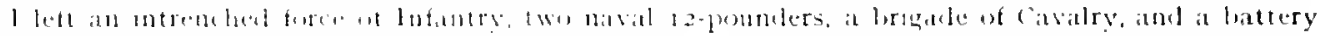

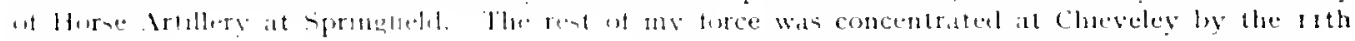
limars.

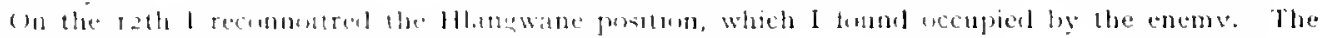

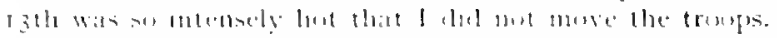

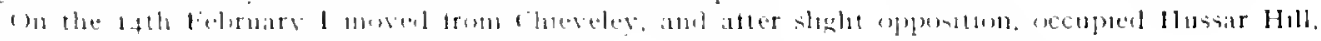

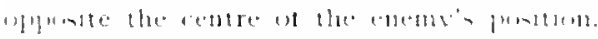

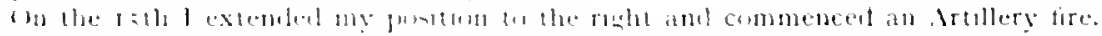

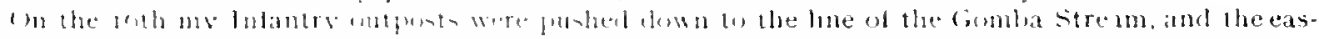

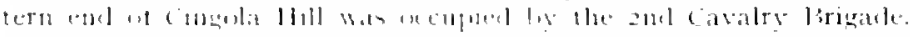

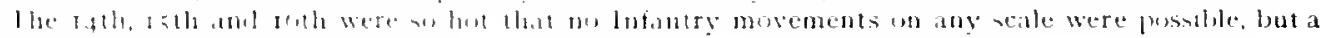

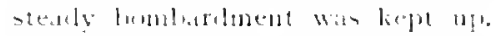

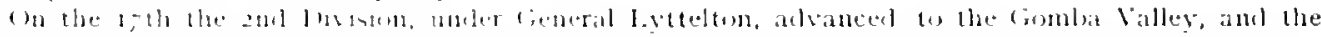

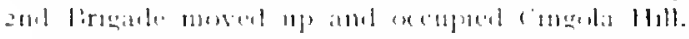

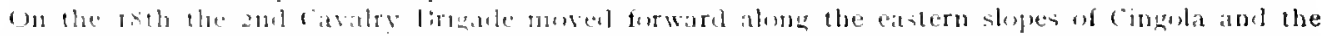

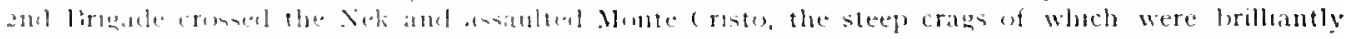

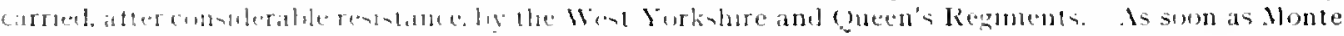

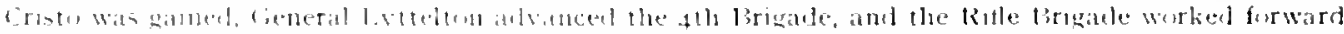

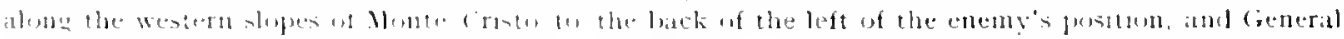

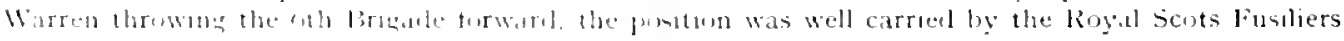

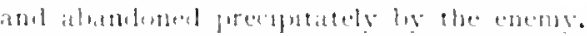

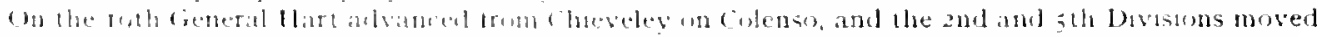

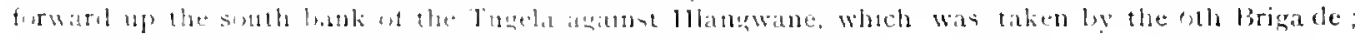

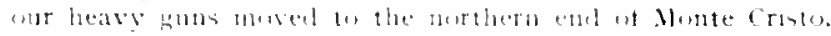

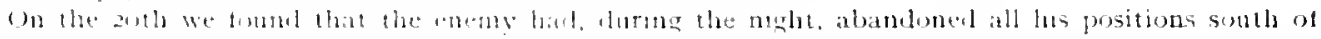

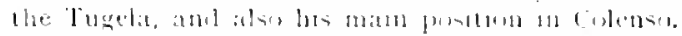

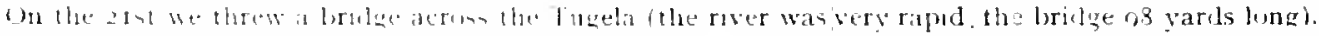

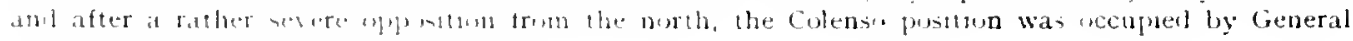

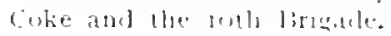




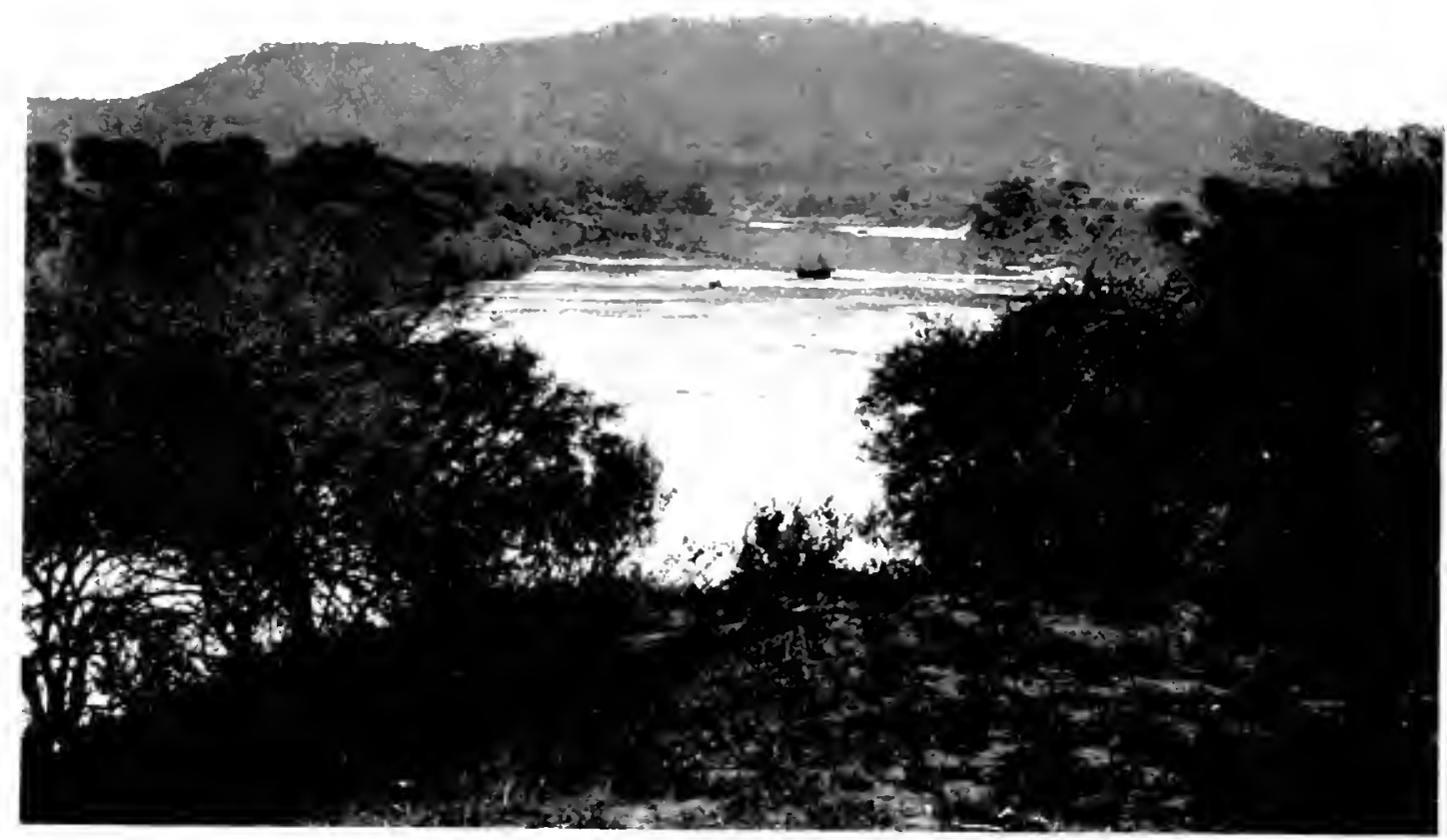

TUGELA RIIR AI COLIXSO, HLAXGWAXF HILL IA IBKKGROLND

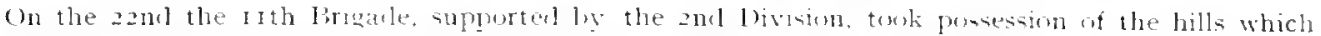

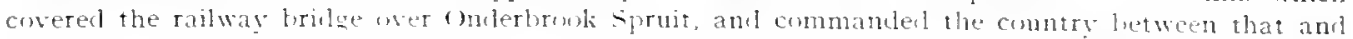

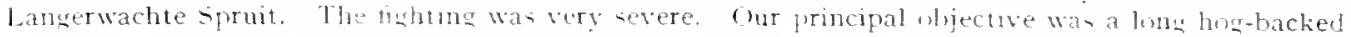
hill runing noth ant woth, which completely commants the valley ut the Lantrumchte spruit.

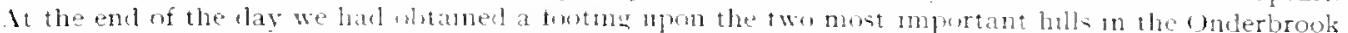

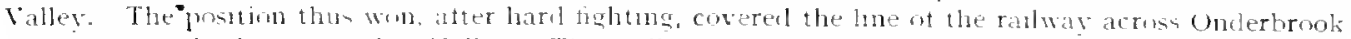

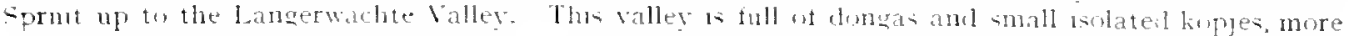

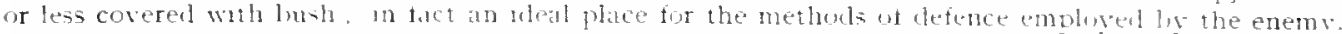
The eastern side of the valley in ched ly a htgh steep hall (Hart"s) which was evilently the enenv"s

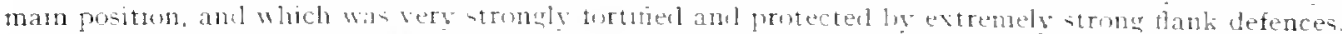

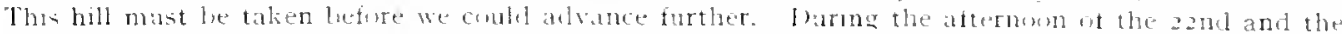

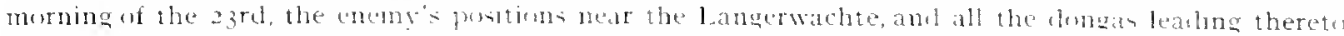

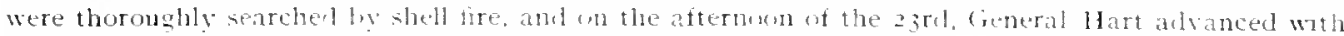

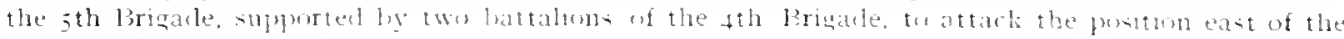
spruit.

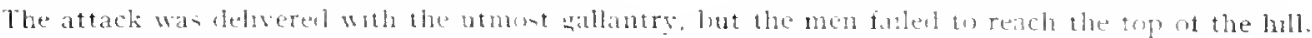

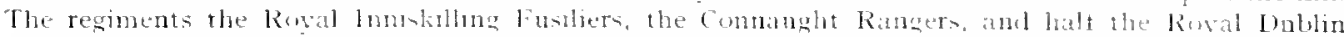

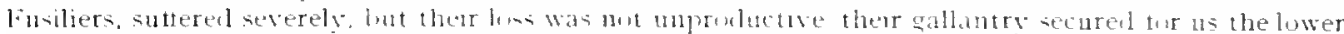

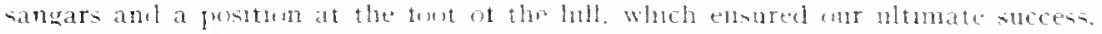

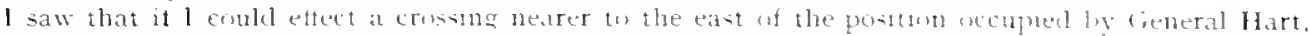

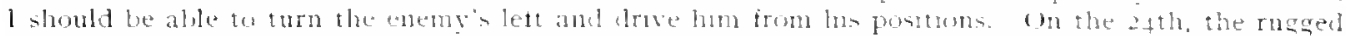

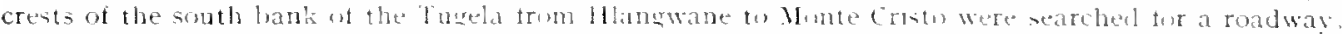
and a Katir path was touml wheh gave acese to the ruber letsw the cildract. exactly at the back of

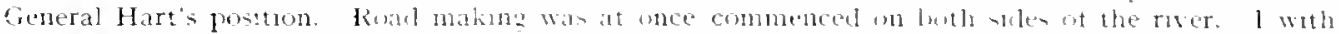

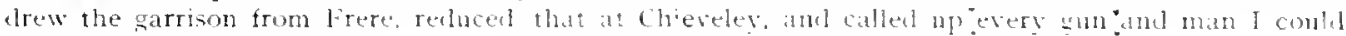
muster for the final assault. 


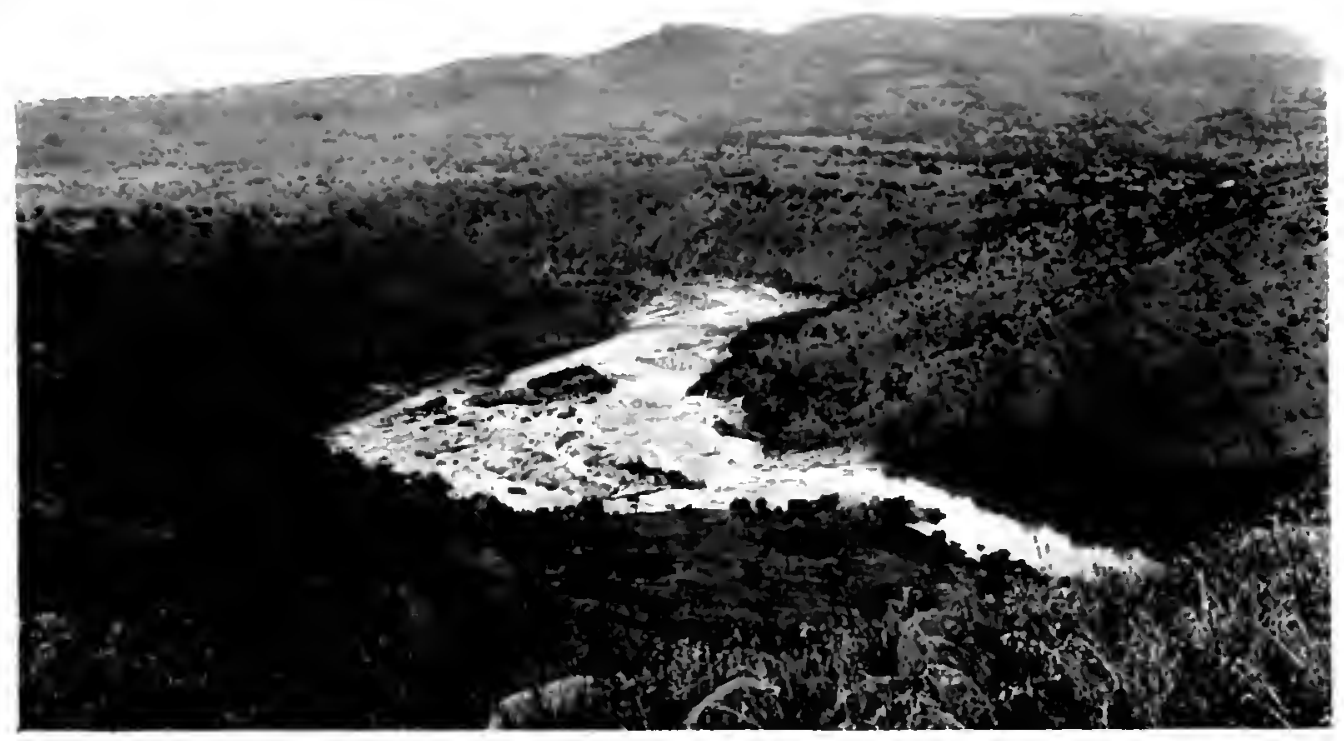

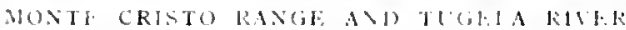

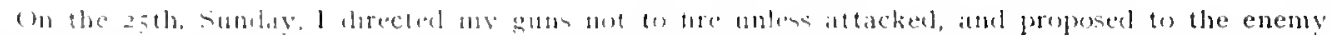

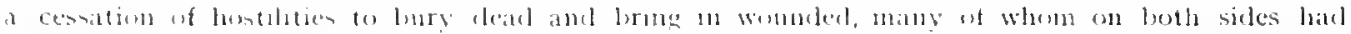

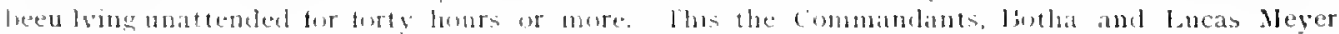
arsented 10 .

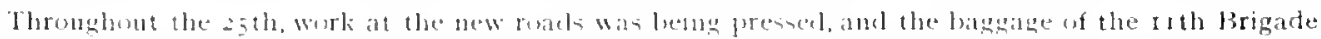

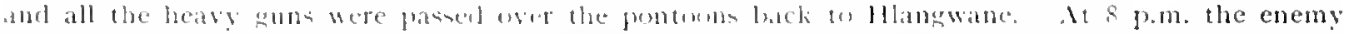

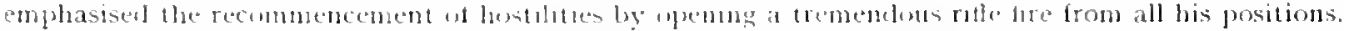

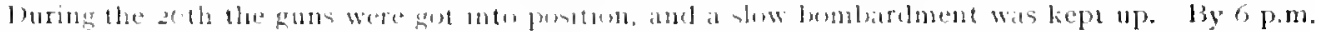

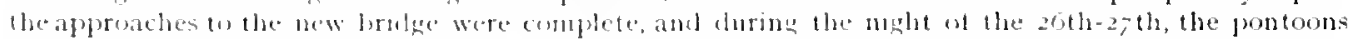

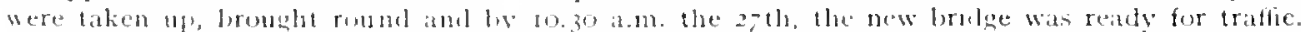

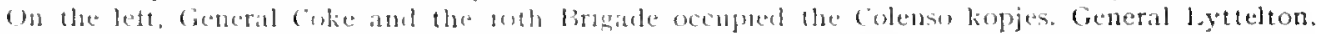

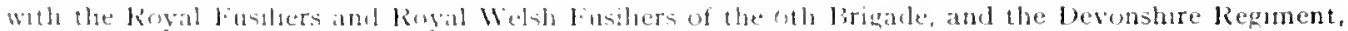

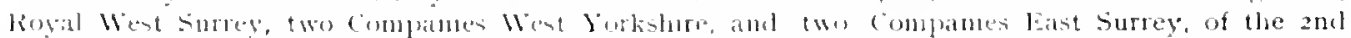

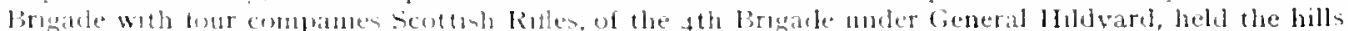

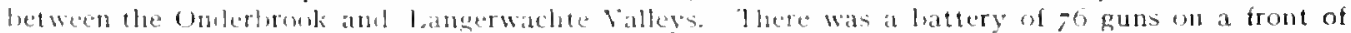

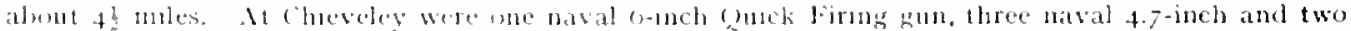

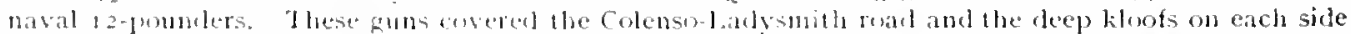
of $1 \mathrm{t}$ which were sery strongly held by the enemy, whe, i thrni, really expected us to attack on that sicle.

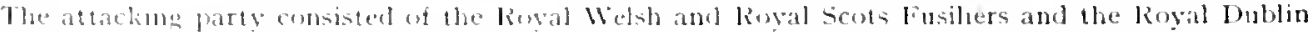

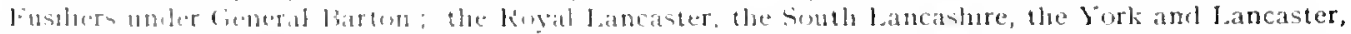

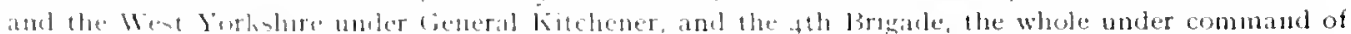
Cieneral Milrrent.

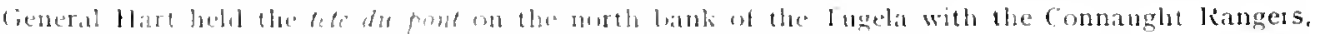

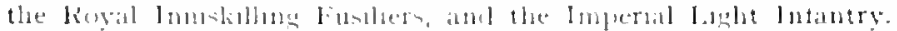

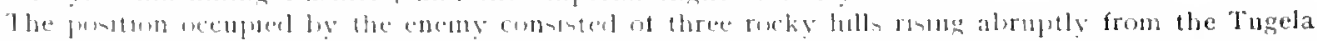

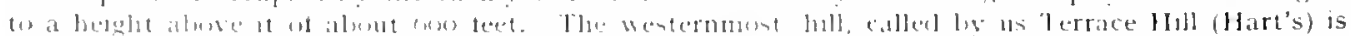

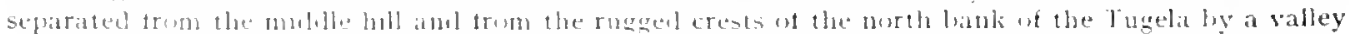

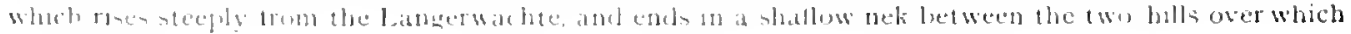




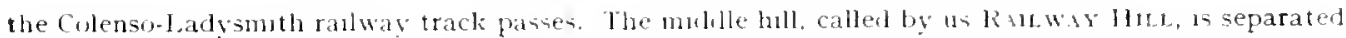
from the eastern, called PIETER'S HIL. by a deep ravine alung the western sule uf which the railway to Pleter's winds through deep cuttungs. Peter's Holl risug steeply on the west from this ravine. falls by gentler graduents to the with eat towad the klp kiver, the valley of which in intersected by dongas clothed in thick mimuia and camel thorn scrub.

Terrace Hull (HART's) was a formulable postlon, it was strongly fortified with three tiers of trenches and flanked by trenches rumung diwn the Langerwachte Sprut on one sule, and up almost to the crest of Railway Hill on the other. The creats of these hulls were about $\mathbf{1}$, joo yards histant from the river which here flows through a deep grorge, the sides of which on the north are almost precuptuus to about too feet, the ground from the crest of this gorge to the crest hue of the hills preatnting an excellent field of fire for a force accupving the crests. Withn this field the fire sangars hat been constructed in every suitable spot. l'uter's Holl was not sh strongly held. but a very consulerable force was, as we found out later, concealed in the ravine letween it anu Ralway Hull. Onr atproaches to the position were of the worat possible descriptum. there was no road. and the attacking column hat to scramble up an almost preciptous rocky chift to gan the erest of the ravine. We harl. though, one great advantage, our Arthlery pustuns were excellent, and from the length of our lune the enemy"s positions were in alnost all cases partly entilated as well av net ly frontal fire.

At $10.30 \mathrm{a}$.m. General bartun's furce crosed the pontom loridge, and scranbling about one and a hatf miles down the edger at the Tugeli, ascended the steep chifis of Peter's Hut unopposed, the rifle and machine gun fire tron the south bank having cleared the north bank.

General Kitchener's Brigade followed General Barton's over the pontoon bridge, and diverting slightly to their right, scaled the shunfler of the ravine, and gained the railway cutting. General Fitchener then thrected the West Vorksure and the Royal Lancaster Regiments to attack Railway Hill. The sansars in the valley were sun taken, anl the Rowal lancaster and South Lancashire pressing on. well supported by the York aul Lancaster m the nght. and the ath Brigade on the left, soon gained the summit of the hill, and the dias was wom

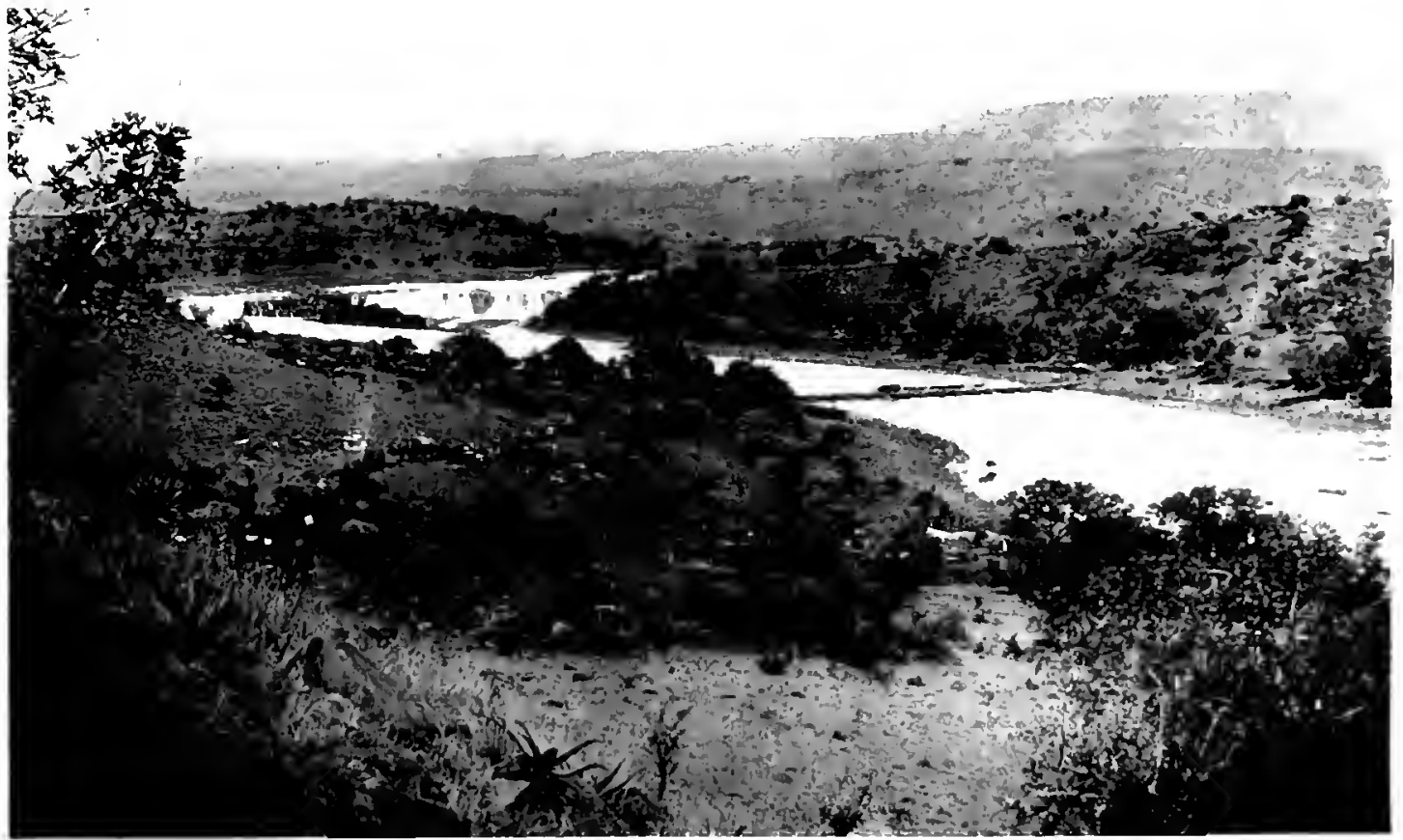

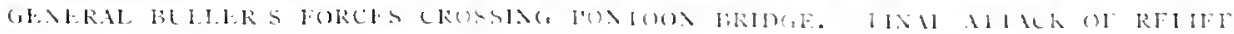

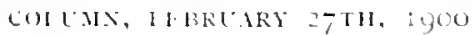




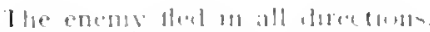

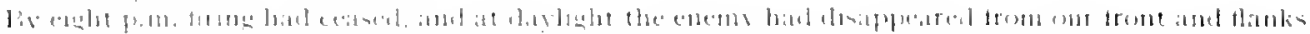

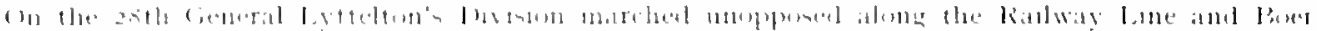

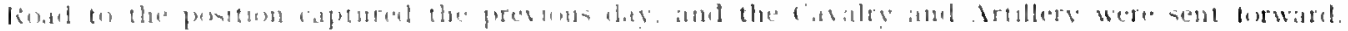

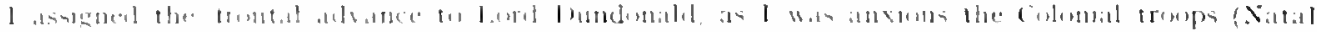

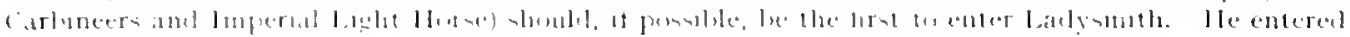

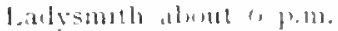

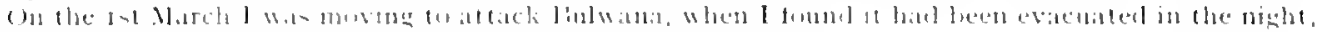

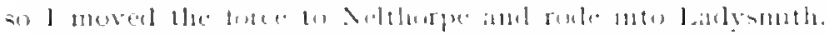

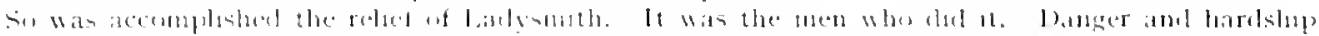

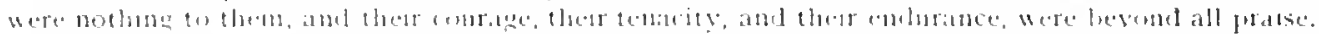

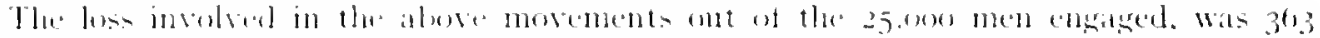

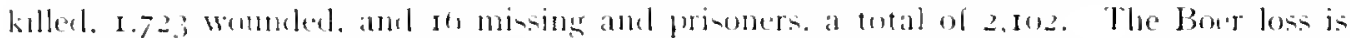
dilicult to assers, but it womlel le very leary.

It is esimated that from first to list the relice of lanlesmith antailed a loss of 7 (us

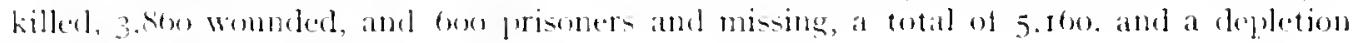
(i) Io guns.

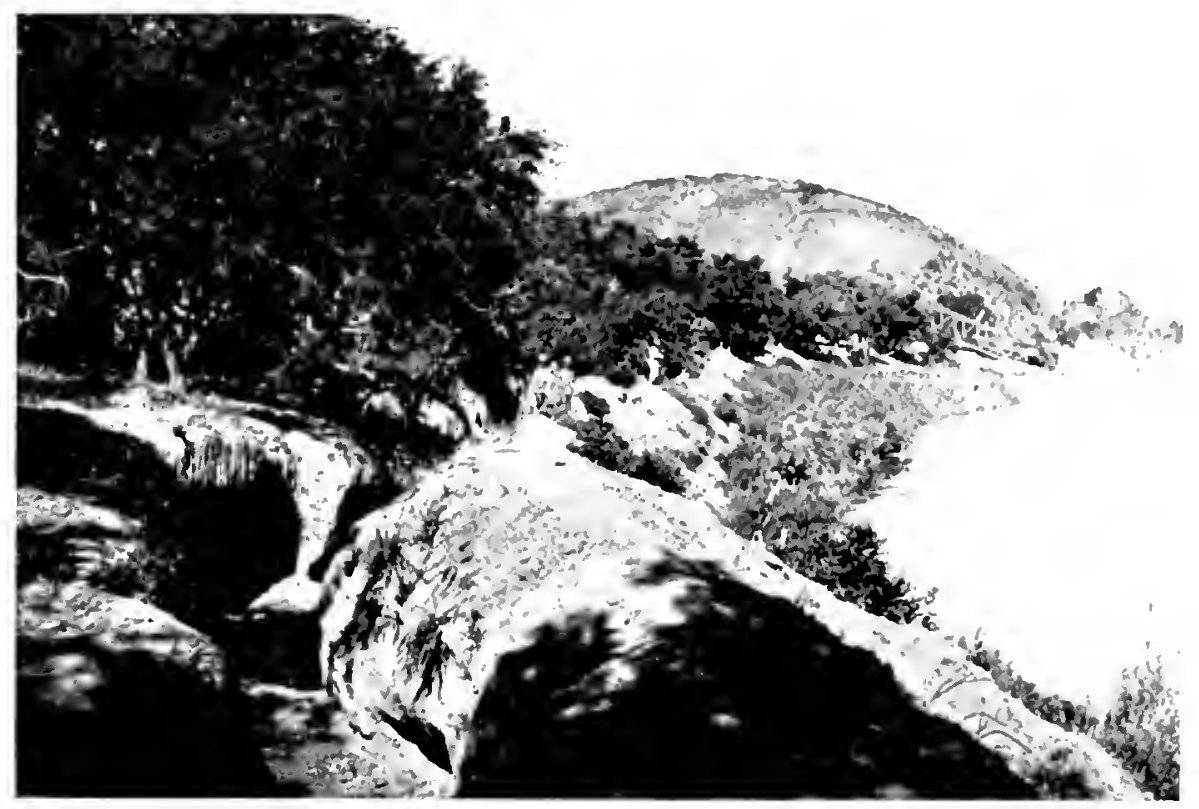

BOER I REXCHES IT COIEXSO

THE BANKS OF THE TLREAA. Stretching tor seven or eight miles mav he traced the tamous bierer trenclies.

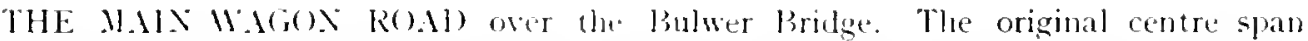
of this prige was shot away lis our Naval guns at Chieveley on the ighth December. Itim, in order to laminger the enemy's movements after the Colenso disaster. The number and the strength of the sangars and gun emplacenents rumning along each side of the rond tor mike-constructed hy the boers in anticipation of the relieving column forcing a passage this way-are particularly interesting. 


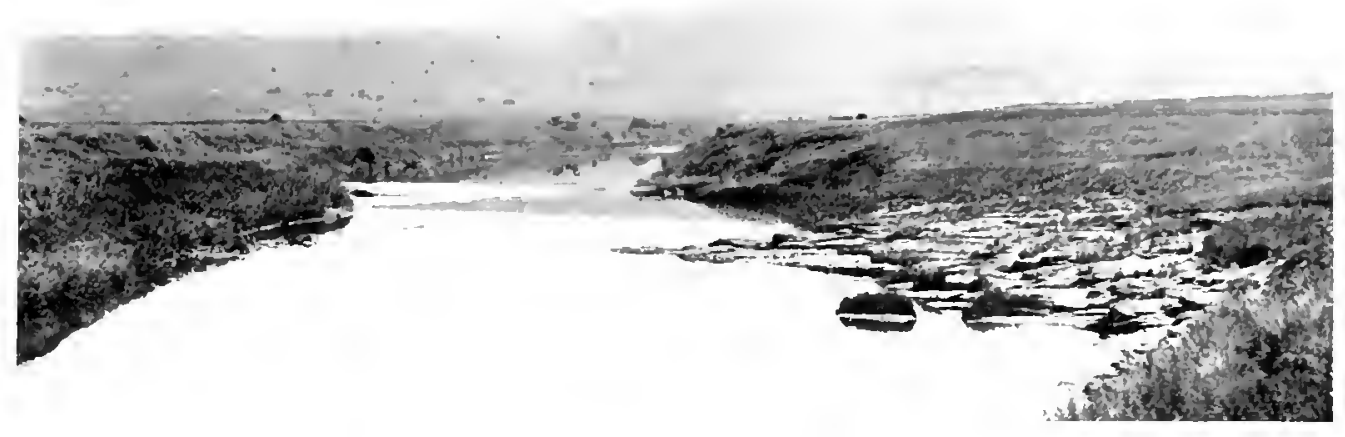

WHERE THI DUHLINS CROSGED THE, TUGEIA, COI I SO

THE POINT OF ATTACK OF GENERAL HART'S IRISH BRIGADE is two miles along the south hank of the Tugela to the west of Colenso. This resulted in a loss of some Ioo men when advancing to cross a mythical drift. The killed were luried near the river. This is the spot, too, where a party of recklessly brave Dublin Fusiliers attempted to swim the river. Some were shot in mid stream, some were dragged down to a watery grave by the weight of their accoutrements, a few reached the opposite bank, but only one or two returned to tell the tale.

NEAR CHIFVELEY is the graveyard already mentionce.

HART'S HII.L was the first of the three famous Pieter's Heights attacked hy the illfated lrish Brigade on the $23 \mathrm{rd}$, and held with such tenacity until victorionsly carried on the 27 th Feloruary, Igoo. The marellous gallantry of the lrishmen. and in par. ticular the Inniskillings, before and after their terrible losses, will never he torgotten.

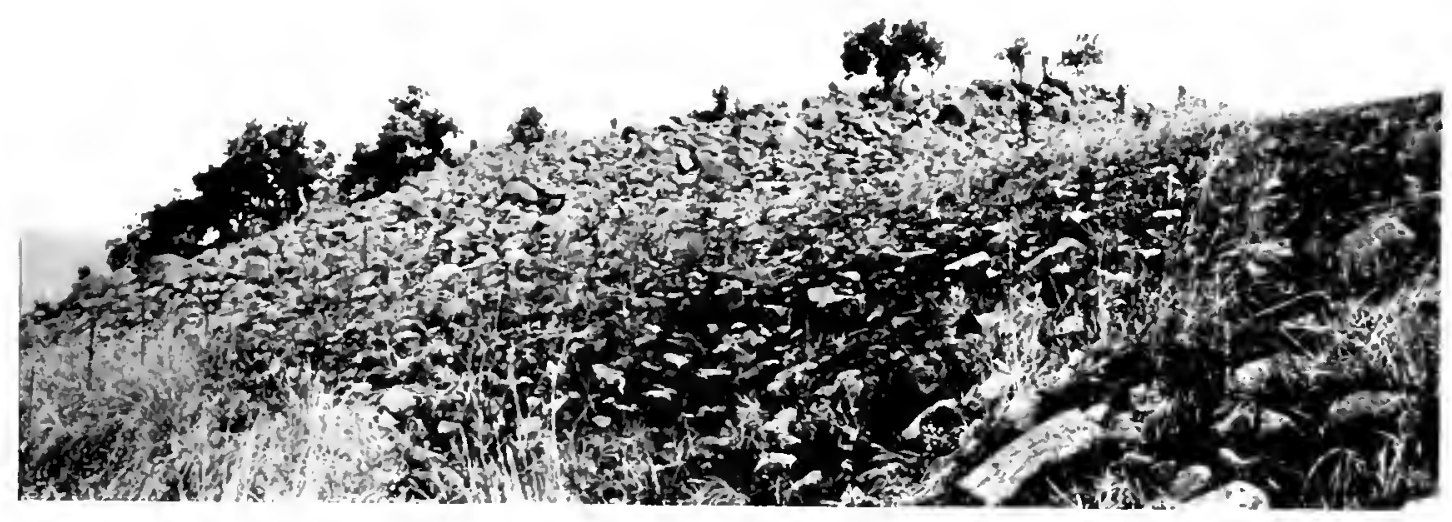

TOP OI RAILWAY HILI, COIEVSO 


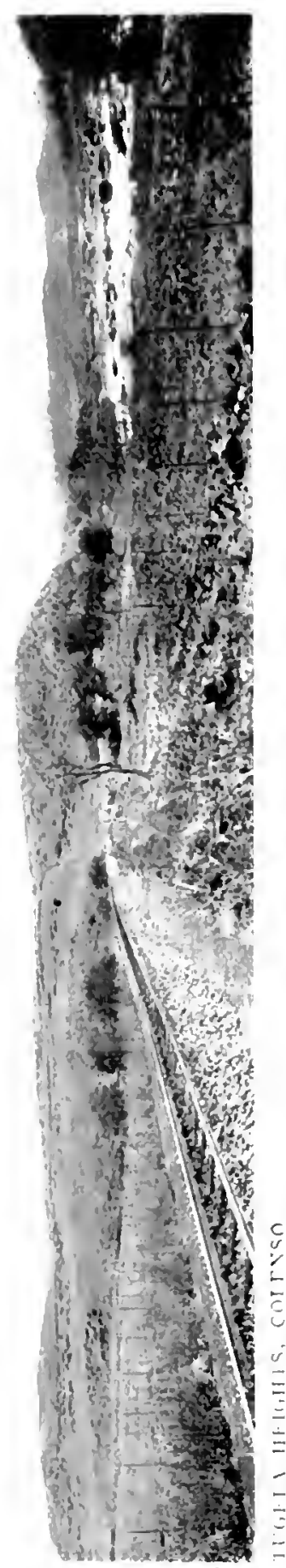

Mang of the gatlant frishmen are hurbel at the fool (1) the hill, and several wellistio have heen erected to

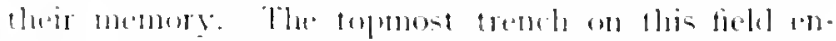
tomber many Thoers.

from the summit of hart's llitl a splemliel viow is

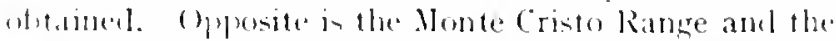
IIlugwane Slopes Irom whish cour artillery covered the andulling forces. On the right lond in the colletion

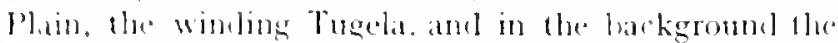

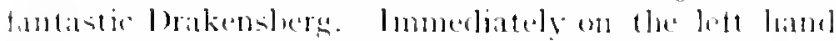

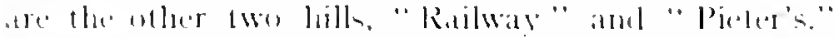

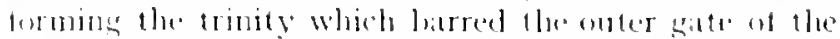

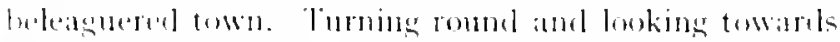
loblymith. Sheba's breants. Comblats and lowom

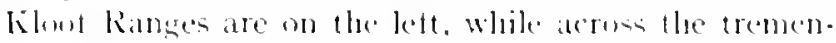
dom platn below, the great Lmbulwana dominate its complnets.

R.111.11.1Y H11.1, .1.1) Pl1:TEK's 1111.1, together with Il.1Rl"s, were the three chief plysical charaters in the closiner scenes of the immortal drama which had

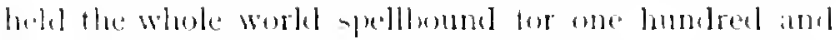
nineleren days.

The grand linale, the l'ieter"s figlat, is thus strikingly "pitumised in "Words hy an eye-witness," by "I Ines. min." - a clever and realdable book:

"The bumbarlment and stormug of l'ieter's $11 \mathrm{ll}$ is at storv

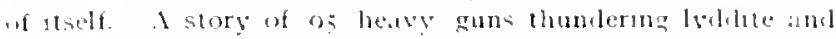

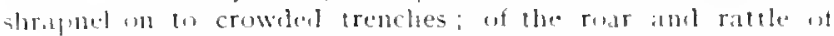

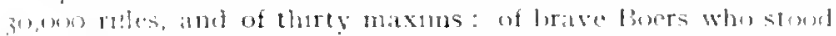

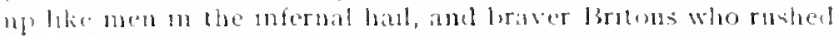

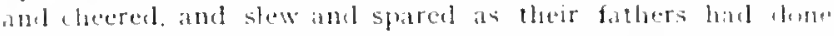

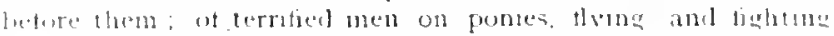

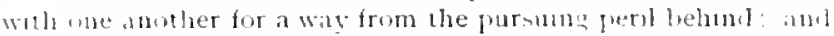

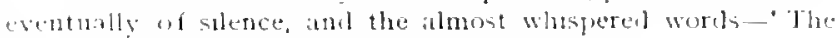

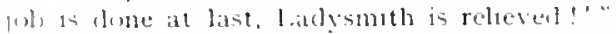

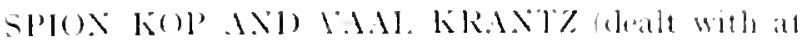

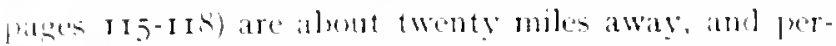

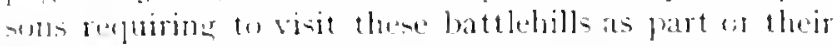
(a)ertas tom, will find every poting tacility at the lmatel, hut it should be stated that the route most Anvenreal is the one tid liallsmith.

THI: HIILS TOWARISA GROBELALRS: THL

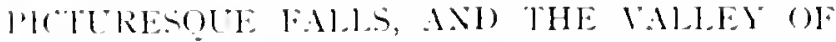

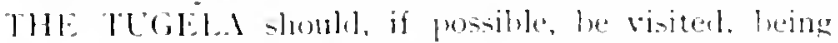
so intimately connected with the operations durine the fomteen bas preceling the entry into larlysmith. The rabluty puses thromgh this area. - See the following ilit?lter. 
CHAPTER IV.

\section{FROM COULESO TO L.ADYSMIIH.}

\section{VA THE VALLEY OF THE TLGIEA AND THE PIETER'S HEIGHTS.}

$\mathrm{T}$

E train journey trom Colenso to Lad smith, is, perhaps, the most interesting of any in Africa, not simply for its splendid woodland, mountain. and river scenery, or for the demonstration of engineming skill in surmounting the rugged country between the two historic places, hut for this, that the sround could tell a thousand tales of heroism, of gallintry, is fortitude. of an intlexible letermination to conquer, tempered with the attributes of mercy and torbearance in the hour of victory, such as was never more transcendent in the histors of the Nation.

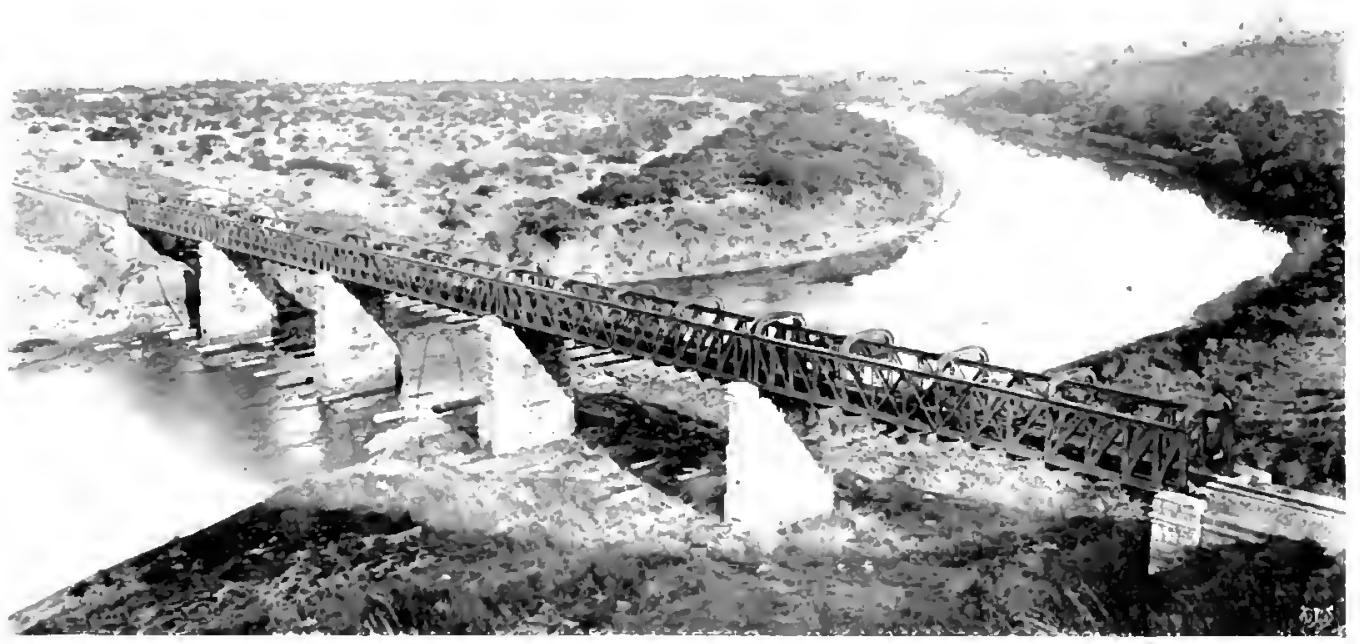

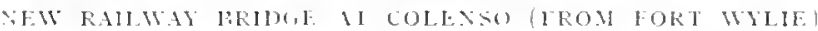

Thundering orer the Tugela, and past Fort Wyle. which watches orer the muddy swirling stream. numbers of shanze will le observed running ul the hills on the let. (In the right is the continution of Hlinewane. and presently the llonte Cristo ranee comes in rew. while on cart sile of the line many grave-generonsty up-kept by the

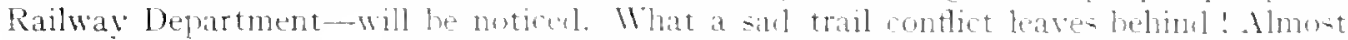

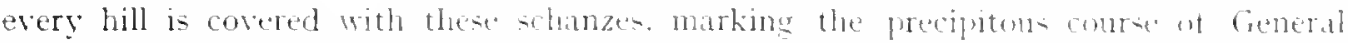
Buller's final attacks. Farther on we expy the lumker-hlockel river, and the smaller falls at the confluence of the Onderbrook spruit. Crobelate in to the leott, and

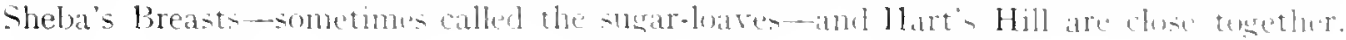




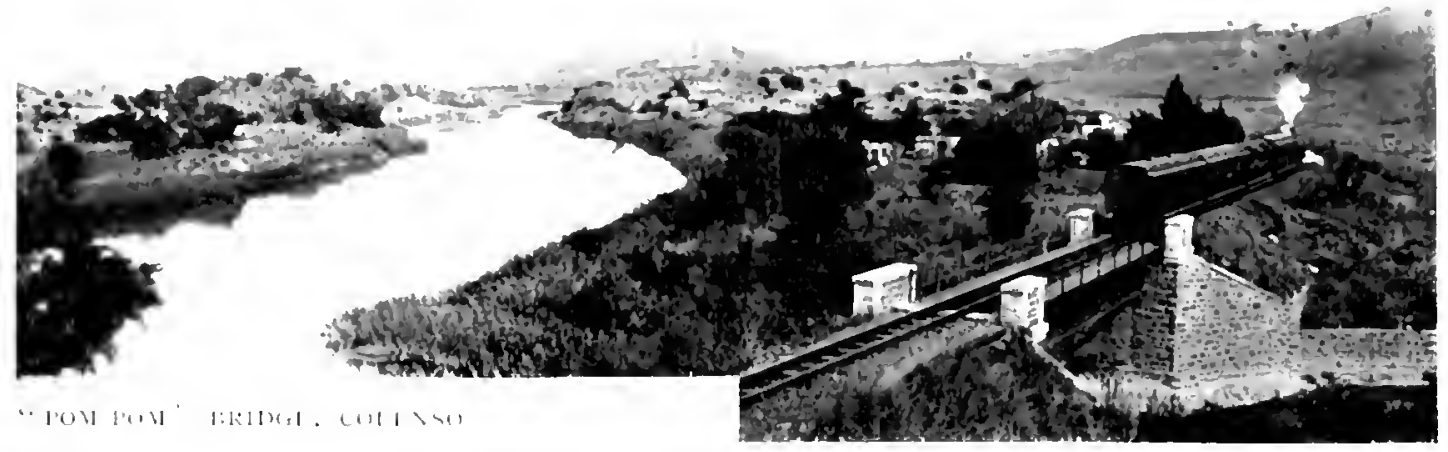

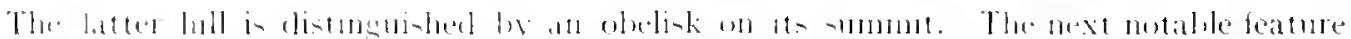

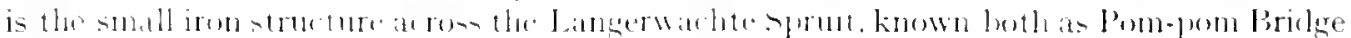

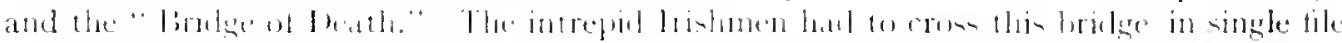

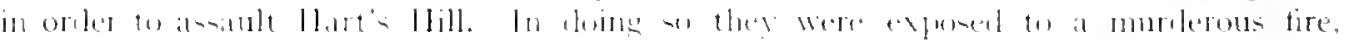

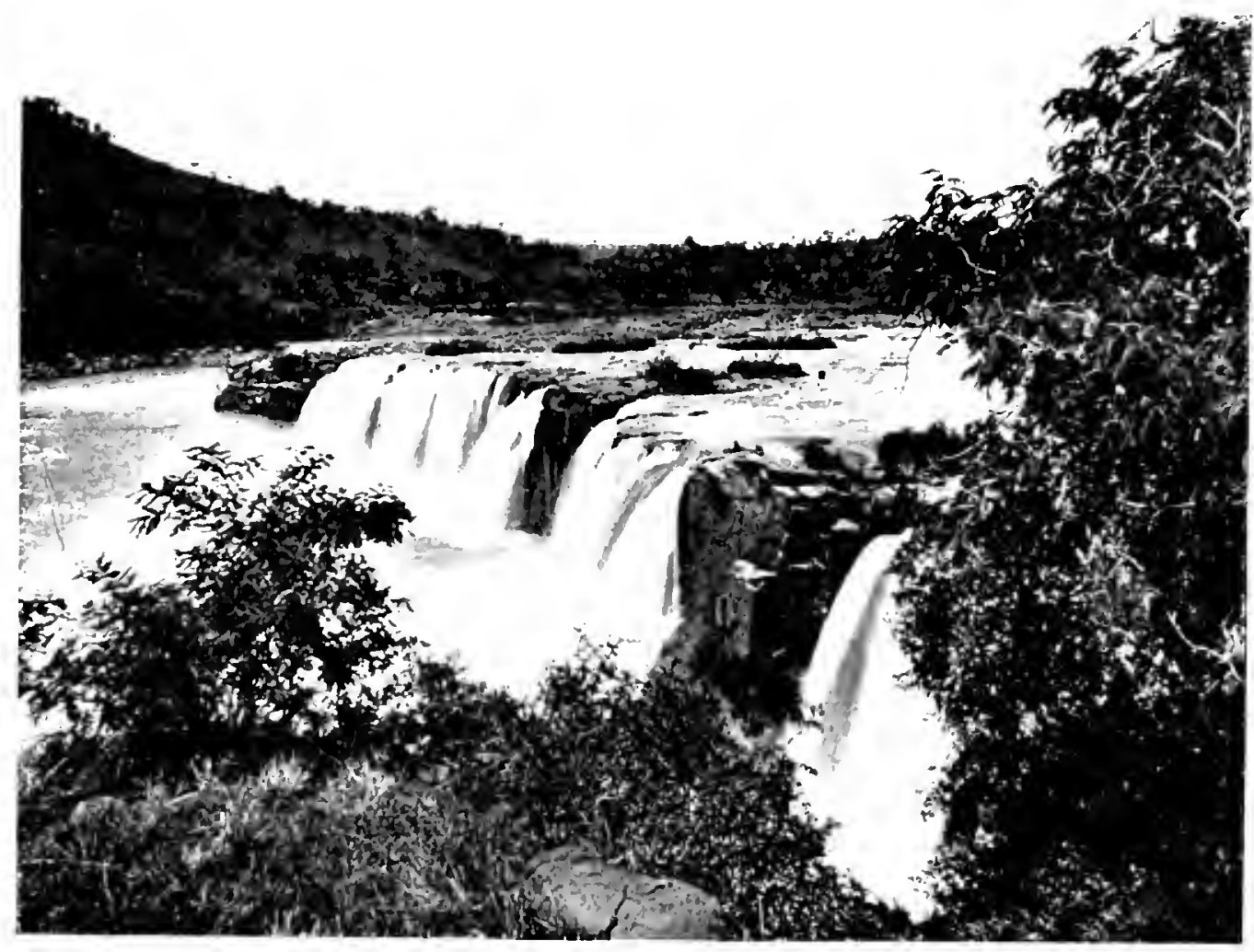


and some sixty were shot luring the passage: fet not a man wavered but looked leath unflinchingly in the face. On the other side of the Spruit. Fort Alolynew. appears. This was vacated during the earlier stages of the invasion.

The train then rises stowly towards HART'S HILL, where a stall station has bera tatalisherl. The line is very steep at this point. and ample opportmity is afforded for viewing the historic surromelings. Almost within line of this hill are the larger and more celebrated FALLs. A fow humired vards on the colenso side of these is the site ot the boer railway-sleeper bridge by which the eneny was able to man and fortify the well-nigh impresuable hills, betore, and retreated upon, the British advance. Alont the same distance on the Larlysmith side of the lalls, was hubl the second pontoon bridge neer which our bores were crossed to attack the PIETER'S HEIGHTS.

The line skirts the tout of the famons hill (Hart's), and the burial gromend of the offictrs and men of the Irish brigate (principally lnniskillings) who tall on the 23 rel Feloruary, ryou. is incicated by a monument at the hear of a long stone-walled grave, while suite close to the rails is the resting place of some of the Dublin Fusiliers and others, marked by a large tombstone.

To the right of llast's Hill is Raikway Jill, and on the opposite side of the railway is the last conmuered hill of all-l'ieters. Towering at the hack of the last. named is the romantio looking lagle's Nest (Aasmgel's kloof).

In prossing onwards an expuisite view of the valley of the Tugela, along which our forces worked to storm the diffecult steeps, upens out. It is a hold and peeuliarly beantiful piece of country, and the sight of it alone would invoke feelings of molloyed affection and unstinted admiration lor on hero "Thomas Atkins" and his beloved and taithful leader, gallant sir Redvers buller.

PIETERS is the next station. There is no hotel in

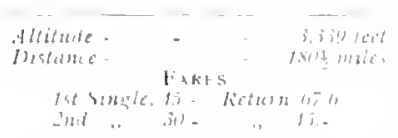
the district and as all the historic hills. with the ex ceptim of the one named atter it, are situate nearer Colenso, the latter place is made the centre for visiting the varions seenes. Another method, howerer, is to take a moming train trom Lidysunth to Pieters,

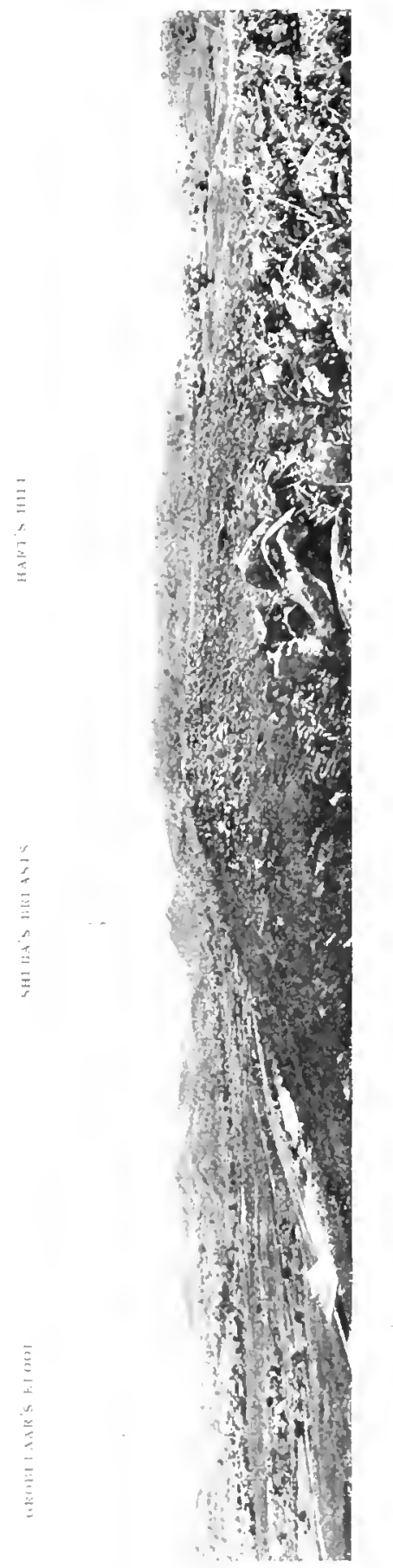




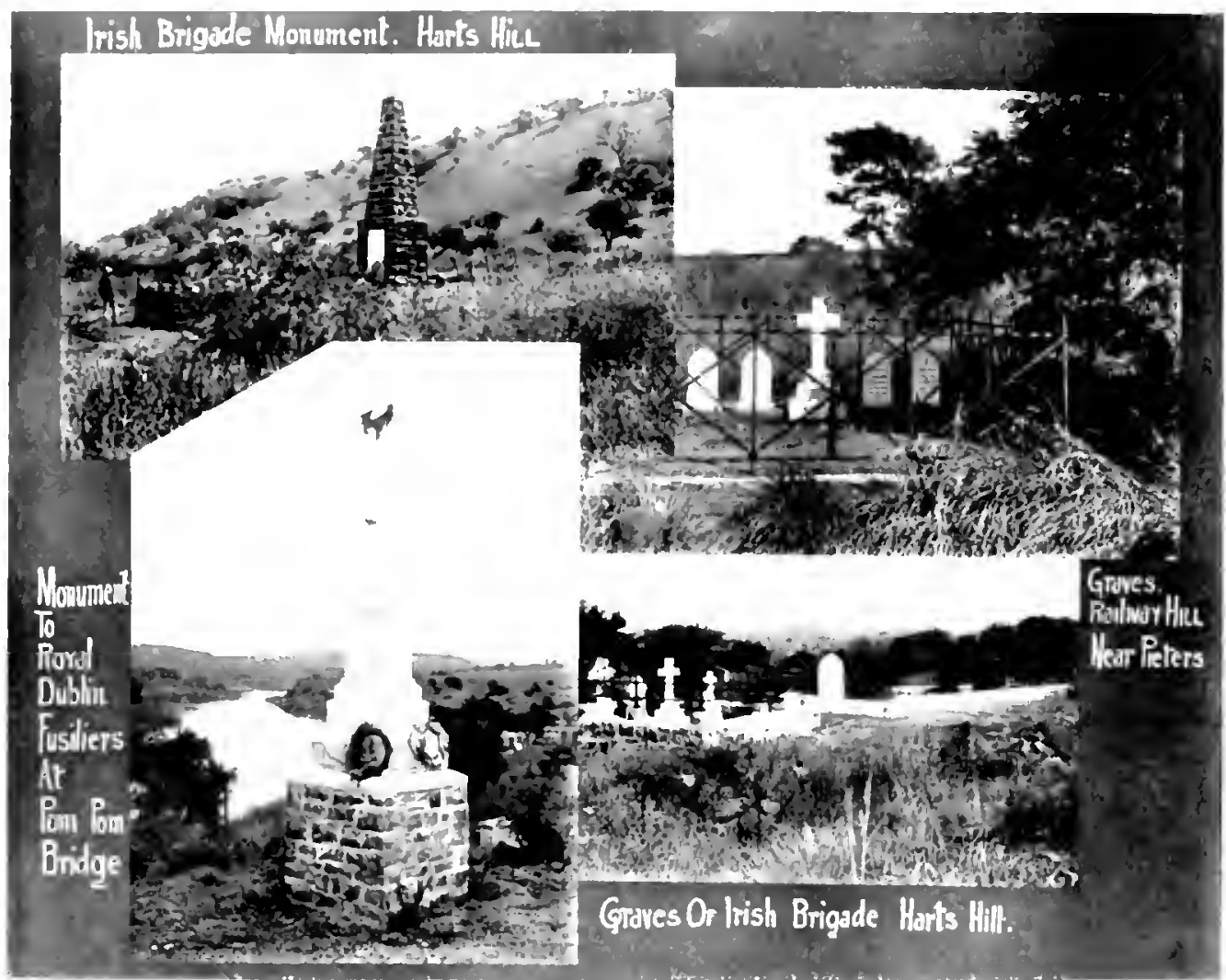

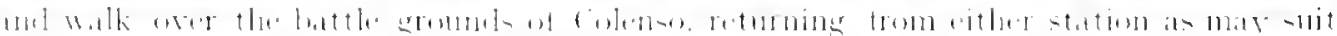

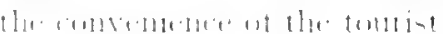

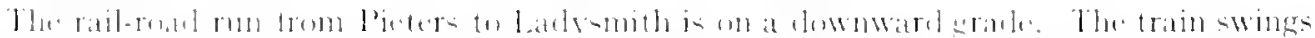

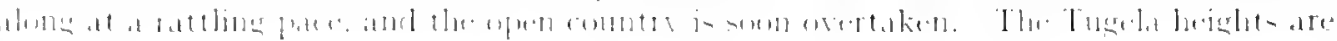

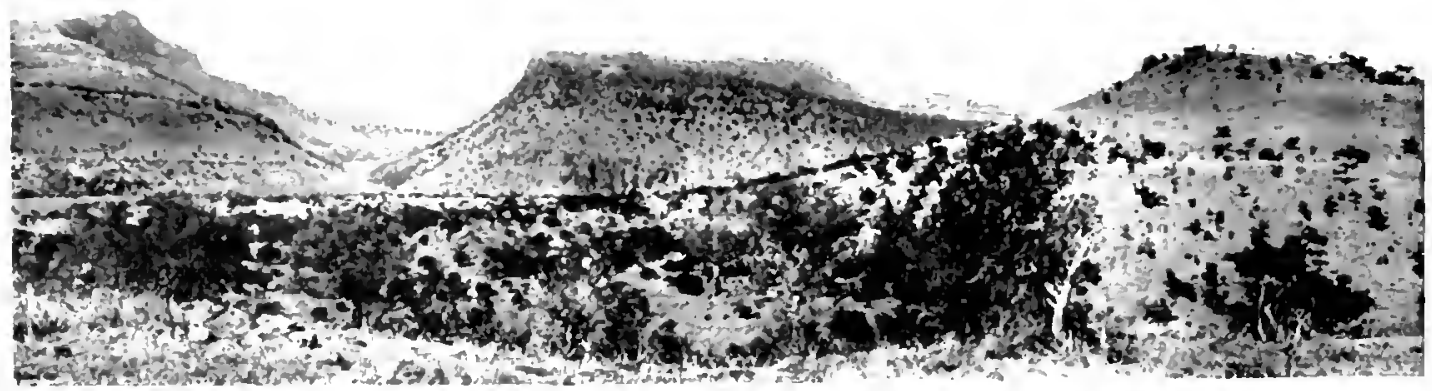


left behind. and in the distance several of the imposing Biggarsberg Mountains staml out in stern relief. Wealie patches and kraals. and happy relling. drishobille hafirs are rapidly passed, and

UMBCLWAXA Station is reached. It is not

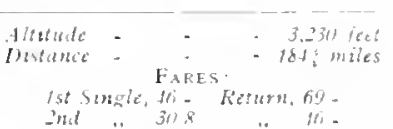
necessary to introduce the luge flat-topjed mountain on the right. nor the winding stream at its hase. Who has not heard of [ mbulwana and the Klip River: How unconcerned they look to-day. and yet what recollections they bring of yester years: The train sinuates along the banks of the river. with the giant mount erer above. until. passing by the spot of the famous dam where the rotting sand-hags will remain for many a day, upon the right. under the bier-like bulk of Lmbulwana. a large square plot of ground with deep lines of healstones and crosses will be sighted. This is the "Intombi" (1nlomba) Cenetery. C'mbulwana. Lombard's Kop. and Gun Hill now come in riew. and on the left is the historic range of hills-Ciesar's Camp and Wasron Hill-with the embattled Drakensherg presiding sombely over all. In the extreme right distance is the bigsarsberg Range, and flanking the train for several miles is at great, grassy plain. Presently the train crosses over the River Klip. and immediately enters the most notable railway station in British listory-Jadysmith.

CHAPTER I.

\section{HISTORIC LADYSMITH.}

T

Hes world-tamous town is situated upon the banks of the River Klip. and within an irregular circte of hills. 30 miles trom the

\section{THE TOWN}

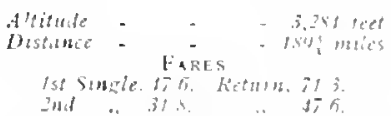

dians, I, fon katirs. anel its properties are valued at f273.720, upon which a rate of 3el, in the pound is levied.

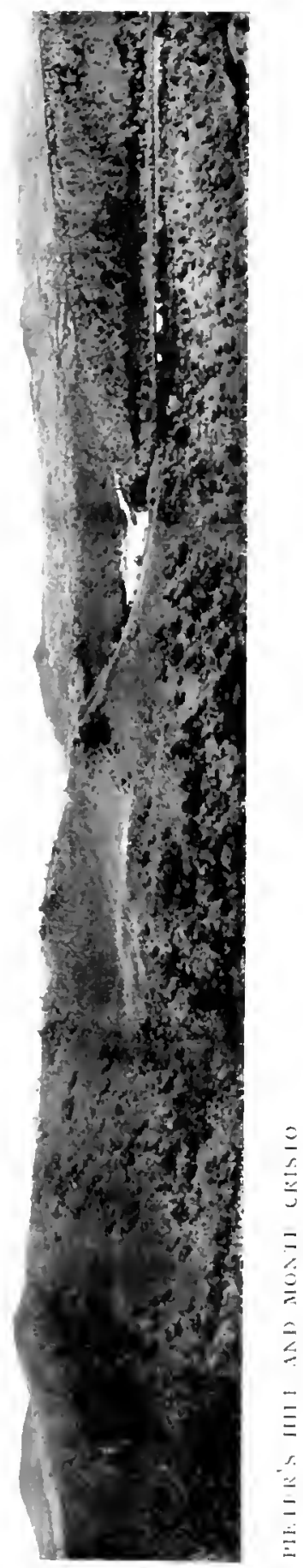




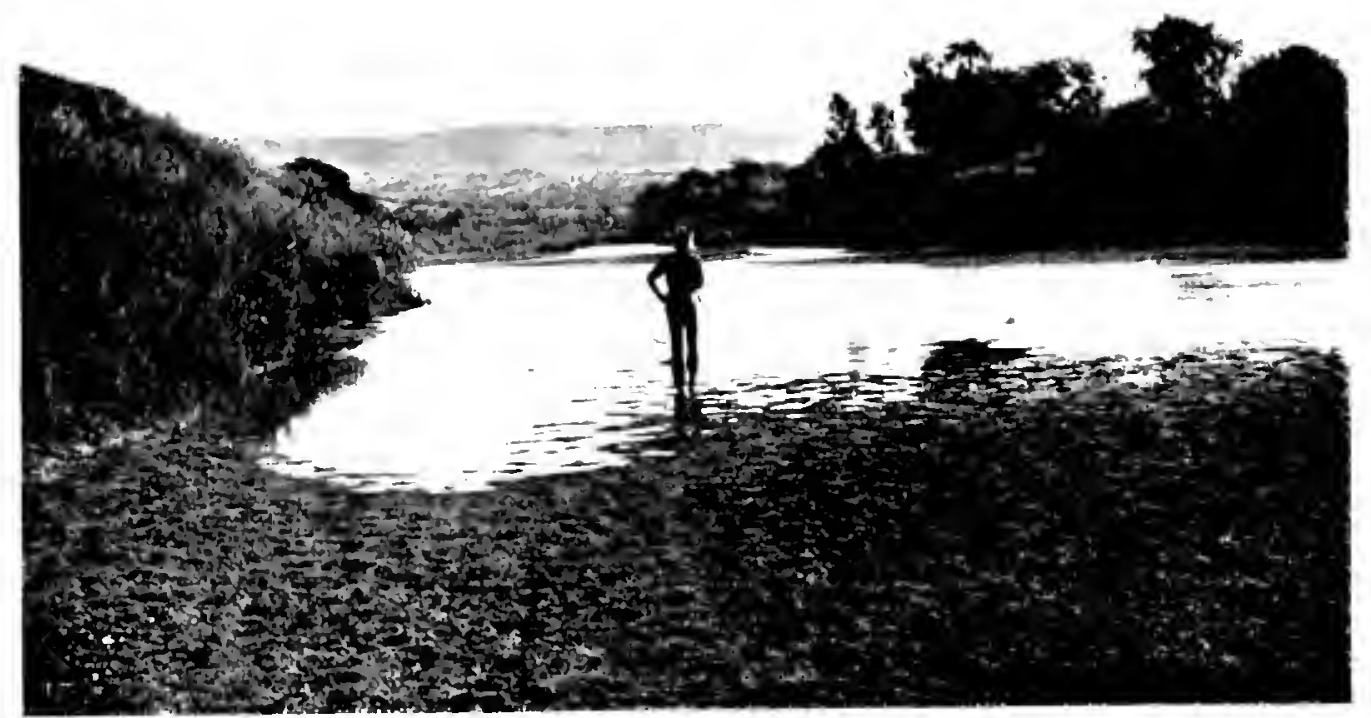

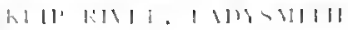

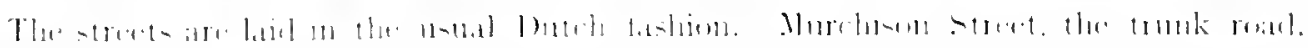

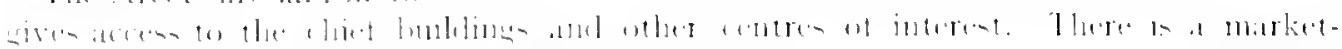

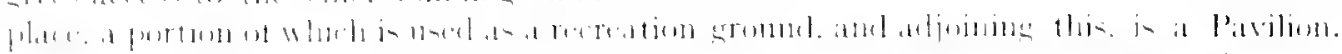

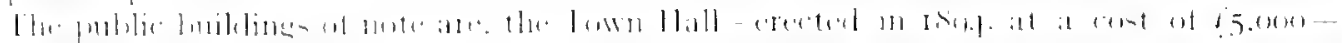

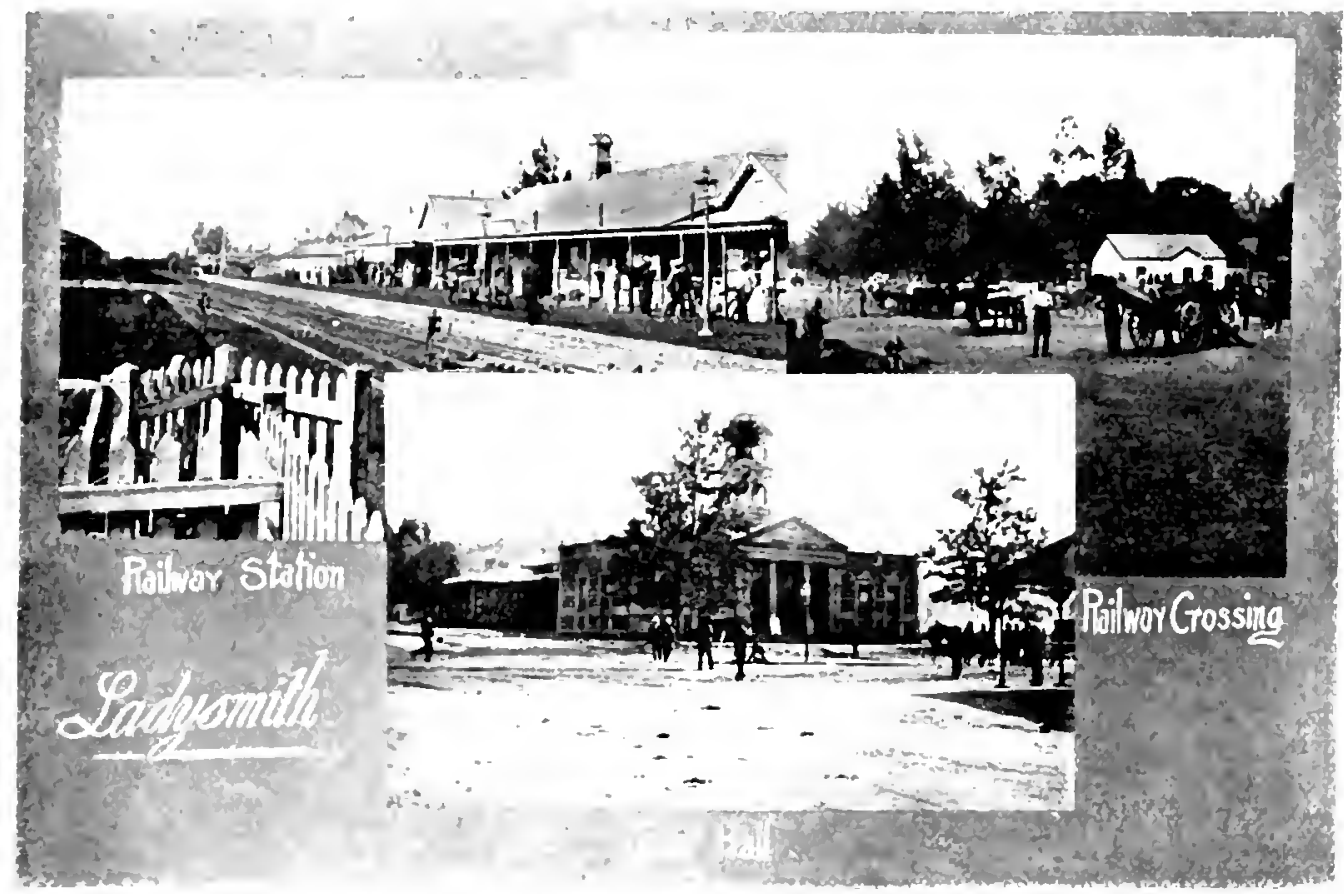


Court House, Post Office, Library and Reading Room, the churches allotted to the several denominations, Government and other Schools, three good hotels-the "Royal," "Crown," and "Railway" and a Sanatorium. Another important institution is the Convent on the hill overlooking the railway station. This was used for some time by the Military as their headquarters during the Siege, and also by General Buller after the Relief. The town is well supplied with water from the Klip River, and is healthy, though somewhat hot in summer. The death rate under ordinary conditions is low, Io per r.ooo. In 1897 the trwn was selected for garrison purposes, and a camp), locally known as "Thin Town," with accommodation for 3,000 tromps and three batteries of artillery, was fixed ahout two miles outside the town, near the waterworks.

The district is principally agricultural. but being the junction for Harrismiti and the Orange River Colony (see pages 2 I 2-220) as well as an important Locomotive centre. Railway employés account for a good proportion of the town's population.

Ladysmith is the post-cart town for Dewdrop, Acton Homes and (pher Tugela. The service is a tri-weekly one (Mondars, Wednesdays and Fridays), and the fares are 7 . $6 . \%$. Ios. and I 5 . respertively.

In passing through this quiet place it is difficult

\section{THE SIEGH} to realies that it is the town which so valiantly suffered the numberless privations, and all

the ghastly ills of a protrarted ciege. Hacl it fallen with its I0.000 combatants. 7 . suns. and a million pounds wortl of stores. how alphalling womld have been the consequence! As a relehated writer sars. the interest of the world, pusibly the desting of the Empire were centred upon it during the long and uncertain one hundred ams nineteen days. But Larlysmith trimmped, and a thrill of reliet, thankfulness and joy, such as generations had not known, courset through the trame of every Britislier throughout the halntable globe. All homon to Sir George White. his able lientenants, and magnificent men.

The historic hills ant sites. and the farions incidents connected therewith. an duscribed in the next chapter, but a tew succinct particulars of the heary and melancholy toll incurred by the resolute braves in keeping the tag flying will be interesting:

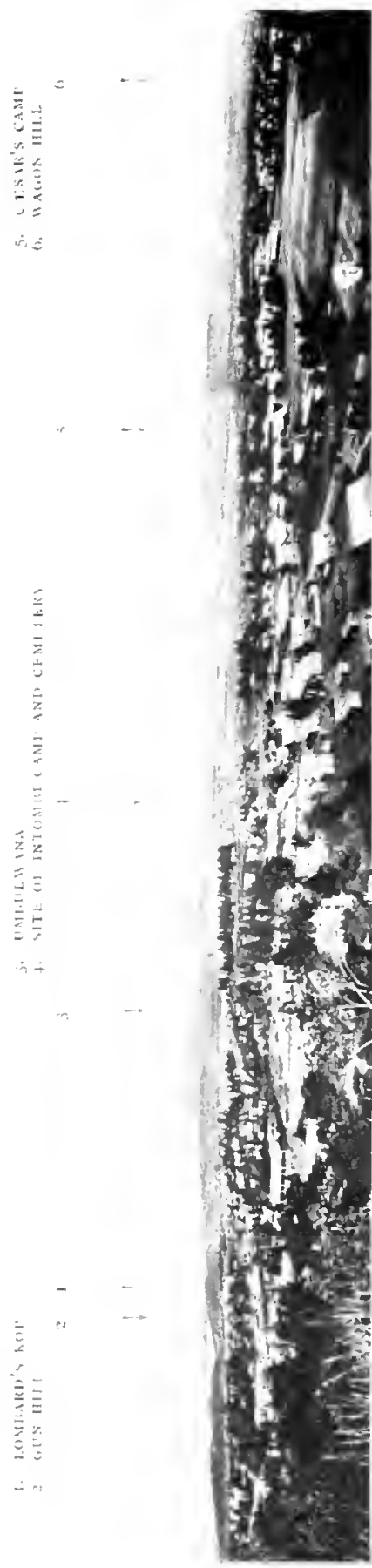




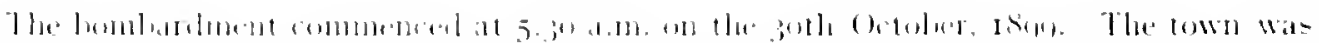

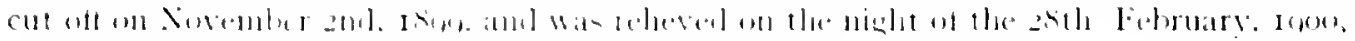

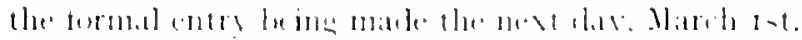

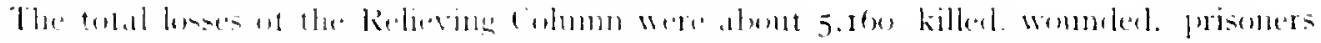

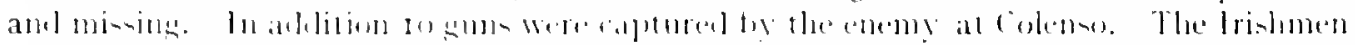

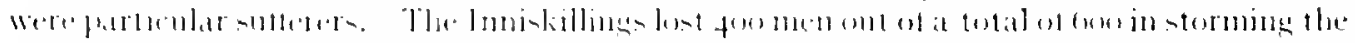

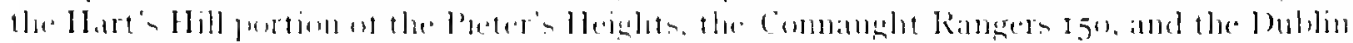

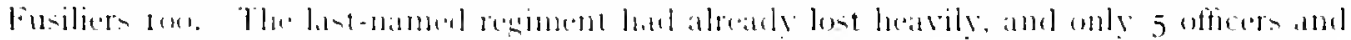

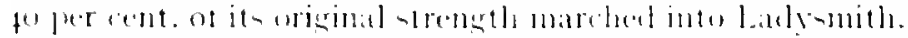

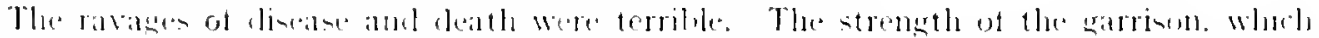

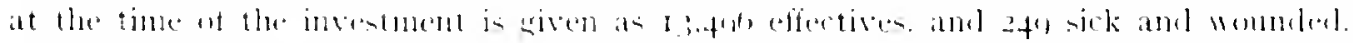

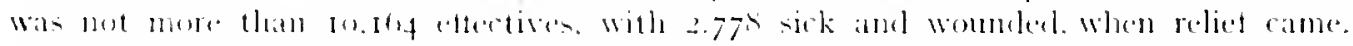

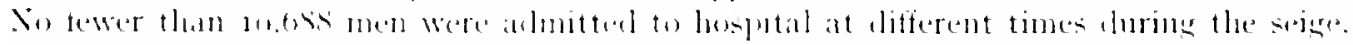

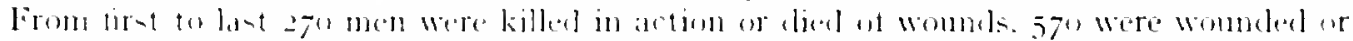

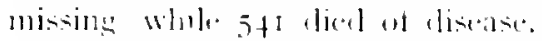

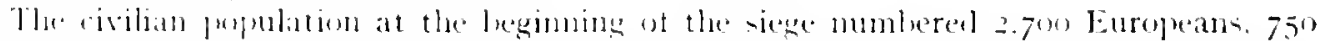

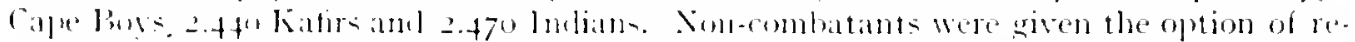

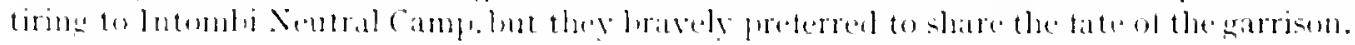

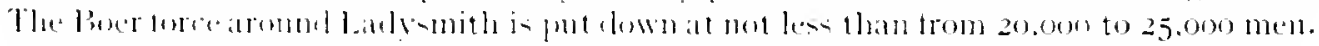

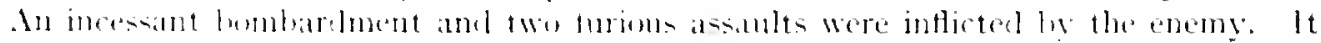

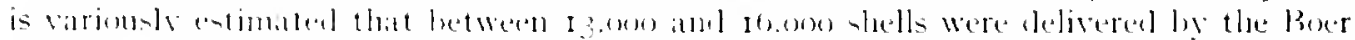

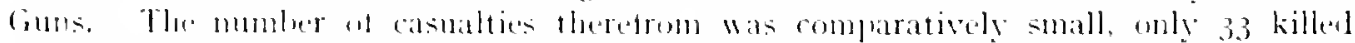
and 232 womblal.

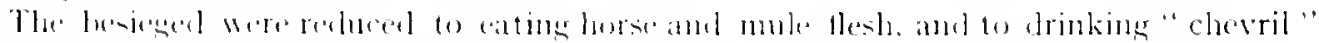

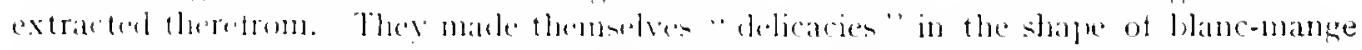

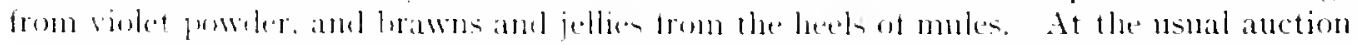

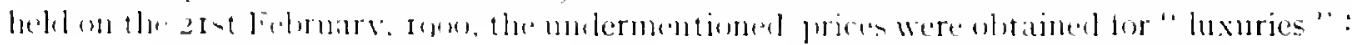

\begin{tabular}{|c|c|c|c|c|c|c|c|c|}
\hline $1,11 \times, 1,1414 \times, 11 \ldots$ & $\cdots$ & $\cdots$ & $\cdot$ & $\cdots$ & $\cdots$ & $\cdots$ & . & 511 \\
\hline In rablematel malk & $\cdots$ & . & . & $\cdots$ & $\cdots$ & $\cdots$ & $\cdots$ & 10 \\
\hline $11 \% 111 \mid x+1 \ldots$ & $\cdots$ & & $\cdots$ & $\cdots$ & $\cdots$ & $\cdots$ & & 11 \\
\hline 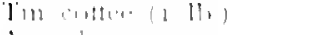 & - & $\cdots$ & $\therefore$ & - & $\cdot$ & & $\cdot$ & $1-$ \\
\hline 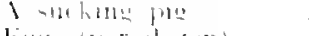 & $\cdots$ & $\cdots$ & $\cdots$ & . & . & $\cdots$ & $\cdots$ & $3 ;$ \\
\hline 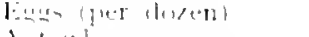 & $\cdots$ & . & $\cdots$ & $\cdots$ & & & $\cdots$ & $4^{+2}$ \\
\hline $11+41 \quad \cdots \quad \ldots$ & . & $\cdots$ & . & $\cdots$ & . & - & $\cdots$ & 18 \\
\hline 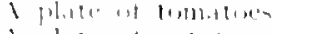 & $\cdots$ & $\cdots$ & $\cdot$ & $\cdots$ & & . & . & $1 \pi$ \\
\hline 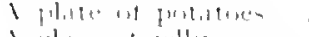 & . & $\cdots$ & $\cdots$ & $\cdots$ & . & $\cdots$ & $\cdots$ & 10 \\
\hline $140.19=4$ jells & . & $\cdots$ & & $\cdots$ & $\cdots$ & $\cdots$ & $\cdots$ & $13-$ \\
\hline 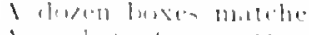 & & . & . & $\cdots$ & & $\cdots$ & $\cdots$ & $13 / 6$ \\
\hline I pholist ot cientreliter & - & & $\cdot$ & $\cdots$ & & . & & $25-$ \\
\hline 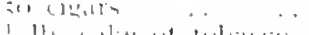 & & . & & & $\cdots$ & . & - & $1 ミ 5$ \\
\hline 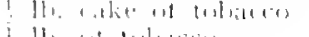 & $\cdot$ & $\cdots$ & · & & $\cdot$ & . & $\cdot$ & 45 \\
\hline 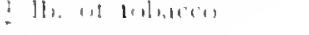 & $\cdots$ & $\cdots$ & $\cdots$ & $\cdots$ & - & . & & $65=$ \\
\hline
\end{tabular}

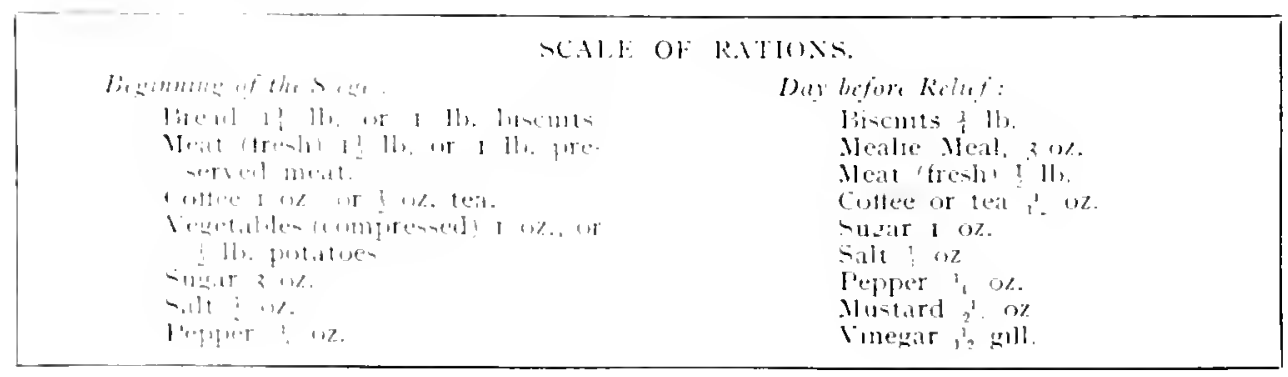


It is but fair to repeat the Royal tribute to the inhabitants who endured the same hardships. disease. and death: felt the same repeated disappointments: and manife-ted the same heroic and praiseworthy determination as the soldiery in the proservation of the prestige of the Empire. The following utterances of H.R.H. the Duke of Comwall and York, in reply to the address of the people of Ladysmith on the occasion of his visit to Natal in August, Igor, will be treasured in the hearts of all true Colonists:

"From the and November, IRng. Ladysmuth lecame, day 1,y" day, the very centre of interest and

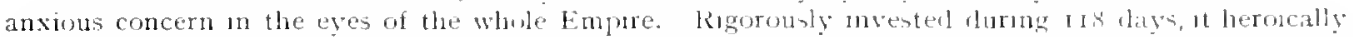
and with dogged resolve 'kept the llig tlymg, and resisted the attacks of the "nemy, of hunger, and of disease, while the outside world looked on whth breathess auspense, at times harbly larng to hope at the repeated gallant attempts to brong her relief. It was the stublurn detence of that ontwork which stayed the advance aganst the cilntal of your Country, and m thanking the perple of ladyomith

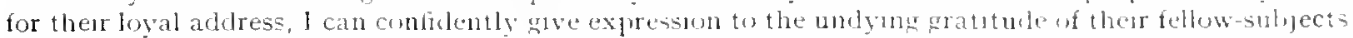

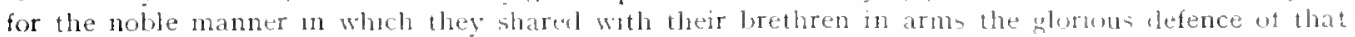
ever-memorable siege."

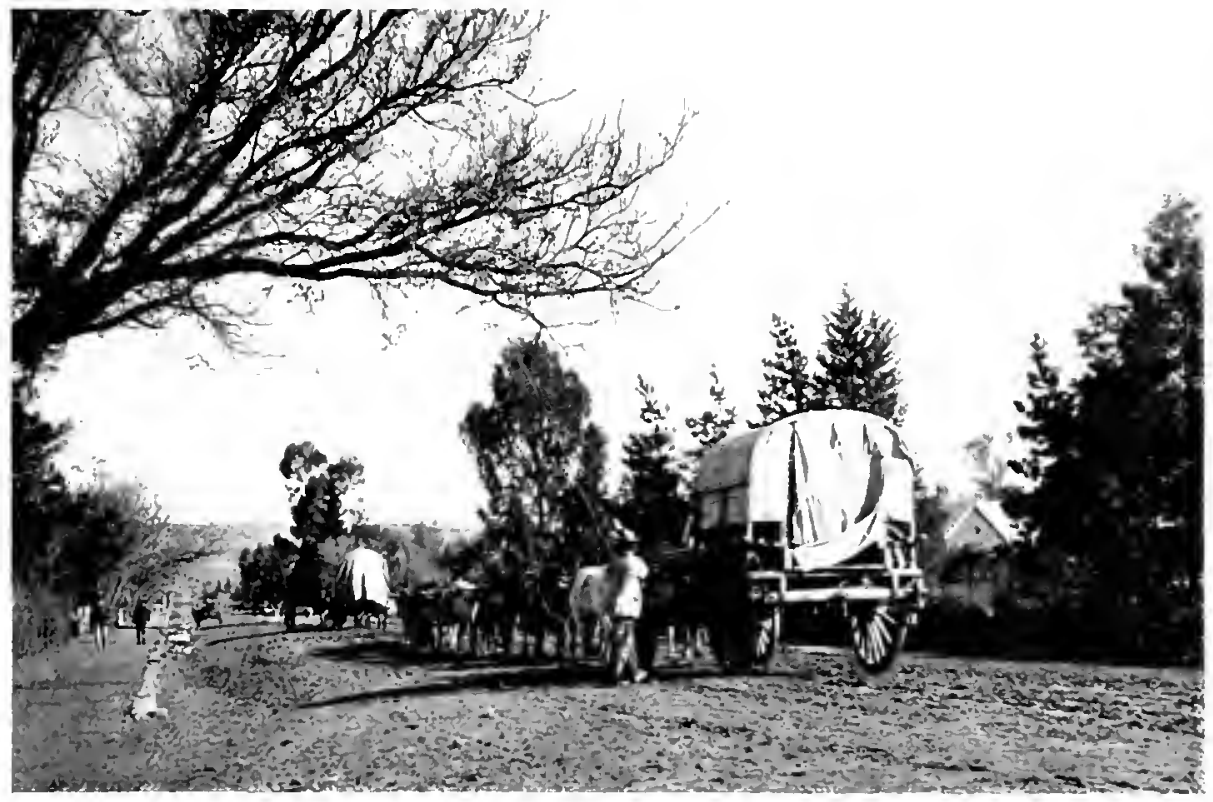

STREET SCFNE, LADYSSIIIH 


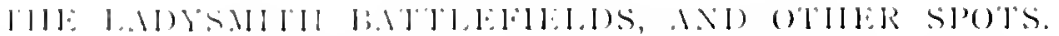

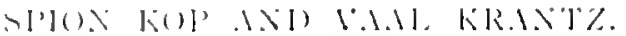

\begin{abstract}
A NOTE. The most husterie of the many hulls around Ladysmeth are, Umbulwand, Lombard's Kop. Gun Hill. Pepworth's Hill, and Surprise Hill wheh were oceupied by the Boers: and Wagen Hill, Ciesar's Camp, Observation Hill, and the hills lorming the permeter of defenes, whoh were in the Britush possession. There are also of course such spots of partecular rememtrance as Farquhar's Farm, Nicholson's Nek, Rationtum, Spon Kop and Vaal Krantz some distance away, and many interior places of much note werthy to be visted, as mentroned an detail below.

The lace mogh te emphasised that visters wilt be able to hire conveyances or saddle pontes, and sciour the servets of well-mformed gudts at the several hotels and livery stables in the town.
\end{abstract}

$\mathrm{R}^{\prime}$

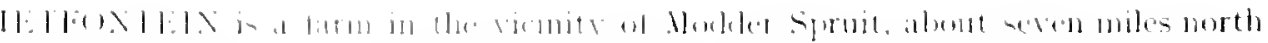

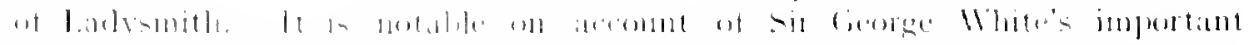

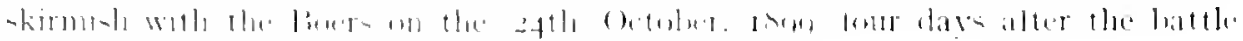

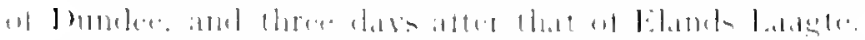

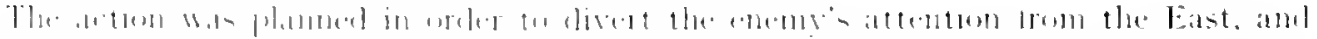

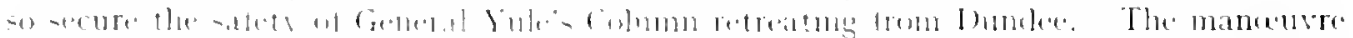

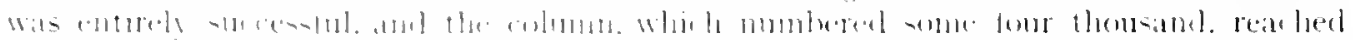

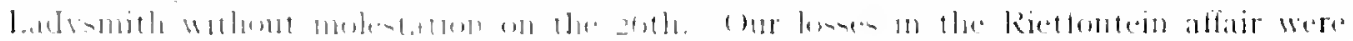

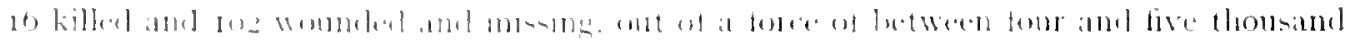

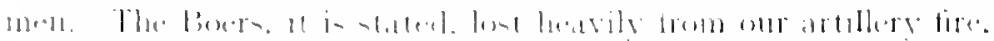

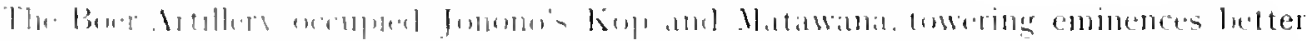

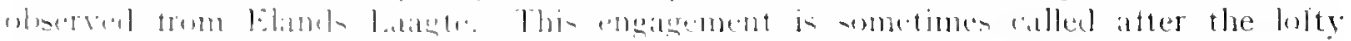

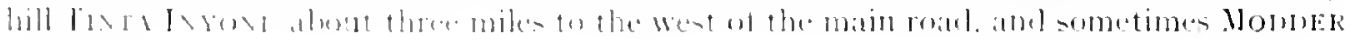
SPlitil.

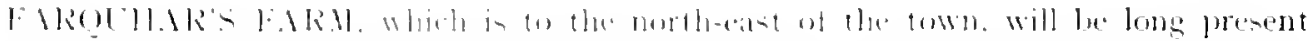

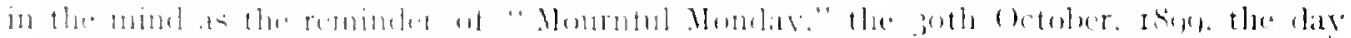

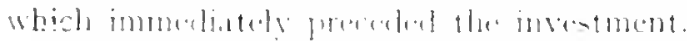

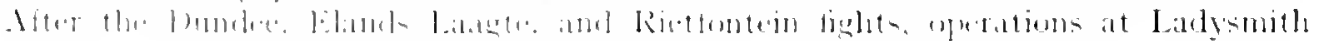

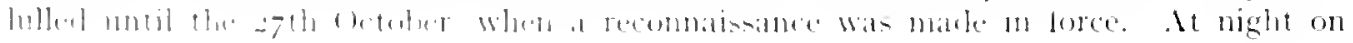

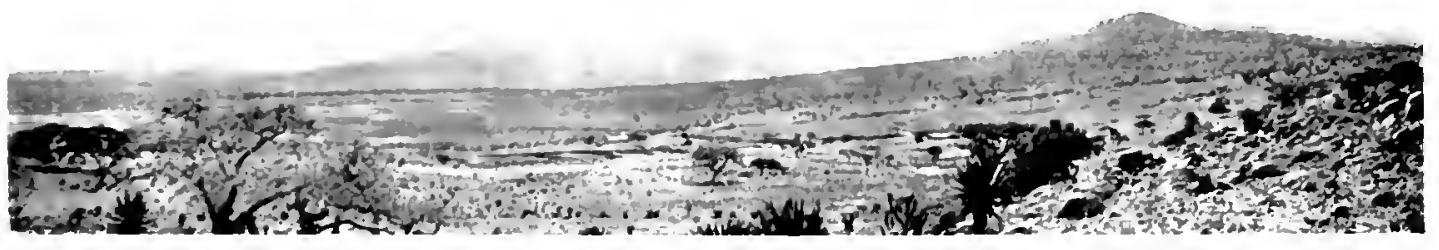

BU,IRSILK 



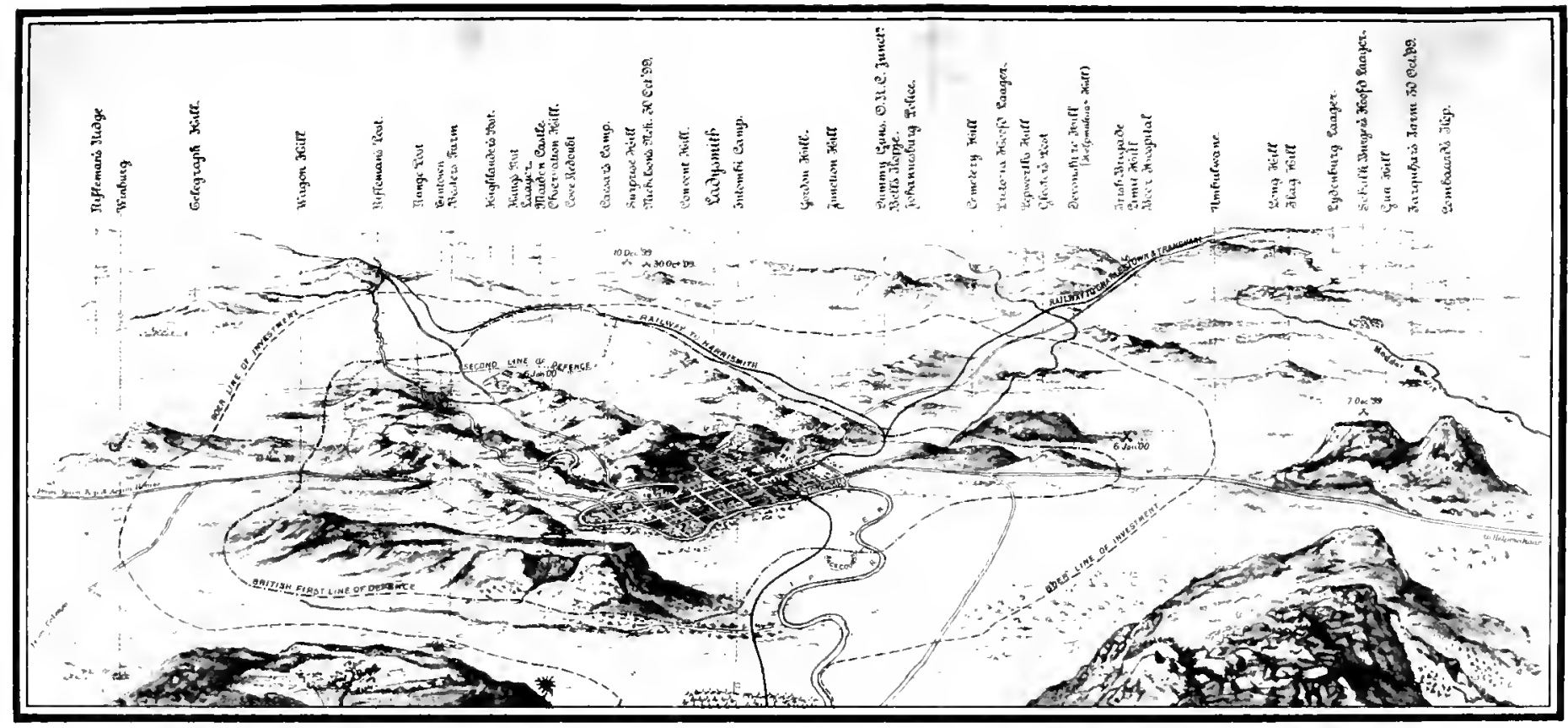

BRITISH AND BOER POSITIONS DURING SIEGE OF LADYSMITH. 
the 29th; the whole army moved out in readiness to attack, in the early hours of the following morning, the Boer position, whirh covered some sev'un or eight miles with "kopjes like chains of fortresses"-for by this time the Boers from the north, and the Free Staters from tlu. west lad settled, or were settling themselves and their powerdul artillery. on the pick of the heights com manding the town. Two intantre hat talions with a monnted hat tery were detailed for isolated operation on the extreme ledt, and their fate is recorded leerealter.

The result of this battle of Farquhar's Farm, or Iombarel's Kop as it is officially set down. is well known. (hor trompls rould] gain little advantage, our tanks were endangered on artillery was inferior in weiglit and dis. tance. It was feasible for the Dutch to turn the attack, and with the overwholming atd of their ab-pounders and ot luer heary comnon, rush the town through our front. or detich a portion on their extreme right to join other incoming commantloses onthank ns, ans effectually rut off onr re. treat. General White har there. fore no otleer option than to retire upon the town. and low to the: ineritable. Thisle disl. lut under a scathing fire. and lint for the gallantry of the 1,itle and 5,3rel batteries in operatims at a mor derously short range Inring the withdrawal of the mbatry, aml the timely, almost prosidential. arrival hy train of captain lambton and his nen with the natral guns, and the immediate silencuns of the big crensot on pepworth's Hill the issue would latre heen

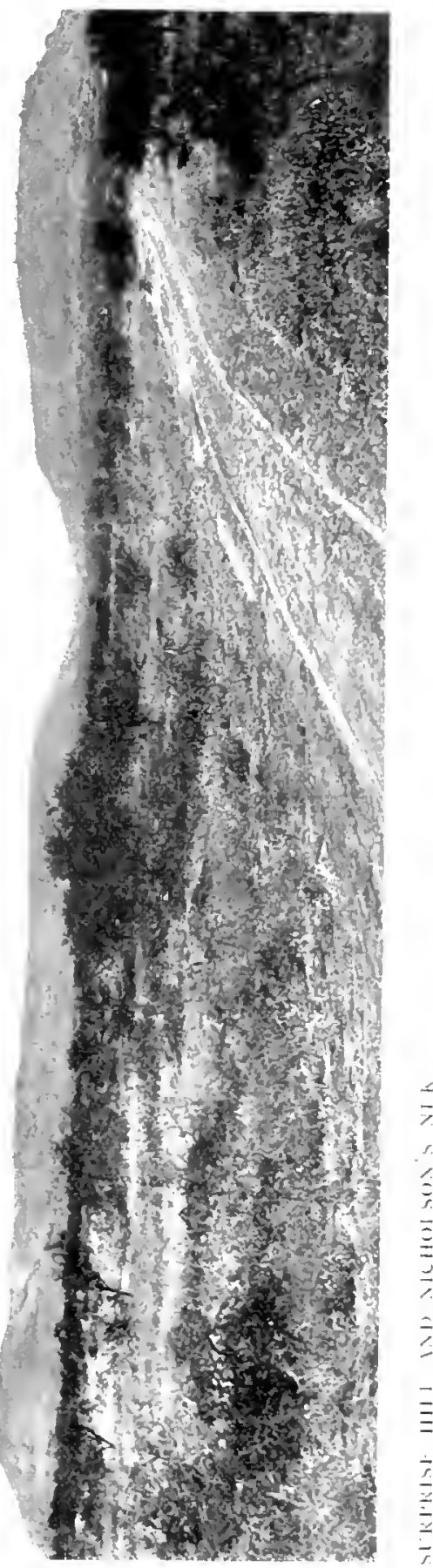




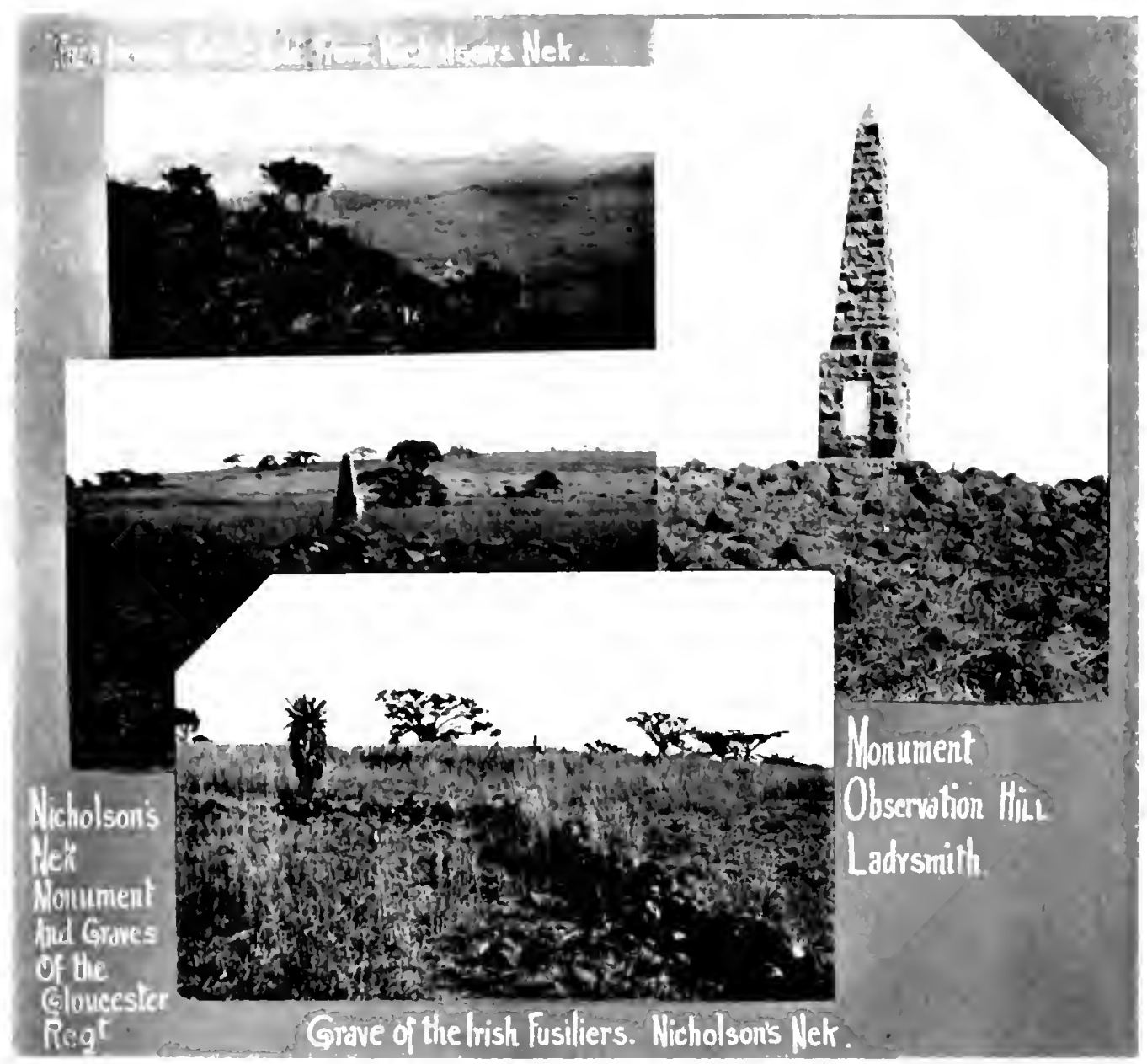

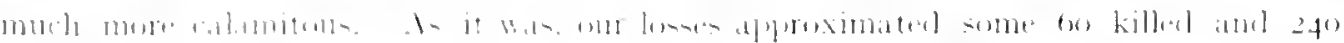
II:

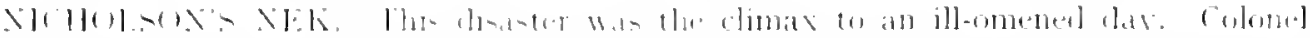

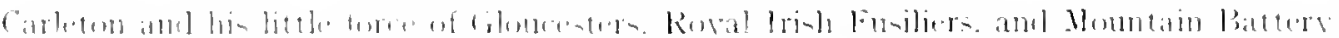

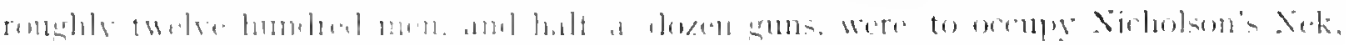

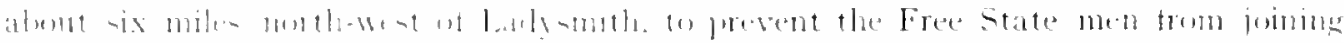

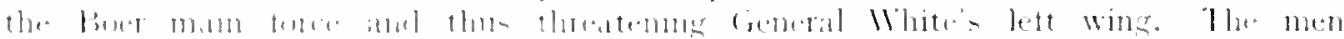
Hatr-luet

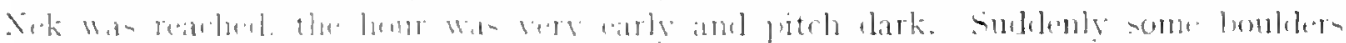

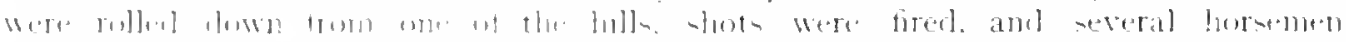

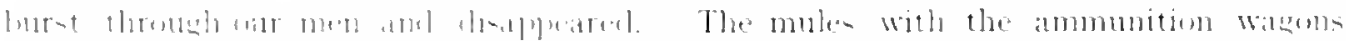

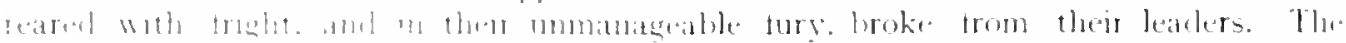

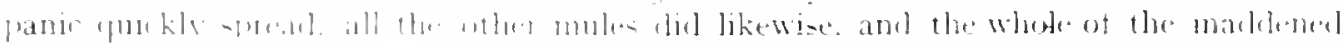

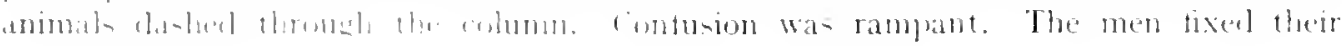


bayonets and carried the hill. But the mules had tled, and the reserve ammunition and several of the mountain guns were gone. The rest is known. The moming laced the force with its real position. Yet, undaunted the men tought to their last cartriuges, hoping against hope that General White had won his battle. which would bring the relief that harl been promised them. Then someone without anthority raised a white flag-who. it will perhaps never he known. Officers and men, it is reported. cursed the day they were borm, broke their sworls. sobbed with rage-it was a tearful catastrophe-they had rather died! But the deed was inne. and 970 officers and men and three guns fell into the enemy"s hands. A number of the men excaped and tound their way latk to Ladysmith. The womndel and deat the former being giren II) by the Boers) totalled more tham a hundred. According to Sir George White's despatch. the total losses on this melancholy lay amounted to 6 officers amsl 63 non-commissioned officers and men killed. Io ofticers and zin non-commissioned otficers and men wounded. in addition to the ahore-mentioned "missing." This was the end of "Mourntul Mrmtay" and Ladysmith wate leesieger.

UMIBLIWANA is tom miles ont, and much risited tor its excellent view of the British positions, the several battle gromuls. the emplacements of the libmous "Long Tom" and other similar guns, the SITE of the GREAT l).A.

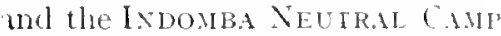

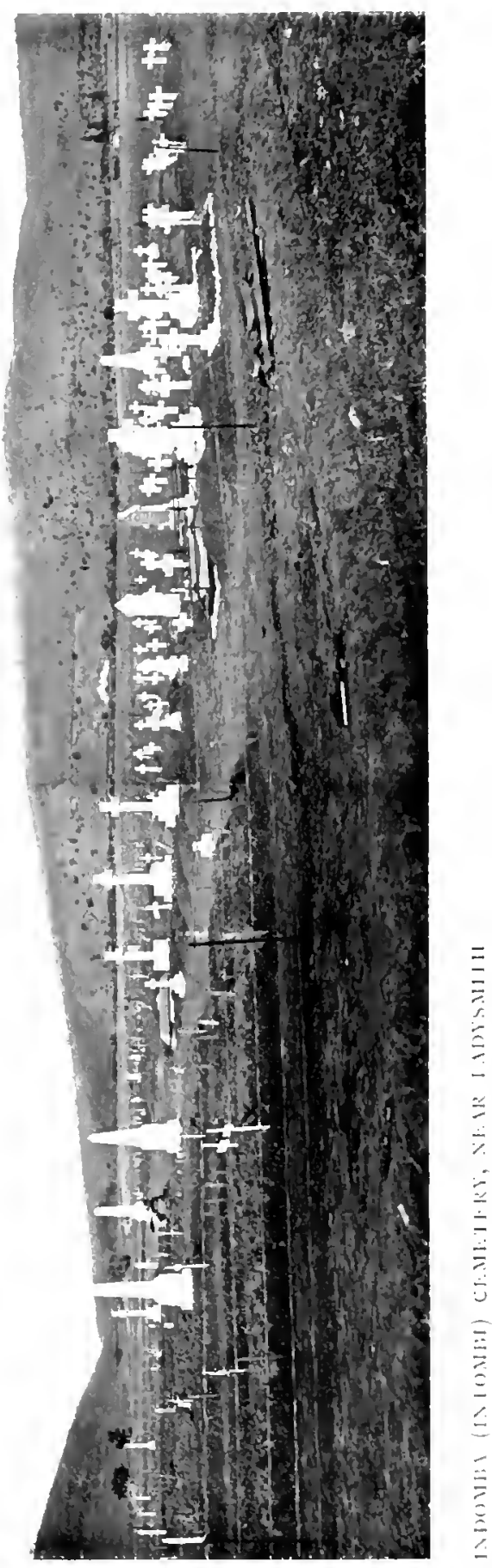




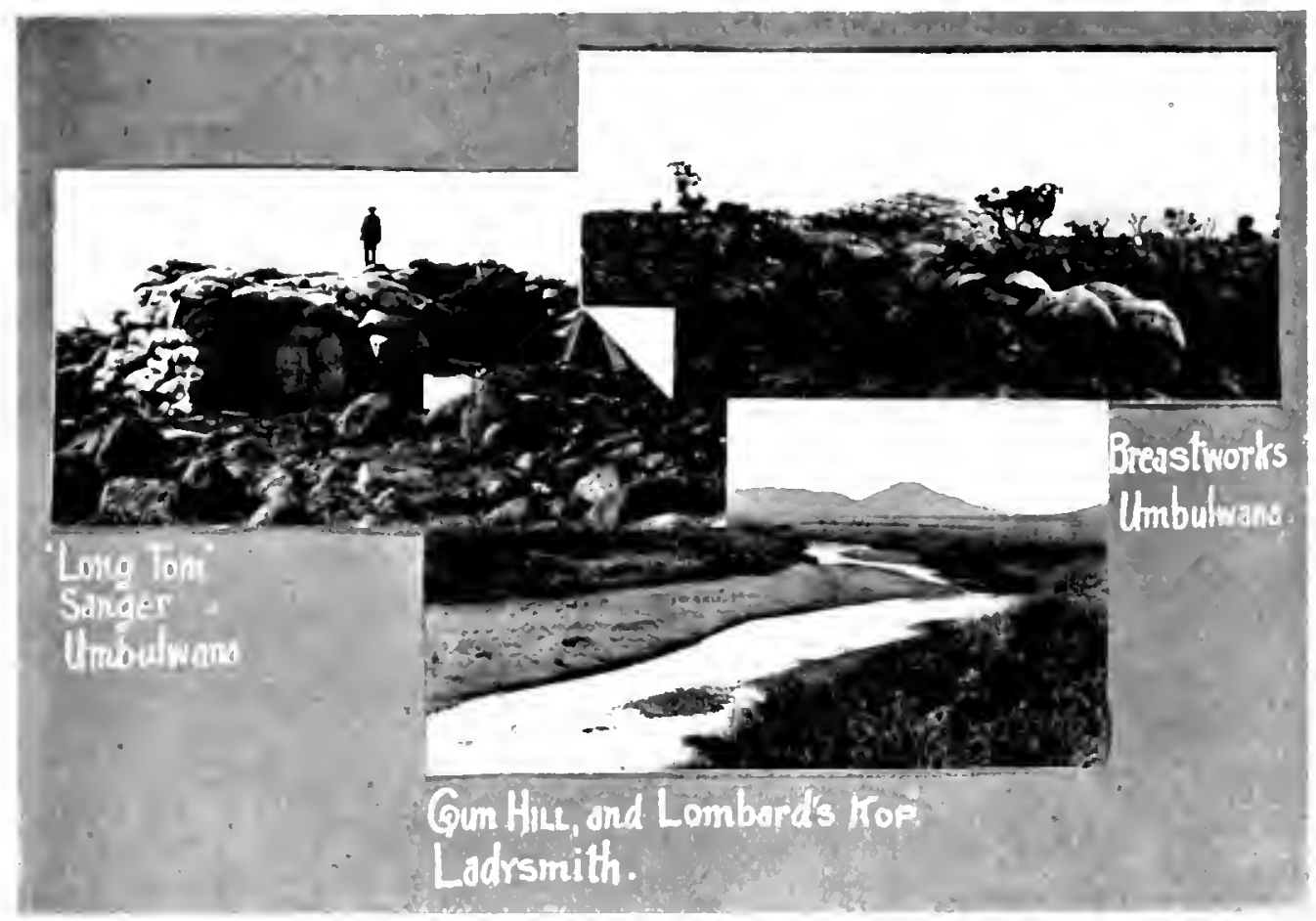

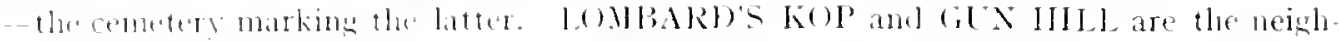

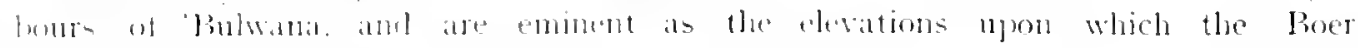

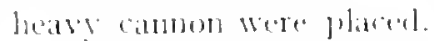

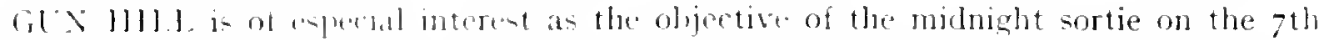

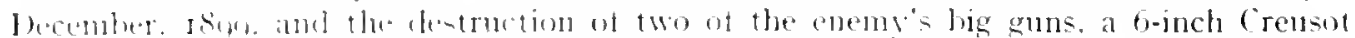

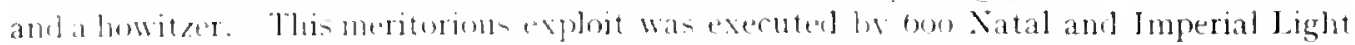

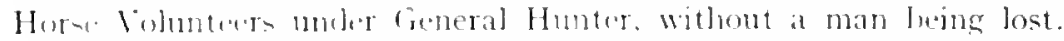

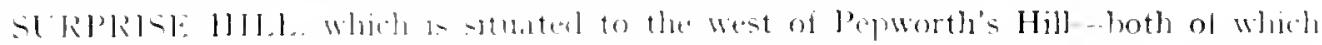

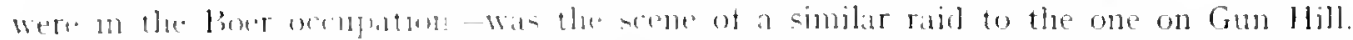

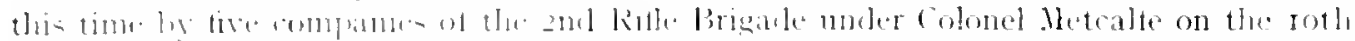

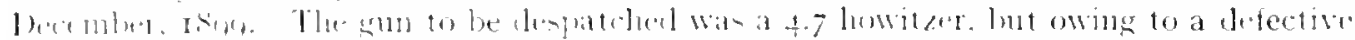

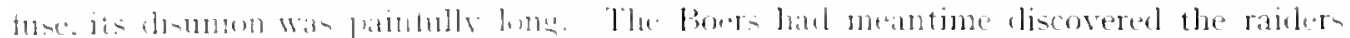

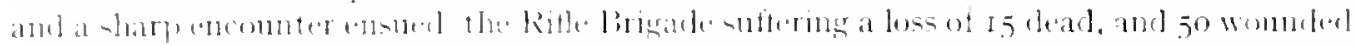

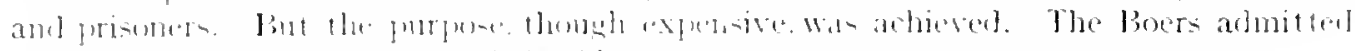

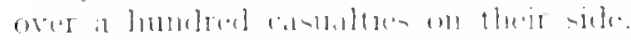

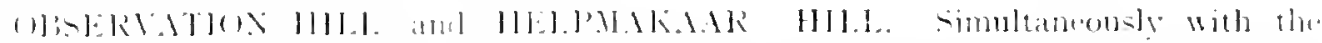

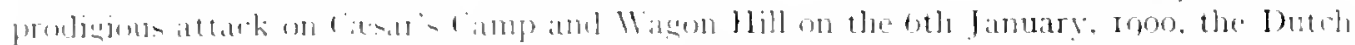

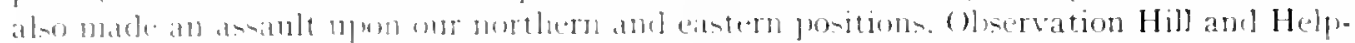

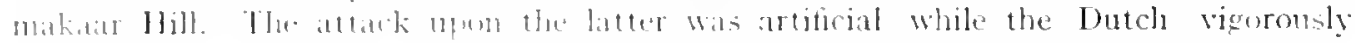

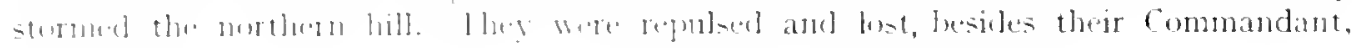
some 50 Int 
As its name denotes, Otservation Hill is one of the best eminences tor a complete survey of the historic country in whirh connection the DISPOSHTHS OI: THE HEAVIER

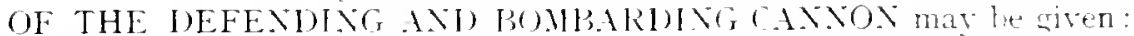

The outer and inner lints of the british defence are slewn on the ladysnith Map.

The heary guns which we hat to reply to the enemy" magnificent artillery, were two

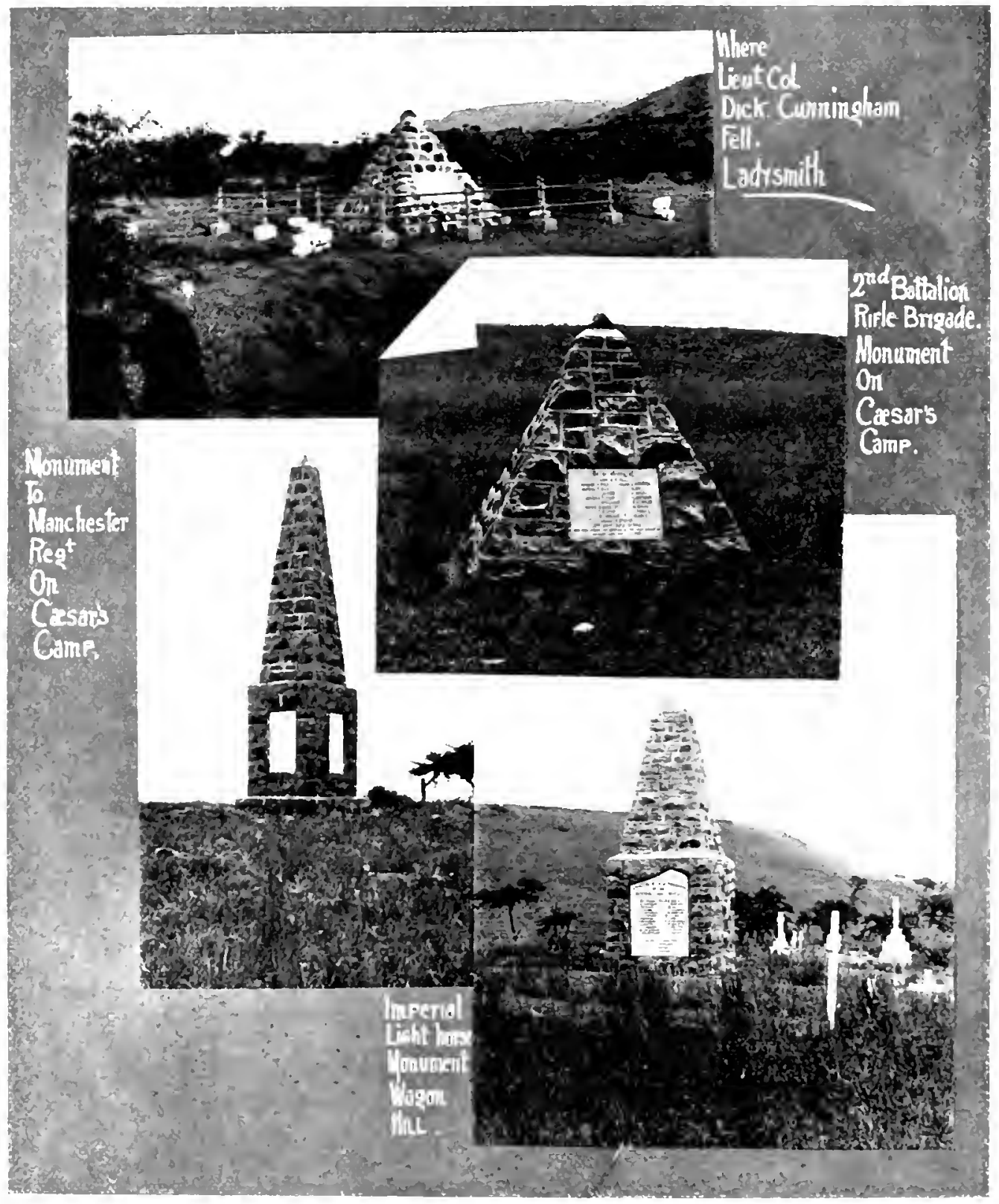




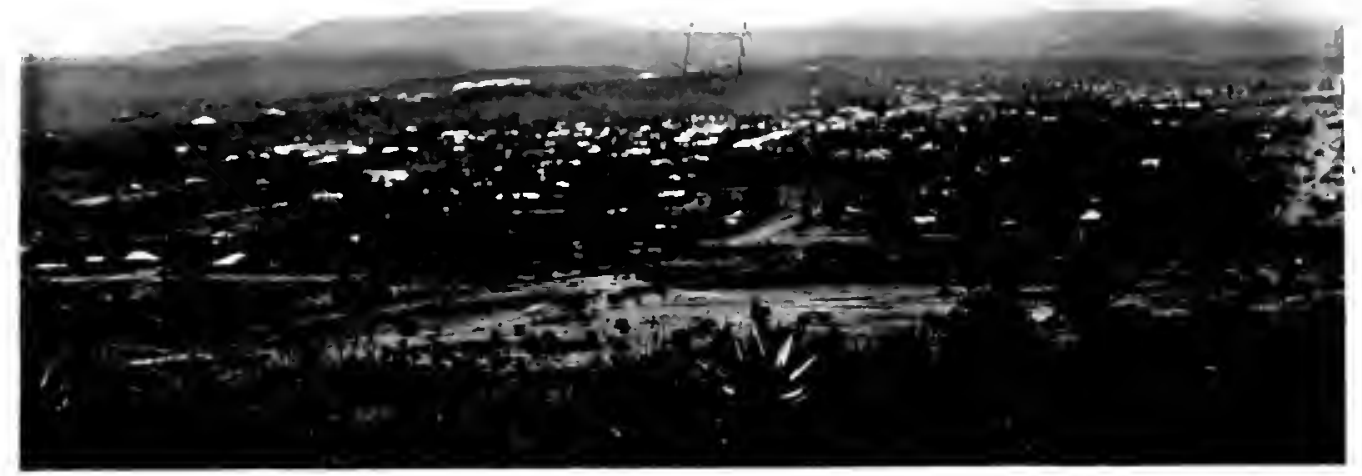

I.AMYSMITH, HROM WAOON HII.

naval guns. 4.7. phacel first in the Cove Redoulst. then on Tumel llill, and after the beginning of January, on Magon Hill: tour long-range naval I 2 poumlers, one on Casar's Camp and the other on forlon Hill: and two ancjent howitzers.

The Poers lad two 7.7 luwitgers and an eigle-mile-range creusot of b-inch calibre on Pepworta's Hill. two +7 lowitzers on Surprise Hill. a 6 -incle Crensot and a +.7 inch

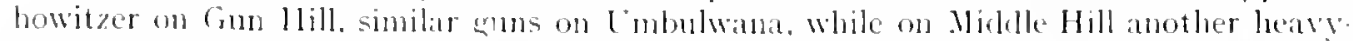
weight appeared. and on Telegraph Ridge there were two 5-ind guns. Field and

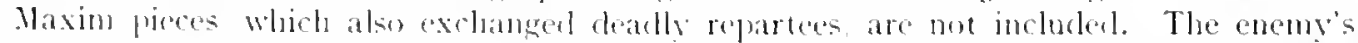
smins were of comrse duly dhritened by the facctions "Mr. Athins." and the no less facetious "Jack," directly thoy disclosed themselves and their peculiarities. "Long" Tom." "Puffing Billy." "silent susan." "Xasty Knox." "Fildling Jimmy." "lVeary" Wille." "rentleman Joe." "The Stinker." and the "Nedler." have each a history of

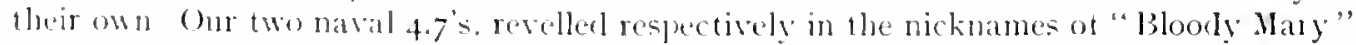
and "Ladly Anne," and the two 6.3 inch muzh-loaders. 25 vears old, rejoiced in the classical distinction of "Castor" and " poltux."

liftertive and sulstantial rechubts, camon-protections, sangars, and slam embrasures, were comseructed on the several hills and are of interest.

"C.ESAR'S CAMP" AND MACON HIL are respectively the eastem and western purtions of a rilge a ful milus south of latysmitls. Looking from these hills our com phete perimeter of fourteen miles. which followed Maiden's Castle. Highlanier's Pont.

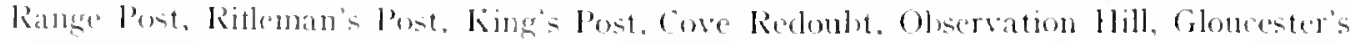
l'ont, Cemetery Hill. Ilelpmakatr Hill (Dosomshire Hill), can be traced. From these

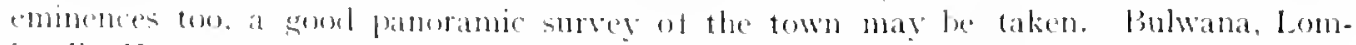

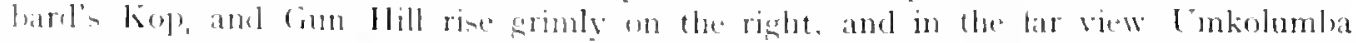

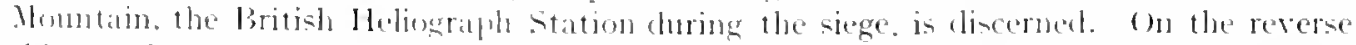
sile of the ridge, detached lith and great plains will he noticed. Tlue noted Bester's Farm. Sinon kop, and other hills can also be detrected.

This famous ridge was the key to the british pustion. and the boers made two cleter-

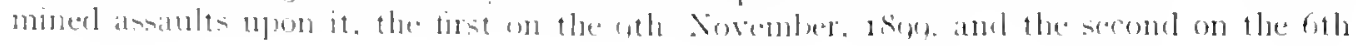


January, Igoo. Both were repulstel, however, and the latter ranks as one of the most illustrious figlits of modern times.

Alter beng repelled on the first-named date, the enemy was content to wait, and wateh, and bombard for nearly two months. But at the beginning of Jamary, ingo, he was, apparently, inspired to think that if Ladysmith were made to capitulate. lee could divide his large besieging lorce and despatch one portion to assist in combating General Buller's augnented forces on the line of the Tugela, and the other to the strengthening of his western army, while a large portion of his heavy cannon coulu the apportiones] to Kimberley and Malcking, and with the surrender of these three important strategic towns, would not the Cape Dutch rise in rebellion, and then would not the I'crklew Hoat from the Zambesi to Cape Agullas? Hence the sound of the Dutchmen's hymns at miehight on the $5^{\text {th }}$ : hence the false answer to our sentry's challenge at two the following morning, and the enemy in possession of halt the ridge at dawn of that day; hence the loss and recapture of our very gun-pits time after time; hence the equal sangumary struggle, hand to hand, hour alter hour. trom end to end of the ridge throughout the burning day ; hence, we might ahmost say, the awtul thashing cannonade of the hearens, and the lashing hailstorm in the atteroosn at four, and atter that, the scattering of the ememy from Caesar's Camp: and then at six, the magnificent charge of the Derons to the southern edge of Wagon Hill (upon which. as it has been truly said, the fate of the garrison, perhats of the Empire. swang for the moment in the balances sweeping the Boers like chaff before the winl in unuterable confusion; and at last, after fifteen hours continuous fighting through mist and darkness. scorching heat and blinding lual ant rain. foodless. parched, exhausted-Victory !

The losses were considerable on our side, numbering If ofteers and Isig men killed or mortally wounded, 29)offeers and 262 men more or less severely wounded, and 2 missing, a total of 500 : and the enemy are said to have suffered to the extent of twice this number. Every foot of the ridge trom east to west is historic, while there are sereral ohelisks. caims, and graves to remind us of the lierce, Titanic strugele. The tortifications and breastworks are also still mdisturbed.

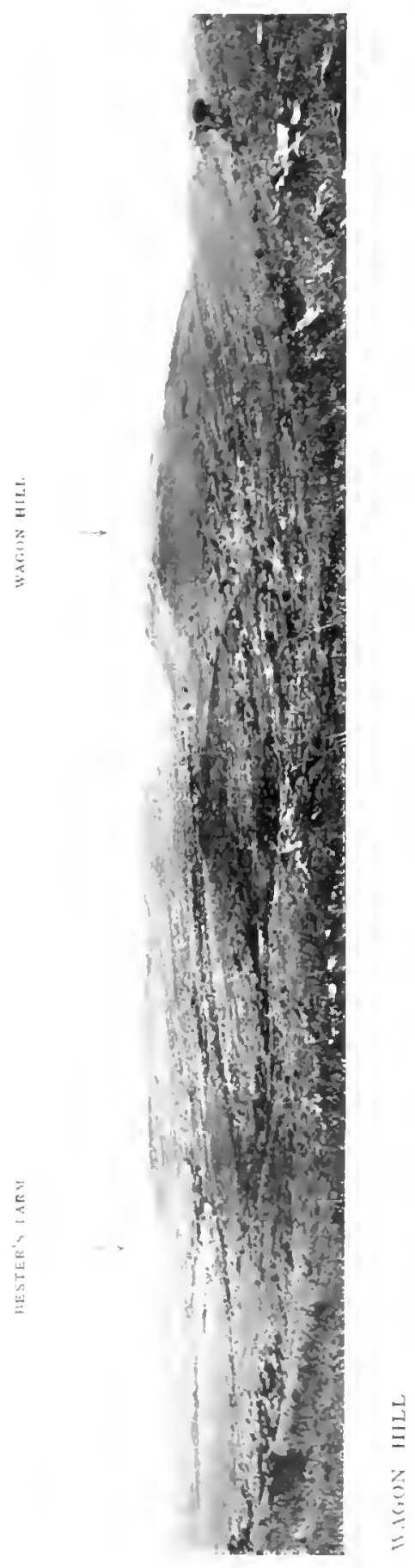



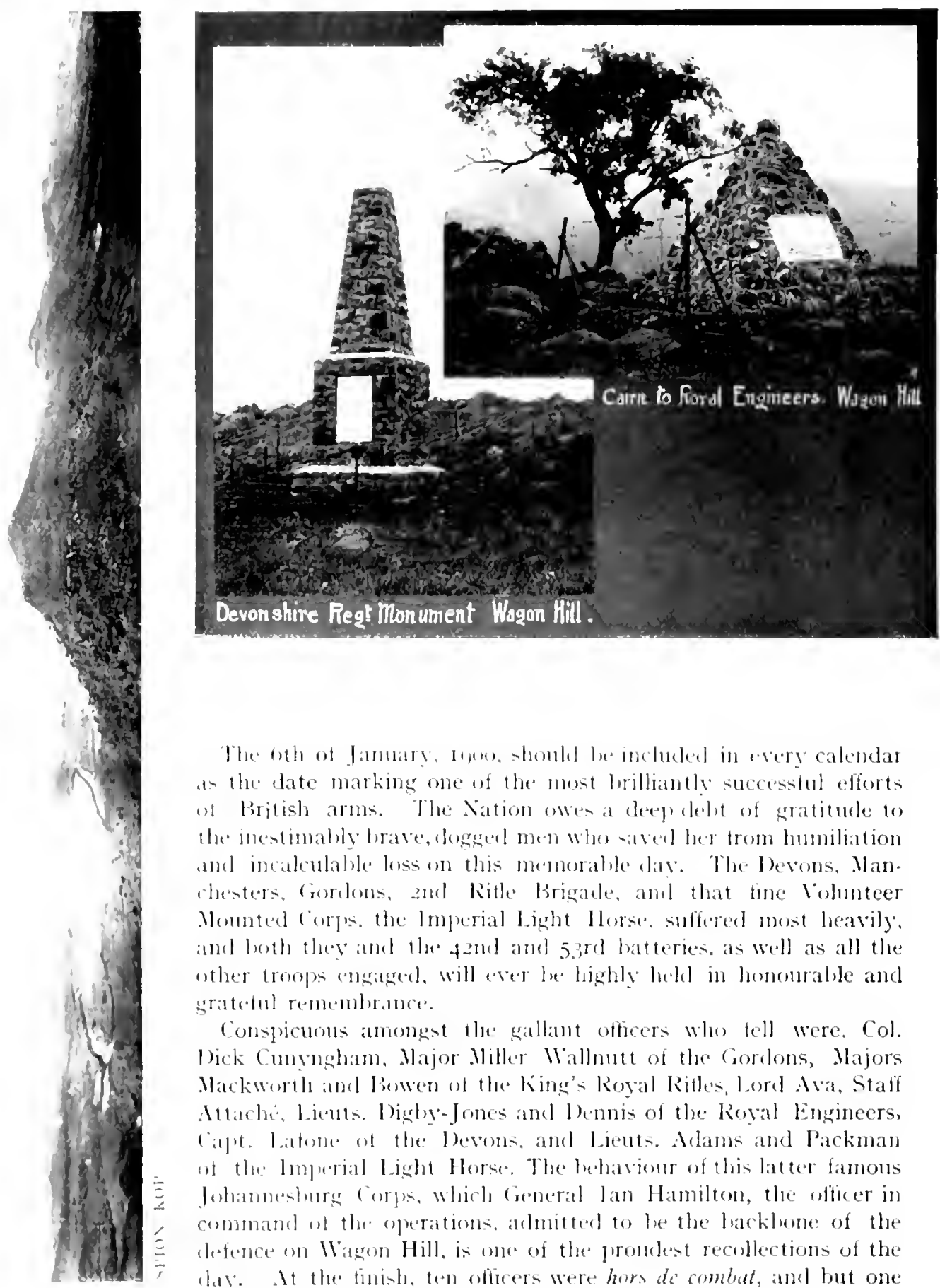

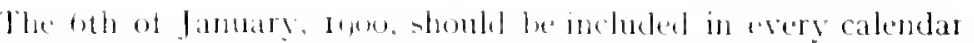
at the date marking one of the most brilliantly successtul efforts ot british arms. The Nation owe a deep dele of eratitude to the inestimably brave, dogered men whe -aved hes trom humiliation anel incaleulable loss on this momorable das. The Devons, Manchesters, fordems, and lithe brigate, and that finc Volunteer Homted forpe the Imperial Light Ilorse, suffered most heavily. and hoth they and the fond and 5,30 hateries as well as all the

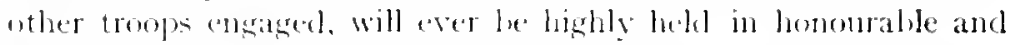
erratedul remembrance.

Conspicuons amonget the gallant officers who bell were, Col. bick Cunvngham, Major Miller Wallnutt of the Gordons, Majors Mackworth and Buwen of the King's Royal Ritles. lord Ava. Staff Atache Lients. Digry-Jones and thennis of the Royal Engineers, capt. Iatome of the Derons, and lients. Arams and Packman of the lmperial light Horse. The behavenr of this latter famous Johlanneshure Corps. Which coneral lan Hamilton, the officer in command of the operations, aldmitted to be the hackbone of the defence on Wagen Hill, is anc of the prometest recollections of the dal. It the finish, ten oficers were hors di combat, and but one hinclieel men combl be mustered out of 500 . 
SPION KOP. In the year I 837 trom the hills of Intabamnyma, a large company of "trekking" Boers gazed longingly upon the fair lace of Natal, for their desire was Peace. From these same heirlits sixty-three vears later, several thousands of the same brave but misguided race, crouched behind big boulders, and concealed themselves in long narrow burrows, and their accomplished wish was War.

Spion Kop, or Intabamnyama, is about is miles from Ladysmith on the Acton Homes and Upper Tugela Roads. The journey can be performed by conveyance in three hours, and affords an enjoyable and interesting drise. Wagon Hill, Ciesar's Camp, Bulwand. and other notable eminences are retained in view for several miles. while the Drakensberg and its famous passes keep always in sight. With the exception of a few insignificant drifts, the route lies across the Great Plain-a huge ant-heap-sprinkled table-land, incised by spruits, and here and there relieved by mealie plots and their duskr proprietors.

Spion Kop proper (whose summit is nearly 5,000 feet above the sea and about I,500 feet from the plain below), is composer] of two peaks which predominate and rise from the ridge Intabamnyama-a long lofty platean whose projecting spurs (two of which were the noted Bastion Hill and Three-Tree Hill), exposed our men to a terribly searching fire from several different directions. From the top of the ridge the whole historic country can be scanned. Looking towards the tortuous Tugela, the three alritts orer which our troops were crossed-Potgieter's, Trichardt's and Munger's: Mount. lice and Zwaartkop where the naval and other guns were placerl; Sjearman's Farm where our forces were encamped before and after Spion Kop and Vaal krantz: and the routes of advance. the direction of the various attacks (trom the I6th to the 25 th January, Igous, and the gigantir retirement across the river again (by the $27^{\text {th }}$ ) of over 20,000 men, horses, guns, and stores without the loss of a man, can all be pointed out.

The second assanlt upon the boer stronghold, and the second reverse, is a matter of sorrowful history. The black, (trizzling night of the 23 rd of January, rgoo, saw I, 800 men under General Woolgate scrambling stealthily, silently, up the precipitous sides of Intabamnyama. The early hours of the afth saw them reach the misty top, heard the challenge of the Boers, and the wild cheer which told that the summit was won. Then the waiting for the dawn and its heartbreaking revelations-our coverless position and but half the ridge in our possession. After that, the gallant rushes to secure the northern end; the splendid capture of the eastern spur; the withering. true. incessant hail of

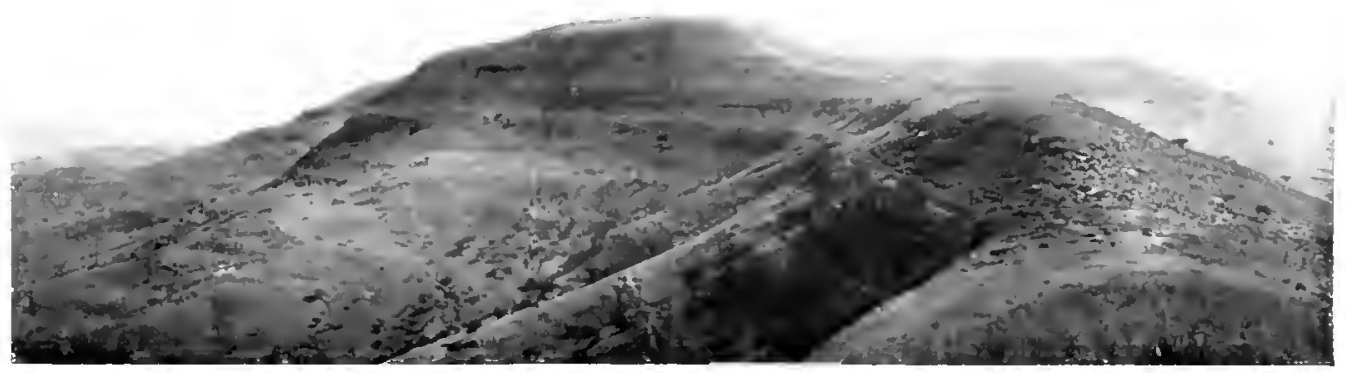

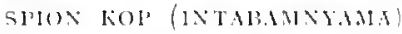




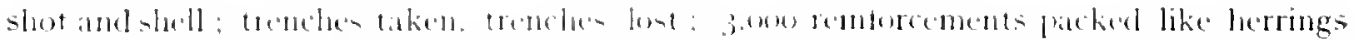

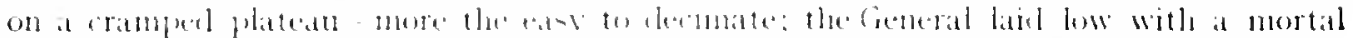

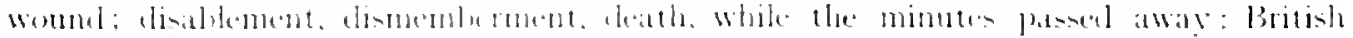

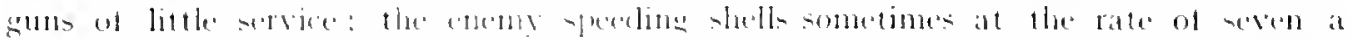

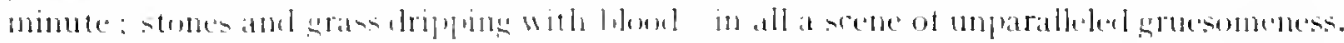

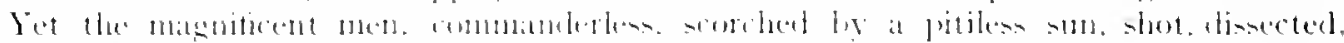

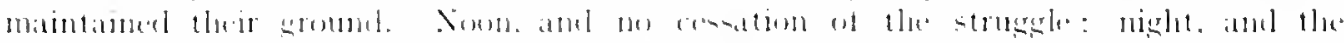

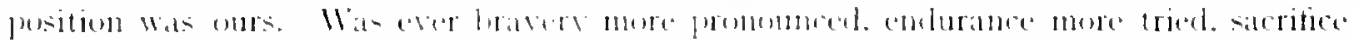

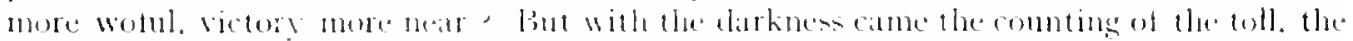

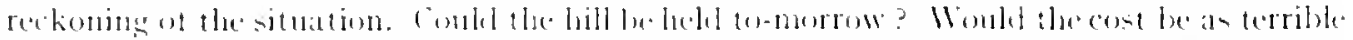

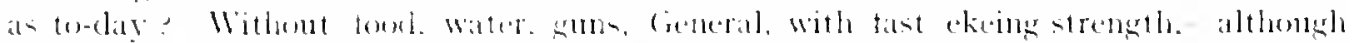

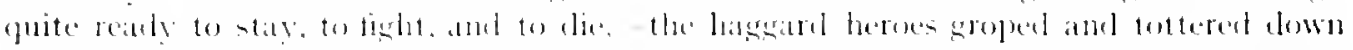

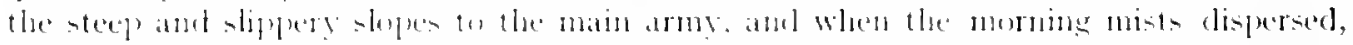

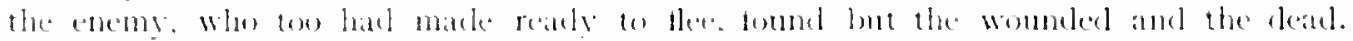
The stalwarts were gone. The lanlyomith key lat leen turned in the lock, lut the gate

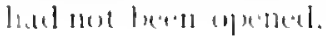

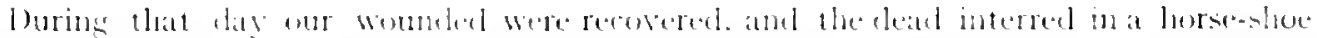

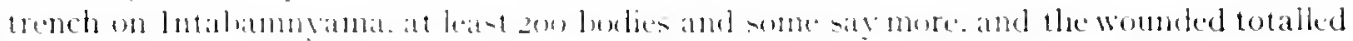

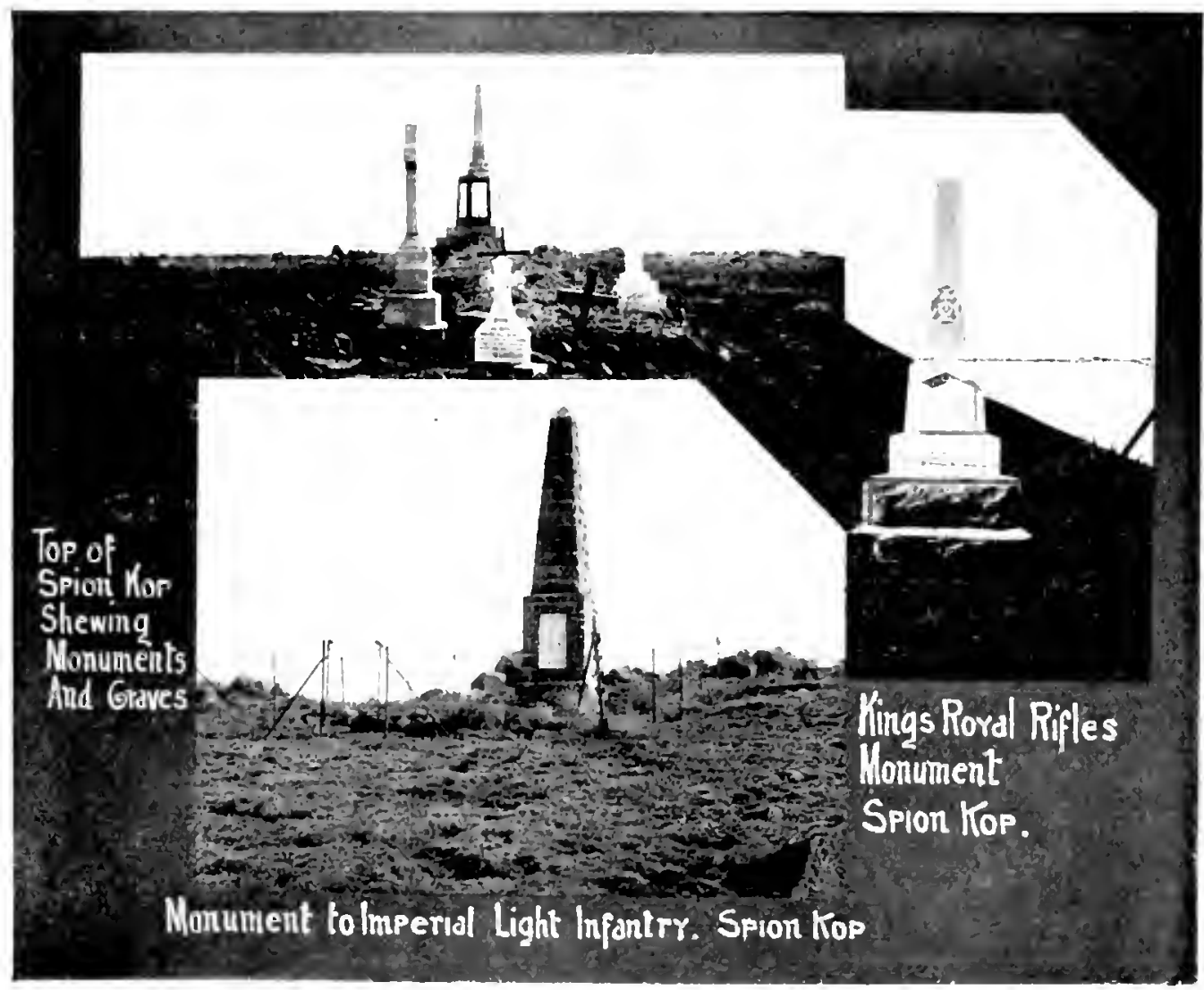




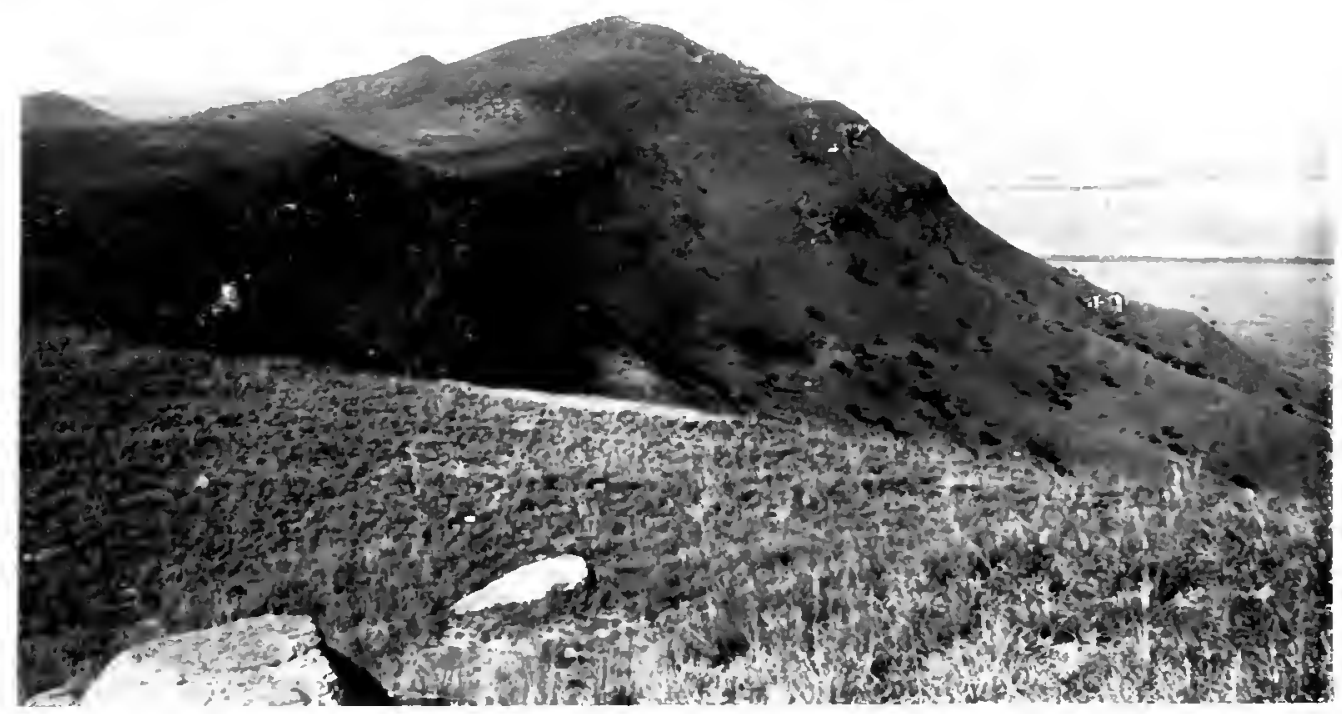

IHE PLIKS, SPIUN lio)

lully another 5oo. The boers contessed to luving their ranks depleterl of 50 killed and 550 wounded.

Of the troops engaged. those who suffered most heavily were the Lancashire Fusiliers, Royal Lancasters. Thomererott's Iounted Intantry. Imperial Light Infantry, Scottish Rifles, King's Royal Rifles, the Middlesex. and the Iorsets.

The total Britich casualties during the week from the $\mathrm{y}$ th to the 2 th (including Spion Kop) numbered 3 officers and 325 men killed or died of wounds. 4 officeis and 1,000 men wounded. + officers and 3 it men mising and prisoners. a total of 1.738.

There are three monuments on Shon kop erected in homur of the deal. A twi-terl iron cross shews the sput where the couragenus llajor-Creneral Woodgate tell mortally wounded.

VAAL KRANTZ. the scene of the third valiant. but unsuccesnul attempt to secure an entrance to Ladysuth. in a rocky rikge standing between the Inorn kiloof and Spion Kop Ranges, to the southeast of the latter. It is passed in the distance on lhe way. to Spion Kop.

With the accession of artillery. suns of areater calthre. and an aduliona 3.0 m men General Buller, whth the heary ling-range cannon still upon Hount Alice and other naval and mountain guns upon Zwarthop -a commanding rminence in aclvance and to the right of Jlount Alice-male a brilliant teint against BRAKFoxtens. situate hutween spion Kopand Vaal Kantz, with the intention of putting the enemy ofi his guard upon the latter. and then he throwing the tull british strength agahot the ridere win a way hetween the two greater ranges named. Vail Krantz was equined, hut unfortunatuly it was discovered to be valueles whthout the possesion of Domn Kloot, the lottiest range along the Tugela line. to stom whith wuld have entangered the lite and limb of thounds of 


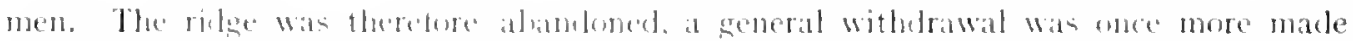

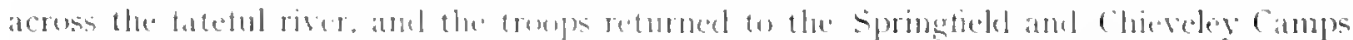

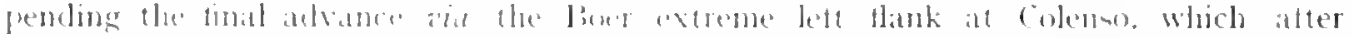

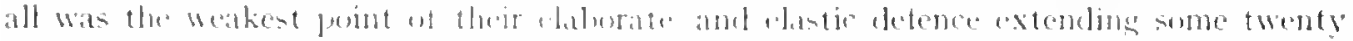

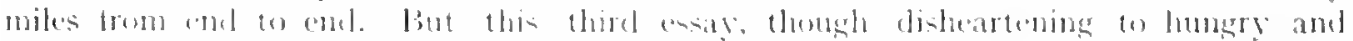

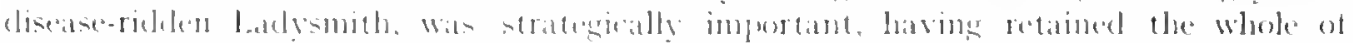

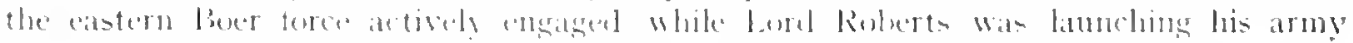
arainst the wextern tox.

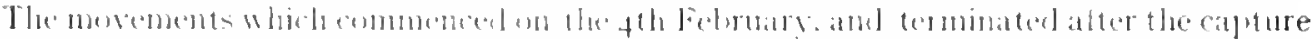

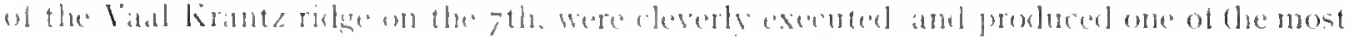

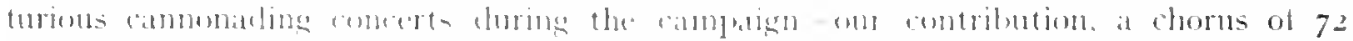

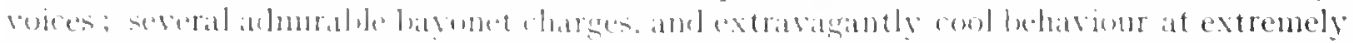

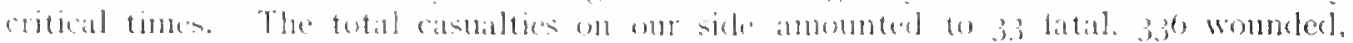

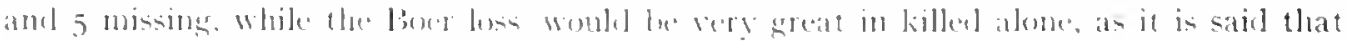

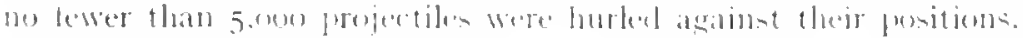

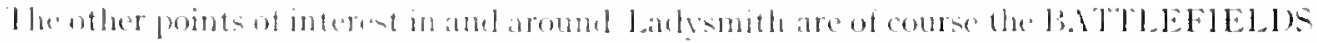

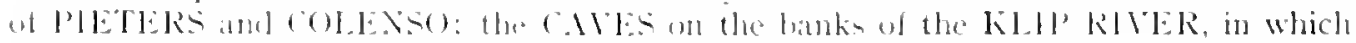

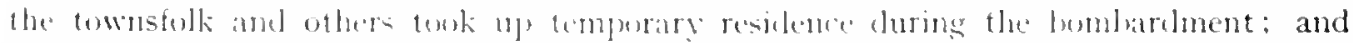

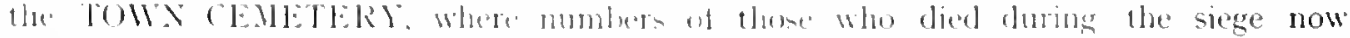

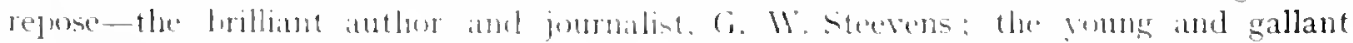

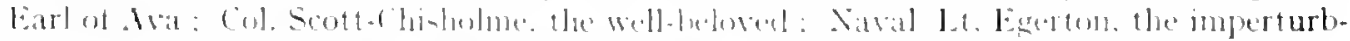

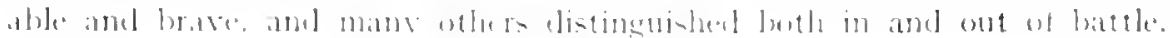

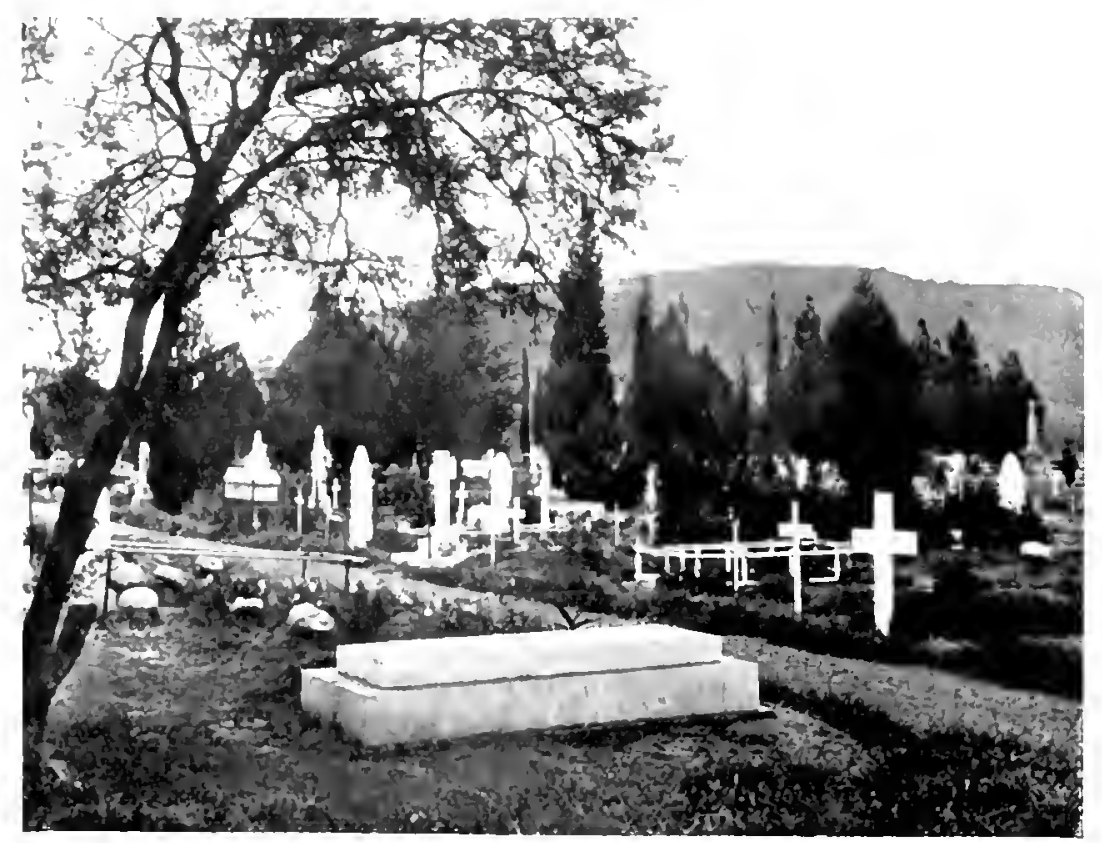

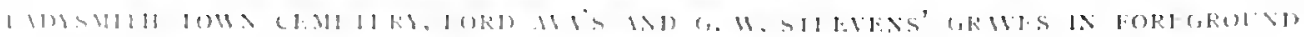




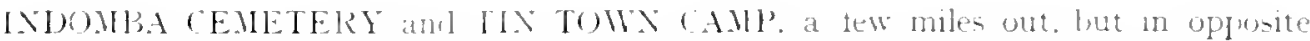
directions. have man vistors, whilt: the hills not apecially described which formed our perimeter of lefence, and thris orcupied ly the enemy and their bis guns, as well as SIR GEORGE WHITES HLAIOLARTERS, the ASGLICAN CHLRCH, TOWX HAl.L. ROY.11. HoTEL. ind ither -tructuren which suffered idamage to a lesser or greater extent during the fumlariment. all share the touri=t" = attontom.

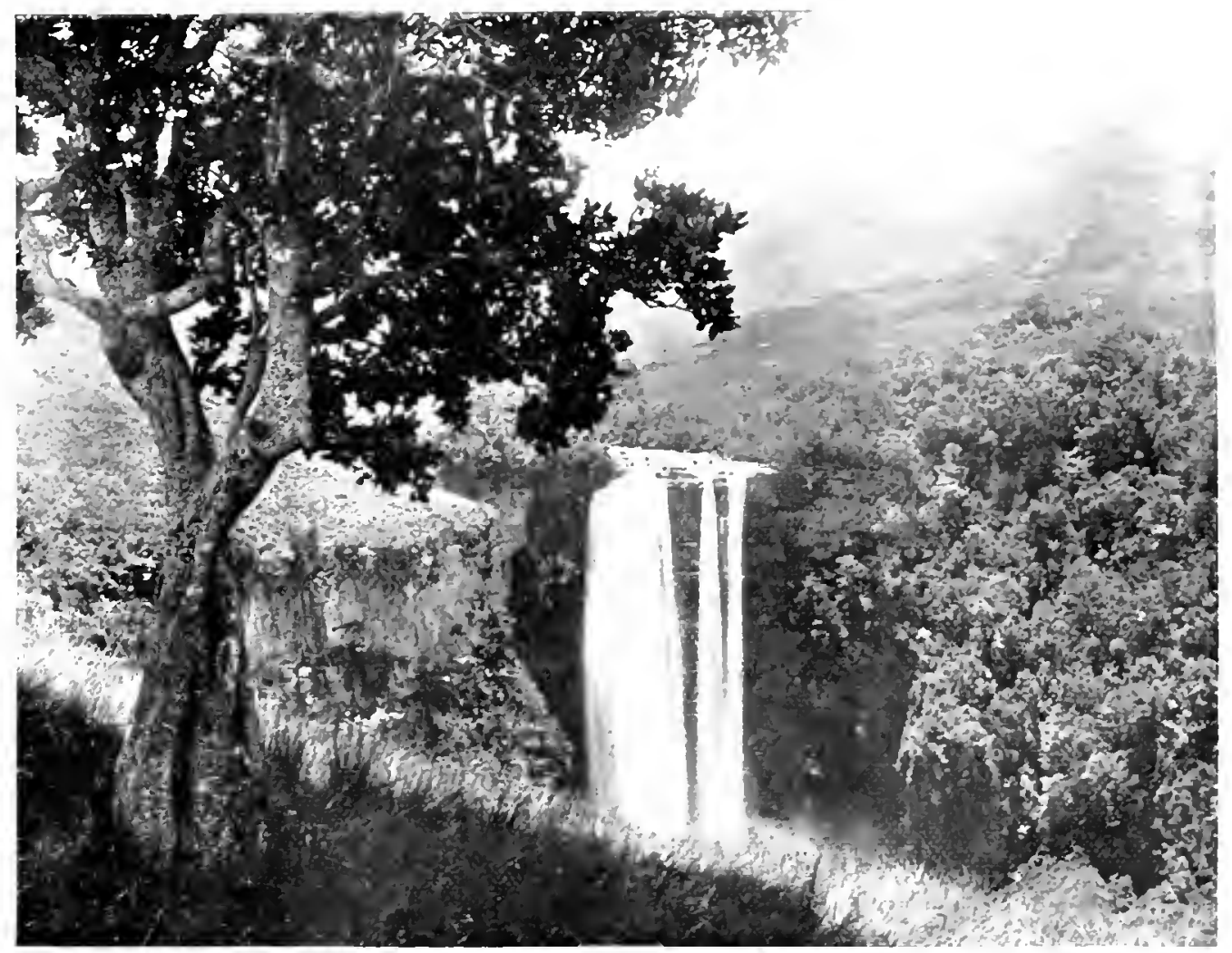

CH.APTER VH.

FROM LADYSATH TO GLENCOE JLXCTOS

AND

THE DUNDEL DISTRICT.

THROUGH THE SCENES OF THE FIRST BATTLES.

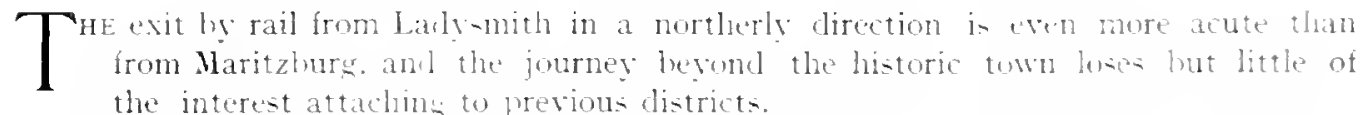

Almost every knoll and hill and mountain has a hintory almost werv arse has received the pressure of besteger and lesieged, pursuer and pursued. 


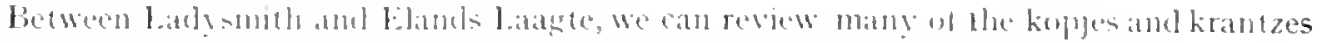
helel lo Briton and buer during the inseatment.

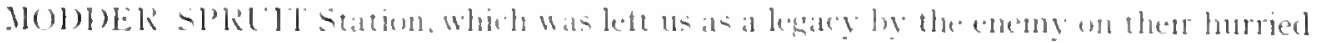

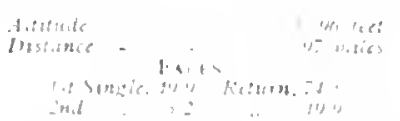

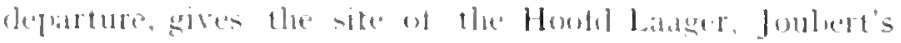
main encampment thring the sienge. Kiethomeon and

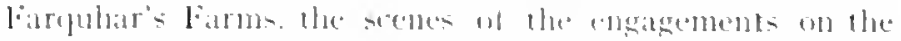

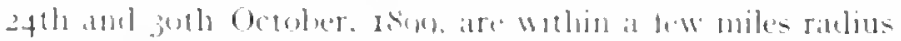

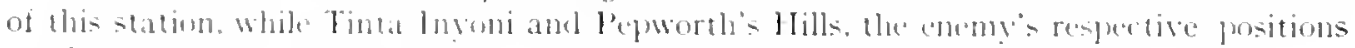

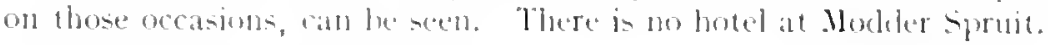

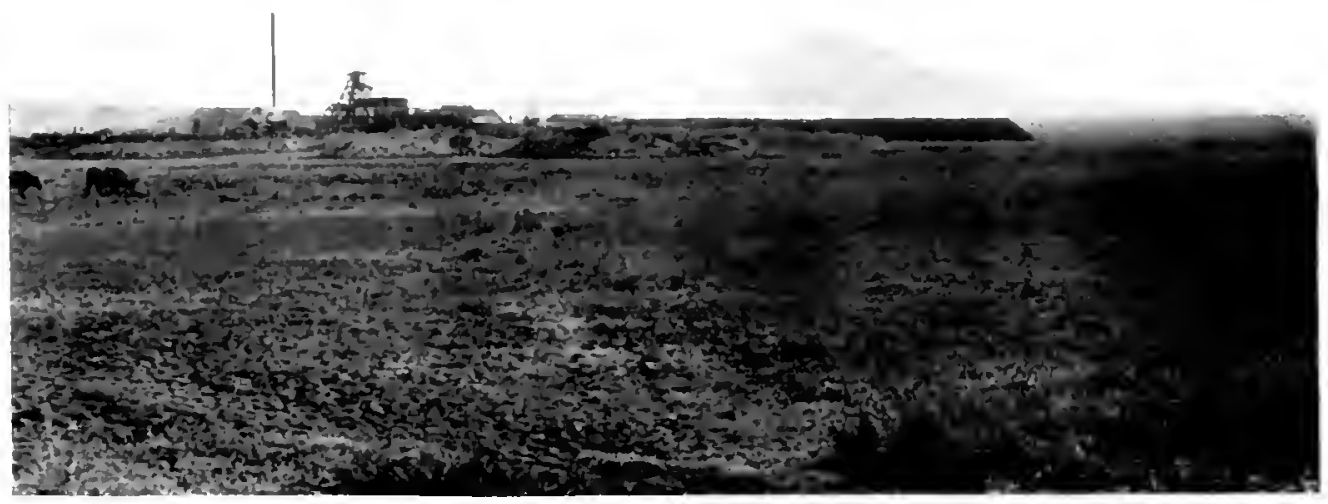

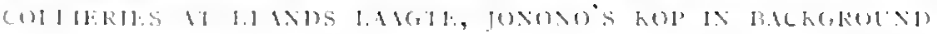

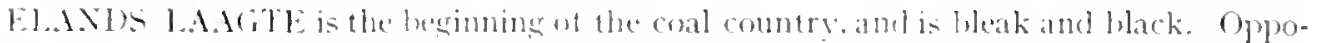

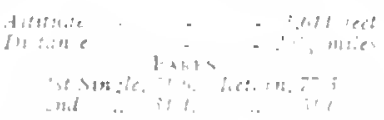
site is at well-lublt hoted: to the ledt of the station will

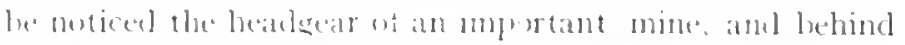

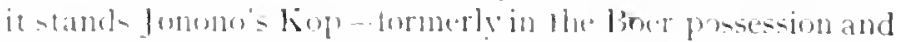
altematrdi in ours. mainly on signalling purposes About

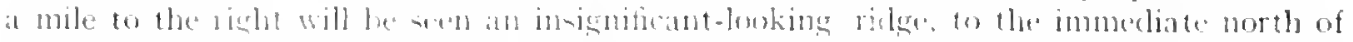

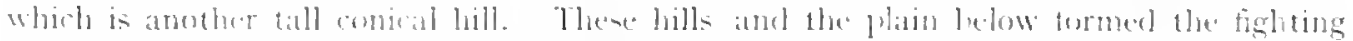

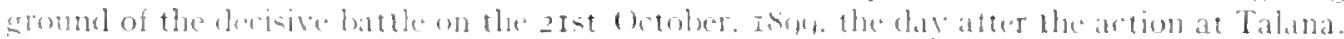

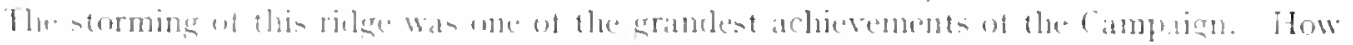

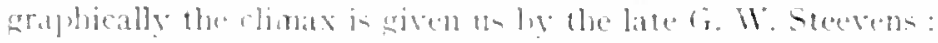

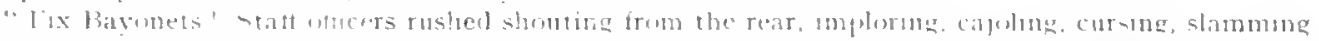

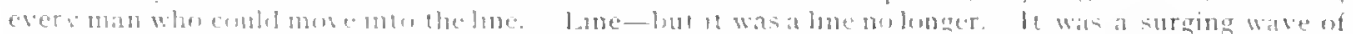

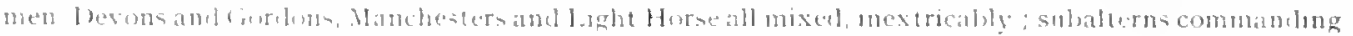

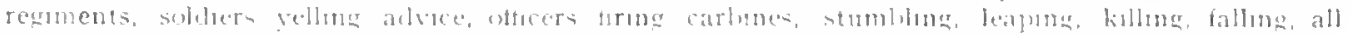

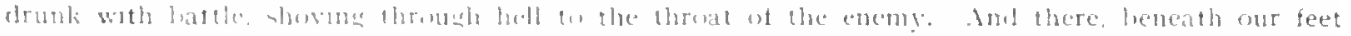

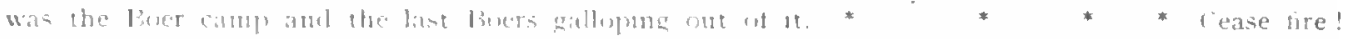

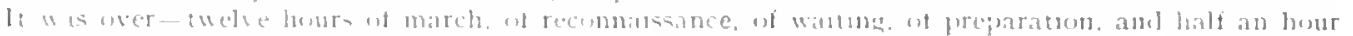

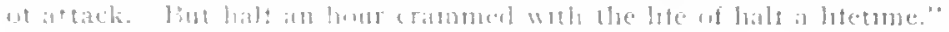

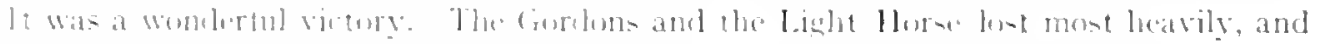

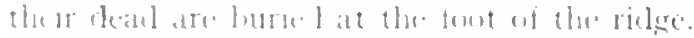

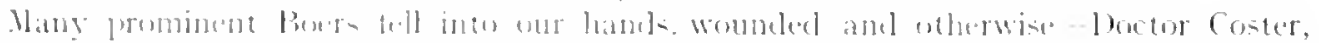

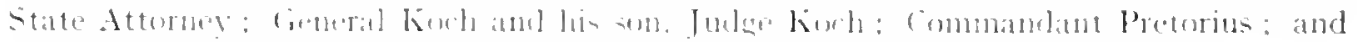

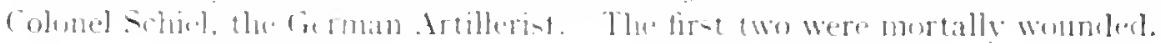


The operations were commanded hy General French. and the Britisl force compriserl some 3,000 men. The enemy"s strength was about the same as our own. Our losses were $6 \mathrm{I}$ killed or died of wounds. Io3 wounded. and 4 missing. The $5^{\text {th }}$ Lancers did remarkable execution, this being the only accasion on which the lance was used throughout the war proper.

The hills must be visited to conceive the unique strength of the boer position. It is one of the finest natural battle grounds imaginable. The ridge recedes in slopes and broad plateaux, and as a last resource there is a nek communicating with the dominating kop.

The district of Elands Laligte will afford great interest to the tourist, and the altitude is a guarantee of healthiness.

Every facility for visiting the battlefields and other attractions in the vicinity can be obtained at the hotel.

Before leaving Elands Laagte, a note should be made of the fact that the original station buildings were burned to the ground hy the Boers on their evacuation. Fortunately. owing to the rapidity of General Buller"s "clearing" movements. the station premists farther north could not be similarly treated.

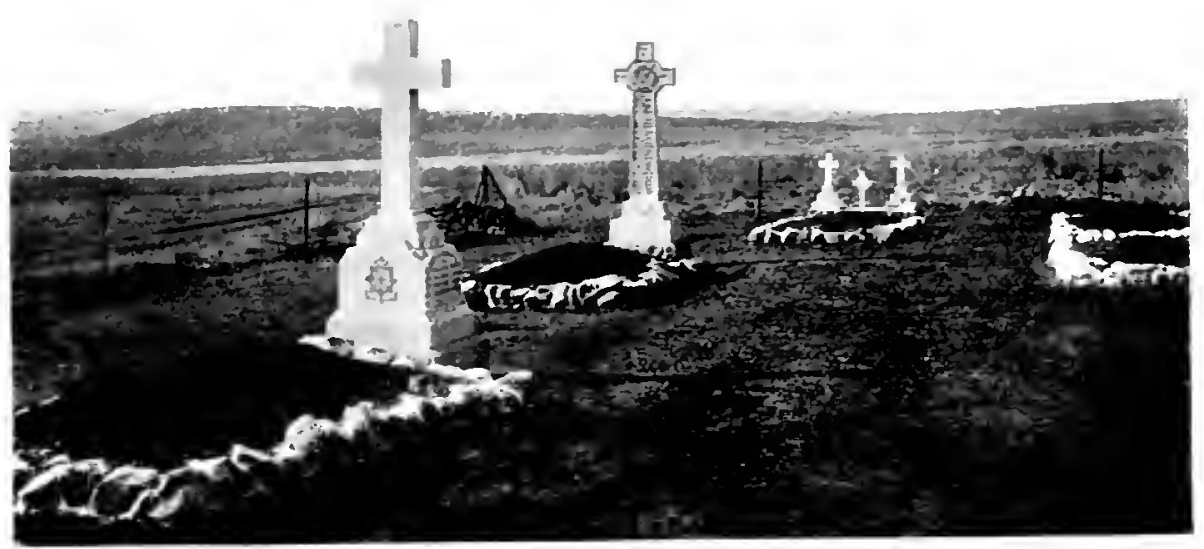

(BRIVES, FIANDS LAIGTE BATTLETELD

WESSEL'S NEK is about four miles on the north side of the Sunday's River-a loco-

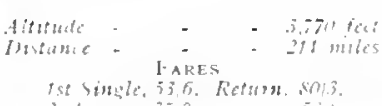

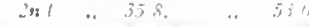
motive water-taking point-to the left of which llatawana. already mentioned. will be perceived.

There are several coal mines in the ricinity of Wessel's Sek. hut otherwise the place is not remarkahle.

WASCHBAXK, the next station, is of a little greater distinction. The Biggarsberg

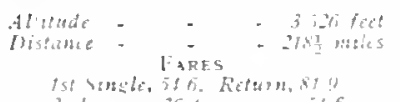
range of mountains crosses the railway line at right angles some distance ahead. Indumeni. the chief peak. 7.200 teet Inigh. is detected on the right. and Hlatikulu, another noted eminence. can also be descried lifting its hearl aloves the rest. Coal mining and farming are in operation. An hotel will be found close to the station. 


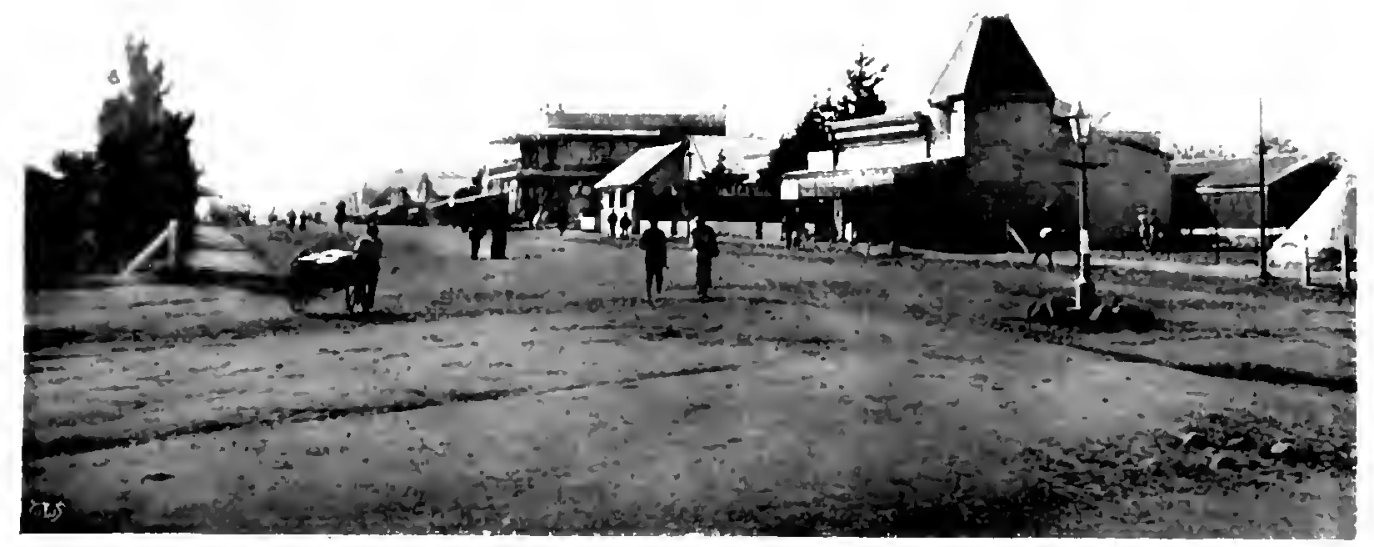

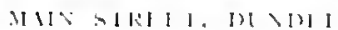

The country between Washbank and citence Jumeton is pretlere and in summer

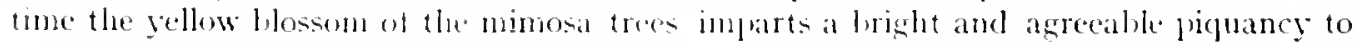
the severe mululations of the lamborate.

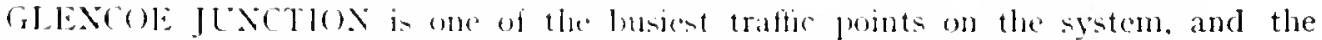

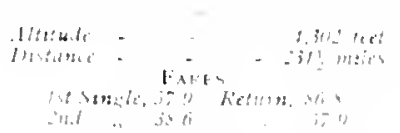
lulk of the colony's cxport and private consumption coalsome $3(x),(x)$ tons. ancl 240.000 tons respectively-passes through this station. It is also important as the con-

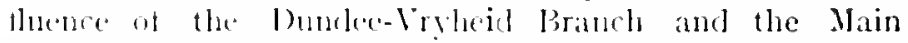
l.ine, connecting trams being run 10 suit all the primejpal passenger trains. Refreshments and meals are oldainalele at all hours at the well-apjointerl rooms on the station, and several hedroms are also availathe it requireel.

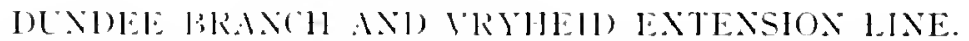

Formerly this branch terminated at the Co.nfletis, seren and a half miles from the junction. It las now been extended to the Buffalo River (2I miles) and is being carried through to Pryleid (59) miles from Glencoe). Vrylued is the most important township in the territory reeently annexed to Natal.

The line as tar as bumlen (lex not boast of any scenic beanty. and is fairly level.

bexDEl has a twofold attration-its lare coal mining operations and war con-

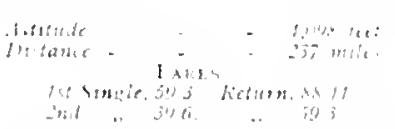
nectomis. It is surroumbed ly hills and, for a colliery centre is floasant in appearance.

"lice European pophlation is roughly 1,500 souls, and in arlibtion there are about 5.200 natives and lndians. In the

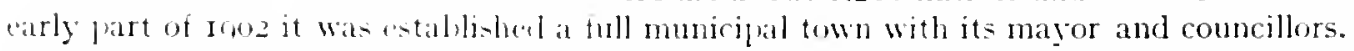
There are a number of goot huldings in the town, public and otherwise-four churches (Clurch of England. Preslyterian. Weslegan. and Swedish); Government School; Court Honse; Postal and Telegraph (offees: Cencral and Nasonic Halls; branches of two 
Banks; and of course several hotels-the "Royal," "Nasonic," and " Victoria." All three, in the same way as other hotels in the battletield districts of the Colony, have increased their accommodation to meet the requirements of an anticipated large tourist business. There are the usual Sporting, Literary, Social, and Industrial Clubs, and a large Public Recreation Ground.

Dundee is the headquarters of the Natal Police for the Umsinga and Dundee districts. and it also possesses a troop of mounted volunteers, a Rifle Association, and Cadet Corps.

A weekly newspaper called the Inudee and District Adrevtiser has just recently been established.

The town is rery healthy, and has a lavish water suply. I luring the last six years. marred somewlat by the war, it has adranced by leaps and bounds, and is still pro. gressing. Dundee has an assured tuture. The battlefields. separately described hereafter, prove a huge attraction of the place.

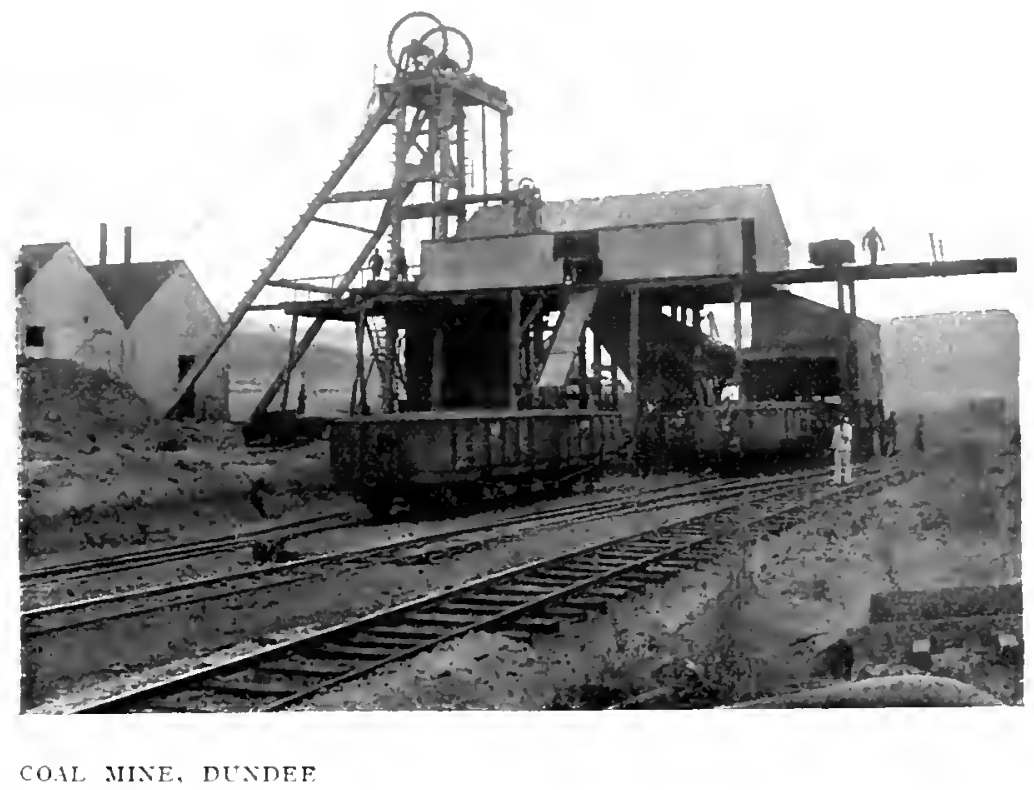

TALANA (COALFIELDS) is contiguous to. and lies a little below, Dundee. Here

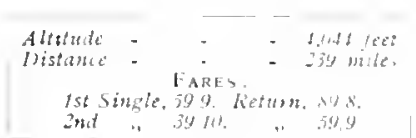
the various mines are situated, and the dibris, piled hillhigh, testifies to the activity of the workings. The yearly. output from the whole of the Dundee mines is about 200,000 tons.

The Dundee district is perhaps the finest coal-producing area in South . Africa, both in extent and quality. An enomous tract of coal country is still untouched, indeed the deposits seem to be amost inexhaustille. Good ironstone is also known to exist in the neighbourhood.

The railway line after leaving Talana station passes over Smith's Yek towards the Buffalo River and Vryheid, and the traveller is horne between the two fanous hilis. Big Talana, and Little Talana. 


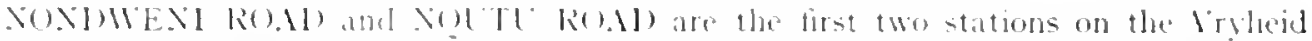

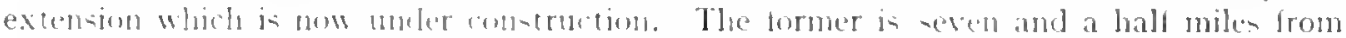

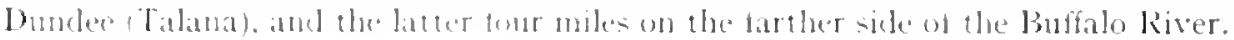

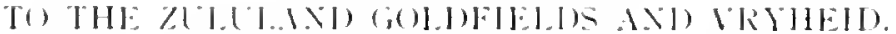

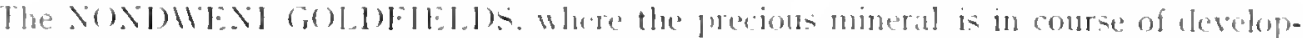

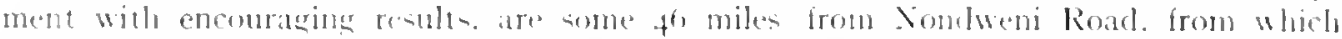
station the pustecart service will froblathy run on resumption of ordinary conditions.

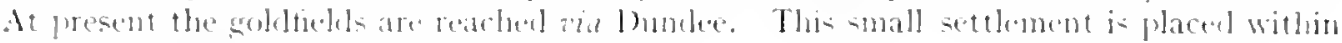
post and tolegraplic communication.

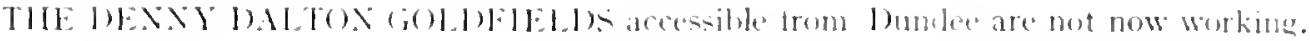

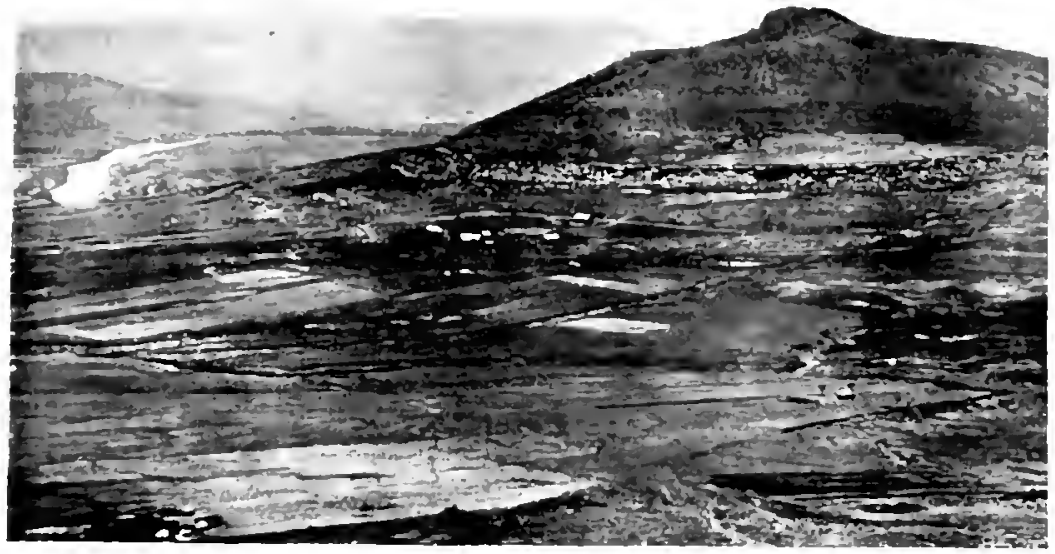

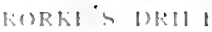

$1 / 11,1:$

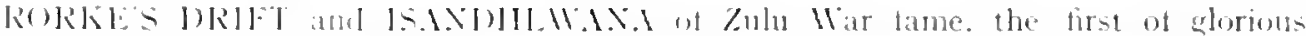

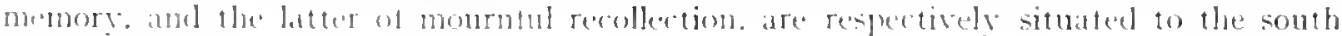
and soltthorats of Xiputu station.

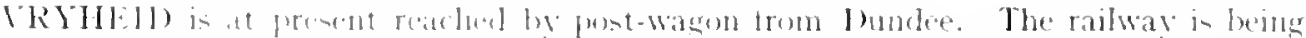

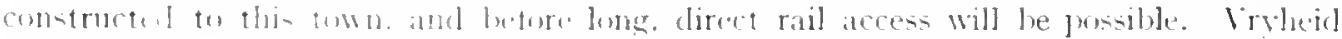

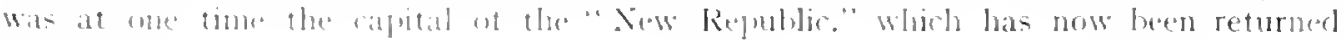
to Nital.

Before the Wia the white mbabituts numbered 2.4m. The town is prettily situated.

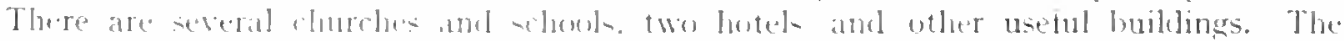

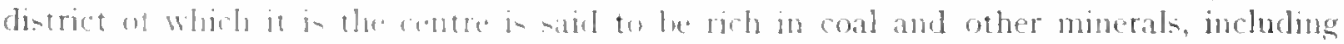

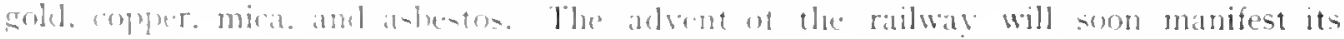
reanters. 
DUNDEE was the scene of the first act in the historic drama, the GREAT BOER WAR, in the theatre of Xiatal. The prologue may be recited :

The plotting of the Dutch since I 836 . for supremacy in South Africa.

Britain's humiliation on Majuba, and concession of selt-government to the Boers-ISSI.

Secretion by the Iutch of tremendous quantities of munitions of war.

Intolerable treatment of the Litlanders on the Rand.

Endurance raised to breaking point.

Petition addressed to the late Queen praying for redress. Nay 24 th, I 890 .

Conference between Sir Altred Nihner (now Baron Nilner) and President Iiruger at

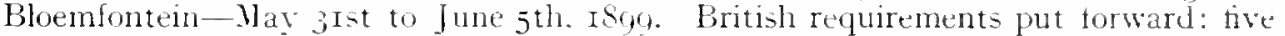
years' ranchise for [itlanders; their larger representation in the "Volksatel"; and the non-exclusion of the English tongue in that House.

Result unsatisfactory.

Diplomatic negotiations prolonged in to september.

British note despatched to Mr. liruger on the Sth of that month demanding the above relorms.

Reply of the Government of the Suth African Republic received on the Ioth, giving an unqualified refusal.

British subjects leave Johannesburg.

Natal Volunteers mobilised september 2uth, Is89. Troops ordered from India.

Boer Ultimatum October oth, demanding withdrawal of British troops within fortyeight hours.

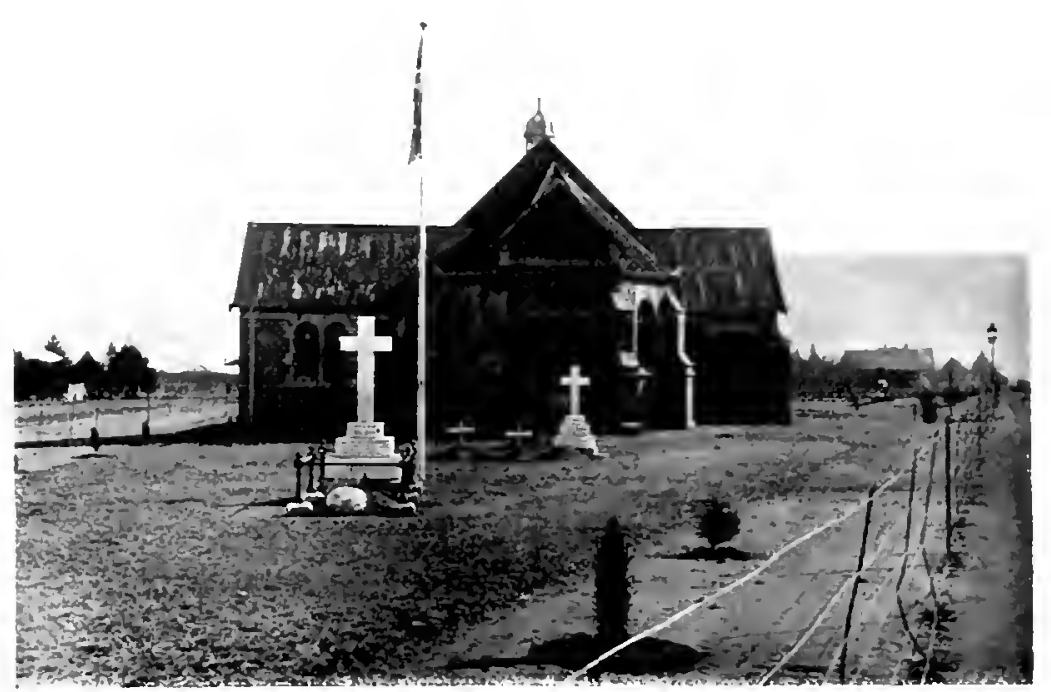

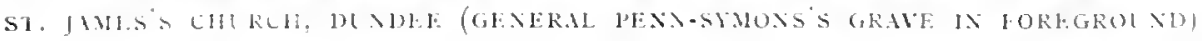




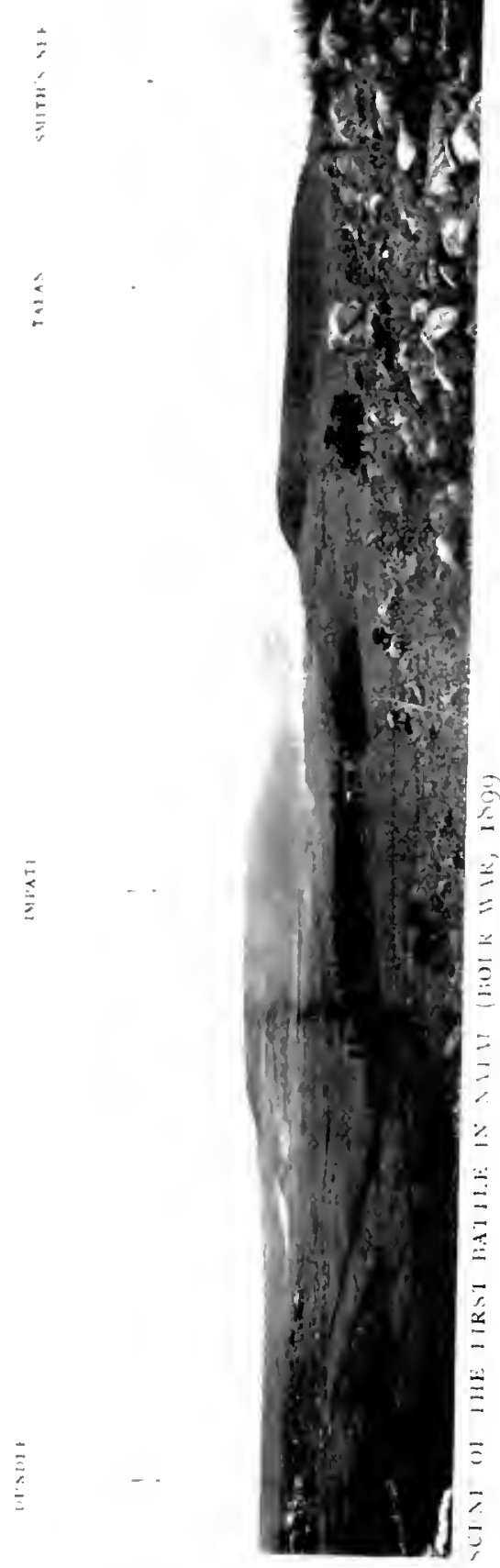

Bratsh Gorenment reply conditions impossible ot itcreptithe

liritisl Agent recolled from l'retoria.

Milr ineritalle.

Grange line State combine Wutlu South African Jáegul lir.

Biners invate britiol territory Octoler 12 th, part througl latng's Ẍck from Transvaal,

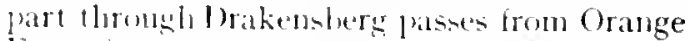
fore state. part across the Buttalo River from Virledel diection.

Evacuation of northernpertion of Natal. Boers

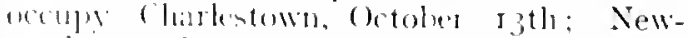

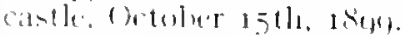

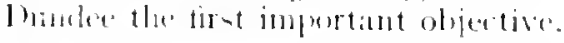

\section{TI11: 1:.1'T1.1: Of" '1:11 IN:1}

letere the retent acpulsition of the "new territury" the Nortuern portion of Natal formed it triangle. the hitio of whicl was the ligrarsberg range of mountaim, and the apex. Charlestown. 1) the loft or western sille the I rakenslerg range thviles Natal from the ()range kiver Colony, and wh the rastem sele the buffalo River separateel it trom the Transvial.

At the time the mltimatum was despatched,

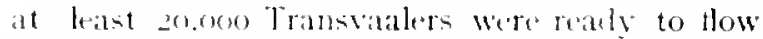
into Xital, one purtion ata Lans's Xek in the moth. aml the sther acrose the linfalo on the east, Whike a further 10.000 liree staters pusessed the potseses of the Drakensterg on the west. This triomste late necensibrily to le abandoned, and British encampments were establisteel at Dundee .mel latlsmitl.

At the commerecment of operations in Natal, sir George Ithite, then Commander-in-Chief, had dhout 1.000 mens and 24 sums at ladysmith, and the late General Sir William Penn Symons, t,600 men and Is gums at Dunklee.

The latter town was entirely dependent on the former for ammunition and supplies. In situaton it was simblar, lostlow set, and dominated lig. ligh hills.

It sumfown on the ath October. Iseg, we Were still wating for the battle-storm to burst.

The emeny had infesteel the northern territory, there had heen a skimish or two, aml a train nt supplies hatel been intercepred at Elands lategte, but that wats all. 
During the darkness of that night, however, the Boers under Lucus Mever converged in large numbers, seized Talana which commands the town, placed their big guns in position, and with the break of day announced their presence by dropping a shell into our camp. The first ominous battle-note lad sounded-the trasic and historic IVar had commenced.

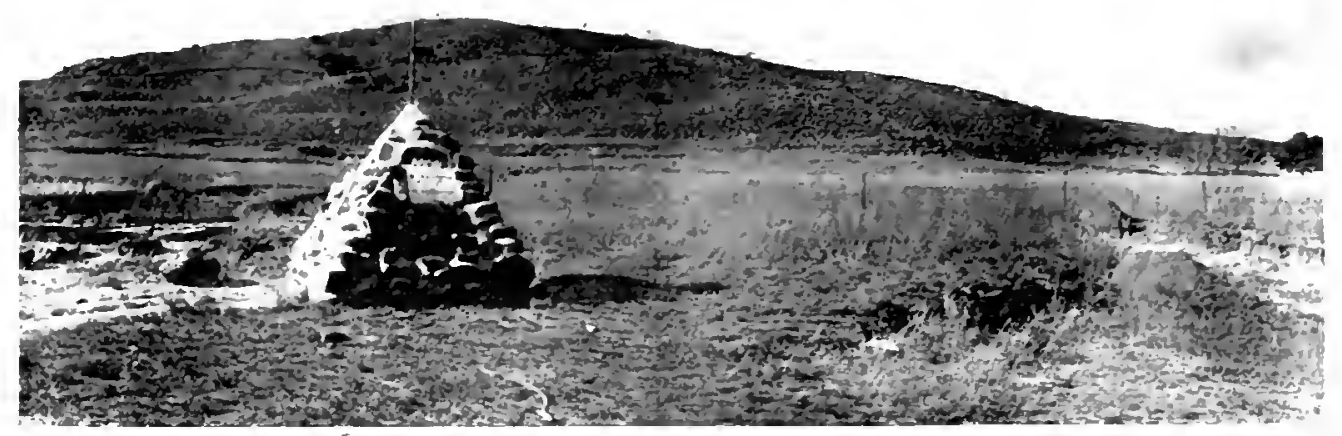

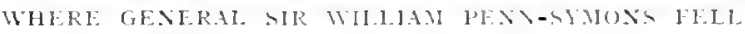

The issue of the day is mere repetition of a hundred-times-toll tale: how the gallant Penn-Symons marshalled his infantry at once for assault. despatched his artillery to reply to the enemy's guns, and his catralry to work round their right flank fand how the I 8 th Hussars and some mounted infantry were captured). How 2.000 infantrmenthe Dublins, King's Royal Rifles. and lrish Fusiliers-stormed this difficult hill in the face of a fire from 5.000 barrels, sure and merciless: and how, after a magnificent rush, the summit was won, and the enemy put to flight: and how, lastly, the brave reneral received a mortal wound while directing the attack and emboldening his men by the example of his utter fearlessness and his encouraging words.

Victory was decidedly ours, hut profitless-our position was untenable. Ammunition low, the momentary possioility of Ladysmith being cut off, the Boers reorganising in more powerful array with heavier guns. Ceneral Yule. who had succeeded Sir IV. PennSymons, wisely ordered the withdrawal of the inhabitants, and fell back with his force upon the main army at Ladysmith.

The retreating movement was commenced at a p.m. on the z2nd wia the Biggarsberg, Beith, Waschbank Spruit, and Sunday's River, in all a distance of some to miles, and, owing to the skilful direction of Colonel, now General Sir J. G. Dartnell, was successfully accomplished on the 26 th October, Ison.

The battle of Talana cost 11 soughly, 50 killed and 200 wounded, and an additional 200 (Cavalry) surrendered. The Boer loss amounted to about 300. Our wounded, including General Penn-Symons, had to he left in the hands of the enemy, who it is only right to state, treated them with erery hindness, and rendered all possible medical aid. The General, sad to relate, passed away on the $25^{\text {th }}$ October, and is buried in St. James's Churchyard.

Dundee was re-occupied by the British on May I5th, Igoo.

Talana Hills, Impati, Smith's Nek and plantation. are full of interest to the tonrist. Graves and cairns mark the historic spots, and from the crests of either of the big hills, 


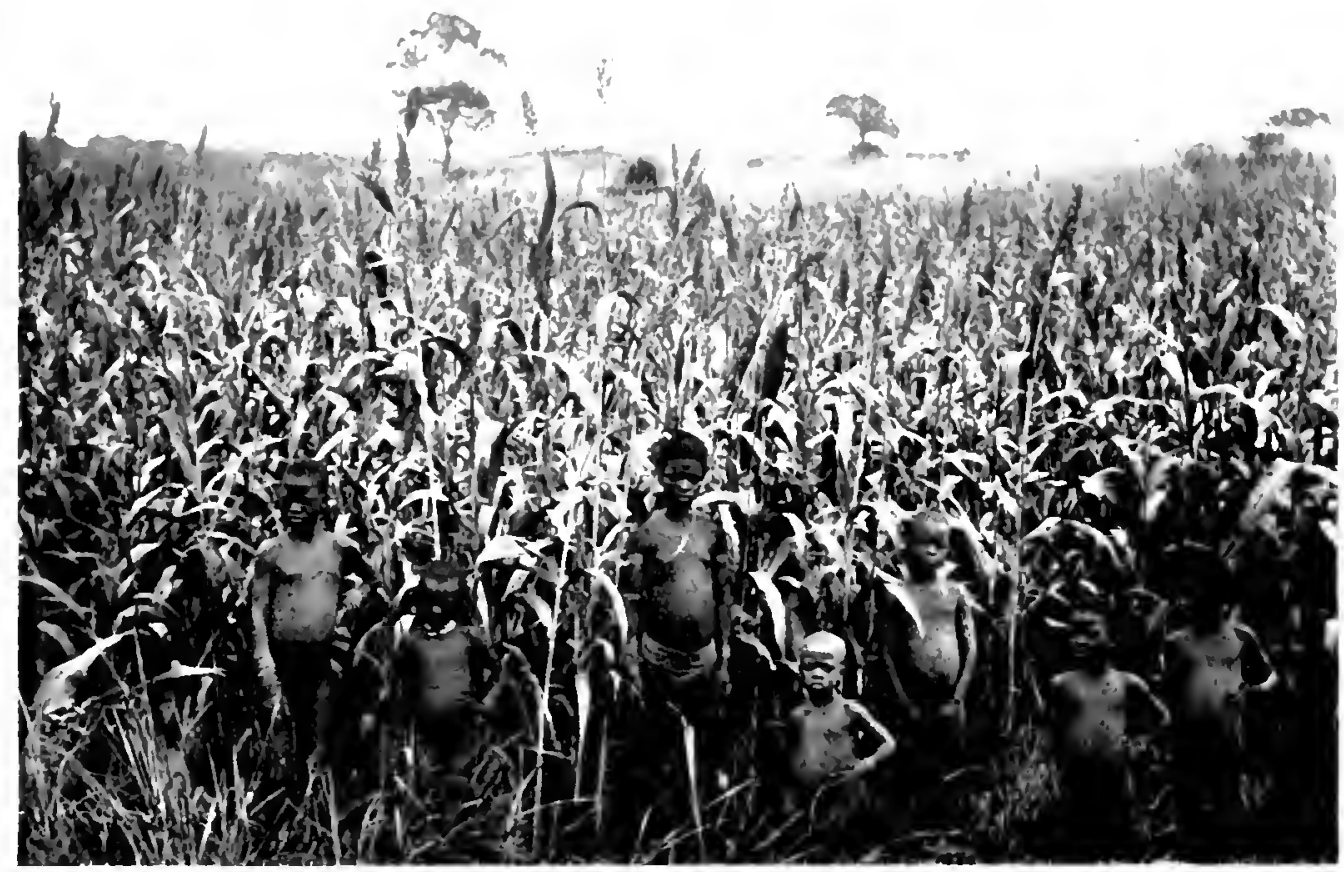

K 111 : ( ) ! )

6. Is Cane

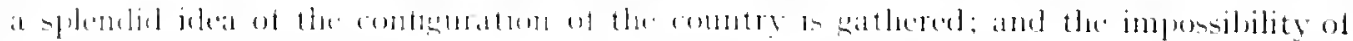

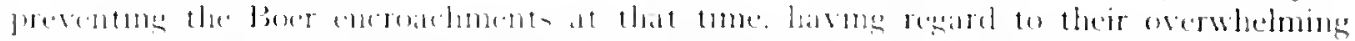

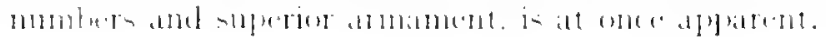

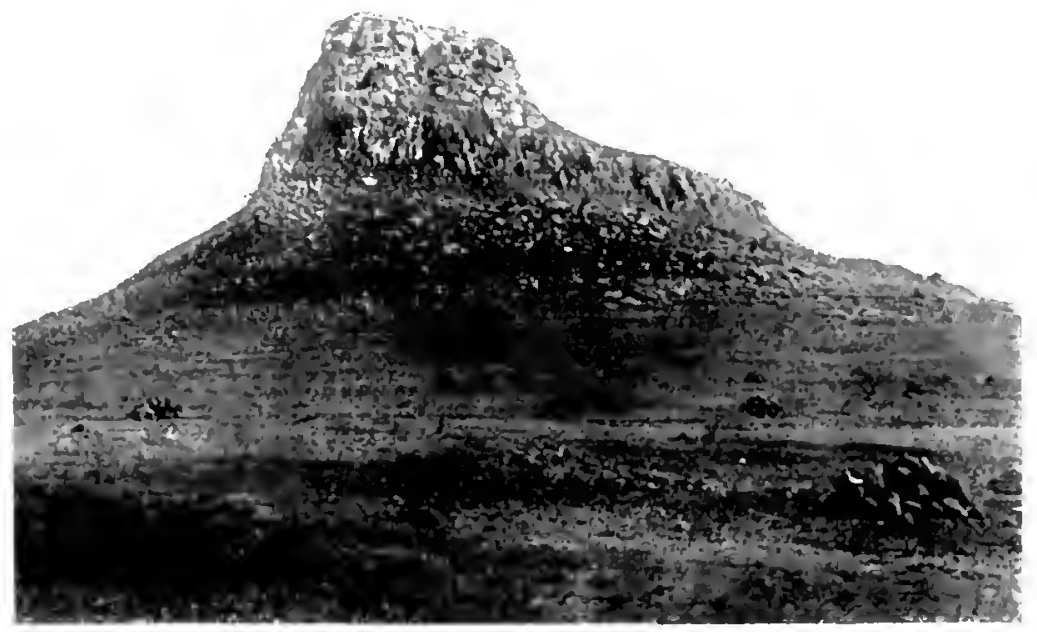

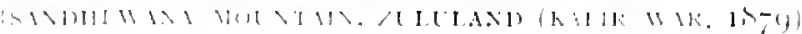




\section{FHOM GLEXCOE JUNCTION TO CHARIESTOWN.}

$\mathrm{R}^{\prime}$

EJorixg the main line. and pasing onwards to Charlestown, the town of Dundee looms clearly in the extreme right distance with Impati and Talana soaring above it. Th" latter hill is denoted by the plantation at its iase.

HATTING SPRLIT is a division of the extensive coal-fields. There are large deposits

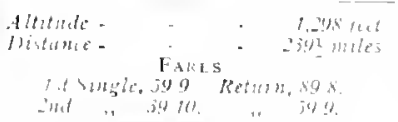
of this mineral in the locality. A private line. four miles lons branches to the right of this station, rumning to the Xavigation and St. Creorge's colleries.

DANNHALSER is the centre of a large stock, agricultural. and coal district. Here

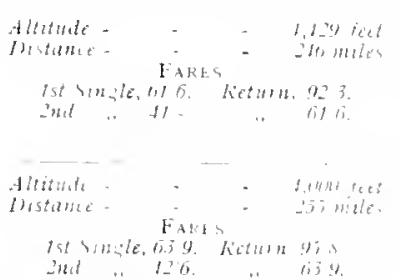
was placed the first of the celebrated blockhouses, fourteen of which were situated in the vicinity of the ralway line letween this print and the horder. It the next station.

ALCOCK'S SPRE'IT. large stone and hallast quarries are locaterl. The stonte need in onme ot the Colomy's most important imildings was taken from luere.

INGAGANE, the succeeding station. has much to commend it becoming a holiday

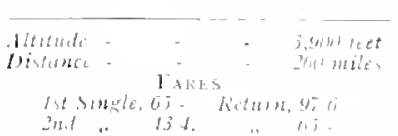
resort. It is but eight miles trom Xewcastle. the climate is farticularly fine, and it has adjacent. many plaresul attraction to the photographer. scientist, and angler. It is also of much listoric interest. In comparatively close

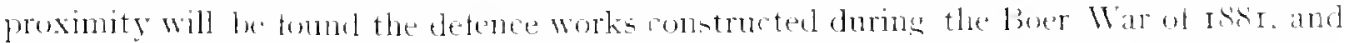
the more substantial tortifications hilt durine the recont contliet. The well-kmon

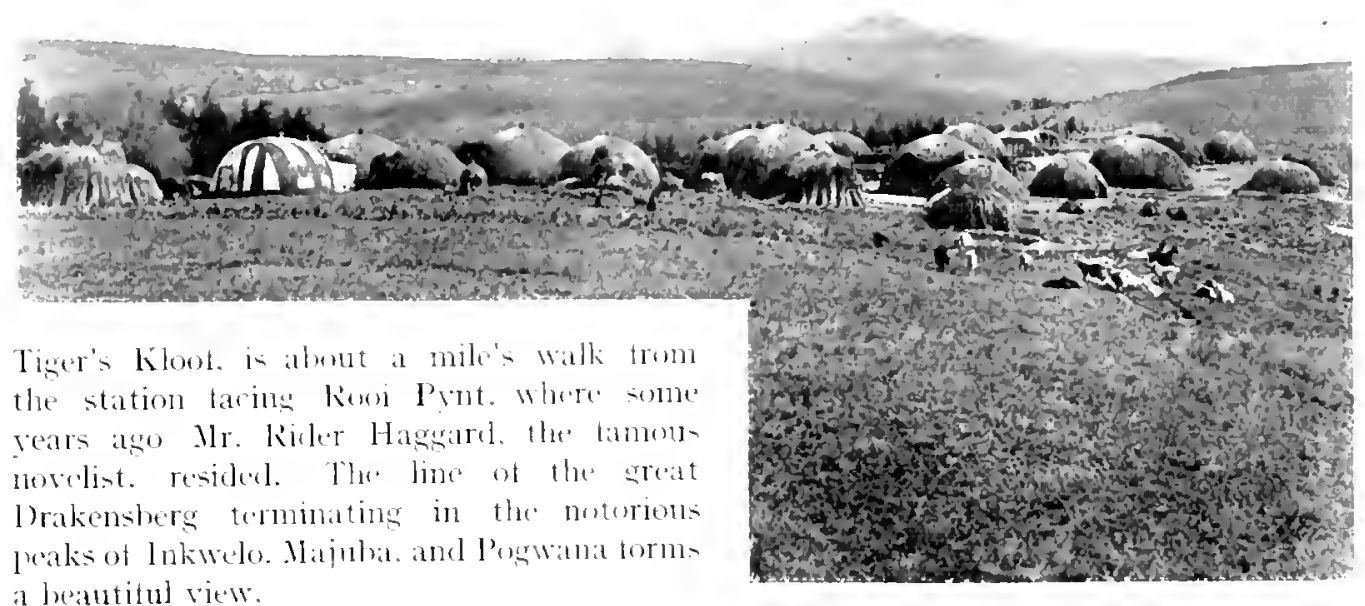
a beatutitul riem. 


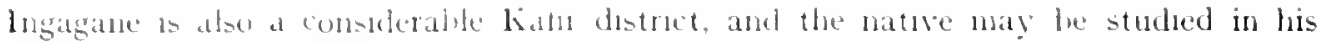

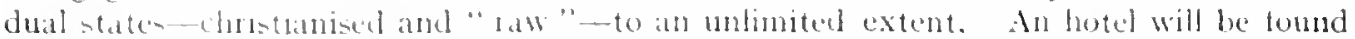
some distance trom the station. Coud eval is being worked a few miles awag.

XEllidsTLE un the Incandu is a municipal town, and trom a picturesque and residential standpoint, one of the nicest in the Colong, the

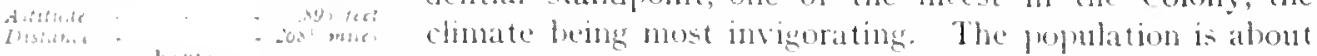

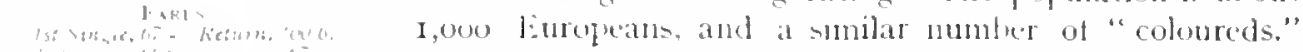
The rateable value of the properts in the burugh at the

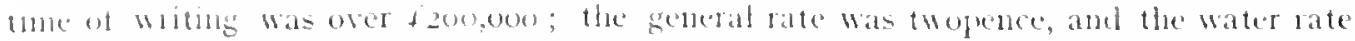
one halfyenny in the pound. The streets are well kept the santary arrange-

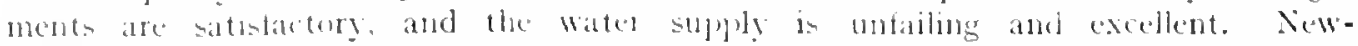

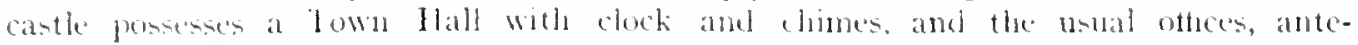
roons, and general consenientes. The main hall will hold fully 500 prople. This structure, Which was erected at a cost of foone to commemorate the liamond

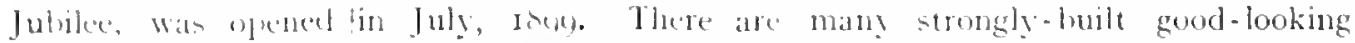
buiklings. ant accommodation for visiters is met ly three combortable hotels and several boarding honses. The princijal societien and lustitutions ase: the Agricultural Society, Library and houling Room. Literary and Mranatic Society, Masonsic and other lodges, several sportung Clubs, and a lible Assuciation. The Church of South Africa, Roman Catholic, Neslevan. Presbyterian, and Dutch Retormed bodies have places of worship here, While the scholistic establishments inchede a Government School and bominican Convent. A weekly news-sheet is printed in Newcastle called the . Nacastle divertiser.

The principal products of the town and neighlourhood are wool, coal, tobacco, and maize. An injortant industry in the shape of a woollen lactory has been working for some years with successtul results. Tweeds and hlankets of rery good quality are produced from the focal wool. There are sceral coal mines in the vicinity, and with the existing railway tacilities, the natural expansion of trade, and the good seame. which have been recently opened up, the out put should increase considerably.

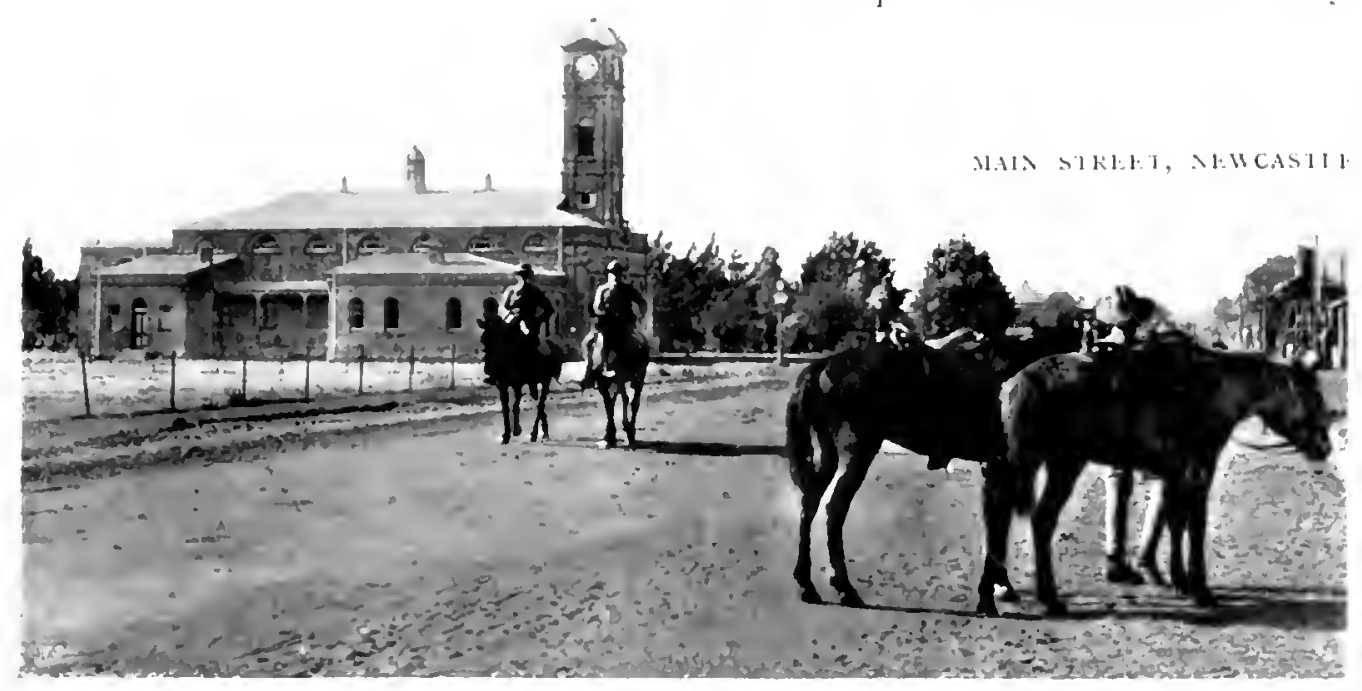




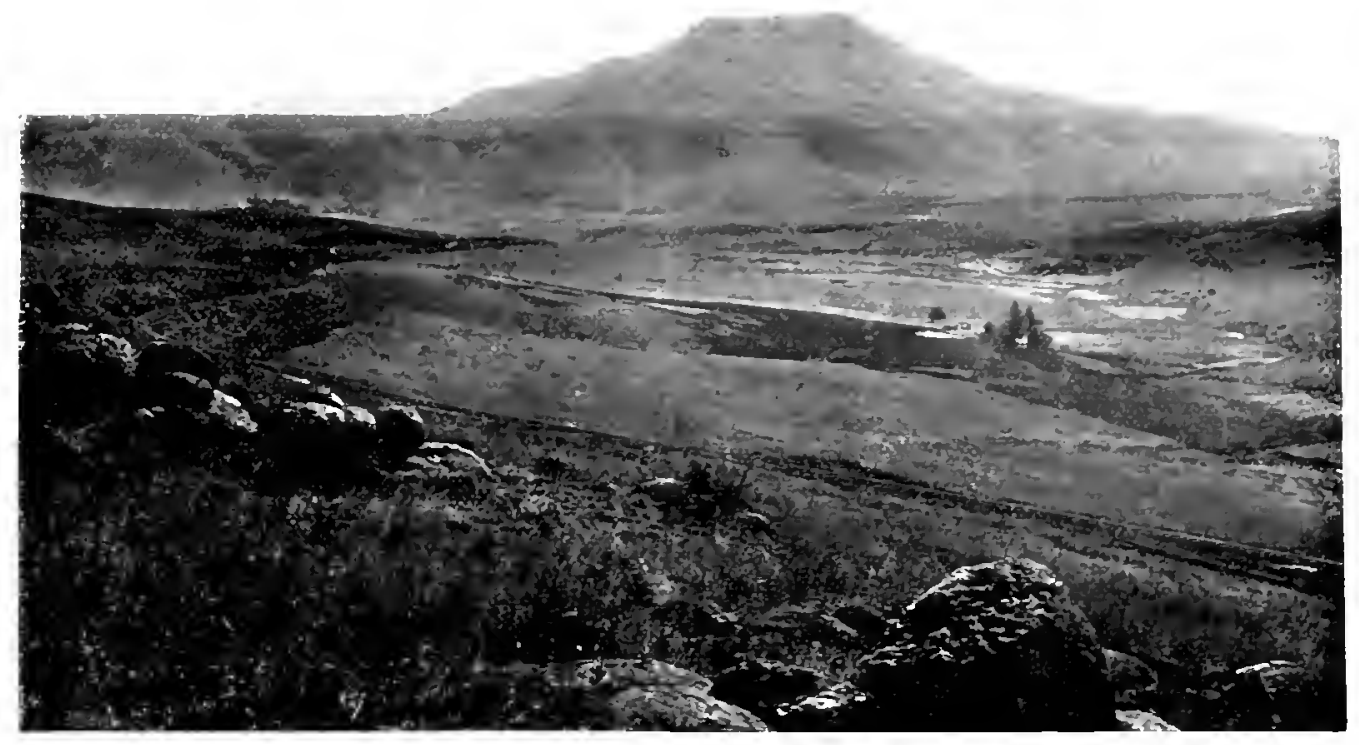

'HAJCBA AND LANG'S NEK

Fort Amiel looks down upon Newcastle trom the north-west. In relation to the IVar.

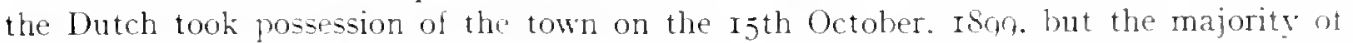
the residents had departed. So great was the affection of the Boers for the place, and so strong their conviction that they had come to stay. that they re-christened the town "Viljoensdorp," and appointed their own civic dignitaries. But they were not destined to enjoy this desirable retreat as long as they desired. With General Buller's sweeping movement into the Transvaal. the "Viljoensdorpites" were pushed back to the places from whence they came. and Newcastle was re-occupied in force by the Britisln on the I \&th May, Igoo. The town was strongly garrisoned, and Newcastle became the headquarters of the Army in Natal during the latter stages of the VIar. A well-equipped Soldiers' Institute has been built in the town for the benefit of the garrison now estahlished there. Newcastle, it should he mentioned, is a Refreshment Roon Station.

INGOGO recalls painful recollections of distant years-memories of martial blunders and

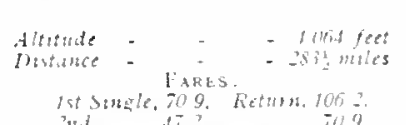
political mistakes. But side by side come the lustrous events, and brilliant episodes of latter vears. Let us earnestly hope that these may be the progenitors of concord and peace. and that former enmity will resolve itself into the brotherhood of friendship and racial affection-an indissoluble union in one people, and one great Imperial aim.

Standing on the platform of this station the traveller will see three hugrever-awing mountains. The centre one is flat-topled and the supporters are peaked. Naming them from the left they are Inkwelo, 0.972 teet high, the world-known Amajuha, 7,000 teet high. and Pogwana about the same altitude. 


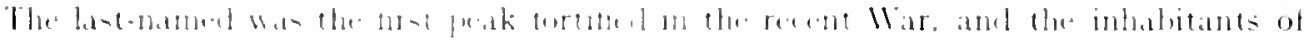

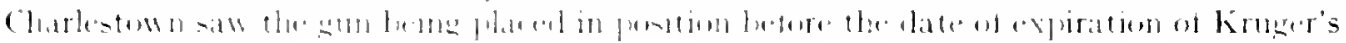
ultillatum.

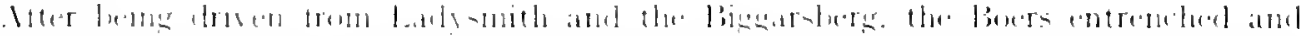

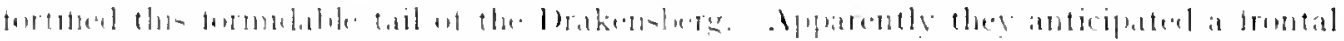

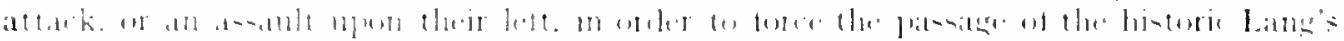

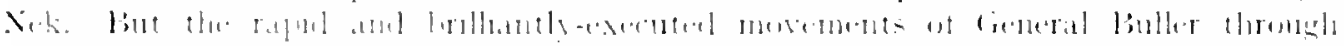

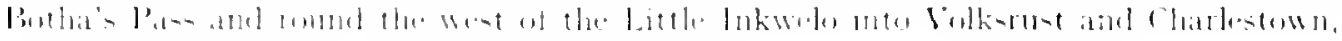

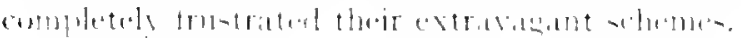

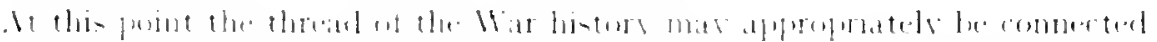

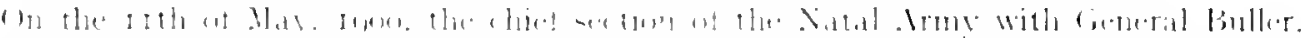

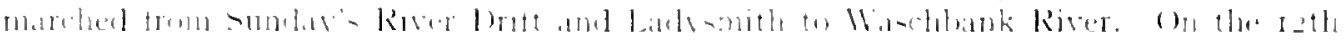

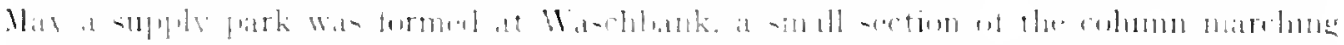

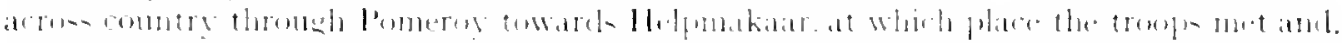

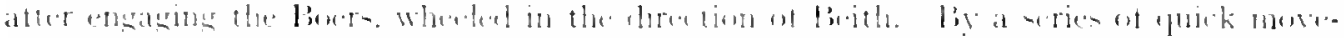

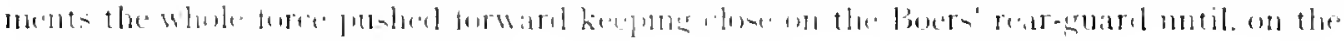

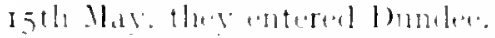

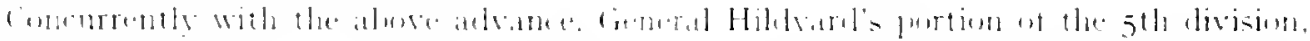

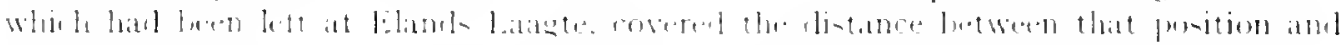
Winthank.

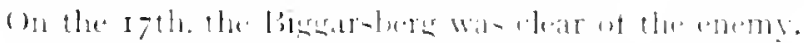

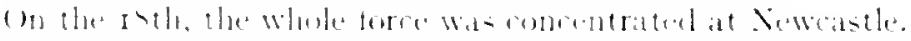

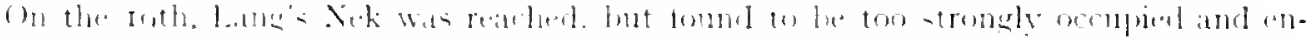

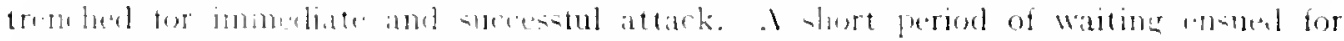
slyply purpeses and rallwat repairs.

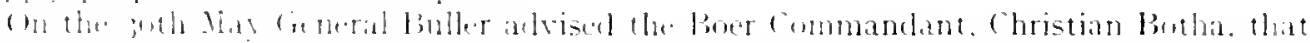

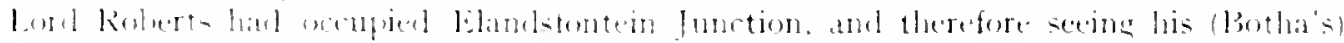

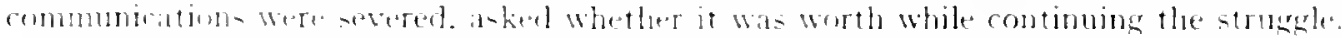

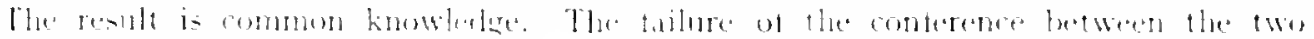

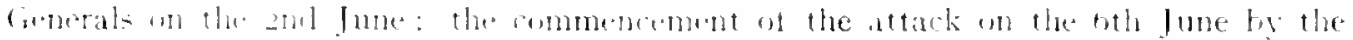

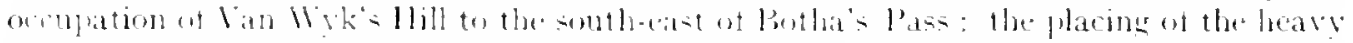

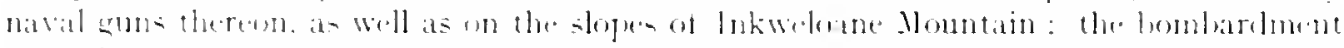

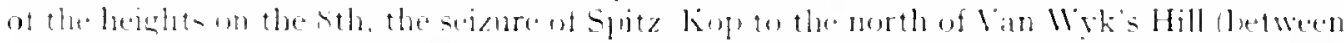

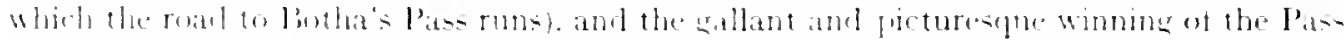

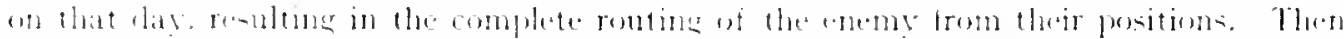

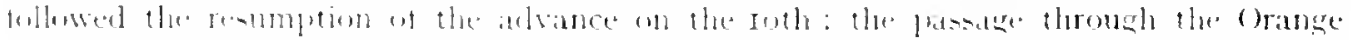

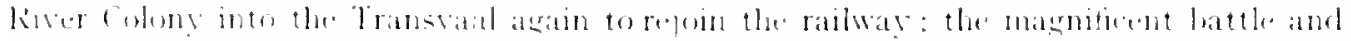

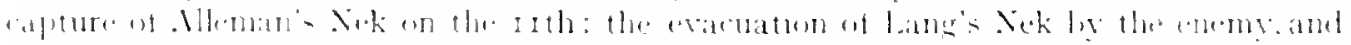

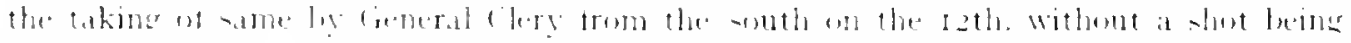

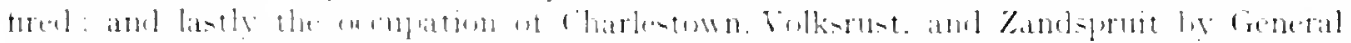

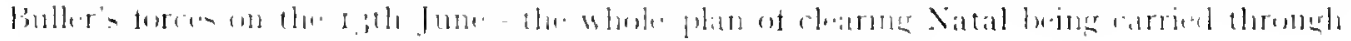
with the - 1 ry

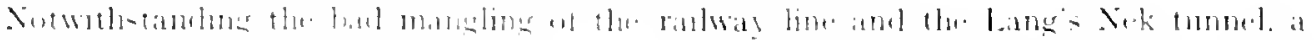

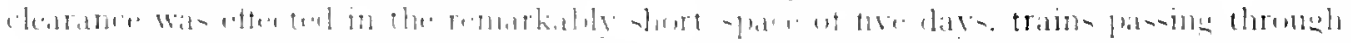

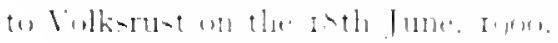

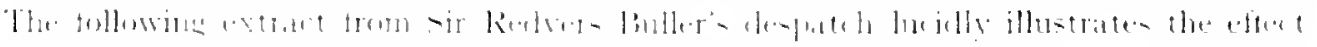

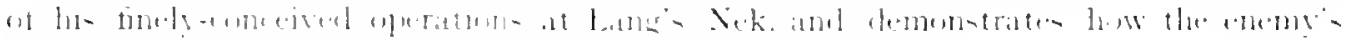
ay 
"By the operations thus described the enemy were compelled to atuandon the position at Lang's Nek to the retention of which they attached the greatest importance, and on the preparation of which they had expended a vast amount of labour and energy. The position, immensely strong by nature. extending as it does along a series of hills for three miles with its western flank secured by Majuba, and its eastern flank by the deep gorge through which the River Buffalo flows. and beyond the nver by the lofty mountain, logwana, was so skilfully and thoroughly entrenched as to be almost impregnable.

"The trenches were so arranged as to be invisible from the front, and yet were so placed that there is hardly a foot of ground in front of the position which toes not come under cross and enfilade fire. On the luastion-like hill in the centre of the position. close under which passes the road over the Nek were two, and in some places three, rows of entrenchments, and on this and the other commanding crests, gun emplacenents wth bombprof casements for ammunition had been dug out of the solnd rock. The slopes of llajulv were all entrenched, and the mountain itself was a mass of entrenchments, every possible approach to it being protected by them. On Pogwana was a very strong and carefully constructed emplacement for a six inch gun.

"Covered ways had been dug to enable the defenders of the trenches to get intw them ont of sight of the attack, and all approaches to the position had been burnt so as to shw up Khaki clothing distinctly. It is evdent that these preparation were not the work of a few lays, lut they had been most carefully finisher in every particular. in fact no pams had been spared to render the position perfectly secure aganst attacli. .ll this lahuur, however, was in van, for it was impossible for the enemy to retan the position when unce our trups were in possession of Vulksirit, as had they done so. they would have heen in a $c u l d c$ sic: the liutialo gorge preventung any escape to the east."

It will make a usetul note tor tuture reference to repeat the figures given by an authority of the British losses in hattle throughout the whole Natal Campaign. namely : ifs killed, t.3 to wounded. a total of 5.288 . This is exclusive of prisoners and minor losses which may be put down al sereral thousand.

The Ingogo District is replete with the War recorels of hoth Campaigns. To the north-

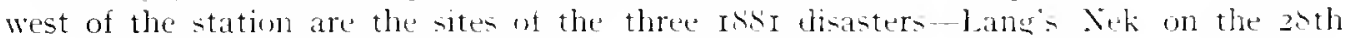

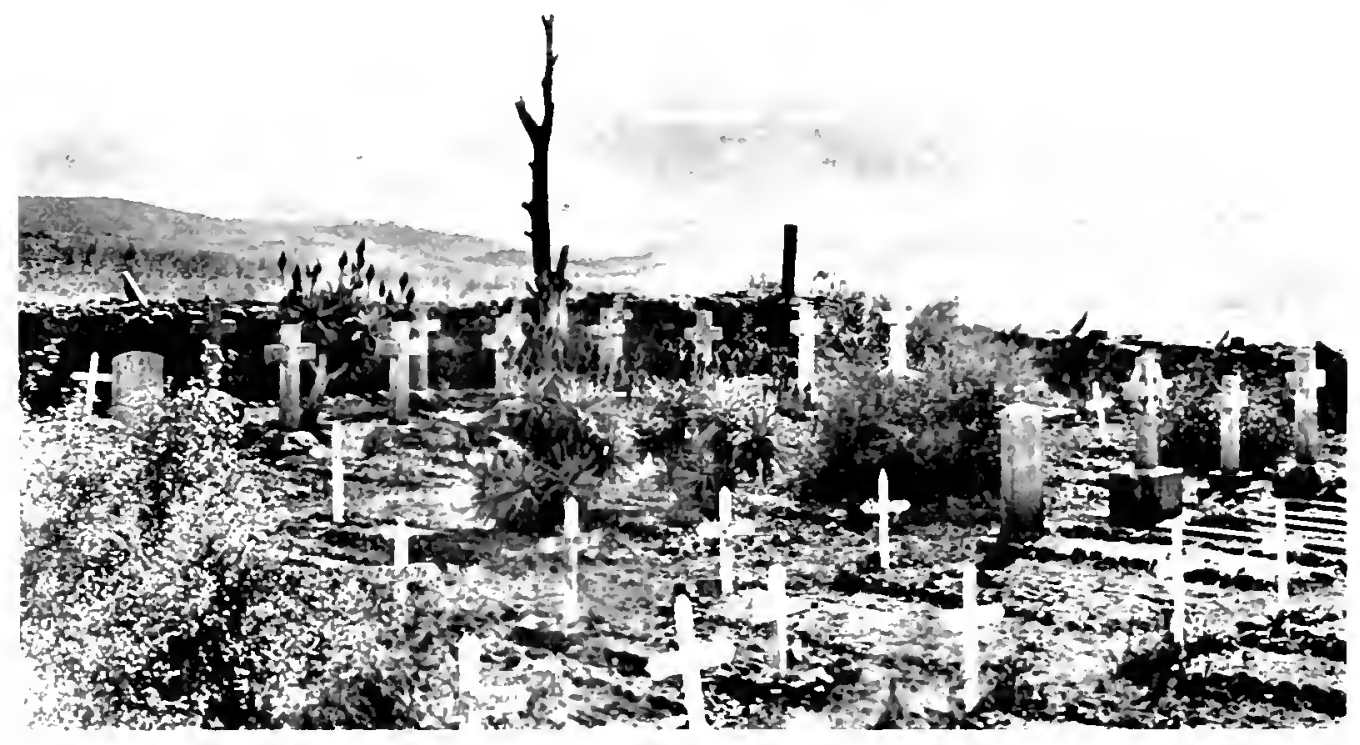

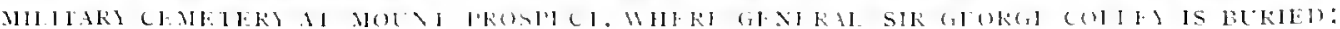

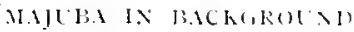




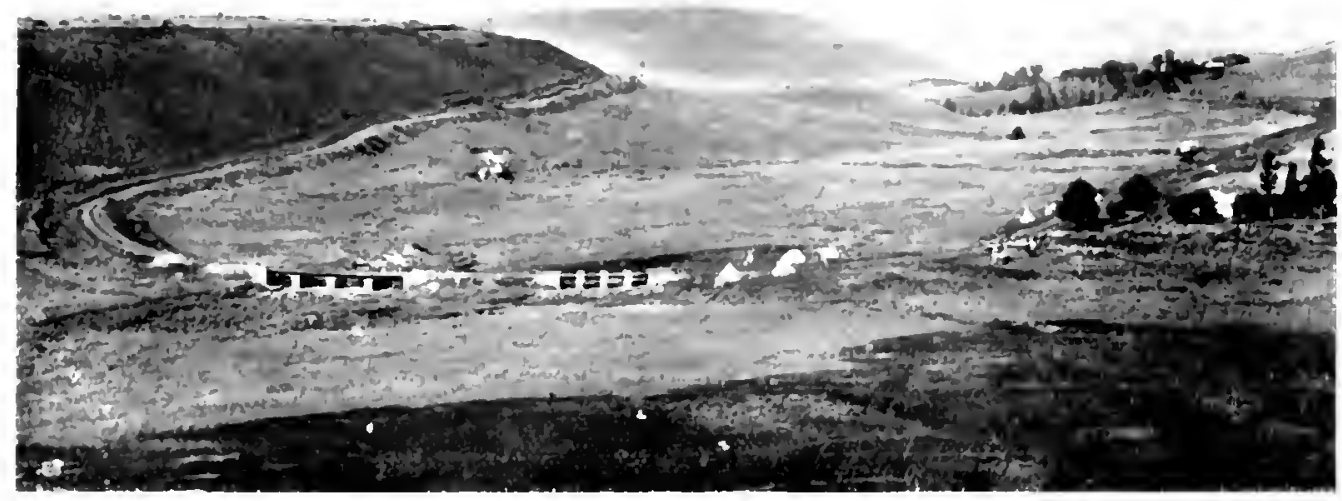

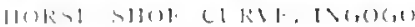

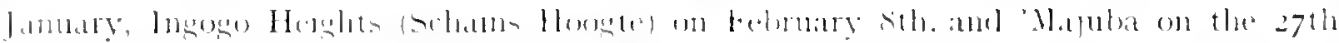

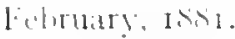

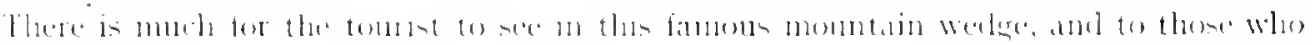

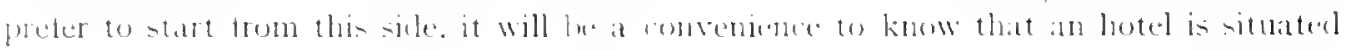

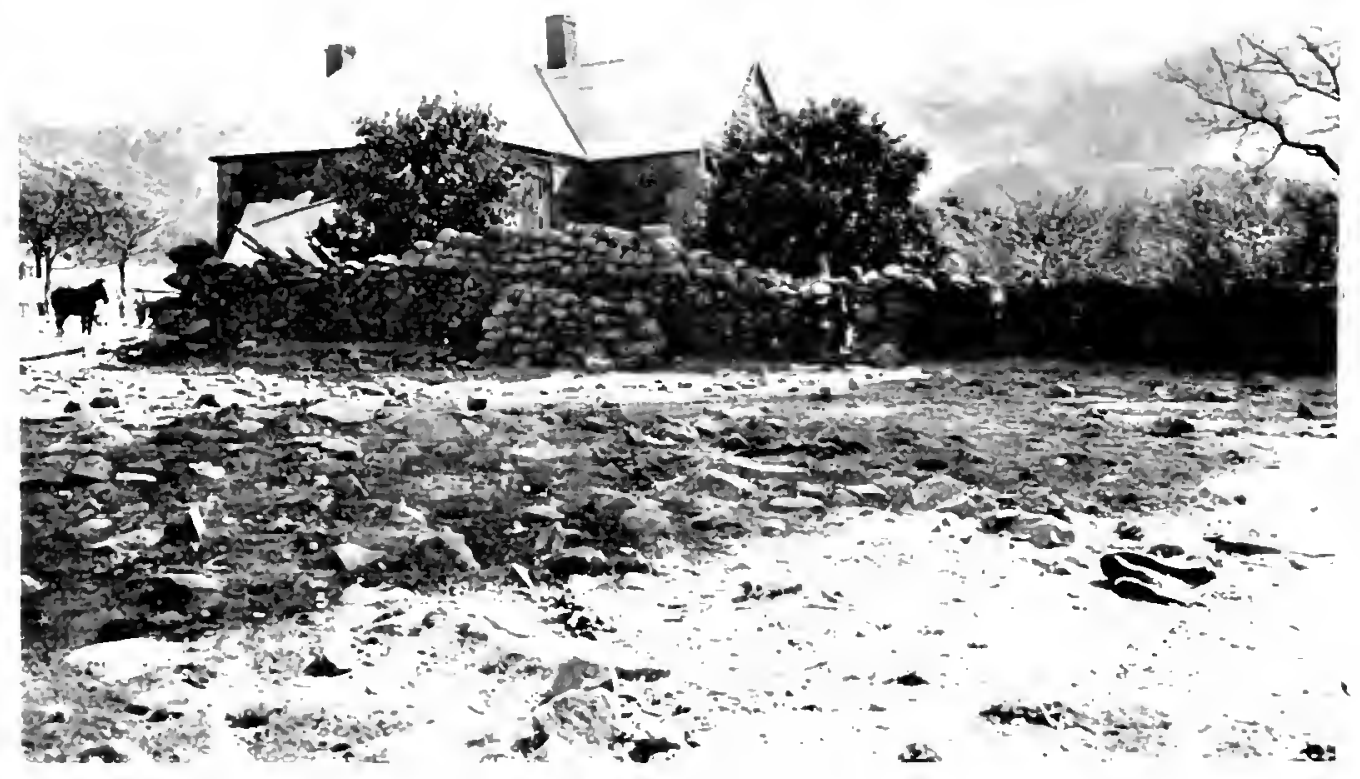


on the main road towards Botha's Pass. two miles trom tuc station. Not only are the mountains of special attraction to the tourist, but the Buffalo River which formerly divided Natal from the Transiaal on the east, and tlows through a wild and tangled country, is peculiarly interesting to the portrayer of weird and lonely scenes.

As the train advances from lngogo to surmount the heights, about two hunired yards beyond the station. on the left. will be observed a narrow plain, and an isolated hill shaped like a dunce's cap. It was aronnd this hill that the attacking forces worked towards Botha's Pass anl Alleman's Nek.

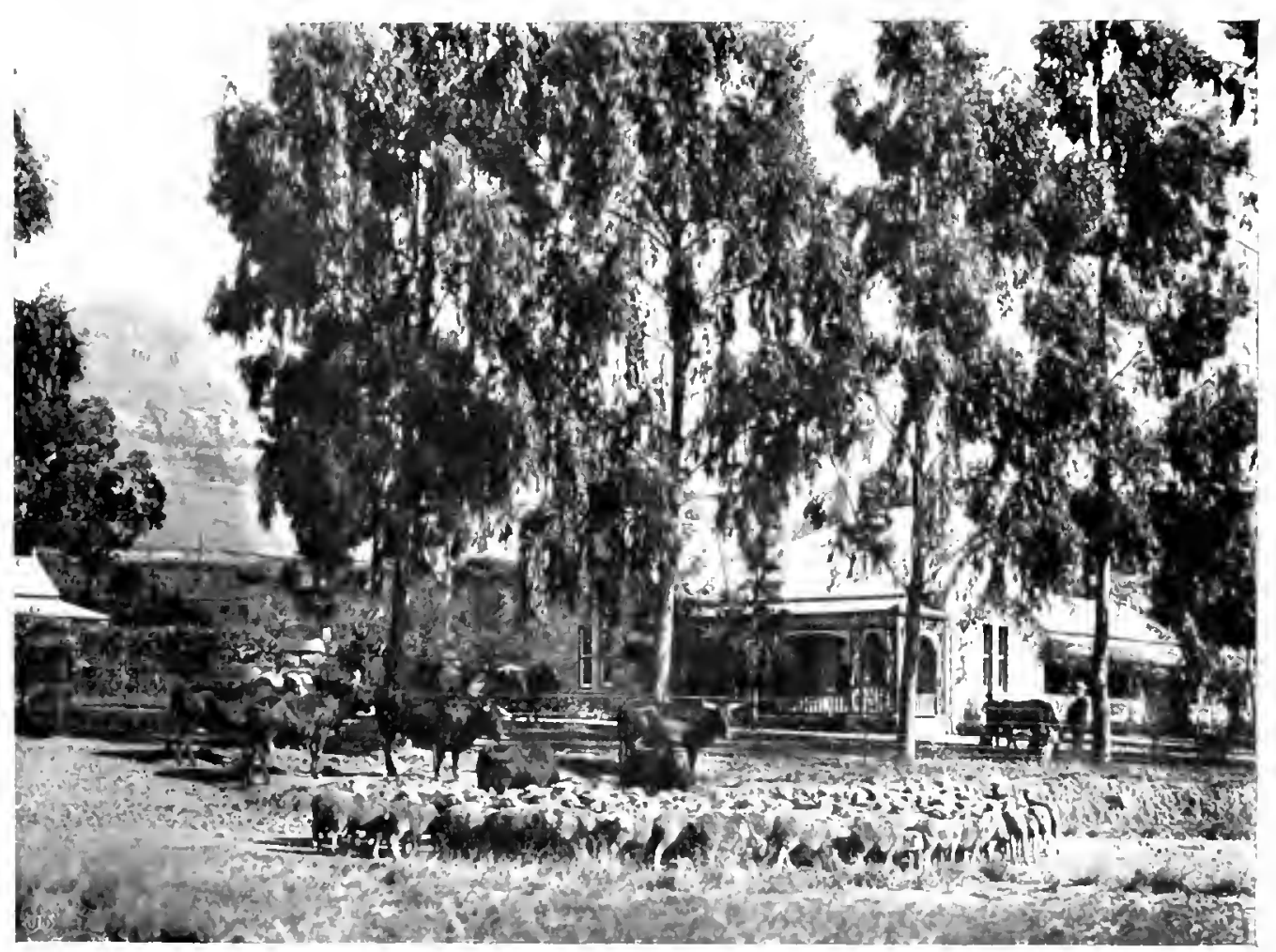

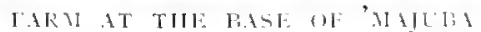

The method of negotiating the Ingogo Heights is distinctly interesting. Instead of tunnelling, which would lave been enomously expensive, the rails are lail on the bank of the mountain in zig-zags, and loy twice reversing the engine the train is raised $1.33+$ feet. On reaching this elevation, a delightful riew of the country below and the railwa track with its horseshoe curve over the three hrilges is obtained. Shortly afterwards the train winds round the hase of 'Majuba and

MOUNT PROSPECT comes into sight. Not far away is O'Neil's house. Wluce the

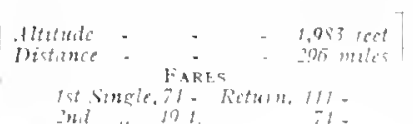
Peace Treaty of $\mathrm{r} \$ S \mathrm{r}$ was signed. After roumding 'Majuha. General Colley's resting placermav he ohserved on the left hill, and the ascent of L ang s Nek (from the Special Stopping Place of that name) would give the site of the rSSI disaster: 
the uraves of those who fell at this engagement : and also learl to the hurial-ground of the brave who perished with Sir cerorge Colley on Amajuba itaelf.

Ias-ing through Lang's Sek Tunnel-2.2I.3 feet long-loth ends of which were shattered b the enemy for zon teet, the borter station.

CIIRlgsToll is reached. Before the line was pushed through to the Rancl in

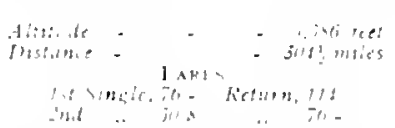

coath-stage period. The station premisen are commodions. and a tirsteclass liefrehment Room is provided.

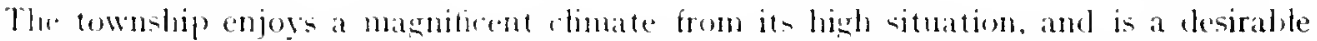
resurt. It has two goul hotek. the " betgrave" and the "forner" the former a new erection in place of the one dentroved by the buers. For the purpeses of a healthy heliday and an enjoyahle tour. Charlestown is without dould the best centre. It is within Walking, ricling, or driving distance of such historie "minences as Amajuba (traversing the

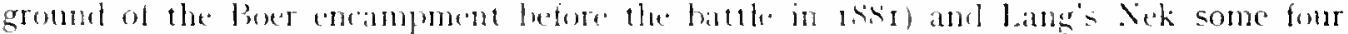

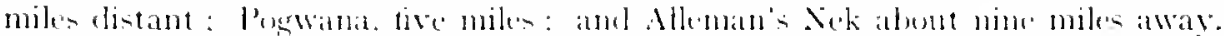

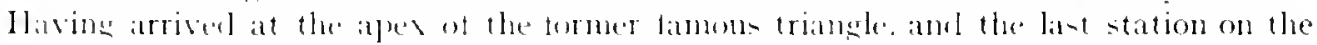

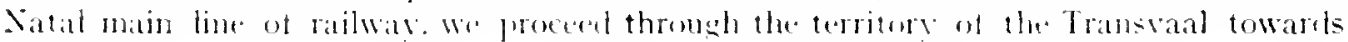
the kintl.

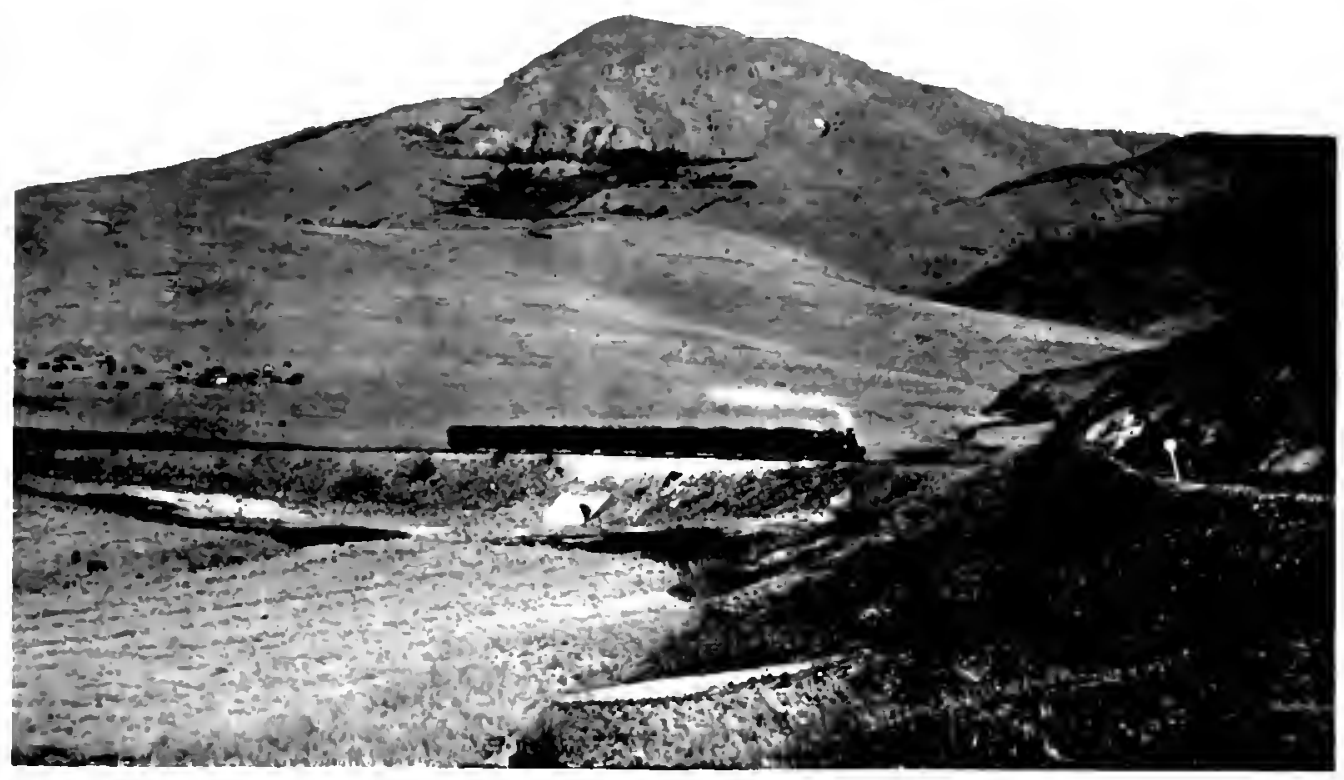

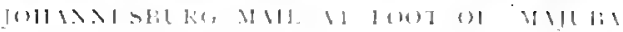


PART FOUR.

TOWARDS THE RAND.

THROUGH THE TRANSVAAL. 



\title{
PART FOUR
}

\author{
CIIAPTIER I.
}

\section{FROH CHARIASTOWN TO JOHANXESBLRG.}

$\mathrm{T}^{\prime \prime}$

IE distance to the border is two-and-a-quarter miles, and the divisional line between Natal and the Transvaal consists simply of a barbed-wire fence. At a spruit in the vicinity, which was fomerly also regarded as a sort of bounlary, Lord (then Sir Henry) Loch met Mr. Kruger in conference on the Swaziland question. After passing the spruit, the train leaves Natal at the furthest limit of its north-western frontier, and enters the Transval. A quarter of a mile beyond the border the town of Volksrust is located.

VOLKSRUST consists of ahout 250 dwelling-houses, built principally of iron. Hotel

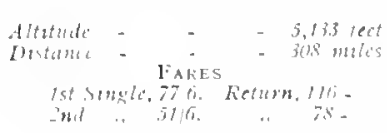
recent War, some $\$, 000$ hales per season changed hands. Volksrust will have its asso. ciations for the historian of the tuture. In September, ison, it was made the principal base for the Boer invasion of Natal, and it was always regarded as a point of consiclerable strategic importance. It conseguently formed one of General Buller's principal objectives in his movements after the reliet of Ladysmith. The contrast between the country which has been traversed hefore reaching Volkstust, and that which intervenes between Johannesburg and l'returia, is most remarkahle. The difference which immediately strikes one is perceptible, not merely in the geological teatures of the comtry, but in the vegetation and in the atmosphere. The vallers and the hilly uplands of Natal have been exchanged for interminable and monotonous plains, which bear a eloser resemblance to the prairies of the central and western Lnited States and the north-west territory of Canada, than to any other part of the lubitable globe. The country in summer is covered with grass, in many spots similar to esparto, and the appearance of the regetation in that season, when thunder-showers are frequent, is by no means unattractive. In winter another leature, which reminds one of prairie life, is noticeable-great grass fires. which are lighted intentionally, in order to secure a richer crop of grass and other vegetition in the coming spring and summer.

Though the ettect produced, at a cursory glance over the land, is that of a level like a billiard table, appearances in this, as in other things. are deceptive. At intervals in this vast prairie are to be found huge tarines - without anything on the surface indicative of their presence-in which armies of 20.000 men and more are swallowed up with ease. To the Boers, who are so well acquainted with every inch of their native country. these longas, or ravines, have proved of the utmost use in the Wir. Ther have heen emplovel as fastnesses, from which the guerillas conld sally forth with ease on a foray, and return without a trace of their movements.

The climate here, as in all parts of the "high veld" of the Transwal, is extremely" bracing, and the hreezy uplands which the railway traverses are among the best parts of the world for people who suffer trom pulmonury complaints. In filet, cenerally spesking, 
the chnate ot the higher Transwal is one of the healthiest known-forming a complese contrate to the malarial region of the low comtry - the western district of the Transiant.

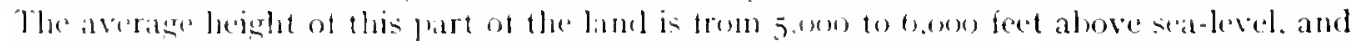

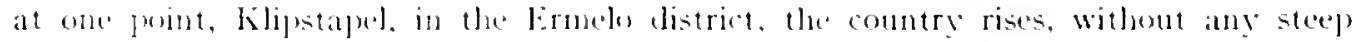
gradiations, 107,000$)$ feet.

In former days this comntry. mow so attractive and well-elowered, was a terra imognita

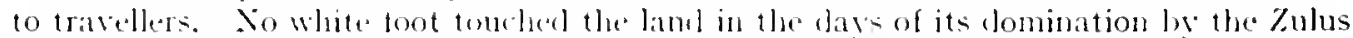

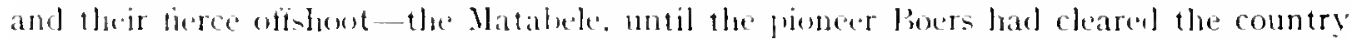

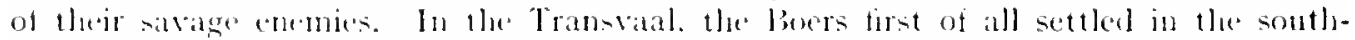
western and central districts Poteleftroom. Zeentst. Kustenburg, and Pretoria, and for a long time the eastern Transwall was neglected. Gradually it hecame habitalue and occujped to a small extent, and litthe way side stations on the road from Natal syrung up.

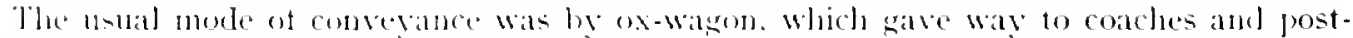
carts, as barbertom. and batterly lohameshurs. lesame centres of attraction. The

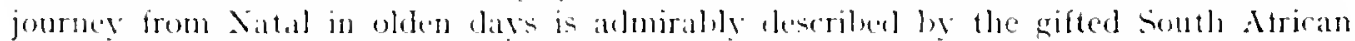

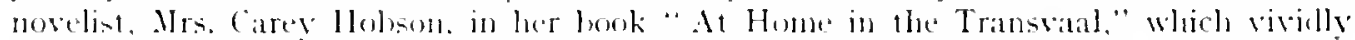

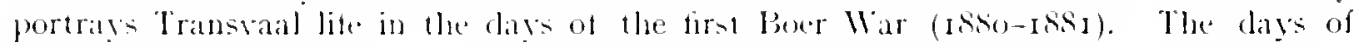
romance are oser now. hut the journey if more prosaic, is more comtortable and experditious.

The latal River is crossel for the hist time at Standerton. Its hanks are there steep and greripitous, anel it is he no means the eleep and phachl stream seen at Vereeniging and lilerkidory?

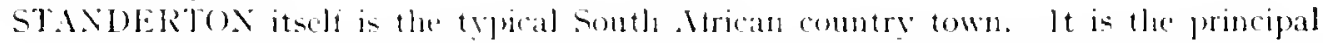

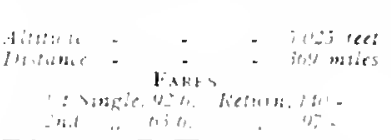
resort of a very large and lertide district and in past days

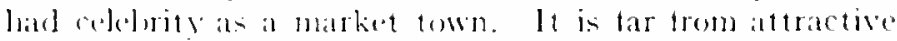
in alplearance. lluere being no natural features of any importanes, it we exegth lac Vial liver. The town, which in

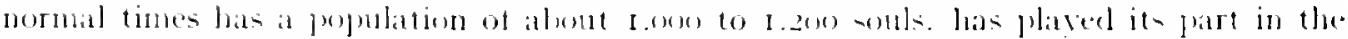

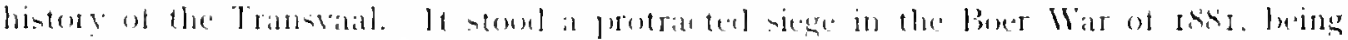

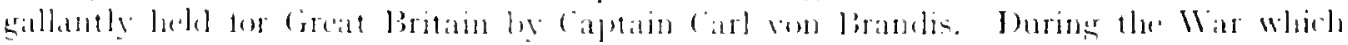

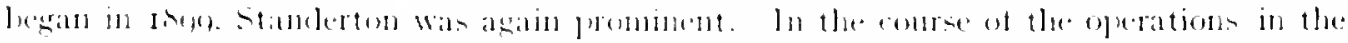

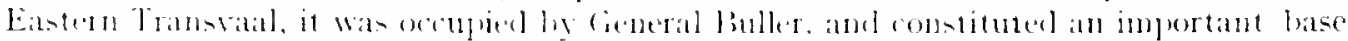

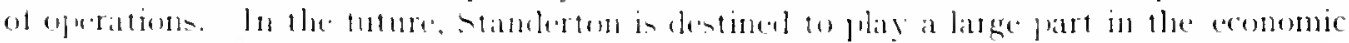

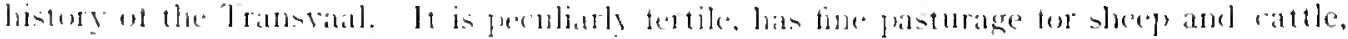

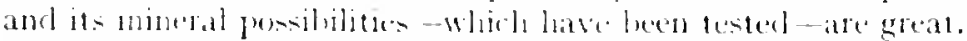

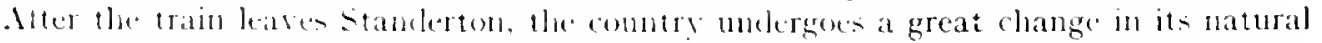
teatures. It is, in the first place diverstied hy mumerous rilges. Which intersect. and give

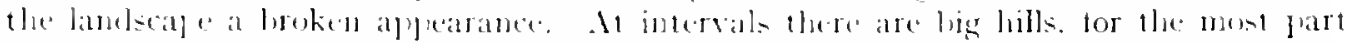

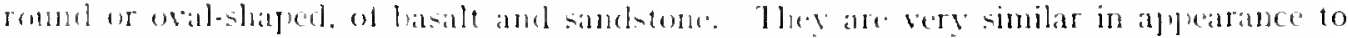

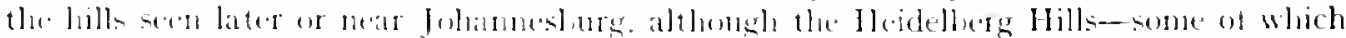
might almos lo tomed mombabis-alle more ruseged. The nature of the segetation,

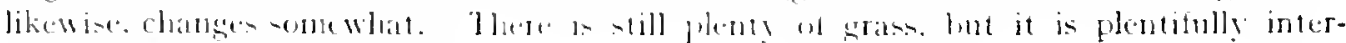

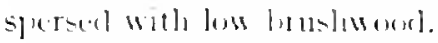

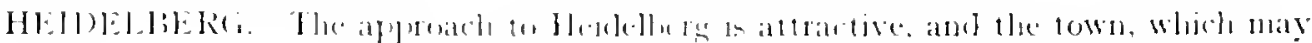

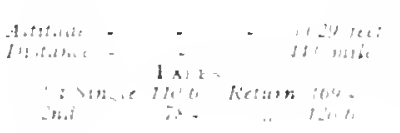

l. viewed an a whele tom the train, a tew miles le fore it in reathed. prenento a mont pleasant picture. The steephe of its ormate clumch may lese seen for many miles around. The town is very flasant in spring or summer. being 


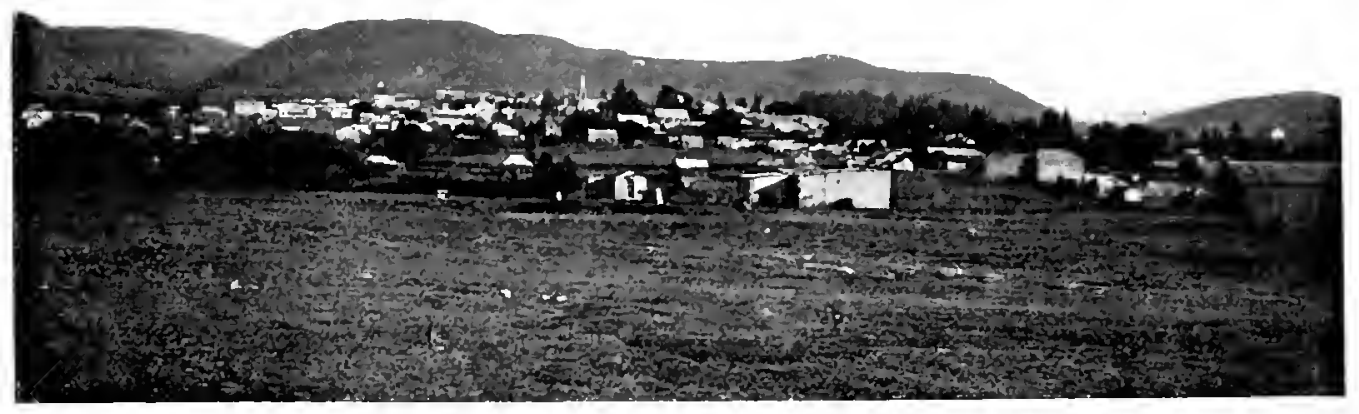

11111)ELBERG

"bosomed high in tufterl trees." It has in its time also plaved an important part in the Transvaal history. In the Boer War of risi it hecame the headquarters of the Bner Provisional Government, or Triumvirate. which consisted of Finger, Jouhert, and Pre. torius. It was here, on December Ioth. ISS, that the South African Repulblic was formally proclaimed, in a long proclamation. containing a summary of the events of the few preceding years, and declaring the arrangements the makontents were willing to make with the British autlorities. From Heidetherg was respatched the force which overwhelmed a detachment of the $4 f_{\text {th }}$ Regiment, at Bronkhorst Spruit on the road between Pretoria and Middelburg, on 1)ecenter 20th, I880. One of the first acts of the Triumvirate was to despatch a large force from Heidelberg with orders to advance inu Nital territory, and seize Lang's Nek.

In later vears. the town and district of Heilelleres grew considerably. The tistrict is not merely fertile, but abounds in golel-bearing reets. the best known and richest of which is the "Nigel." It has tremendous nineral possibilities, and reliable anthorities prenlict that in time to come. it will he one of the richest gold-producing distriets in the workl. ranking second to the Witwatersand. Unker the boer Government, the Witwatersand Goldtelds were officially included in the area of the district of Heiletherer.

The locality is interesting, from an antiquarian point of view in that it was the principal seat of Nloselikatse (or "Path of Blool"), the tamous " Lion of the North." and lombler of the Matabele nation, the traces ot whose chief kraal are still to be seen.

Heidelberg may be recommenderl as a flearant health resort. It boasts of some excellent hotels, stores, and private houses. Its population is ahout 3.000 to 3.500 .

After Heidelberg, the railway approaches the upland lowns of Witwatersand. The first indication of proxinity to a mining centre is atforded by a glimpse, on the sk $\mathrm{k}$-line. of the gaunt heatgear ot the mines on the East kand, near Bokshurg. Suldenty there is a wonderful metamorphosis, and the train leaves the quiet comtry-sicle. descending upon a forest of chimners and staging which indicates the very " hub " of the mining industry-Gemiston. Germiston is thanked by Elantstontein, the principal railway" junction of the Transtaal, through which, in ordinary times, trom 250 to 300 trains run daily. Southwards from Elantstontein, a line of 1, ino miles in length runs through the Orange River Colony to the Cape. I line runs south-westwards to Johanneshurg, and another northwards to Pretoria, and one astwark to Bokshurg. In time Elandsiontein 


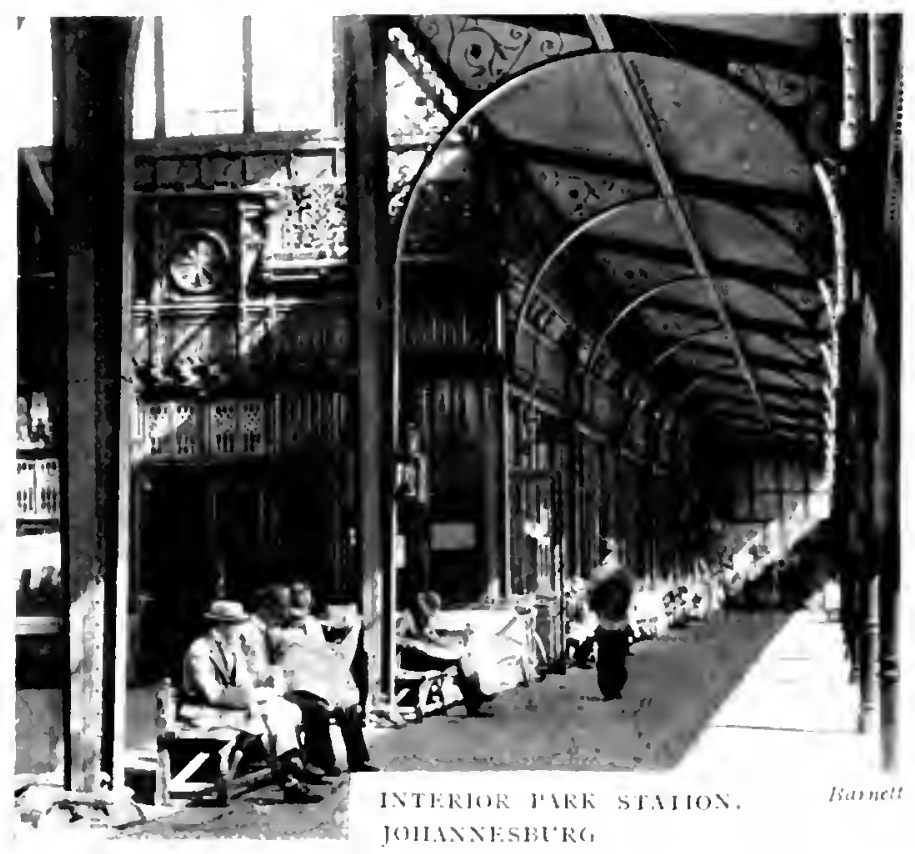

whll be one of the busiest railualy stations in the British Empire, with the exception of those in and near l.omlon. The station possesses a comfortahle huffet.

To Jolanmeshorg the train rums througla a lalurinth of mines and mining works, which affurd a novel spectacle not to leseon anywhere else. The offert producel by the numerous reservoirs ant glistening tailings-leaps is not lunpioturesque. The more imprortant mines have their awn little railway stations, at which. howerer. through trains do not stop. These are the Simmer and Jack, the ciekdenhuis the Jumpers. ant the George Goch. At the last-named, a huge plantation. which is only one of many that surround Johamnesburg on all sides, is reachecl.

After this, Jeprestown, one of the largest suburbs of Johanneshurg, is reacheet. It is attractive from a residential point of view. heing regarded as one of the healthiest parts of the city, standing, as it does, on elevated ground. Adjoining the Jeppestown station is a pleasant place for visitors, the Grant Station llotel.

Next comes Doornfontein, which has for many years been pre-eminent as the most fashionable suburb of Johanneshurg, though it is threatened to he slorn of its glories by Parktown. Doorntontein lies in the heautiful Bezuidenhout's Valley, which charms the eyce with its arenues of magnificent trees.

Leaving Doornfontein, the train proceeds througl a long cutting, and funally draws up at Park Station, the principal passenger-station of Johameshurg. On the north side of Park Station are the spracious recreation grounds of the IVanderess' Chub, while on the soutl the station opens directly upon the town.

\section{CHAT'TIR II.}

JOHAXNESIBURG.

$\mathrm{T}^{\mathrm{n}}$ IE first object that strikes the eye on leaving the lark lailway Station is the Jewish Synagogue, beyond which is the striking tower of the Telephone Exchange. A drive of three or tour minutes along Eloff Street or Rissik Street hrings one past fashionable l'ritchard Street (the Regent Street of the kand) to the very heart of

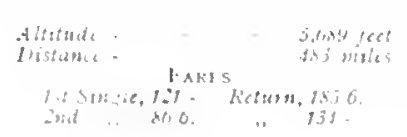
the town, the Narket Square. A glance at the P'ost Office and surrounding buildings. many four or five storeys in height, serves to indicate the wondertul prosperity and the immense prospects of Joluanneslurg. 
After leaving the Market Square, one comes to Commissioner Street, in and near which are the offices of all the great financiers, and that centre of sceaseless excitement, the Stock Exchange. Everything is redolent of the great industry--gold. It will, theretore, be appropriate to give a brief sketch of the history of the mining industry in the Transvaal.

The Bocrs were always a pastoral people, and their sole object in settling in the Trans. vaal was to acquire homes for themselves, and plenty of room for their flocks and herds. The desire to found a purely pastoral community was, in the first place, responsible for the aversion the Boers had to the incoming of intrusive foreigners, on the look-out lor precious metal. Thus, when gold was first discovered in I854, the Government of the day, fearing a foreign influx, prohibited prospecting under heavy penalties.

Herr Carl Mauch, a distinguished German traveller, discovered in 1867 , auriferous formations in the northern districts of the country. The Government shortly afterwards withdrew its prohibition, and in 1872 the first Gold Laws were published, and rewards offered for the discovery of payable fields.

Alluvial gold was found near Lydenburg, and a considerable number of nuggets unearthed, some scaling up to 2 I5 ounces.

In I882, attention was directed to the DE KAAP VALLEY, where a large block of farms was thrown open. In I886, the discovery of the Sheba Mine created a fever of excitement. A limited liability company was formed, and men in hot haste began to flock

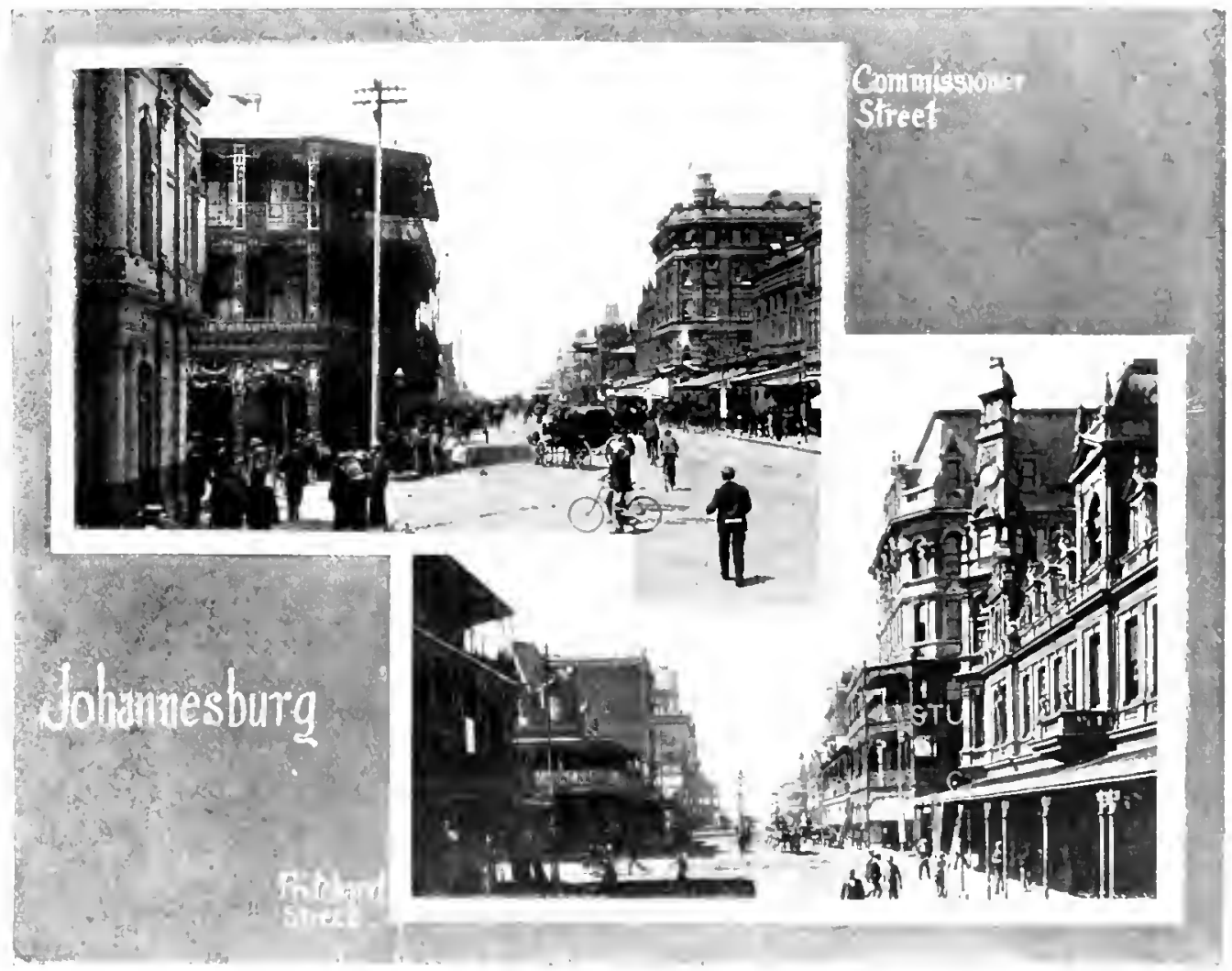


from all part of the country. It one time the ir slares of the Sheba Company rose to fou. In Isis, over ten thousand persons were in the district. and the town of Barberton was luilt. Immmerable companies were floated. aml the wildest schemes inaugurated. This, of eour-, resulted in a speedy collapse, and in a very short time only the permanent and weltefeveloped reets were kejt open. At this period the out put of Barberton was

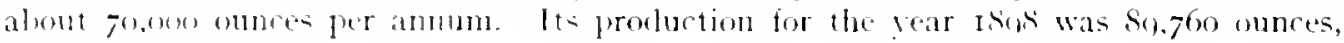
valuet at init $+7+2$.

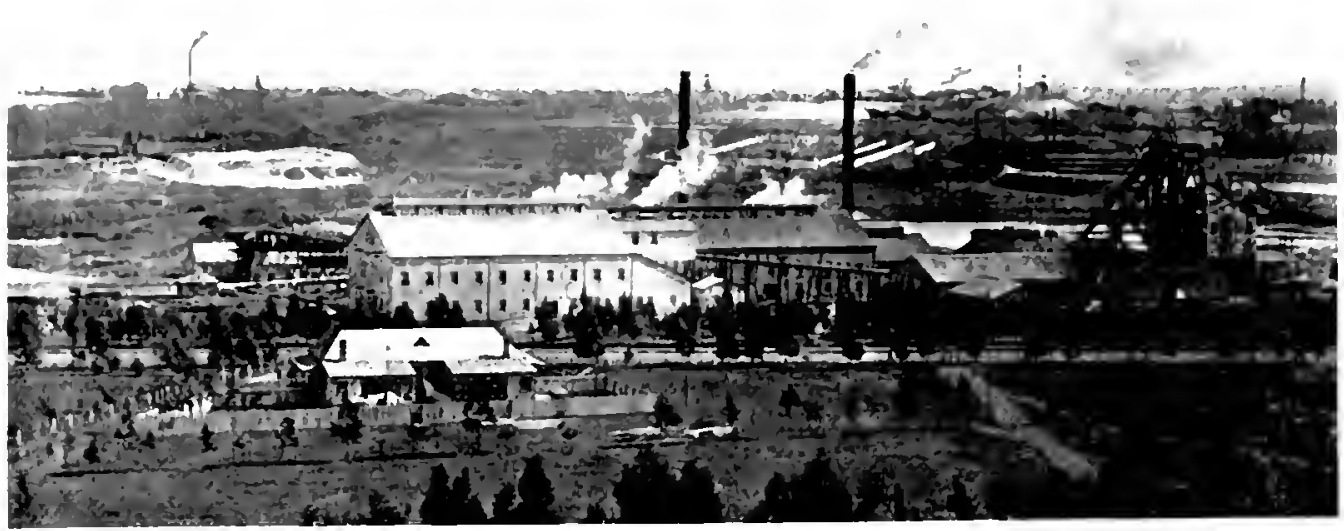

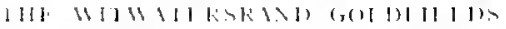

lins net!

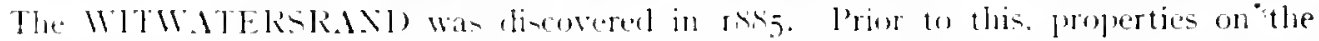

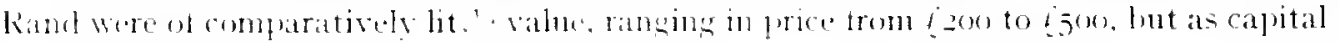

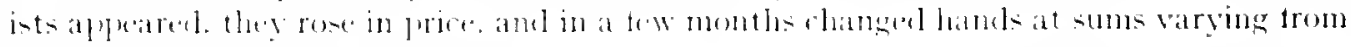

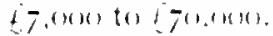

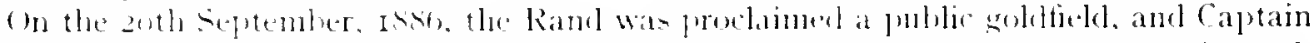
Von brandis alpunted first Commisioner. I fovernment sale of building stands, each

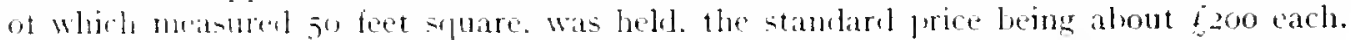

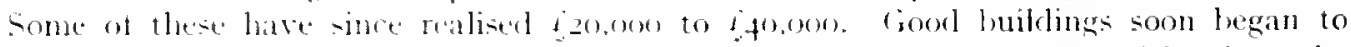
appear. and the Johamelnurg of to-flay rose as a matural conseguenre, resulting from the continully increasing output of wold. statistios of which are here given:

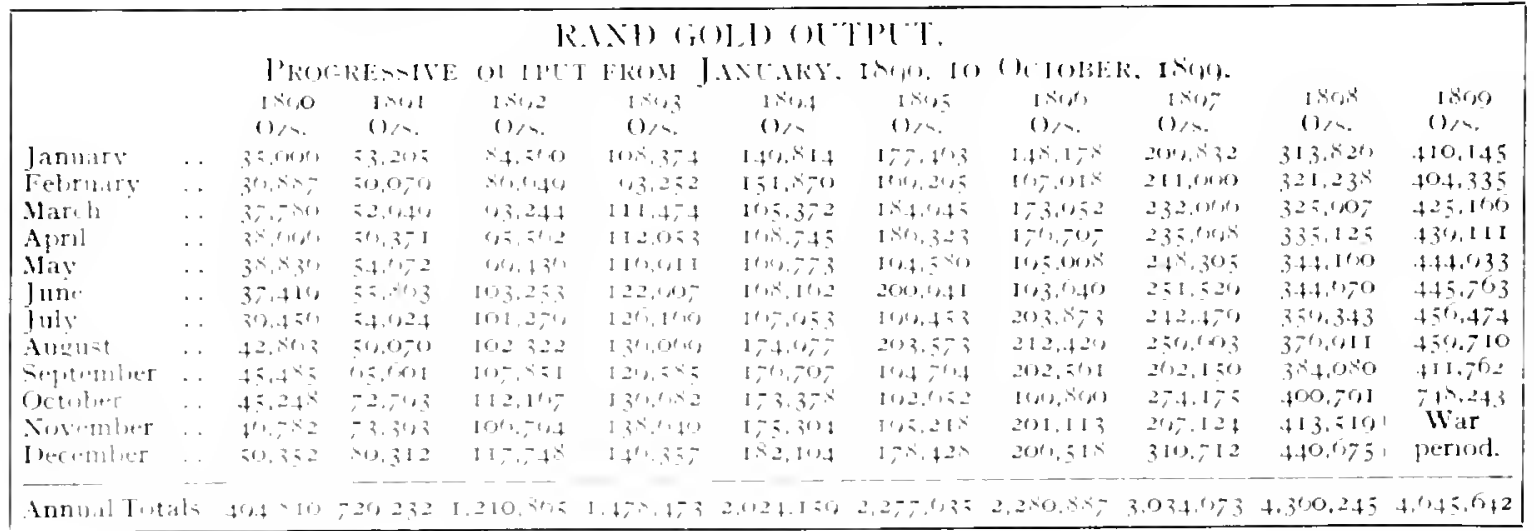




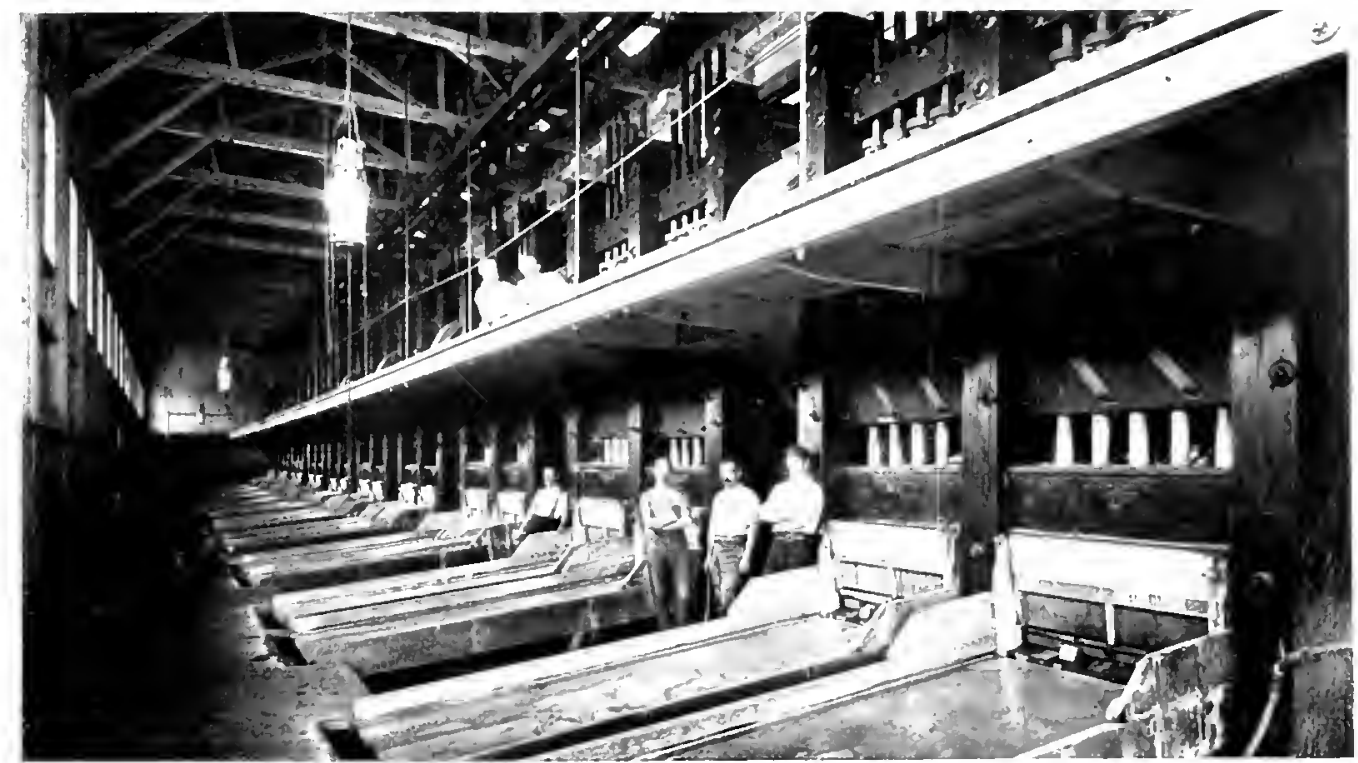

BATLRY OF GOLD MINI ON THE RAND

The total output of gold from the combined mines of the Transvaal for regs was valued at $156,240.630$. During the same vear $\mathrm{I}_{2}, 4 \mathrm{I} 3$ white men and 89,000 natives were employed on 37 mines. The value of gold-mining machinery and plant in use during 1808 was $69.409 .05 \%$.

The population of Johanneshurg just prior to the War was set down variously at between 100,000 and 120,000 . It is difficult to estimate it correctly, as the floating element is great. It is made up principally of whites, and jossesses amongst its numbers, some of the smartest business men in the world.

The cost of living in Johannesburg, at one time monstrons, is now reduced to more reasonable limits. althumgh house rents are still high.

Provision is made for the needr, who can obtain shilling meals, and at the same time no huxury is beyond the reach of the wealthy.

The town was once. betore the introduction of any system of sanitation, unhealthy in the extreme, but nore modem methods have remedied this evil, and Johannesburg is now far healthier thatn many European cities, and its elevation. 5,68 , feet ahove the sea level, at once bespeaks its invigorating chmate. The result is that people, on the average lead a more active lite, and work harder than they do elsewhere. This hard work demands a compensating amount of recreation. which is aftorded by numerous sporting chub of all kinds, and ny-to-date theatres and music-halls.

Social life in Johanneshurg is very plabant. The keenest interest is taken in politics and other contemporary morements. Churches connected with almost all denominations are to be found. There are several excellent newspapers issued daily in Johannes-

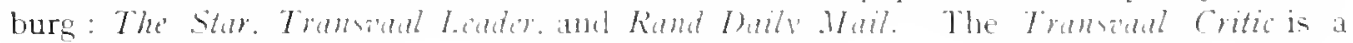
weekly pulication. 


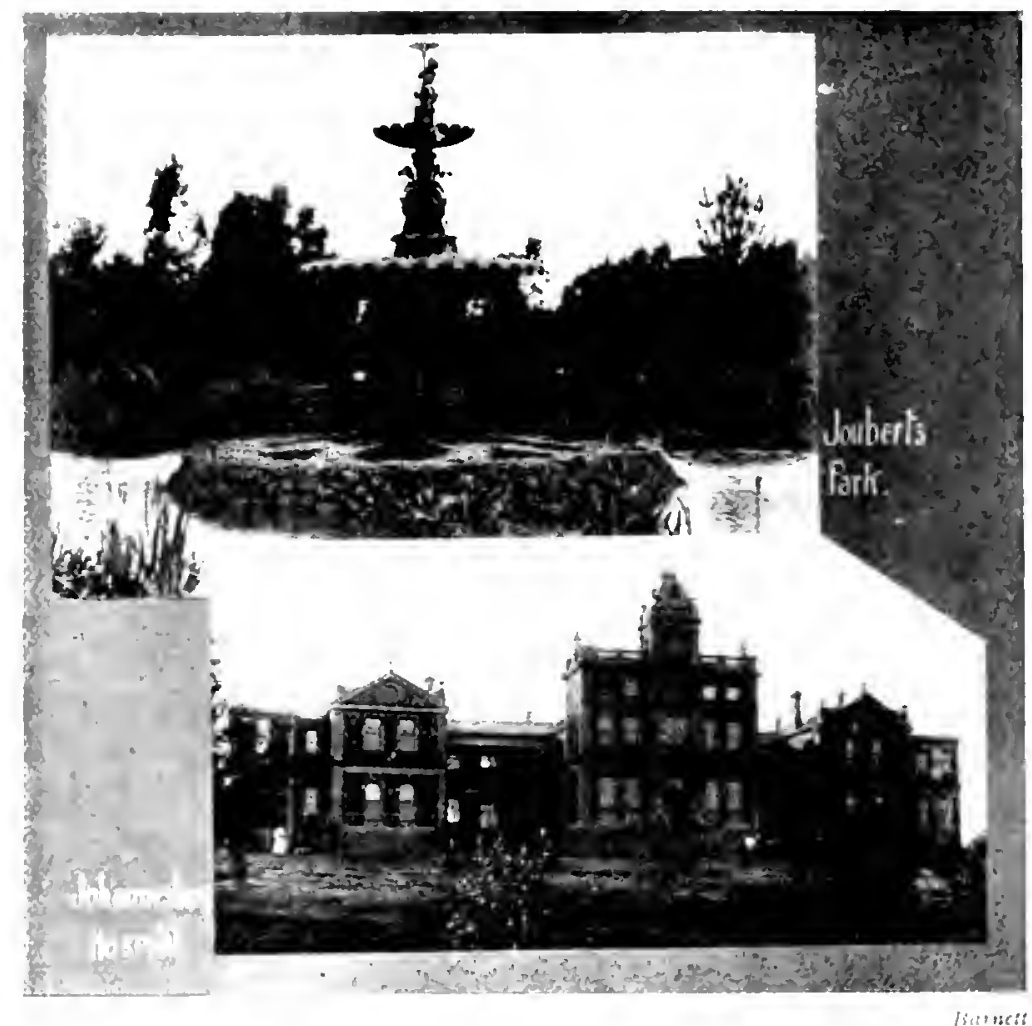

The history of Johanneshurg durng the past decale is part of the history of the British Empire. and does not need lengthy discussion in this place. In becember, Is95, came the Iameson Raid. which was preceded hy the departure for the coast towns of a large number of the inhabitants. Atter the Raid came the trial of the Reform l'risoners, four of whom (lieut.-Col. liank Rhodes. Messrs. Lionel l'hillips, John Hay Hammond, and George Farrar) were sentenced to leath, and the rest to varying terms of imprisonment. Then followed a long period of clepression. The lopes of the people were raised by the appointment. in ISo 7 , of an Industrial Conmission to encuire into the commercial grievances of the lithanders, but the labours of that commission were stultified by the action of the Transvaal Government. In 2 sis a vigorous agitation against the oppressive rule of the Kruger clique liegan, and resulted in a great demonstration on the shooting, in December, I8rs, of a subject named Edgar ly a Johannesburg policeman. Messrs. T. R. Dodd and Clem Webl, the leaders of the South African league, were arrested under the Public Meetings Law, and released on the excessive hail of 1 1.000. During the year I 899 great mass meetings were held by the Cithanders. and finally the Boer Government broke off the negotiations consequent upon the Bloemfontein Conference, and issued its ultimatum to Great Britain. During the War, many of the Johannesburgers fought bravely, principally in the Imperial Light Horse and South African Light Horse, and showed that the inlabitants of the town were fully capable of self-sacrifice, and of rising above merely material considerations. 
From the Reef Mr. II: Bleloch estimates that 2.87 I millions of money's worth of gold have yet to be extracted. The town will, in all probability, grow in proportion. It will be assured of a plentiful water supply, and a Water Commission has recently been considering the best means of providing a great and permanent source. The Towr Council, under its Constitution. has wide powers, and it is expected that sanitation. anc the paring and care of streets and electric locomotion along them. will proceed on the most approved and modern lines.

Johannesburg" has a' areat "future hefore it.

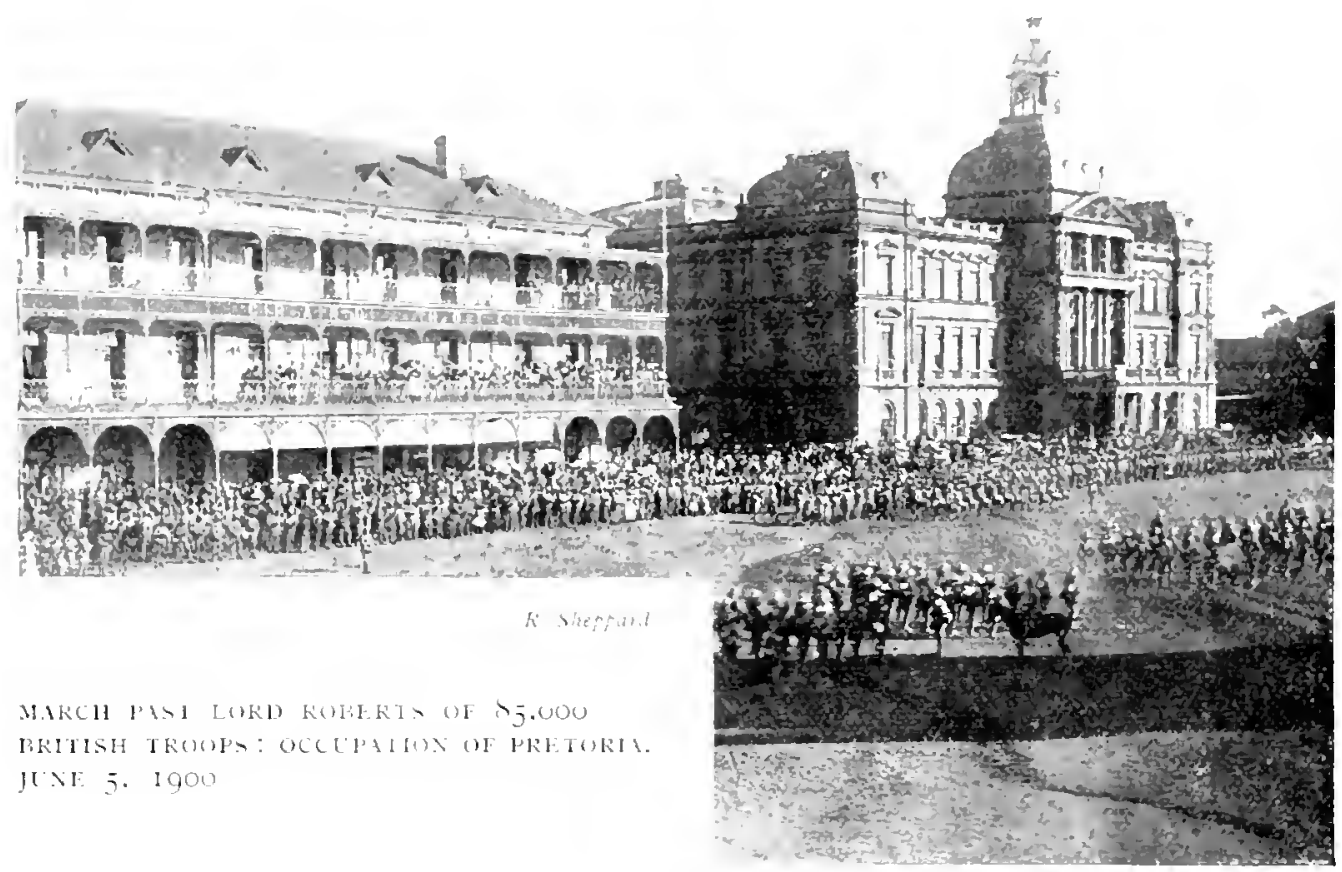

(H.1PYER HI.

PRITORIA.

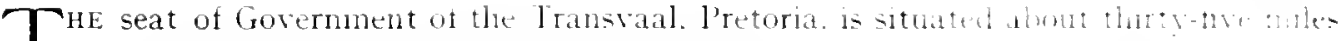
north-east by north of Johanneshimg.

On leaving the latter. the line traverses the town tor some distance and

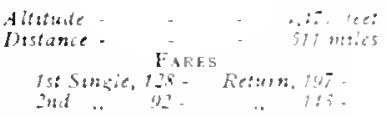

the olserver is impressed with the extent of tree-plantung which has been carried out. For many miles a successon of young forests can be seen. and in tact the greater part o: the route is enlivened and heautified hy shrubleries.

The town of Pretoria is situated in a circle of hills. and may fairly he lescribed as unt of the prettiest, if not the prettiest. of interior towns in South Africa. Viewed from the ton? of anyone of the surrounding hills during the summer season. the place has the appearance 


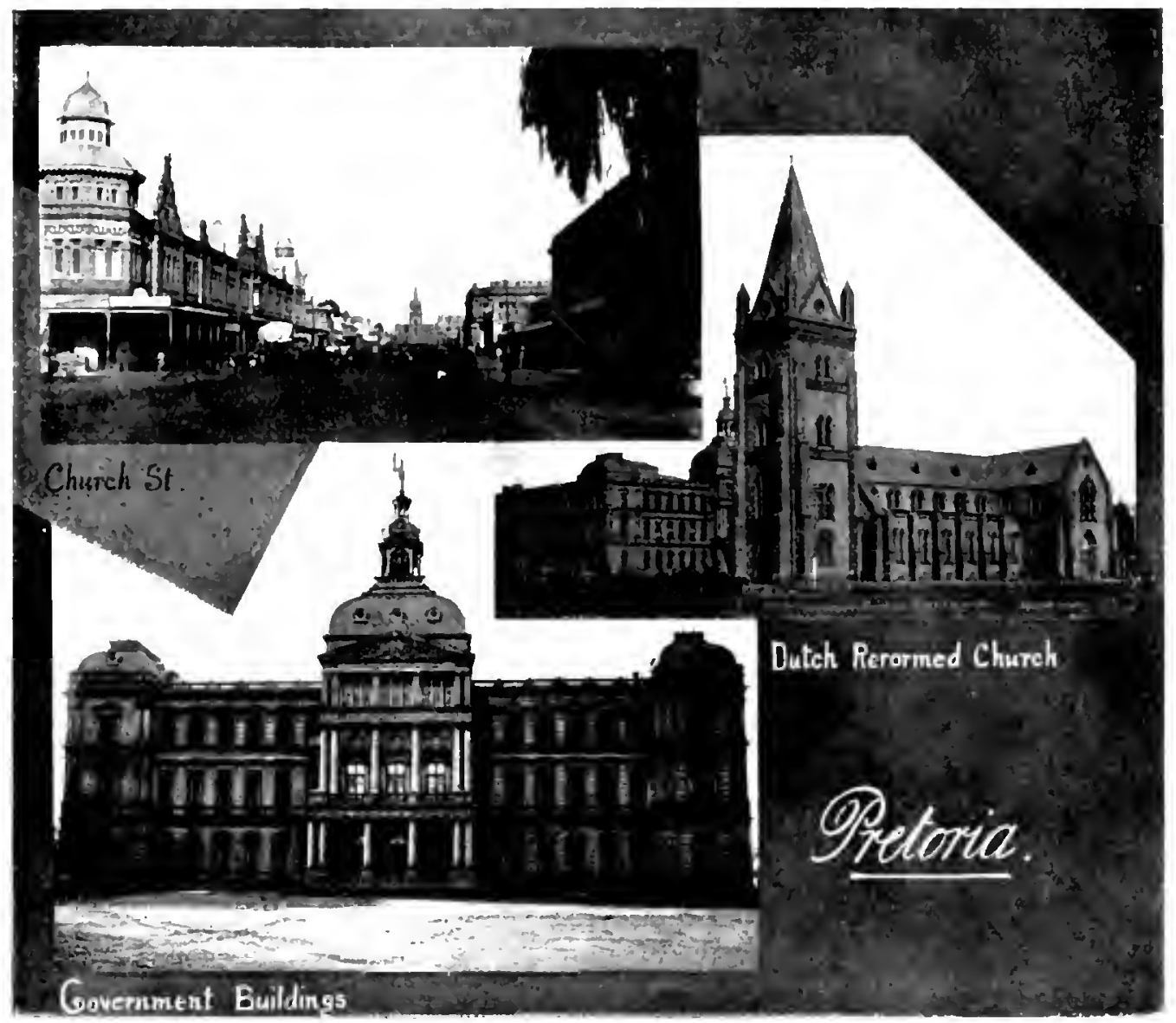

bitinet

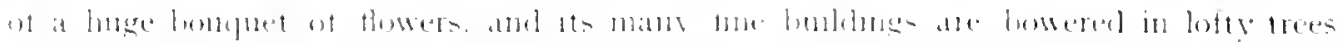

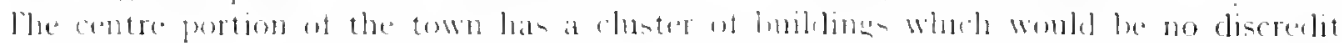

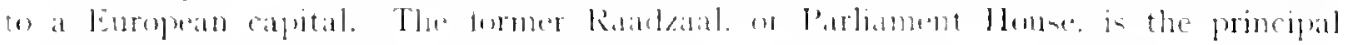

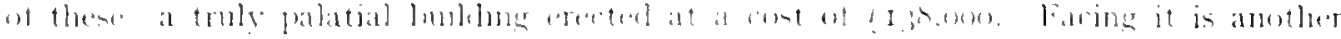

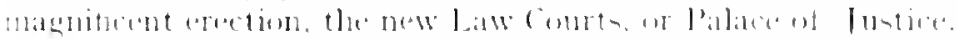

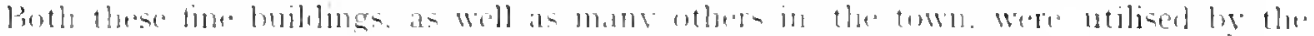

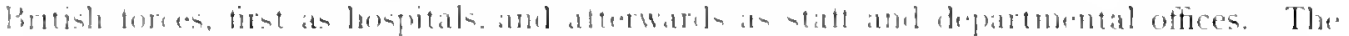

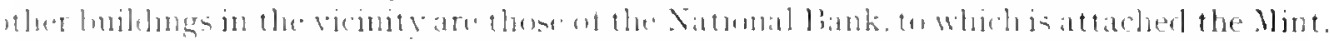

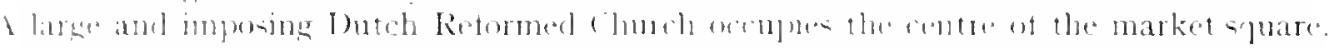

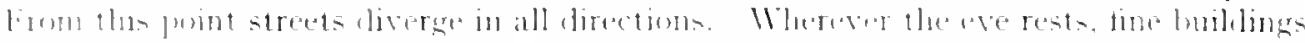

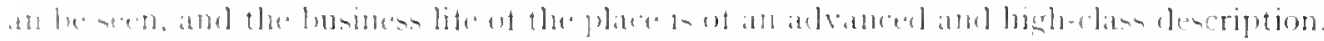

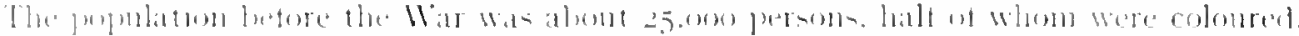

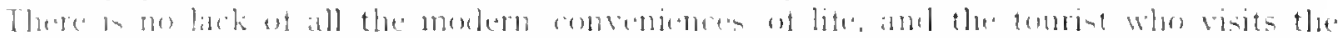

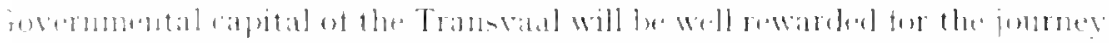

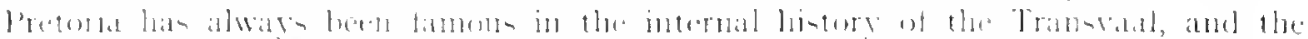

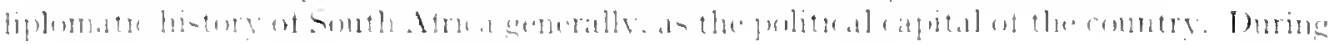


the War of IS8I it formed the hearl quarters of the British troops. and endured a protracted siege. As the seat of Government it was always prominent in Uitlander eyes as the place to which resort must le had when Johannesburg wished any of its numerous grievances remedied. It is interesting to note that Pretoria has now become the actual capital of the Transval, as the repeal of the Republican Constitution has done away with the claim of Potchefstroom to being the capital, as apart from the seat of Government. It will grow in importance from an industrial point of view, as there much gold, iron, and other minerals in the district. Diamond mining is already a focal industry of no mean importance, and will improve in the future. The district is exceedingly fertile, and offers great possibilities to agriculturists.

\section{CHAP'TER IN.}

\section{CONCLRNING THE TRANSVAAL.}

$T^{\prime \prime}$ HE Transval Colony lies between the $22 n d$ and 28 th parallel of South Latitude, and the $25^{\text {th }}$ and $32 \mathrm{ml}$ degrees of East Longitude. The area of the country is I 13,6 f2 square miles. The population given by the last census, i.e., hefore hostilities, was $167, \mathrm{I} 50$ men, I 22,350 women-a total of 289,500 whites, and 580,126 natives.

Under the republican regime the country was divided into the following districts:-

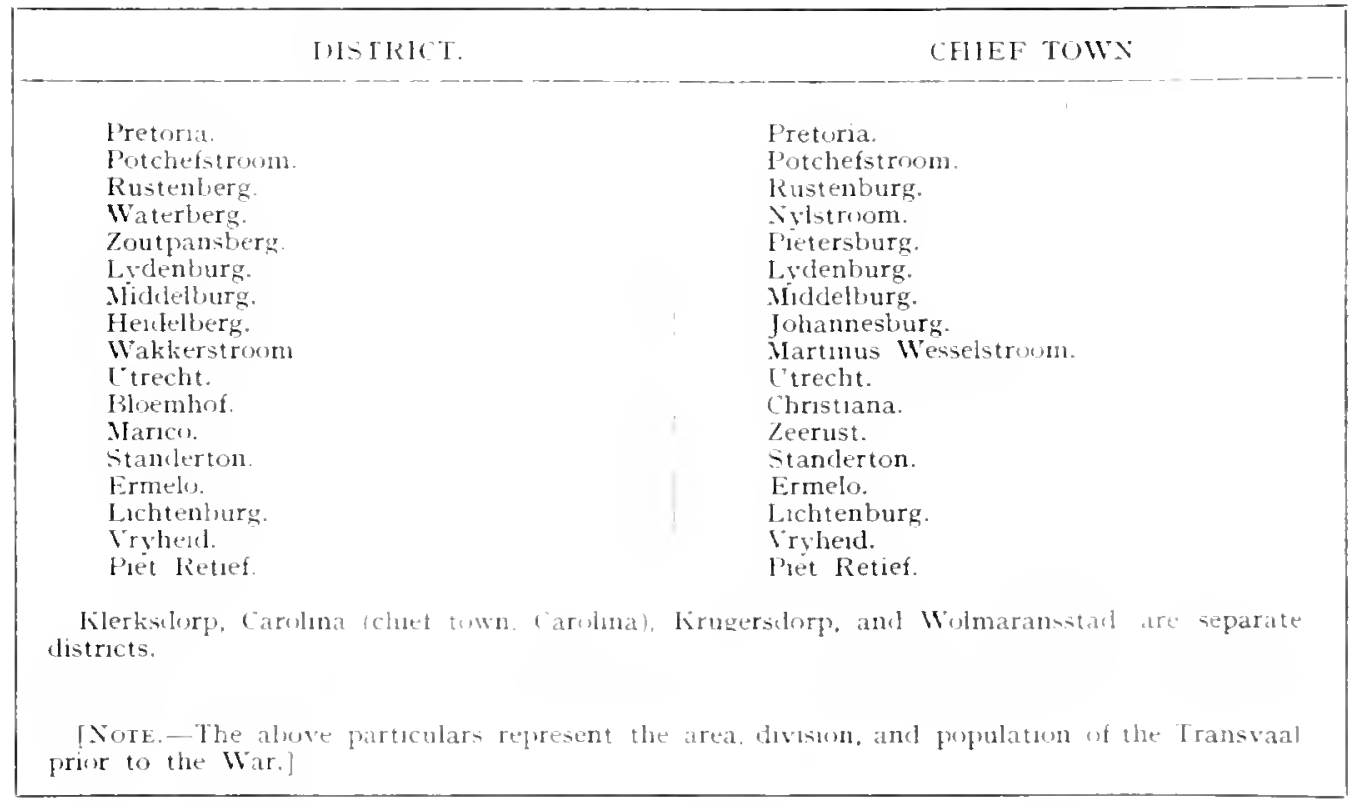

The southern portion of the Colony is traversed trom west to east hy a high plateau, which forms the watershed hetween the rivers running south and those running north, of which the chief are the Vaal and the Limpopo. Besides this plateau. called the Hooge Veld, there are three mountain ranges which cross the comtry from west to east, of which 
the most northerly is called the Zoutpansherg, in the district of the same name. Detached ranges, which are continuations of the Drakensberg. extend from the Natal boundary across the Olifant's River as far as the Iimpopo, the northern limit of the Transwal. These rise in places to some 7,000 feet.

Owing to the elevation of the country, which is over f,ooo feet above the sea, the climate is healthy, the winter being especially bracing. This scason extends from $A$ pril to August, and is generally dry. The monthly mean temperature during the summer ranges irom $65^{\circ}$ to $73^{\circ}$, and during the winter from $51^{\circ}$ to $65^{\circ}$.

The country is well watered, as in the Orange River Colony it is supplitel with numerwus pans and lakelets, the largest of which is lake Chrissic. 36 miles in circumference. Horses, cattle and sheep thrive well. and in the middle and northern parts of the Colons. vegetation is hxuriant, and many extensive forests occur.

The Transwaal, generally, has before it a future such as has been open to but few counsies. From all points of view, agricultural, pastoral, mineral, industrial -it has boundless possibilities. The practical faith in its luture is shown by the fact that capitalists have purchased huge tracts in various parts. in orler to commence and carry out mining and agricultural operations. The country can support a vast population with ease, and there is no reason why, within comparatively few rears, it shoukd not rival and outdistance such prosperous American States as Ohio and lllinois. All that new-comers, who intend to settle, require, is a tair amount of capital with which to start. Witl a settlement by a new population distrihuted throughout the country, the leaven of progress and civilization will spreat, and the conseduences of the recent War will speedily be forgotten. The country has vast recuperative powers, and in a short space of time the unfortunate bistory of the past twenty years will be forgotten for ever. 


\section{PART FIVE.}

THE NORTH COAST BRANCH LINE TO

ZULULAND. 


\title{
PART FIVE.
}

\author{
CHAP'TLR I.
}

A NOTE. The North Coast Branch line is distinctly an "industrial" one, and for the main part serves the immense sugar and tea bearing areas. It does not hug the seashore in the manner of the South Coast line, but from the time it wheels away from its junction, Durban, it keeps several miles inland.

The scenery, though decidedly interesting, is not strikingly picturesque, but nevertheless the Branch is not without its compensating attractions.

The number of pleasure resorts is somewhat linited, the principal being Umgeni, and the Mount Edgecombe, Tongaat, Unvoti and Umhlali beaches; whilst Eshowe in Zululand must not be forgotten.

The Durban-Verulam section of the line described in the next chapter (Ex. "The Colony of Natal") is supplied with a frequent service of trains, and a thoroughly pleasant afternoon may be spent in visiting either the sugar nill at Mount Edgecombe, or travelling further on and touring over the oldestablished town of Verulam, returning to Durban the same evening. The trip to Umgeni is atso a most enjoyable and popular excursion.

The through service of trains to and from the terminus of the Branch is conveniently arranged to suit alt passenger requirements.

\section{C'HAPTER II.}

\section{FROM GREYVILIE TO VERLIAM.}

REYVILLE, the first Station on the Branch, is a popular suburb. Here the principal railway locomotive sheds are situated. Looking on the right of the line, a good view is derived of the Durban Flat, or Eastern V'lei, stretching to a long wall of bush-clads and-hills. This flat is artistically decorated with

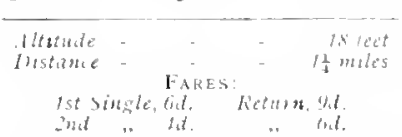

a suburban stopjing place. Several rifle butts are situated here. fine specimens of euphorlia-cactus, hlack nimosa, flat crown. and palm trees. in addition to many beautiful varieties of wild flowers and ferns. and patches of the odorous arum-lily. Churchill Road, a little further on, is STAMFORD HILL, the following Station, is a continuation of the lovely Berea Ridge.

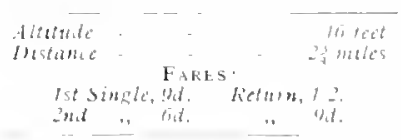
It is a very favourite residential neiglhourhood. There are a match factory, brick works, and a high-class poultry farm in the vicinity. About a mile in adrance a high wooded hill will be observed, from the summit of which candelahra-cactus trees stand out with peculiar effect against the sky. This is Lagexi IIILL. Around its foot is the village of that name. It is a busy corner, and possesses some good buldings. The principal iron-foundry in the Colony is situated here, as well as extensive wool-washing mills, a large collee factory. a tannery, a distillery, and a cigar and tobacco manufactory. Coast fruits are grown in large quantities, and maize is by no means an unlucrative cultivation. 


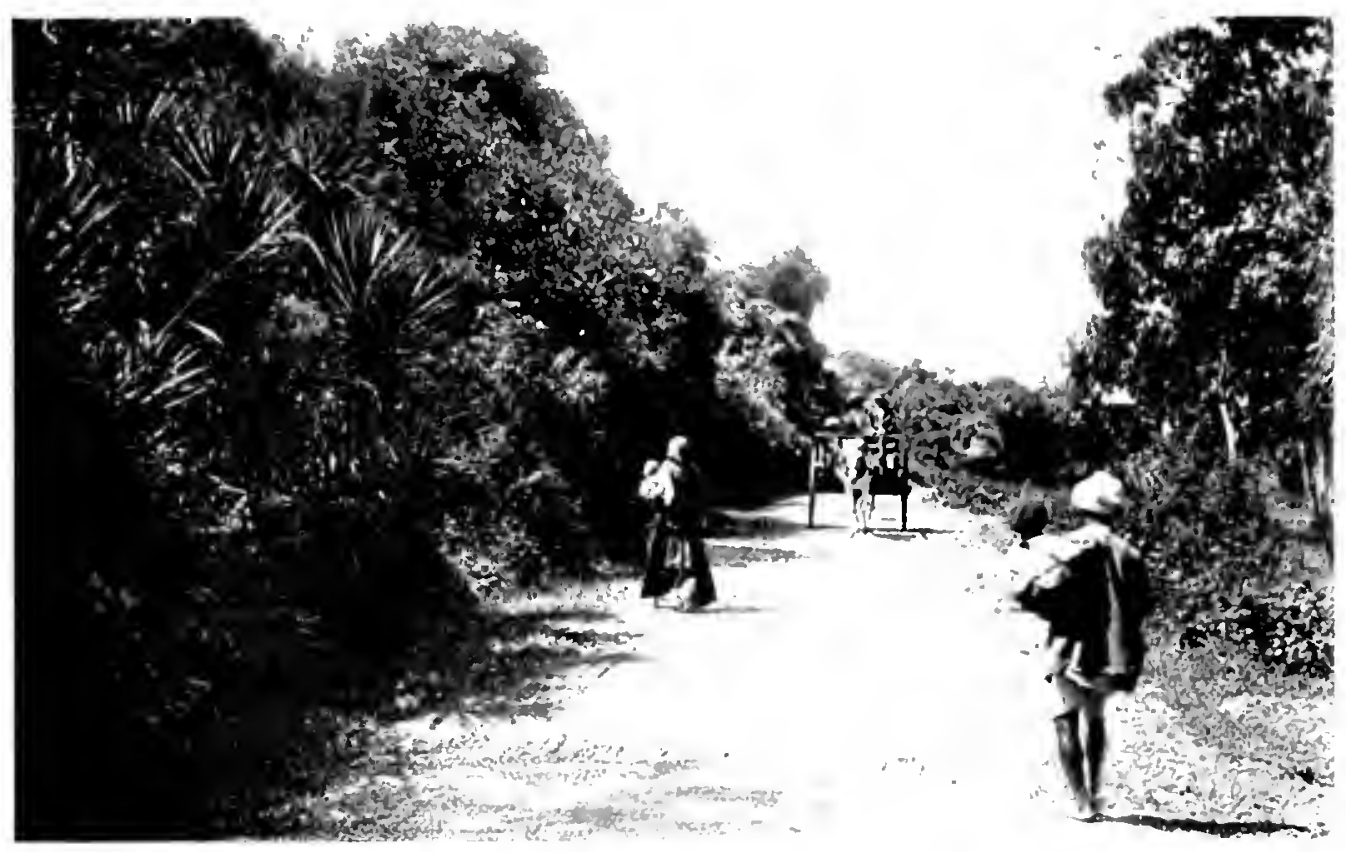

a) $1111 \quad 111.1>11011$

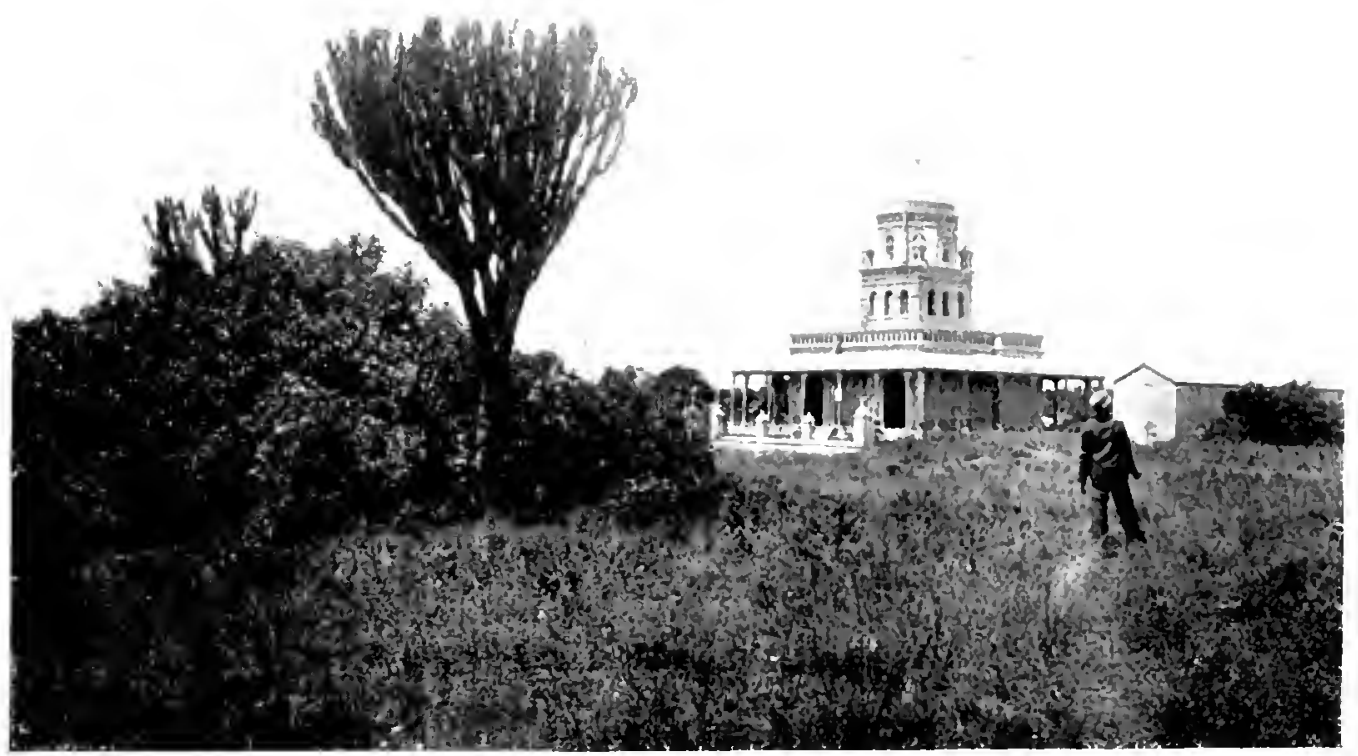

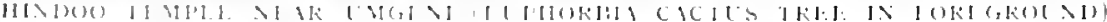


UMGEN1 is a suburb of Durhan, and, althongh having a comparatively small poptr-

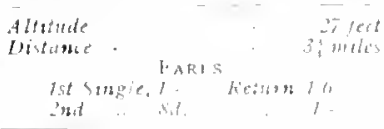
lation, is of repute by reason of its various businesses and picturesqueness. The charmingly-situated hotel near the bridge, is a fashionable rendezvous. Glancing eastwards from the station. the eve catches a glimpse of the blue Indian Ocean at the point where the river flows into it. This is a favourite resort of anglers and pleasure-seekers. The lagoon or still pool. at the mouth, is harred from the sea by bush-studded sanch-hills. Turning to the westward, the tourist will see the famous stone-quarres where the "hard-labour" gangs of convicts are forced to make the period of their incarceration useful to the community by quarrying the stone for streethardening, and harbour purposes.

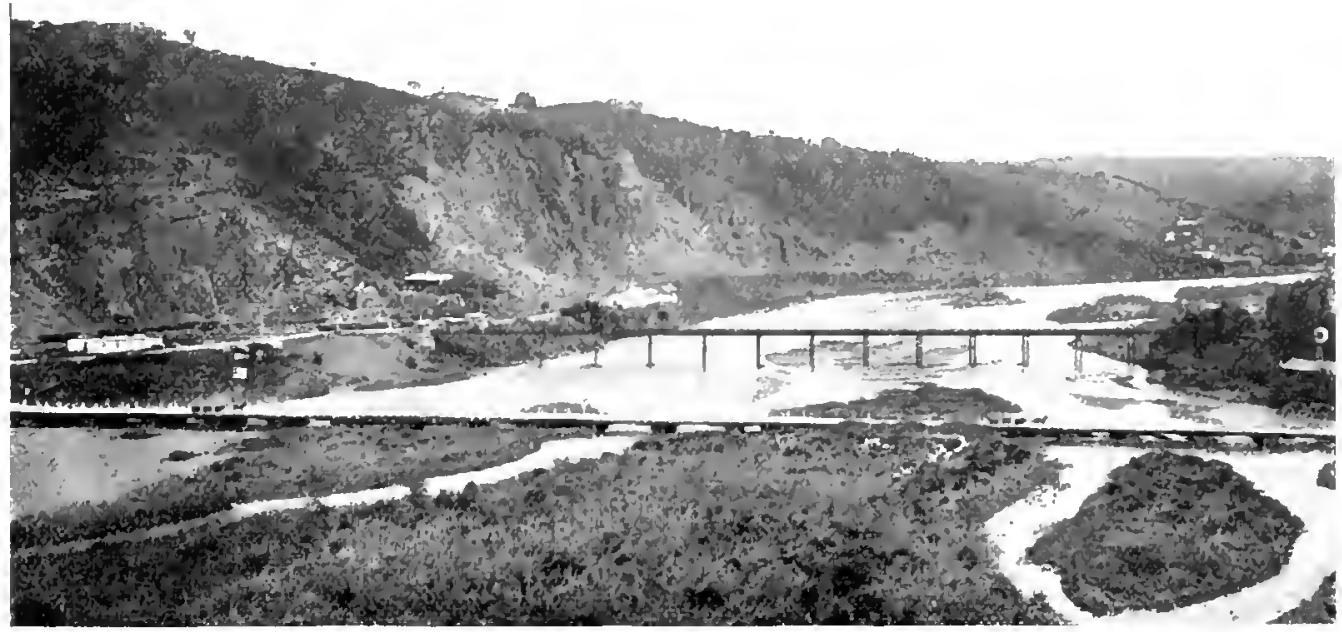

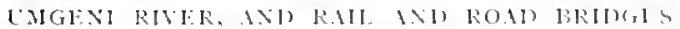

The Lmeni River, which divides the Durban and Victoria Counties. Iroad and studded with reedy ishanks, is a pleasant feature in the scenery. The iron railway bridge, I,oso feet long, by its height and strength. sufficiently denotes that, when the stream is in flood, it is a formidable torrent.

The view up the Lmgeni, as the train crosses the bridge. is a fair sample of the scenery to be met with in the lese interesting parts of thel Colony. On the Zululand side of the bridge, to the left, is the well-known Sea Cow Lake, until quite recently the habitation of hippopotami and crocodiles. Though ont of sight, the Lake is within easy walk of the Umgeni Station. On the other side of the line is an arrowroot manufactory.

The journey onwards through the Victoria County lies through extensive acreages of sugar cane. The contour of the country is very uncven, and prevents the rapid progress of the train. Hills are sighted ever and anon, and several brick-making works are seen, as the train moves towards

GREENWOOD PARK. The country around this attractive suburb was at one time

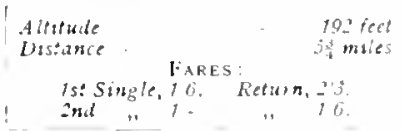

densely wooded, and enough primeval forest remains to impart a distinct characteristic to the place. The RED HlLL, through which deep railway cuttings have been made, and at which a stopping place has been established. 
has even yet a sprinkling of small game. While orchids, honeysuckle, mistletoe, and other familiar phants, together with sarsubarillat, nightshate, and cante, combine to remind the traveller that this is Atrica and not lingland. Passing on we reach

Alex. There is no village at Aroca, only a few houses, a sugar mill, hotel, and a

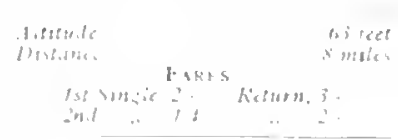

the train arrives at concert hall. Thitse are all located near the station. In the vicinity there are two sugar plantations, and the monster estate of the Satal Central sugat Company com. mences here. leabing diocate atter two miles steaming.

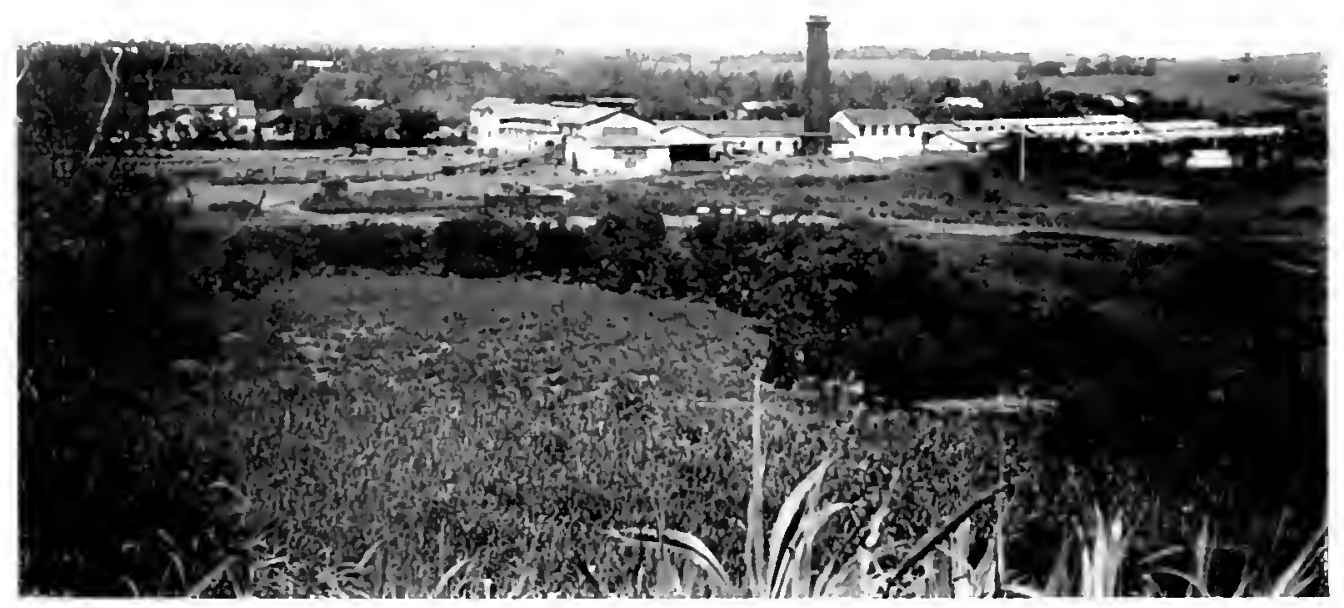

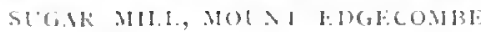

DLFF'S ROAD. To the eastward of the station a long rounded hill, named llount Moriah, will be spied, its slopes seamed with rows of sugar

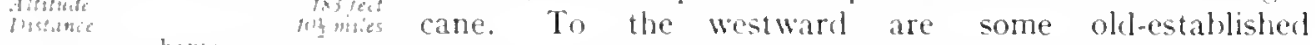

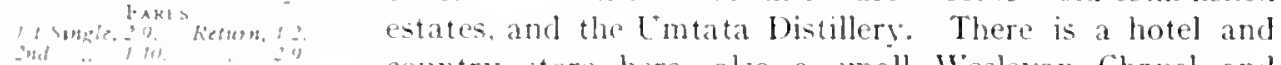
'nd " in country store here, also a small lresleyan Chapel and gravegard, where sleeps many a staunch old colonist.

PlOExlX, the next stoppage, has no individual attraction, and the train wends

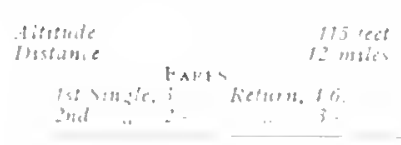

MOL:T" EI)CECONBL:

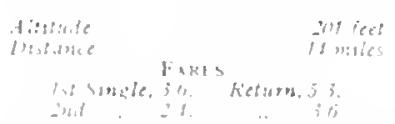

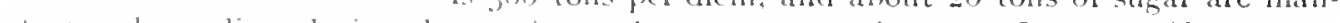
utactured per diem during the cutting or harvest season, between June and March. As one approaches the factory trom the south, long slecls containing hagasse the refuse of its way through a country almost completely covered with the broad sworl-like leaves of the sugar-cane, in all stages of growth, from tiny little green shoots to wellgrown plants eight feet in leeight, until

noted as the station for the factory of the Catal Central Sugar company, is entered. The original cost of this mill. machinery, and estate was II 00,000 , hut since then it has heen largely added to. Its cane-crusling cajacity is 300 tons per diem, and abont 26 tons of sugar are man- 
the cane after the juice las luen extracted) stand in ranges. (juen spaces deroted to drying this article, which is used for fuel. flank the sheds. Next to these is the tall chimney, ninety feet in height, beside which is the mill house. In front of the crushing door, in high piles. the uncrushed canes lie awaiting treatment, while long lines of trucks, with towering loads of saccharine-yielding canes, stand ready for discharge. A travelling table, attended to by rows of coolies, bears a constant supply of the cane to the rollers, which are just inside the entrance. These rollers are huge, grooved. iron affairs. set in such a position as to extract the juice, and pass the bagasse out at the other side of the mill. The canes are crushed twice, to ensure complete extraction. All this time a constant stream of juice is falling in a veritable saccharine cascade into the broad troughs prepared for its reception. The grey, watery-looking fluicl then passes through the various processes of boiling, condensing, purifying, crystallizing. and finishing, until it emerges in beautiful snow-white, golden-yellow or brown crystals. It is not necessary in this place to deal witl the manufacture in detail, but the visitor to the mill may be assured of a hearty welcome. The extent of this Company's estate is over 20.000 acres, and the careful management, carried out on practical and economical lines, cannot tail to win approval from the most casual. The latest scheme is that for utilising the refuse from the mill, which formerly found its way to the streams and caused their pollution. It is now collected in huge tanks, pumped three-quarters of a mile and then distributed over the land. It makes an excellent manure. The mill turned out in Iqor over $t .7$ co tons of sugar from its own and adjoining planters' canes. The estate emplors $25^{\circ}$ Kafirs, I,500 Indians (men. women and children). and about 30 families of whites as managers, sub-managers. engineers, and artisans.

A convenient hotel adjoins the Mount Edgecombe Station. The sea is four miles away and above the beach several summer resi. dences have been erected. The scenery along the rocky coast, and in the forest near by, where charcoal burning is carried on, is very beautiful, and only the pressure on space precludes the further sounding of its praises. It should be briefly recorded that good bathing. fishing and botanizing may be obtained. Shortly after quitting Mount Edgecombe for Ottawa. some fine specimens of date palms are to be seen.

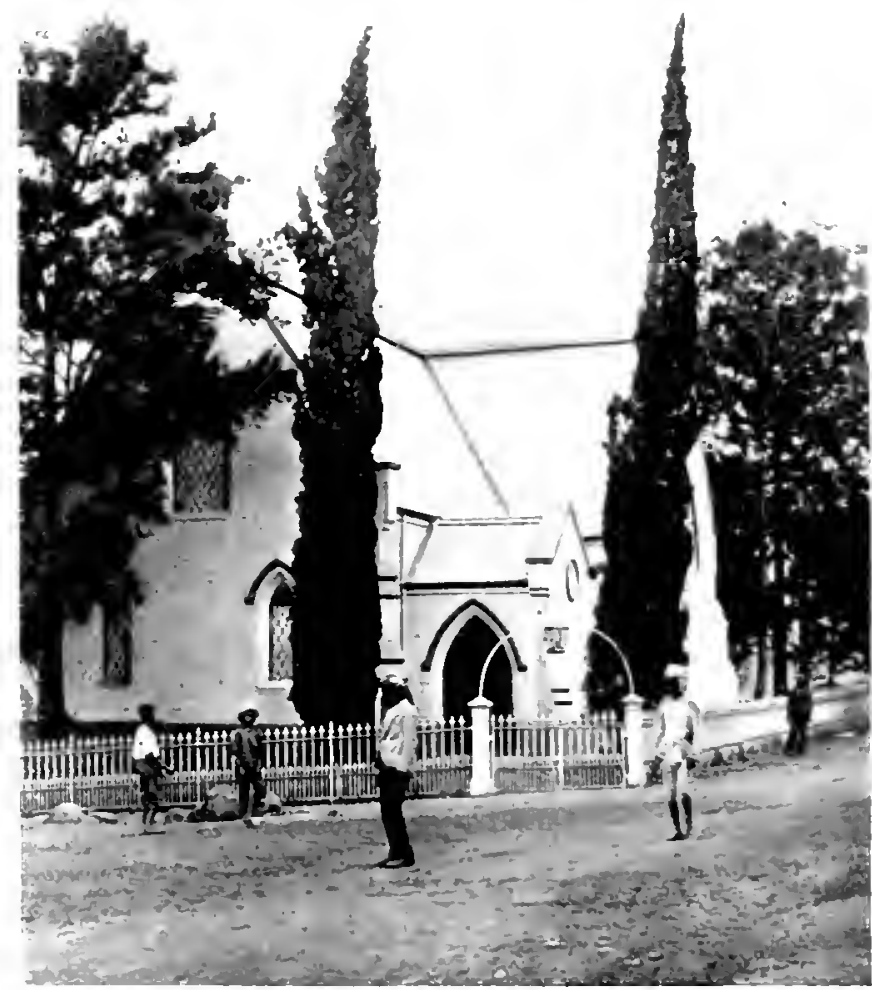

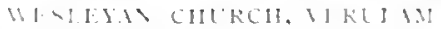




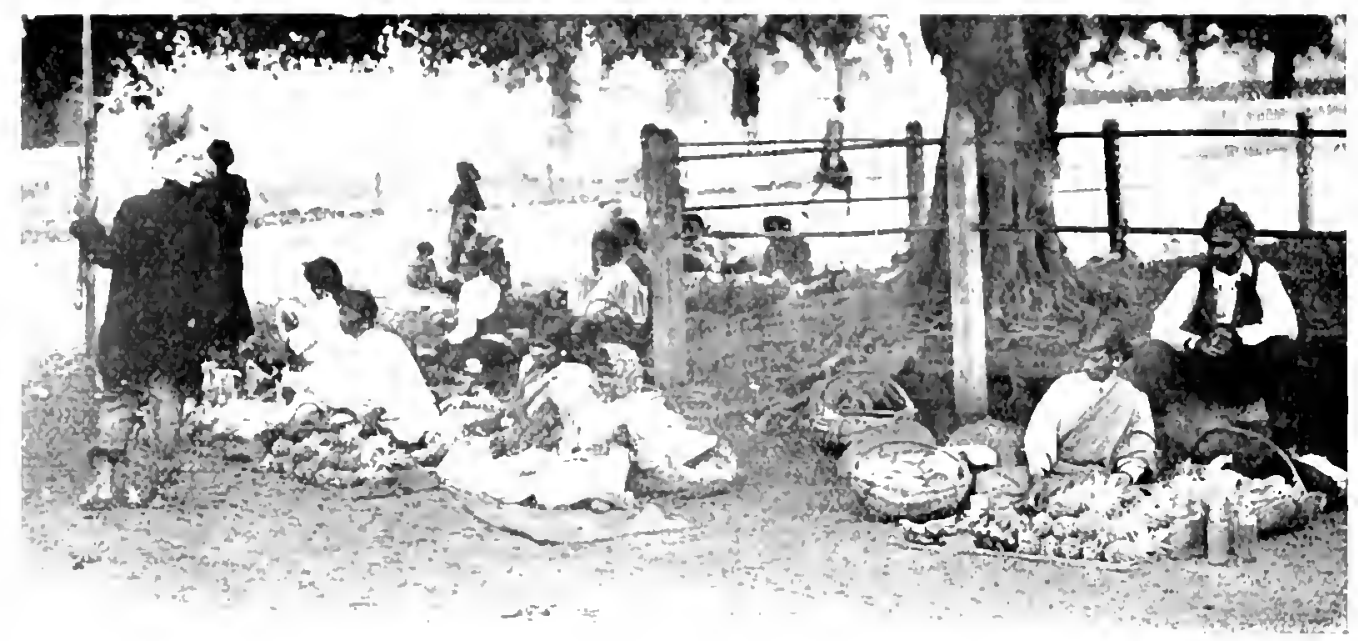

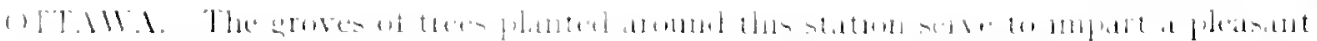

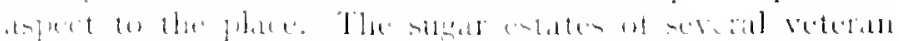

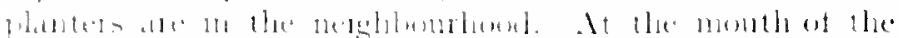

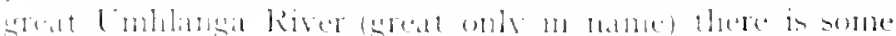

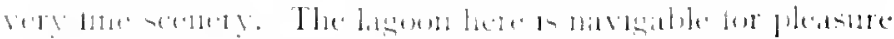

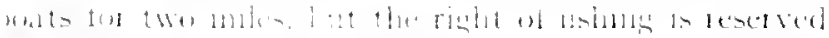

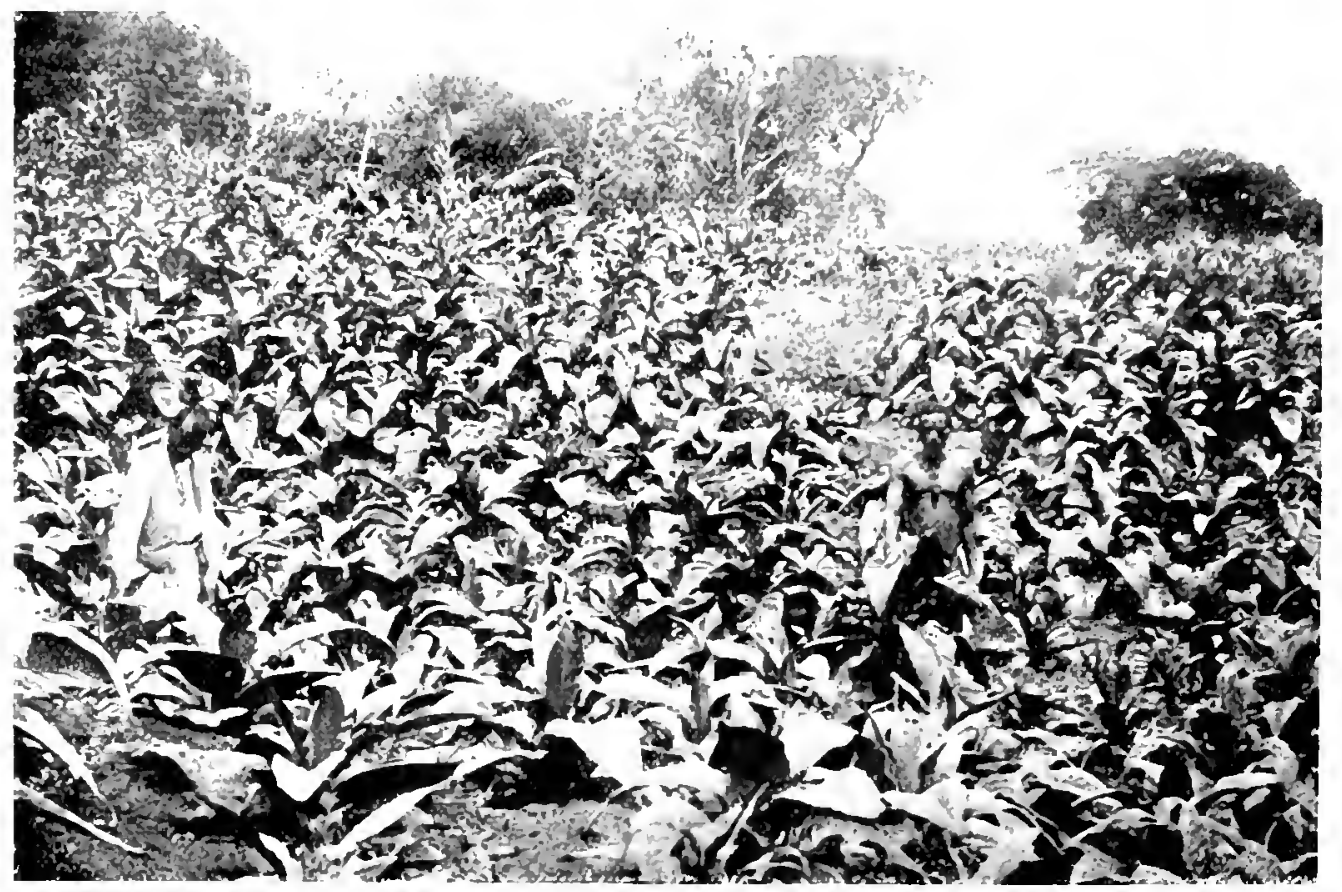


Advancing from Ottawa, the train speeds past an open country, under a forty-feet viaduct, and then passes through a tunnel, I 3 teet long, at Kahtsliop. On emerging from the latter, and turning a bend in the line, a glimpse of the Umhloti River valley and the town of Verulam is obtained, and a moment after, the train steams into the station.

VERULAM. The first sight which greets the eye is the comfortaljle two-storeyed

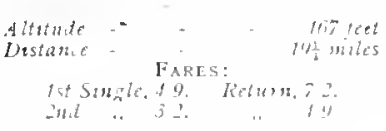
Railway Hotel. Next come the Wesleyan Chapel and the Market Square, on the northern side of which is the Court House. There are five long parallel, and three cross streets in Verulan. Several stores and many dwelling-houses line the main thoroughtare. A three-storeyed corn and general mill, moved by water power, is situated on the banks of the Lmbloti River, at the far end of the town, and two wagon. building establishments and two tohacco and cigar factories are also in working. A good view of the town can be obtained from the Zululand Road, rising towards Fuller's Flats, on the further side of the river, and from Kahtskop to the southward. From this latter vantage-point the scene is interesting. In the near foreground the Indian Hospital, with its red rool, forms a pleasant contrast to the somewhat stunted loliage of the mimosa which skirts the highway. Further on, the Cenetery, with its cypress trees and welldesigned tombs, occupies a rounded hill. Beyond it the fine Government Scliool is seen. Here a large number of children are daily instructed under competent teachers. Below this again is the Church. Beyond this the main street, with its stores and residences. trends towards the river. In addition to the Hospital and School. in the way of institutions, there are a public library (containing 2,000 volumes, amongst which there is a goodly sprinkling of standard works, and a good supply of periodicals and journals), a Recreation Room, Volunteer Hall, Rille Association, several Benefit and Missionary Societies, Church Guilds and Temperance Lodges, and Tesleyn. Episcopalian. and Roman Catholic places of worship. The Divisional Headquarters of the Natal Police are also here, their centre being of course at the Magistracy. Verulam was founded in 1850 . and was named by the original settlers after St. Abans. Its population is about 500 whites, and an equal number of natives and indians. The assessed value of its properties is about $\$ 50,000$. The climate is very healthy, and the death rate very low. Within a tew miles of the town. to the eastward. the mouth of the Lmhloti River serves the district as a place of pleasure resort.

The trade depends principally upon the sugar industry, and the original forest lands are now supplanted hy sugar cane. extending for miles around. The "Iree" Indian is prominent in the district. and chiefly pursues the avocation of a vegetable and maze cultivator. The tropical fruits grow abundantly. while mealies and heans are large productions. Tobacco-growing has also made good stricles. The tea industry has not yet risited the district, although it is well suited to this enterprise. To the westward. at a distance of eight or nine miles out, the long-estallished Listuer Missiox Stutios is located, where the student of Alrican character will find ample scope for investigation. Close to the Mission House, an establishment devoted to the training of native girls 15 placed. A laundry business is carried on by the industry of the girls, and a great deal of Durban's washing is done here.

Before leaving Verulam and its environments. It may be alike mteresting and relieving to peep at the wild and romantic country round about the IxAXDA RAxGE of Motrisas. which adjoin the Mission Station. These bold and bluff-like buttresses of Nature jut out into a veritable wonderland of beanty, where loaming rivers. black torests, canons. and long lonely plains, are woven together into a mass which only a trained fredestrian will 


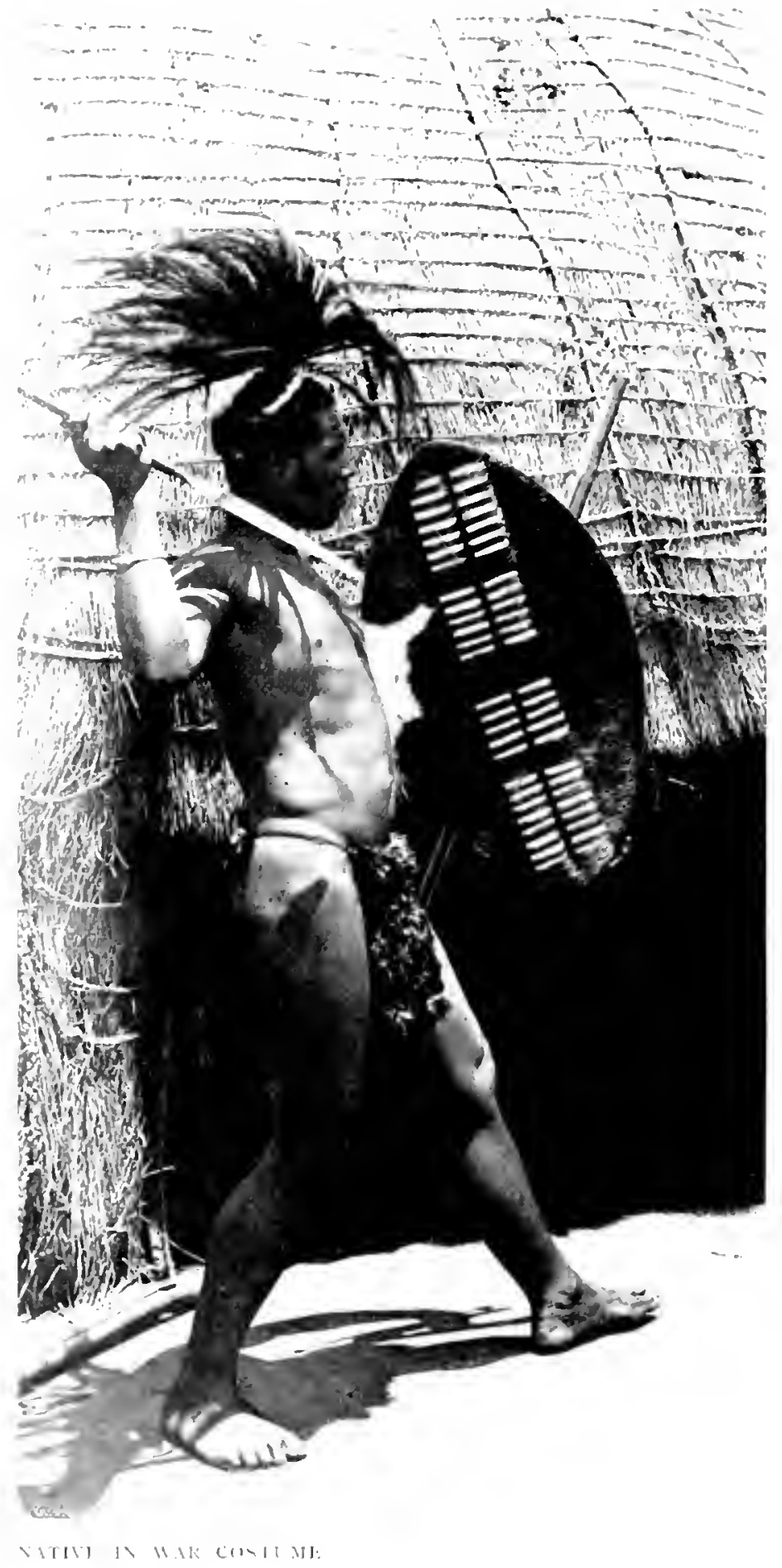




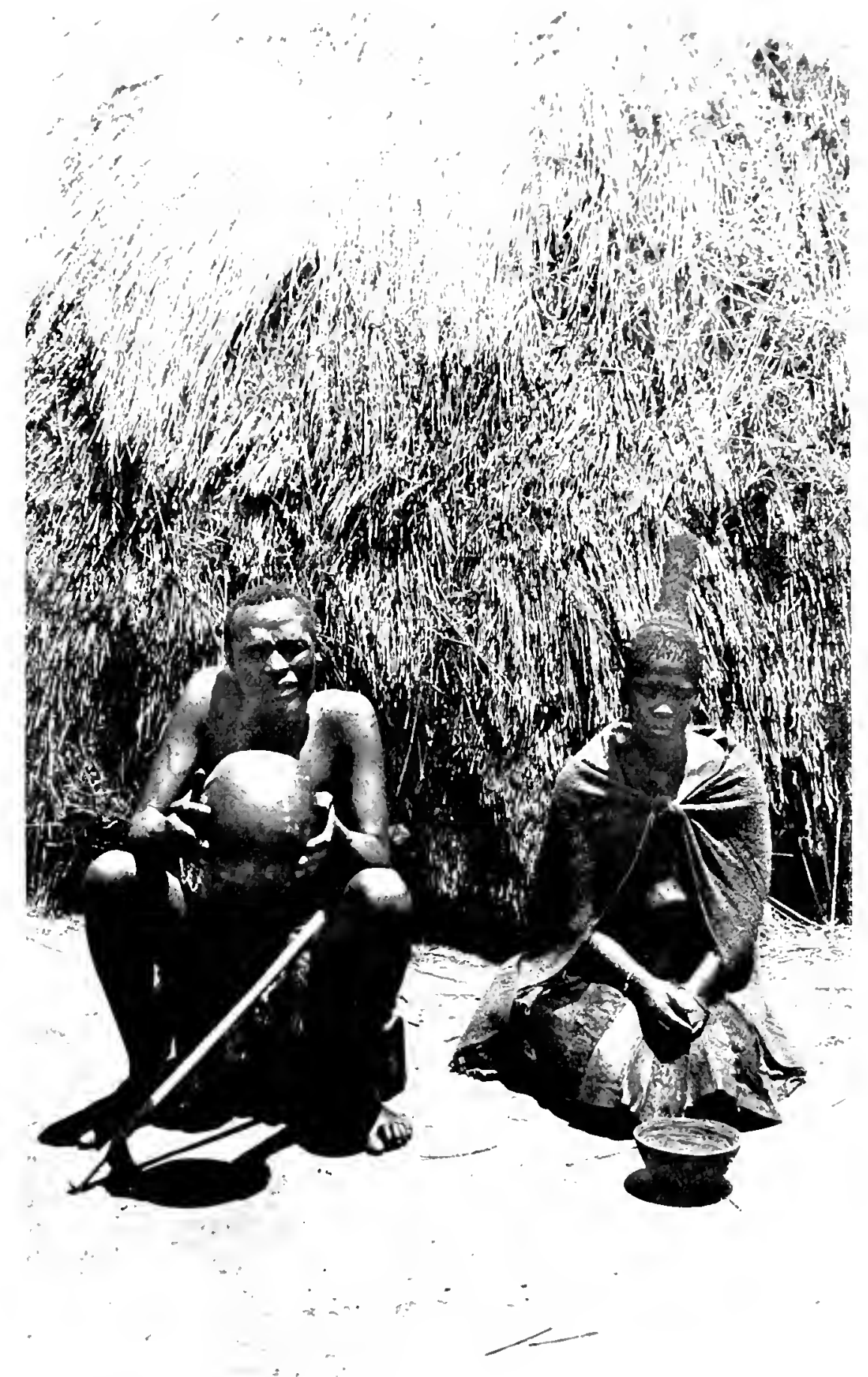

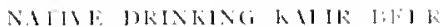




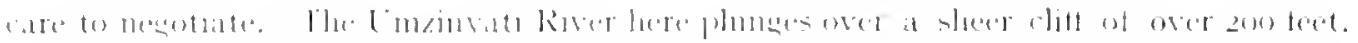

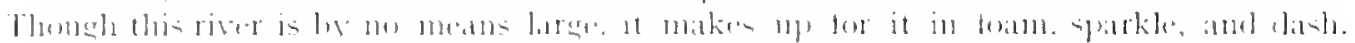

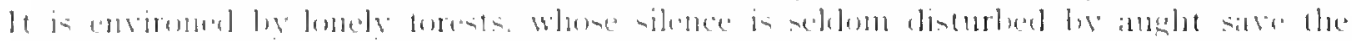

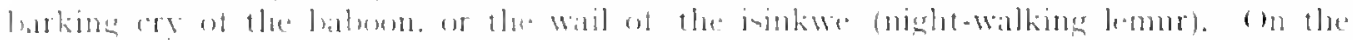

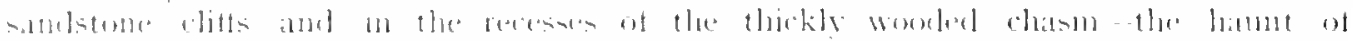

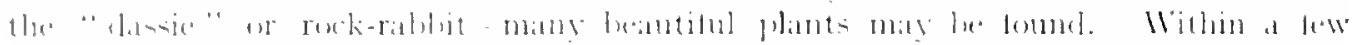

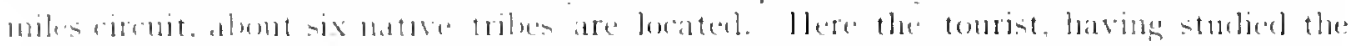

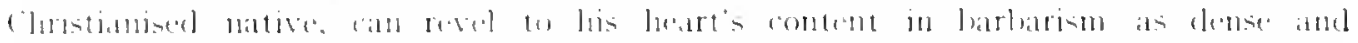

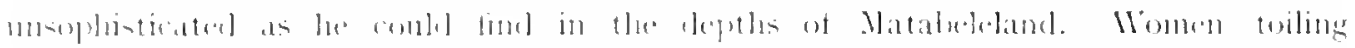

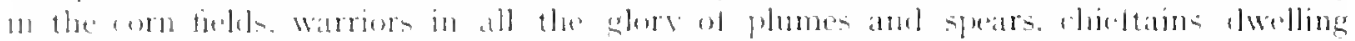

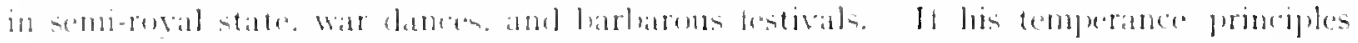

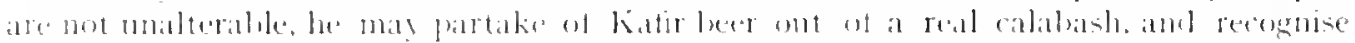

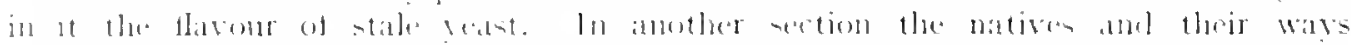

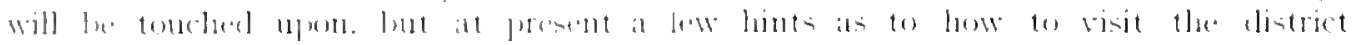

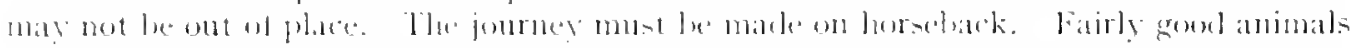

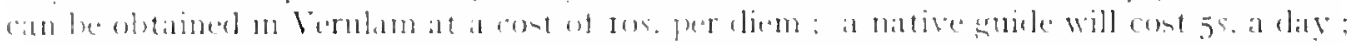

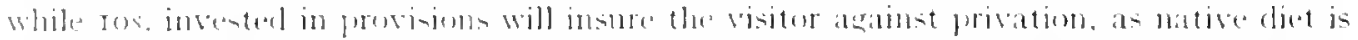

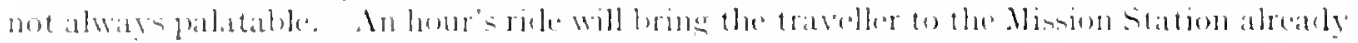

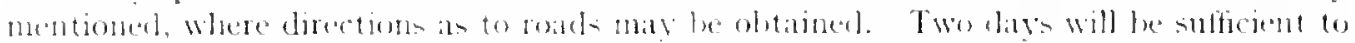

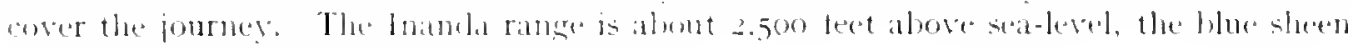
() Which can be clearly seen trom its summet.

\section{(11.11\%1K 111.}

\section{FROM IJRLL.AN TO STANGER.}

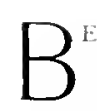

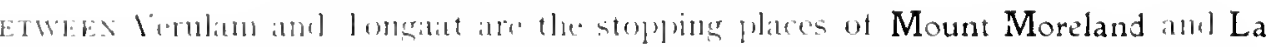

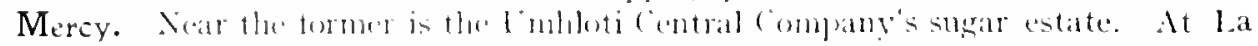

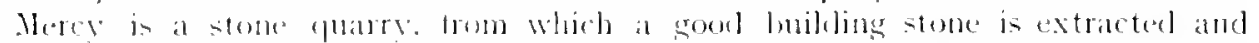
drensed. These operations an be witmesed from the train. Beyond the batter place

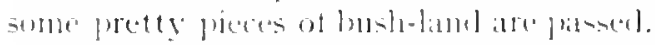

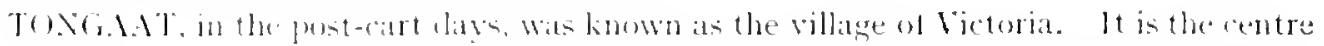

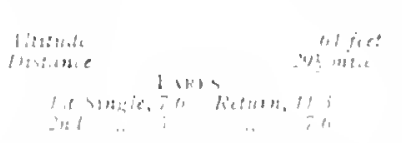
of at thring and prosperous district, land having risen in

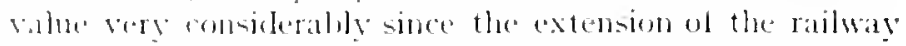

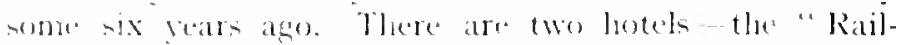
way." neat the station, and the "Chehmsterd." situated on

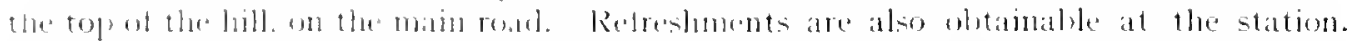

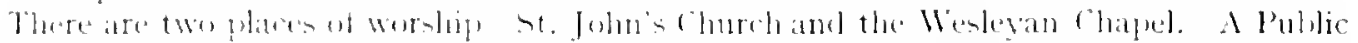

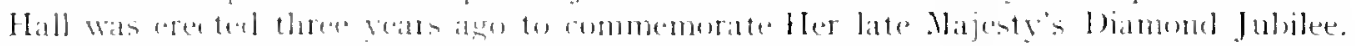

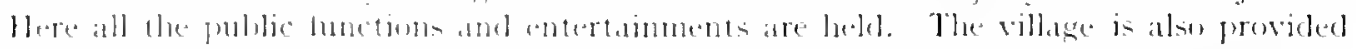

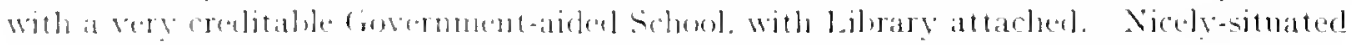

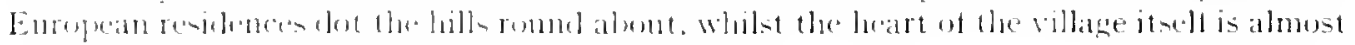

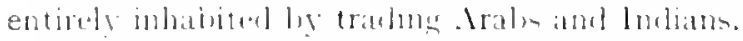

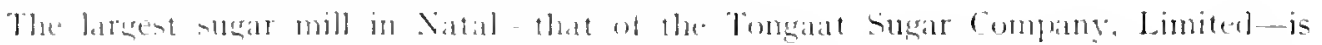

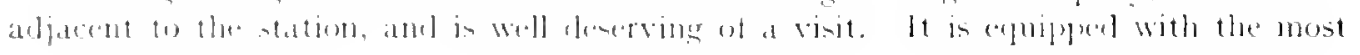




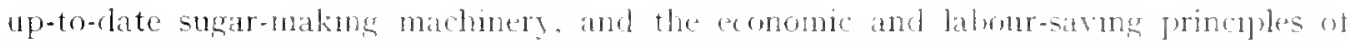

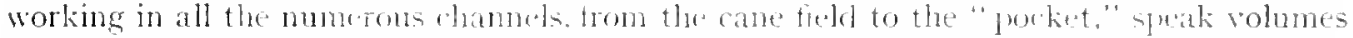
for the progressive and enterprieng direturate and manugement. The total area of the estate is about 6.000 acres. 5.000 of which are under cultivation. A consilerable quantigy

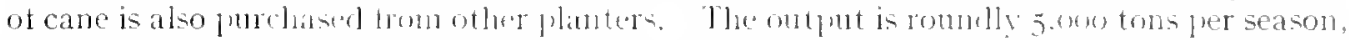
and the full caparity af the mill is $7,0(x)$ tons. The cane fiells are servel by 24 miles of a

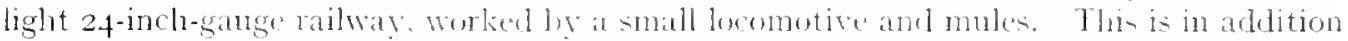
to cartage. The estate emploss in its varions branches some r.zoo Indians besider a good

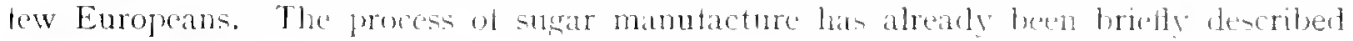

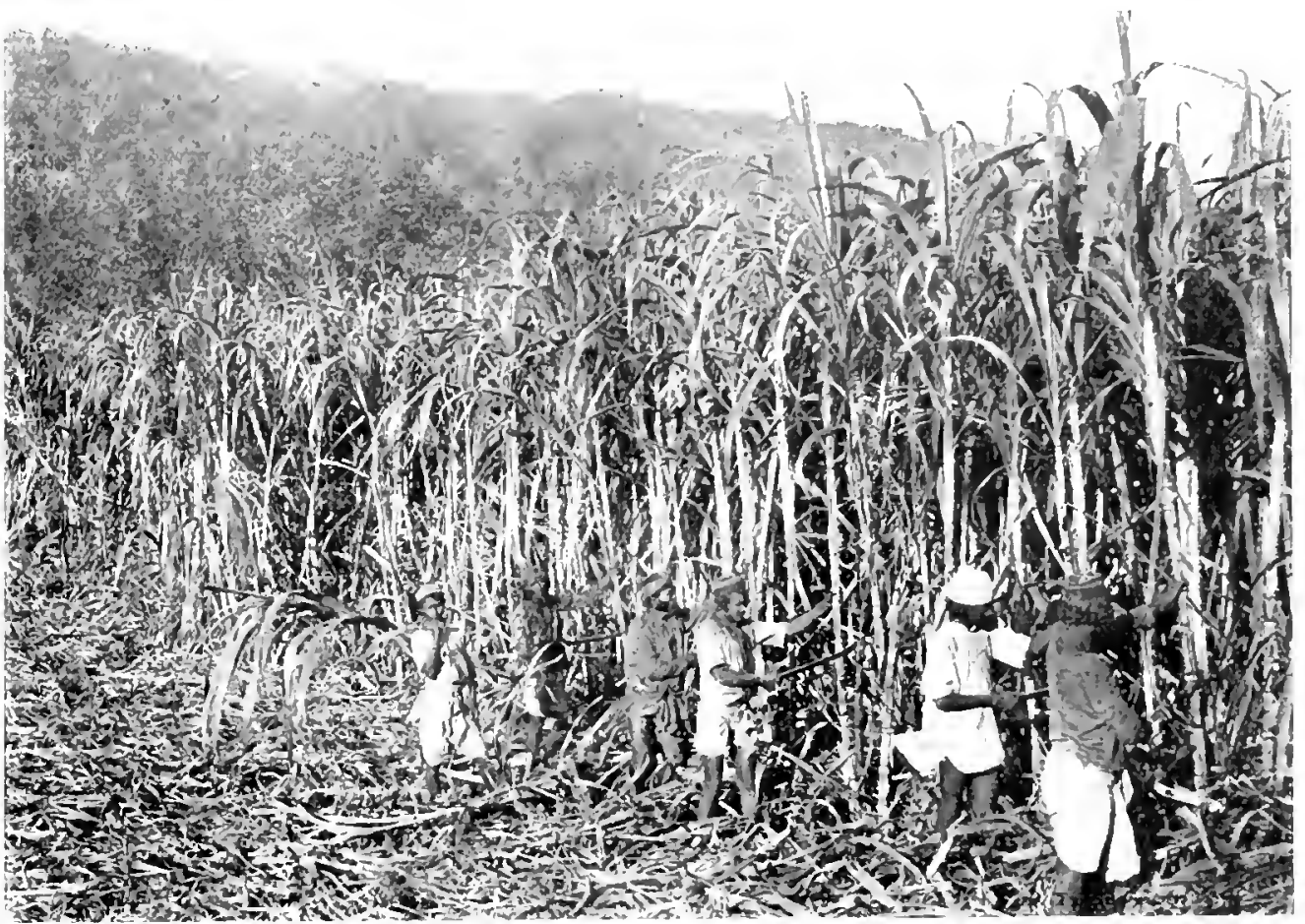

CITIVI, SI*GIR C IVI

under Mount Elgecombe, and. whth a few technical exceptions. this system aloo ohtains at Tongat.

Some twentr miles north of Tongat, near the "Esidumbeni" Mission Station, is a curious cave. known as the "Inlmueni." at one end of which it huge pillar of rock stamla like a petrified sentry. The roof of the cavern is formed by a single stone weighing some two to three thousand tons, and the matin chamber would sheler several humedred persons.

Ahout a mile beromel the raliday atation. the Tongat River is crossed by a strong iron structure. which sirves the dual necks of train and wason hridge. Further on the labdscape loses much of its sumar-cane manting. and heomes more pastoral. althom there are still occasional estates, as Eraser's Siding indicates. Umhlali Village stopping place is then reacled. This is ned ly visitors to the Cmhlali beach (32 miles), where 


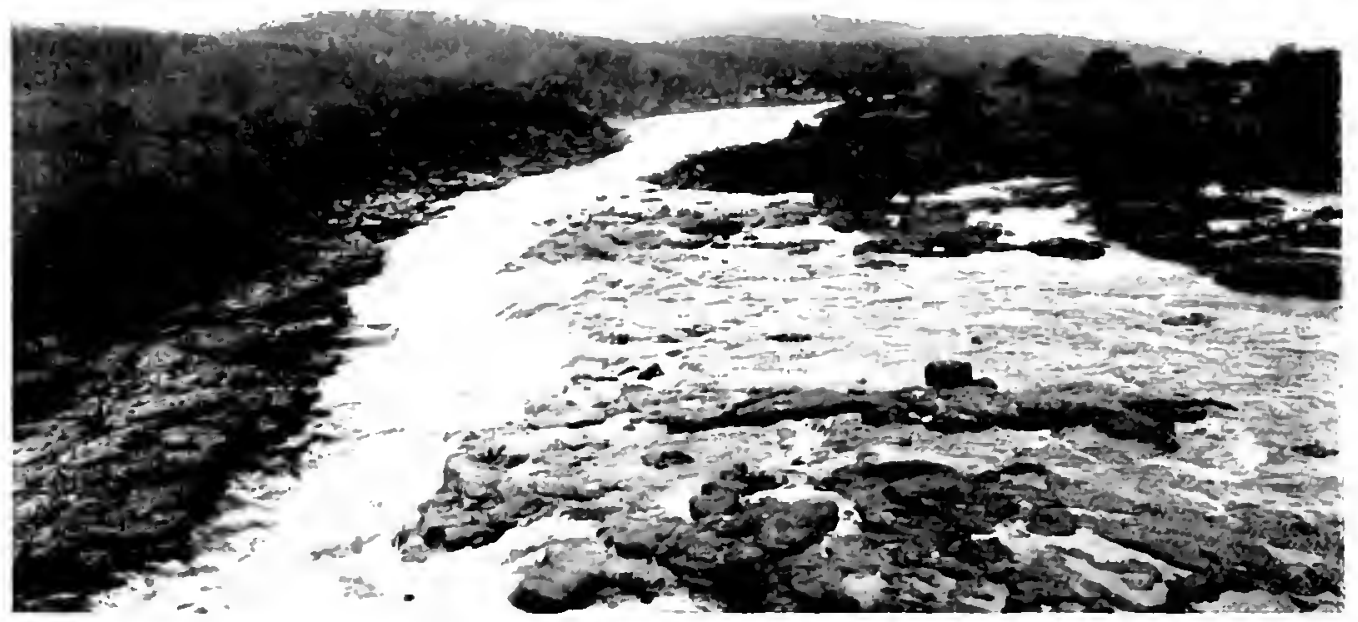

J:III:R I.YHI II I

the fisling and hathing are said to he the hest and safest on the northern roast. A gond number of people are attracted hither. some of whom have cottages on the Beach.

CHAKA'S KRALl is a pleasant litte station. The district is favourable to all the

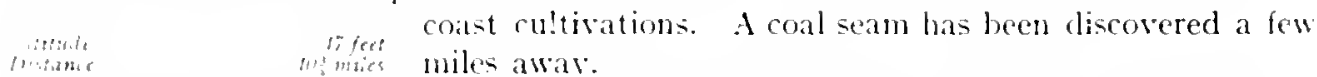

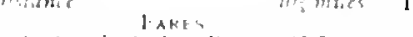

thinge Healing now for Stanger. Hulett's and Umvoti inter. mediate stopping stations are passed. The Grontrille Mision Station is situated in the locality served by the latter. The country round for miles is of gentier cast and more extensively wooled, white the land is plentifully besprinkled with kafir kraals.

STA.NGlik is historic. It was the capital of the blood-thirsty Zulu king Chatia. From here the "confuerer. the scourge, and the pride ot all South African natives," issued his

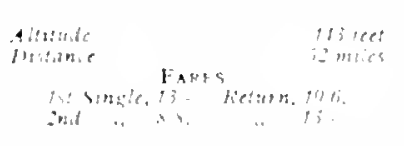
manclates of life and death. Here. too, it was that the usual fate of the trrant overtook him and he fell slain be the spears of his own kinsmen. His burial place is within a few varts of the scene of his assassimationabout a quarter of a mile from the present village. Truly, the Stanger of to-day is vers different from the "Duguza." at it was. and still is. called ly the natives. Cow a peaceful little township. with a masket sprare flanked by hotels and stores and other luildings. replaces the military huts. with their thromes of plumed warriors. Round the grave of Chaka a few erven have leen reserved hy the Government.

The flace was named after Ir. Stanger. the first Surveyor-fencral of Xatal. It has a strongly-built laager, Court Houses, and Hasisterial Offices, two comfortable hotels ("Victorja" and "Stange "). two churehes (Church of England and Weslegan Wethodist),

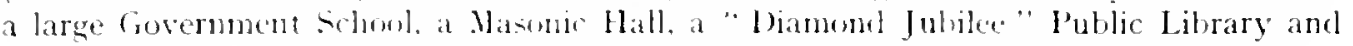
keading Room, ant a fine casteltated Police barracks. The fopmlation is about 2.50 . 11 
is twe miles from the sea, and at the mouth of the Umvoti seaside cottages can be hured, good fisling and fair shooting being obtainalle in the season.

Stanger itself is growing in importance, and. as is well known, it is the centre of the largest tea plantations in the country, Although the railway arrived only in August, I\$gs, its benefits are evident, and a good fillip has heen given to the various cultivationstea, sugar. tobacco, fruit corn and maize.

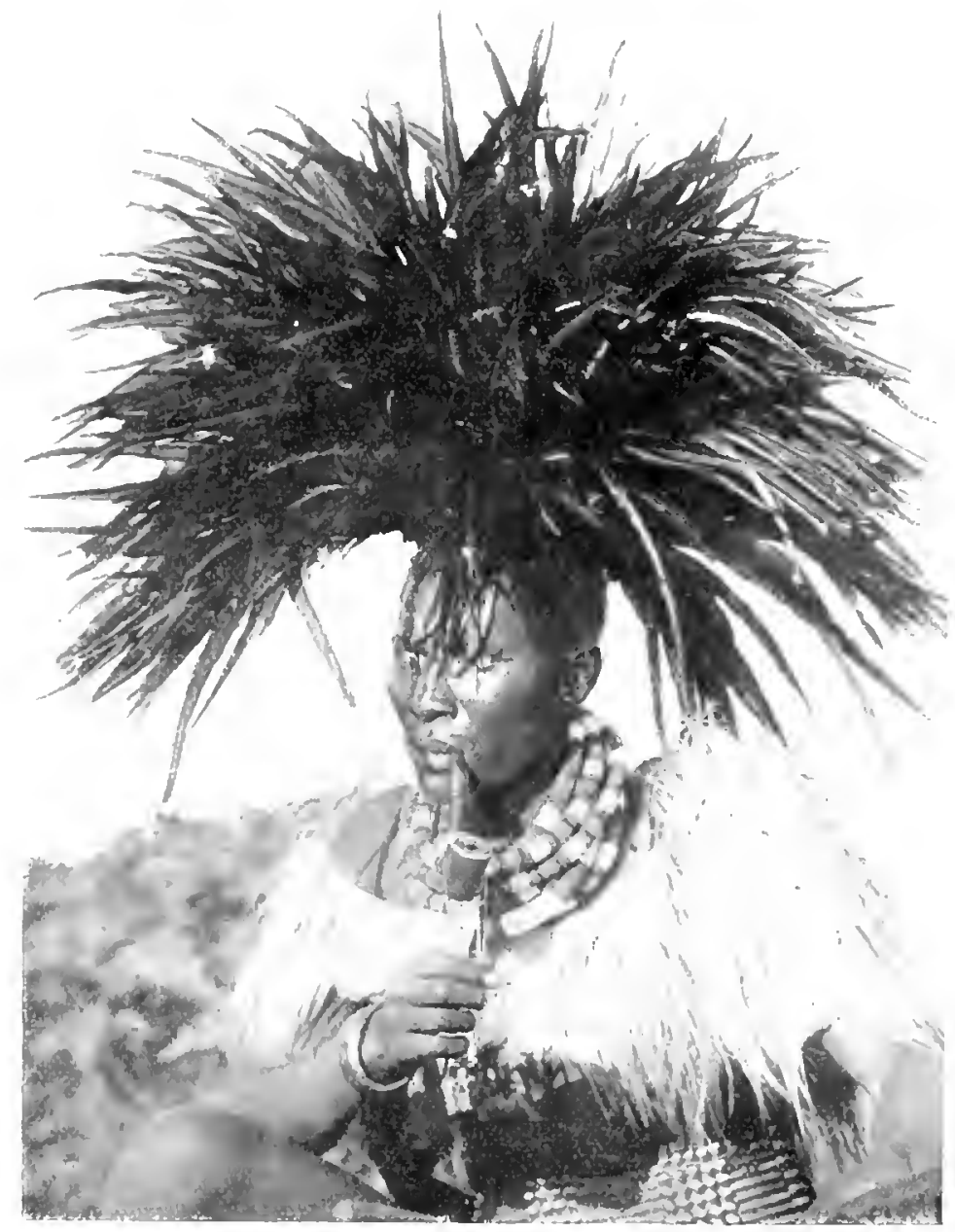

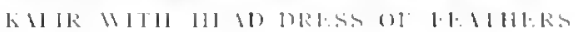

Thopouts, Wantun:hit

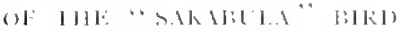




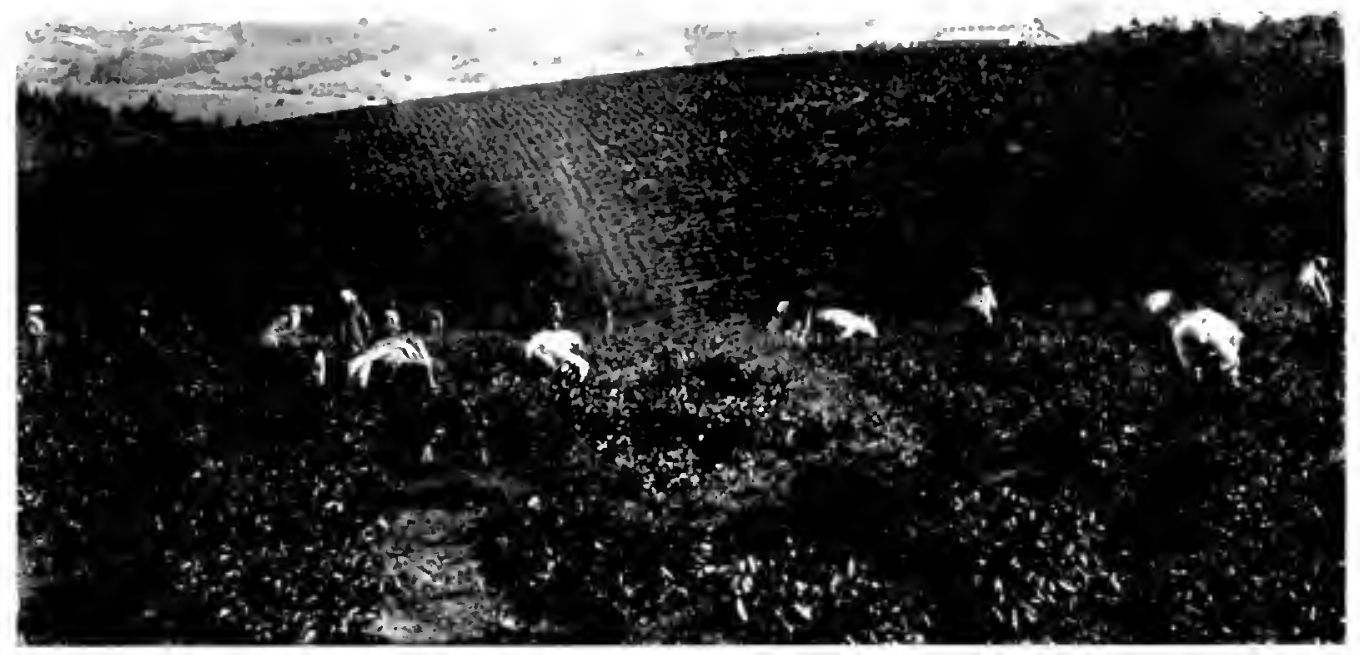

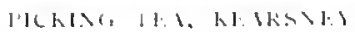

(H.MTKR

\section{THE TEA DISTRICT.}

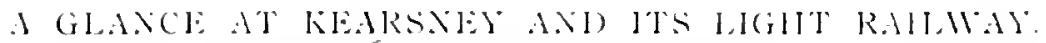

$\mathrm{T}$

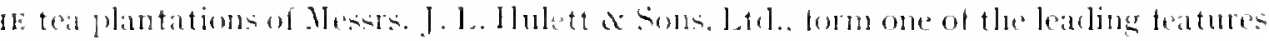
in the industrice of the coloms. They are simated at kearsmes. to the northwet of Stangers and a light railway rums from Stanger station to the factors, a distance of eisht miles.

The construction ef this admiralde little line was undertaken on the intiative of Messers.

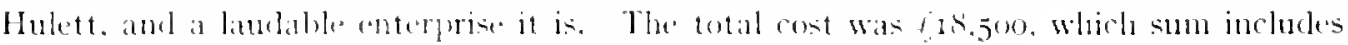

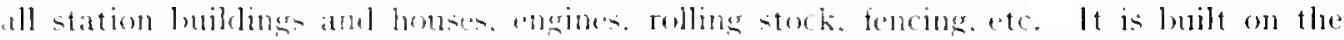

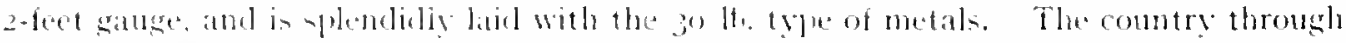
which it parses is molulated and preturesegue. The ruling gradtent is one in 30 , and the

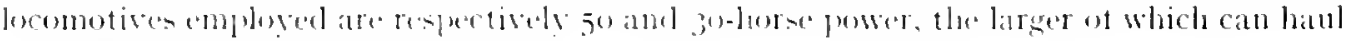
with ease a load of zo paringer toms.

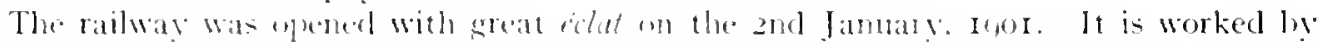

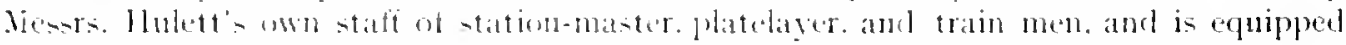

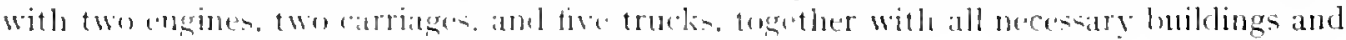

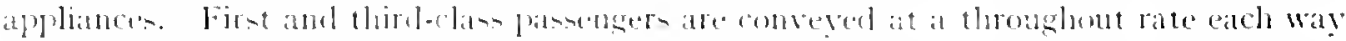
of Is. fits-class. and bit. thitel-itass.

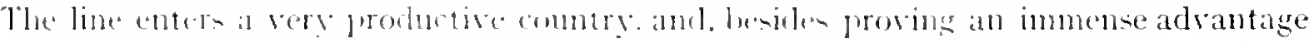

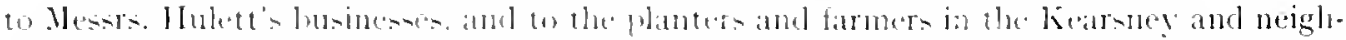

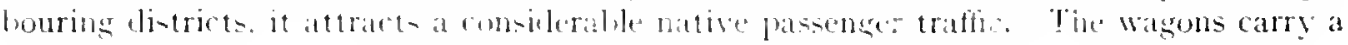


net weight of five tons. being jrincipally used for convering the heart teat tratfic from the: mill, and returning with coal and stores. Pasengers and goods are of course transferred at the Stanger Station to the Crovernment trains. The Kearsney train makes connection at Stanger with the pasienger trains to and from Durban.

This novel and acceptable methol of visiting the principal tea estates in Natal in ile. lightful in itself, and only surpassed by the pleasure of touring orer the tha manufactory and the splendid denesne of the founder. Sir James Liege Hulett. I.P.. M.I.A.. Speaker of the Legislative dssmbly tor many years. and a very valuable and progressive colonist. Those who elect to go to Kearoner matrekon wum a kindly welcom. from that gentleman. or his reprementative. Should the train not suit the tourist, however. a most agreeable six miles Jrive from Stanger will land him at the mill drors.

The kearsney Factory is one of the most perfect w tea establishments. It consists of a lare building. constructed of brick and cement. five floors in height. giving a withering space and manufacturing cajalility of $I .590 .000$ his. of tea per annum. The dimensions of the main withering-floors are each I 50 hy 70 teet. to which there are annexures for engines, furnaces, and boilers. The work of all necesary departments in connertion with, not only the manutacture of tea. but its packing. are carried out under one root. Boxes are locally macle, rery often from Natal timber. Steam saw-mills and carpenters are emplosed on the estate. The lead for lining the boxes and packing the tea is importei from London. The Factory is fitted with the most modern machinery, the whole of which is operated by electricity.

Itessrs. Hulett's estate is composed of several plantations. the chiet of which are Kearsner. and Firkley Vale. The total area of these is I 3.500 acres. alout $\mathrm{I}$ thoo of which are under

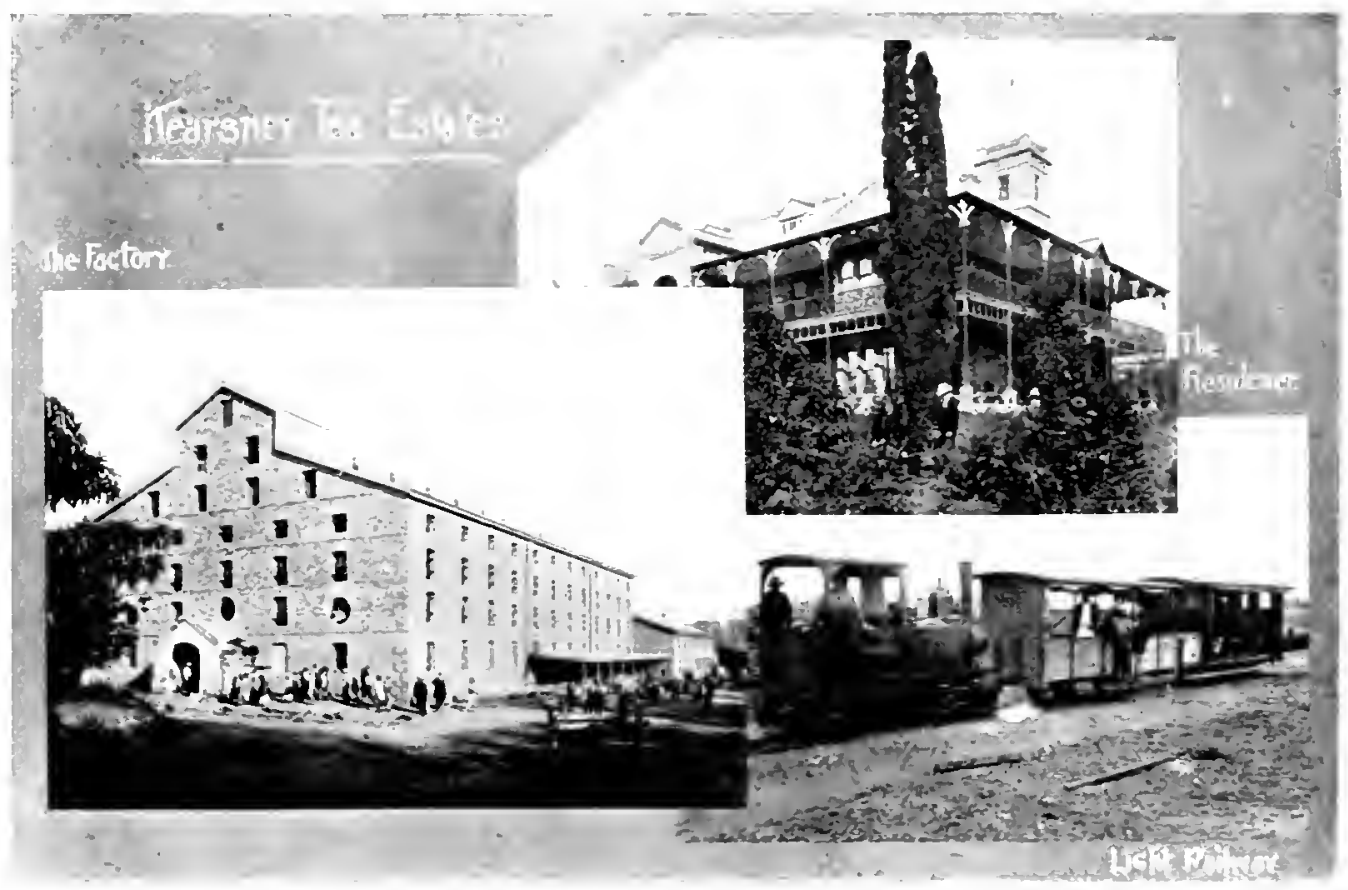




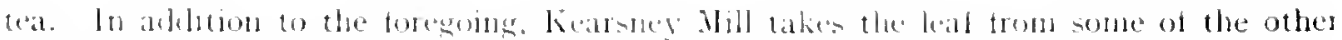

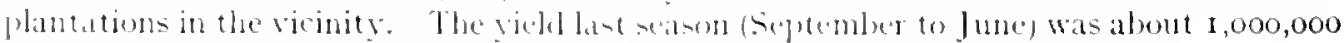
lhs. The total number of lndians complosed in the tea industry is mondly $1,000$.

Apart trom their latge operations in the direction of teas. Messis. Hulett are turning then attention to the cultivation and manutacture of sugas. two ('states with a total area of 6,000 ares of land heing the property of the Compans. I mill is leing arected on onc of these estates on the [mblali River. the machinery hor which will be the most modern that can be obtainel. This tactory will not only inanutacture trom the cane grown ly the proprictor, but also from that of other planters.

These are sereral other excellent tea factories in the neighbourlowel, and amongst others

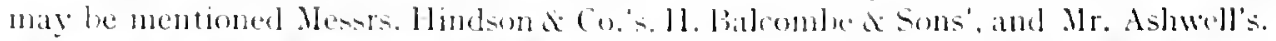

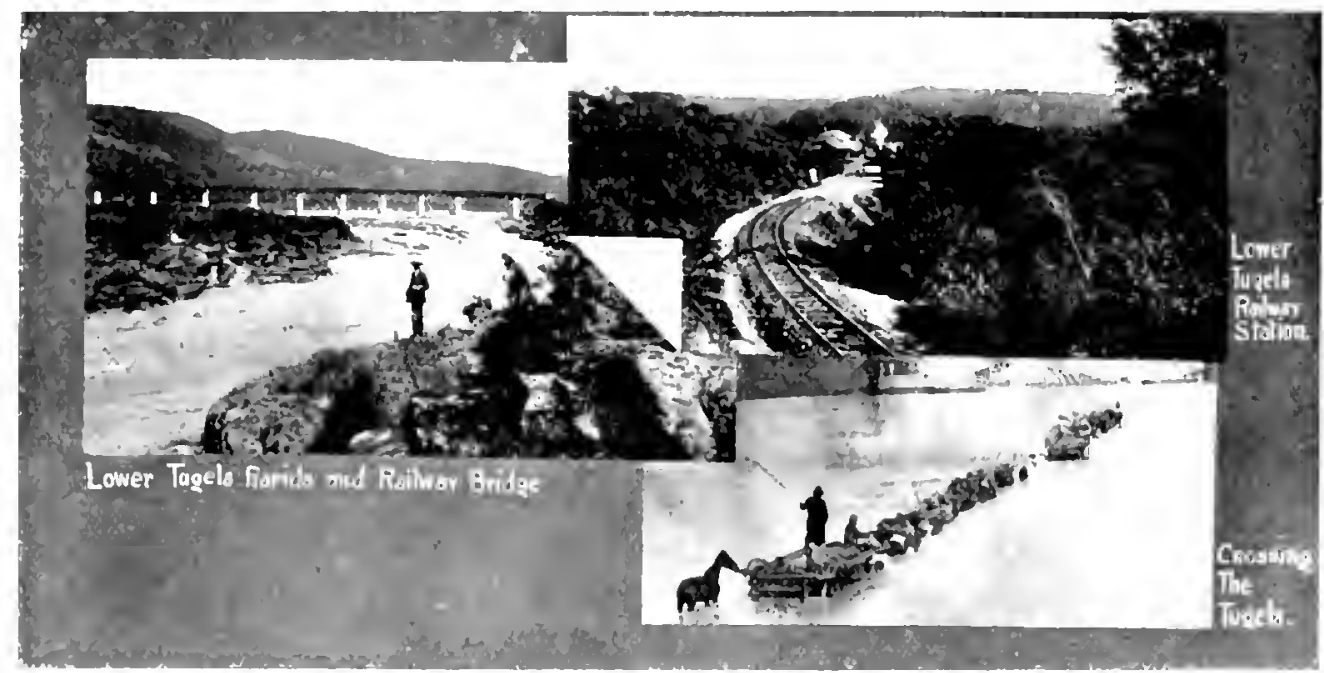

('H.IPTHK V.

\section{FROA STANGER T( \%LILLAXV.}

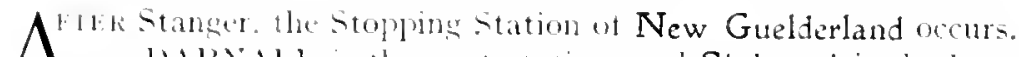

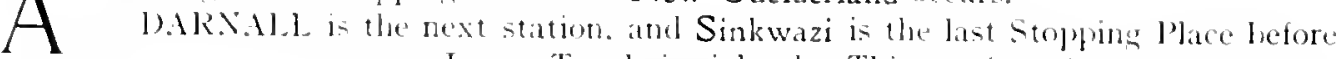
abmbe Lower Tugela is siglatel. This portion of the coast is very

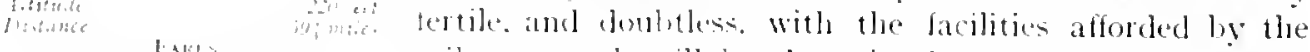

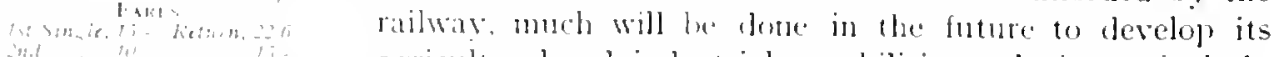
tatourable to tea and sugar. agricultural and industrial capalititjes. It is particularly

1.OIIER TLGELA. As its name expresese this station is situated on the banks of the

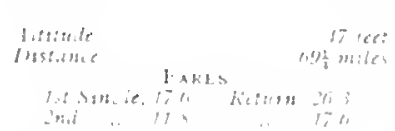
largest and most historic river in the comtry, the Tugela lere diviling the two large territories of Natal and Zululind which are connected about a mile beyond the Tugela Station. Ly the finest and most massive bridge in the whole colong-I,330 teet long. This gives a good iclea of the breadth of the oft-times treacherous stream. 


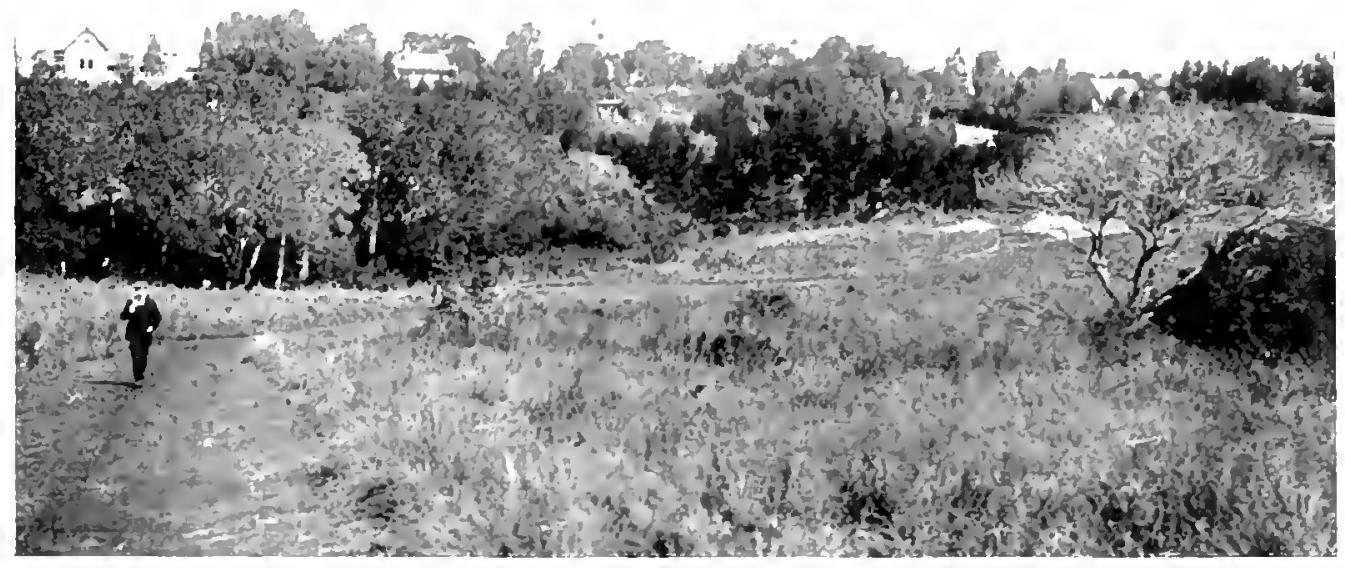

ESHOW:

The rillage is prettily situater in a valley. and contains two small lotels. and one or two private habitations. Fort Pearsm. one of the first tortifications fomed during the Zulu Vhar of 18,0 , and the burial place of a number of british soldiers is about six miles off, on the south bank of the river. From this point that War may le saill to have started.

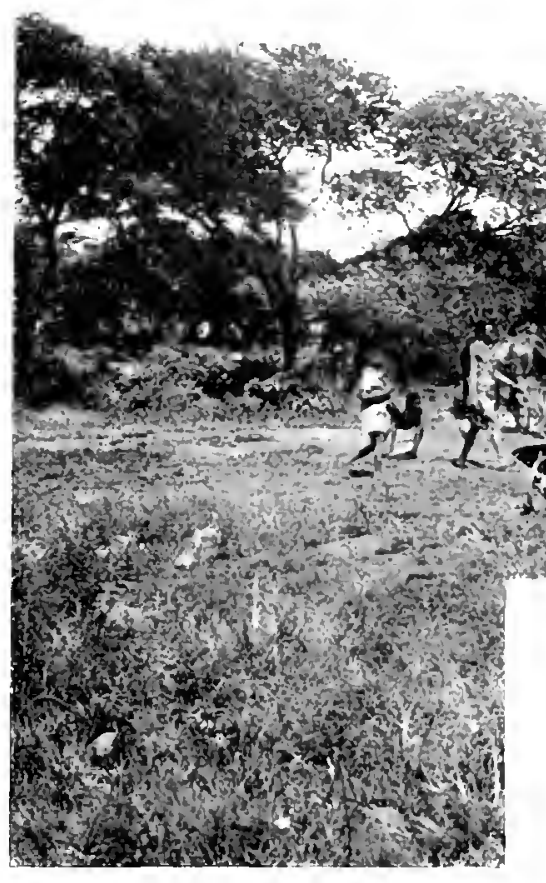

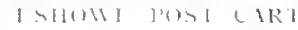
Luwer Tougla was formerly the terminus of the North comst line and the station for Eshowe.
The first section of the Zuhuland Extension now leing open, the daily PustrakT SERvice With Esilowl: lus heen transterred to




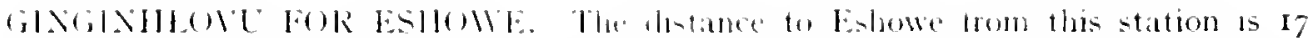
miles. and the fomtecart fare is 155 . The roule lie's through

liatisise

lit id int

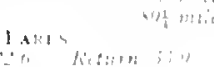

1. 1 ,

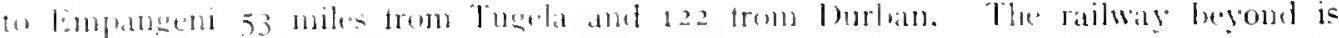

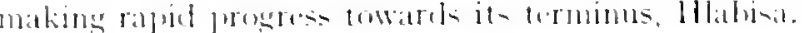

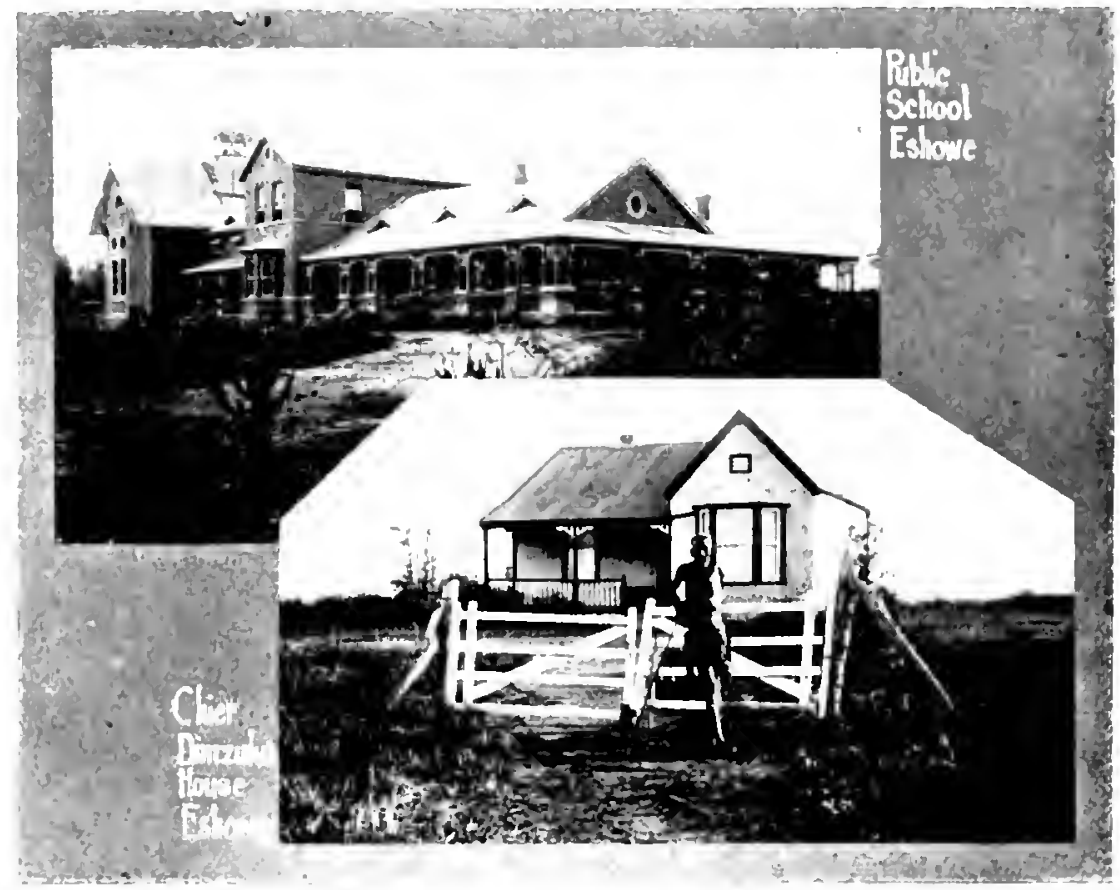

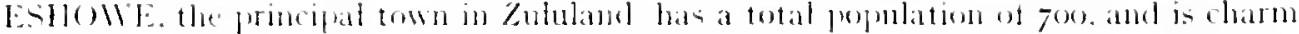

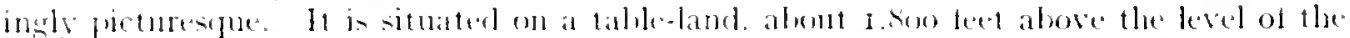

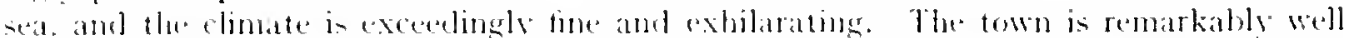
set out. English-lowhing. ant clean. and the resielences and other erections are styli-h and

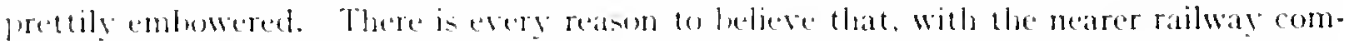

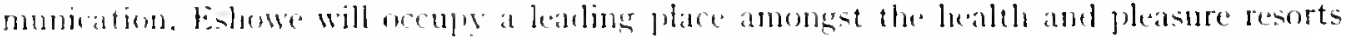
of the coloms. It hats eservething to comment it.

There are some goos huldings. Goremmental and otherwise riz: the Episcopalian

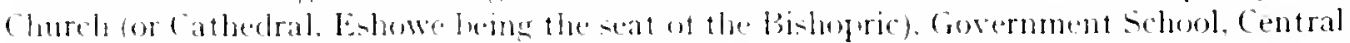

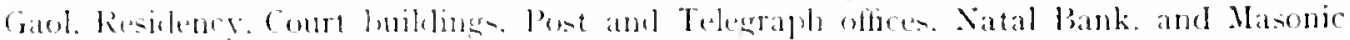

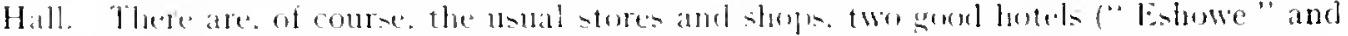

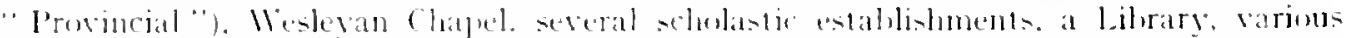

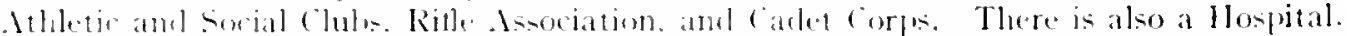

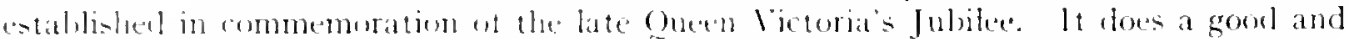
moth atpreciated work. White the forwegian Mision station, which presides over some 
500 natives, is a pattern of usefuness. Another of the town's unique enjoyments is the large open-air and secluded Swimming Bath. This has been made in one corner o! the lovely "Bush" and can he exhausted and replenished with fresh river water at will. The "Bush" referred to encompasses some hundred acres of enchantines woodland. Pathways traverse it in all directions, and there are the most leatutitul arenues and leafy alcoves for those who wish to hear

-or otherwise.

"The sweet leaves playmg wh the subte art,

In damty murmurng,"

Eshowe has a small garrison. stationed just outside. This is supplemented by a splendid Native Police Corps, the Nongies, whose cmbatted barracks are on the west side of the town.

The district is well timbered and watered and most capable for general farming and pasturing pursuits, but its situation so far away from the railway restricts any very great advancement being made. A considerable local trade is done in bricks.

Eshowe possesses some historic renown. Amongst the many grassy hills and mountains which surround it, that of Signal Hill. a mile or so away, is pre-eminent in height and reputation. It was the signalling station with the Bluff during the Zulu War-hence its name. It will be remembered that, atter the lsandhwana disaster, Eshowe was fortified, and held

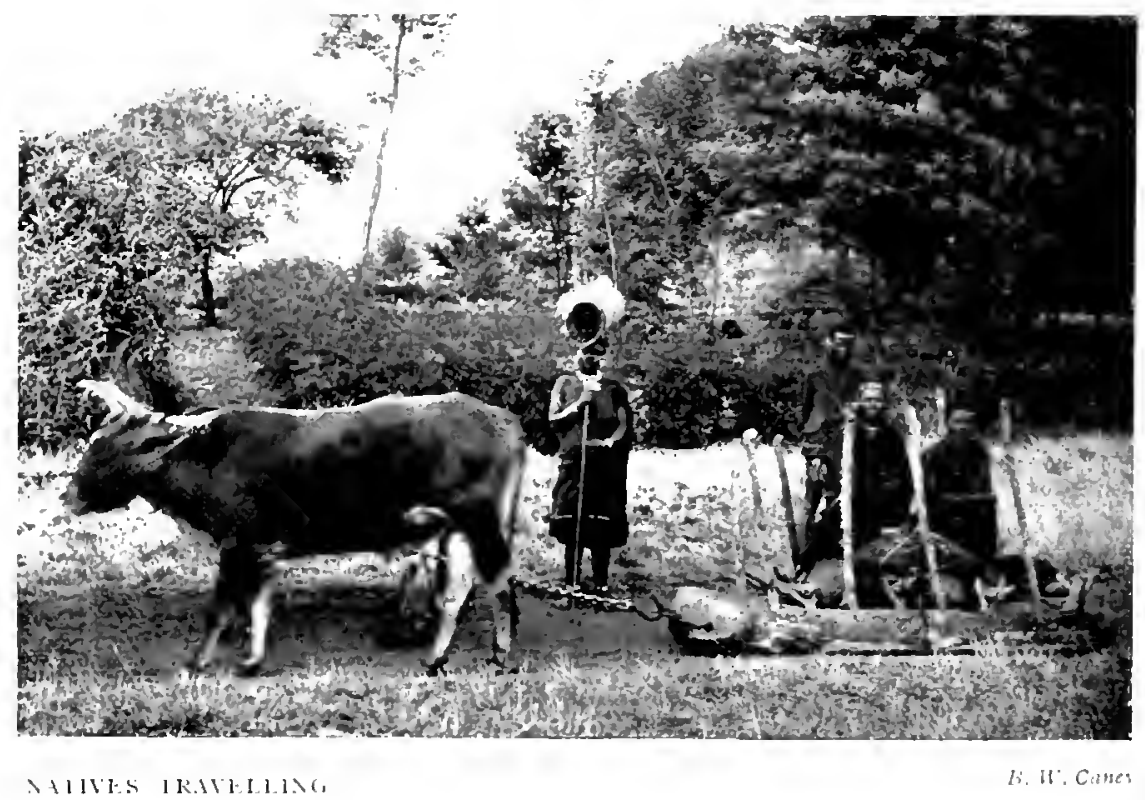

by Colonel Pearson and I. 3 wo men for two months against an expected attack from the main Zuhu army. The assault was never delivered, howerer, and the leeteaguered town was eventually reliesed ly Lord Chelmstorl's column. The site of the old fort and the military grave-yard will he tound some two miles out of town. near the Vorwegian .lission Station.

In passing, it is notewortly that the resilence of the well-known Zulu (hict Inizulu (son of the great Cetywayo), who rose in rebellion against british anthority in Is-s, was 
conveted of high treason, bumshed 4, st. llelena for ten years, and returned to his native land in $\mathrm{s} S \mathrm{~s}$, is situated aloout a mile trom bshowe.

MEI.MOTH is reached ind lishowe, and is 30 miles north of the latter place. It is the centre of a Dutch farm. g locality, and the stat of the Masistracy of the Emtonjaneni Dis. trict. There are but tew hullings hesille the Court House. Residency. Satal lolice Barracks, and Dutch ketormed (hureh.

UI.CXII, near the seat of the Maldalntini llagistracy, the place of Cetrwayo's royal kraal, and scene of the last great hattle of the Zulu War, is about 30 miles nor th of Melmoth.

MOUNT PROSHECT. whith newed in the Zululand operations during the Boer War, is not tar from Jelmoth, while Je()T ITAL.A. whose sucessful and heroic defence against the formidable attack under Commandant General Louis Botha in his attempt to remvade Natal in Oetoler. Iay excited such universal atmiration, is about 30 miles away.

\author{
CIHAPTIR I\%. \\ CONCERING ZLULLANI).
}

$T^{\prime \prime}$ HE territory of Zululand was annexed to, and became a province of Natal in December. ISo7. Its area is approximately ro, $45^{\circ}$ square miles. and its population $\mathrm{r}, 263$ Europeans, 21 3,000 natives, and about Ioo Indians.

Amatongaland. the northern extremity of the province. gives a further 5,300 square miles, and a native population of fo.ooo. Zululand is divided into deven Magisterial Districts, vis: Eshowe, Emtonjaneni, Noutu, Mahlabatini. Ndwandwe, Ubombo, Ingwavuma, Comblazi, lower [ mofolozi, Hlalisa, and Nkandhla. The first three are connected by telegraph, and the next hour ly tedephone. with the rest of the Colony. The remainder are unconnected. The seats of Mighistracy are, on an average. 30 miles apart. Nkandhla is noted for its proximity to the must beautiful and extensive forest in the country. The Insuzi Goldtield is about Is miles therefrom. The Nondweni and Denny Dalton Goldtiells are dealt with mmer DexwEE-page I z

With the exception of the townships of Eshowe and Nondweni, and that portion of the Emtorianeni District including. Melmoth, the whole of the land in the province is unalien. ated Crown land, and occupied almust solely ly natives. A few traders have established stores in rarions parts, their license to trate being their only title to remain in the countrv Lnder this license thev are boumd to provide accommodation for travellers.

In the low-lying portions of the country, malarial fever is prevalent during the summer months.

The $r$ arls to all listrict-aregowd. With the exception of the post-cart services between Ginginhlovu and Eshuwe. Hundere and Nondweni and Noutu, there ase no established tacilities for reaching the different parts of the province, and all travelling has to be done on lorse-back or by private conveyance.

Sative education is comlucted by the Bishop of Zululand, and the Norwegian, Swedish, Catholic, and other Missions and Societies, their schools being aided by grants from Govern. ment.

Zululand sends one Mrmher th the Lewislative Council, and two Members to the Legislative Assembly.

The Province has progressed steatlily durmg the last tew years, and the new railway line, which will run along the coast lumb, terminiting at the extensive Hlabisa Coalfields, near 
St. Lucta Bay, a distance of a hundred miles from Tugela. will prove a very material in. centive to rapid and important developments in the future. The districts served are suitable for the cultivation of sugar, tea, coffee. tohacco, maize and rice, and will undoubtedly draw many enterprising settlers. when arrangements are made for the opening up of the lands. Zululand is well watered, splendidly wooded, and rich in mineral deposits-coal, gold, copper, mica, and asbestos having been found. Many schemes are on foot for their development. India-rubber is another large possession of Zululand. Game is fairly plentiful. and specimens of most of the fauna indigenous to the country are preserved, but may not be shot without special permission. The rivers Amatikulu, Umhlalazi. Umfolosi, and Umyalazi afford excellent fishing.

The future of Zululand is full of promise.

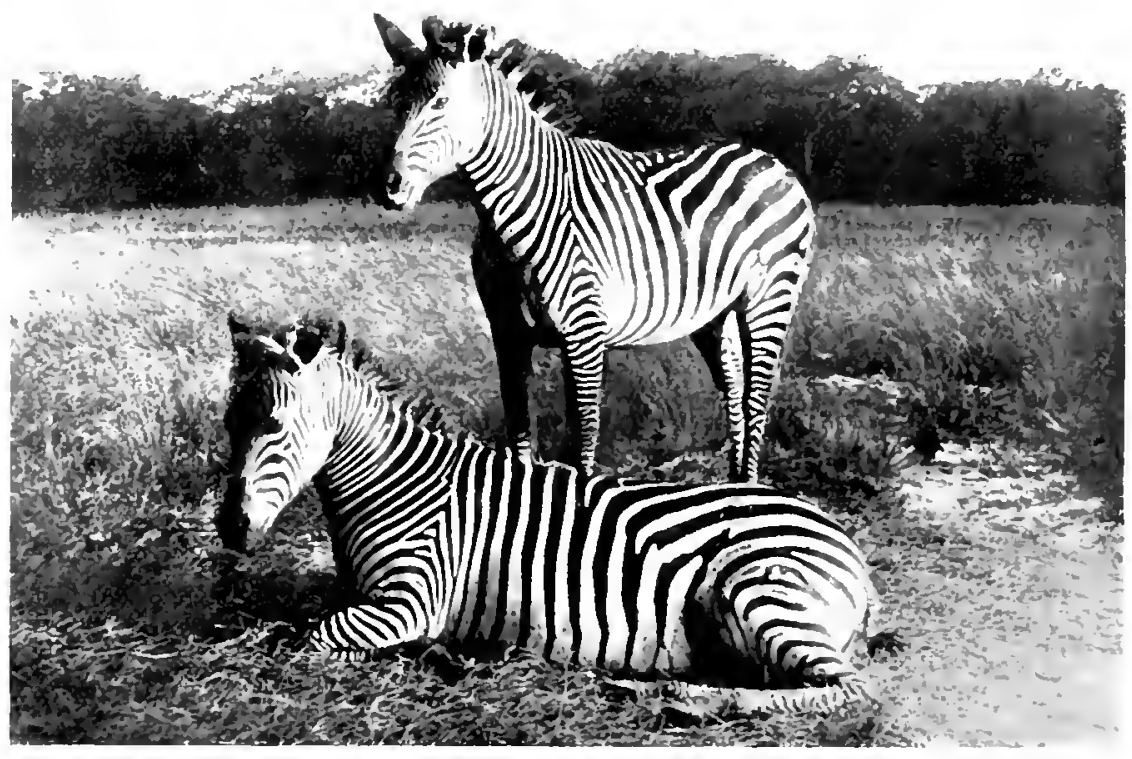

Z.EBR.AS 


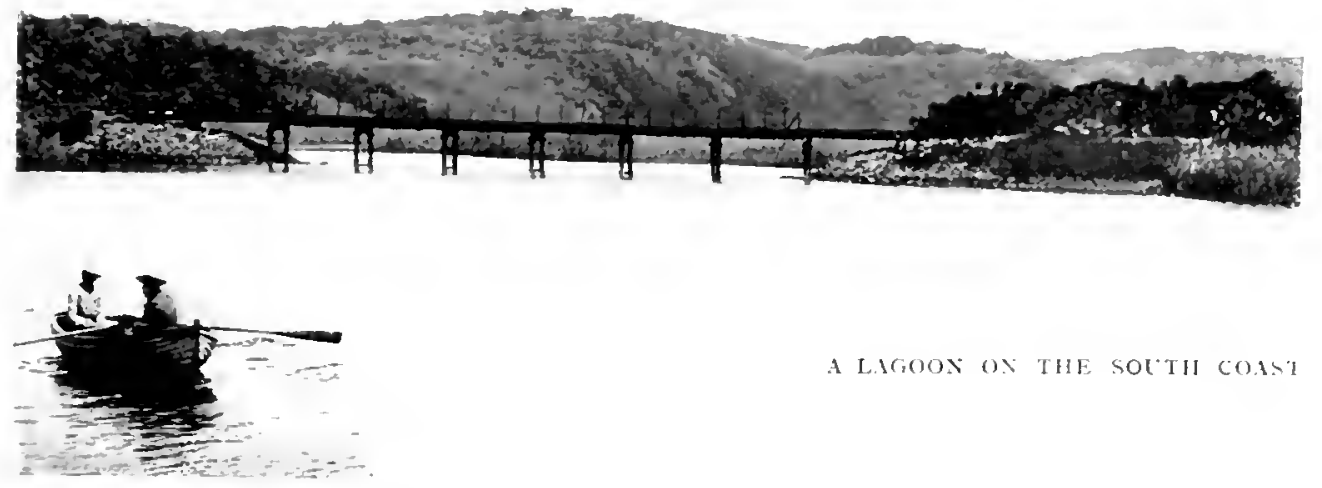

A LAGOON ON THE SOETH COAS'

\section{PART SIX.}

\section{THE SOUTH COAST \\ BRANCH LINE.}

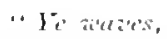

"That o'er thintirminable dean areathe

"lour crispid smiles."-Discolvels. 


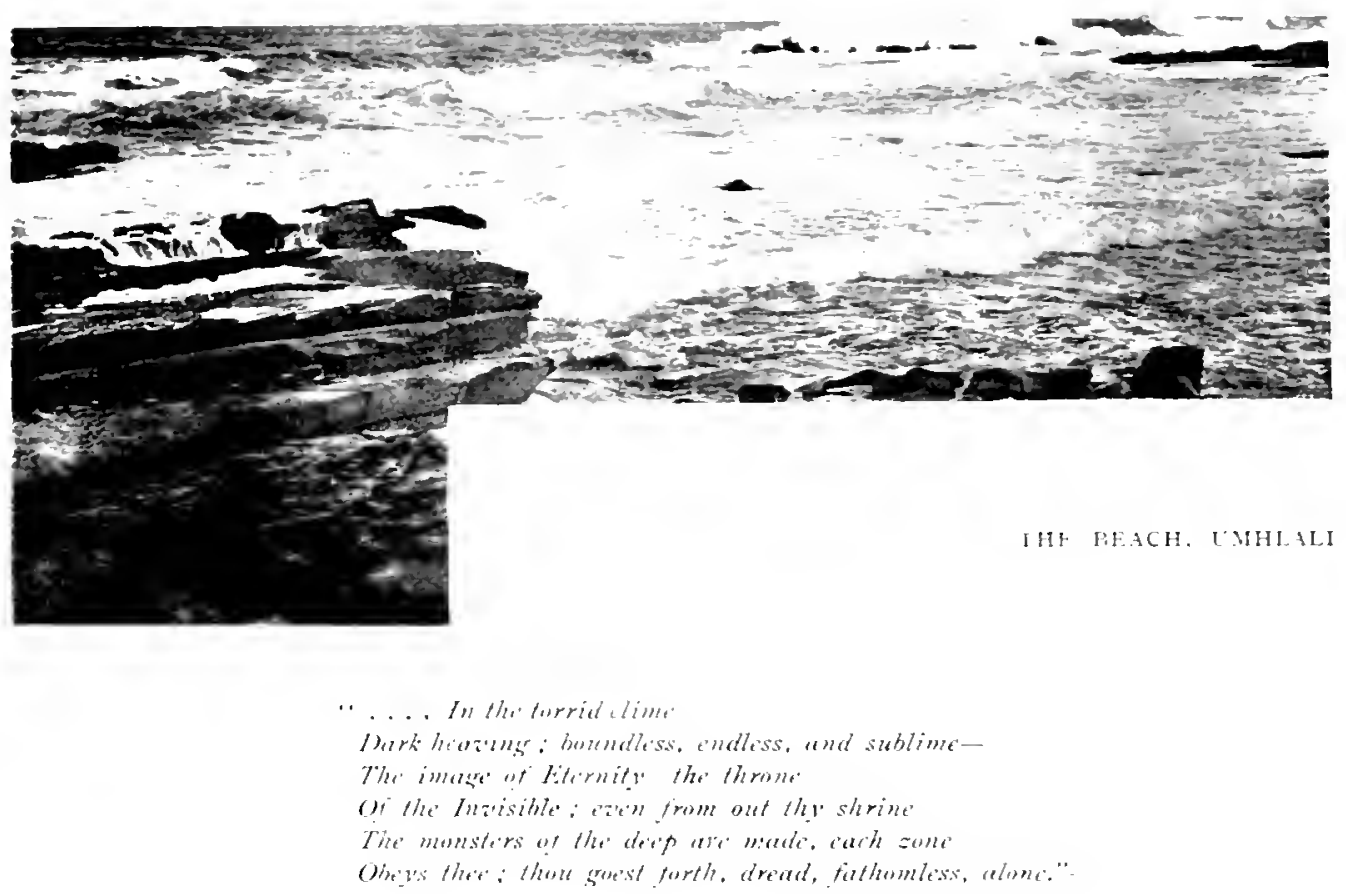

Birow ( (hilde Harild).

\title{
PART SIX.
}

\author{
CHAP'TER 1 . \\ HINTS TO TOURISTS AND OTHERS.
}

7 HE South Coast Line is furnished with an excellent serviee of trains, and the times of eartan of them arz altered on Saturdays and Mondays to suit the convenienee of visiters to the several week-end resorts. At most of the seaside places, cottages on the beach can be hired for varying periods.

The fishing and shooting are good the coast through. All kinds of she!l-fish are found in atundance at many points along the coast, and at the mouths of some of the rivers.

A warning should be given to bathers not to venture upen a "dip" tefore assuring thanselves as to the sale spots. At some places the siop: of the beath is so acute, and the baik wash so exceedingly strong, that an element of danger would be ancurred by ignering this preiauton.

Besides their many attractions and health-giving properties, the various resorts also afferd great scope for the student of botany, entomology, geology and moneralogy, naturalists and ether selentists, as well as artists and photographers.

The products of the South Coast lands are treated under the respective stations and districts. 


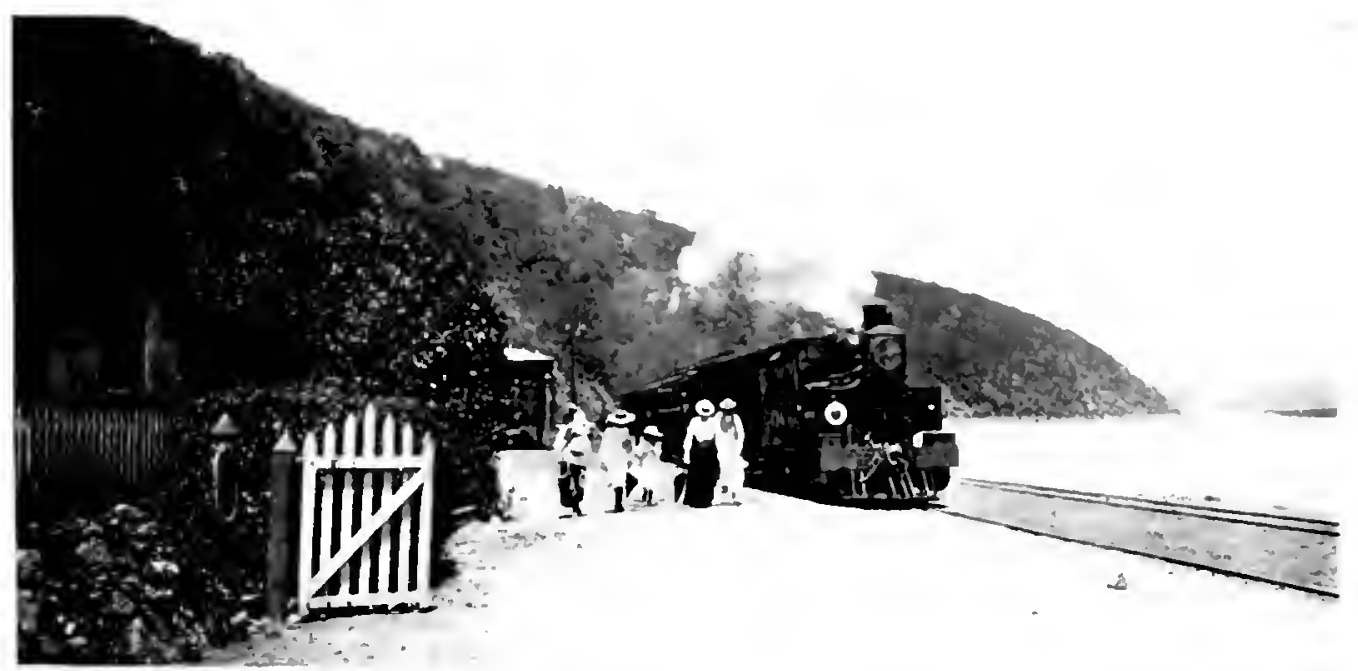

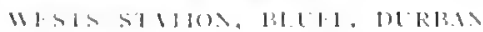

C'HAl'TlKR II.

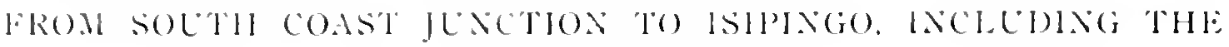
BI,LET: I.INE.

$\mathrm{D}$ Evintarifom the main line at South Coast function, the branch train bowls along on a fevel track, past the Satal Jatch Factory and the Chemical Manure Mill, across the midge of the river L'mhlatuzan which trails through a country singularly pretty' and well foliaged, though bright red cuttings, into the Junction station of the Bluff Line,

CLAIRIIONT. This is a well-known picnicking place. It is also being developed

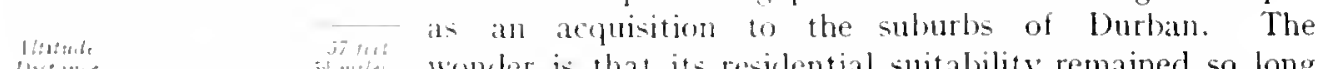
liasinc

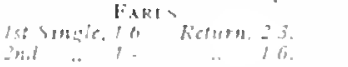
undiscovered. considering the good train service, the pleasant situation, and the tact that it is the centre of good brickfelds and stone quarries. In the vicinity is a large Catholic Native Settlement.

The BLCFF LIXE radiaten from Clammont. and sweeps round the edge of the bay, passing the undermentioned Stopping Places in the order given: J ACOB'S, WENTWORTH, KINGS REST (named after the doughty Richarl King). FYNI.AND (this in memory of Henry Finn, who, with Lientenants Farewell and King, were the three recognised leaders of tha eutly English attlers), and NEW BRIGHTON, terminating at

WESTS, the healland station of the Bluff. This alternatue mode of reaching,

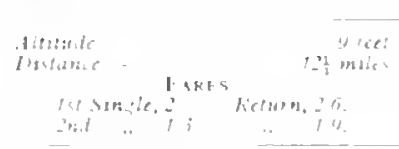
or returning from the avourite pleasure-ground of the Durbanites is greatly used.

The Btuff Line is destined to rise to much greater importance in the future. Portions of the richly wooded slopes are no longer the sole haunt of monkeys. bush-buck. reptiles, and birds: man has set his halitation there, and the beautiful Berea has a rival. A tew rears hence, too, and the "Bluff Side" will be a large component of the Harbour. On leaving Clairmont, the train cuts through grassy plains to 
MEREBAXK, which is chiefly notable as the site of the largest Boer Refugee Camp

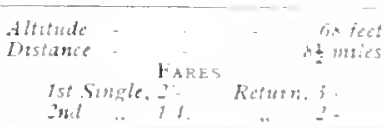
in Natal. At the time of writing some 8.500 Dutchmen. women, and children were concentrated there.

Beyond Merebank. large sugar-plantations and mealiefields open hefore the view. thick clumps of supple bamboo bend with measured grace in the breeze the thatched dwellings of the ubiquitous coolie are scattered far and near, and the dusky tenants may be espied in the cane-fields, or diligent in other directions. The siding to the Lmlas Wool-washery and Sugar and Nealie-mills is shortly passed, the Lmlaas river itself is crossed by the second longest bridge in the Colony (I, I6o feet), and

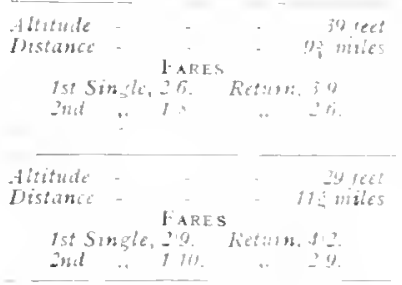

RELXYN. a quiet little station, in the heart of sugar. bearing land. is overtaken.

ISIPJ NGO. the next station. is a livelier place, hut much of the importance it boasted when the terminus of the branch. has departed. It possesses a church. a chapel. a Government-aided school. two hotels, a library, and various stores. It is a convenient distance from Durban. and. by reason of its gool road. is much visited by crclists and others.

Before the more southern seaside places were accessible. Isipingo was a favourite resort, but the beach being two miles away. it is now less popular, although its attractions, boating and fishing on the lagroon and river, and rambles on the beach and over the seaworn rocks, are still enjoyed by a good number of risitors. especially on public holidays and during week-ends. It should not be omitted from record that in the Isipingo cemetery will be found the tomb of Richard King.

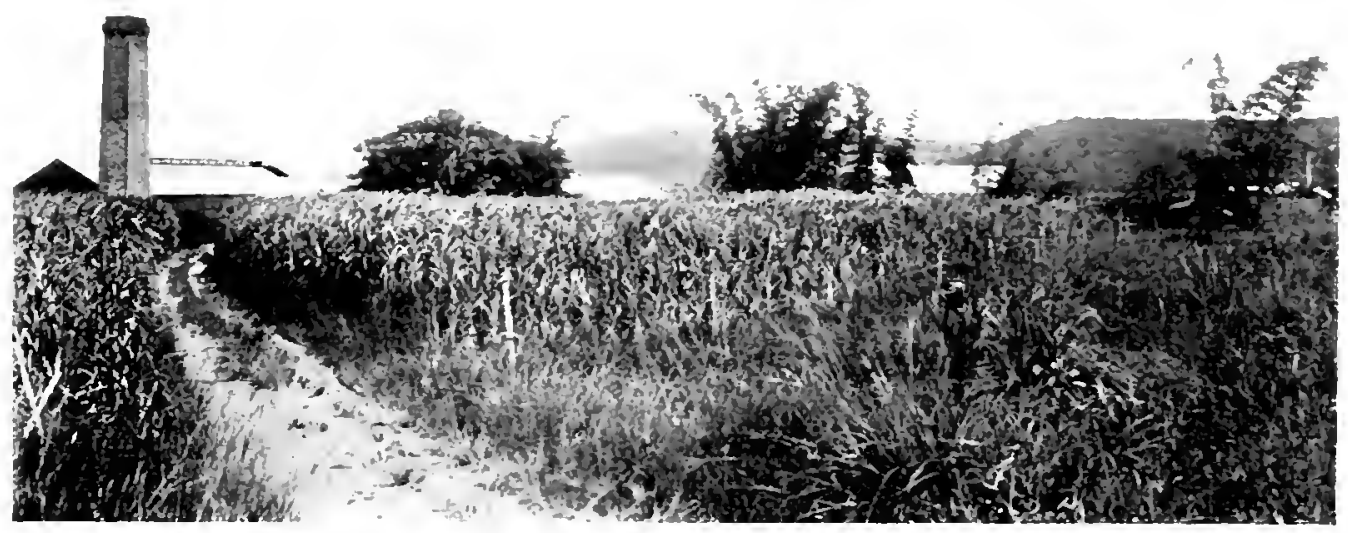

SIGAR WHL AND CINH FIELDS 


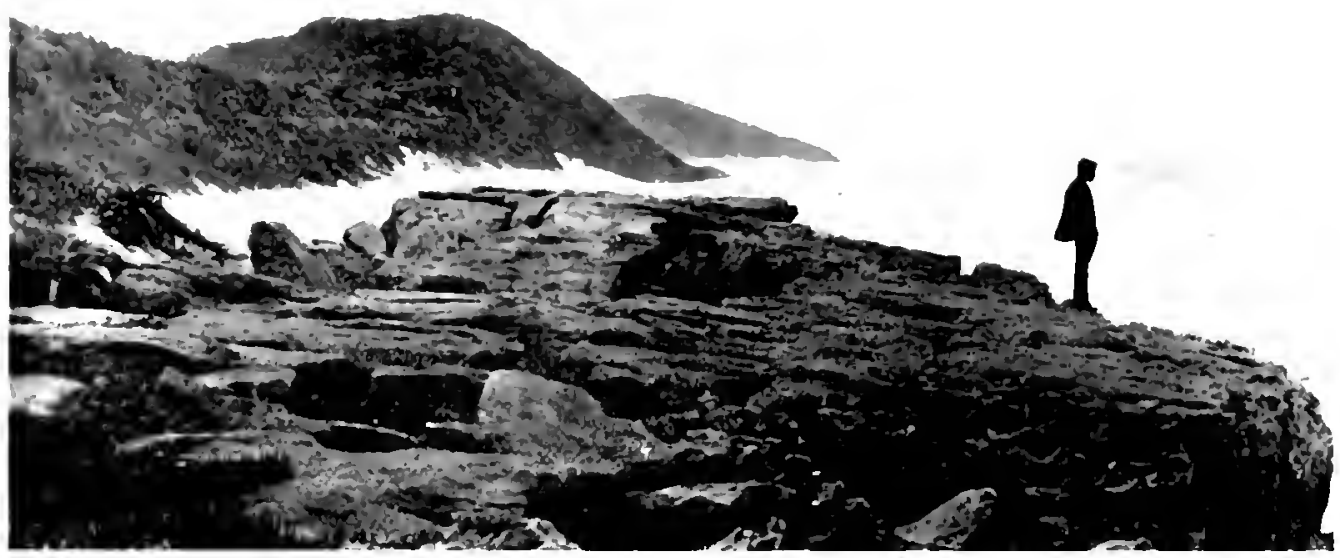

$111 . \quad 1: 1,11.12111>0,1$

C'HAPTER III.

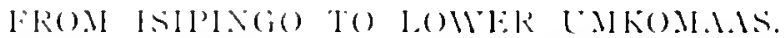

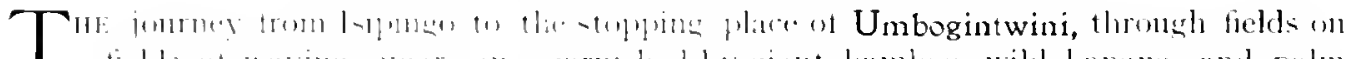

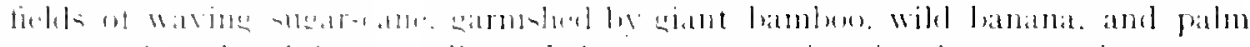

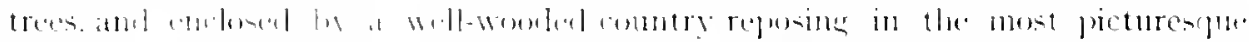

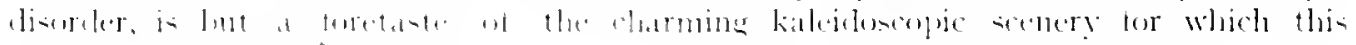
line is or ju-l|r remowned.

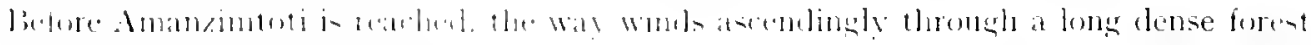

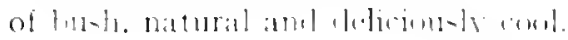

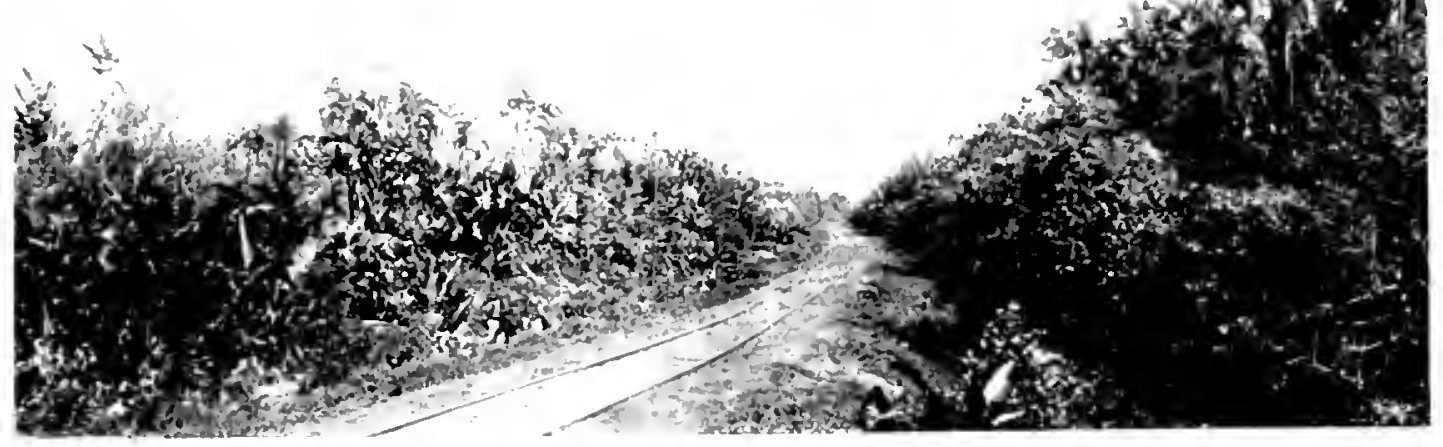

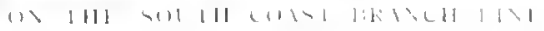




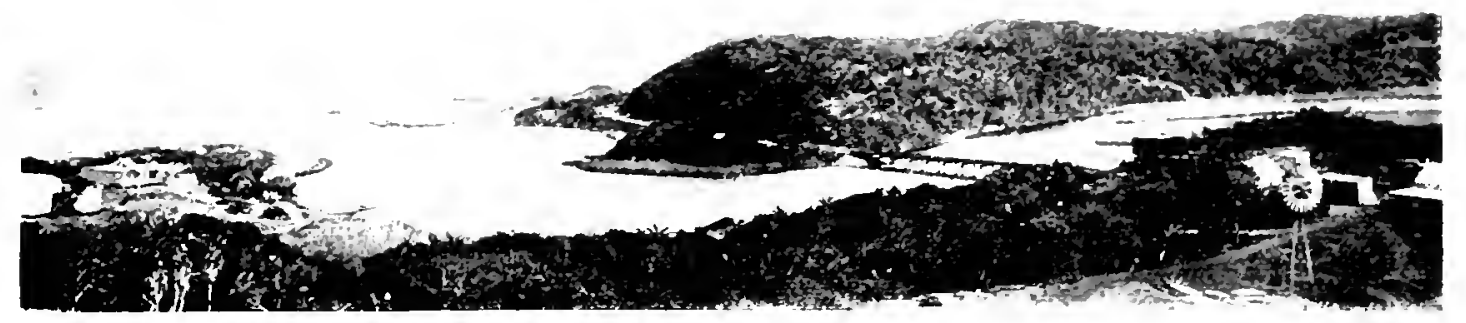

1.11 $12 / 13101$

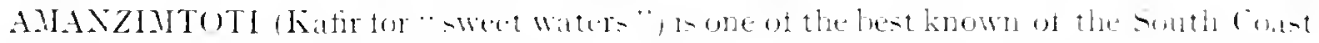
Jitristiti reorts. and well merits it= native name. . a saturdir. Ibintice

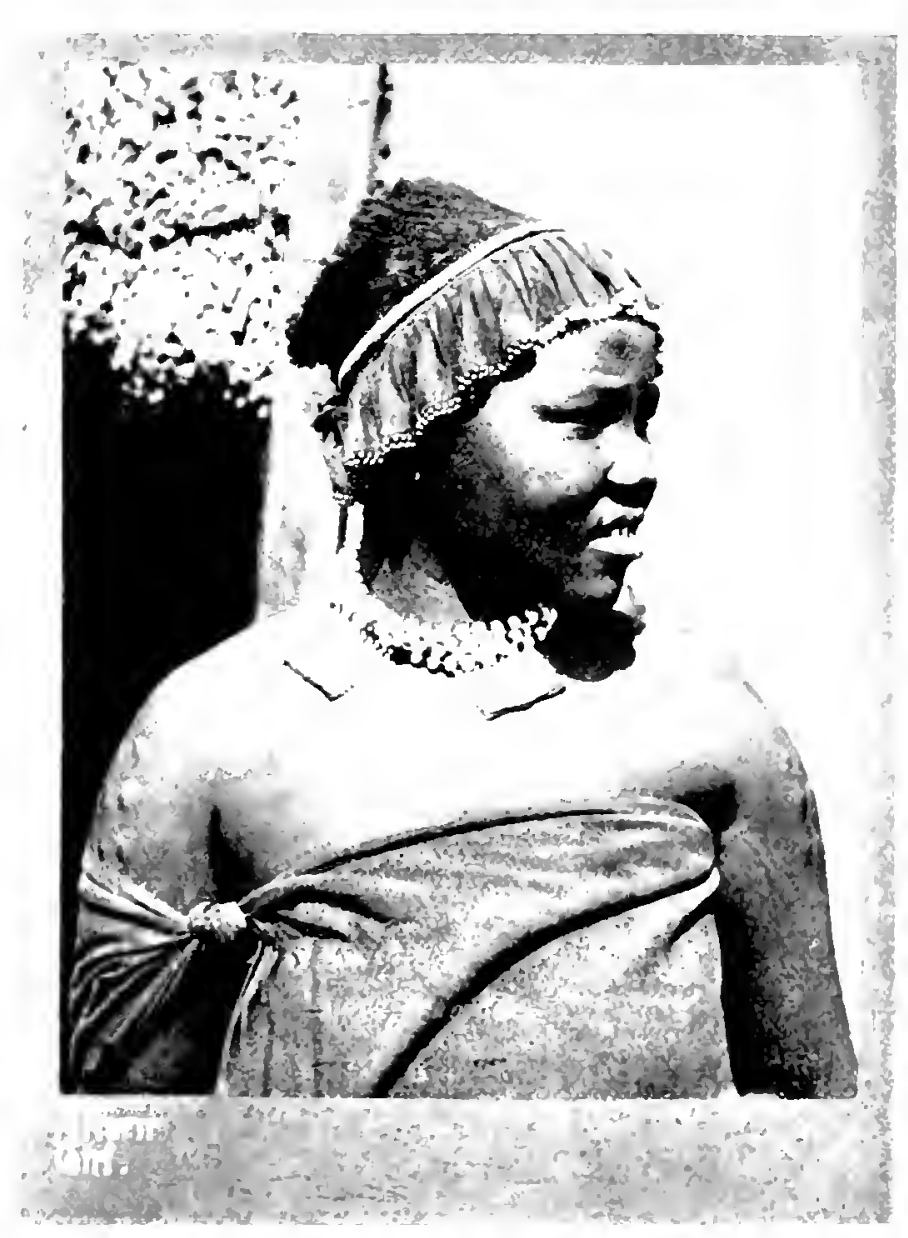

to-Munday rendezrnu. it iof especial suitalility. herbus within only an hour aml it quarter's ride of Iturlan. The lotel is commandingly situaterl in terraced grounds. and. like most of the hotelson the south Coast. is commodious and we.tl appointed. It controls al splendid view of the pleasure-eiring leatures of the neighlourloos? -on the lett hind. the seat and shelly leach : on the risht, the loroad lasoon and reedr isle. the sracetnl river. am the. bush ondulations which e. tend for miles.

Boating. shootme. fillines bathing. and temnis compun the general enjoyments. While the artistic and photonraphic ere will discover numerous scenes worthy of attention. The beanties of the river. which is navigalle for several miles. are by no means olutrusive they require to be conted but, when tound. les womlel lx. an unimpressionable mortal 
whe was not clatmed whl the many alphwatmes spots along its palm-fringed banks, Which rise at pointe to ibmost perpendiculan ledghts on which the wild banana, aloe, and candelabra-like euphorbia. comer asertiong threngh the sub-tropical thickets.

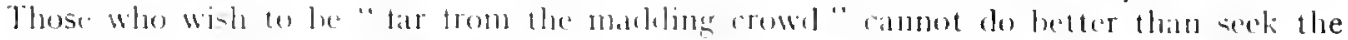
sweotly ejuied nowlis lusicle the . Imanzintoti.

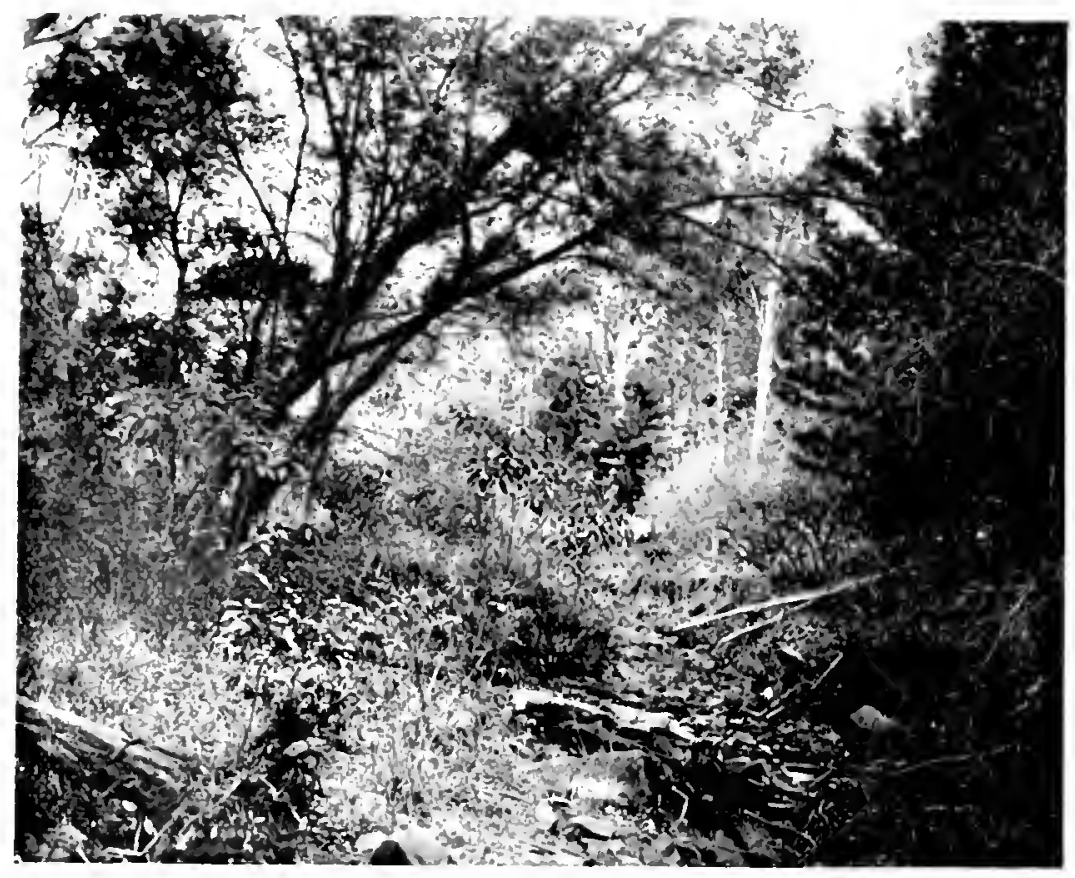

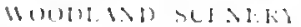

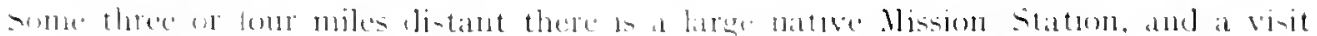

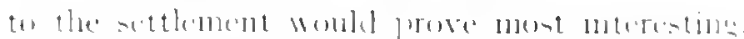

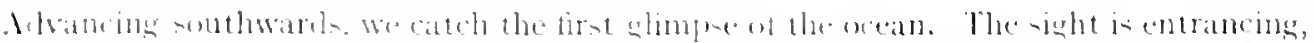

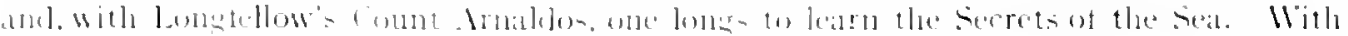

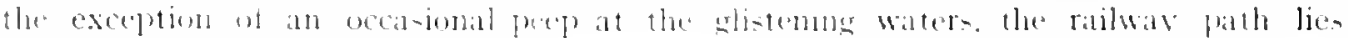

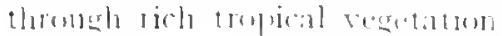

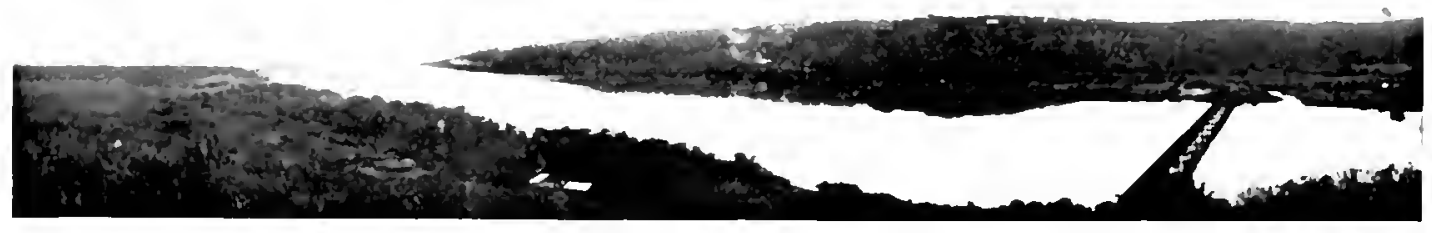




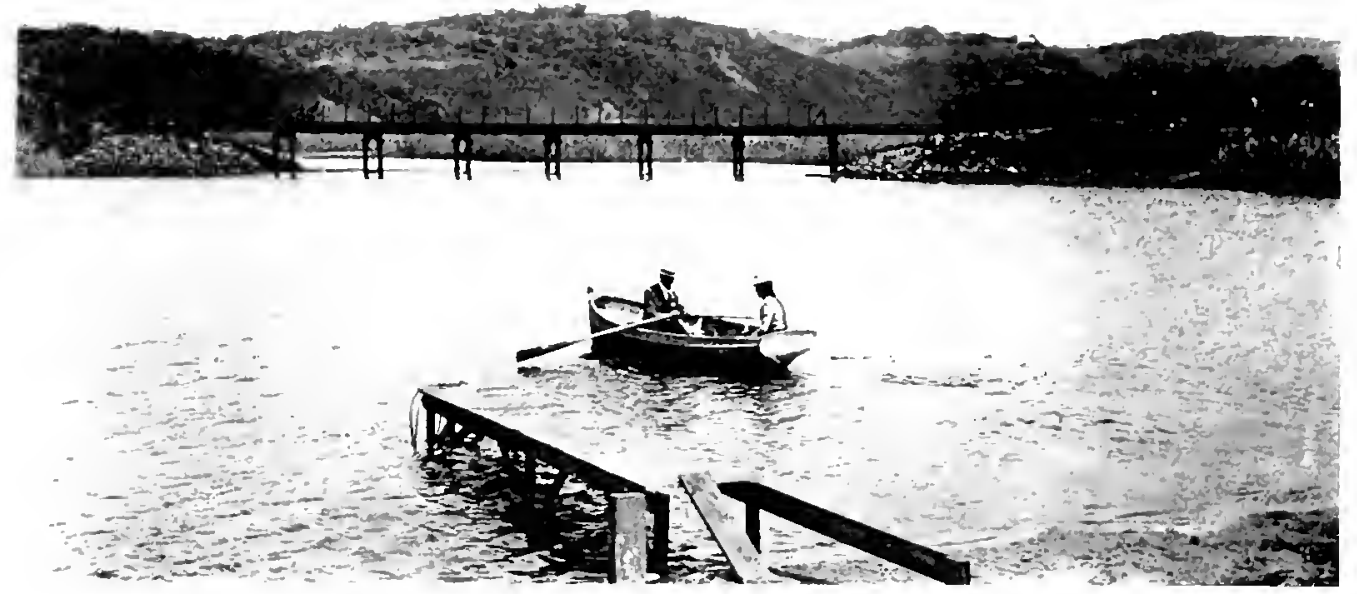

LAGOUN AMAXZMTOTI

WINKLE SPREIT, the next hatting place, is a farourite camping-unt -ituatim. It is a pretty little spot which titkes its name. not trom the leser liuht in tle l'ickwickian fimament, but probalily trom the tiny - hell-finl found on the clu-ter of hlark rocks at the mouth of the stream. wherved in pasing wowards

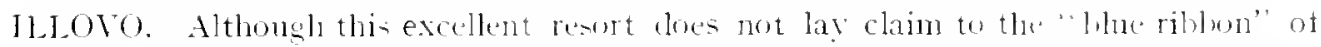

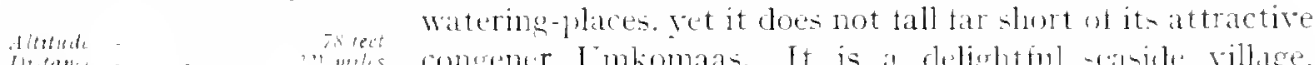

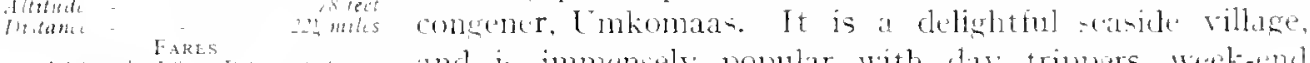

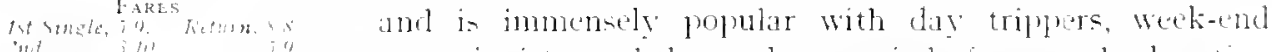

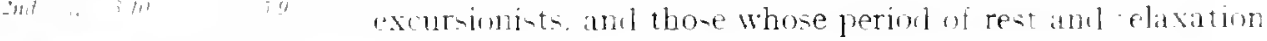

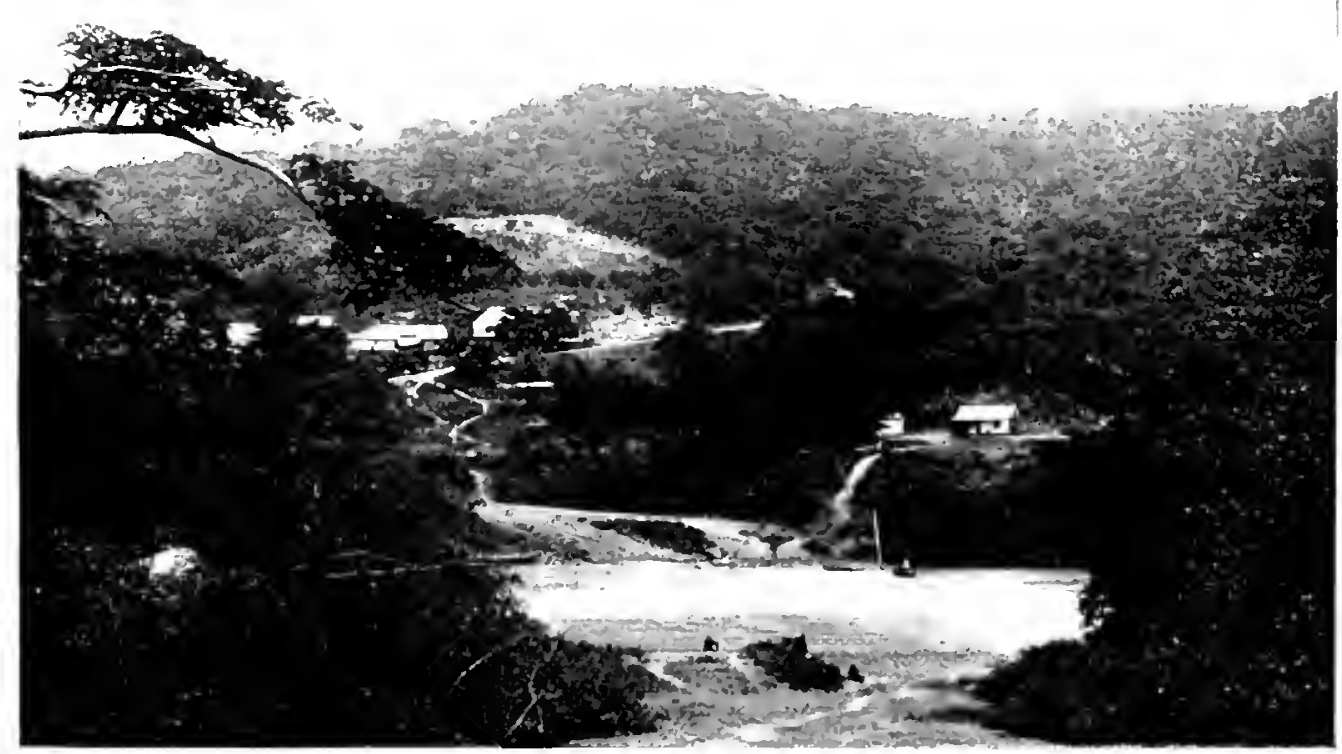

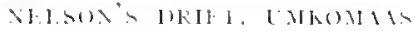




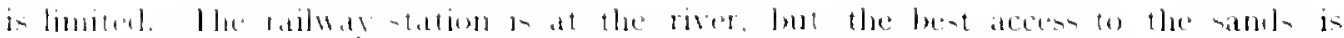

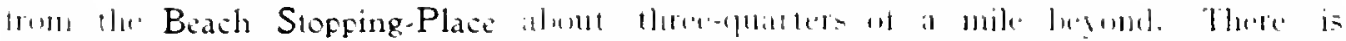

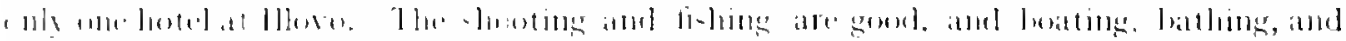

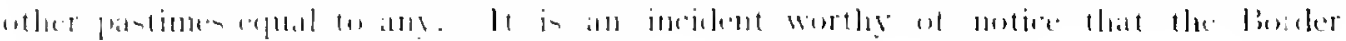

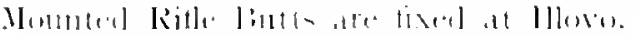

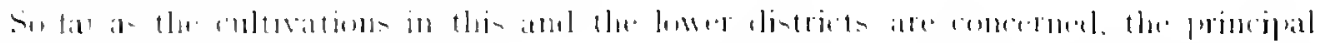

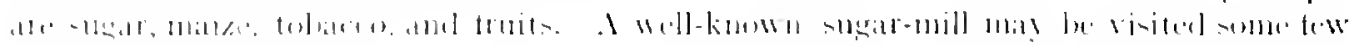

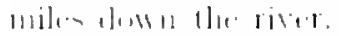

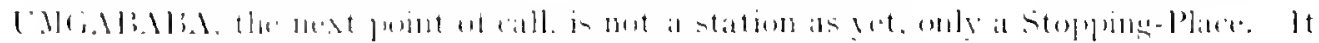

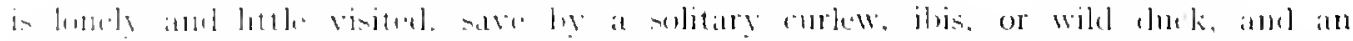

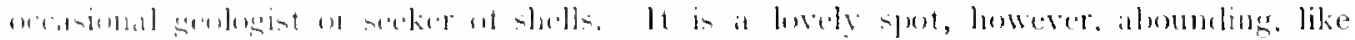

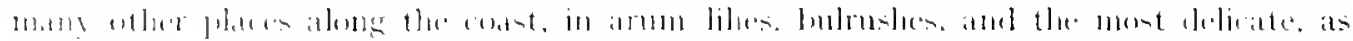

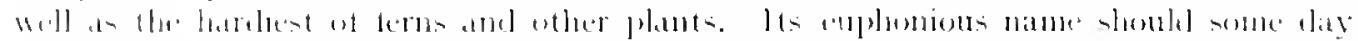

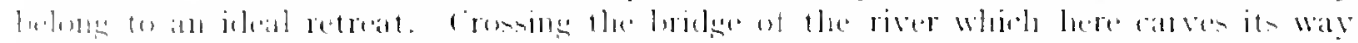

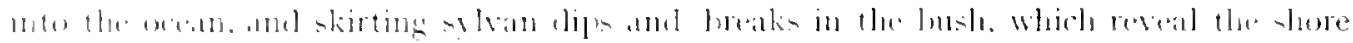

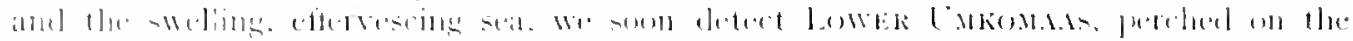

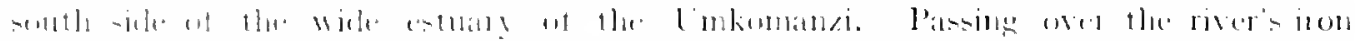

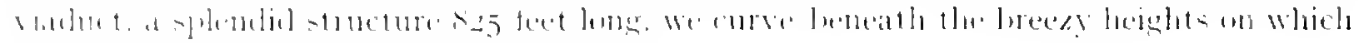

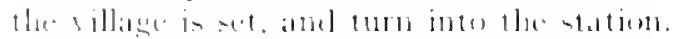

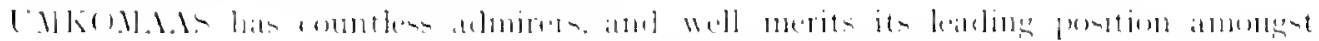

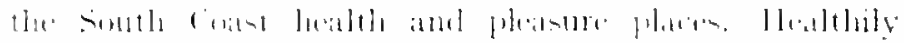

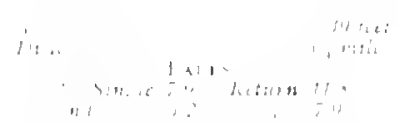

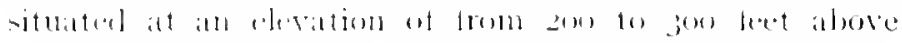

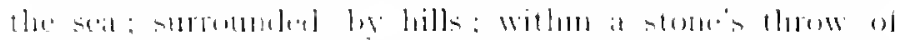

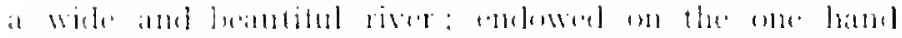

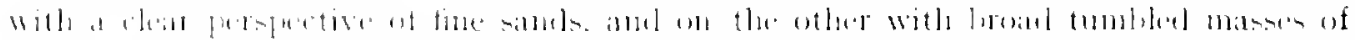

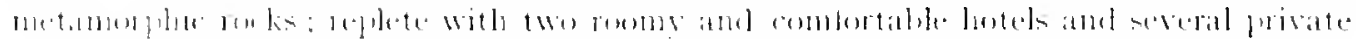

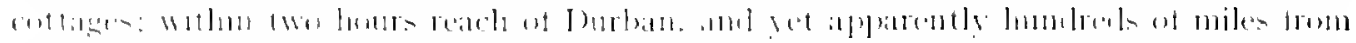

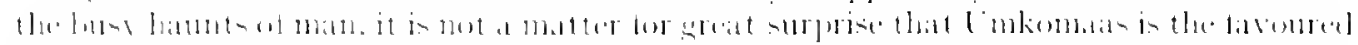

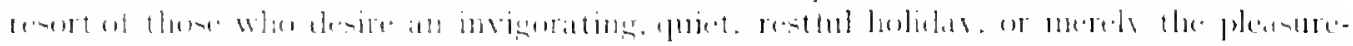

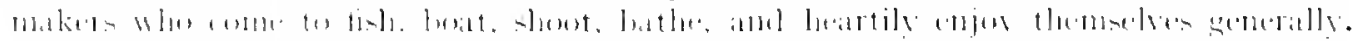

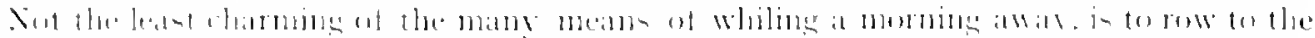

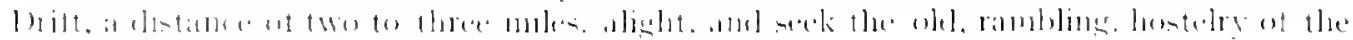

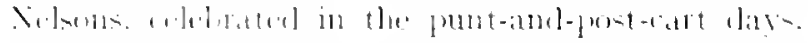

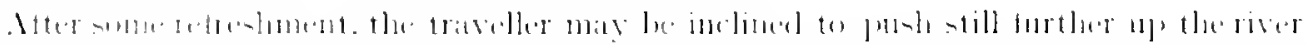

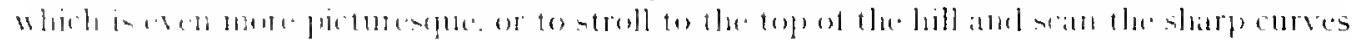

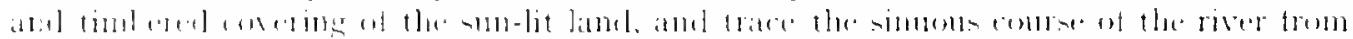

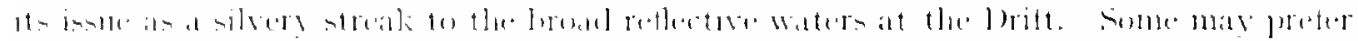

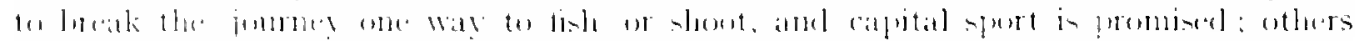

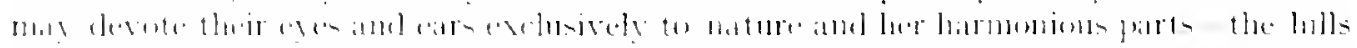

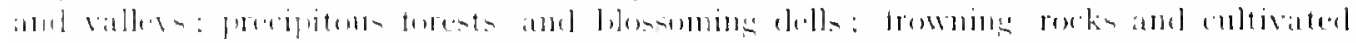

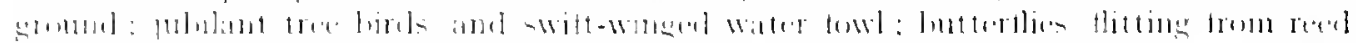

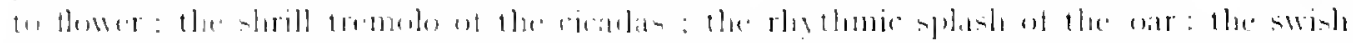

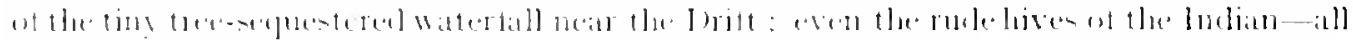

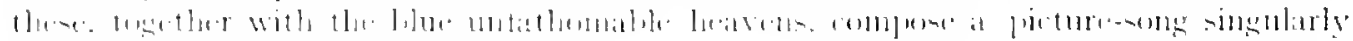

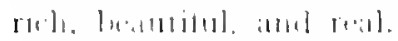

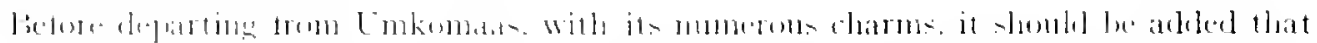

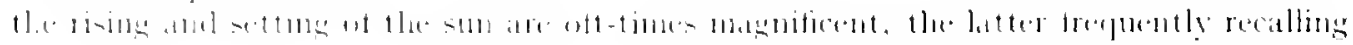




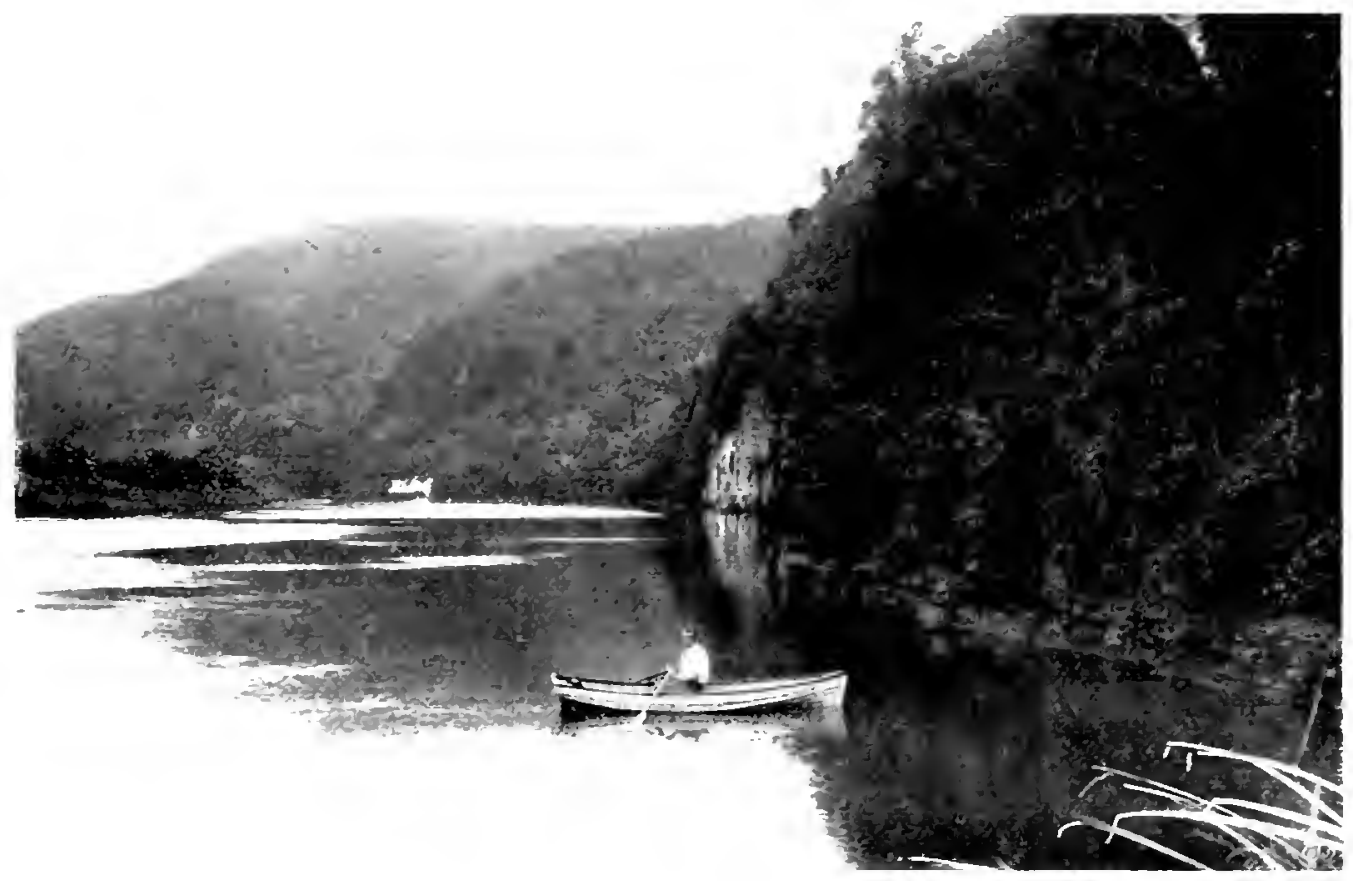

ON THE IXKOMA

the elegant lines of the talented wite of the poet southey :

$$
\text { " Mafentically shew }
$$

[he sun poes down in giorv-

Witre abse, wave below,

Uringe and preen, and gold,

Russet and crmson-

Like an conlormered zulle, ancertral word-

Clise round on all sides:

Thuse agan begirt

In wary undulatwon ol all hute

To the horzon's verge bo the deep torest." 


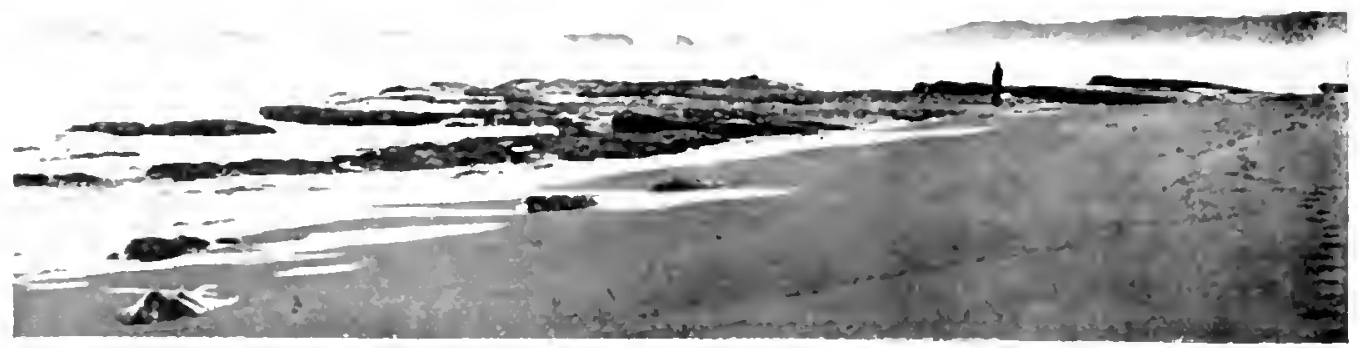

CHAYISK M.

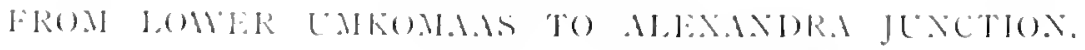

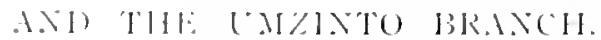

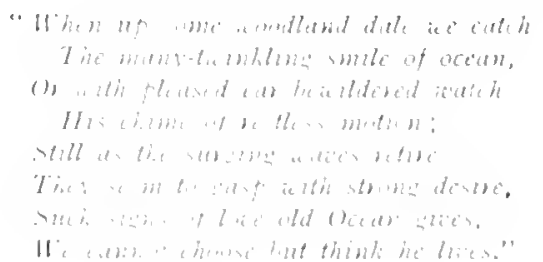

パトは1.

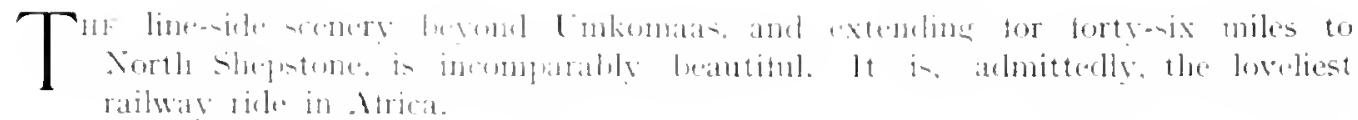

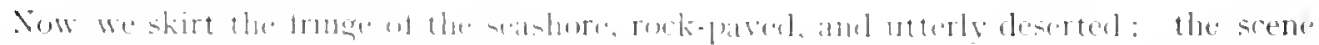

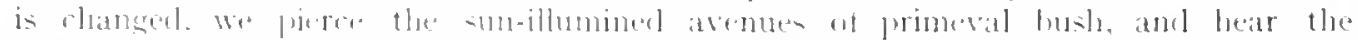

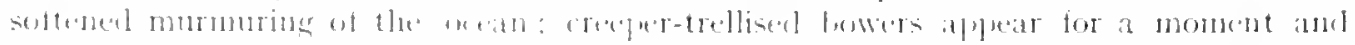

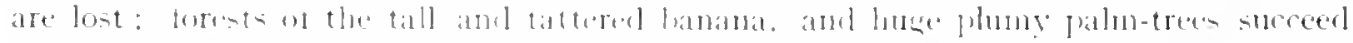

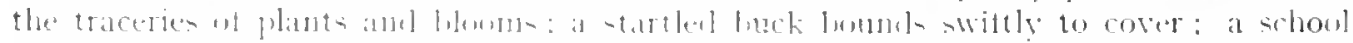

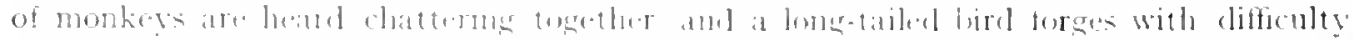

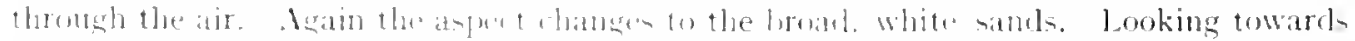

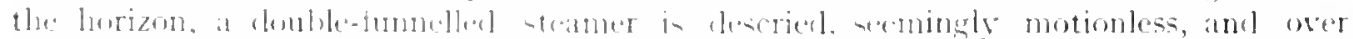

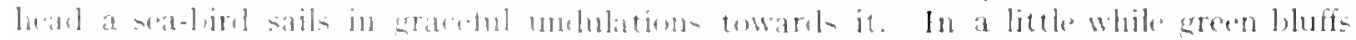

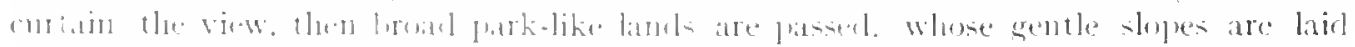

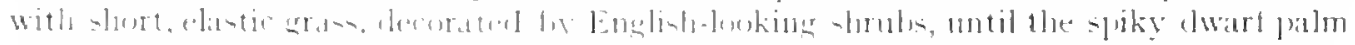

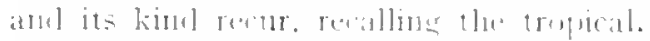

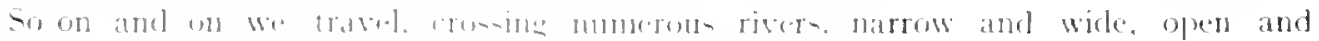

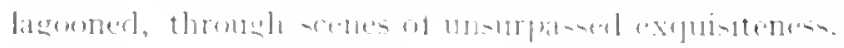




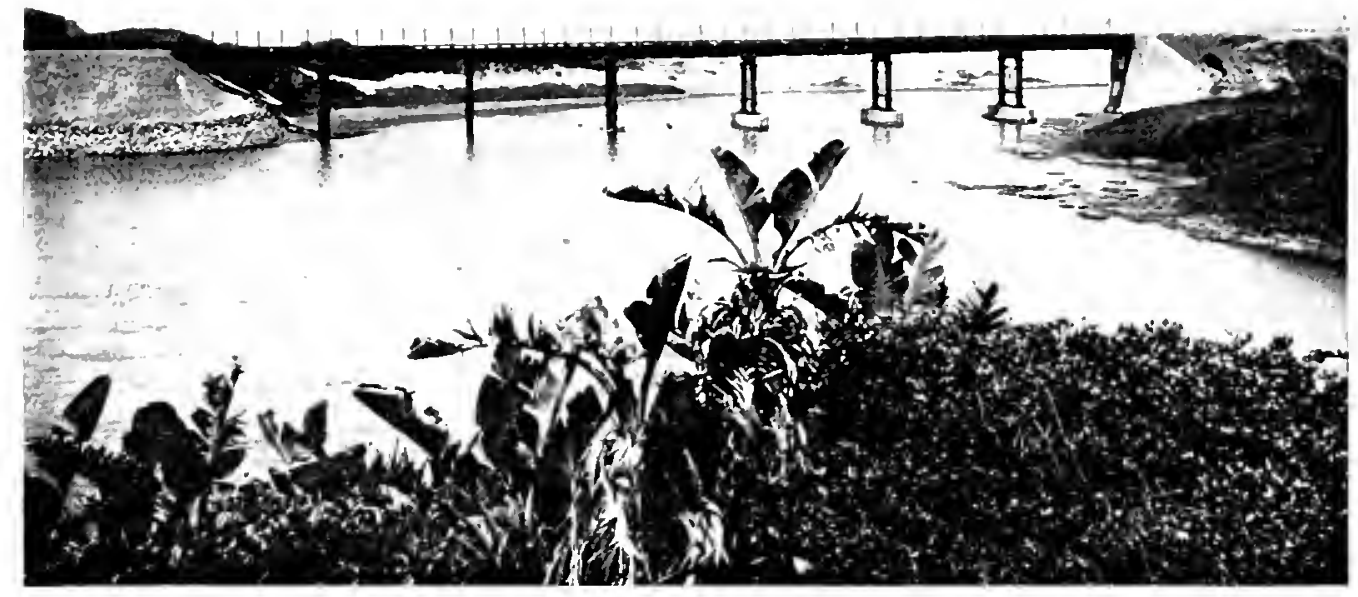

RUIWA PRIJGE, SOLIH COISI IIXI

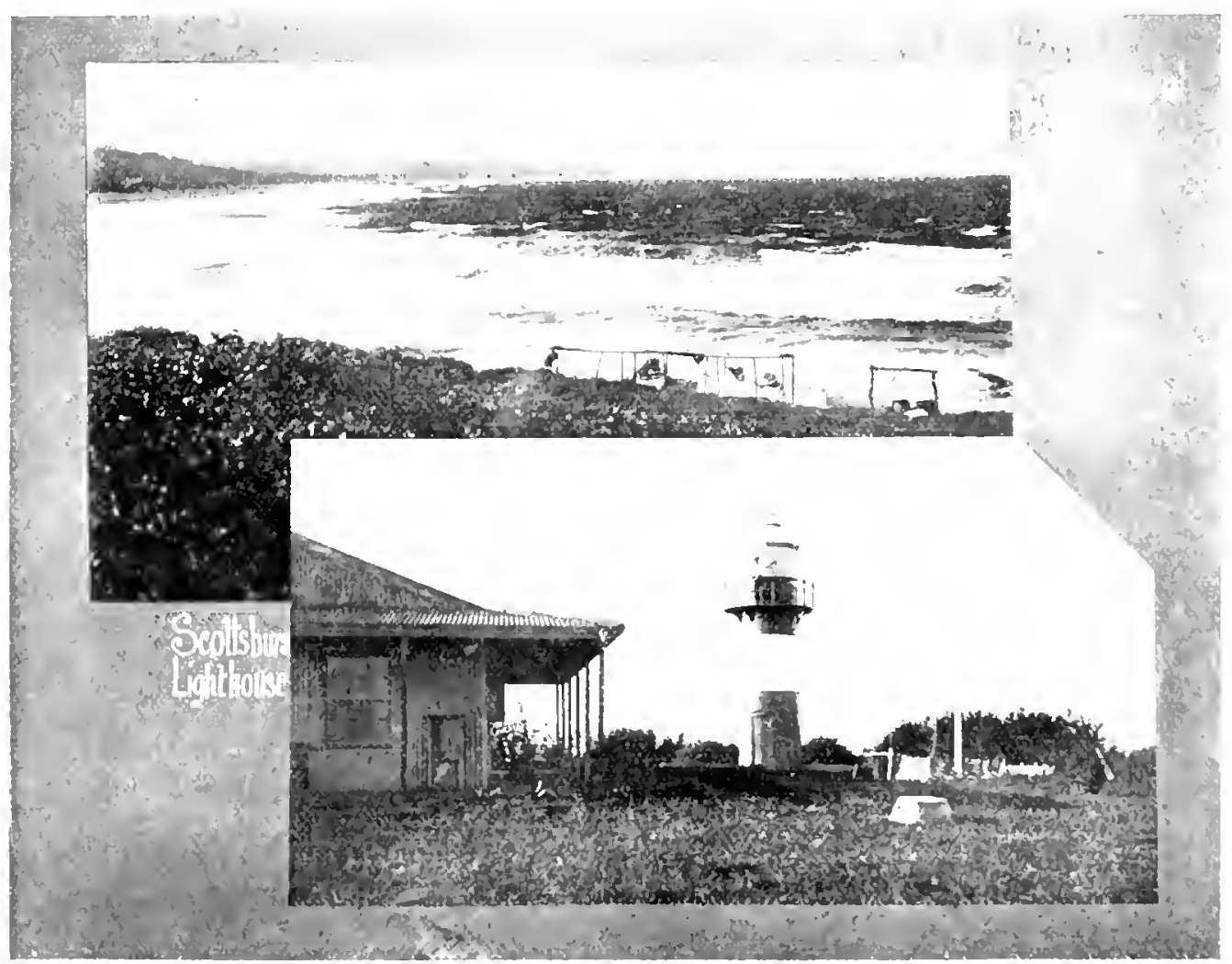




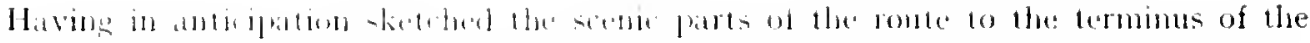

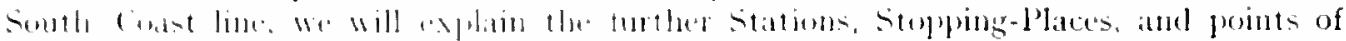

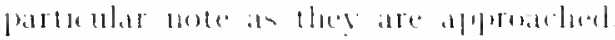

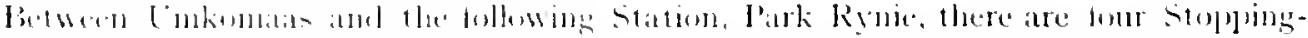
Plites. manty: Widenham. Clansthal, Crook's Siaing, and Scousburg. The tirst

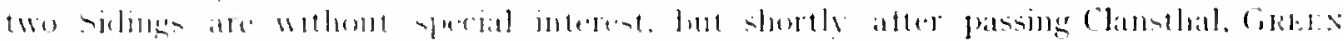

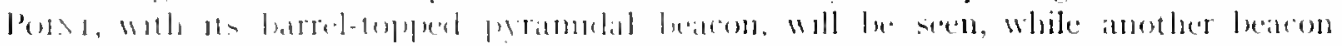

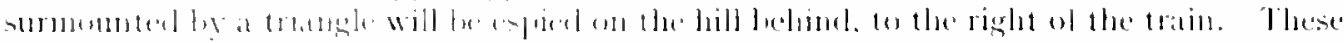

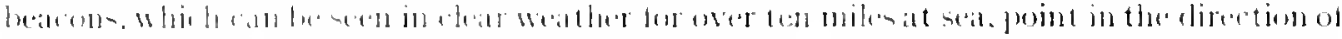

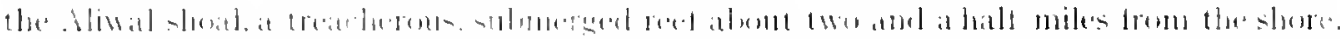

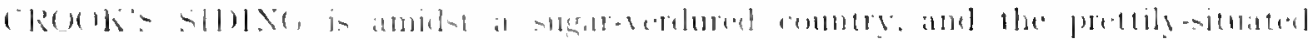

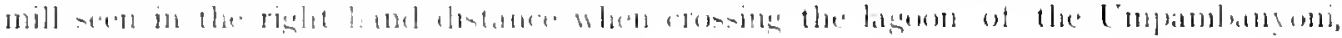

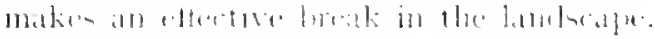

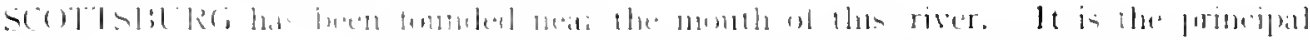

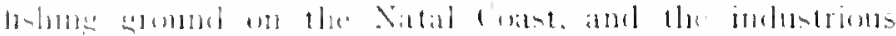

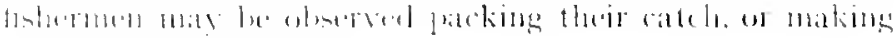

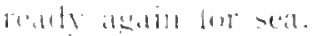

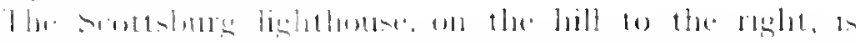

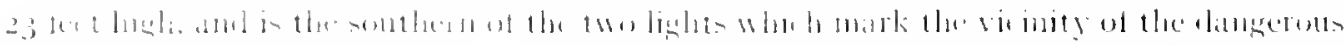

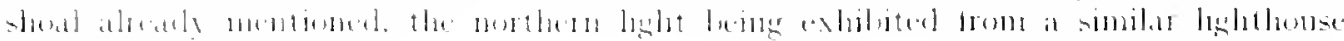

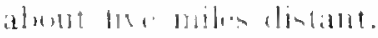

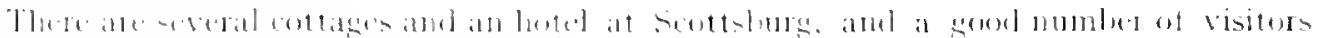

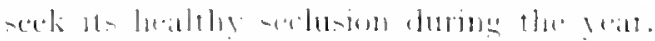

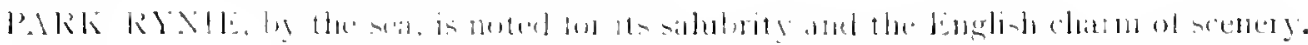

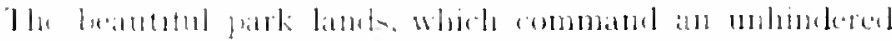
li.

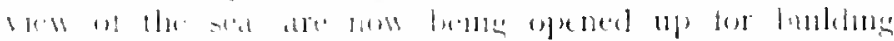

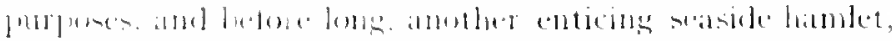

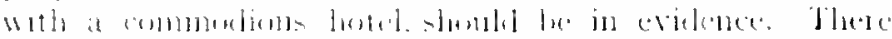

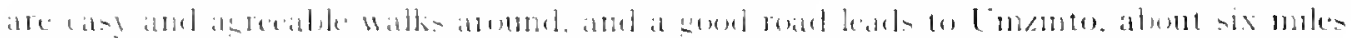

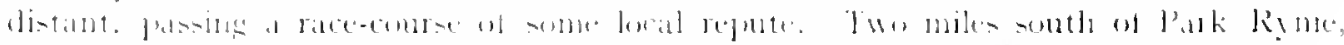

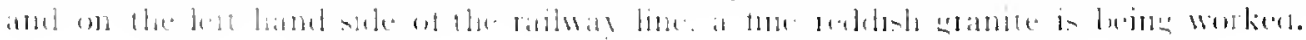

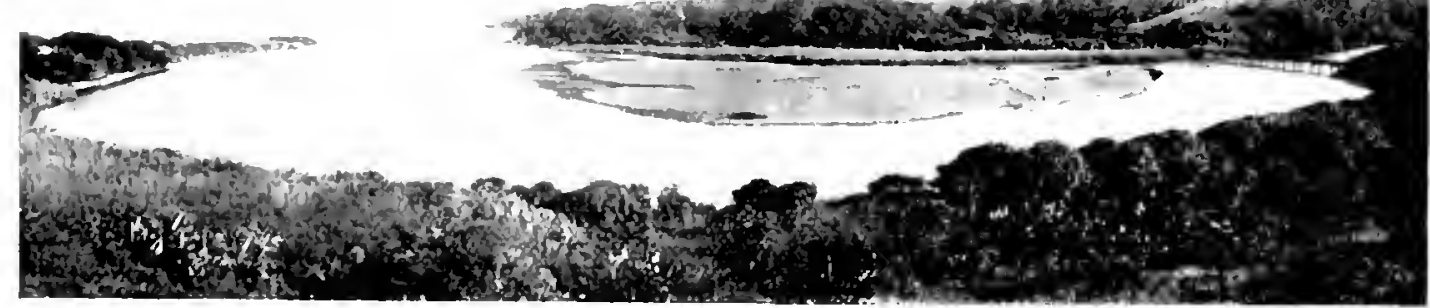

1.1(r) 


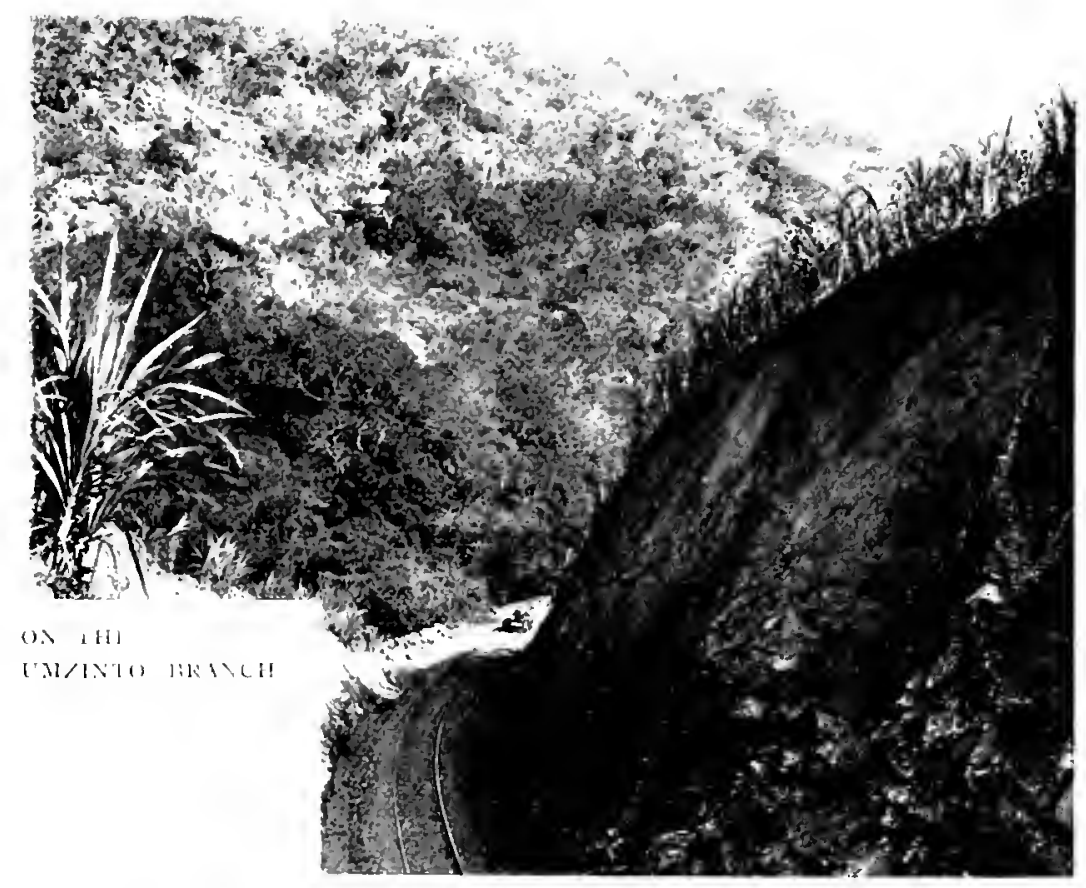

ALEXANDRA JCXCTUX is a station on the lageon of the Lmein to River, at the

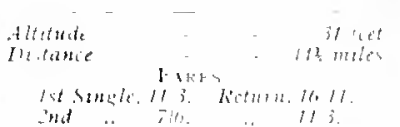
joining of the Cmzinto Prancls. The environment is excedingly choich. and a lovely view is gathered from the hill behiml the station. where an hotel is seen. Similar outuone enjorments are obtainalile here as at other resorts along the coast. and the provision of a tew beacli cottages would do much to popularise the place. A Railway refreshment-room will be found on the station plitform, and travellers are allowed the nstal twenty minuter for meals.

\section{THE LN\%INTO BR.N(H.}

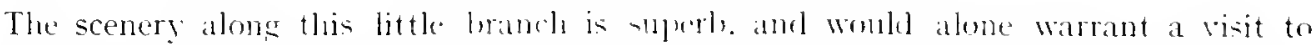
Umzinto. One may aisily imasine himselt transured for the moment to some remantic

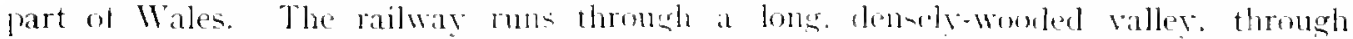
which the river lonzinto mednclers, now silently as it glinkes hy tall, rustling reeds

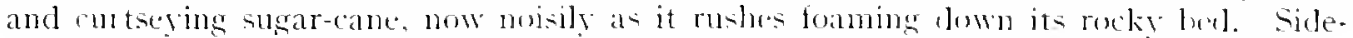
vales retreat at sudden intrablo from the sreater valley, which is inclesel

\footnotetext{
Gne vast mirss

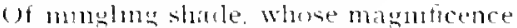

isrow valles emblusm "
}

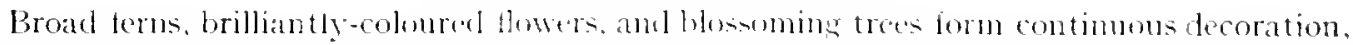
while libls are piled on hills revealing the preseme of manr-hued srante. The line follows the winding river for several miles, and some vers heare antings have had to be blasted. The only station on the branch, althomgh there are sertral sielings tiplping the sugar-rane torks. is 


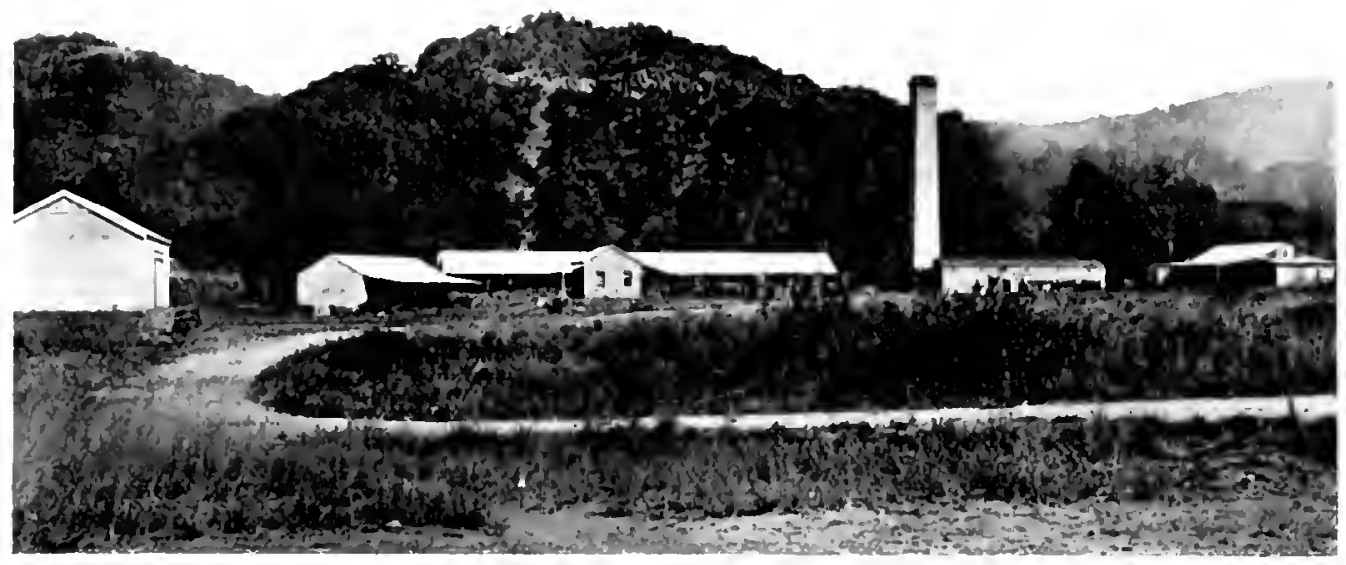

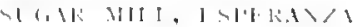

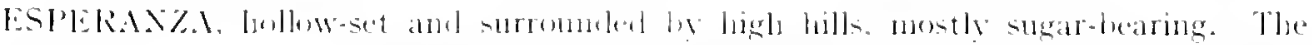
extersive sugar-mill and Distillery of the lisperanza listate

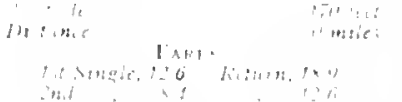
is lexte. It comprises some 5.5000 actes and gives am. plosment to mer toon Imelians. The prolific Equeta distriet contributes a lares quantity of the cane.

The neighlouring country is ereatly contorterl. and the singular formation would print

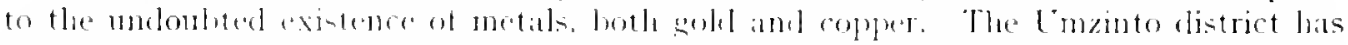

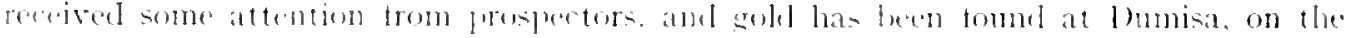

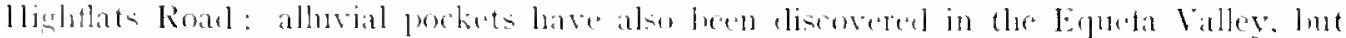

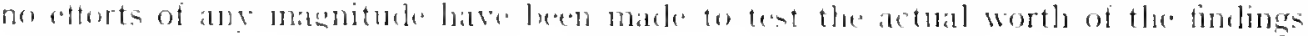

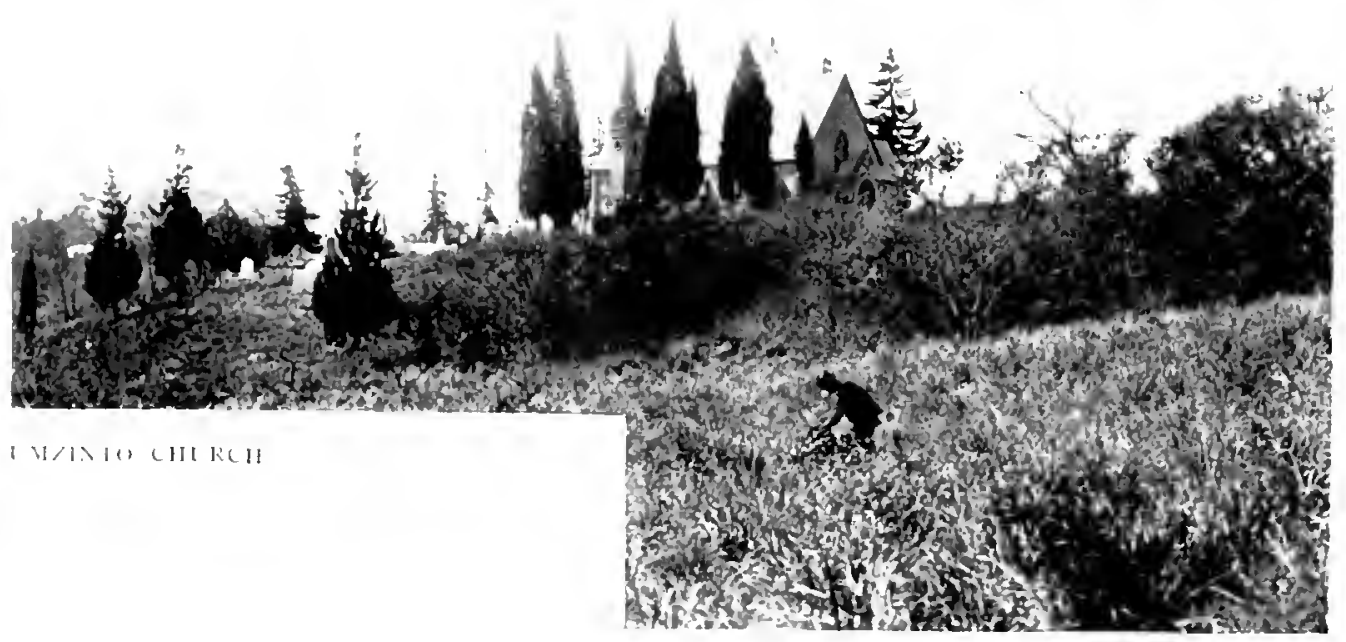


UMZINTO is a targe-sized, pretty, healthy sillage, qoo leet above the sea, in the vicinity.

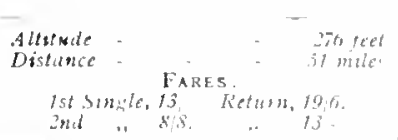
of some of the finest sugar-land in the Colony. The hilly approach to the main portion of the townlet is picturesque, and the Public Hall and adjoining temis courts and recreation grounds passed on the way, are very pleasantly situated. Umzinto is the seat of magistracy for the division, and possesses such useful and necessary buildings as a Magistrate's Court, Post and Telegraph Offices, Police Barracks, Volunteer Drill Hall, Armoury (this being the headquarters of the Border Mounted Rifles), Government School. Church of the Province of South Africa, and a Hospital. There are several mills, wagon-builders and blacksmiths' establishments, four hotels and a good few stores. The population consists of ahout 500 Europeans and a large number of Indians. The latter have their own schools and hospital. There is a Roman Catholic Mission in the neighbourhood. Besides the staple sugar, mealies. tea. tohaccu, and truit are imprortant productions.

Umzinto is $6 \frac{1}{2}$ miles from the South Coast Line at Alexandra Junction, and the Isranch train makes connection with the several passenger trains to and from Durban.

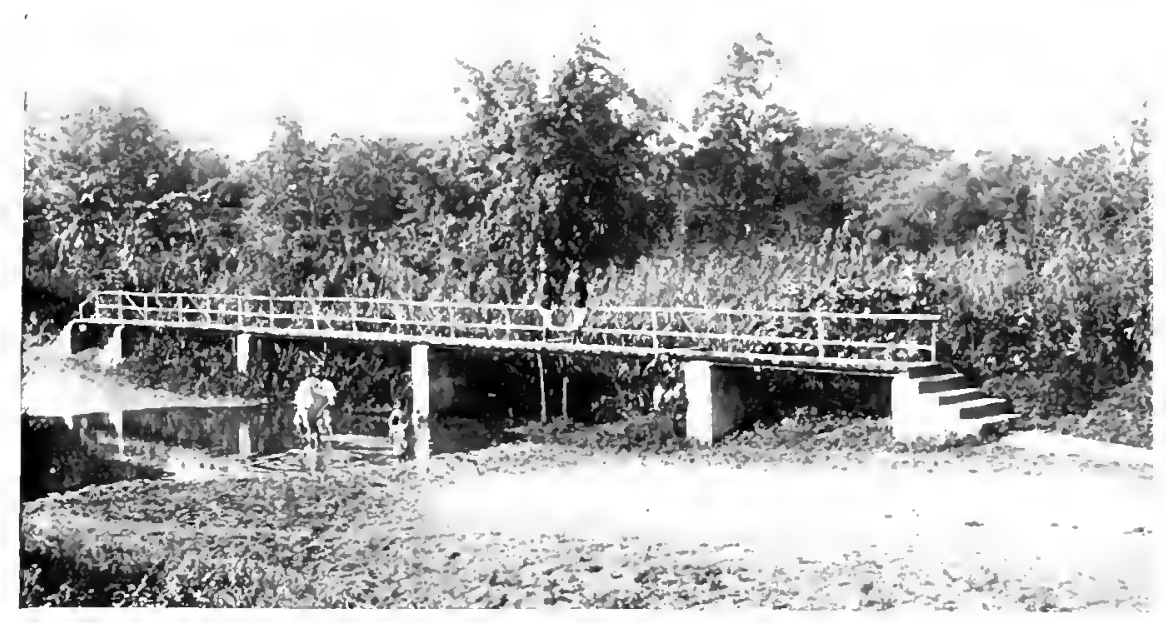

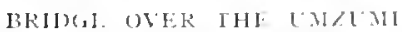

CHAPTER I.

\section{FROM ALEXANDRA JUNCTIOA 'TO PORT SHEPSTONE.}

$\mathrm{R}$

ETURning to the South Coast Line. Between Alexandra Junction and Lmtwalumi. the next station, the Stopping Places of Pennington, Isezela, and Ifafa are located. Ifafa is the best known of the three, and is one of the latest recruits to the health and holiday-resorts on this coast. The estuary of the river of that name is a striking sheet of water, and the general attractions are in no way inferior to those at other points, the only drawhack being that at the time of writing there was no hotel in the vicinity. 


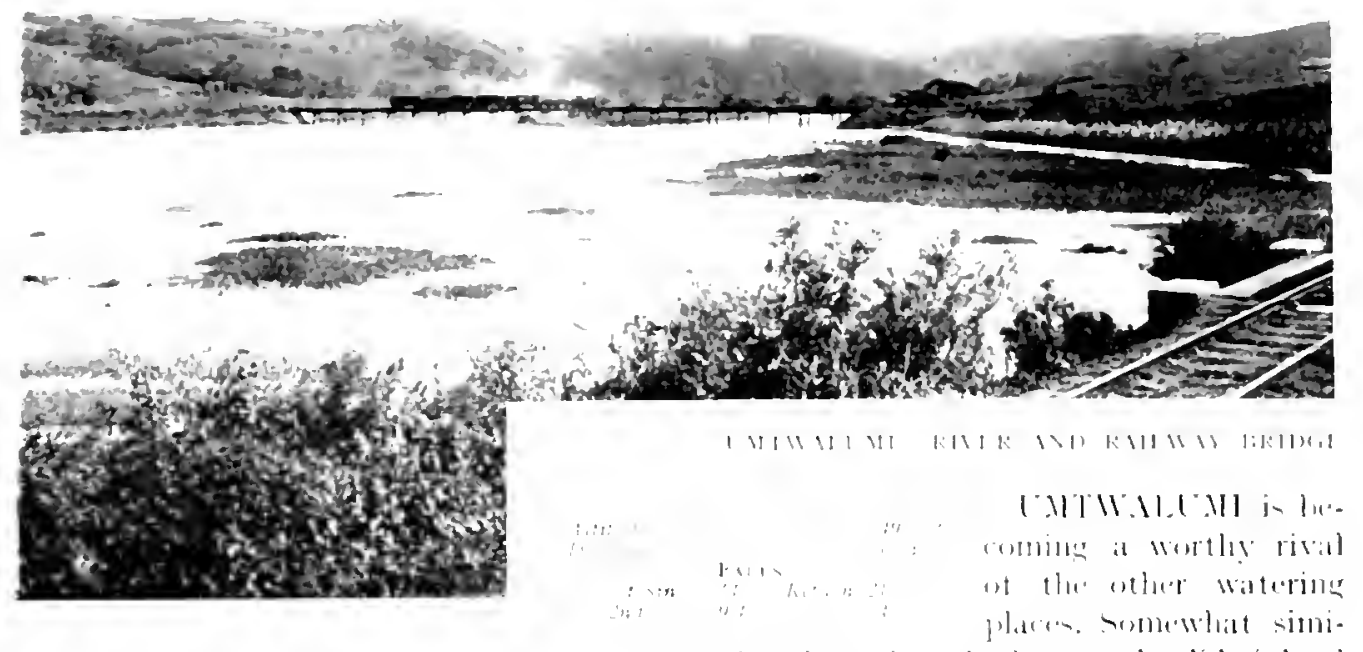

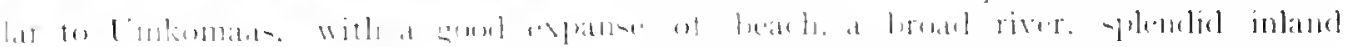

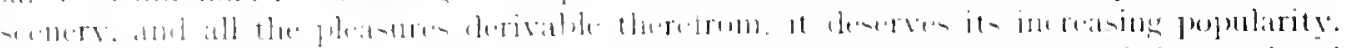

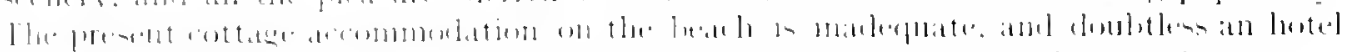

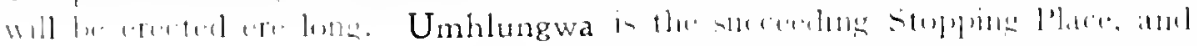

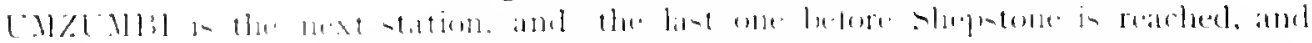

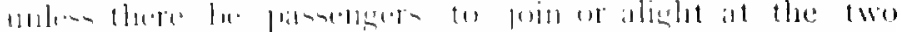

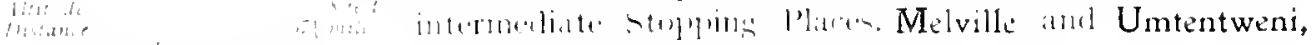

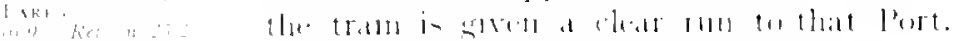

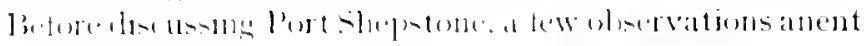

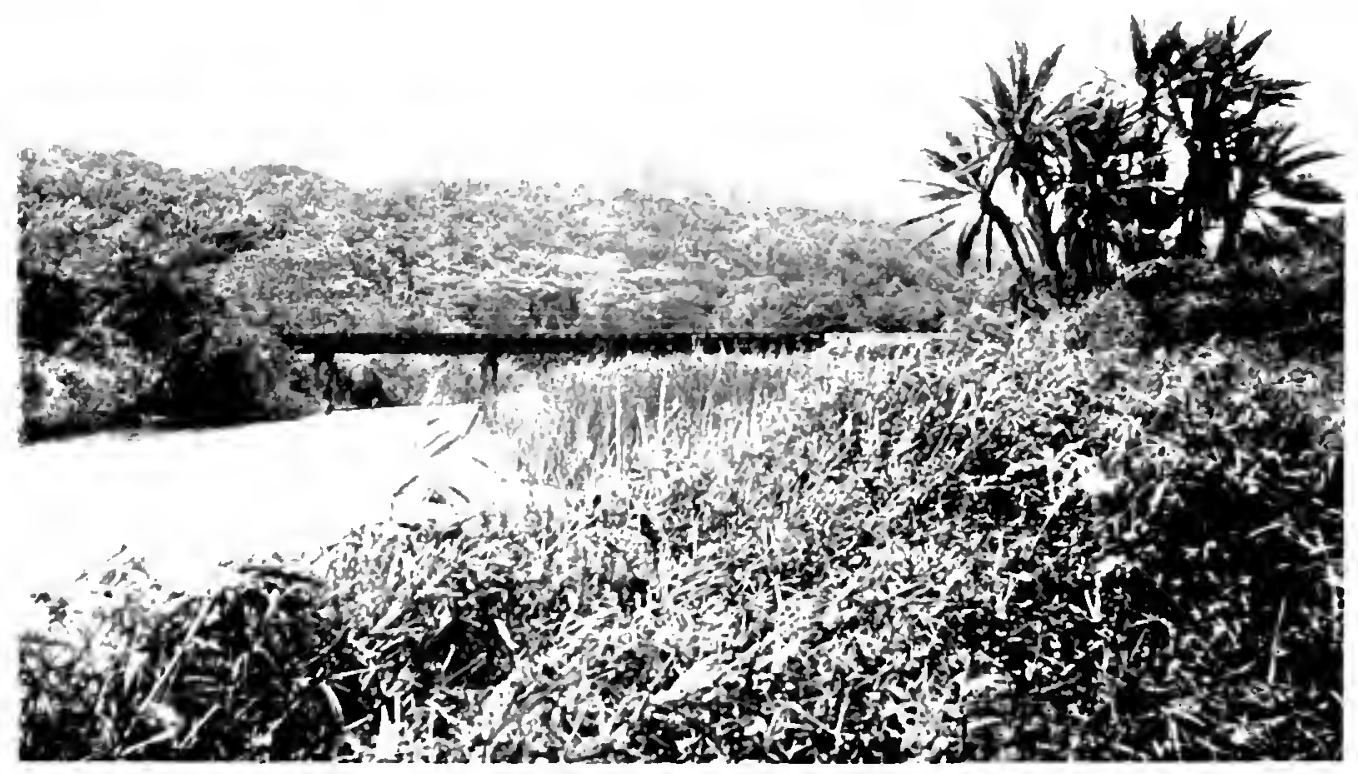

$40111(0) 1510151$ 
the railway and the country through which it passes may prove not unnteresting. The final section of the line from Untwalumi to North Shepstone was opened anidst much local jubilation, by His Excellency the Governor, Sir Henry McCallum, in July, Igor. The engineering difficulties in the construction of the line will have been appreciated, the chief of which was the crossing of the abnormal number of rivers and lagoons. lisetween Park Rynit and the present terminus ( $36 \frac{1}{2}$ miles) there are twenty-two rivers, involving no fewer than 5,730 feet of lnidging. The two longest bridges are those over the Ifafa and Umtivalumi, 720 and 630 feet long respectively. It is manifest, therefore, not only from this fact, but from the tresh and exulerant appearance of the country throughout, that the natural irrigation of the land is exceptional, and with the railwa advantages now existent, immerse encouragement will be given, not only to the agricultural and general farming spheres of labour, but also to the proving and development of minerals, granite, marble, and other rich deposits in this section of the Colony, which operations, with a tew exceptions, have hither to luen neglected.

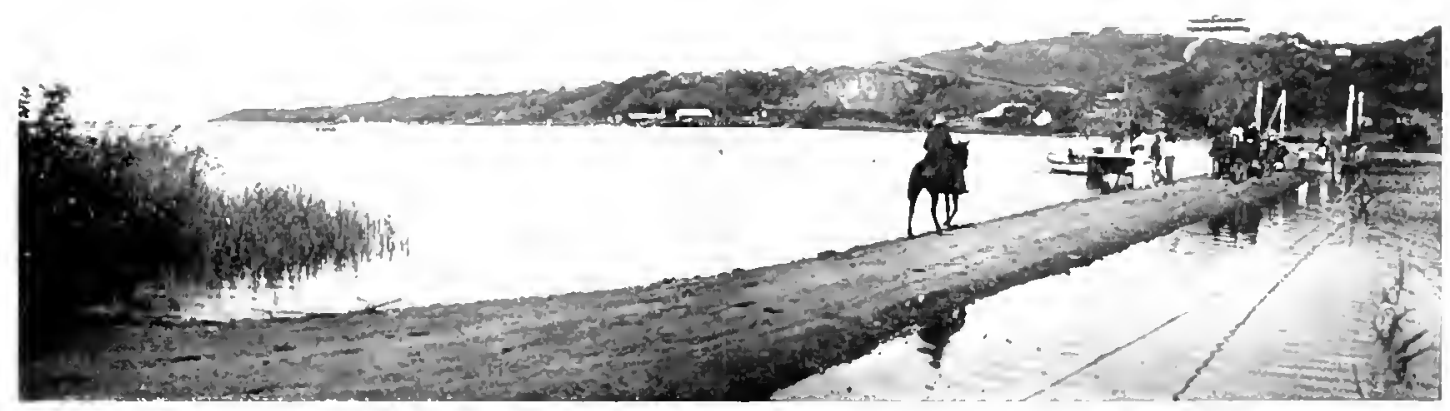

HORT SHLPSTONL:

PORT SHEISTOXE is situated at the moutly of the river Lmzimkulu, and was created

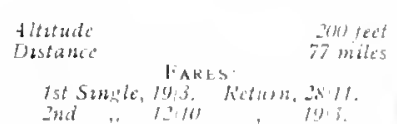
a full fiscal port in 1893 . It is the magisterial centre of the Division of Lower Umzinkulu, extending from Umzumbi River on the North, to the Umtamvuna on the South, an area of about sixty miles in length, by twenty-five in breadth. The settlement was pioncered in 1877 , and is named after one of Natal's ablest and most honoured colonists, the late Sir Theophilus Shepstone. The railway terminates on the north bank of the estuary, and the village, which is established upon a ridge of hills on the south sicle, is gained by the Government punt or ferry-boat. Train prassengers are taken over tree of charge, but other persons, animals, and goods are crossed according to tariff. When the suggested hurther extension of the railway is effected, the estuary will be bridged about three-cuarters of a mile from the sea. The line will then run at the base of the hills on the South side, and round the promontory upon which Signal Station stands, the Railway Station being transferred to this point.

Unfortunately, the liver Umzimkulu is choked at the moutls by a sand-spit, and the open channel to the sea at the time of writing was very narrow, witl an average 


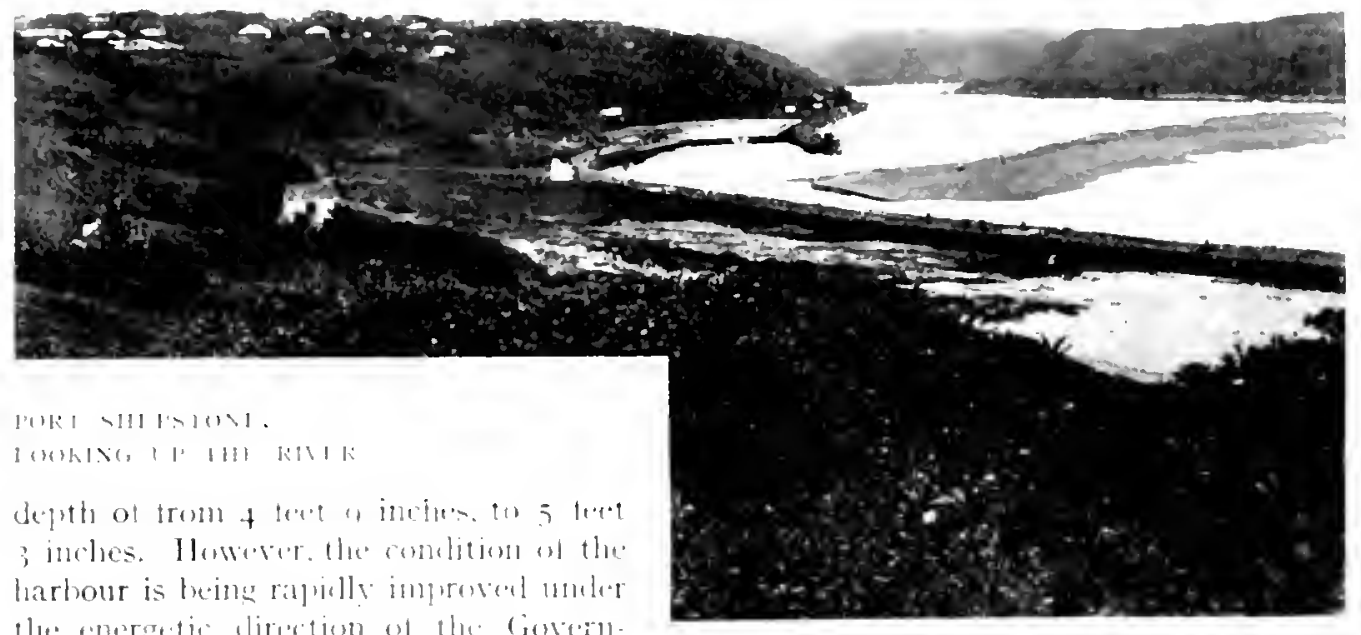

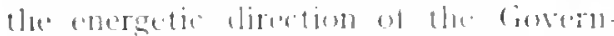

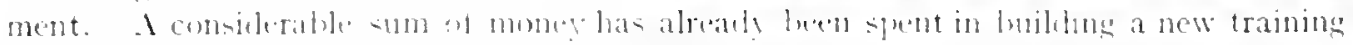

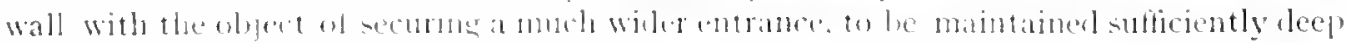

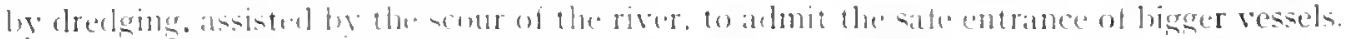

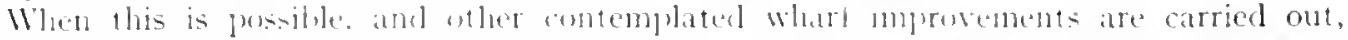

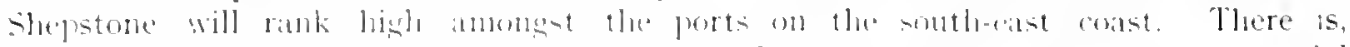

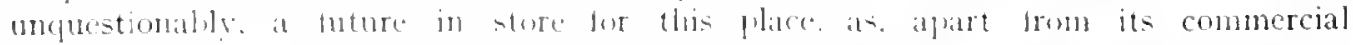

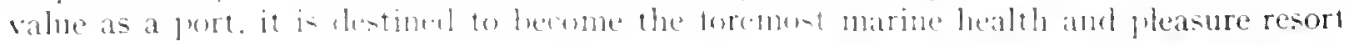

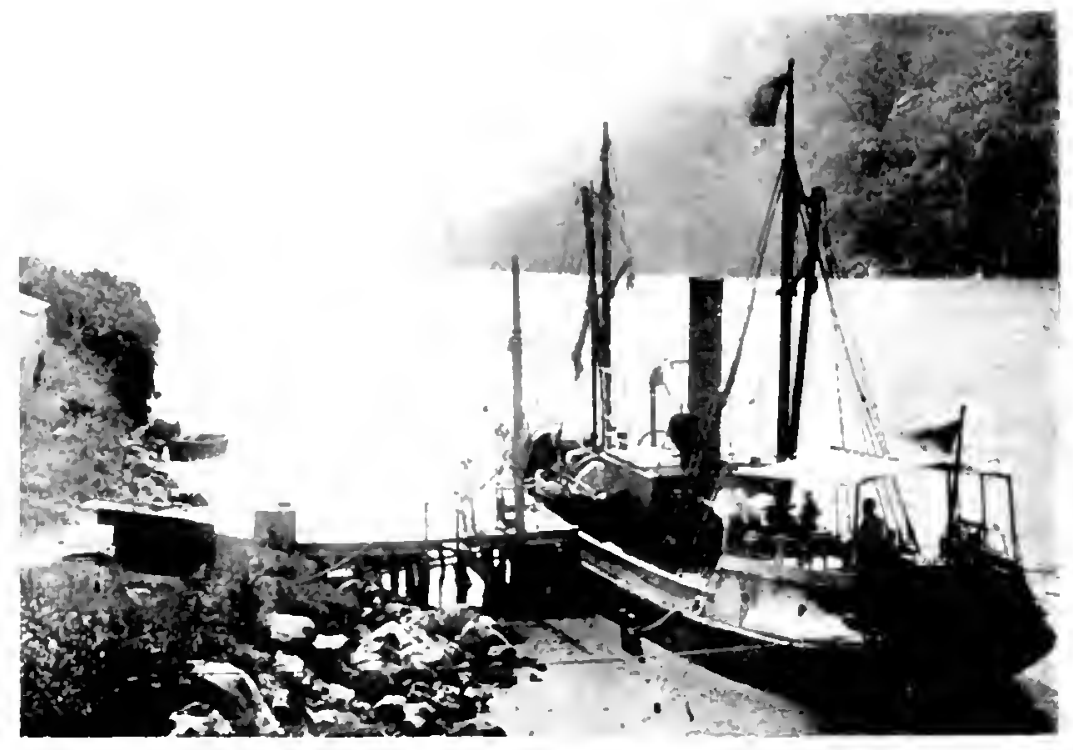

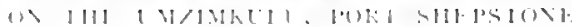


in the Colony. The possibilities are obvious. The better harbour would frermit travellers on pleasure or on business bent, to land or embark here at any time of the rear; circular trips could be arranged. giving the passenger the benefit of the equally enjorable journey by land or sea: launches could he placed on the beautiful river, which even now is arcessible to this class of hoat for some eight miles: and in numerous wars the natural advantages of Port Shepstone could be more pleasurably and profitably employed.

A few notes may be given as to the trade of the Port. The district is very fertile. and splendidy suited for the cultivation of sugar, tea, maize, and the rarious tropical fruits. The L'mzimkulu Sugar Estate and the Barrow Green Tea Estate. situated a little listance up the river. are noted for the excellence of their respective productions. Iinie, cement and marble are also important items. and the railway facilitic slould inerease thr outputs rery considerably. The fibre industry is being re-expermented with, and gond

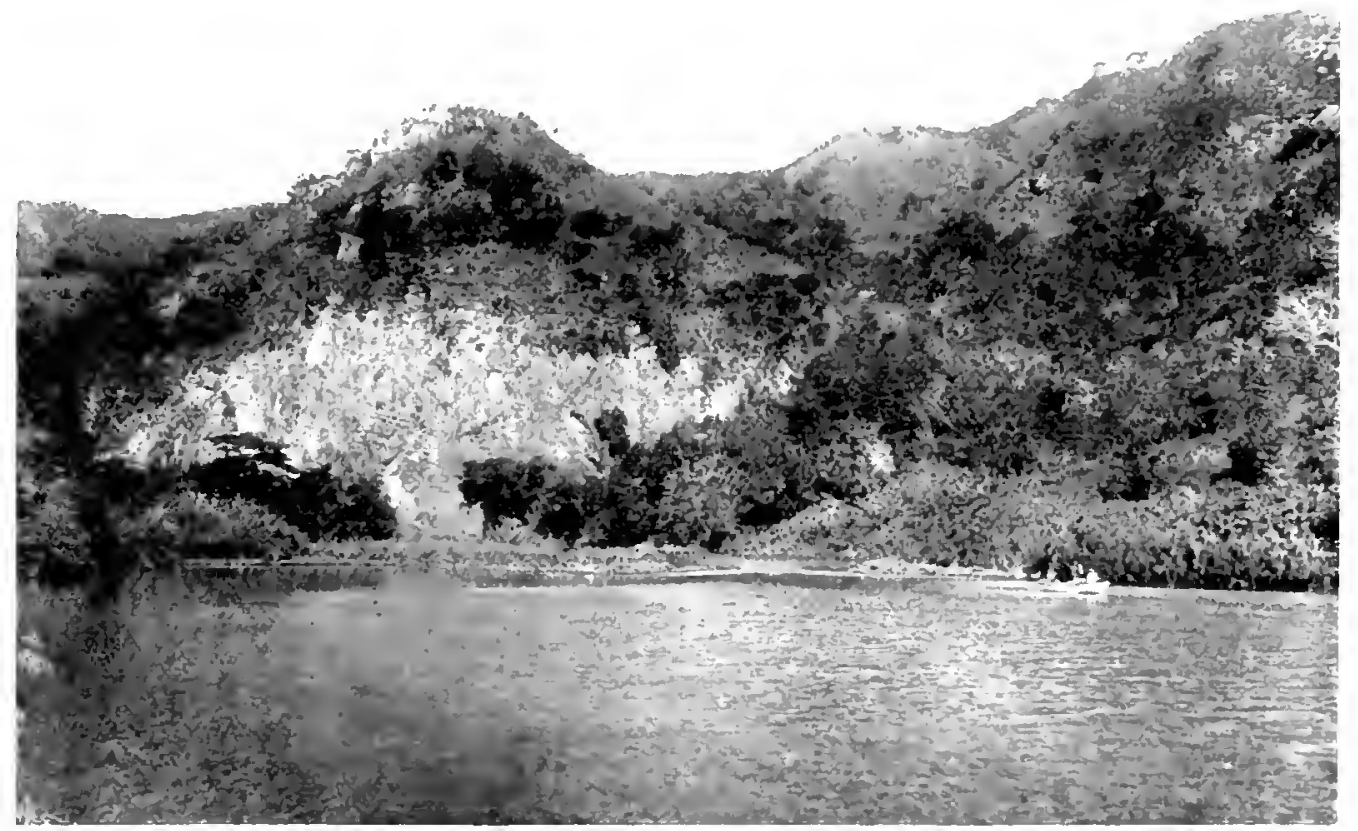

ST. HELEX'S ROCK, UMZIMKLLC RHER, PORT SHEPSTONH

results are anticipated. In addition to the foregoing. wool. hicles. horns. tarm-problec. and wagon-wood are larger traffics. Shepstone also boasts a prolific fishing ground.

The Village of Sirepstoxe and Exvikos: Glancing across the river, and sweeping the gaze over the sonthern ridge, which rise slow and unwooled at the sea. and ascends to lofty forest-hills, seamed by sombrous vales. little can he seen of the village. It nestles on the foliaged summit of the eminence, above the square-towered Custom House. Turning to the north side. which is somewhat similarly fashioned. hut few dwellings can be preceived, although the Govermment lands sold as building sites-one of the blessings: resulting from the railway-will doubtless soon be occupied. The hroat and heautiful river divides the settlement, and the sea confines it on the east. 
Although shepsene contains all the huldings and residences incidental to a magistracy and tomship, it is moge in size for a watering place and port, but, with the buikling operations wow procestims a little while shomle sec it equipped with the requisite accommodation for a large intlux of visitors. lesiles the many settlers who are sure to be attracted hither. To the anterprising there are splemblepportunities at Shepstone with its unique and altogether ideal situation. In mother part of Natal has Siature trimmphed in her scenic skill as here.

coming to the individud attractions of lont shepstone. the linest is, of course. its regal river. which is natigahle to the first of the three tapids. a distance of aloont eight miles

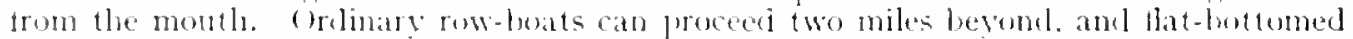
ones even another five miles. So many lave destanted upon the glories of this replica

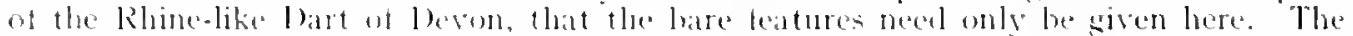
firs: fwo amel a half miles of the river are straight, amel maintain a wielth of a humelnel amel

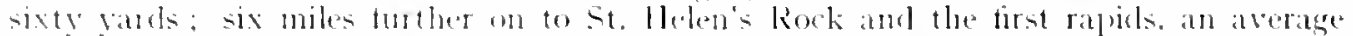

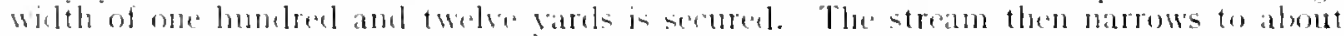

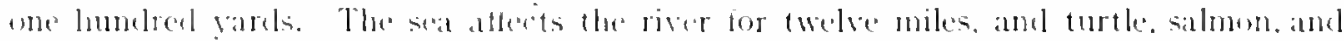
isuanas are common sport therem. The first object te clam attention is the unforiable

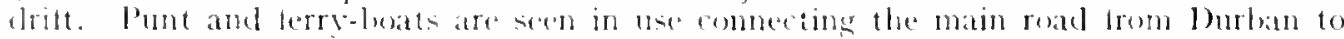

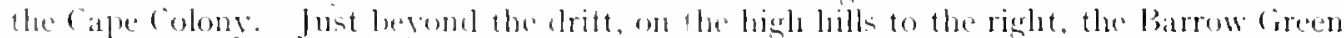
"leat Estate is situated. and a mile or so turther down, on the left bank of the river. the

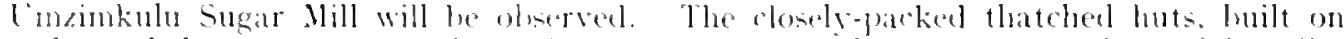

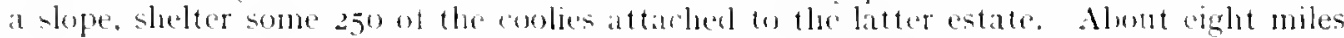
from the mouth. and in the vicinity of the alene (bilere) plantations, and the celebrated st. Helen's Rock, the tirst raphels are encountered. Small vessels elrawing 5 feet 0 inches of water an run thus far. In oreler to vint the majestic precipare which conceals a leep cave, or to push up the river to the Marble Quarrien. the launeh must le exchanged for the row-boat. The irst and seromel rapists are in chose proximity to one another, but the thire are some distance higher up. and ocasionally impassalile. The question of diverting the stream at this pont is now reviving the onsideration of the Government.

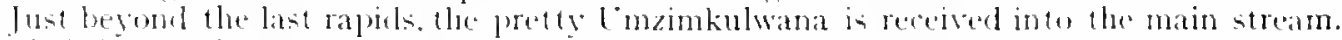
Alighting at the point where a shed will be noticed. and bollewing the tram-line we the grand valley of the Lomzimbulwana a matter of a mile. the visitor will reach the lime-kilns at the darble betta company. The extent of the white dazeling erystalline rock. which in burneel to probluce this articles seems unending. both the lime and the cement-mate

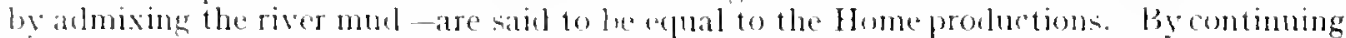
dionn the valley, about a mile and at hall beyond the limeworks, the levely retreat called the "Giritto" will be found.

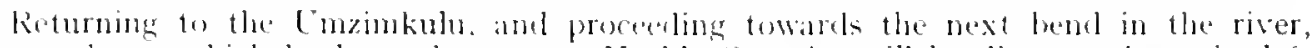
the pathway whith leads to the tanons Marble Quarries will be discovered on the left lank. There Well merit a visit, and "10 ramble through Nature's Marthe Halle and

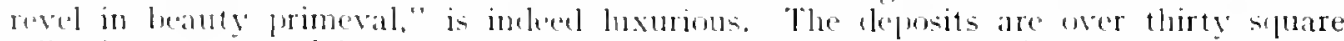
miles in extent, and in some parts over a thousand feet thick. The marble iarles in rulour trom red to white, and great results are expected when guarring commences in earnest.

The Marlle guarries genterally terminate the river tour, but as alrealy mentioned, the stream is still navigable for several miles further. Gookl sport in hush-luck. deer and game is posshle in the sason. While ledpards may oceasionally be found in the forests. Apart, however, trom this inducement. the scenery is of such thrilling loveliness that it would amply relay a leeper penetration into whe wilds of Natal, where

\footnotetext{
lhe hush of human lite

leets the low volice he heard-

The Jow sweet, sislemn vore

()t the deep wourds.

It mystical murmurnge

Xow swellong bnte choral harmony
}

Rich, full, exultant :

In tremulous whispers next.

Sinkungr away

1 sparitual undertone,

Till the conng of the worel pugeon

is heard alune." 


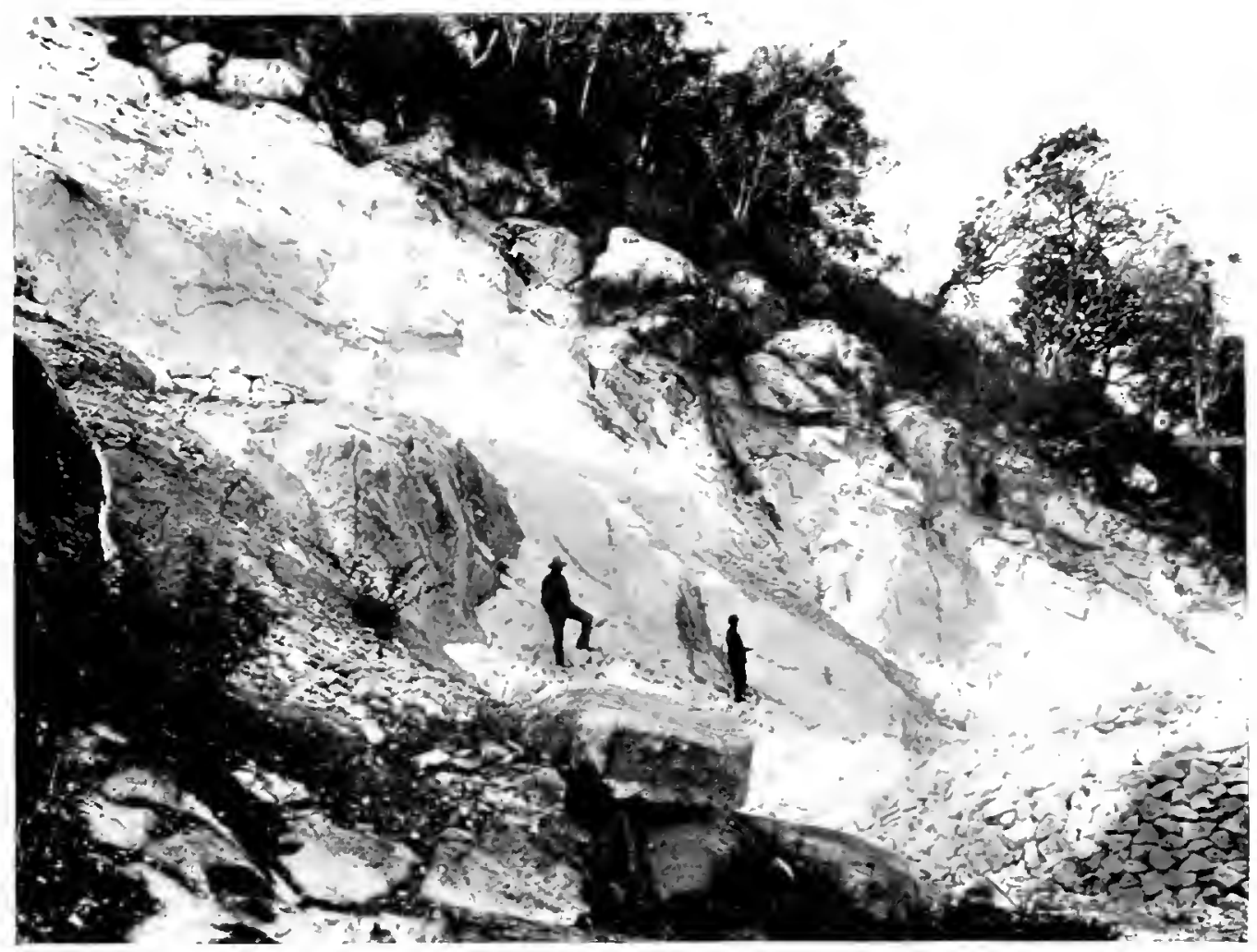

MARPIE ULARRIES. HORT SHIPSTONH

Of the other attractions at Port Shepstone. hesides boating. bathing. fishing. and shooting nav be cited the charming hridle paths and roads by river and sea-and in land tooand especially the one along the bank of the river as far as the drift. Then there are the beach-rocks, about a mile rom the railway station. to be visited. for ther recall shuddering memories of the bartaric dass of the Zulu lings. Anrone will point out the "Place of Death," or "Devil's Hole." as it is called. where the sable monarchs of old were wont to wreak so terrible a vengeance upon their unhappr victims. A hole satanicalenough in all conscience, apart trom its one diabolical association-black, narrow, deep, perfectly: smooth, with an opening at each end admitting the terrific rise and fall of the boiling sea. Into this the wretcled culprits were dropped and left to a helpless and inhuman hattering to death by the incessint rush and recoil of the maddened waters - a more ghastly mode of execution improsible to conceive.

IARBtRG must not be forgotten. It is a small Norwegian farming-settlement three miles away. and affords an interesting walk.

Shepstone, the most Englinhlike of Xatal's resorts, and situated in an atmosphere particularly bracing. and most delightfully equable, has fascinations for one and all. whether health-secker. pleasure-secker. artist, scientist, sportsman, businesi man, planter or farmer, and its prosperity should be writ large before many years. 


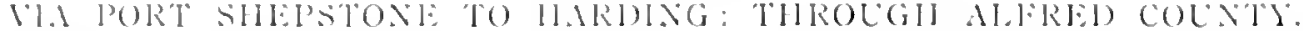

$\mathrm{T}$

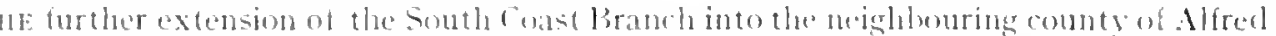

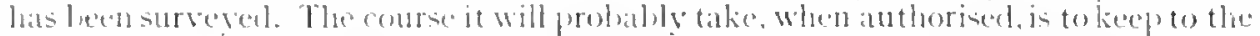

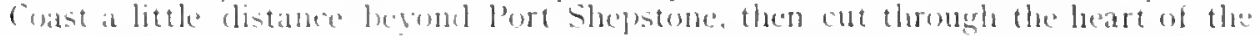
connty, passing near Harding, and terminating on the horder at a point which will

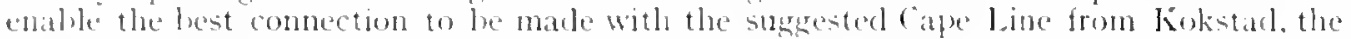
captat of East Griqualand. Wherely a shorter route between Patal and the sister colong wou'd be abialable.

Dlired $r$-unty is eminently favouralle, near the Coast, for the cultivation of the same commolitis as the Alexandral County sugar, tea, tohaco, maize. fruits and hibrous plants: and the richness of the inner pasture land is aldmirable for latiry farming and stock. while outs and forage would yelel good crops. The alvent of the railwaly will greatly promote the farming and industrial activities in this resonrceful, hut as vet. manakened shire.

Harding, the capital of Alired County, has lut a small population and few buildings. stock larming is the principal vocation. In the vicinter of the Ingeli Mountains, whels diviale Mhred County trom Griqualand bast. large quantitits of graphite have been found, and the workings liave proved three parts carbon. Some of the finest timber torests in the Colony atre also situated in that locality.

The present access to Harding is 19 post-cart. I hally service runs trom Richmond,

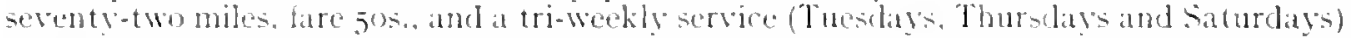
trom l'ort slepestone. 5 si miles fare zos.

betore equiting this southernmost division of the colong, it might be stated that the Lmamvuna River, the boumlary line between Natal and Pondolind is a very beatiful stream, and of striking similitude to the lmzinkulu.

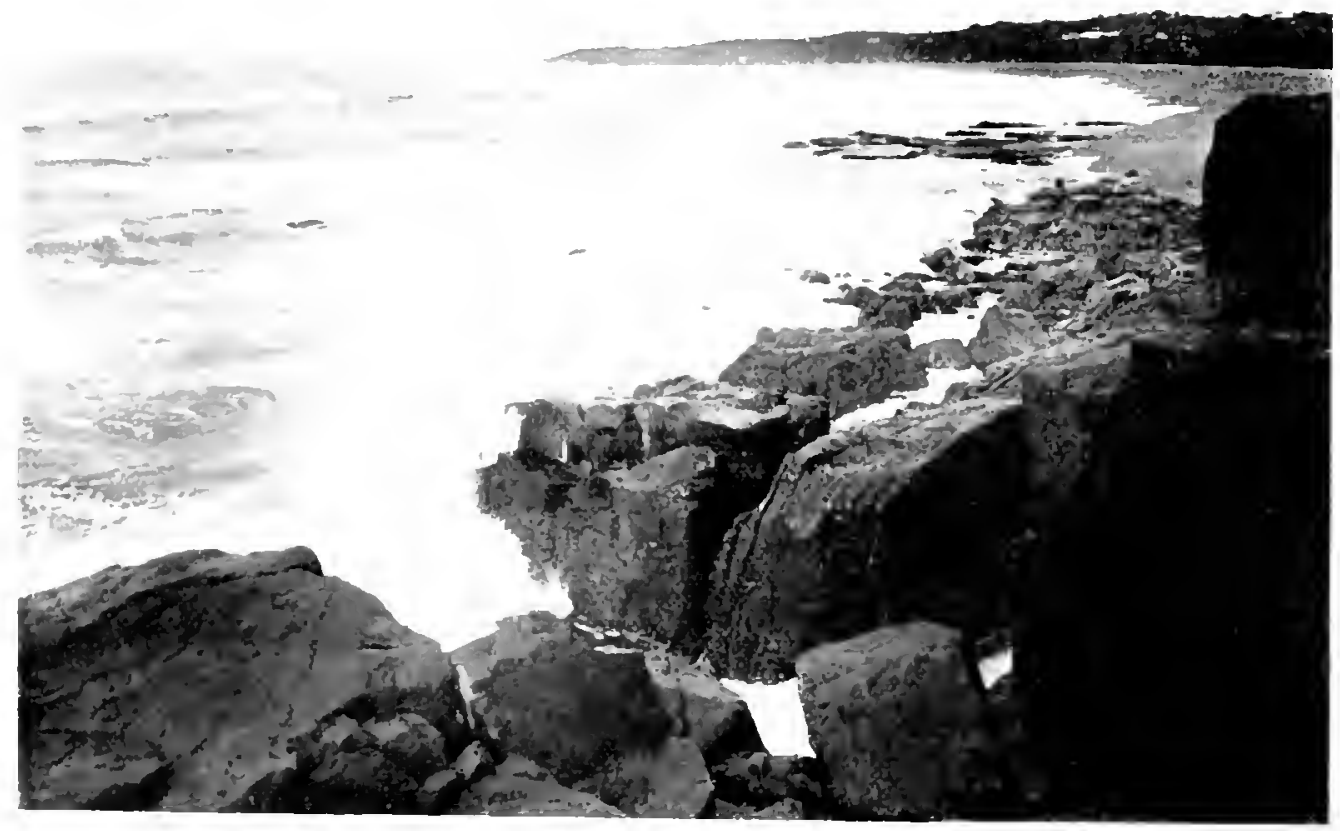

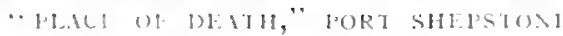


PART SEVEN.

\author{
OTHER BRANCH LINES OF \\ RAILWAY AND POST CART SERVICE \\ TO BULWER.
}





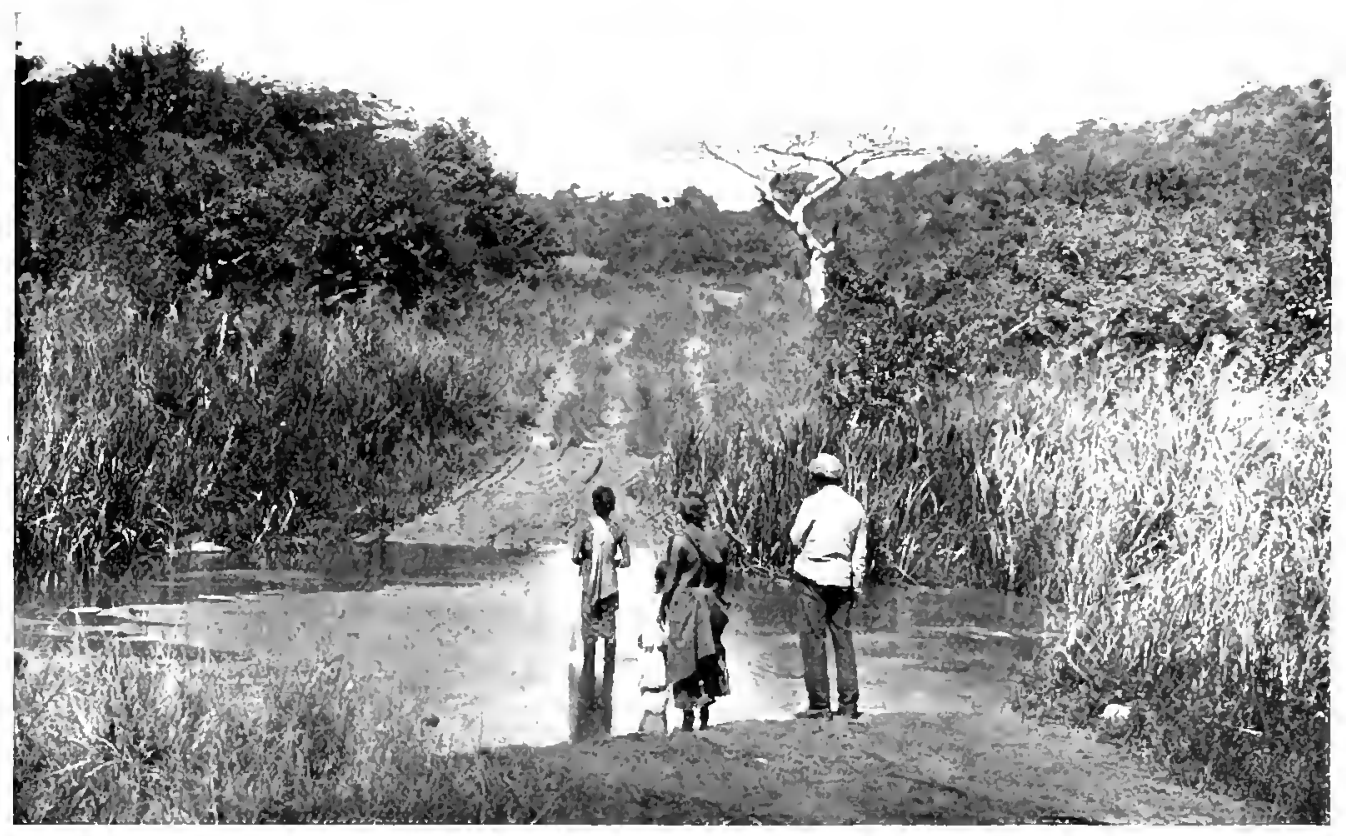

INDIANS CROSSING I DRHI

\title{
PART SEVEN.
}

\author{
CHAPTER I.
}

\section{THE RICHMOND BRANCH AND BEYOND.}

$\mathrm{T}^{\prime}$

HE Richmond Branch was opened in December. Ifog and is I miles in length. It shoots from the trunk line at a proint just south of Thornville Junction. Its passenger service is two trains ach way per diem.

NEl.'S RLST is the initial station. Its traftic is principally in diniry produce, a

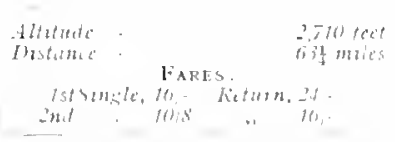
considerable quantity of the milk and crean consumed in the Colony emanating from this district. Wattle. growing is also largely indulged in. The most extensive acreage employed in these pursuits is undoubtedly that owned by Mr. Joseph Baynes, C.M. . ., M.L.A., a gentleman noted tor his scientific farming and progressiveness. One of his heneficial ventures is the well-known creanery, which 


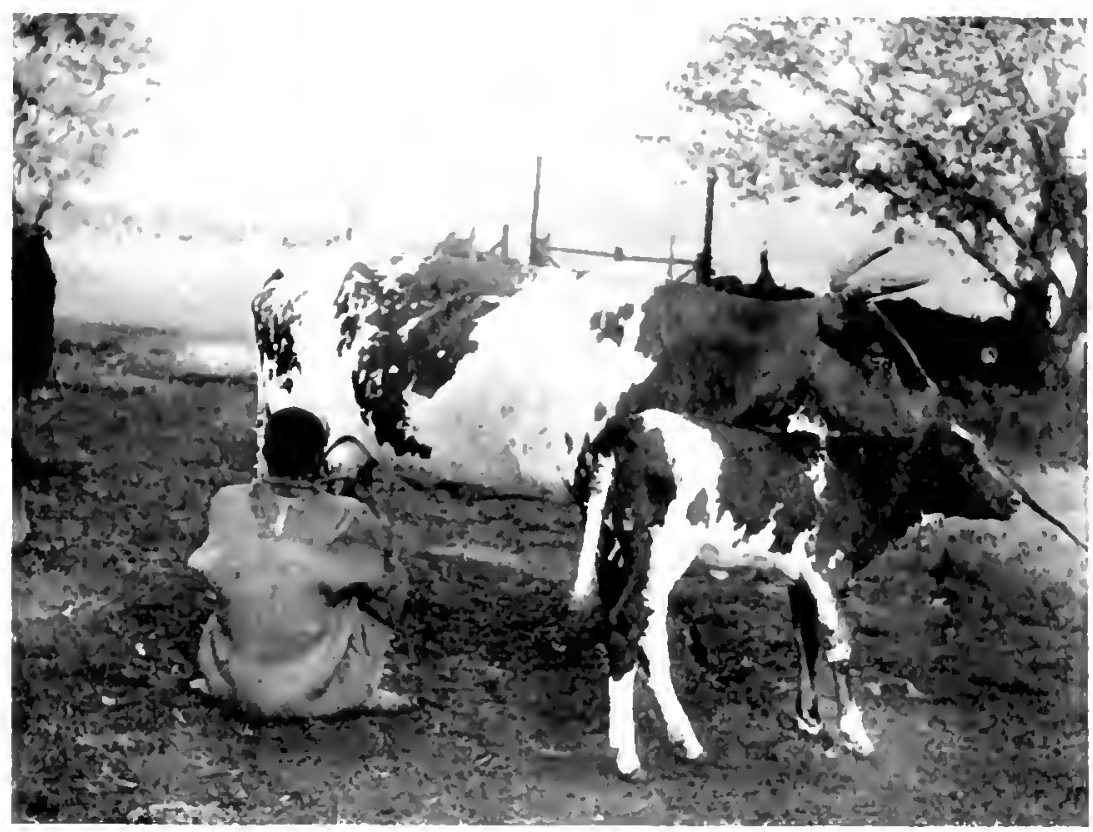

KII IK IIIKIS,

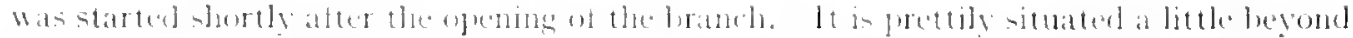

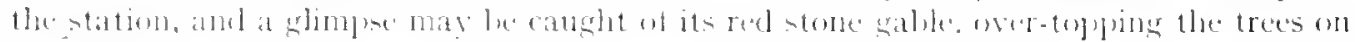
the officle ot the train.

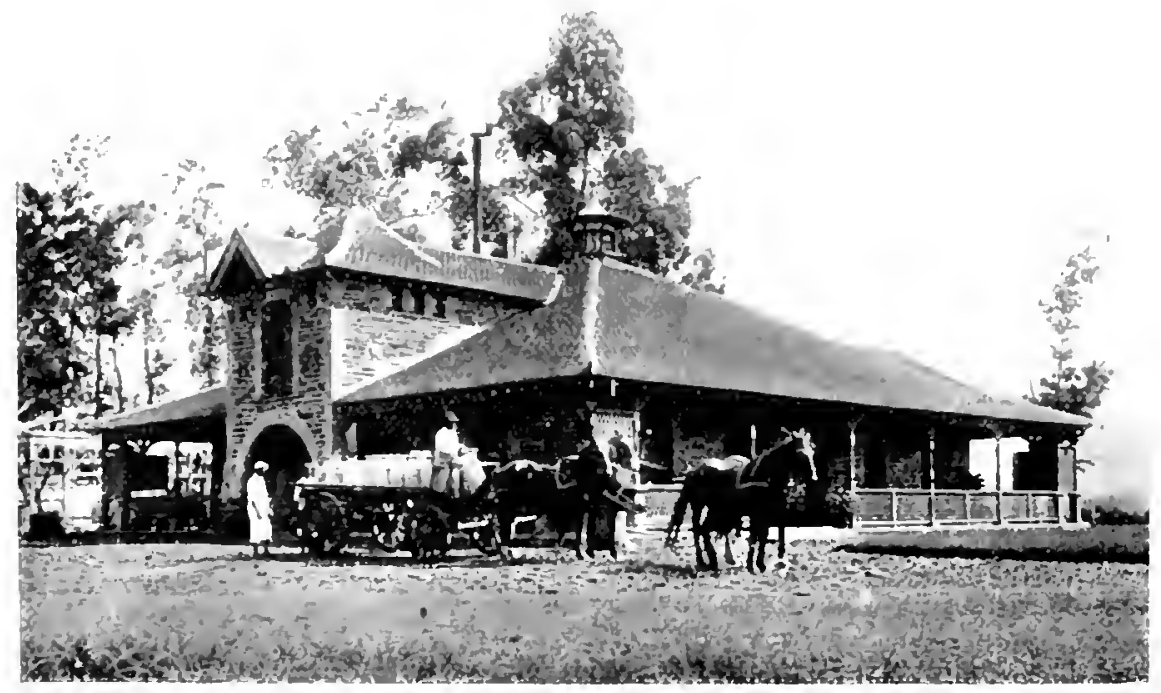

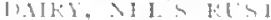


Beyond Nel's Rust, the irregularity of the country is more pronounced, but there is little to entertain the eve, except a farmstead here and there, a clump of trees, a few cattle, or a casual kafir kraal.

ARNOLD'S HILL is the second point of call. and, when necessary, Green Hill and Durban Road the following ones. These wayside places serve the farms in their respective ricinities.

From the last-named siding the train has an uninterrupted run throngh more agreeable scenery to the terminus of the Branch, and, before a curve is made into the busy little station, we obtain a comprehensive view of the village.

RICHMOND, on the Illovo, has a population of about 500 all told, and, like its more

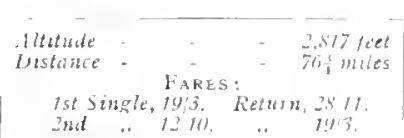
aristocratic and historic namesake on the Thames, is pieturesquely pretty. In its formation it is similar to the generality of South African towns, and is presided over by a tall peaked hill, called the "One o'clock." which

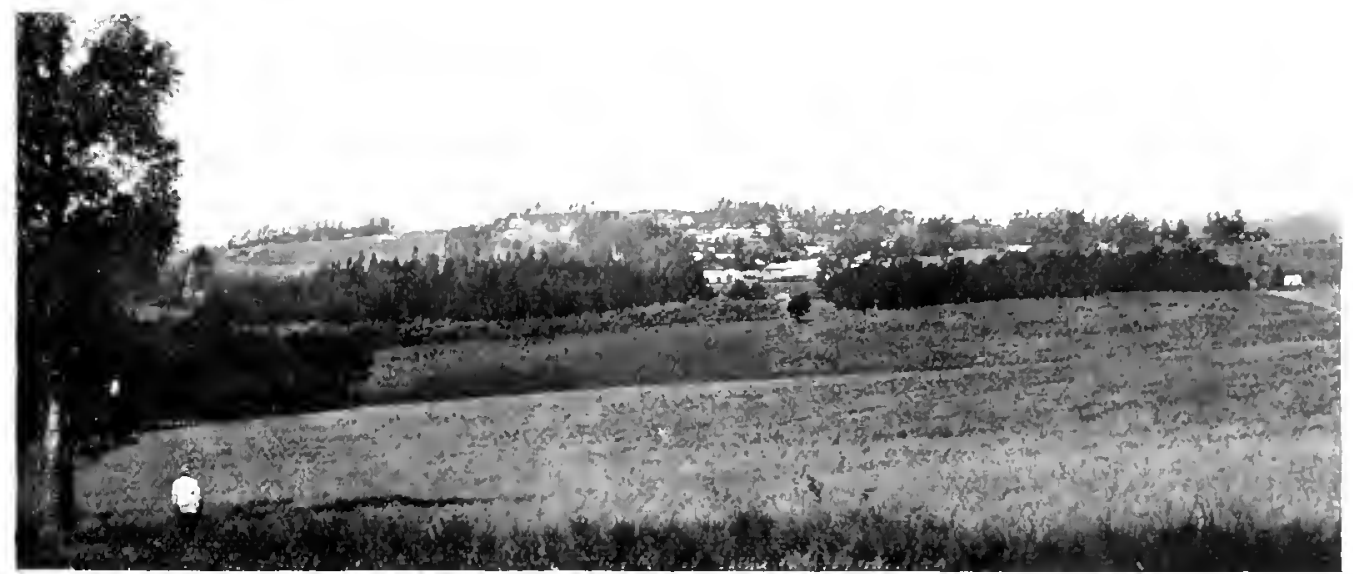

RICHMON1)

rises rather abruptly at the north end of the village. From this eminence. or from that of its neighlour, "Byrne," espied a little to the left, a good view of the country" is secured.

The main street leads through the centre of the village. and a walk along this tidy: thoroughfare reminds one cxceedingly of the Honelind. The neat, tile-rooferl houses set amid a wealth of flowers: the hurtching arches of clustering eglantine and rose: the weather-beaten church with the vicarage ensconced in the leafiest corner of the village; and the willow-bowered grist mill by the river, conjure sweet visions of a fardistant scene.

With public and other buildings the townlet is plentifully stocked. There are three churches, a commodious double-storeved liotel. Goverment School. Post Office. Agricultural and Masonic Halls, and miscellaneous Stores. It is not lacking either in Social and Industrial Institutions and the like, possessing Agricultural. Literary, and Glee Societies; Rifle and Farmers' Associations: Cricket, Tennis, and Croquet Clubs, as well as a good Library. 
The water supply"

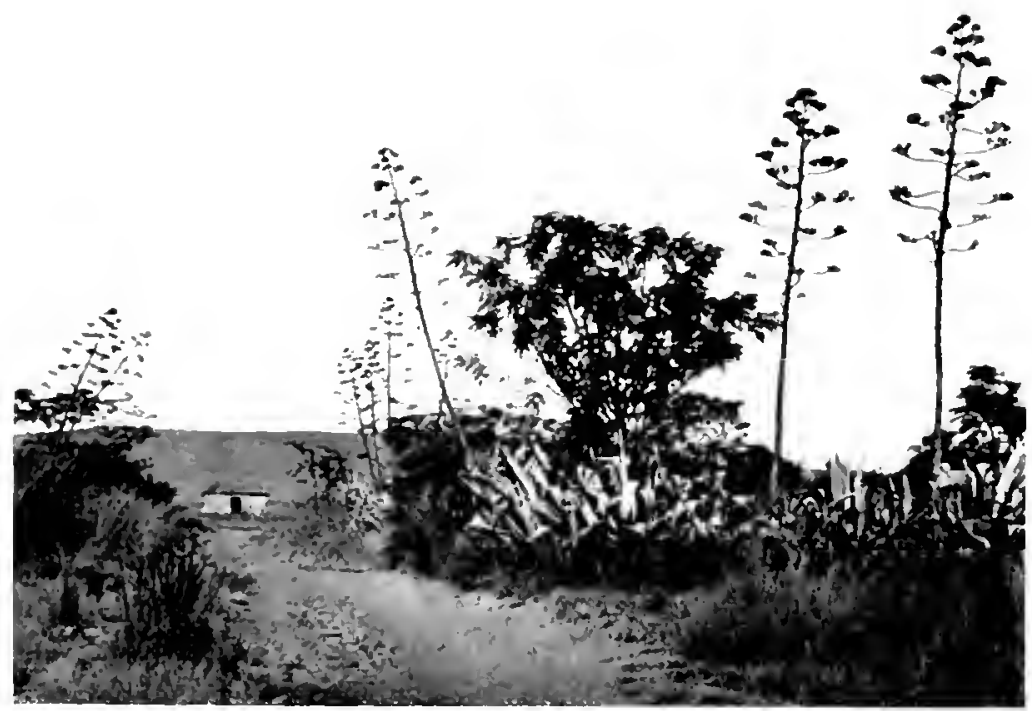

is is prominent fea. ture. This is secured ly gratitation from a coprons spring in (1610 of the hills, and is conservenlin cove "redrederroirs. It is "laid on" to evers" hollso, andel is re. markialle for its coolnues. exen on the luottent days.

The villatge is rery laraleliy and emimently suited both as a recuperative andaploasure bace. lts comenient train service alsoplaces it

within easy reach a a werkend resort.

So far as its trate and farming facilities are comeromed. Richmonel is at consequence. It is the centre of a laree and flomishing agriculumal and pastoral district. in which

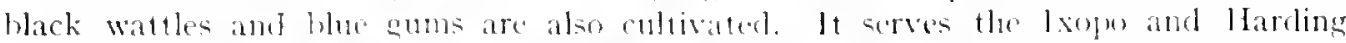

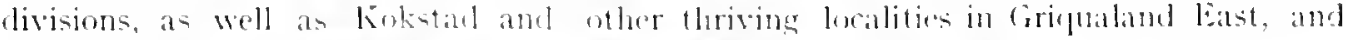
Pondoland. I glance at the axtont of the aresi represented will grive a gond isterat on the large volume of tracle in viriontis products. live stock, wool. werel. lark, ant whlue commodition, that is of necterits drawn to Ricl monel at the neatr est peint atfording rail aceess to the Colons =own am mereicl emporia. and thene lesecond the seas. How long this fulare is

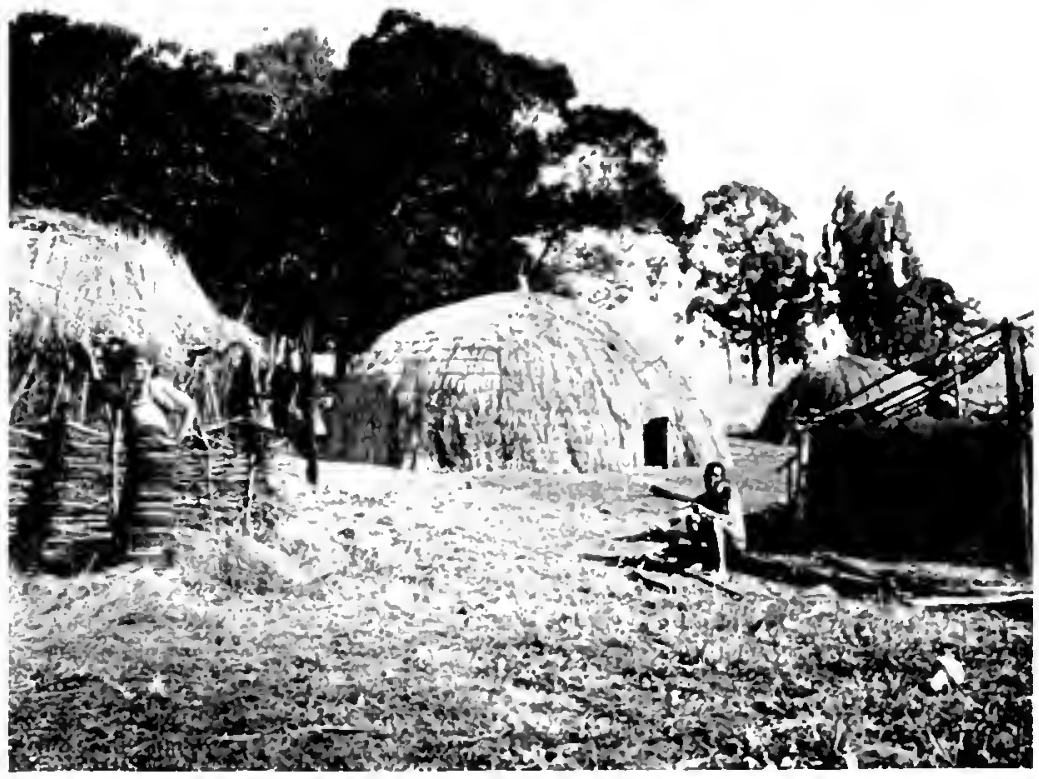
destined to be the 
hand maiden of the important agricultural and other industries in the district namerl, is at this period difficult to accurately determine. Suggestions have been marle for the continuation of the raihwa heyond Kichmond in the direction of Griqualand East, but nothing definite has been decided.

The new route to the Cape Colong, which it was anticipated would he prolonged from Richmond, will bifurcate from the Katal trunk line at Jaritzburg, passing through a new and prolific country to Riverside, on the Griqualand (C.C.) border. Branches to tap the Impendhla, Underberg, and Ixopo districts have also been surveyed.

Reference should be made to the once flourishing bacon-curing industry. (owing to a series of misfortunes, commencing with the rinderpest and ending with the prohibitive prices of mealies, this had to be alandoned, but there are still hopres that the languishing "Chicago of Natal" may even yet deserve its former designation.

For the information of persons requiring to reach the under-dealt-with districts, as well as Umzimkulu, Kokstad, and other places, it should be stated that the post-cart meets the incoming train at Richmond station every week day, and leaves about ro o'clock a.m. The post cart fare to Umzimkulu ( +4 miles) is 30s., and to Kokstad (Ion miles) 7os.

\section{My POST-Cakt from RichnoND.}

STUARTSTOWN (IXOPO) is at present only in road communication with the principal centres of the Colony, and lies about 30 miles to the south-west of Richmond. Pending the establishment of rail connection, the journey is accomplished by post-cart from the latter station. The fare is $20 \mathrm{~s}$.

Stuartstown, being the seat of magistracy for the division, is naturally the most influential village, having a population of 300 , accommodated by several stores, butcheries, hotel, and trades; possessing also various societies, and athletic clubs. There are a number of erections, including a church, school, and hospital. The climate is very fine, though somewhat subject to extremes of heat and cold. The division is splendidly adapted for stock, as well as agriculture and wattle-growing. is well watered, and provides good shooting and fishing in the rivers Limzimkulu and Umkomaas.

DRONK VLEl is an agricultural settlement in the above vicinity, comprising over 30,ooo acres. It is a good grain-growing locality: and all the govermment allotments have been taken up. Although not far removed from Bulwer in the Polela district, the Richmond route is more generally used.

The main line of the Natal-Cape Extension Railway will pass through Dronk Vlei.

HARDHNG is the capital of Alfred Countr, and is described on page Ins. The post-cart service from Richmond to Harding ( 72 miles) is a daily one, fare 50 ., and from Port Shepstone (58 miles) tri-weekly-Tinesdays, Thursdays, and Saturdays-fare 30 .

\section{CHAP'TER II.}

\section{THE GREYTOWN BRANCH AND IBEYOND.}

$\mathrm{T}$ He junction station of the Greytown Branch is Pietermaritzburg. The line was completed in July, Igoo. It is $64_{4}^{3}$ miles in length and is provided with nine stations and six stopping places. Two passenger trains to and trom Greytown connect daily with the important up and down main line trains.

Swinging sharply to the right after clearing the Maritzburg station. the Branch train runs round the outermost limits of the city at the base of the Zwarthop Range, past 


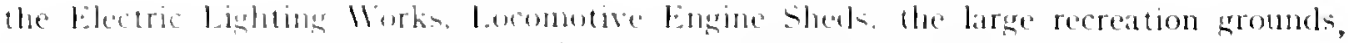

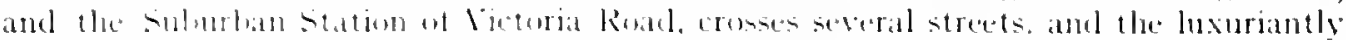

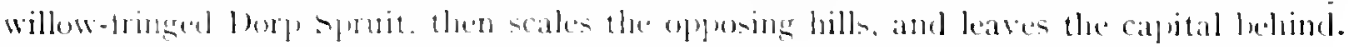
The combery through which the line trath is just as eccentric information as other pror-

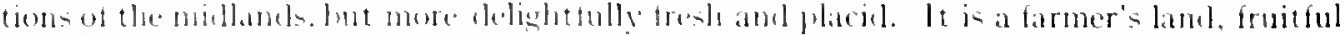

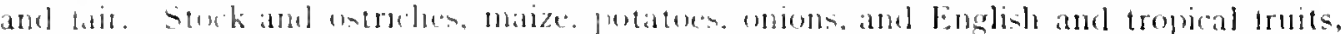
thrive well in various parts of the extensive distriet: darving is another large emplosment,

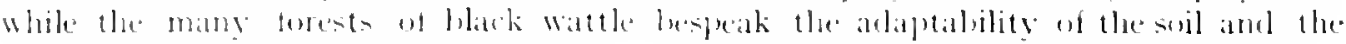
importance at this industry.

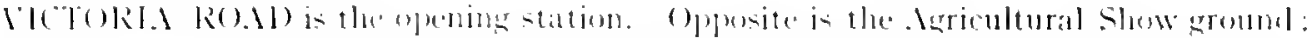

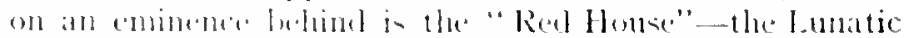
Lat:i: ' Arblum: to the lett of this is the main wagon road over the Town Mlll: to the right is the fretty Clane balley.

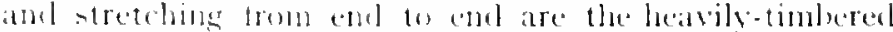

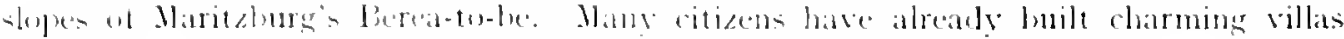

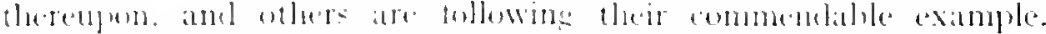

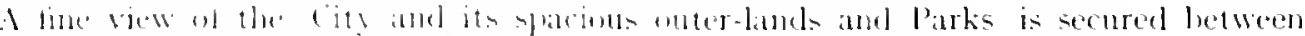

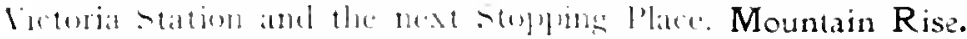

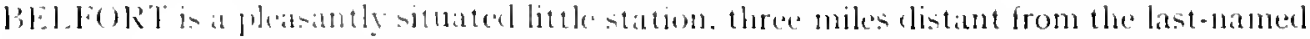

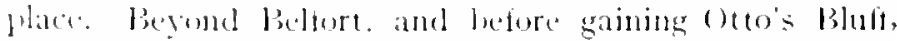

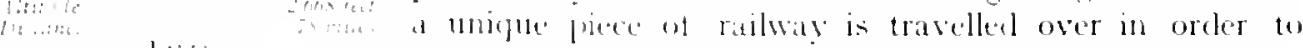

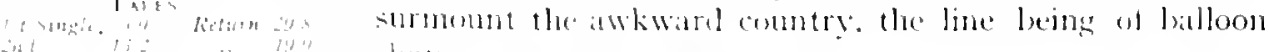
hisine.

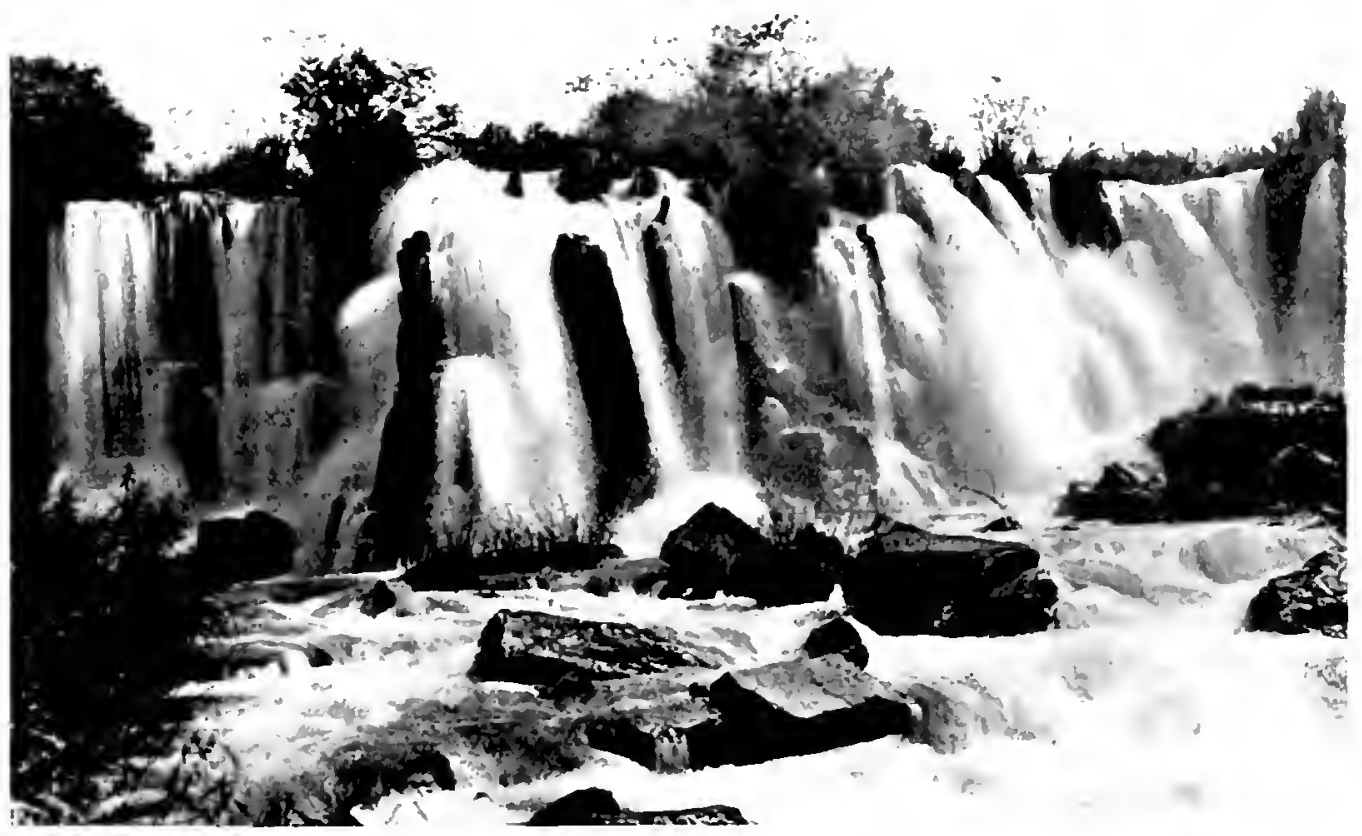

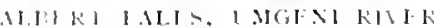




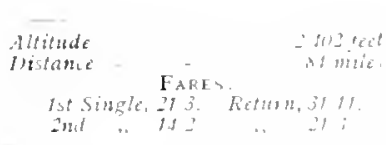

OTTO'S BLLFF takes its name from the abrupt hearllike hill opposite the station-a reduced replica of the famous laathdhlwana. in Zululand.

ALBERT FALIS is the succeeling station. and is one of the best inland pleasure resorts in Natal. It is only possible to devote a

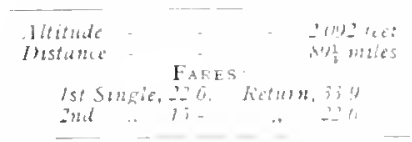
little space to its attractions. but the visitor may lie sure of passing an excedingly agreeable time. buth in summer and in winter. While as a weekend retreat it cannot be surpassed. Besides the beantiful broad talls, a few hundred yards from the station. there are long stretches of boatable water, good hahing, etc.

The country is hilly and chietly pastoral. and the noble Kar Klouf Range, with its dense virginal forests, gives a striking and artistic finish to the landicape. As regards the climate, it is invigorating and everything that conld be desired. It might be mentioned that there are two comtortable hotels at Albert.

Pushing on to New Hanover, the riew is most picturespue. Wattle wools abound, for this profitable industry, with its theefold return of lark. mine props, and firewood, is quite a feature of the Branch.

The Stopping Places of Cramond and Impolweni (for York) are afterwards pasted.

NEW HAXOYER village lies in a hollow some little distance from the Station. This

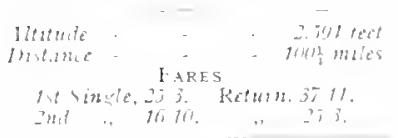
is a prosperous taming district. Coal has been tound on a farm a few miles off (near lork). and is now lneing tested. Wagon-building and wattle-grinding are carries on, but hefond these there are no other industries. Game is plentitul in the Blinkwater Bush, and the Sterk Spruit. a quarter of a mile from the Station, is a farourite haunt of anglers, hut it is necessary to obtain permision from the landowners to either shoot or fish.

NOODSPERG RUAD, the following Station, serves the settlement of Noodsberg.

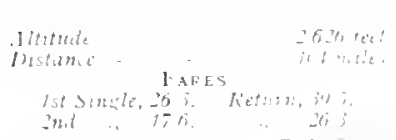
In the post-cart dars it was the half-way house to Greytown. The locality has no particular pretemoions beyond its poultry larming, and we run direet to

DALTON. At the present time this is one of the moit productive Stations on the Branch. Mealies. Wattle-bark, and timber form big traffics,

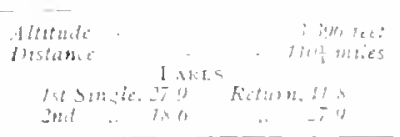
and fruts (oranges. lemons, ete.) and vegetahles are also grown in large quantities. The community around is, to a very great extent, composed of Germans of long and friendly standing in the Colony. It is very patent that the railway has rapidly proved its elesicleratum in encouraging more extensive operations, not only in this neighbourhood, but generally in every branch of tarming along the line.

Dalton has a good lrick hotel. and every accommodation will be found here by tourists: but although the climate is hracing. the attractions are rather sants, and prohibitively far away. The "Edwards" Falls. however, some seven or eight miles off. are deserving of remark. They are shintly hroken at the head. then phnese sherer some I5o feet. Horses and converances can be hired at the hotel. should picnic parties or other visitors desire to visit this spot. 


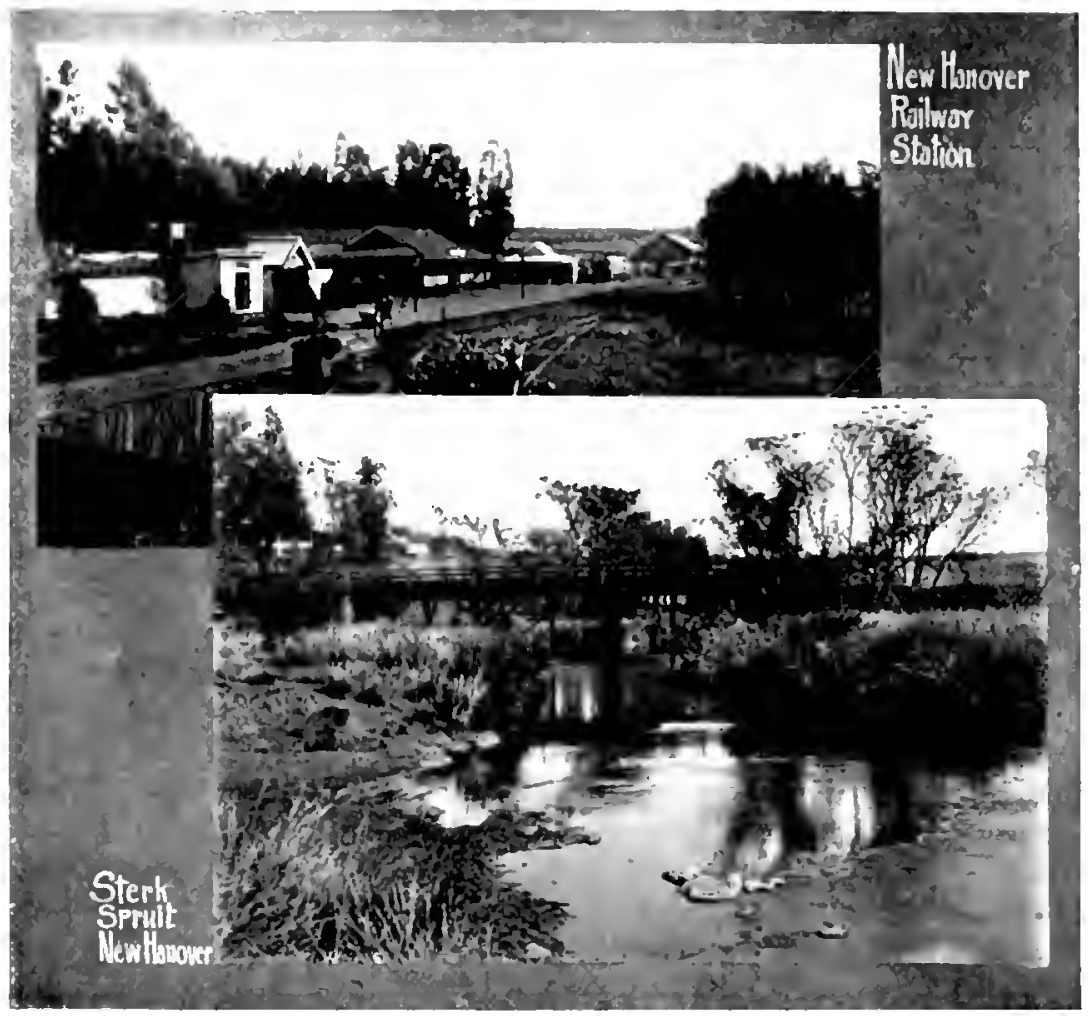

Dalton is the nearest station to the Soodsherg Mountans. which attain a lewght of betwern three and four thomand tert. Ravensworth and Harden Heights are stoplung llaces which octur hefore the next station is reached. The surrounlings and froductions are similat to other pertions of the Branch.

SEVIXX (OAKS is the prettiest and most invigorating altitude on the Branch. (In the left of the station is the magnificent Blinkwater Hill.

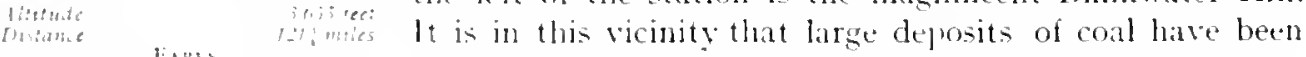

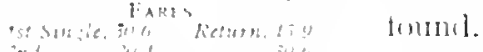

ant ... Looking in the same direction. numbers of hartebeest may otten be espicel. They are large and splendid creatures, but, heing jealonsly preservet. it is very diffioult to obtain a specimen. The herd, which numbers some soo, is the latresest in the Colony.

() n the risht of the Station is a horely morsel of comtry, and an hotel will be seen amidst the abk and wattle tress. Alent four miles along the main wagon road will be fennd the l'mvoti River. the diviler of Pietermaritzhurg and Lmroti Counties. This stream attracts picnic and fisling parties. both from Seven Oabs and Greytown.

The locality is so singularly rerchant and peacetul that one can readily imagine he scans the ricli rolling fields of Somerset or Deson. For the already recited reasons, it will he surjorising it the place remains long unknown, as it has the making of an excellent health resort. 
Hermansburg Road intermedrate between Seven Oaks and the terminal station of the Branch. is the Stopping Place for the Crerman settlement of that name. It is famed for its school, tanners, and plantations of fruit trees.

GREYTOWX is the capital of Lmsoti County, and among the oldest towns in Natal. The population numbers 800 Europeans and ahout 600

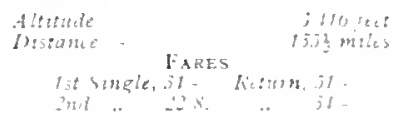
coloured people. The valuation of the township property at the last assessment was firt.326.

The following is a short sketch of the town: In fashor, strictly Dutch set out on a slope, exceptionally pretty. gum, oak. and fir trees lining the red soil roads. A long steep hill bounds the lower end of the town. The houses are nearly all of brick. Nater runs in sluits at the sides of the streets. hut this ancient mode is giving place to the modern "fripe" srstem.

There are three churches.-Dutch Reformed. St. James's Episcopalian. anrt Weslevan. Also three hotels.-"Commercial." "Greytown." and " Plough."

The town has a commonage of some yo.000 acres. which is a great boon to the inhabitants tor cattle-grazing jurposes.

The Public Buildings are all near the Uarket spuare. The oftices of the Local Buard are the most striking. being Jistinguished by a tower and a "Diamond Jubilee" clock. The construction of a capacious public hall is under consideration. Then there are the Court House, Post and Telegraph Offices, and the Gaol.

There is a good cosernment School. a Huguenot Seminary. particularly noted for it. advanced education and thorough training for young ladies, several other educational establishments. Agricultural and Masonic Halls. Public Reading Room and Subscrivtion Librars, and all kinds of Clubs and Associations-athletic and otherwise.

The Barracks of the Natal Ifounted Police are perched conspicuously on a hill outslie the town.

Greitown is undoubtedy advancing. Building is in active progress. the bricks beng

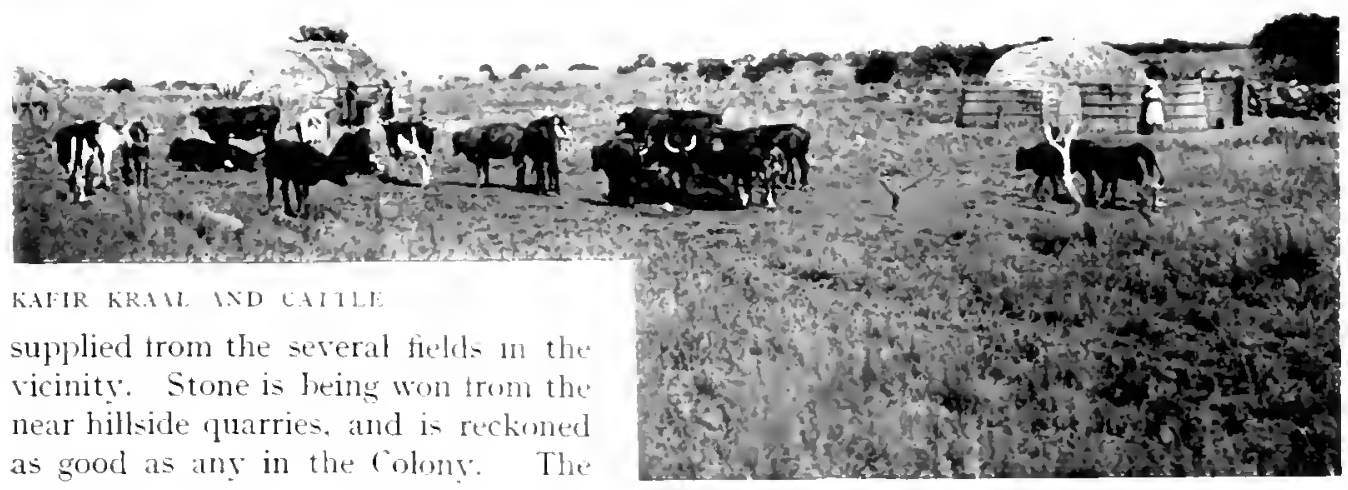




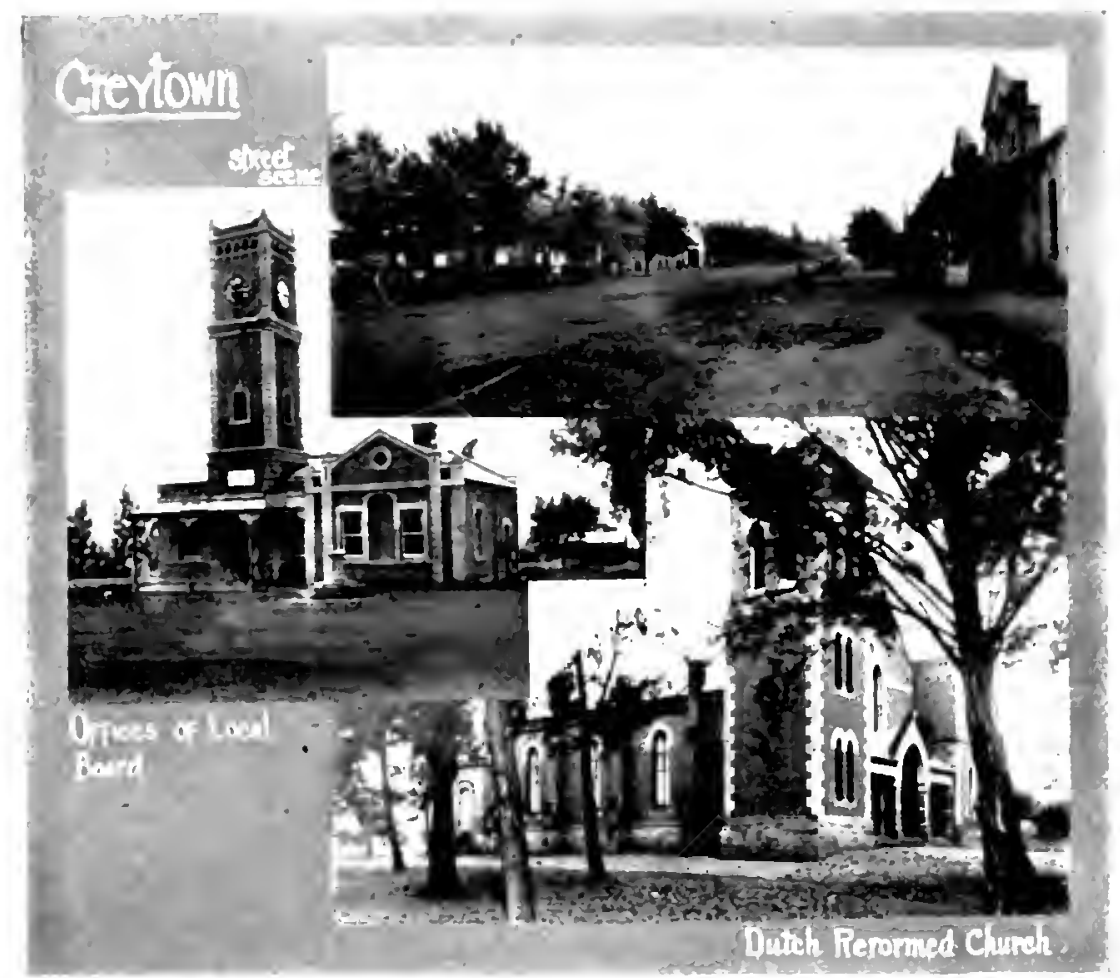

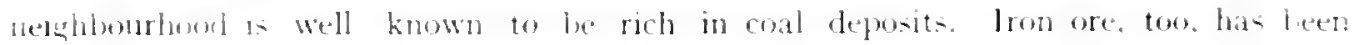
tound, testad, and given excellent results. but developments are at present unrertain.

The chmate ss particularly exhilarating. and cool in summer. therefore cregtown has iubstantial claims as a holiclay resort.

It has also some historic assoriations. It was the birth place of the late Commantant-

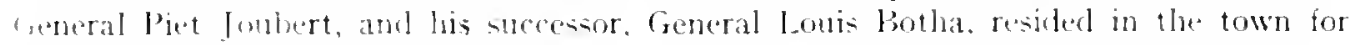
- weral vears.

So bar an the productions of the locality heyond are concerned. they are consileralle in quantity and various in nature. The County is adaptable in an eminent degrete is atl agricultural and pasturing occupations, while its stock. especially, is perhaps the best conditioned and most prolitic in the Colony, Engtish fruits, too, are erown in ereat ahundance. The watle cultivation has increased to a large extent. and wids greatly the the beaty of the country. Tobacco of tine quality is another large arowth.

Greytown, sinct the arloption of local Government. has come wonderfully to the front: the valuation bas increased nurly fifty per cent., and the population has practically doubled.

Since the opening of the Railway in July, who, at great impetus has been given to the buikling trate. in the town, and the farmers are taking eager arlvantage of the Railway. a) send their various protucts io Maritzlurg and other markets. 


\section{BEYOND GREI"TOWN.}

There are a number of settlements of interest and importance berond Grevtum. ". which the locomotive has not ret penetrated. To the west is REIT VIEI: to the east are ThE Thorss and Kraxtz Liop in the Tugela Valley: and to the North are the Lusisga GOLDFIELd and the Battle-Noted DRifts of ZCLllasi. These are severally described below :

REIT VLEl is distant about twenty miles, and lies hetween Grevtown and hlooi River. The latter station is the one principally used. and a post-cart runs therefrom twice weekly. Some of the best stocked, tarms in the Colony are in this vicinity.

THE LWIOTI THORNS represent a thichly wooded tract of country is miles out of Greytown. They cover an immense area.

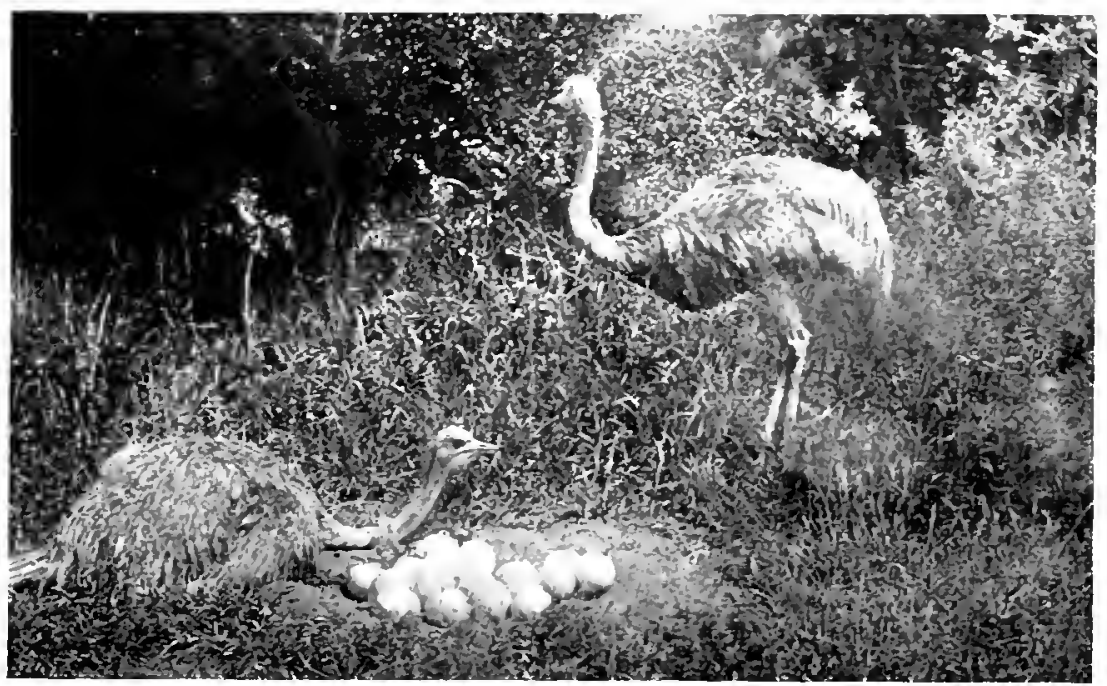

OSTRICHLS AXI) EGGS, NAHAI

J.E Mulliebrook

KRANTZ-KOP lies just beyond the latter, and is ahout 23 miles from Grertown. with which it is connected by telephone. It is the seat of magistracy, and consequently. is possessed of a Court House, Gaol. Police Barrachs. and Post and Telegraph Offices. A good hotel is also there. A tri-weekly post-cart service will probably be established shortly.

Both the "Thorns" and Krantz lop are excellent farming districts, and the agricultural implements that have lately been imported speak well of the progressiveness and increased activity of the farmers. The thorn-veld is well adapted for ostrich-rearing. and large numbers of these valuable birds are to be found in the neighbourhood. The bia growth of onions in the "Thorns" is also a noteworthy feature. whilst lime-burning is another business which is engaging attention. and should eventually prove a profitable industry.

In the matter of communication with the above places. there is as vet no recognised public service. but horses and conveyances can be hired in Grevtown. The journey. to the "Thorns " occupies about two hours. and to Krantz Kop four hours. It is worthy" of remembrance that around Krantz Kop, and in the Tugela Valler: the grandeur of the mountain, woodland, and river scenery is almost unrivalled. 


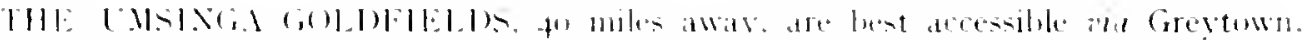

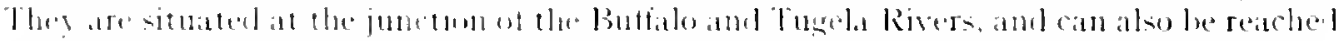

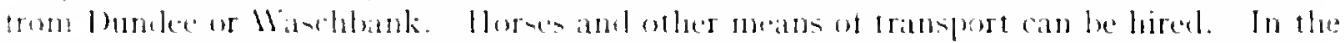

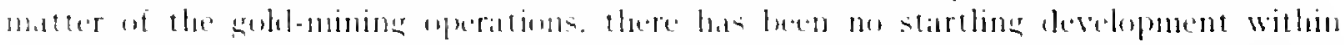

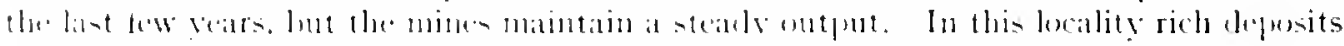

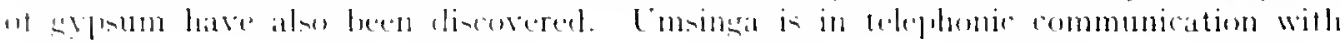
ritertumn.

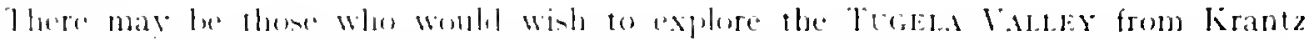

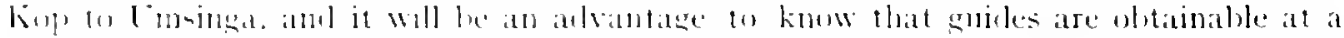

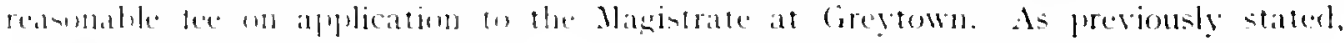

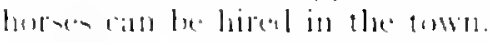

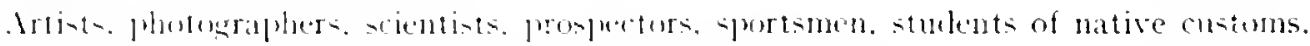

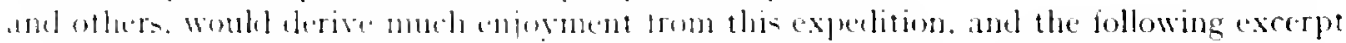
from the "colomy of Xatal." maty asefully be given :

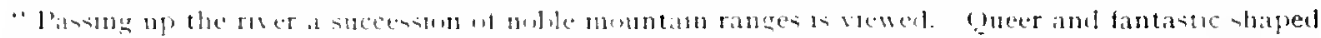

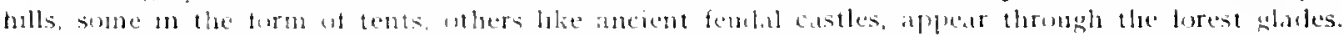

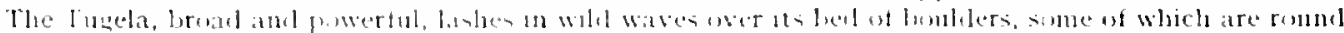

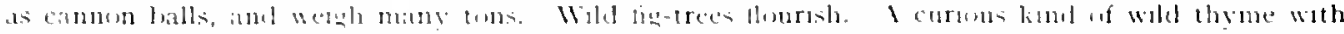

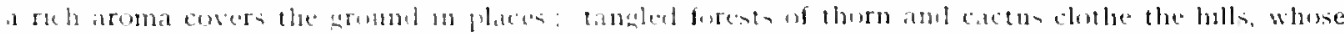

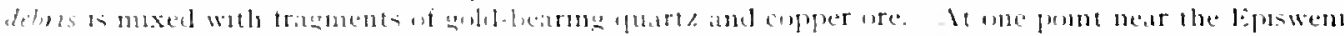

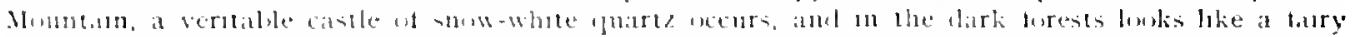
patace tif enchantment.

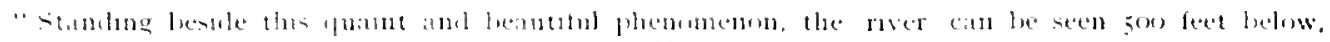

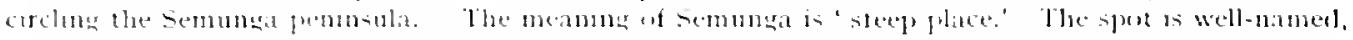

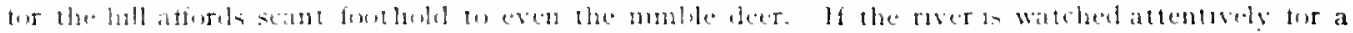

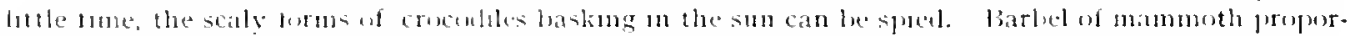

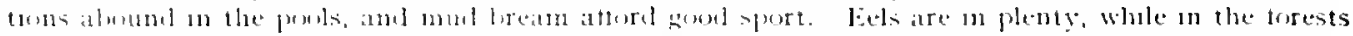

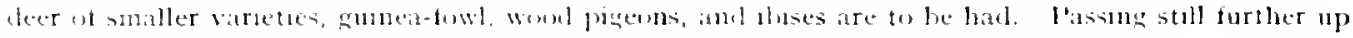

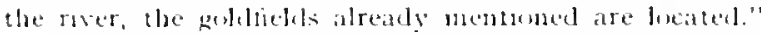

WLCITIEES IRIFT RORKE'S DRIFT, ISANDHIMAXA Mountain, and other

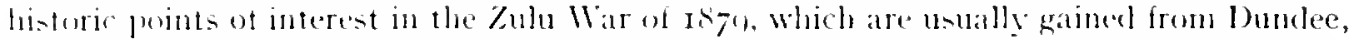
"1he Railway station near the Bulfalo River. can also le visited as a continuation of this

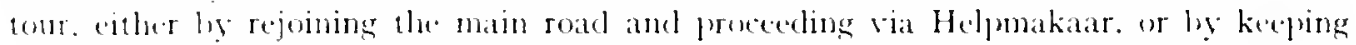
to the Buffalo River. But gersision would recpuire to he mate beforehand for the longer leave trom civilization which this womld entail.

\section{CHAPTIR HI.}

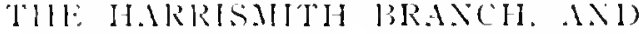

\section{T"II: OR.INGI: RIVIER COI.ON!.}

$\mathrm{T}^{\prime \prime}$

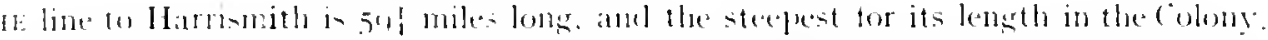

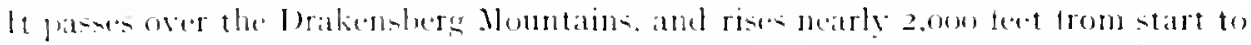

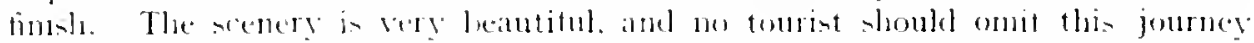

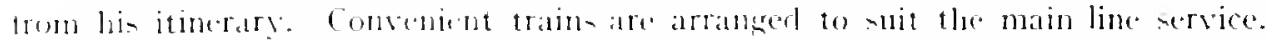

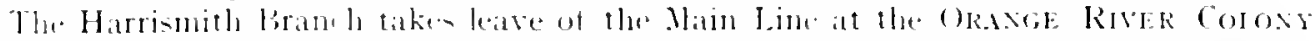

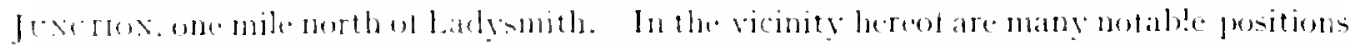

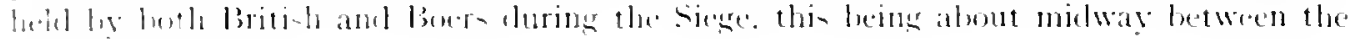
nowning loster 


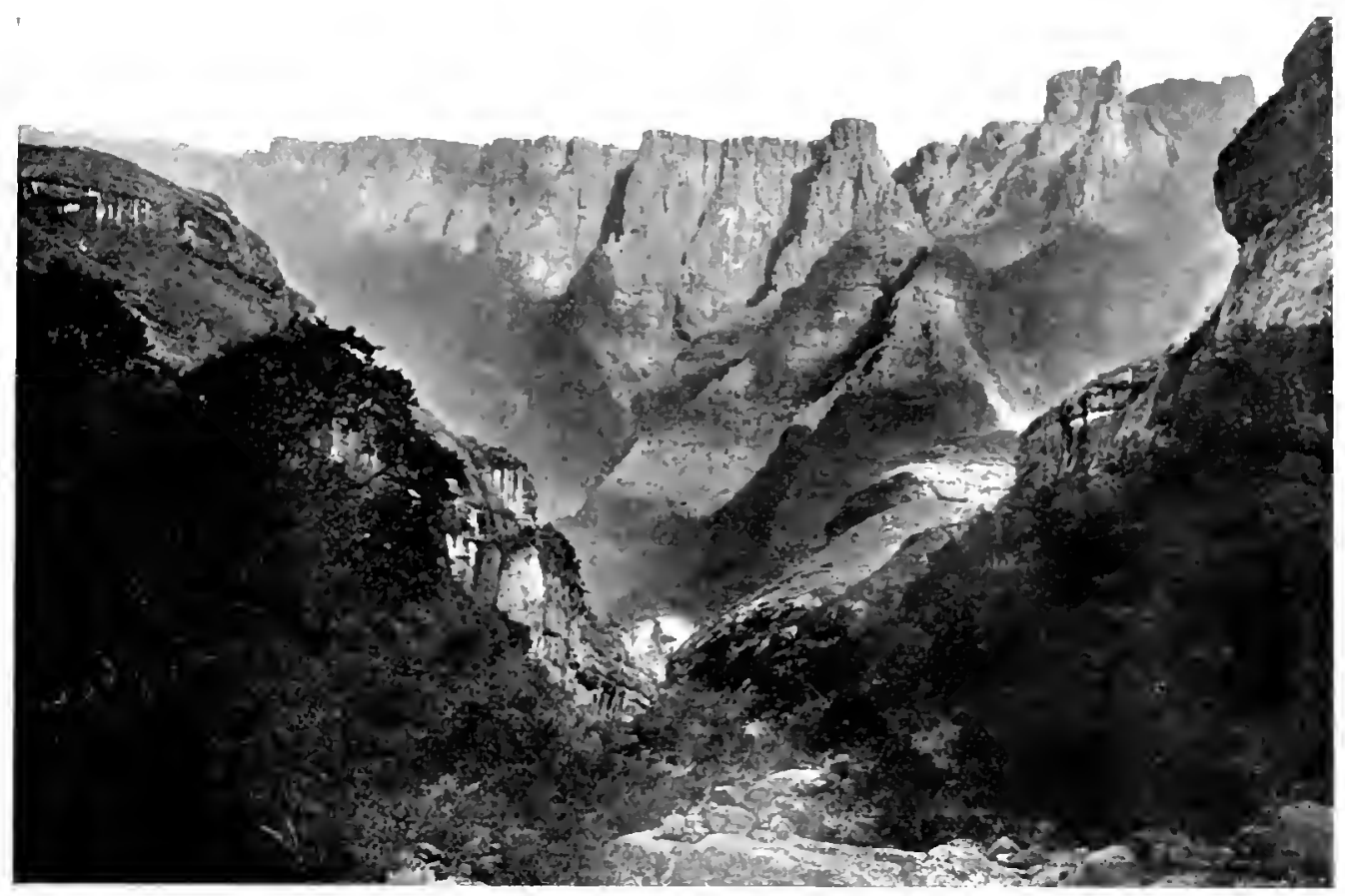

THE DRAKFNSHERG

After clearing the Junction, the line passes through an open country. westward, to the Stopping Place of Walker's Hoek, ten miles distant. The Klip kirrir heing crossed. the Drakensherg is revealed in all its majests.

\section{"Huge as iecharr. as it in wearnesz}

The melancholy mountains vawn."

At the hase of the monntains are many large stock farms. and thounand of sheep pasture on the expanding plains.

BESTER'S is the first station on the branch. and is set in the midelle of a larere grazing

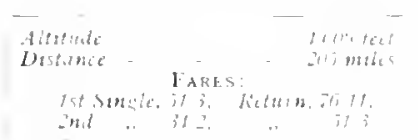

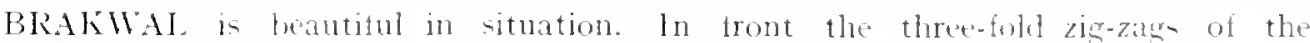

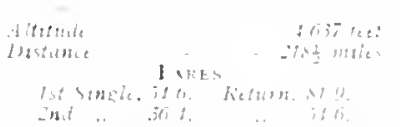
Reversing station maly be seen. and it is intere-ting to note that. within tle short space of half an hrom. the loco. motive. with its dead wejght of severil hundred tons will have climlext a thousand feet.

The writer of the fomer guicle (Mr. J. F. Meram) has given so graphic a description of the joumeg between Brakwal and l'an Reenen. that it is repeatud. wh the tew emendations necessary to adiph it to the present time:

"On the right the stately. Orakemstere rises in terraces, piled stect on steep. A tew moments' halt at the Brakwal Station, and away goes the train. Whilst the traveller almost with bated hreath watches the first angle. Visions of disaster trom broken 


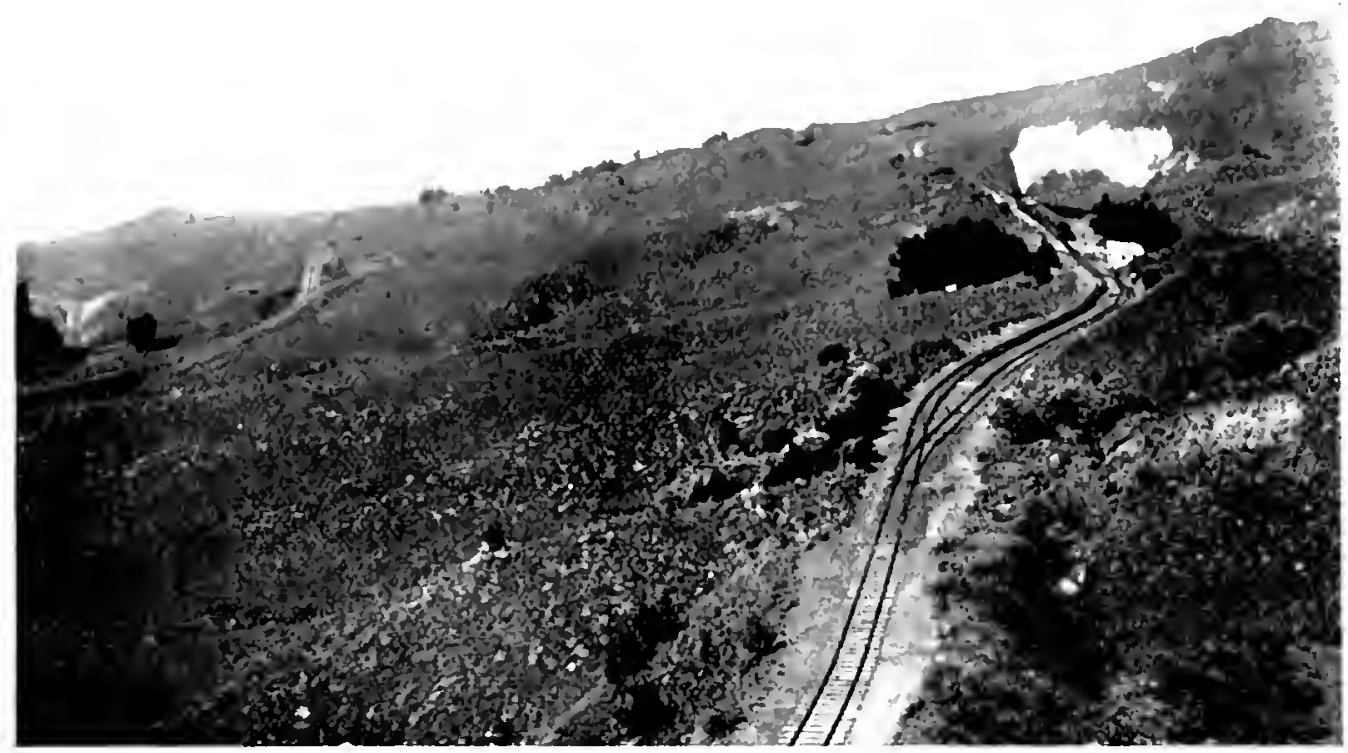

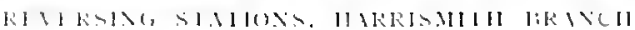

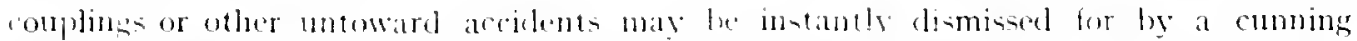

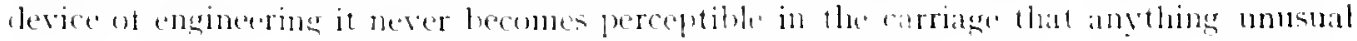
is taking place. The riew trom the windows is entrancing. Away to the somtli-west, Tintwa Hountain, like a Titan lootress, alpuats through the drifting clonds, which look like the imoke of heary ordnance. (One could almost imatrine that warfare was being

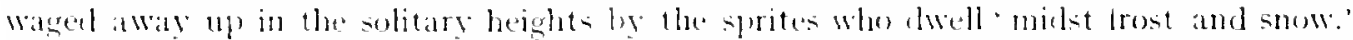

The palms of the const hate now been replared be luather: wikl popples nod their drows heads beside the line, and quaint sugar hush trees with fire-like comes, stretch out their storm-stratued limb orer the hue clistane beneath them. The day darkens as the train speeds on: above and below there is bright sunshine-a passine cloud has leerll piercerl-that in all.

A the train sweeps through the dense white mist. the red glow from the engine is setlected on the vipour. Then ont it rushes inte the smolight again, along one angle atter the other, each perceptibly hisher than the last, mut the reversing station has leen past, and with an exultant shriek trom the engine the task is complete, and the train, leaving edhe behme her, whirls along through rarified air over level plains 5,520 Het aluse the seat.

Approaching Van Reenen's, the road passes through a theatre of scenery which can he lescribed in all truth as sublime. A tew miles to the eastward of the station a prompert is revealed which no human heing can regard without a thrill of the most esquisite and reverent delight.

It Wat trom the magnificent vantage point that the early Boer voortrekters first vivwert their land ut promise. their future refuge and home. Words are but feeble when called in refutsition to descrife the majesty of the scene. Nountain range after mountain range. hill atter hill can be traced. Broat and apparently endless vales, forest belts amel rivers are commingled in such a wealth of beauty as 10 rival many an 
already famed land. There is no douht that Piet Retief, the heroic leader of the Boel emigrants, simple farmer though he was, drew from this scene that courage and inspira. tion which enabled him to face the terrors of hostile barbarism, and to win for himself and his compatriots the glory which has caused their names to be enshrined for all time in the pages of African history.

In the section dealing with the physical geography of Natal, the altitudes and configuration of the Berg are fully dealt with. therefore it is unnecessary in this place to touch upon the subject again.

VAN REENEN STATION is situated on the western frontier of Natal, and leaving

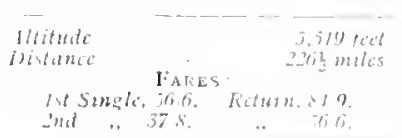
it, the Orange River Colony is entered. In the vicinity of the station there is a hotel and Custom House. "lo the left of the line, great isolated mountain masses are risible, each one standing like a palace of mystery, with the summits swarthed in clouds, and kloofs dark with impenetrable forests, amidst whose almost untroden solitules are Bushmen's Caves, containing on their rocky walls curious representations of beasts and hirds. These Bushmen, now almost an extinct race in South Africa, are no doubt a wandering branch of the pigmy tribes discovered by Sir H. M. Stanley in Central Africa.

Their history forms a strange study, for while they were undoubtedly possessed in a high degree of primitive artistic and imitative powers in a pictorial sense. they were and are in almost every other respect herond the pale of the lowest class of humanitr:

Withont a single scrap of generous impulse, devoid of the virtue of gratitude, they invariably waged a war of harassment on their white and colonred neighbours. Peaceful and kindly overtures meant no more to them than to a tribe of those baboons to which they hear such a striking physical resemllance. Little wonder then that the Boers and early settlers did all in their power to exterminate them, even to the extent of organizing Bushmen's hunts, when the little, but nimhte and ferocions manıkins were shot down, not, however, whithout tearing down a lew of their provoked and exasperated assailants."

The Kiloofs, the Bushmen's Caves, and such noted mountains as Renshurg Koj, Nelson's Kop, the Three Sisters, and the Kinucles, also the historic Van Renen Pan.

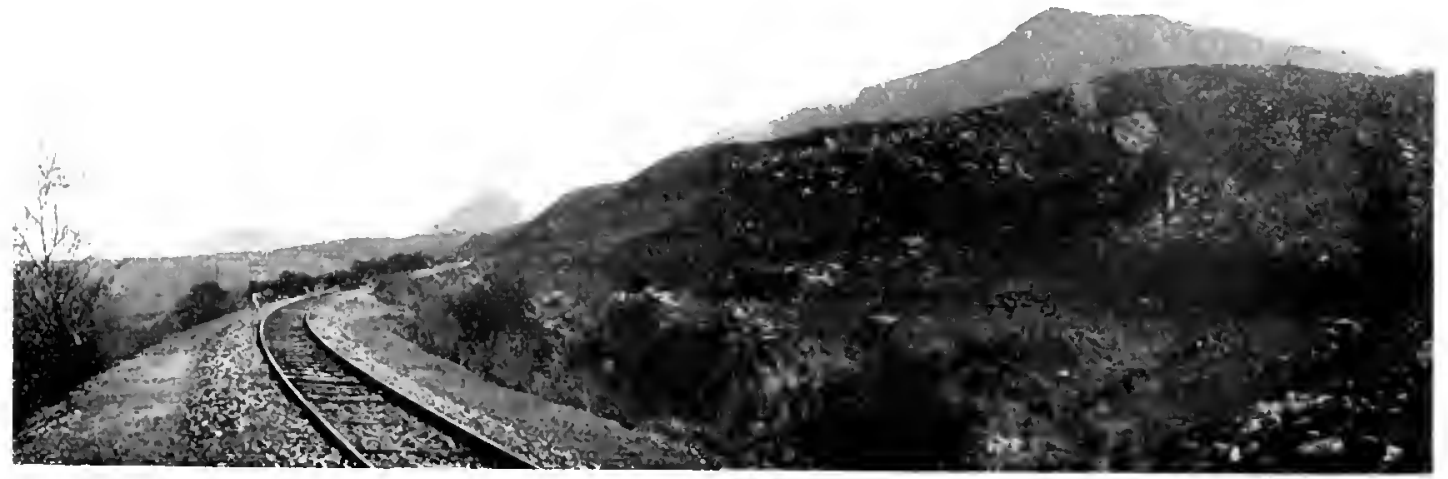

TAN RELNEN'S PASS, N.G.., IIARRISAIIH BRAXCH 


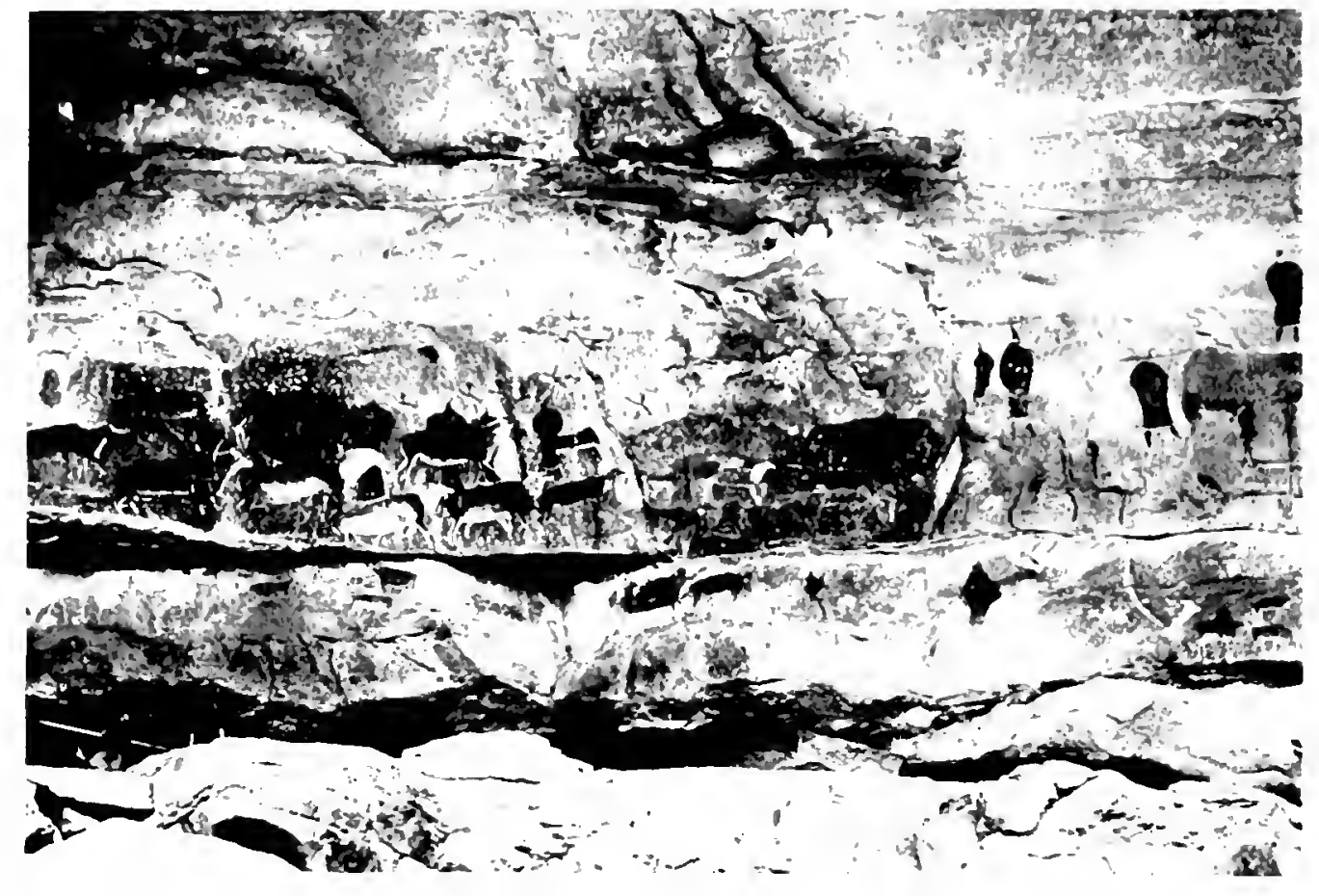

$141>1131>\rightarrow 11: 311131,5$

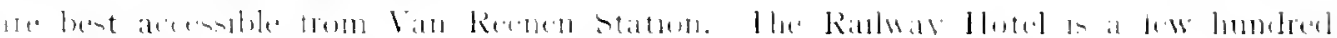

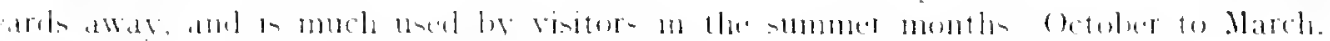

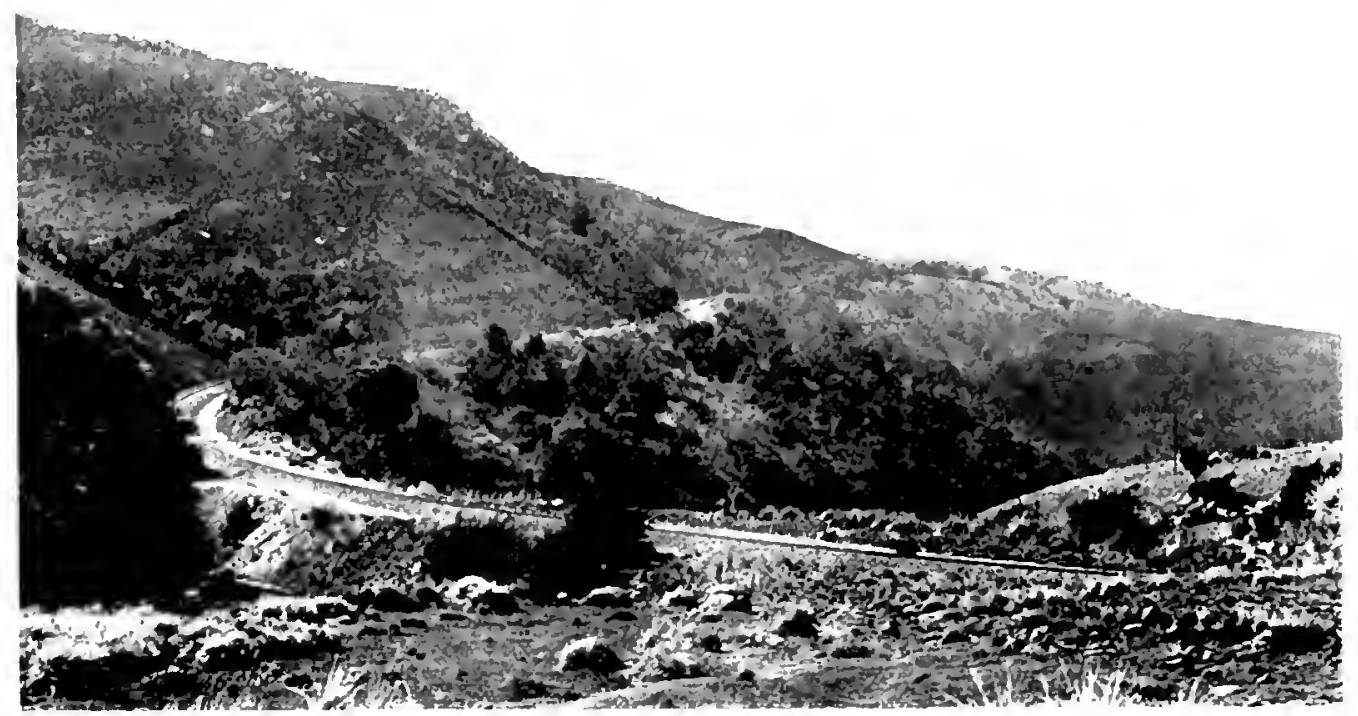


The excellent shooting also attracts a large number of sportsmen during the seasonllay to August.

Leaving Van Reenen Station, in a little while the Wilge River comes into sight. Still on and on. through a region of uncounted lakelets. or pans. as thes are locally ralledl. the train, relieved from its mountain climb. whirls along with redumbel pued.

The ridge of mountains forming the water shed of South Africa liaving now been fris-ed. there is a perceptible tall in the country toward the west. The rivers lave revered their courses, and flow from the berg into the Atlantic. instearl of the Indian Ocean.

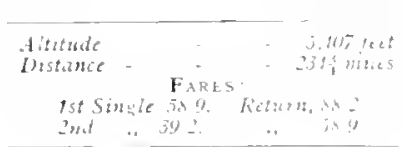

ATBERTIN.t. the next station to Harrimith, has no remarkable features of interest other than it- proximity to the lierg. and the River Ilige, which latter in plentitully stroked with fish.

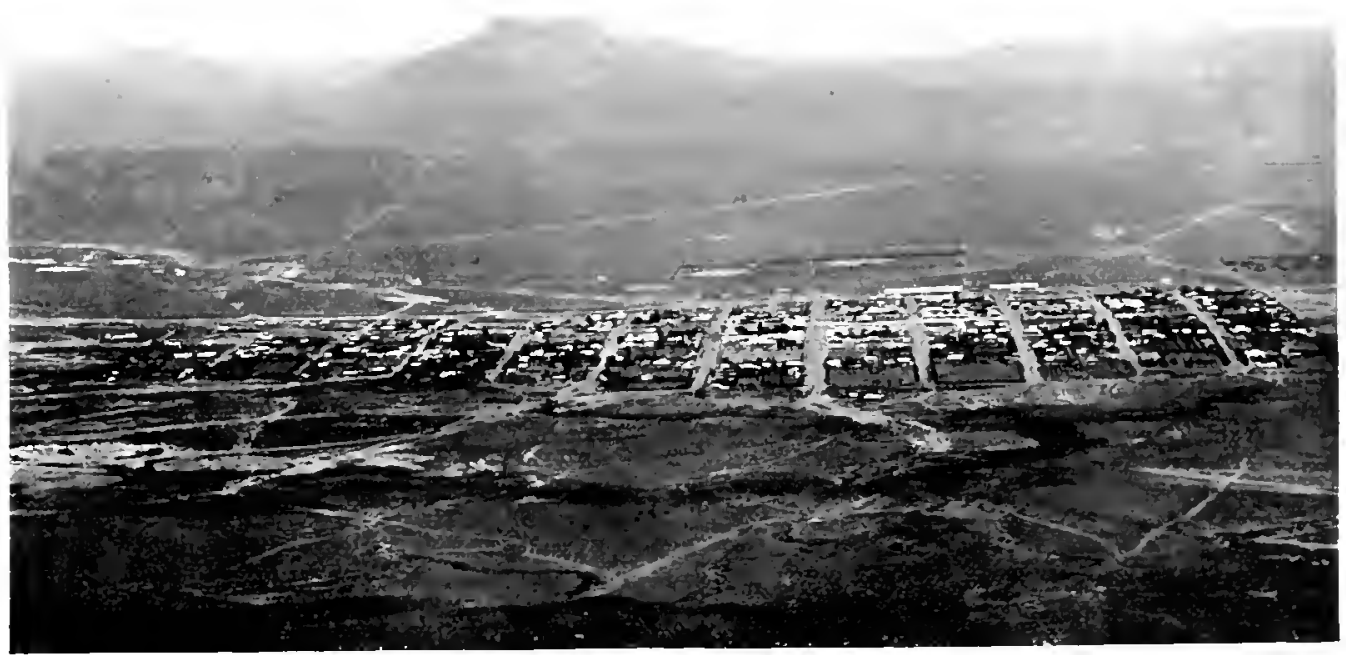

H.ARRISMITH : PLAATBERG IN B.ACKGROLYD

HARRISMITH. This noted Dutch-fashoned town is situated m the norul eastern

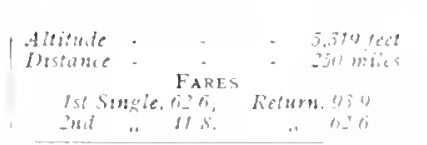
angle of the Orange River Colony. It hat always been essentially British. and. in addition to its considerable agricultural and trading importance. forms a sreat health resort for people from the "Garden Colong." during the summer season. The altitude and rarity of the air are recommended as ling peculiarly beneficial to consumptives.

The population of Harrismith, according to the official return, in 1.127. viz: r.020 English, I93 Dutch, and 7 It natives. The value of landed propory is asenced at $\$ 232.000$. and the town lands at f60.000. The general rate is one penny in the pumb. The water supply ant sanitary arrangements are grood.

The town possesses a tine park. containing lake and athletic grouncts, a polo ground, golf links, and race-course. There are a number of well-de-igned public buildings, churehes, 


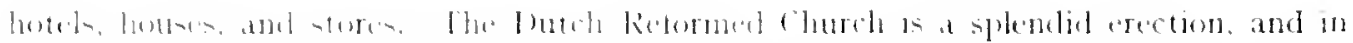

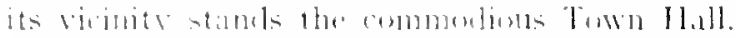

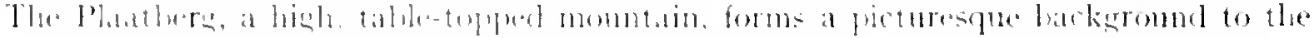

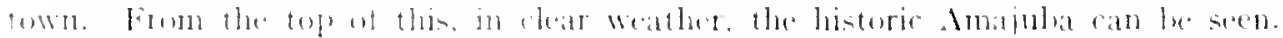

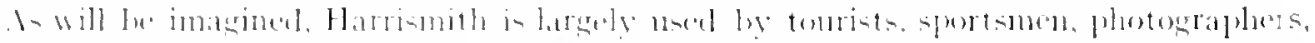

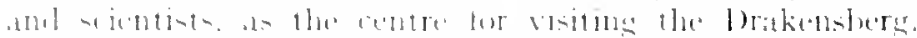

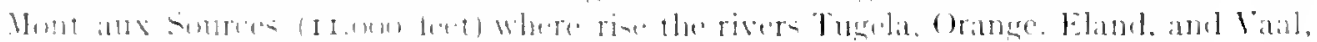

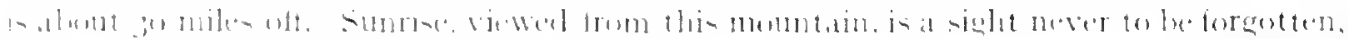

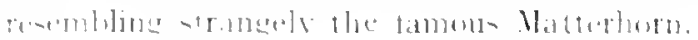

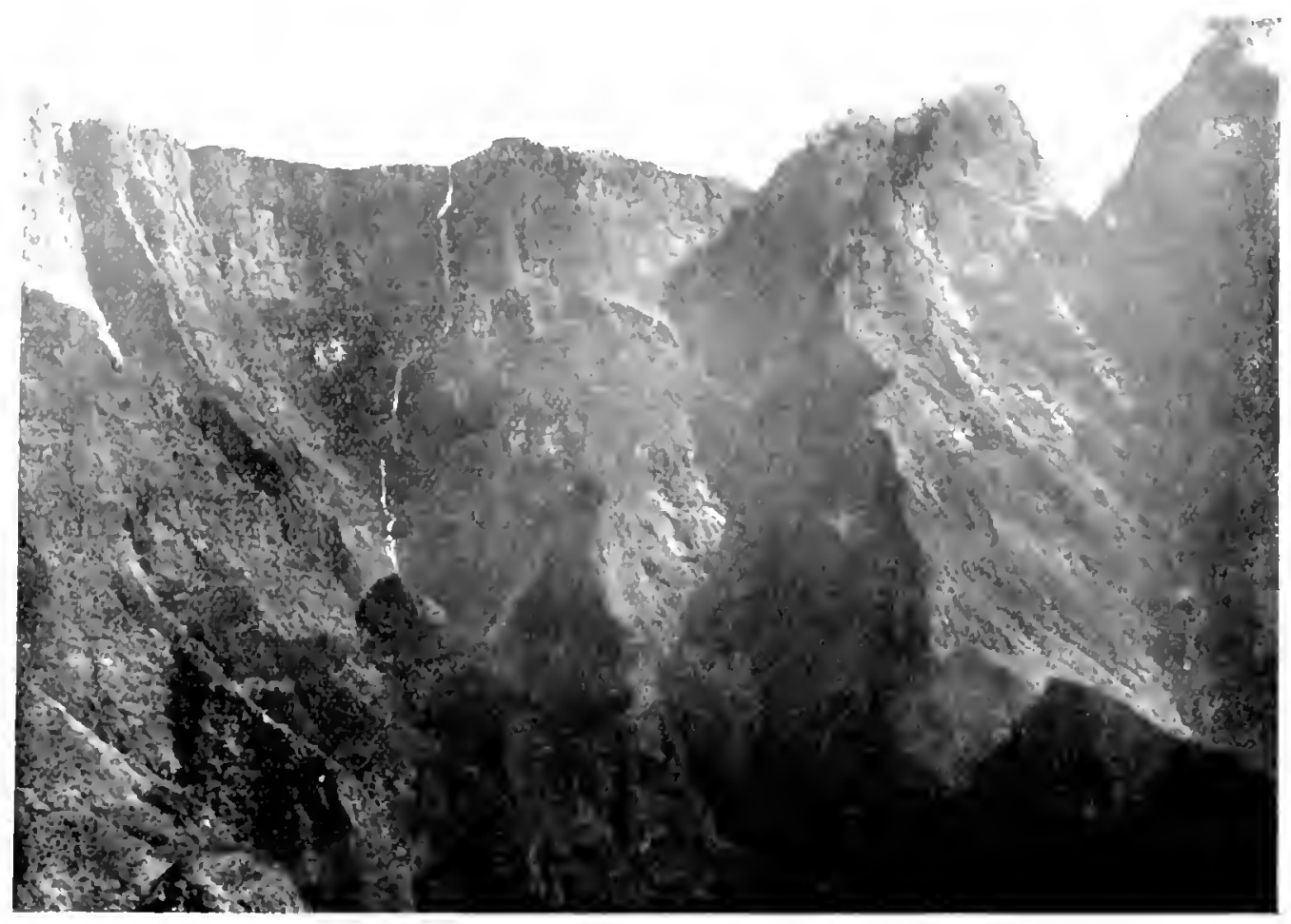

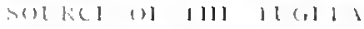

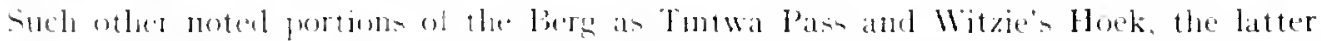
of interent as the last strumghalel of the bers in this pertion of the country, lie also in

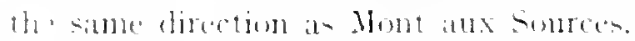

Tinus on the Joakinsterte may he oreanised locally, and all necesary arrangements make at une of the houel ("knsal," "Commercial," or "Central") for pack-horses, amping kit. provisons. etr. There are several boarling and farm louses in the verinity of llarrimith.

Hartinnth is a large trading centre, worl, hides, horns, and coreals constituting the chee experts. The capalibities of the district are immense, and great developments

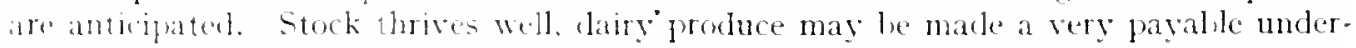

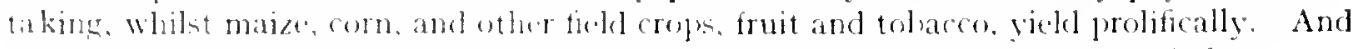
What is sabl of Harrismith applien equally to the Orange River Colony as a whole. 
The construction of railwass will be one of the chief factors in the arlvancement of the land, and it is pleasing to note that new lines are being urgently pushed forward, or proposed. The schemes which will prove most welcome to Vatal. are the extensions of the Harrismith Branch to bethlehem, and from the latter place to Winburs and posibly to Kimherley. When completed, these will afford more direct access to Blomfontein. the capital of the Orange River Colony, and to the trunk line of the Cape Territory, mutually advantageous to each of the colonies concerned. ank will furnish an even thorter route to Cape Town than the one now under construction ald Harituburs. Riverside. and Indive.

\section{HARRISUITH AND THE WAR.}

Harrismith played a passive, but not altogether unimportant, part during the great campaign.

At the beginning of September, Isom, when the resources of diplomacy were alout exhausted. the burghers of the then Free state were busily preparing for th exjected fray: and the attitude of that State in the inevitable struggle was almost inmerlicitely disclosed, the now defunct fovermment resolving to carry out in word and spirit the terms of the defensive alliance entered into with the Sister Republic on Harch izth. ifot.

Commandeering commenced on October sth. Isqa, but prior thereto many of the British subjects left the State. Witl the exception of the Natal Government Railway staff, no one capable of bearing arms was exempted from this order. After this date tents lollowed each other in rapid succession. On the oth October, a large commando, numbering some four thousand men, fassed through the town on its way down to seize the Tintwa Pass.

By the Ioth, a force nearly eiglit thousand strong had mustered at Nelson's Kop.

On the IIth October, about noon, alter the arrival of the train from Natal. the Free State Authorities seized the Railway. This placed an engine and a small "puantity of rolling stock in their hands, and gave them control of the line as far as Brakwal, a Free State Commando. about a thonsand strong. having occupied Van Reenten Pass on the same day, and rendered it impregnable with their superior armament, also destroying the line at the Reversing Stations. The Railway officials heing no longer required. they received orders to quit the country. and left under passport for Natal.

Then the "stern realities of war" commenced in deadly earnest.

Harrismith was the principal hase of supplies for the Free State Forces lying around Ladysmith during the investment. and the appropriated train was used for ruming down stores as far as Smith's Crossing, and bringing back the wounded.

The enemy were doubtless very disappointed that our troops did not engage them in the passes. From information subsequently gleaned from some of the Free State leaders, it appears that the plan of campaign. which ther had so sangrinely urepared, was for the Free State forces. nuter Prinsloo. with the Transwalers under Joubert, then lying at Zandspruit. anel the commando under Lucas Never from the Vryheid district, to join hands north of Ladysuith, and crush the garrison. atter which the whole of Yatal would he open. and their march to the coast unopposed. But the fondert dreams are but rarely realised!

For ten months Harrismith remained cut off from all communication witl the ontside world; it was not until the th of Angust. Inoo. that the late Sir Hector Macdonald entered the town. Five days later railway communication was restored, and Harrismith was then established as the headquarters and hase of supplies tor the troops operating in the eastern portion of this extensive Colony. 


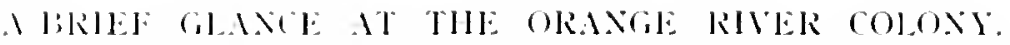

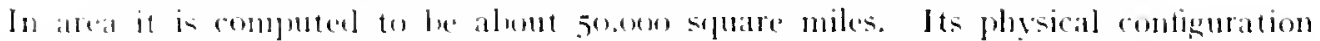
is of the simplent consinting fractically of an enomms plain. with a gradual slope to

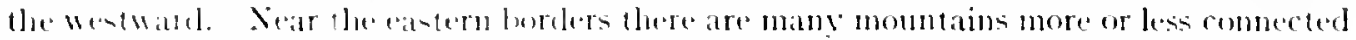

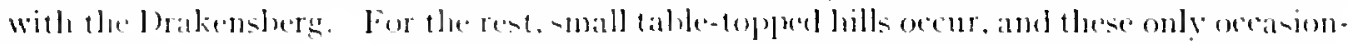
alls:

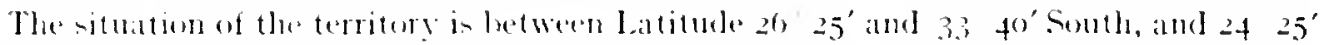

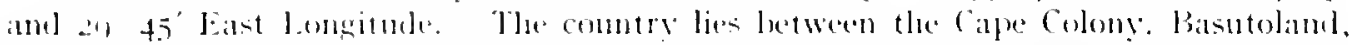
Xatal. and the Transial. The las censts taken ly the date Free State fovernment

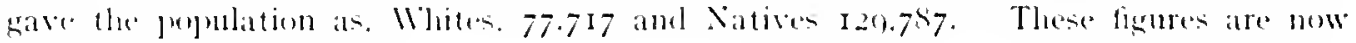
useful anly lor reference.

L'neler the lutch administration the Stalle was divided into lhe following eighteen districts:

\section{Histicl.}

Pilacmentein.

Calectorn Ruer

jomtesituth.

Jarremith.

binbure.

lirensiatal.

instureft.

l'bulipjolis.

kethulie.

licolostial.

Romxville.

bethlebem

langliramel.

lleilierm.

Iropstad

Vepener.

virile.

ricksliura. clice lowns and villages.

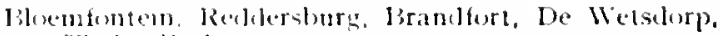
Thialut 'Dehus.

simllatelal.

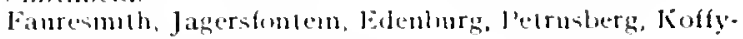
tontem

llarrismutl.

Minburg, Ventershourg. Seneliat.

liromitial, Virelefort, lieitshurg.

Jiosintt.

Jhilpindis.

bethulie.

Jacolisdal.

kouxvolle, Zastrom.

Bethlehem, ] indley. Reitz.

Latlybramd.

Helibron, l'aris.

lloopstad, Bultonlest.

Wejener.

irecle. lirankforl, Villuers.

jeckshurer.

A party of Boers first "trekked" into the country in Is20. Inut it was not until ists HISTORY. that Briti-h swereignty was extended wer the territories north of the Orange kiver by a proclamation insued by Sir Harry Smith. some of the Boers. most of whom hat come with their leater. Andries Pretorits, from the territory lying north of the Valal River. resisted. but were defeated at the battle of

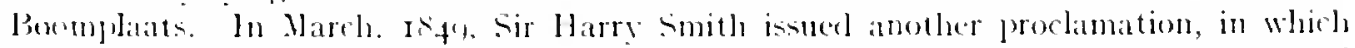
the territory was named the "Orange kiver sovereignty." the limits being the Vaal

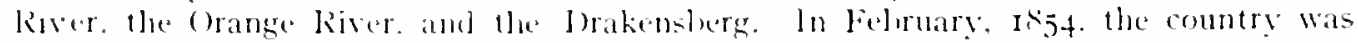

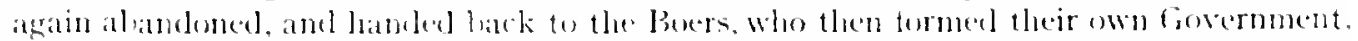
which was recognised low the liritish. and wats matintained until its coalition with tle South

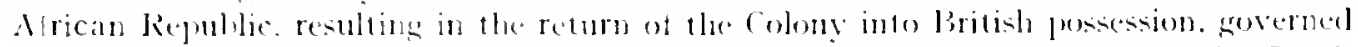
ly a bepuly Administrator. under the uristietion of the High Commissioner for South Africil. 


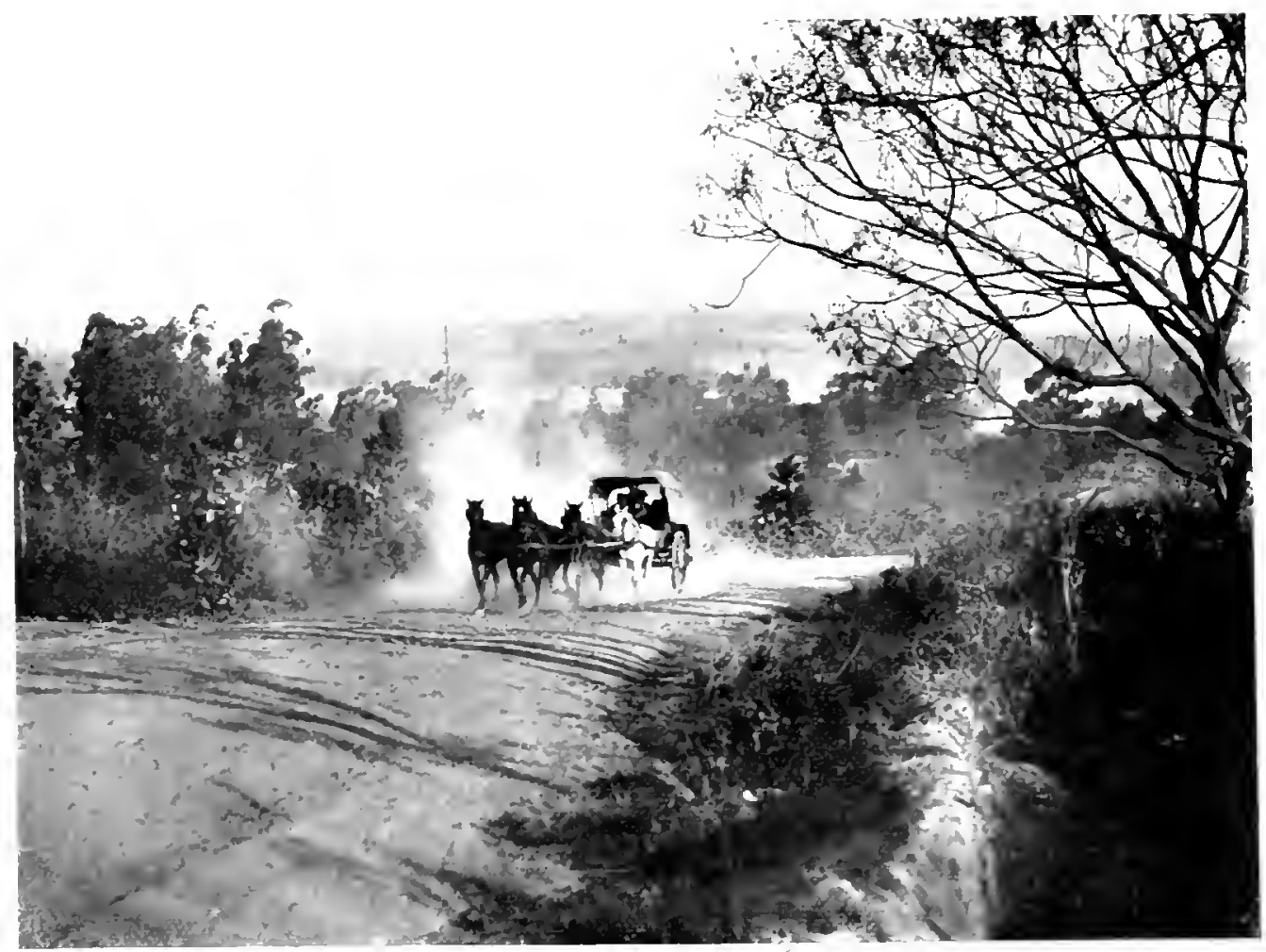

THE BLLWIR FOST CART

\author{
CHAPTER IV. \\ BI POST-CART TO BLLIVER AXIN \\ THE IPOLELA IISTRICT.
}

THE NEI" NATAL-CAPE IIIE.

B

LI.WER is an important farming centre in the district of I polela, 58 miles from Pietermaritzhurg. It is now gained hy poit-cart, which runs wic lidendale and Boston, and leaves the City at 7 a.m. daily. except Sundays. The journe occupies about eight hours, and the fare is z2s. The fare to Edendale is Ss.. and to Bstun. IIs. The ride up lill and down dale is intensely interesting. Wilgetontein, a goml agricultural district a few miles out of Maritzburs. being passed, and the L'msindun River crossed, the route lies through the Edendale Wission property. Asteep hill has then to he negrotiated, from the summit of which a charming panoramic view is obtained. The village of boston is soon afterwards reached. and a welcome stay is made at the hotel for tedrehments. Proceeding. the picturesque Eland'= River is pased, and Lundy's thill is ancended. the road cutting through a delighterl pitec of bush. Then comes the lovely valley of the

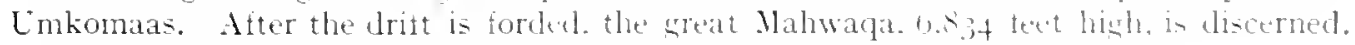
and in a short while, the town of Bulwer. which reposes at its bate is arrived at. 


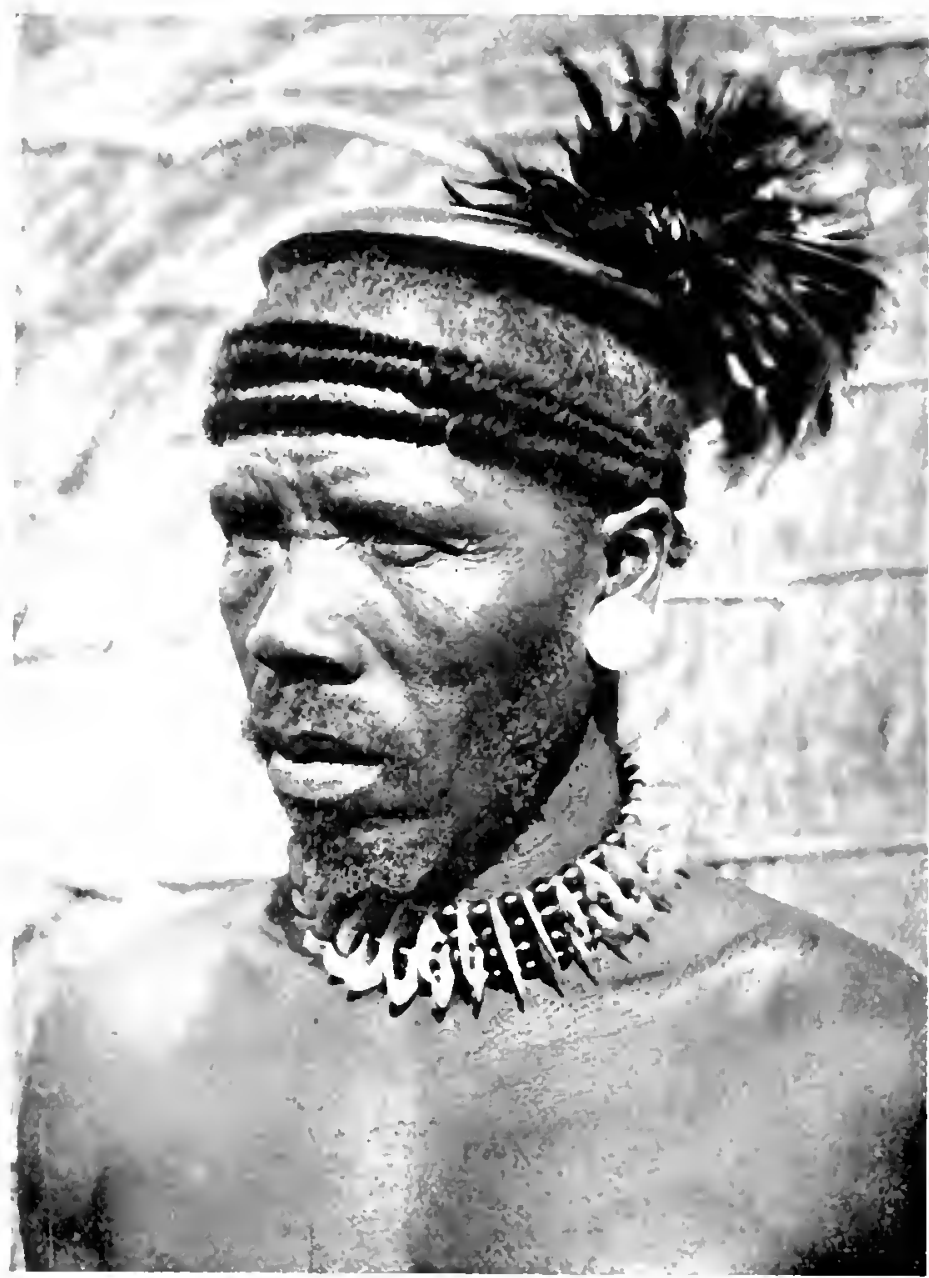

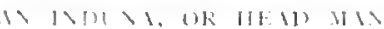

l, whis:
So tat as tle tom It selt is comentuel. it $1=$ mom -alulurmus, laville all altitule ot 5.000 le.e It a a malgintall bill the [1-1hal finceltumlent

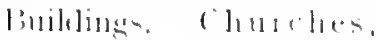

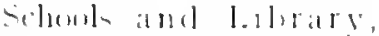
Temmic and othererlubs, Ieriondtural and Jorli (11]tulal! Simietios, and on

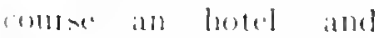

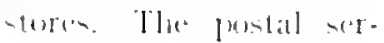

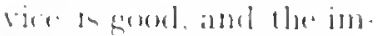

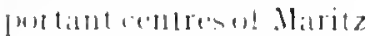
lutge. Jimetom, and len

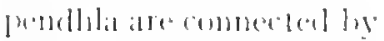

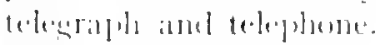

Tha new townshije of

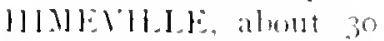
mile west af bulwere, near llu. lierge is prougressing baflully, amel a magistrary is polnised. A post-cart wrice has recenth heen establisluel, rlunding from bulwer on llonday, llolnesligs, and lirilas"s-bite ios.

Jir rebition to the larminger aldel other qualitius of the I polelis distriet

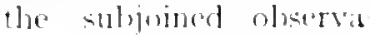
tions mat |x० grivels:-

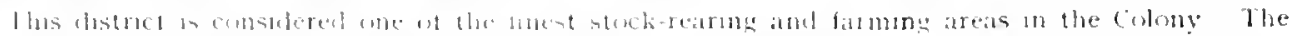

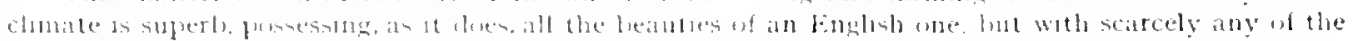

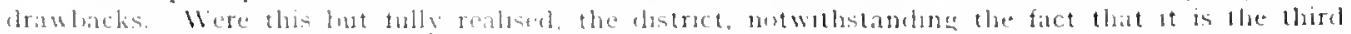

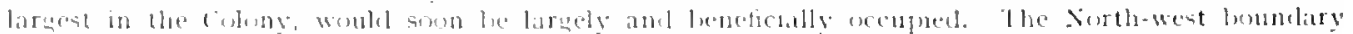

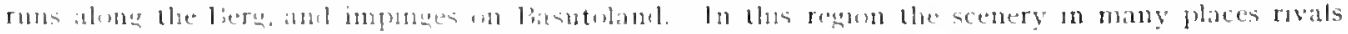

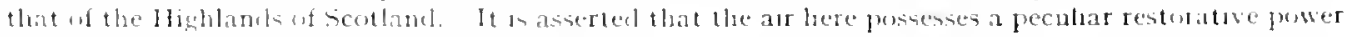
us combecion with rlieumatic attectons.

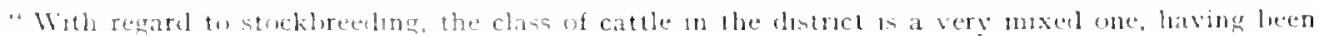

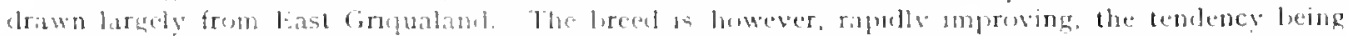

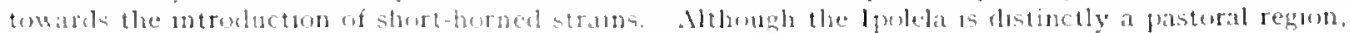

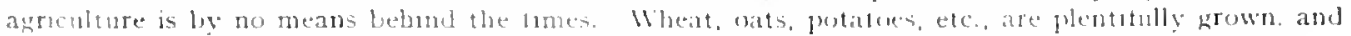

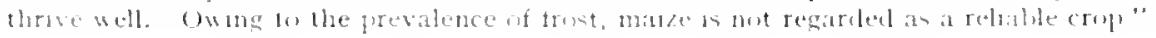


THE NEW RAll,WA LINE THROLGH THE 1 POLELA DISTRICl TO CAPE COLONY.

Alter weightycon sideration, the line of the new connection with Cape Colony, which will shorten the existing route to Cape Town by oner 200 miles, ant promote at considerable traffic between the two Colonits. has been fixed to start just south of Maritzburg Station, and run itu Edendale, Eland's River. Donnybrook, and I)ronkvei. making junction at Riverside on the Griqua land East horder. with the new Cape line which will be prolonged from Indwe viu llatatiel ancl Kokstad. When the line is laid, it will pass witlin about eight miles of Buker, and the means of access thereto will be provided from that point instead of from l'ietermaritzburg, as at present.

The work of construction of the Natal portion of the line (ahout roo miles in length) is being rapidly prosecuted. Branch lines to serve the important Impendhla. ['nderberg, and Stuartstown (Kxopo) districts, have been survered.

There can be no apprehension as to the profitable issue of the scheme. having for its object the development of a rich pastoral and agricultural country, and the fostering of new industries.

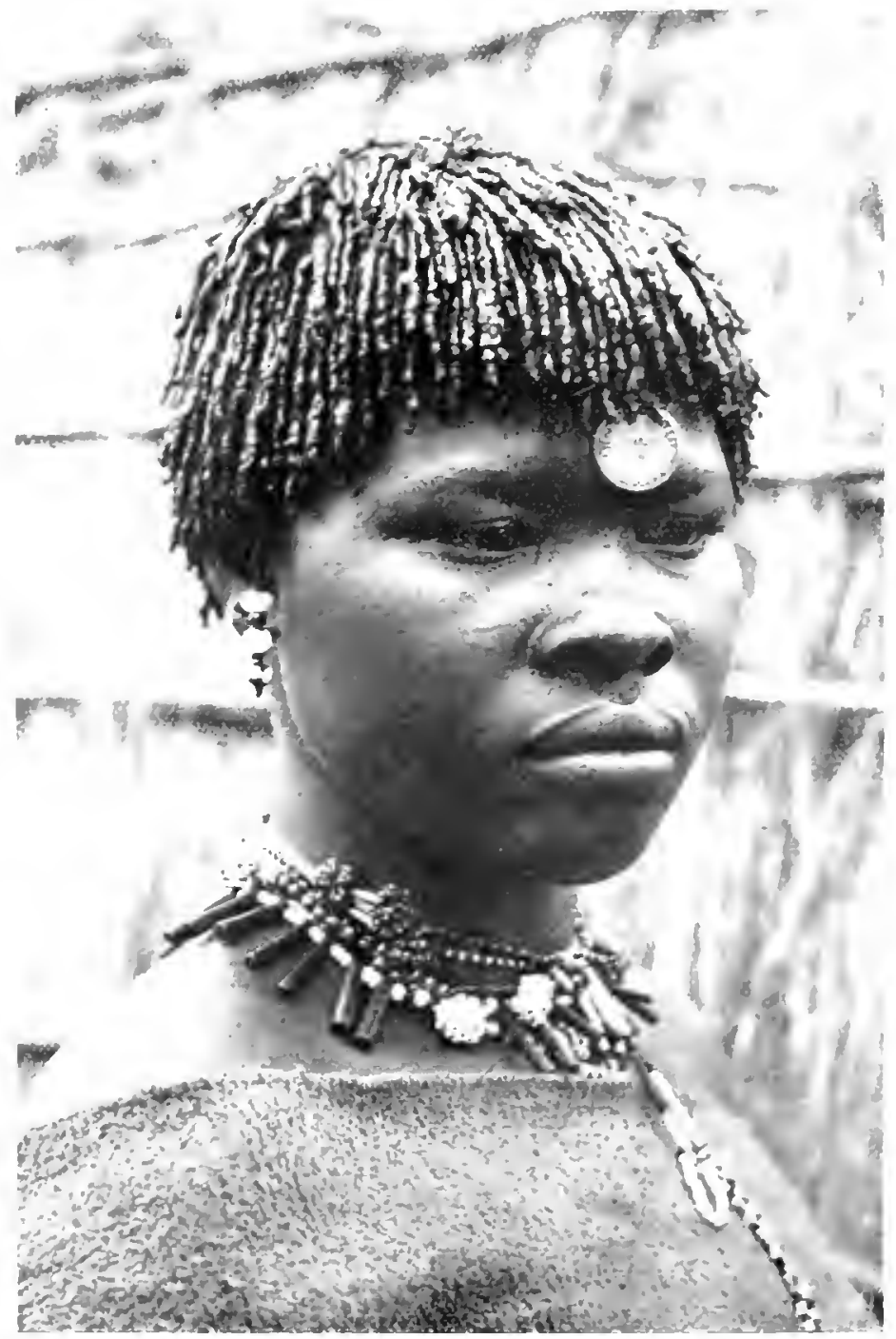

WIFE OF A KIHIR CHII:T 



\section{SECOND BOOK.}

HANDBOOK

OF

GENERAL INFORMATION

RELATIXI TO THE

COLONY OF NATAL

$A \backslash D$

A SHORT REVIEW OF THE RAILWAY SYSTEM. 


\section{INTRODUCIORY NOTES.}

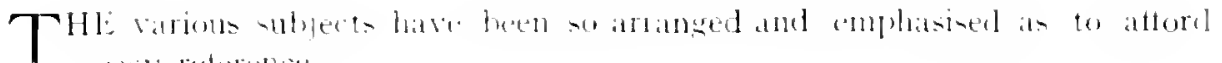
(isis relerence.

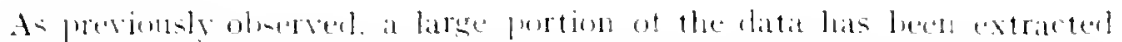

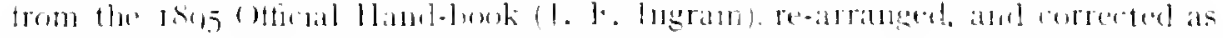

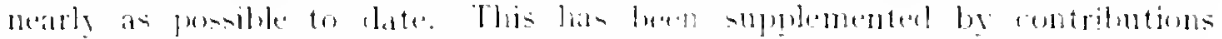

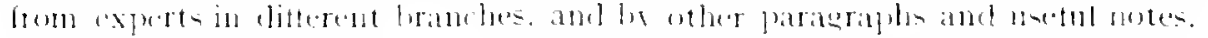

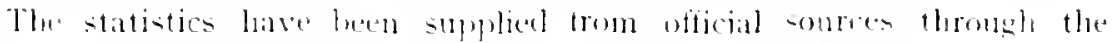

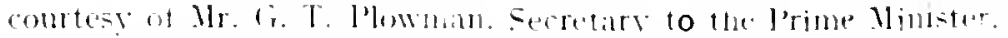

The eneneral phan en the Colony was specially drawn in the survertor

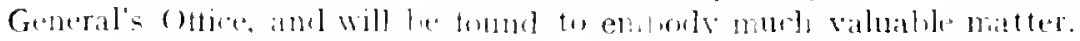

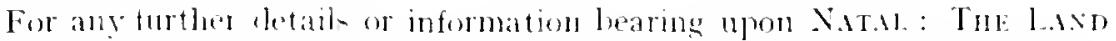

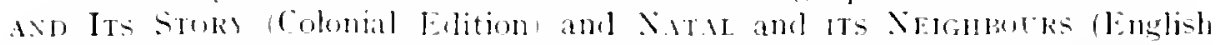
Erdition). the realer cannot he better than reter to Mr. Robert Rusedl's books

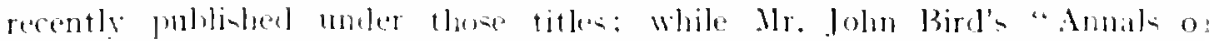

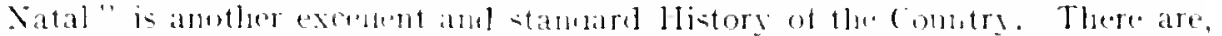

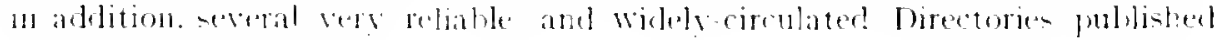
ammually n the colom?
} 


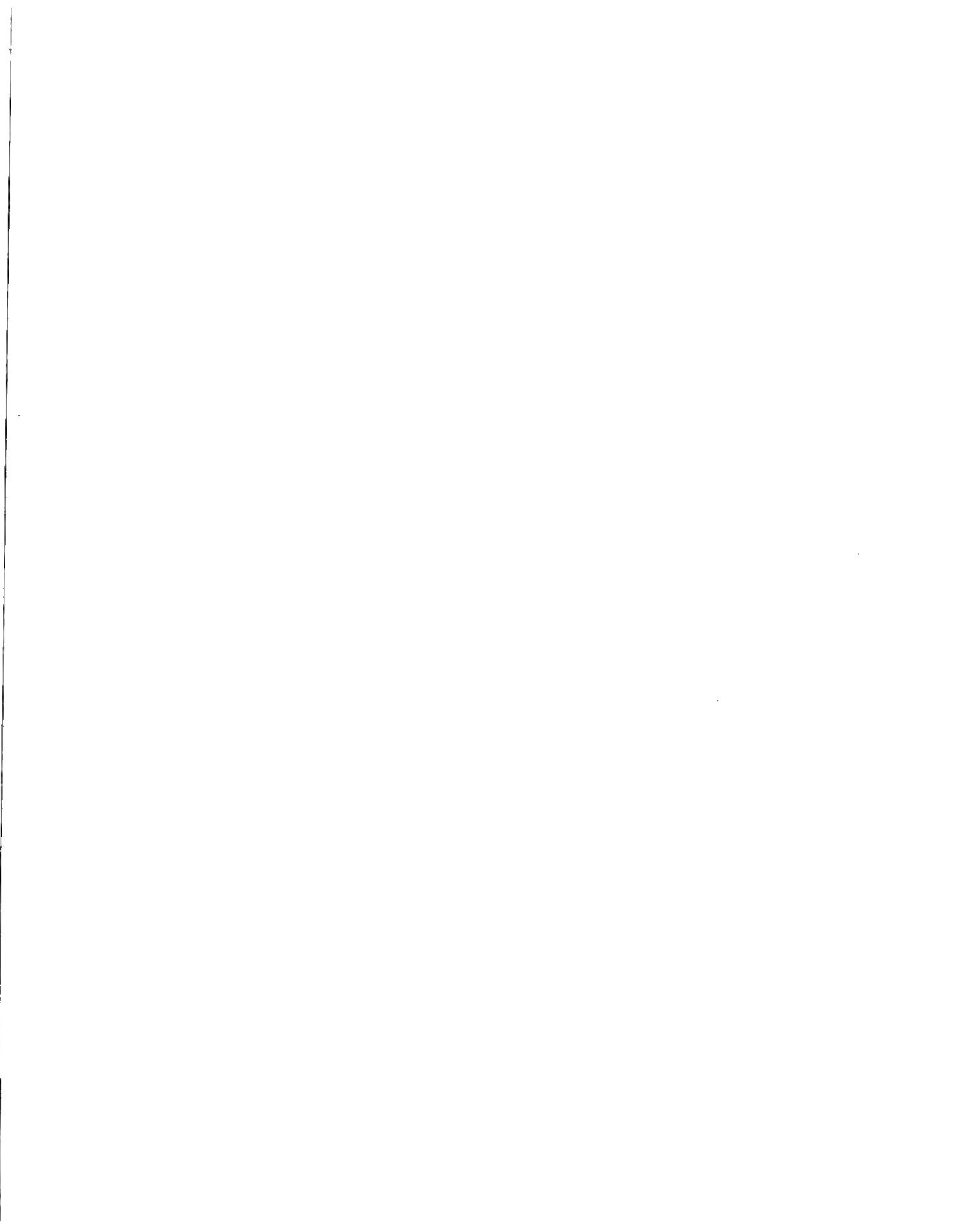




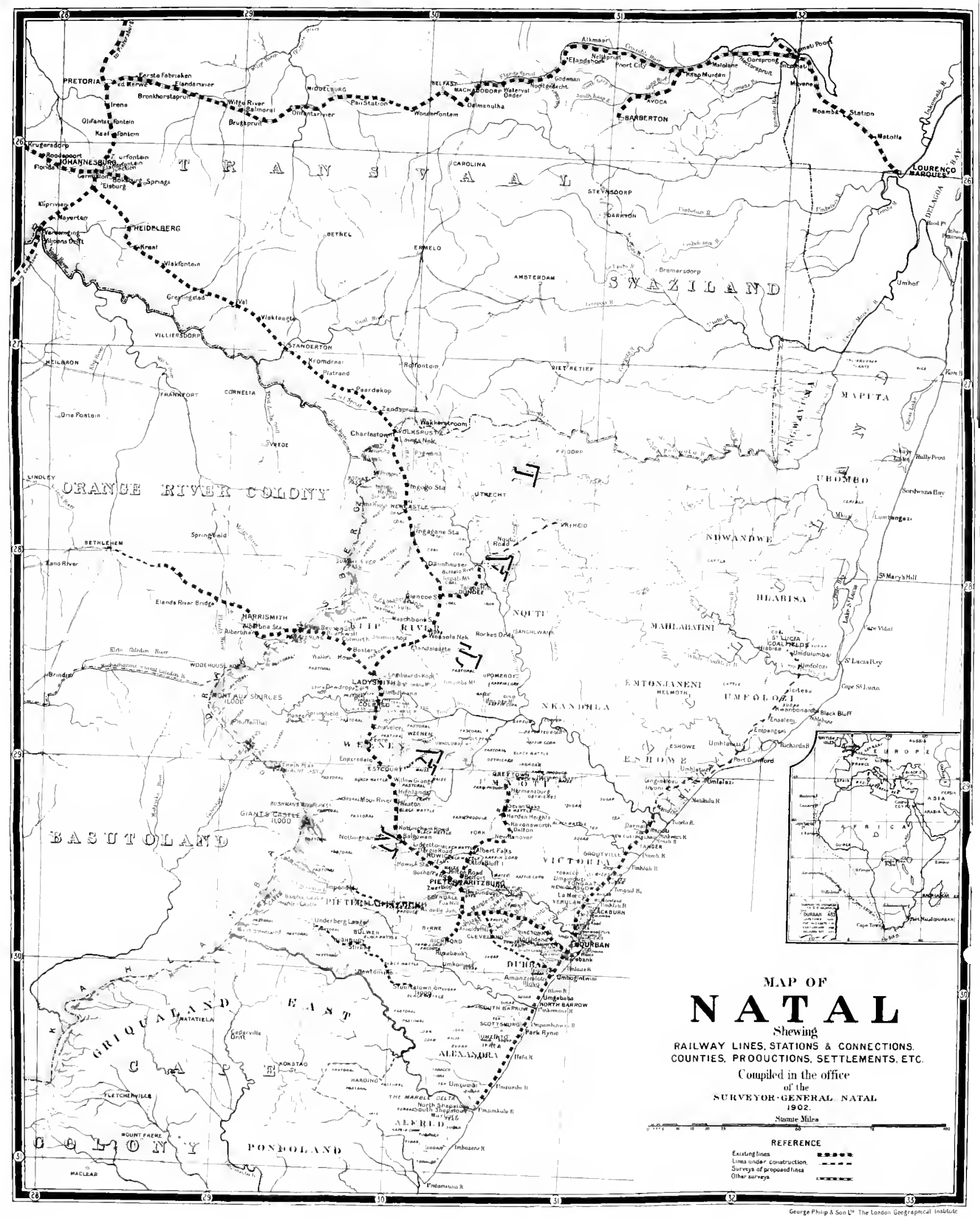




\section{HANIMBOH OF GENERAL TNFORMATION.}

$\mathrm{T}^{\prime \prime}$ HE COLONY (JF NITAL is situated on the sontherast const of Africa. between $27^{\circ}$

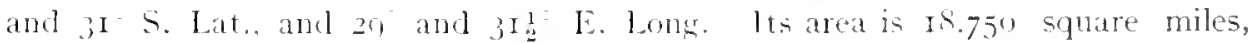

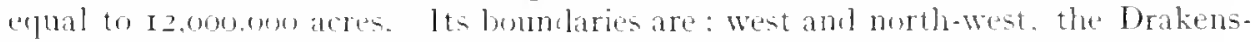
berg (a towering range of mountains separating it trom basutoland, the Orange River Coloms: and the Transraal!: on the north-east, the Puffialo and

POSITION ANI) AREA Tugela kivers divide it trom the Transwal colony and Zululand: and on the cast it is lumbled by the sea The southern frontier runs along the Emtamsuma River to the lugeli Nomntans. and thence up a somewhat intricate course to the [pler Umzimkulu, therehy separating the

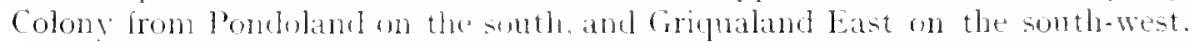

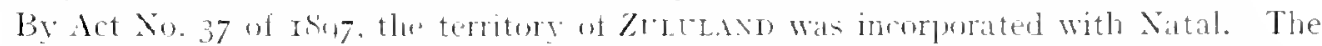

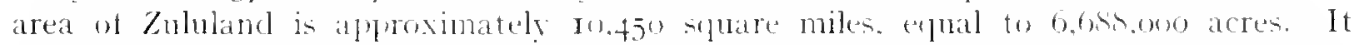

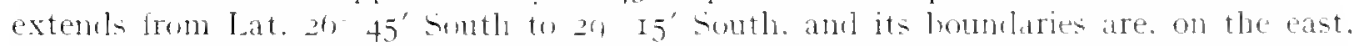
the Indian (tean: north-west, the Vrrbed bistrict and Swaziland north, Portuguese East Africat; and on the south. Satal.

Including Zululand. Natal has a seaboard of about 34' miles. Its ureatent leneth is 330 miles, and hreadth I 5 is miles.

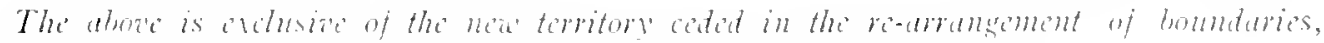

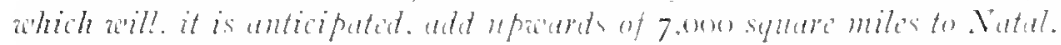

The Plysical Geograjhy of Natal is not difficult of description. Starting trom the coast. the Colony, by a series ol almost regular steples. attains

PHYSICAL GEOGRAPHY an altitude of two and a puater miles above sea level at the Drakensbers. Where snow-clad peaks are no uncommon sight. The main rivers, hereater mentioned. traverse the colony from the Berg to the ocean, and to and from these a countless and almont confusing labrinth of tributaries and comecting streams seam the combtry in every direction, all ot ionre trending towards the sea.

The Terraces or Steppes of Xatal may be set down as follows: The first from the seat extends about tourteen miles inland. and attains an elevation of alwut roon teet. The second. starting trom thim point. is ahout twenty miles broad. which brings us at a dintance of thirty-four miles trom the sea. to an altitude of 2 jou feet. The thirel terrace alout twenty-five miles in brealth. sweets to an altiturle of 3.700 text. The fourtho of almost

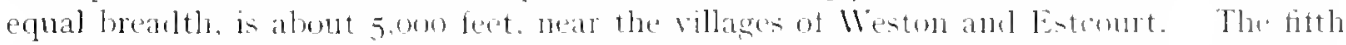

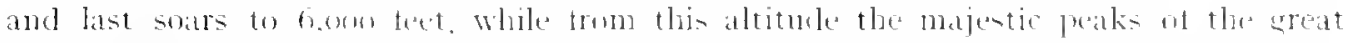

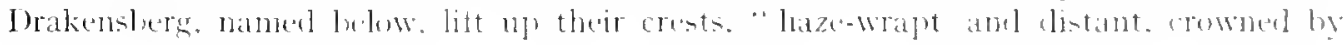
Heecy cloumls."

The mountain system of Natal is ome of the most interesting tedtures in the culong

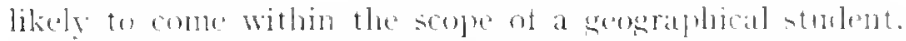

MOUNTAIN SYSTEM

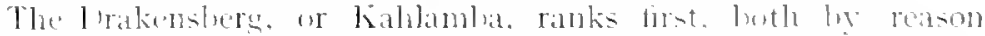
of its size and grambers, and the tact that it forms the most important and striking toiture of the inland trontier. The most

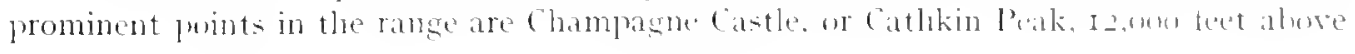




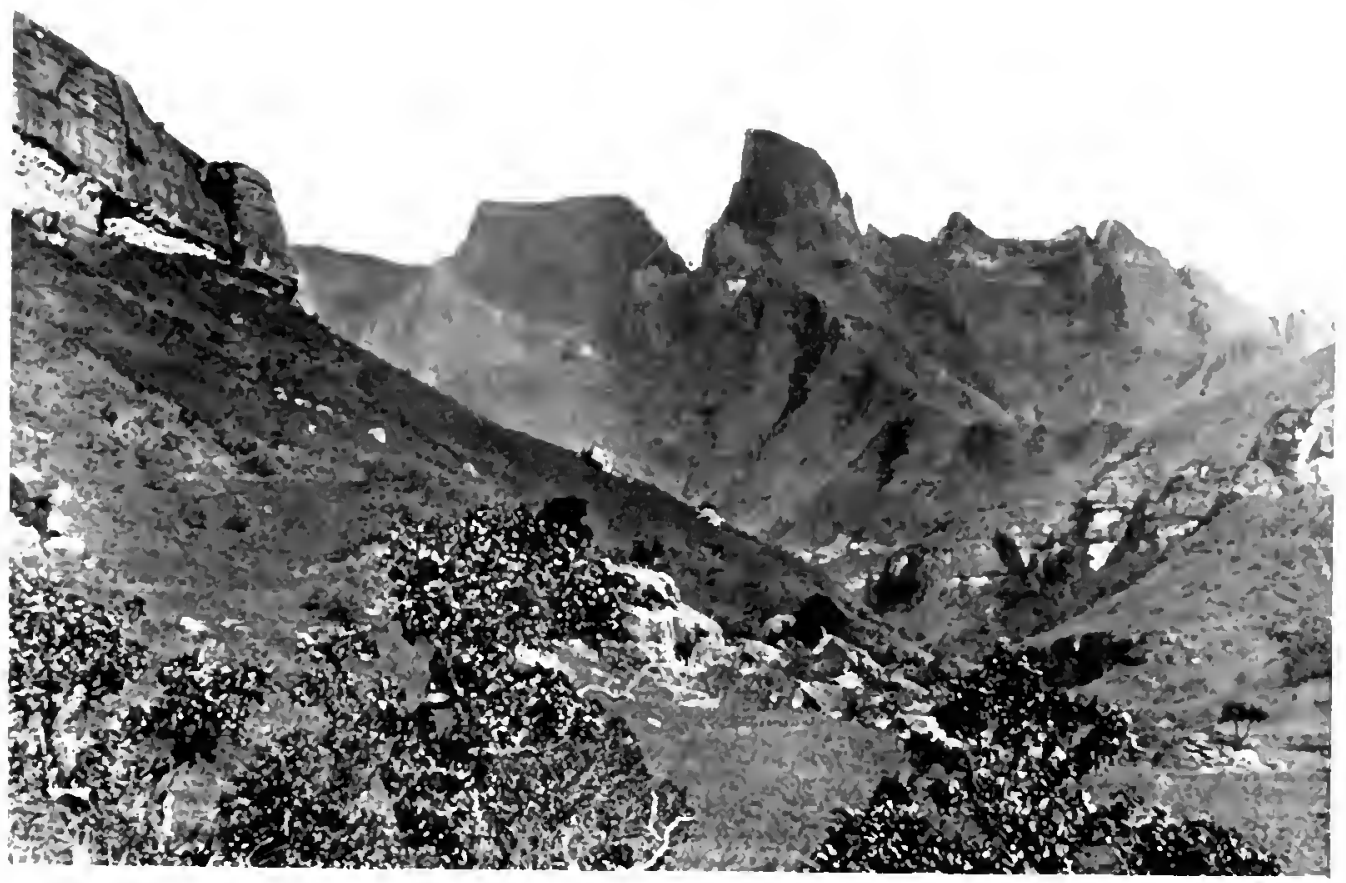

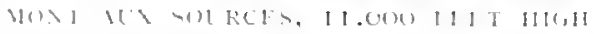

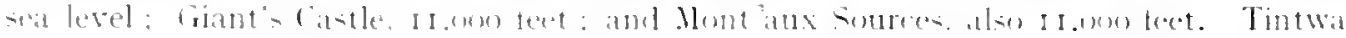

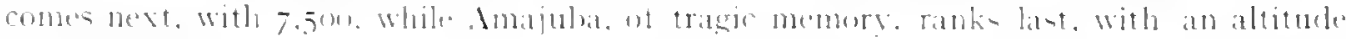

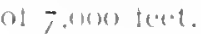

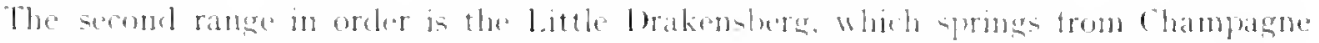

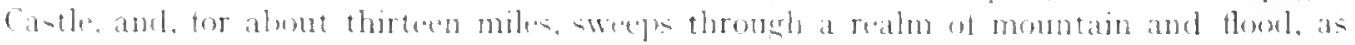
gramelly beatitul at the heatt ot man can destre.

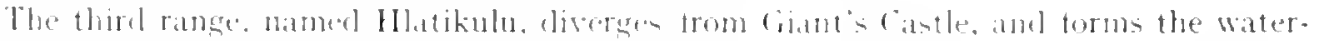
slumel hetwen Bu-luman's and the Hexi Rivern.

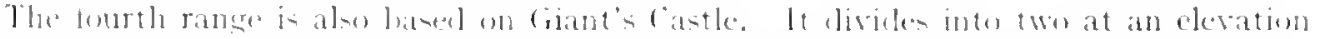

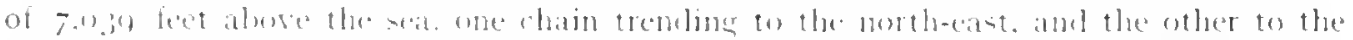

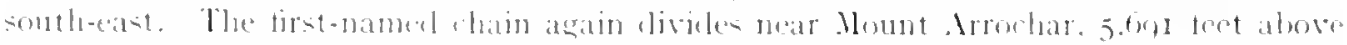

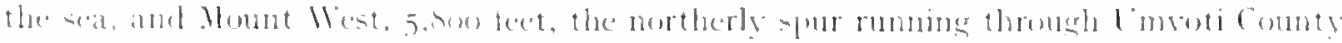

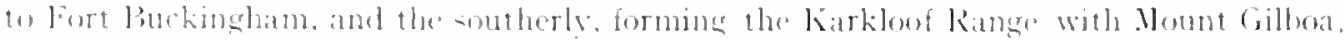

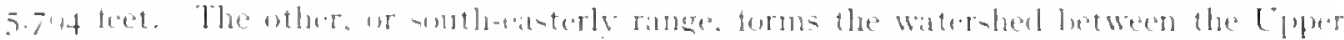

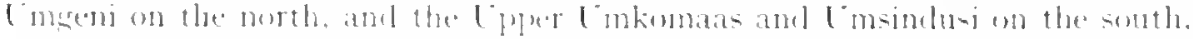

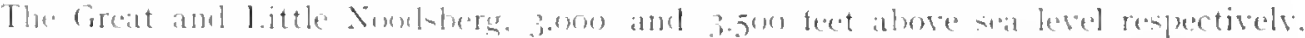

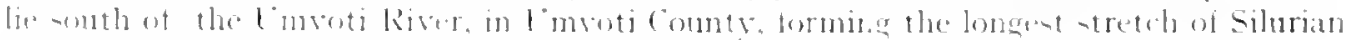

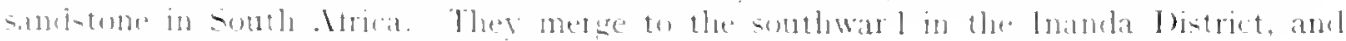

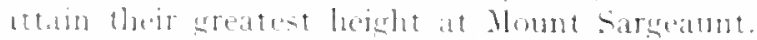

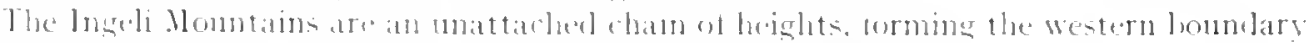

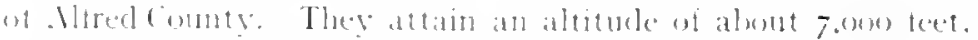

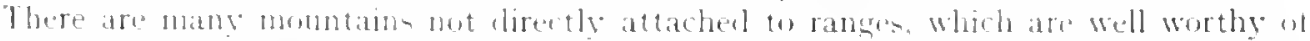

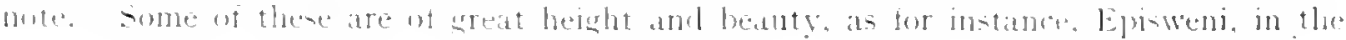


Tugela Valley, in 'Lmroti County, and Tabamhlope, or White Mountain. 6,512 feet, near Estcourt.

Owing to the configuration of Natal, it is unhappily the case that but two Rrvers in the

\section{RIVERS} country are navigable at all, and those only for a few miles from the coast. The very circumstance which bestows on the Colony its rariety of climates-that is, its steppes or terraces,-cuts off this cheap and easy means of transport and pleasure.

Of first-class streams there are three-the Tugela, the Lmkomaas, and the Cmzimkulu. The Tugela, which is in the north of the Colony. is the longest anrl most beautiful. Taking its source in the Drakensberg, as already stated. it leaps with one bound orer a cliff I, 800 feet sheer. into the Colony. At sixty miles from the sea the Tugela is joined by the Buffalo River. The chief tributaries of the Tugela are the Klip. Sunday's, and Buffalo Rivers from the north, and the Mnwe. Umlambonga, Little Tugela, Blaauw Krantz. Bushman's. Mlooi. and Inadi Rivers from the south. These, again, hare numerous tributaries, such as the Sand, Inkunzi, Waschbank, Incandu, Ingagane, and lngogo.

The Tmzimkulu ranks next to the Tugela in size, and long before it in usefulness. Its scenery is rich in grandeur, and especially beautiful at the mouth.

The Lmkomaas (Gatherer of Waters) rises in Giant's Castle. and flows through wild and interesting scenery. which here and there becomes more distinctly. English and homelike than that of the Tugela. On the whole. however, it retains its quaint African characteristics. Its most important tributaries are the Lzani. Eland's. and Linkobeni, from the north. and the Inhlaveni and Ixomo from the south.

There are five second-class rivers in Natal, viz.. the Lmvoti, Lmgeni, Lmlaas. Hllovo. and Lmtamruna. Amongst the third-class streams, commencing to count from the

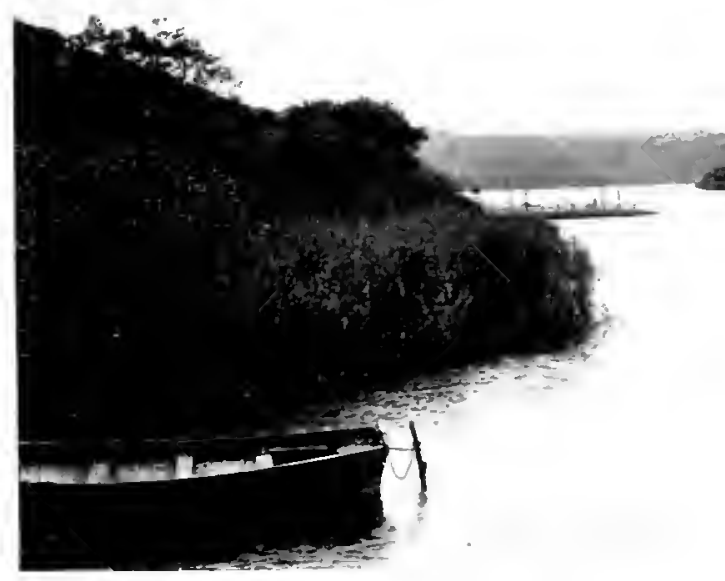

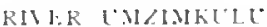

northern trontuer. are the sinkwazi. Xonoti. Emhlali, Tongat. Lnuhloti, and Great and Small Lmhlangas, in Victoria Countr; the Lmbilo. Lmhlatuzan (tlowing into the Bay at Durban). Cmbogintwini. and Amanzimtoti, in Durban County; the Amahlongwa, Lmpambanyoni. Lmzinto. Ifafa, Lmtwalumi, and Lmzumbi, in Alexandra County; and the Lmbizana. in Altred County. The tributaries of these minor streams are far too numerous to particularise here. but. from what has heen set down, the reader, bearing in mind the size of the Colony. will realise how well-watered and fertile it is. 


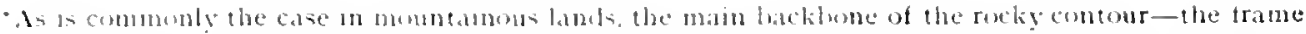

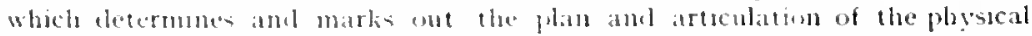

\section{(it) ( ) C ( i)}

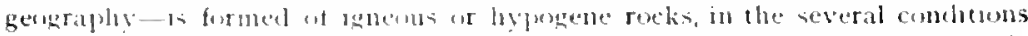

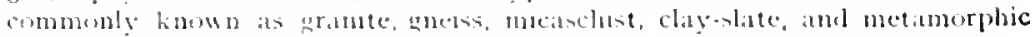
limesconte.

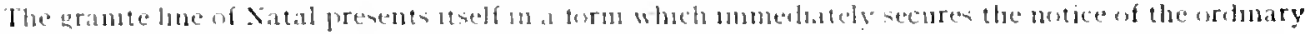

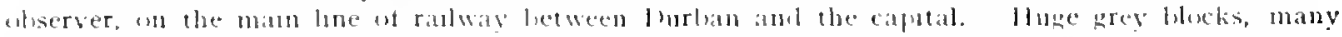

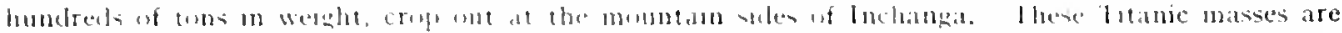

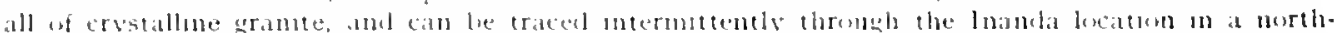

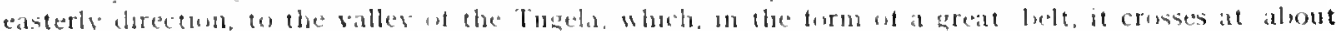
serenty moles trom the seat In the upuste durectum it enters the aceatn cumblerably somth of the

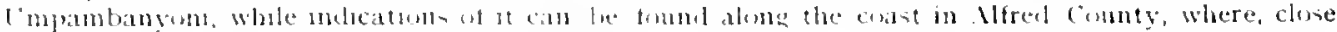

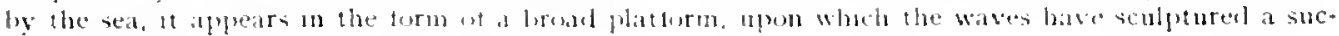

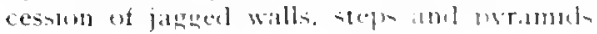

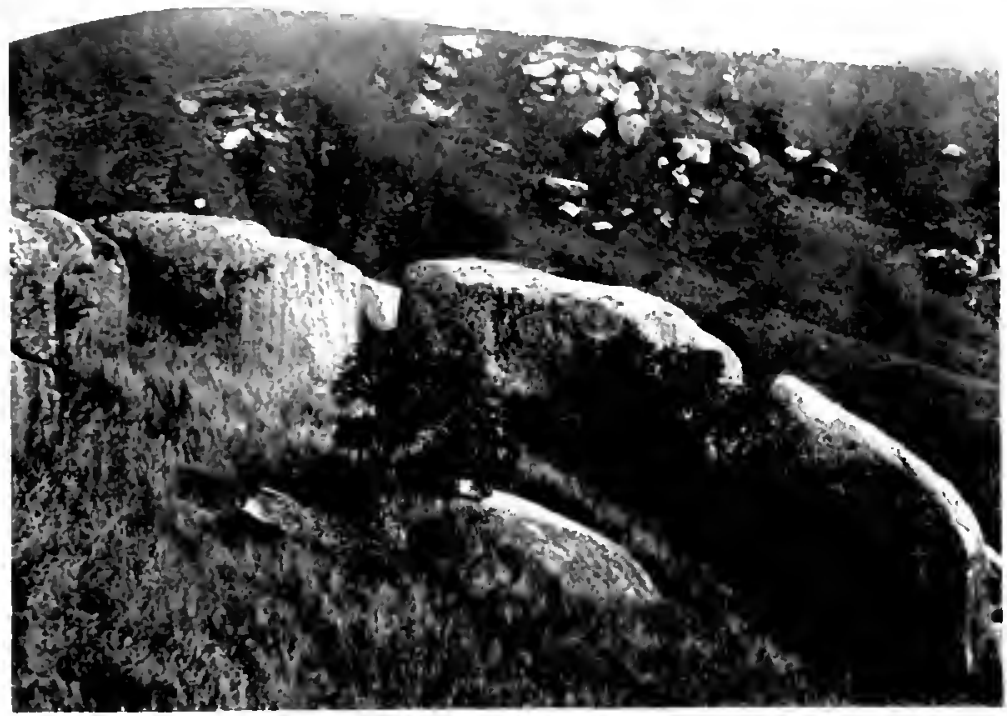

GRINITE OLTCROV YEAK IXCHATC

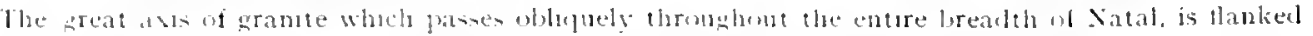

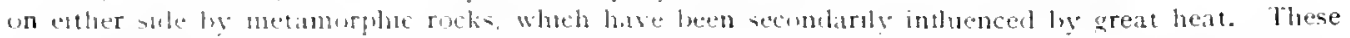

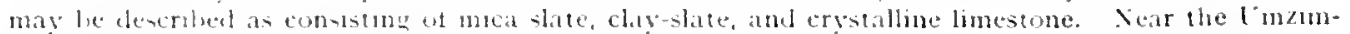

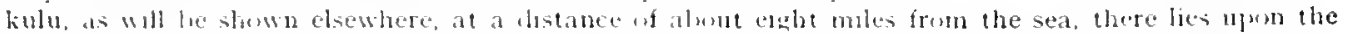

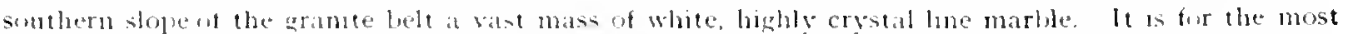

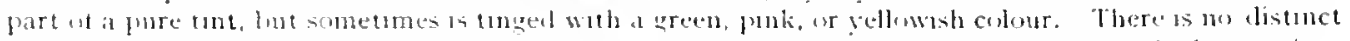

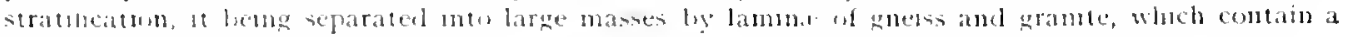
consulerable fuercembage sif quart\%.

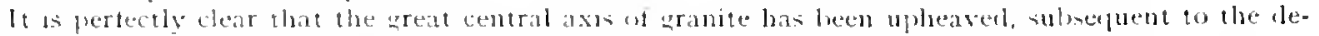
posit if the neiglaburang heds of rocks, many of wheh are broken, talted up leg an, and, when in ats manediate proximitg, changed an thear numeral character.

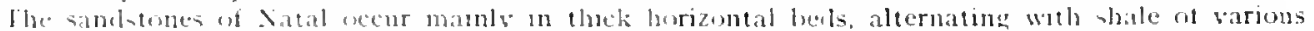

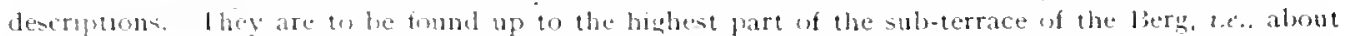

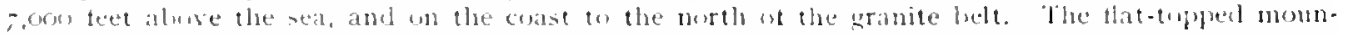

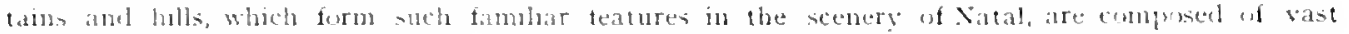

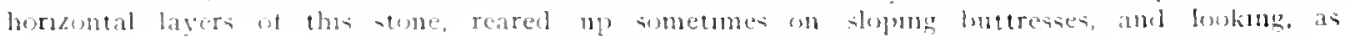
I In: 
Mr. Henry Brooks says, "like broken slals of the uld pavement that was shattered by the earthquahe throes on the upheaval of the grante."

The rivers of the coast, while mut unfequently flowing through the stratutied roclis tu the iranite beneath, often pass hetween preturesclut chits of reddish sandstone, sume of whach most protably belong to the Devonan and Siluran systems, and some to the gounger age if the new red sandstone. Others, again, are assiciated with altermatme lavers ot gritty sandstone, which unguestuonably is uf the carboniferous age. Dykes of green stome-trap constantly pierce the simblome formatuns, whtle "faults" are frequent.

Coal occurs in Natal anomgst the carbomterous sandstones in varuous places, and, fortunately for the Colony, is abundiunt.

Sext in wrler, as regirds frequency of wccurrence, is ereenstone and trap un one or wher of its protean forms. The telstmes, greenstones, and urante are continually found in all countres. clusely assuciated, and occasionally pass mto earh ether in the same comtunums muncril mass. At the Ungeni Falls, near Howjcl, three distunct beds of trap rock occur, separated ly intervenug layers of carbonaceons sandstone and shale. Some little distance to the sciuth withe lumzunkulu River. there is a mmature "trants" Causeway," wit the shape of a plattrom of colmmar liasialt extending

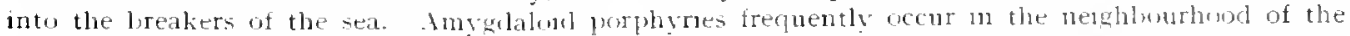
intrusion of trap dykes. Agates of preat heanty and sax-suded prisins of rock cryatal are carried down by the rivers from the eiges of trap vens expued w the higher mowntus. it has leen found that the best soil in the Colony is located n thase places where the stratulied roclis are mont broken through by the intrusive eruptom of trap.

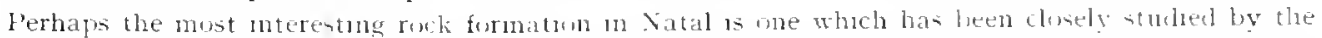

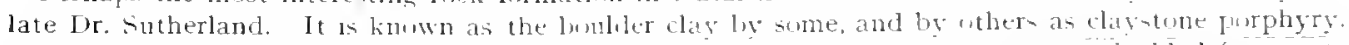

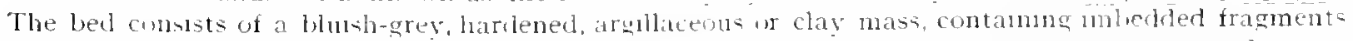

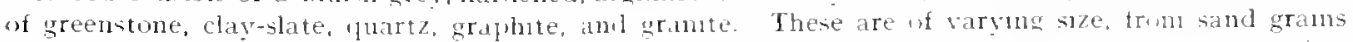
to blucks measuring six feet acrus. The fracture et the rock is not cunchind, and thete la nandest in its substance, a disposition to wav stratificaton. The thickness of the beds virles comaderably

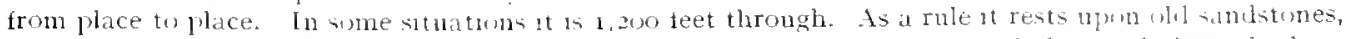

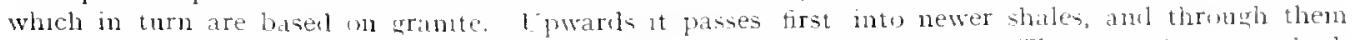
into the sandstones and shales whch are assocrated with the coal depusits. The tranition is aralual, and shows nu distunct hne of denarcatum. This formatron flanks the long line of sindstone bills which

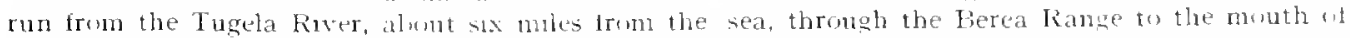
the Cmbilo. It also crops out near Maritzlours, atretching away through the Lmaeni and linvot

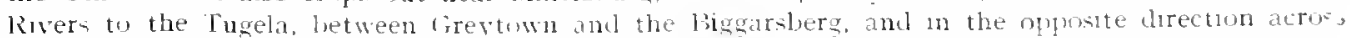
the Inkomaas to the sonthern tronter of the colmy. It trends away then, acrusis the St. Joln's River to the Cape Colony. Foulder clays of this class wecur in varbous conntres. The me wheh has had most attention desoted to it is luated in Carnarroushire. Frofesanr Ramsay cunsiders that there is only one known agency wheh is allequate to the production of all the curcumstances met

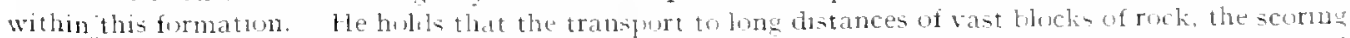
of the subiacent iurfaces of sanbstone, and the smultaneous deposition of muntes and grans and

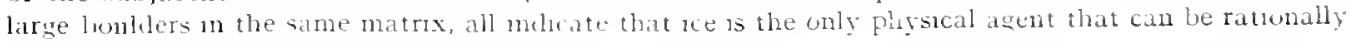
credited with the creation of these clays.

The lomestmes are nucli mure sparmuly represented m Xatal than these samlstonea. In the Tugela Valley there are deposits uf nolular lmestone. The presence orytallume metamorpho marble has already been mentmed. The leds whoh solely represent the cretacena system occur on the southern coasts if Natal, and are uf comelerable geoloncal interest. In phes, the lieach is

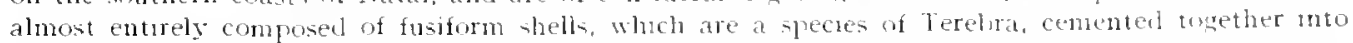
a solu mass, imomgst which are tusks and lunes of verteluate animals, and trunks uf larat trees.

A whe field of stuly here lyes open to those who have the skill and tme to dewite to st, and pages might easily lie tilled with olservatums, eath one of which would be of scientitic value.

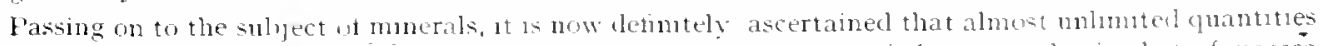
of iron ore occur in the (olons, in the torm of hods and concretums of clay-mon, alsis in that uf masses

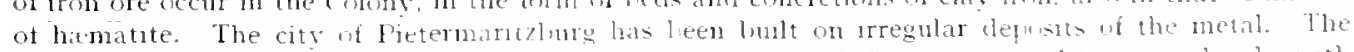
ores are in some instances su roh thit the nitives have worked them into nietal fur spear heads. whth the rudest appliances imasinalile.

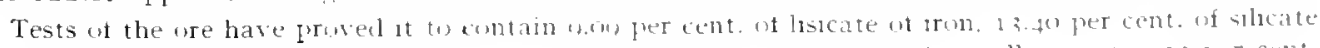

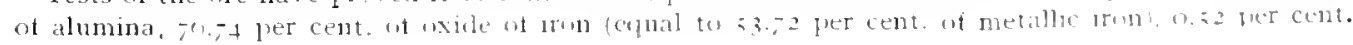




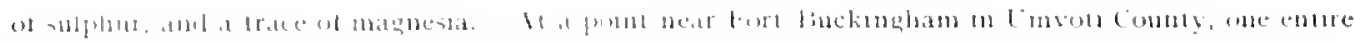

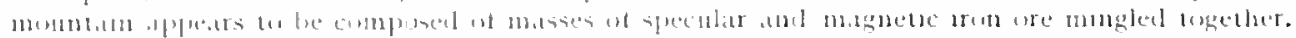

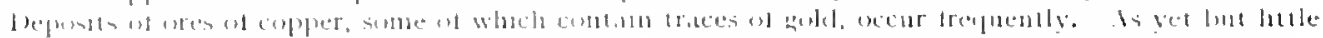

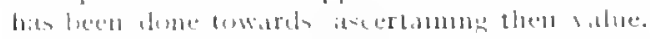

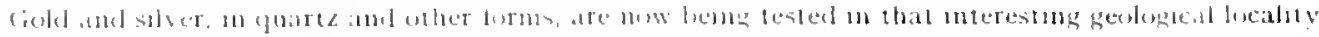

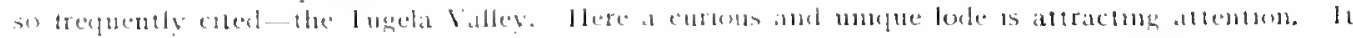

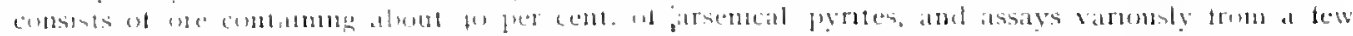

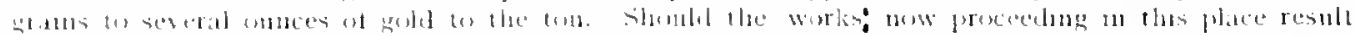

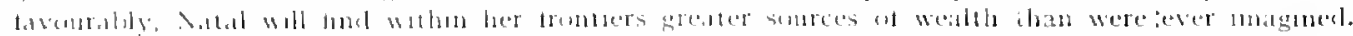

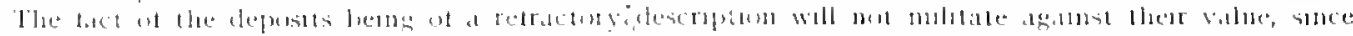

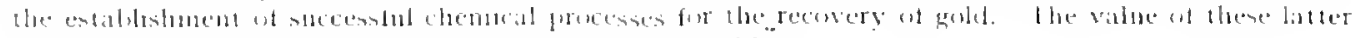

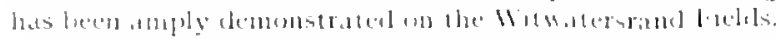

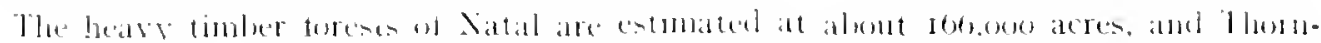

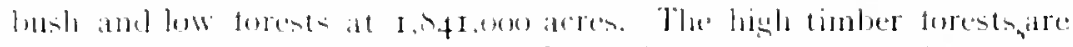
FURESTs for the greater part stmated along the lorakenolerg kiange of

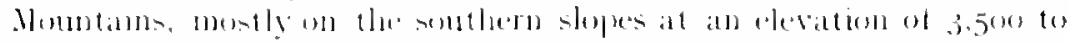
6.tros teet. Where the mean annual temperature ranges from 52 to 59 . The uprighte

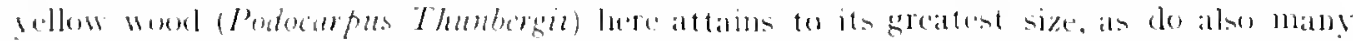

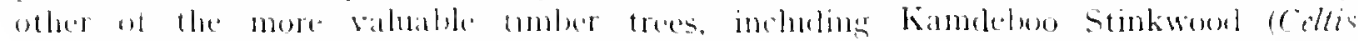

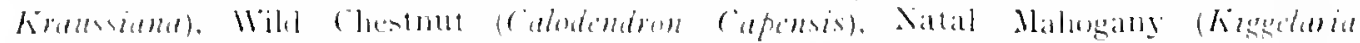

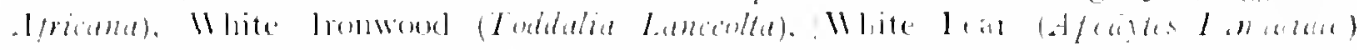

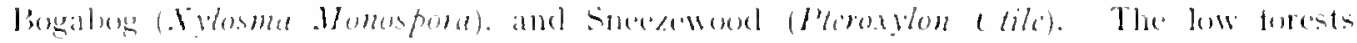

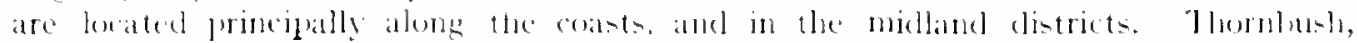

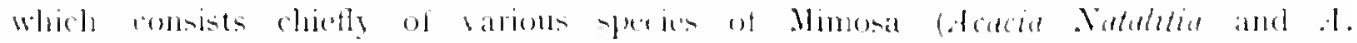

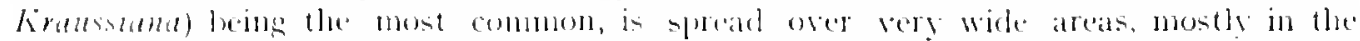

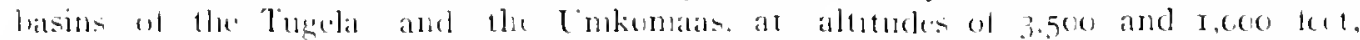
ledow which it intermingles with the chast loresth. In this region the mean amual

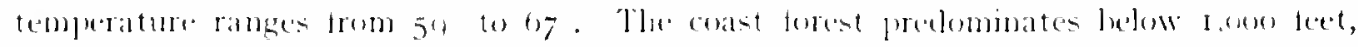
whe the chmate becomes sub-tropieal. and the mean annual temperature ranger from

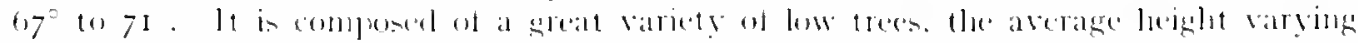

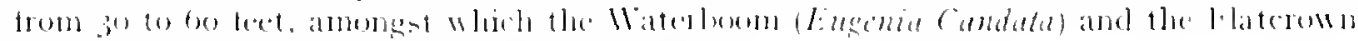

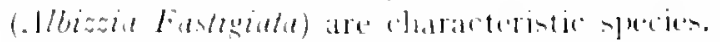

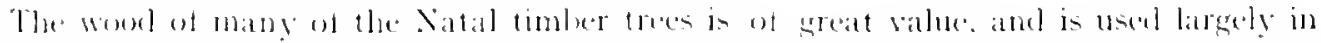

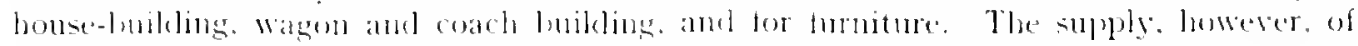

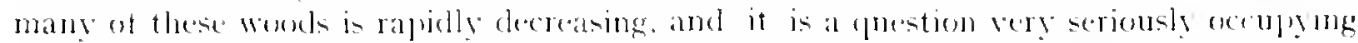

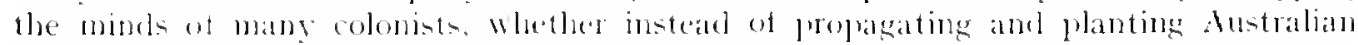

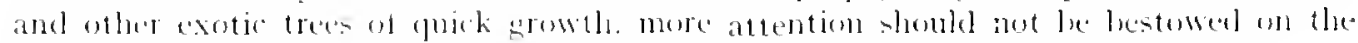
consersation and plunting of trees indinemons to the chimate and soil of the combtr.

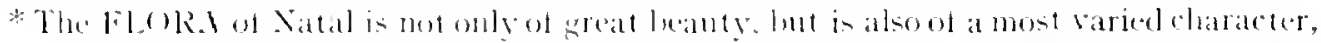
Fl(MA, FKITTS, CEREAIS. GIRASSLS, Si. ranging trom an alment tropical regetation in the coatst distriets to a sub-alpine we on the crests of the l)rakensbers, and to emmerate even a tithe of the leatutiful thowers trees, ancl climbing plants included in it woukl

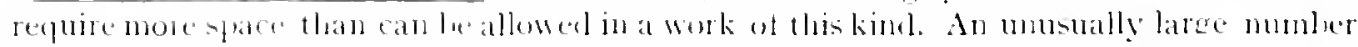
of the indigeness planto ot the Colong have heen cultivated in Emope, and some of them

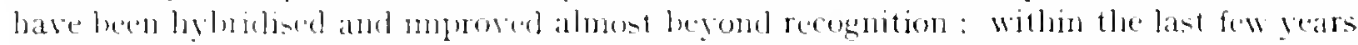

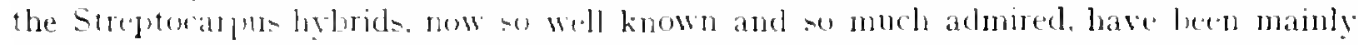

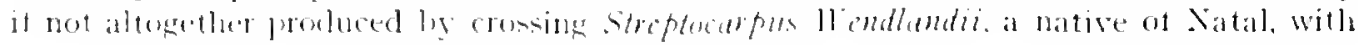

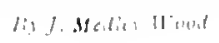


S. Dumii, a Transvanl plant. and the jorogeny of the plants is said now to rival the Gloxinias in beauty. Some of our Gladioli, Clivias. Knipholias and others have heen similarly used and are now great favourites in cultivation. In the coast or sub-tropical district flowers are to be found almost the vear round, but in the upper districts during the winter months they are lut litte sem, the velel being hrown and quite hare of flower, and the forests dark and sombre, with scarcely a flower to enliven the scene. As soon as the spring rains have tairly set in this is quite changed, the young grass becomes emerabd green and the reld is studeded with flowers of the most varied colons, and a railway journey in the upper districts tecomes a real treat to the lover of flowers. The traveller at this season can hardy lail to noto how important a part the railwars take in the distribntion of our native plants: and heing fenced on both sides and cat the excluded. the niants come to matuity and bear their seeds which are scattered fur and wide for long thistanres. while ontsidel the railway lencts, especially towards the close ot the season, all is harren and dull, cattle and sheep having eaten and trampled down the plants until but tew flowers are seen. It is unfortunate that onr railways in the upper districts clo not pasi neir to any of the large torests, for it is 11 and arouml the margin of these forests that our floris is seen at its best. Inside the forest the el ming plants find their way to the tops of the trees, where they hear their thowers and mature their seeds. while the brancluts and stems of many of the larger trees are trequently covered with epiphytal Orchiels of ditferent species, mosty bearing white or vellowi-l flowers, which, however, are ot butanical interest only, while the margins of the brooks are literally covered with many charming and interesting ferns. and from the trees and rocks are olten seen hanging in profusion the

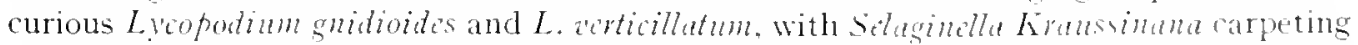
the ground beneath. Though our epiphytal Orchids are not rely showy, many of the terrestrial ones are excedingly so. They commence flowering when the spring has fairly set in, and the different species flower in succession until about the end of March, an excertion being the pretty little Swan Orchid (Cynorhis compata) which flowers in July and August; it is peculiar to Natal and is rather rare. It is much to be regretted that purple will persist in digging out the roots of these plants when they are in flower, with the result that not one in a lundred survives, the plants at that time not having matured the tuber for the next season's flowering.

Amongst the forest trees hearing conspicuns thowers we may mention the Cape Chestut (Calodendron capense) with large trusses of lavender-purple-spotted flowers: Natal Bottle Brush (Gregia Sutherlandi) with spikes of brilliant scarlet flowers: several species of Erythrina all with scarlet papilionaceous flowers, and the singular fllowh magna of the midlands, whose tlowers are a dullish red. hut whose winged sepl-resels hecome brisht searlet and remain a considerable time on the tree, rendering it conspienous ren at a considerable distance. In the upper (listricts Dais cotinifolid with prink towers is often seen and admired, and on the coast the Lmzimbiti (Millottid affra) with purple flowers: Isifiti (buphil racmosa) with white and orange sweetly seented llowers. and Schotir brachypetala with deep crimson ones.

Belonging to the genus ExpHorba we hate many species ranging from the small. $E$. sanguinea, which is trodden under toot wu waks and hare places all orer the Colony, to the large arborescent species such as $E$. grandidens. E. urboresens. and E. firmolli, which are found on the Coast and in the midlands, and are often mistaken for Cacti. to sone members of which order they bear a close resemblance. The two first-mamed species are singular objects, being alpurently leatlens. and standing gannt and hare on the hills 


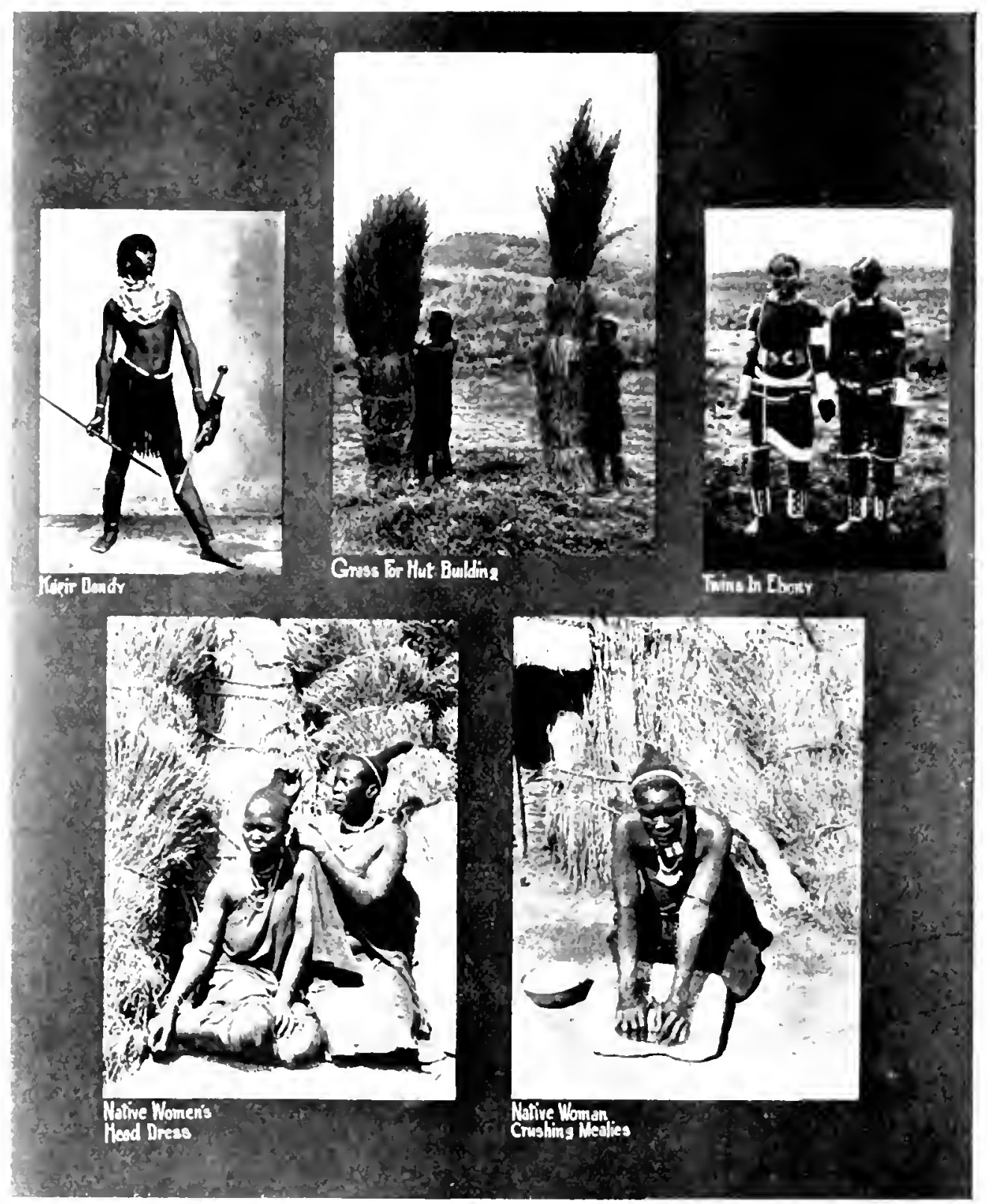

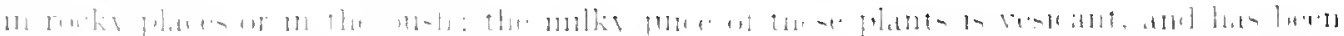
II

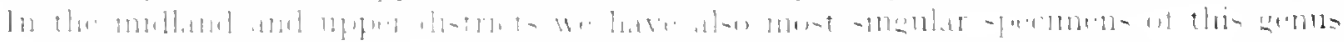

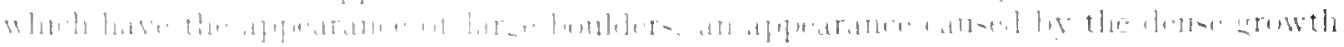


of the numerous stems which are closely appressed to each other, and only at tain a height of Io to 5 inches. Another singular genus of plants, some memlers of which are often mistaken for Cacti, is Stupelia, belonging to the order of Asclepiads: the headquarters of this genus is Cape, Orange River Colonies and Transtaal, hut the species bearing the largest flowers is a native of Vatal. and is known as Stupelia gigunted: all, or nearly all, of the flowers of this genus of plants are unpleasantly scented and are popularly known as "Carrion Flowers.".

In rocky places, edges of precipices, and occasionally in open ground at from 2,000 feet above sea level to the Drakensberg. are found three or four species of Enciphalartos; these plants belong to the order $C$ ycadacede. and are a connecting link between the flowering plants and the ferns, having the renation and sometimes the vernation of the ferns and the fructification of the conifers: they have a trunk sometimes reaching to nearly twenty feet in height, crowned with a rosette of fronds each four to sir feet or more in length, which are renewed every second year, in the altemate years the plants bearing cones. those of the female plant containing a number of scarlet seeds, those of the male, pollen only; in

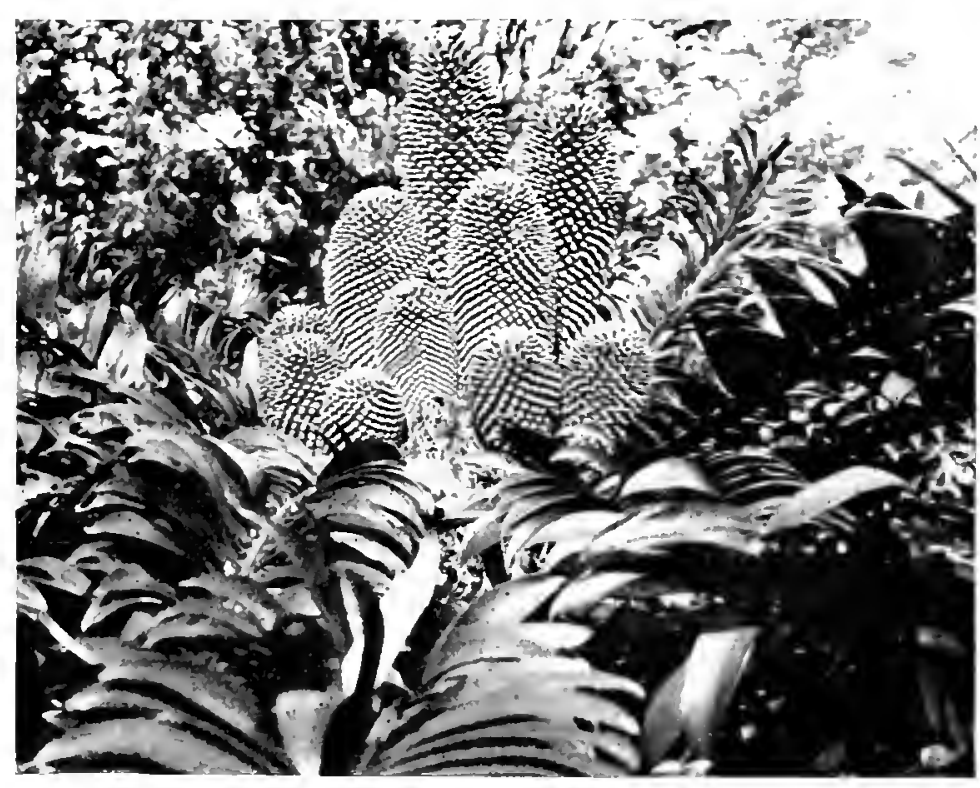

EXCEPH II IRTOS ALTHXSIHAl the wild state these plants seldom bear more than a single cone in each season, but a plant in the Durban Botanic Gardens hore in one rear. $I_{3}$. and in another i cones, this being a male plant.

Of PALMS we have two species only, Hyphene crimita, having fan-like leaves, and being a near relative of the "Domm Palm" of Egypt (Hyphane thethioa); this plant is never, in Xatal, found far from the sea coast, nor does it, except in faroured -ituations. attain a large size. though in some parts of Zululand it is very luxuriant: a fine specimen of it may be seen in the Durhan Botanic Gardens. but unfortunately it is a male plant; the other species is Phoinix relinatu, and is found in great hxuriance in the const listricts reaching to 2,000 feet above sea level. its rery gracelul feathery tronds giving yuite a tropical aspect to the scenery. Another plant found in the same localities and often in

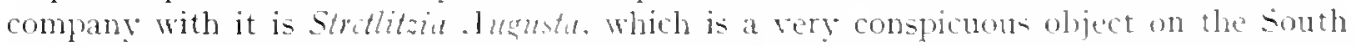
Coast line after passing lsipingo, its enomous smple leares. and curious orange and blue bird-like flowers are very attractire, and it is one of the few plants that are tertilised by birls:; it is much grown tor ormament in Europes and can be seen on the soutlo coast 


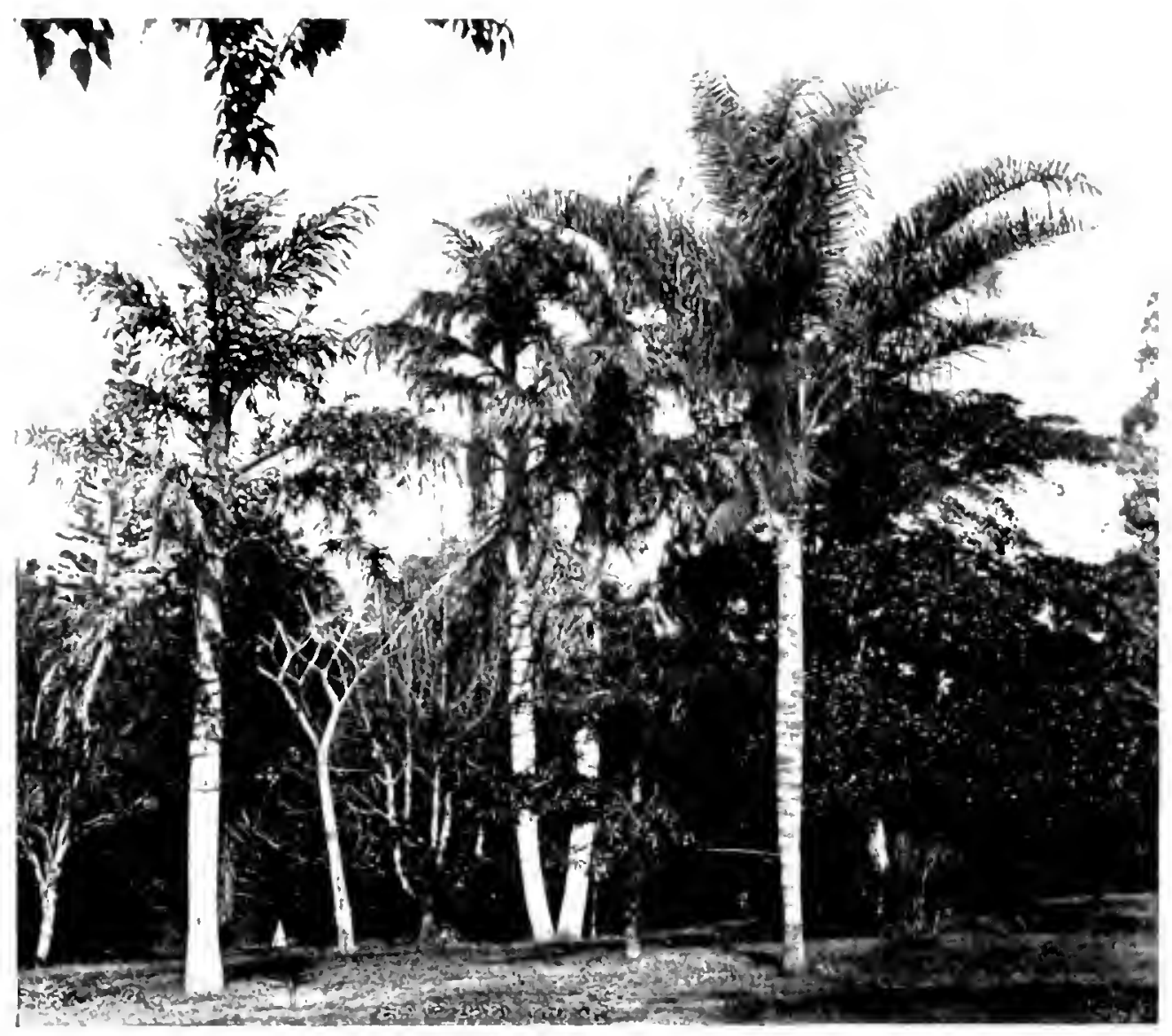

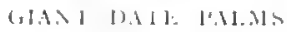

line in company with the Hyllate and lhoems. In the valley of the Tugela river, and perhapsin a tew other plares in the colong is 10 be found a tree known as Kigeliu pinnutu. a tree which is perlage more plentiful un some parts of Rlodesia than in Natal; it bears very large dull purple flowers thre or four inches in diameter. followed ly a fruit hanging troma long footstalk which lengthens an the trut matures: this fruit is cylindrical in shapes. and lated and woody, weighing several pounds. Two specimens of it ase in the Durban botanic Gardens, where they regulaty bear their flowers and truts.

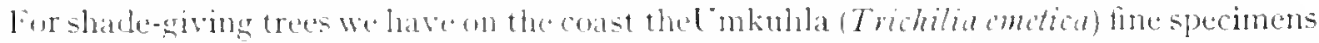
of which may be seen on the bereat. and which as a beautitul shade-tree can scarcely be

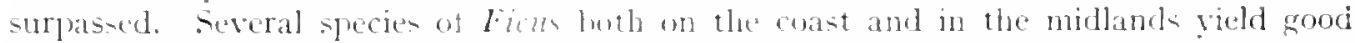

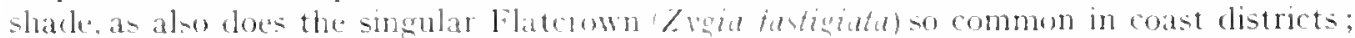
Mibiseus tiliacons is frequenty phuter in the streets of Durlan, but it is essentially a

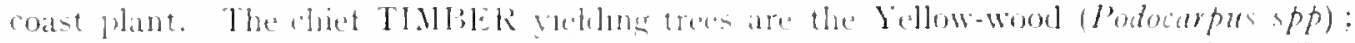

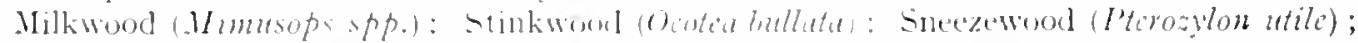
filatcrown (Zigia latightal) and a tew other of lese importance.

Though Natal can lardly get be walled a lasgetrut-producing colong, thete are indications 
that it may soon become $=0$ : hitherto the great hindrance to fruit yrowing has been the large number of insect pests that truit-bearing trees have to contend witl. lut since the appointment of a Government Entomologist. the life history of these insects is being better understood, and means employed for keeping them in check, as has perforce to be lone in most parts of the world where fruit is extensively grown.

The principal FRLITS grown in the coast districts are: Avacado Pear. Banana. Brazil Cherry, Cherimover, Custard Aple, Granadilla. Grape line, Guava, Lemon, Litchi. Mango, Nandarin Orange. Iulberry, Saartje, Orange (common). Pawpaw. Pincapple. Raspherry, Rose Apple. Strawherry. Sour Sop. Sweet Sop. and to this list have recently. been added the Sapodillo of S. America (Sapota achers). and the Star Apple of the Mest lndies (Chrysophyllum cainito).

In the upper districts. reaching from Naritzburg to the slopes of the Drakensberg.

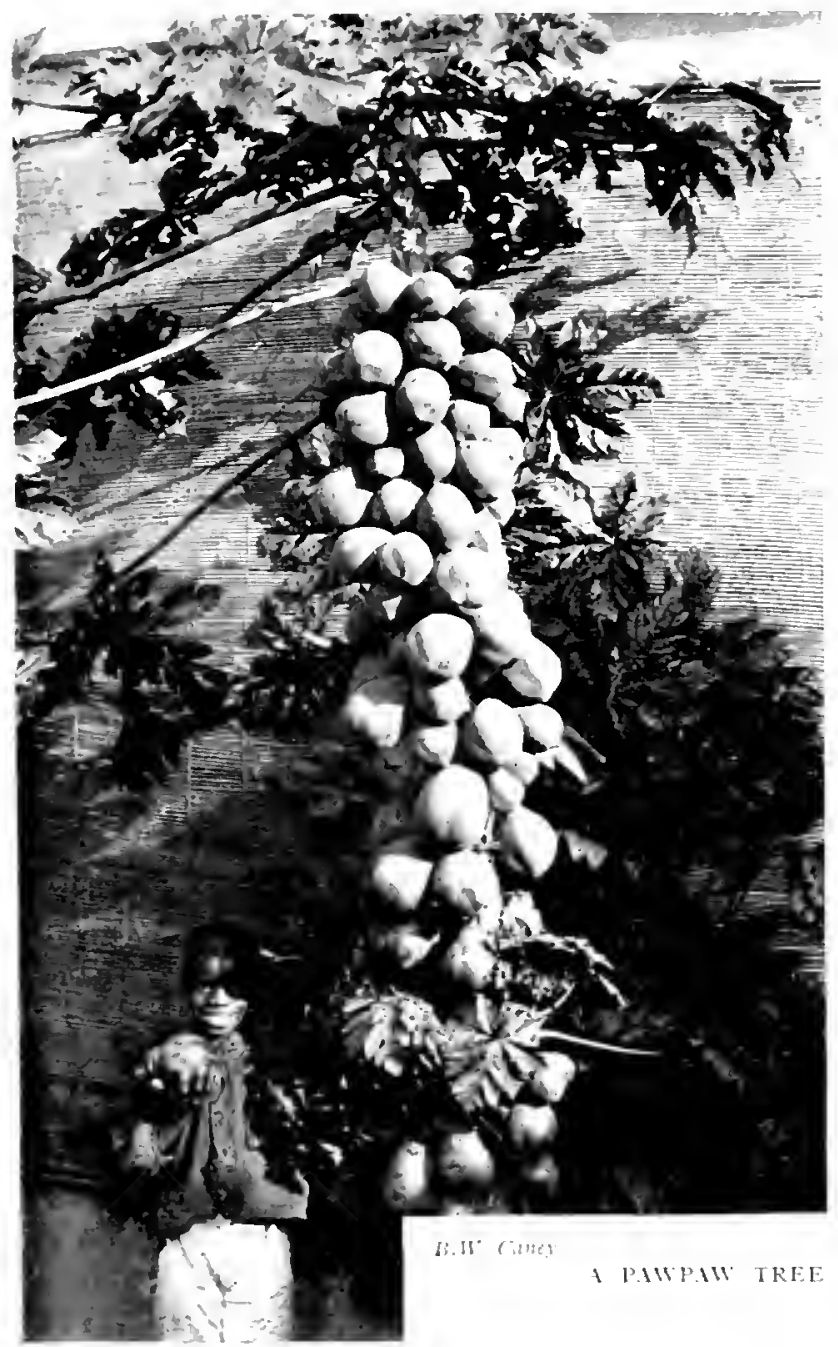
the following fruts are commonly srown: Apple. Apricot. Almond. Bla kberry. Fies Grape. Wedlar. Mulberr:" Nectarine. Peacli. Persimmon (l)iospros sp.). Plum. Plum Japanese. Pomegranate. Ouince, and $11 \mathrm{~V}$ lnut. but Cherries, Currants, and rooseluerries, though often tried. have not ret luen successtully grown in quantity in Satal.

ot wild erlible truits we have but few of anyimportance. The Amatungulu (ravisa uramdiford), and the Cape croseberry (Physalt fermanal). take the first place and are much used: we have also, two -precters of rine, Ititis Capensis, and l'itis cunciftict. the fruits of which are used for preserses. the ('mmonin

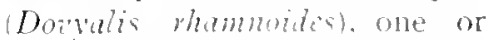
two speies of ficus. sereral species of Mimmsups, Haterhoom (Eugintal copduda). two species of Rums, and a tew others, the truits of which are eaten by natives and chileren but are not worth emmeration here.

Most of the MECETABLES known in England aremlivated almost all over th? Colony. except. perthaps. (Onions, which are only -recesstully grown in 


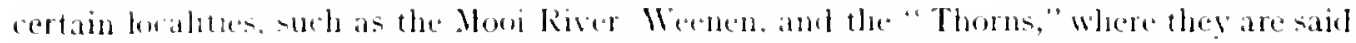
to suceent tamly well. and in aldition we have sereral culinary legetahles that are not commonly met with in Bngland. such as the Eger truit. Tree Tomato. Ochros, and one or

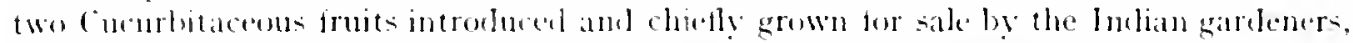

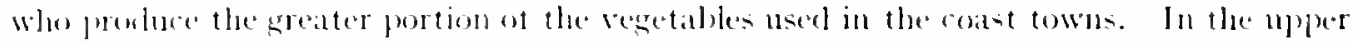
districte collections of regetables numbering form thirty to torty species grown by buroguan ane sometimes reen at the flewer stows.

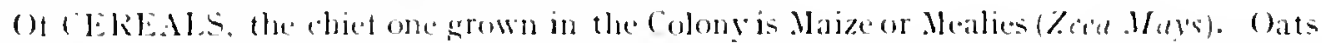

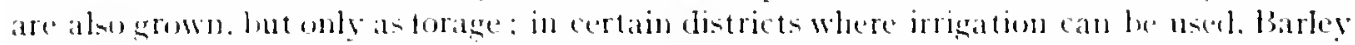
suceeds well. Int Wheat cannot be successlully grown in many parts of the colony.

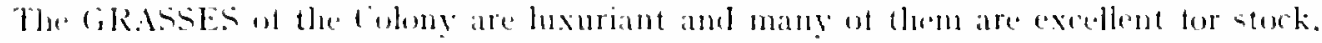

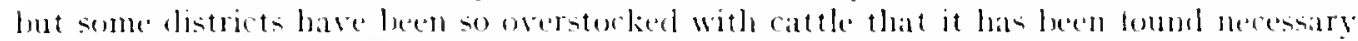

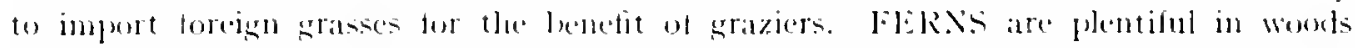

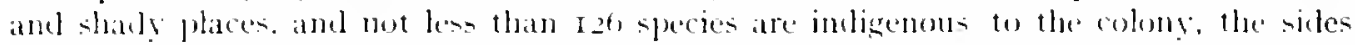

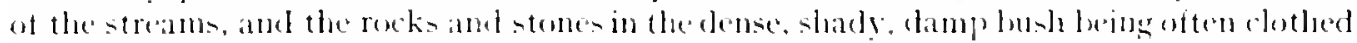

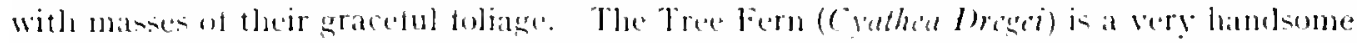

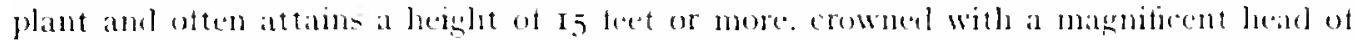

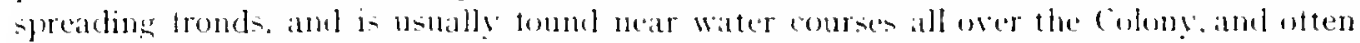
on the seles or at the toot of iry hills: one only other free fern indigenous to diat is

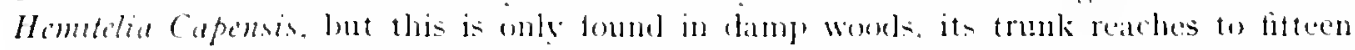
or twenty feet in height. hut unlike that of Cyathea bregtei it in selelom straght, and often

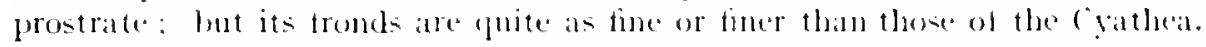

The chied CROPS grown for export in the cohmy are. in the coast and midlands: Sugar. lea, Coffer, Arrowroot. Maize. and truit of different kimb, and in the upper distriets Maize and fruit, while lareve quantitien ol different cropse are grown as food wor cattle the upper distriets being better suited for cattle and sheep than tor arable farming.

fillikl has been and still is produced but not get in large quantities, the plant grown for the purpose being a liourerosa, the fibe being commonly known as Manritius Hemp, but it in quite posslyle that this imbstry may ret flomish in Natal. and that fibre may

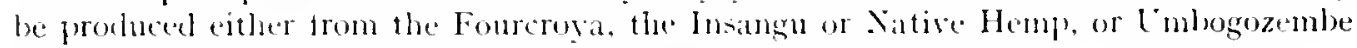

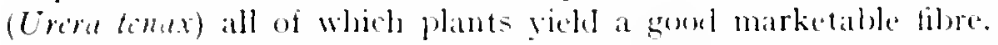

IX1) lti() has lately been suggested. and as the phant Indigoferd orrecta which is considered to be the hest species for the manufacture of the pigment is a native of Saltal there seems to be litte reason why it should not be extensively cultivated here in the tuture: the seed ot our plant has been collected and sent to fara. where it hat realised a high price. Fom recent information it appears quite likely that the natural article will be able to compete succestully with the artificial one now bejng probluced on the continent of burupe, and the plant is tound growing in profusion nearly all over the cisheng.

For information as to the stematic botany of the coloms the reater is referred to "Hancey's Cenera of South Atrican Plants." "Flura (alpensis." "lopular Description of

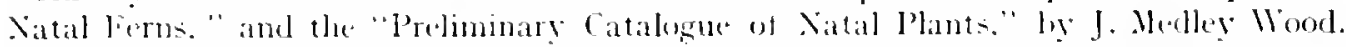

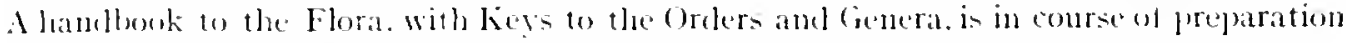
and will shortly le issued trom the Colonial Herbarium.

() big game there is but litte lett in Satal. A lew hippopotami. near the Cingeni,

F.II YA are ahout all on record ot this chast. Hyena- are still aldundant in the wilder portions of the Colong. There are three varieties known, the

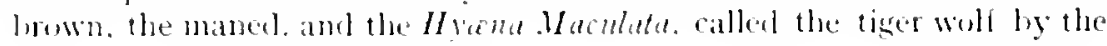


Dutch. Jackals alon abound in places. Leopards, localls called "tigers" are somewhat rare, but may occasionally be encountered in the more remote fastnesses. Wild boars of two varieties exist. The porcupine, though nequent. is a particularly shy animal and most difficult to capture.

Of rodents thete are many varieties. Two lescriptions of hares are constantly to be seen on tlie upland.

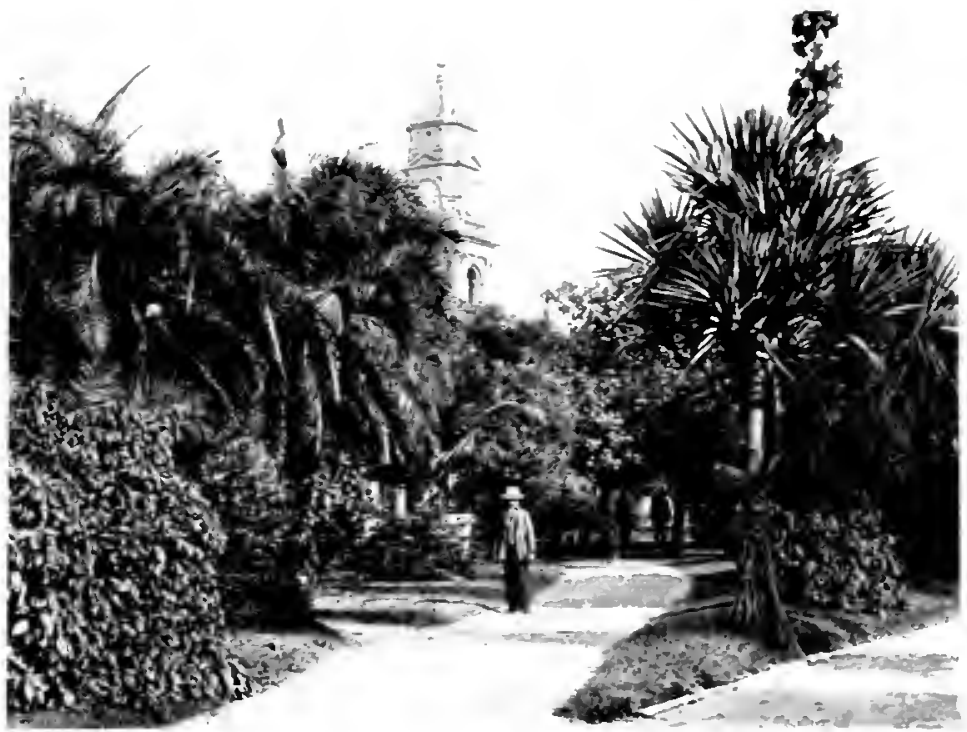
white an engaging

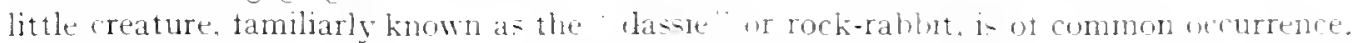
The ant-eater of Satal is a curiou and intereting animal. and can hut rarely he shot.

It is, however, in antelopes that the comtry is richest, about ten varieties heing extant in the iolong.

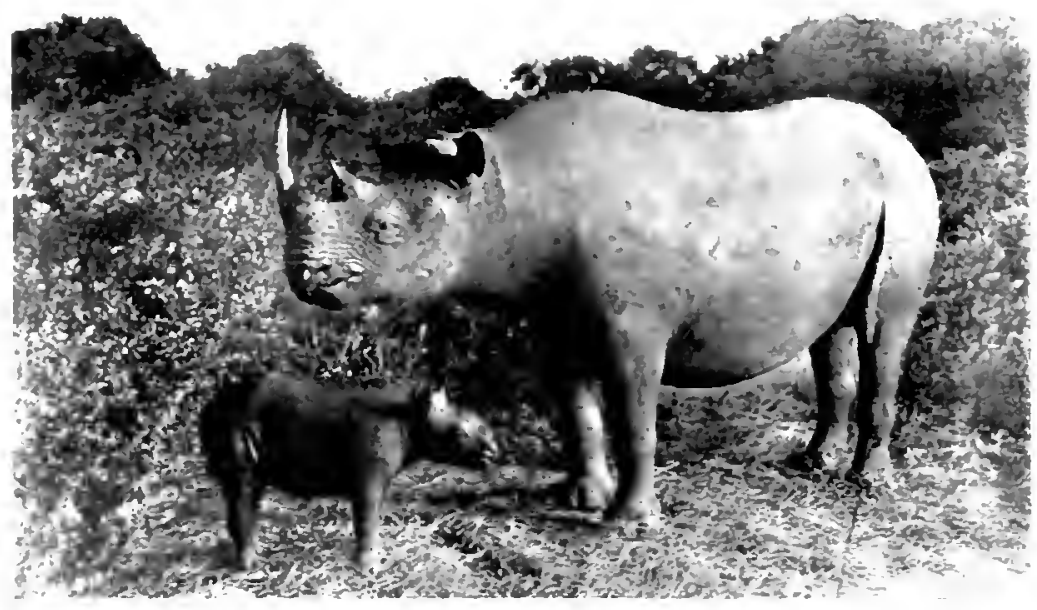

THI BACK RHINOCEROS WIIH C.1.
Babmon-otereat sje abouml in the mountain ranges. while droves of blark-faced monkeys ran ronstantly be sech in the large toresto.

Crecolile= haunt the rivers of the coast. hut attract little attentien, as it hut-rhlom happens that damage is canserl hy them. ()ters are tound in some prortions o: the Coloms.

(1) : repliter and insects there is a larse and inter. usiberariety. 
Key a Photographic Plates of a complete collectom of

\section{$H O R N S$ the SOUTH AFRICAN ANTELOPE ....}

Wha land and Scientilic Xames.

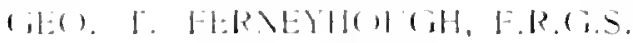

13C-Mbick

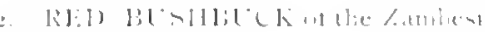

I. Y I I I

$-11.111 \times 1$ (i.)

5. $3: 11018 \mathrm{CK}$

1:1.1) R!1:1:டk

V.11 k11:1: k

91:1:131 C

(ilisistock

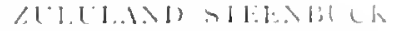

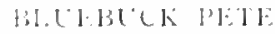

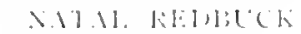

13:) 11:1312k

[1 IKI:K

arsicilickis

KI,H' SPRIMGI:R

P.M.T.1

WITRLICK

kooldous

I.8.(II)I:

(I. I. (. 11$)$

11.1Rl1:131:1: 1

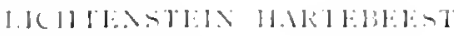

(1)-113)

lil. Islick

120.1 $>.1 .111 .01 \%$

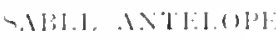

(i) 1 . -13 C C

() Ril:1

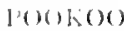

I:1 1:110

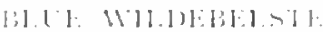

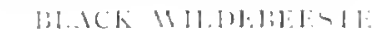

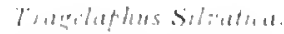

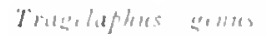

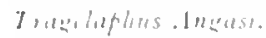

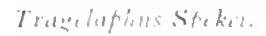

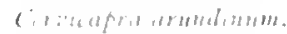

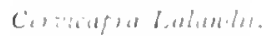

l'ibataproins.

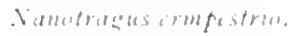

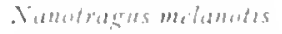

coums amb Sipions

riptialelaphes momedola. ciphbiluphus nabulonsis.

Jamulis plenarum.

Ciphahiaphus arrmmmi.

ritathe tithore

(1) estateress saltatur.

Jiflicros malamitus.

Kabus ellifsifymums.

silitisicons lindu.

hivions leches.

Creas cannu.

Jubulis Canma.

butalis bribtenstem.

Dumalis hundus.

Dumalis albifrous.

Jifpetraens a yminds.

differragus neger.

6) ratiazella.

Dinotraens so ofurins.

Kinlous lionlonth

lios Cilfir.

Cinmondatestantems.

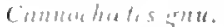



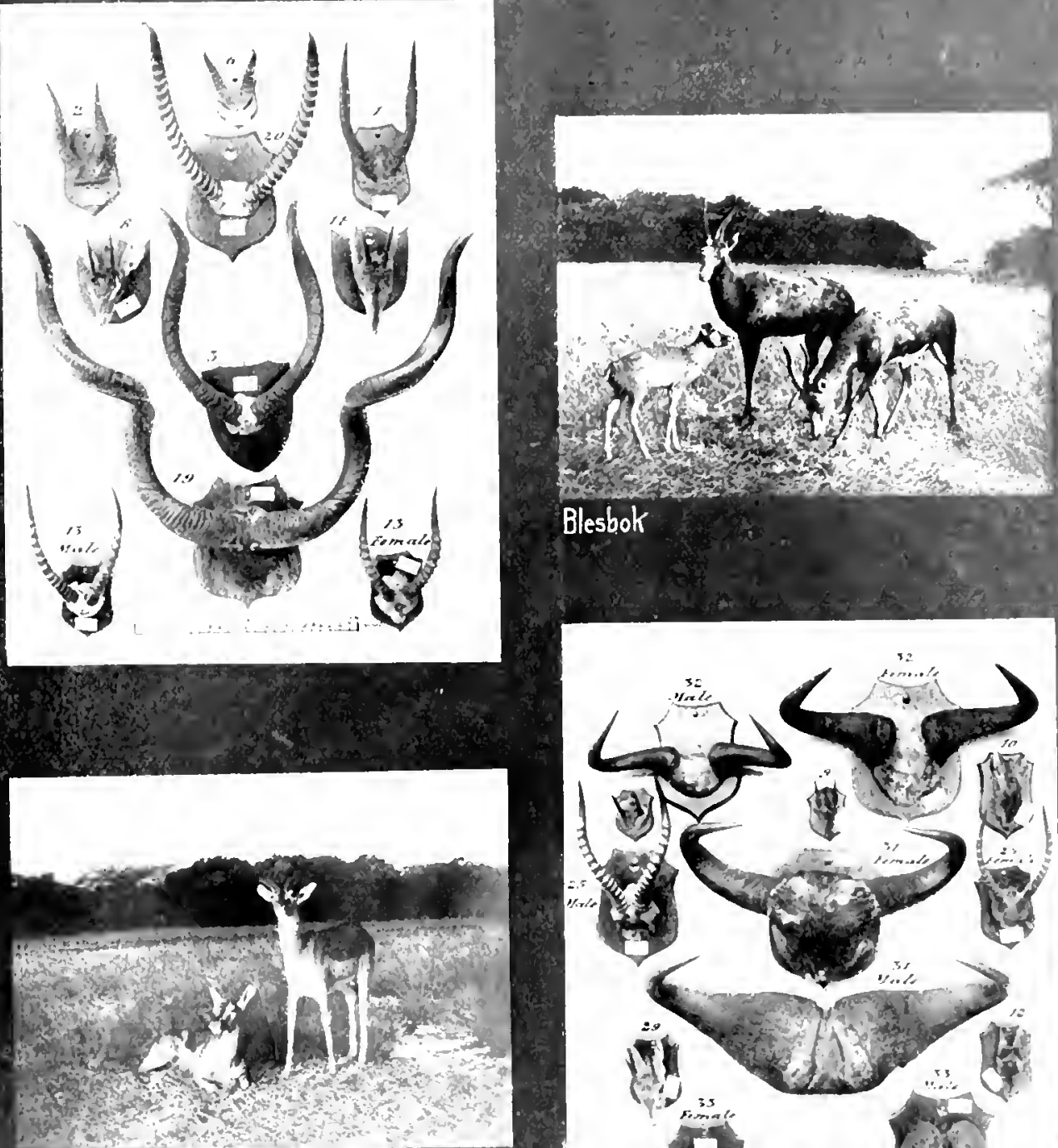

Porrbok

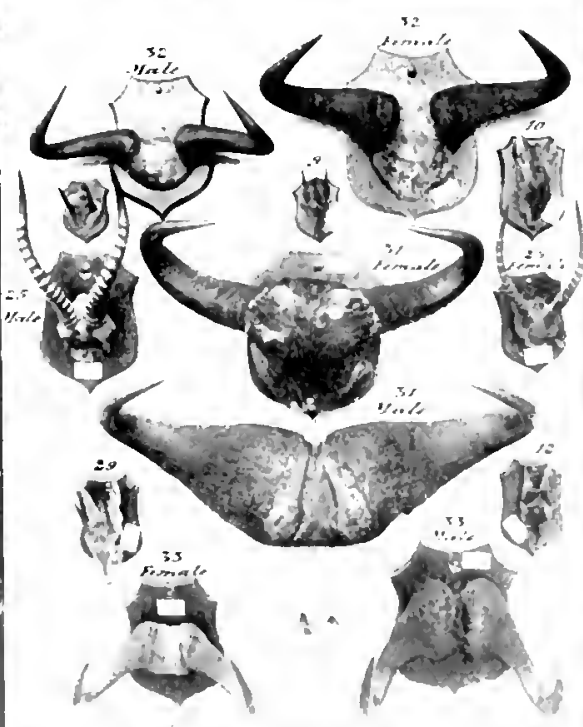



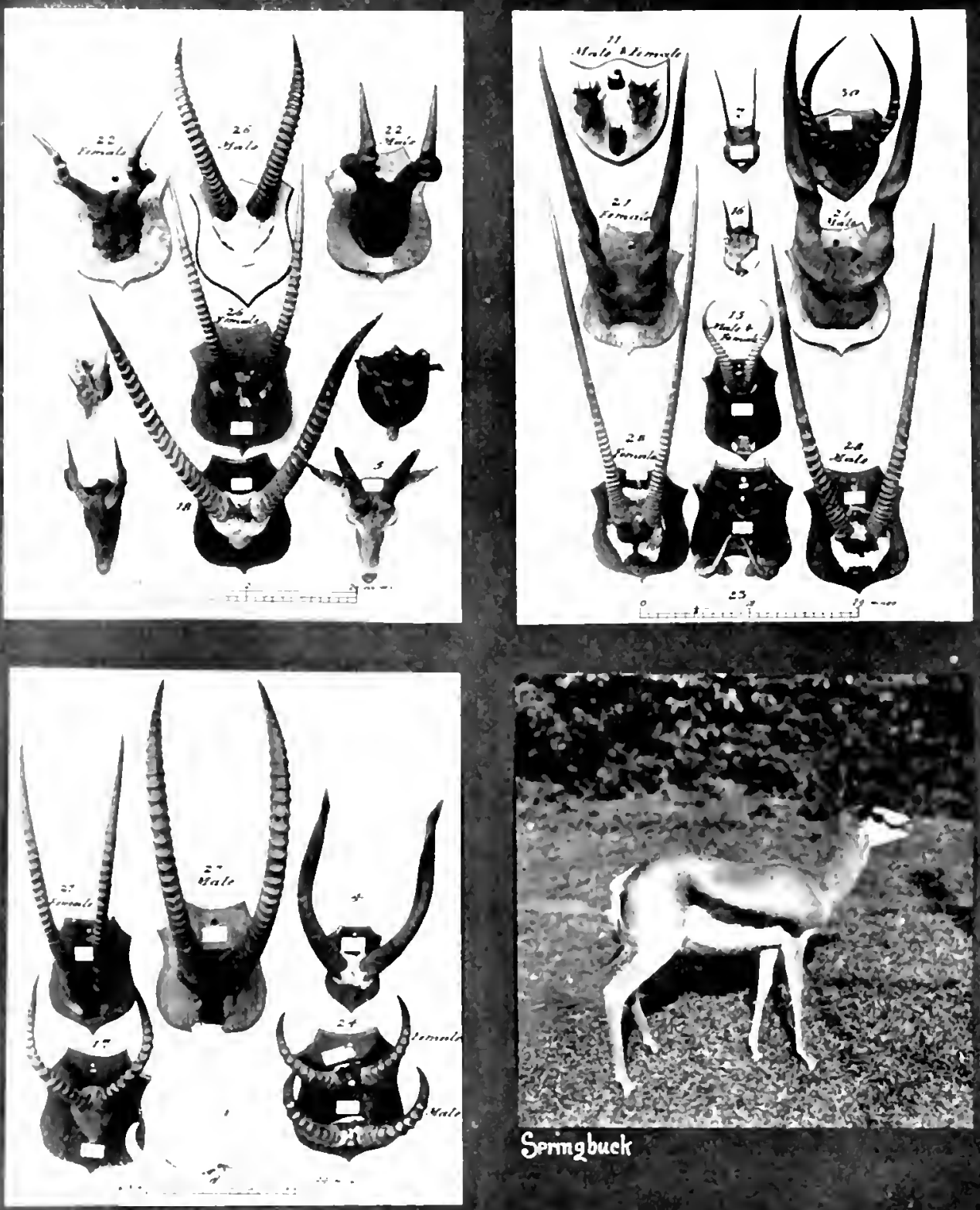


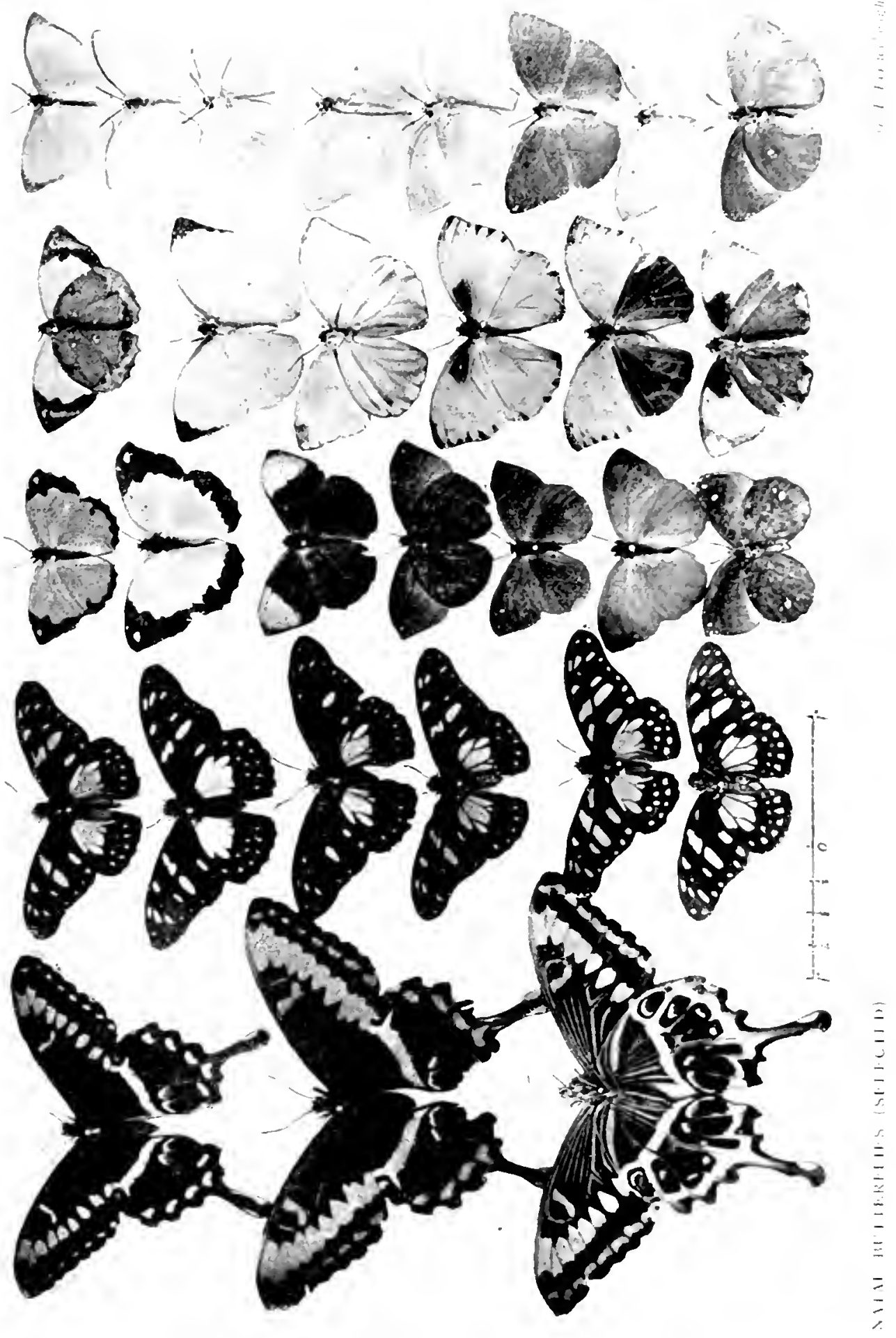



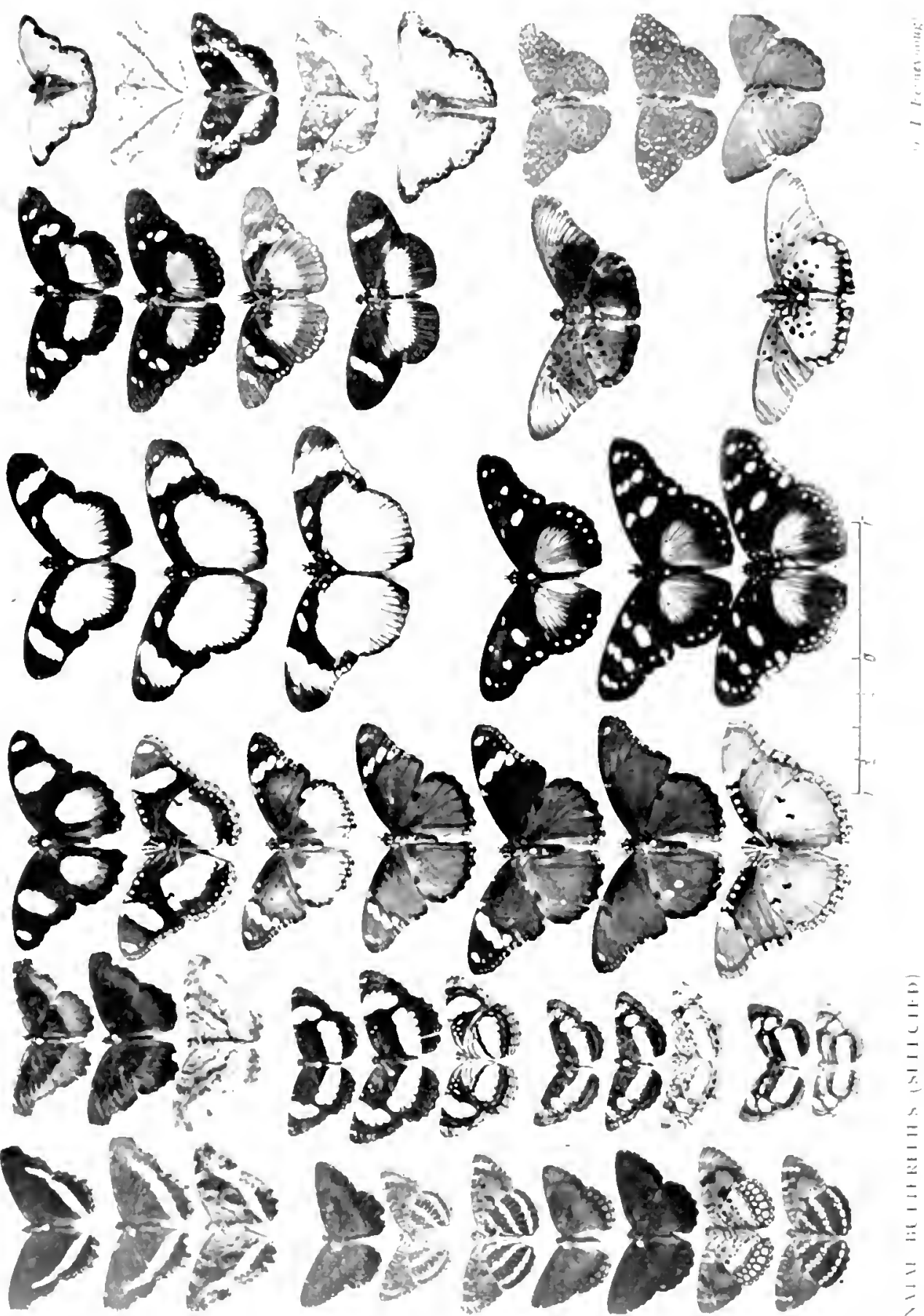
Pythons attain a considerable size. hut are very harmless. ()f poisonoun and deadly serpents there are many, chief among which mas be mentioned the lulack mamba, whose bite is said to cause amost immediate death. The puft-arlter ranks next, but although its bite is deadly, its morements are so slow as to greatly minimise the danger.

There is a great rariety of hirds. Those coming under the catewory of game would alone make a heary list. Partridge, pheasant, quail. and pigens are all well represented. The wild bustard. or "paauw" is a manijficent creature. sometimes standing fire feet high, and showing an eight-feet spread of wing. Stilted birds, or longlegged waders, are in considerable force, while curlew and snije. wild duck and geese abound by the lonelier rivers.

With respect to fish. much cannot be said at present. Of local varieties. there are sand and mud bream, harbel, and tels. and trout and salmon ora have been introduced in many of the streams.

The kloofs and river valleys teem with myriads of the most beautiful and delicately. coloured insects. The late Professor Henry Drummond. in his "Tropical Africa" dealt with this department of science, and the stuclent would do well to study the work betore commencing his researchin.

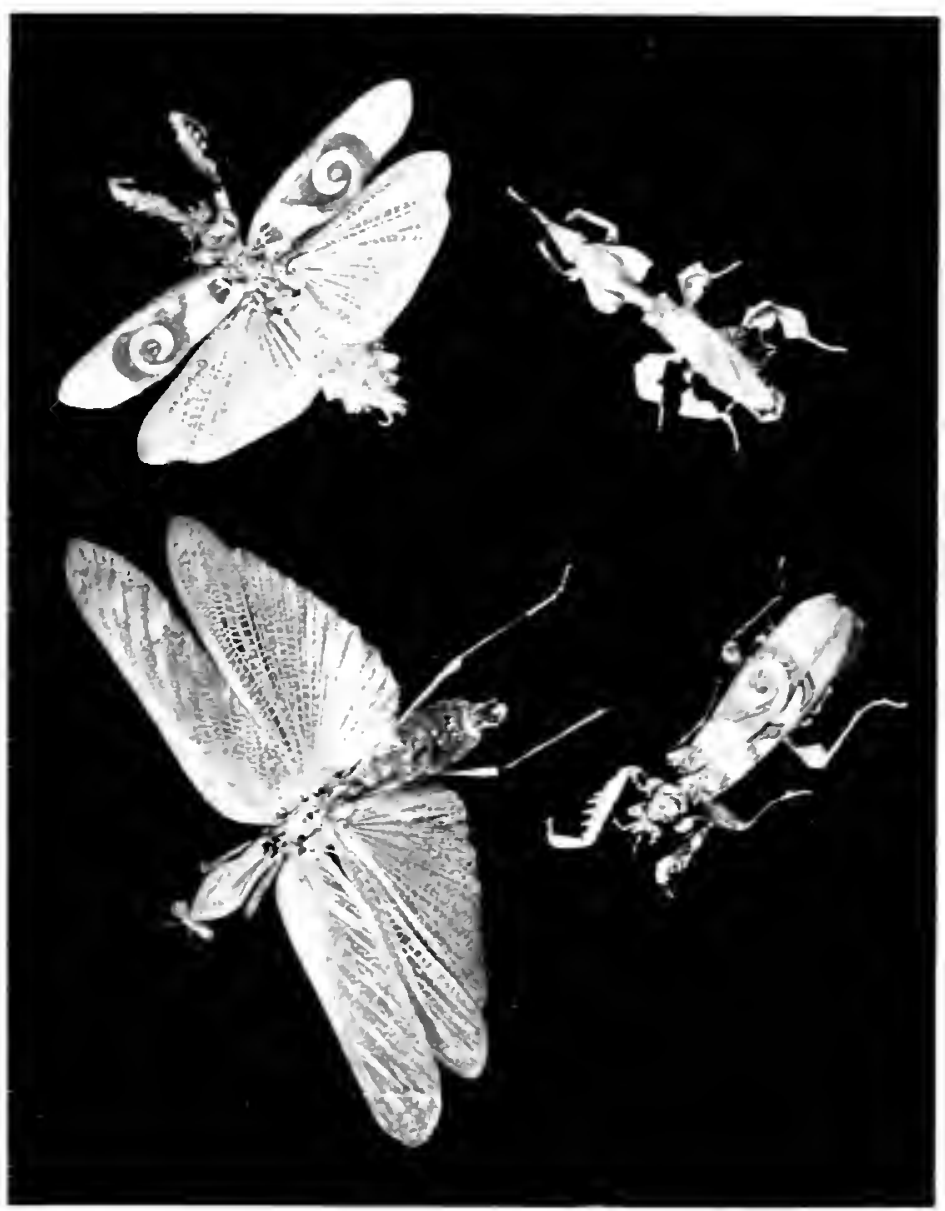

I'sibl I

HEHING, MAN1IDS (HOTIINTOI GODS)

\section{* From the cutomo.}

logical point of ricw the insects of Xatal-many as the are-are an unknown

ENTO $110100 \mathrm{OICAl}$

quantity: scarcely anything being known of their natural economy. their lite cycles and habits : only a small portion ut them havine been sistemationlly classified and deseribed.

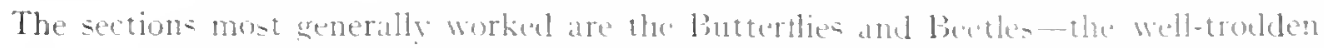

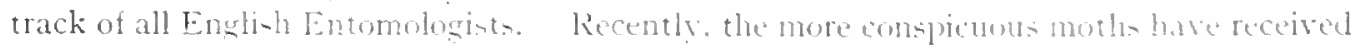




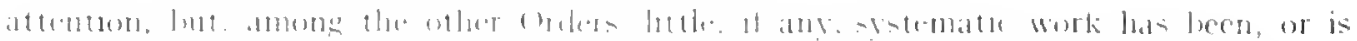

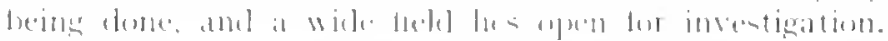

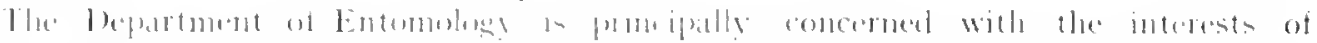

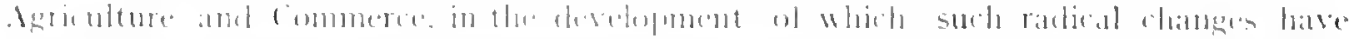

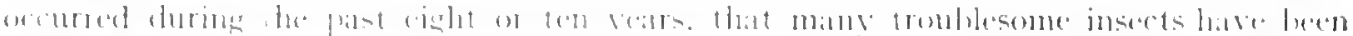

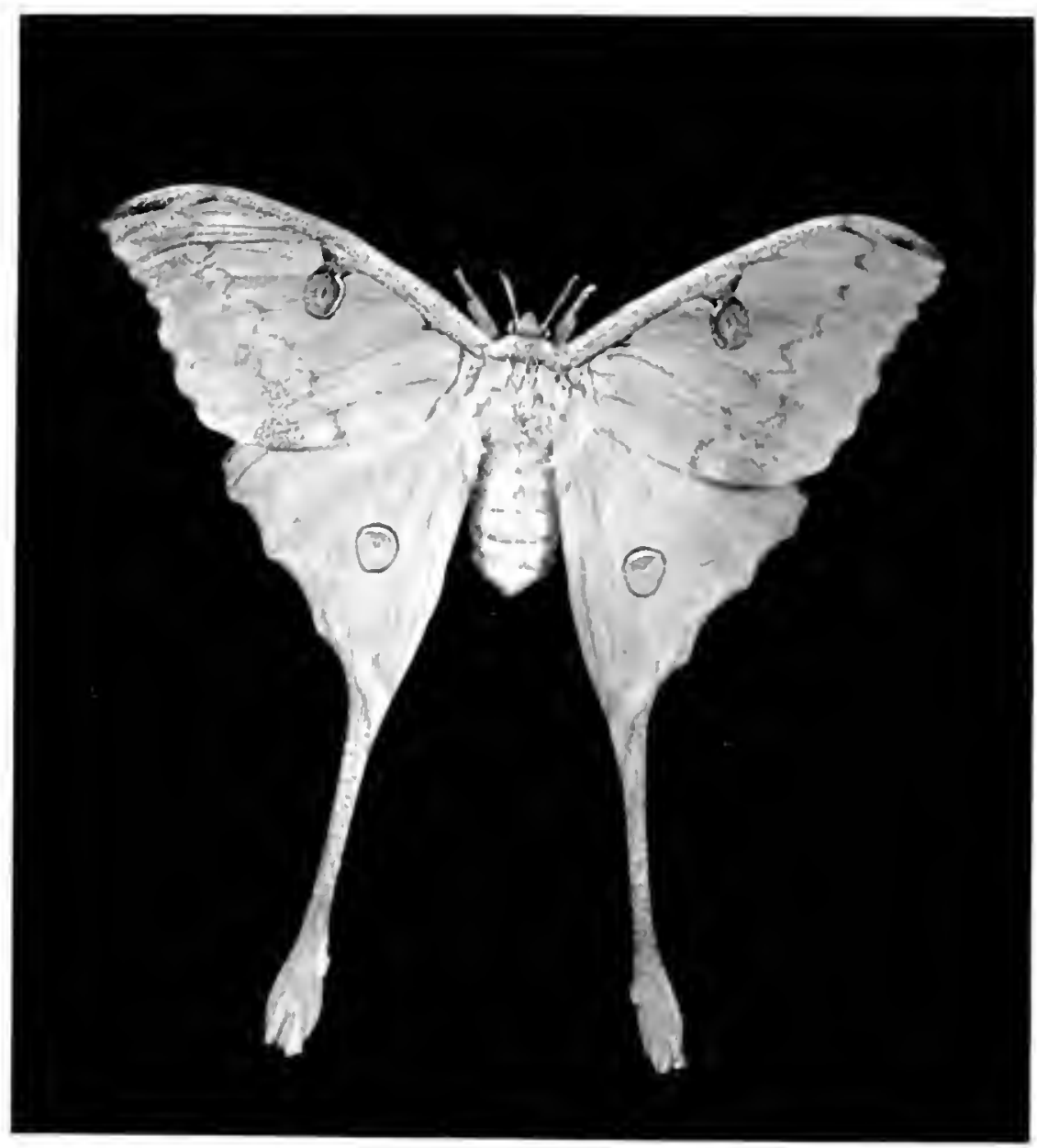

Iiuld $I I$ |

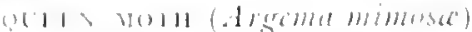

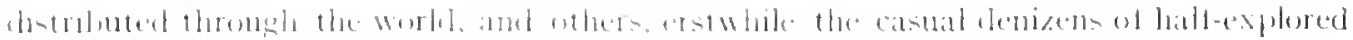

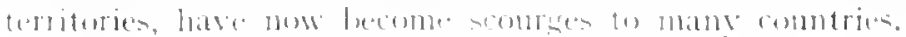

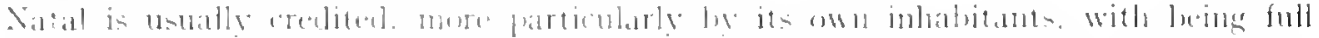

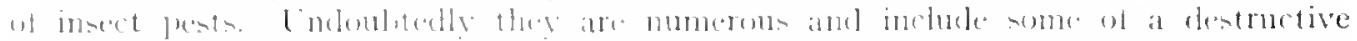

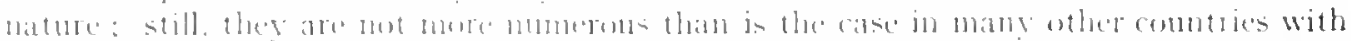

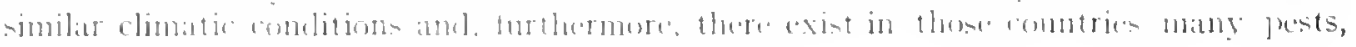

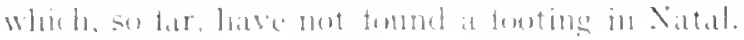


The agricultural pests which do occur are, perhaps on account of the mixed farming which prevails, nore felt by the community than is the case elsewhere: and, were it possib]e to limit the operations of the farm to a less number of branches, the effect of the pests which attack stock, trees, and crops, would not be felt so much as is now the case.

The accompanying plates illustrate several Natal insects which have been selected rather for convenience than effect: hut which cannot fail to arouse some interest. Plate 1 . is devoted to a group of Praying Mantids, or, as they are more popularly" known, "Hottentot Gods." These camivorous insects ocenr in Natal in great varieties both of colour and shape: and feed voraciously upon other insects, as well as upon one another, when occasions arise. They gain their common name of Praying llantids from the peculiar and devout attitude which they assume just before meals. According to an old legend, St. Francis Xavier, on seeing a Mantis moving slowly along with its forelegs raised as

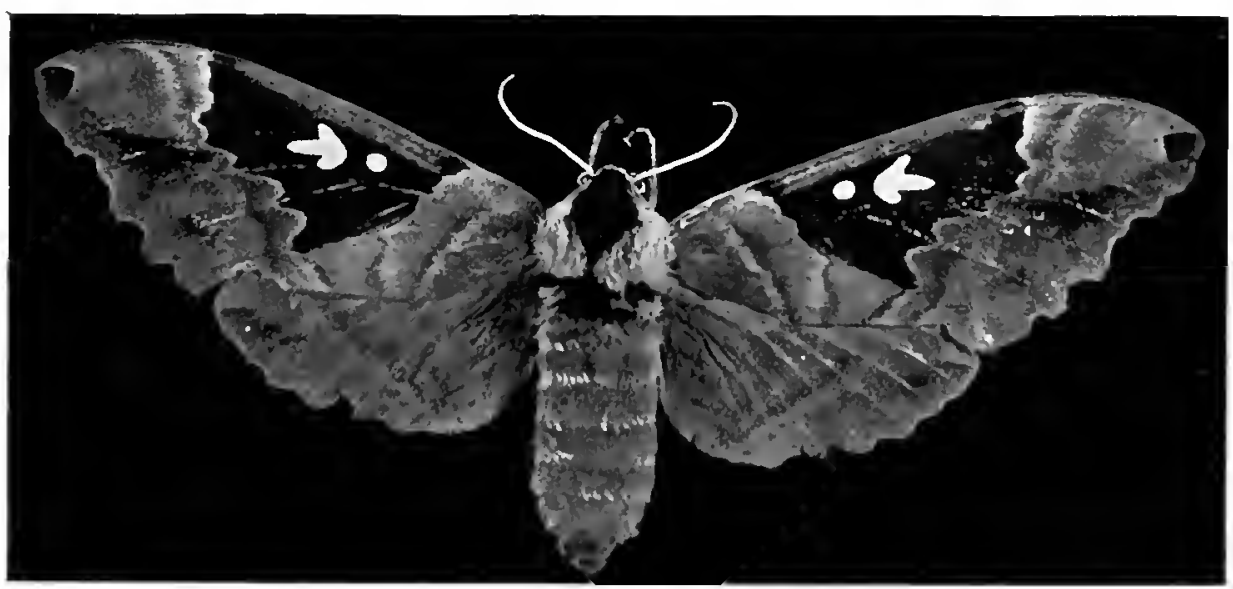

(Ilate III.) Natal coast moth (Lophostithus dumolinii)

if in devotion, desired it to sing the praises of God, which it immediately did in a very. beautiful canticle. But strictly speaking. it is more a "preying" than a "praying" insect, and is characterised by the remarkable front legs, the function of which is to seize and hold any hapless insect which may fall in to its relentless clutches. Plate Il. illustrates the handsome "Queen Mtoth" of Natal (Argema mimosa). a beautitul sea-green insect, whose wings measure, when outspreach, more than five inches from tip to tip. The caterpillars of this species feed upon the foliage of the Thormbush or Mimosa. and the silken cocoons which they spin are familiar to all visitors to Natal, in the shape of the rattling anklets worn by 'ricksha hoys, who gather the cocoons after the moths have emerged. place a few peblules in them and close the holes by first moistening and then twisting up the loosened strands. I'late 11]. ilhustrates a very fine moth (Lophostithus dumolimii). found upon the coast of the colony. This moth gives an expanse of wing of over six inches from tip to tip.

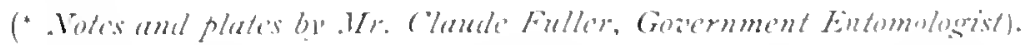




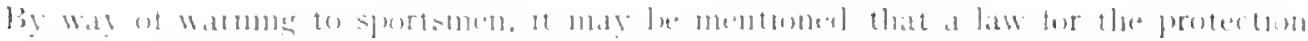

$1.111: 1.1115$

$\backslash 1111$

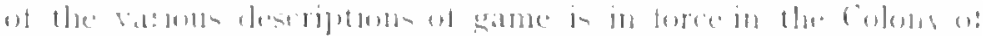

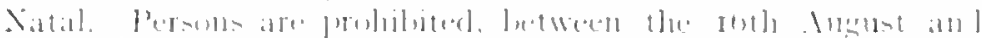

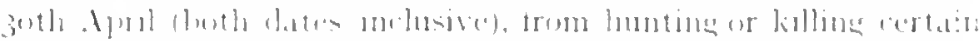

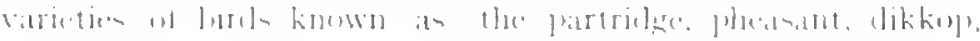

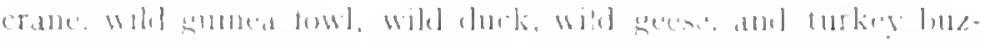

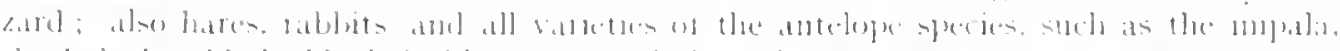

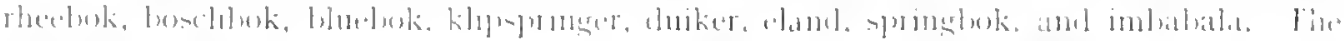

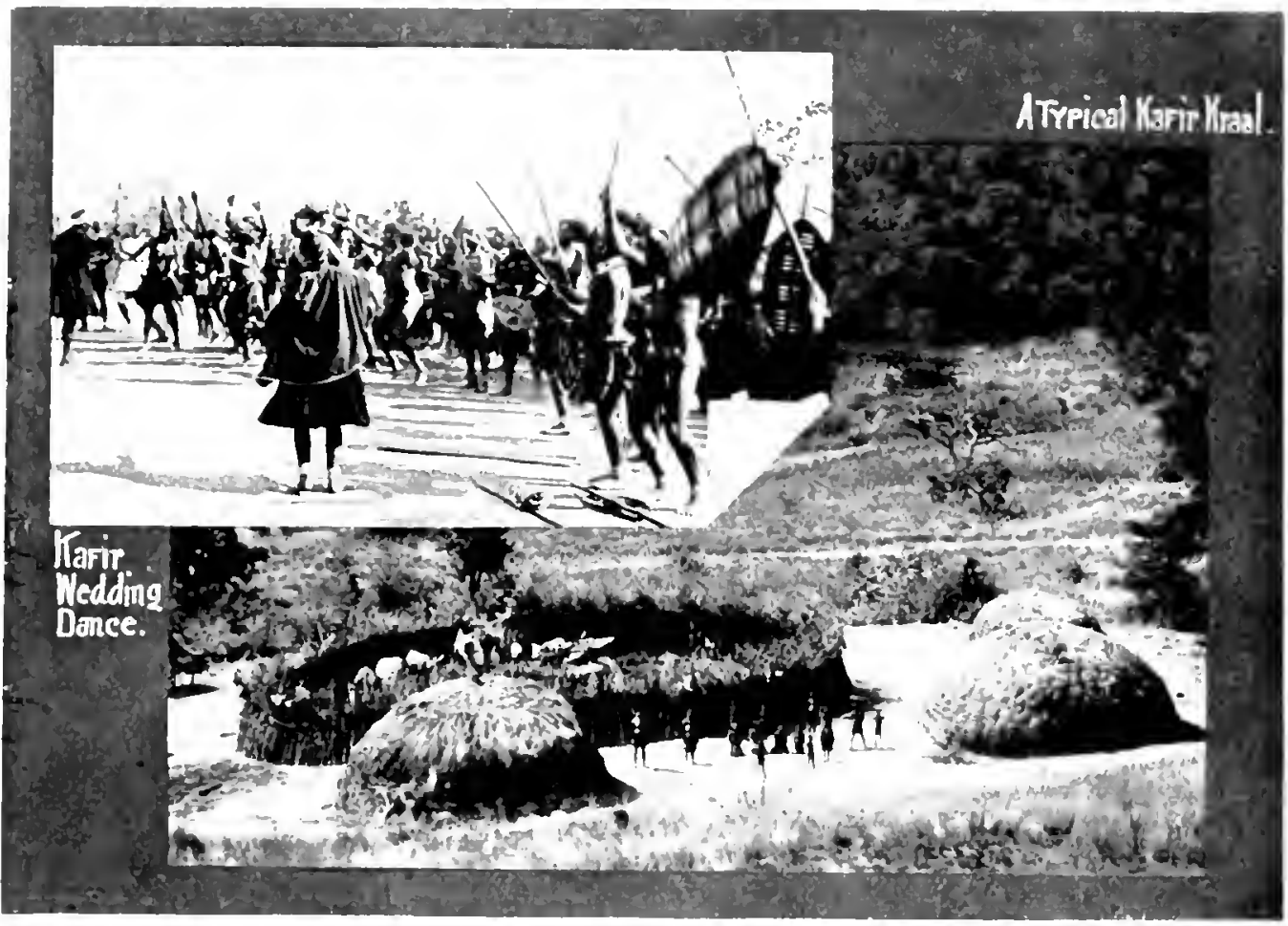

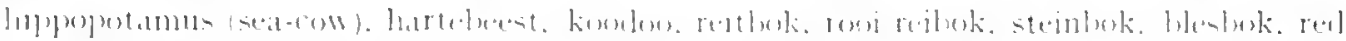

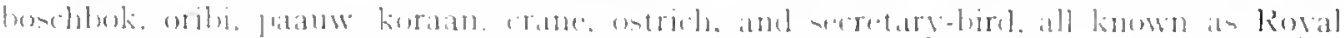

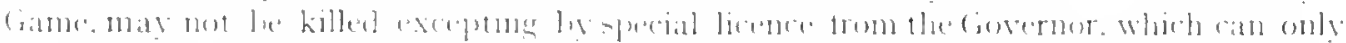

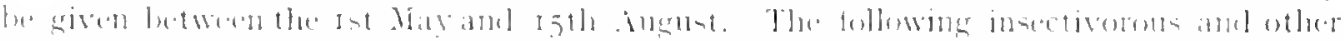

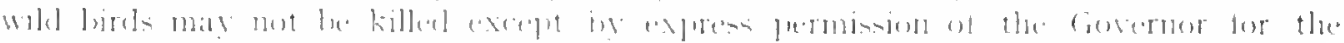

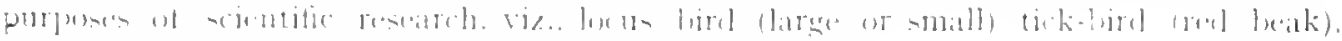

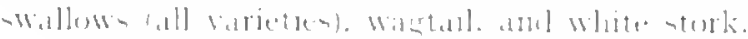

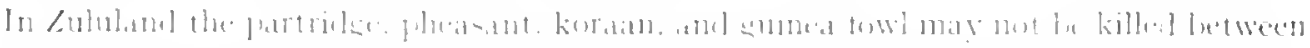
$1.11 .11)$

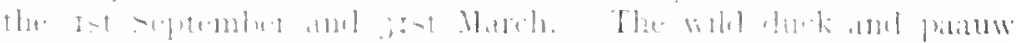

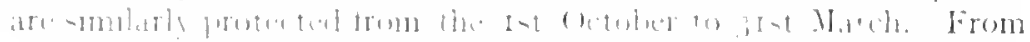

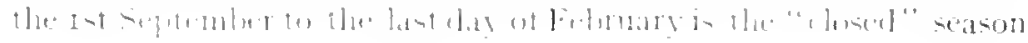


for hares, rabbits, huffalo, waterbuck, wildebeest. gnu. koodoo. klipspringer. in red buck (inkumbi), rheehok. steenhok. reithok, boschbok, bluebok, and duiker.

The following may" not be killed without a written permission from the Governor. of Resident Commissioner: the elephant and white rhinoceros, the roan antelope, impala. oribi, and invala, the quagga, zebri, eland. hartebeest. springlok, liestonk ostrich, secretary-bird, and turkey huzzard.

The hippopotamus and black rhinoceros may only be kitled on frament of fo for each animal named in a special licence to be oludined from the forvernor, or Resident Commissioner: Dut not more than two of each of these animals may be killed hy the same person in any one year.

On game preserves. the killing of large game is prohibited. unless by special licence costing fio per month, which can only be issued on certain conditions.

By reason of the fortunate position of Natal on the earth's surface, it is not only one of the most salubrious countries in the world, but it,

\section{CLIMATIC AND OTHER CONDITIONS} as lias already been pointed out in a general way. enjogs a scale of climates not often olitainable in one country. and in such a comparatively limited area.

Being in the South temperate zone, about 230 miles at its northern point trom the Tropic of Capricorn, its climates may be described as warm, temperate subtropical, and in some cases cold.

The steppes, already described, rise from sea level to an altitude of two and a quarter miles above it, in the distance of little more than one hundrert miles. The various climates of these steppes are clearly marked and detined, thereby rendering the colony one of the finest of health resorts. At Pietermaritzlurg, the capital, 2.218 fete the arerage yearly TEMPERATURE is about 64. At rare intervals, during a few days in Summer time. the temperature rises as high as $98^{\circ}$. while in Winter it sometimes falls as lou as 28. These, however, are occasional extravagances, for as a rule the mean is well maintained. At Durban the average is $602^{\circ}$, and the extremes or and 42 . The average Jaily range does not exceed 20 however. In the Winter months frost is sometimes seen on the coast lands, even at the sea level. Snow storms occur rearly in the ujlands, and, as already stated, snow-clad peaks are no mommon sight ufon the Berg.

Disregarding light showers the average number of rainy days in Durban is $52 \mathrm{in}$ Summer and $2 \mathrm{I}$ in Winter. The number of thunderstorms averages $2+$ during the sumner and 5 during the Winter months, but of late the number of thunderstorms accurring in the neighbourhood of Durban has nnelerente a marked diminution.

Roughly speaking there are only two SExsoxs in Satal, Summer and Winter. The tormer commences in Uctotuer and ('Inls with Ifarch. It midsummer the sun risen at tive and sets at seren oclock. It minwinter it rises at seren and sets at fire. The wiligh both in Winter and in simmer is exceedingly short. The spring and tutumn are both brief, and so blended with the other stasons, as to be difficult of recosnition. 


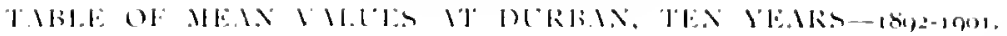

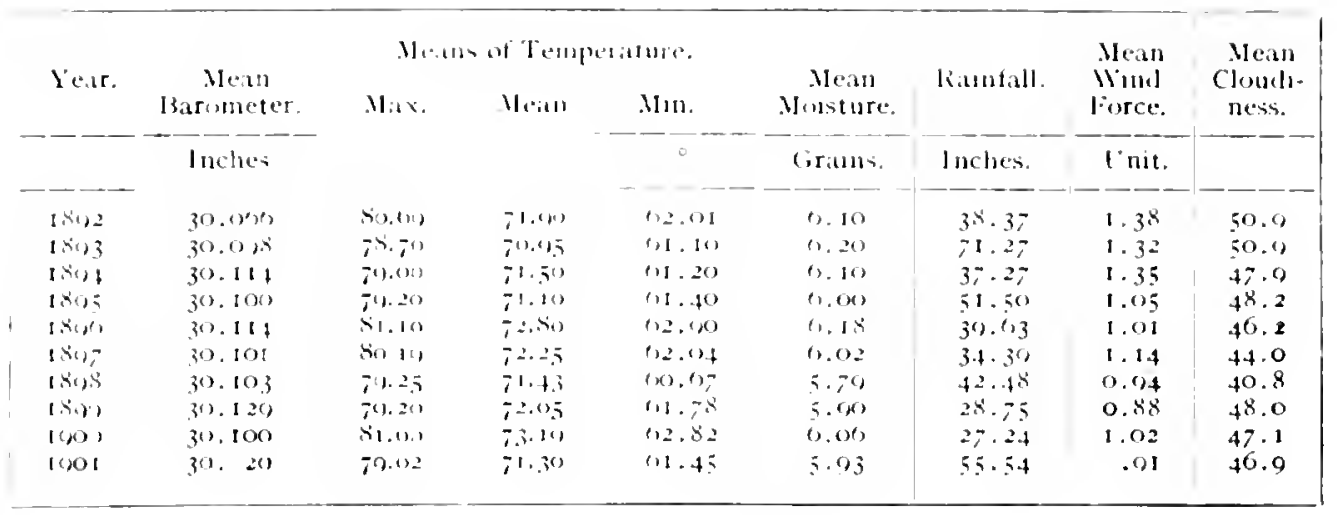

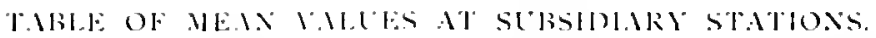

\begin{tabular}{|c|c|c|c|c|c|c|}
\hline \multirow{2}{*}{$\begin{array}{l}\text { Sulisiduary } \\
\text { Statum }\end{array}$} & & \multicolumn{2}{|c|}{$\begin{array}{c}\text { Werage Temperature } \\
\text { for : lears. }\end{array}$} & \multirow{2}{*}{$\begin{array}{l}\text { Average } \\
\text { Highest } \\
\text { Innual } \\
\text { Temper- } \\
\text { ature. }\end{array}$} & \multirow{2}{*}{$\begin{array}{c}\text { Average } \\
\text { lowwest } \\
\text { Annual } \\
\text { Temper- } \\
\text { ature. }\end{array}$} & \multirow{2}{*}{$\begin{array}{l}\text { Average } \\
\text { Annual } \\
\text { Kaisfall. } \\
\text { for } \\
5 \text { years. }\end{array}$} \\
\hline & & $\begin{array}{l}\text { Diuly Max. } \\
\text { (1I) shatle). }\end{array}$ & $\begin{array}{l}\text { Duly Min. } \\
\text { (in shade). }\end{array}$ & & & \\
\hline Stanger & $\ldots$ & $\begin{array}{l}\text { Fahr. } \\
\text { si. }\end{array}$ & $\begin{array}{l}-F a b r \\
e x, 2\end{array}$ & $\begin{array}{l}\text { Fatir } \\
\text { los. }\end{array}$ & $\begin{array}{l}\text { Palir. } \\
\text { th.o }\end{array}$ & $\begin{array}{l}\text { Inches. } \\
38.04\end{array}$ \\
\hline Fermlam . & & $x 2.1$ & $(x), y$ & $10=\ldots$ & 41.0 & 35.34 \\
\hline Grevtwwn . & . & $7 \times 1$. & 56,2 & $0,1.2$ & $31 . x$ & 33.20 \\
\hline Newcastle & . & $7 x .1$ & 52.2 & 101.3 & $27 \ldots$ & 33.70 \\
\hline Estcourt . & . & $-x$ & 90.1 & $90 .+4$ & 21,11 & 27.93 \\
\hline Richmons1. . & . & 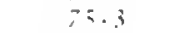 & $\therefore 2.11$ & 102.2 & 33.11 & $3^{8} \cdot 30$ \\
\hline Port shepstone & . & $m i d$ & $(x) . x$ & $6,8.1$ & +5.8 & $45.0 \mathrm{~K}$ \\
\hline Maritzlures & $\ldots$ & 70.8 & 33.0 & 100.0 & 32.0 & 3.30 \\
\hline Howick .. & $\ldots$ & $\because 7.1$ & 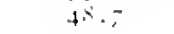 & 100.2 & 24.6 & $31.0 \mathrm{x}$ \\
\hline Vieenen & . & 83.1 & $4 x .4$ & $10 \% .2$ & 23.0 & $24 \cdot 34$ \\
\hline
\end{tabular}

MFRMGE: RAINFALL-TEN YEARS 42.63 INCHES.

Disthingted ener

\begin{tabular}{|c|c|c|c|c|c|c|c|}
\hline January & $\cdots$ & .. 4.23 & Juches. & July . . & . & .. 0.13 & Inches. \\
\hline i.turmary & . & . 4.15 & .. & lugust & . & $\ldots 1.4 .4$ & . \\
\hline March .. & . & . $-4 \cdot 4.8$ & .. & September & . & $\ldots 5.1 x$ & .. \\
\hline April . & . & . 3.4- & .. & Octuler & . & .5 .50 & .' \\
\hline May & $\cdots$ & $\ldots 1.75$ & .. & Sovenber & $\cdots$ & $\ldots 4,13$ & $\cdots$ \\
\hline June & . & $\ldots 0.02$ & .. & [lecember & $\cdots$ & $\cdots 5.20$ & $"$ \\
\hline
\end{tabular}

The poptration of Natal includting \%ululand. in the rear Inor was: Europeans 63.421 . POPLLATION fot whem thly per cent. were horn in the Colonyl Natives

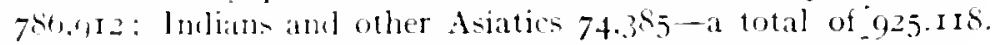
Mlilitary, aliens, and retugeses are mol induded. The new territories recently annexed represent approximately a turther 8.000 white inhahitants, and 50.000 natives. 
The ENGLISH settlers devote their encrgies chietly to commercial, agricultural, and PEOPLES industrial pursuits. The I) TCH ar mainly matoral and agricul. tural workers. Nost of the English occupy and cluster round the various towns and villages, while the Dutch affect the more outlyng districts of the country.

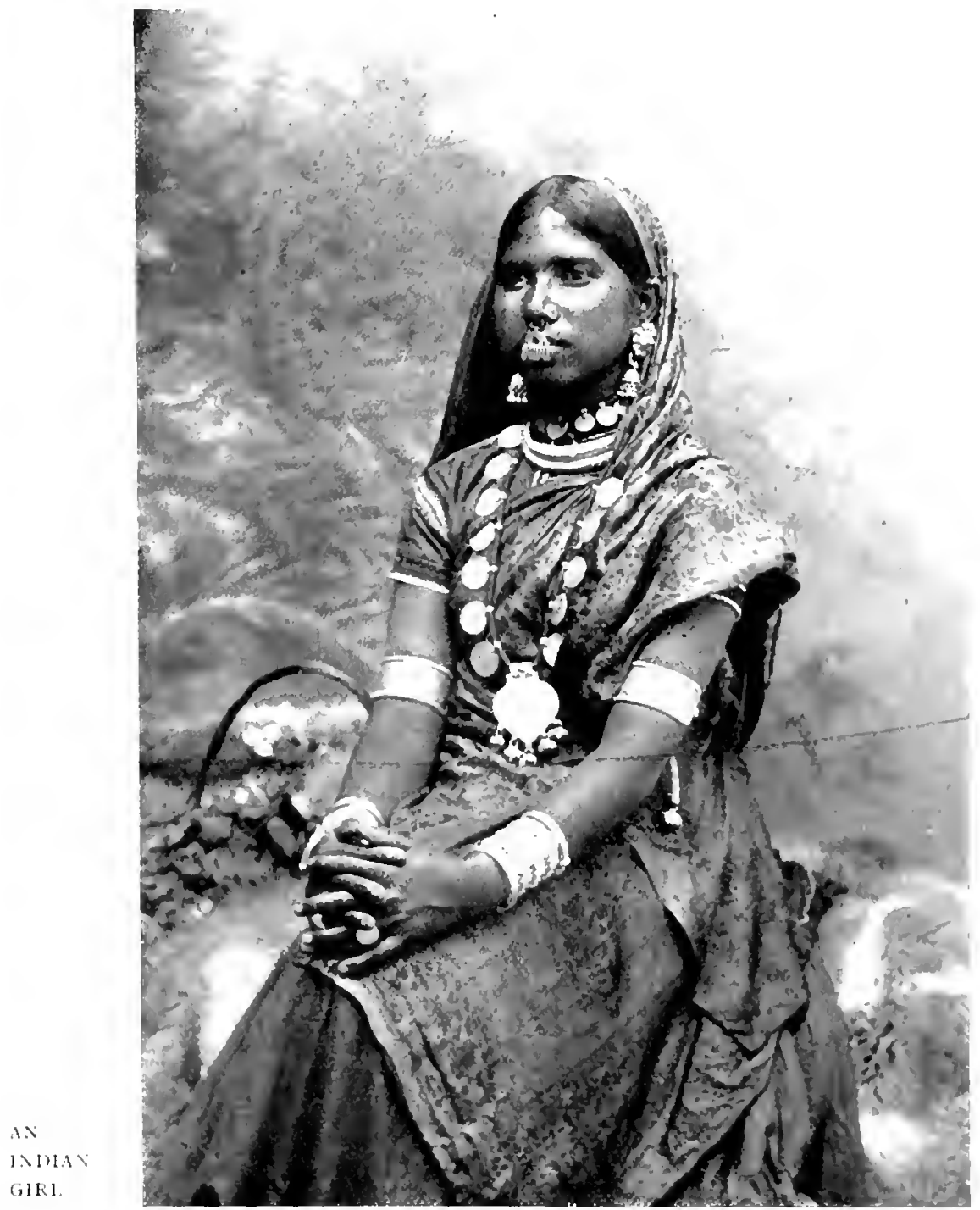

There are also a good number of Gromans, Fituch Creoks. and other nationalities in the Colony:

The INDIANS are generally speaking, taken trom the blouting classes of their own country. Indian labour was introducel to Natal hecause the natives, who are not vet tducated up to the necessity of daily toil, were so intermittent and unreliable as workers. 


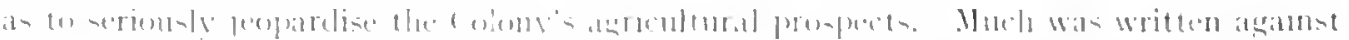

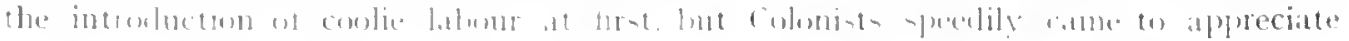

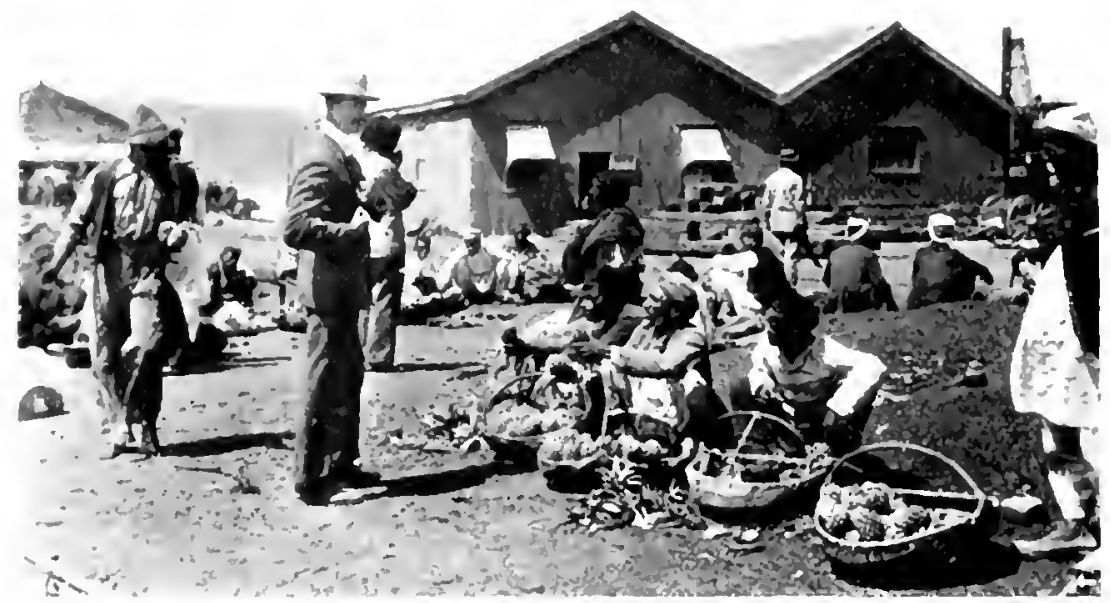

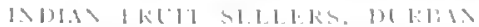

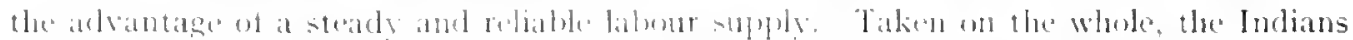

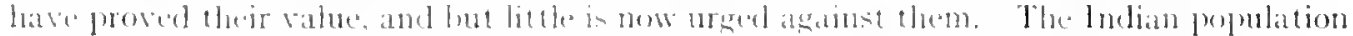
is umber the "sperial care of an official called the "Psotector of Indian Emierrants."

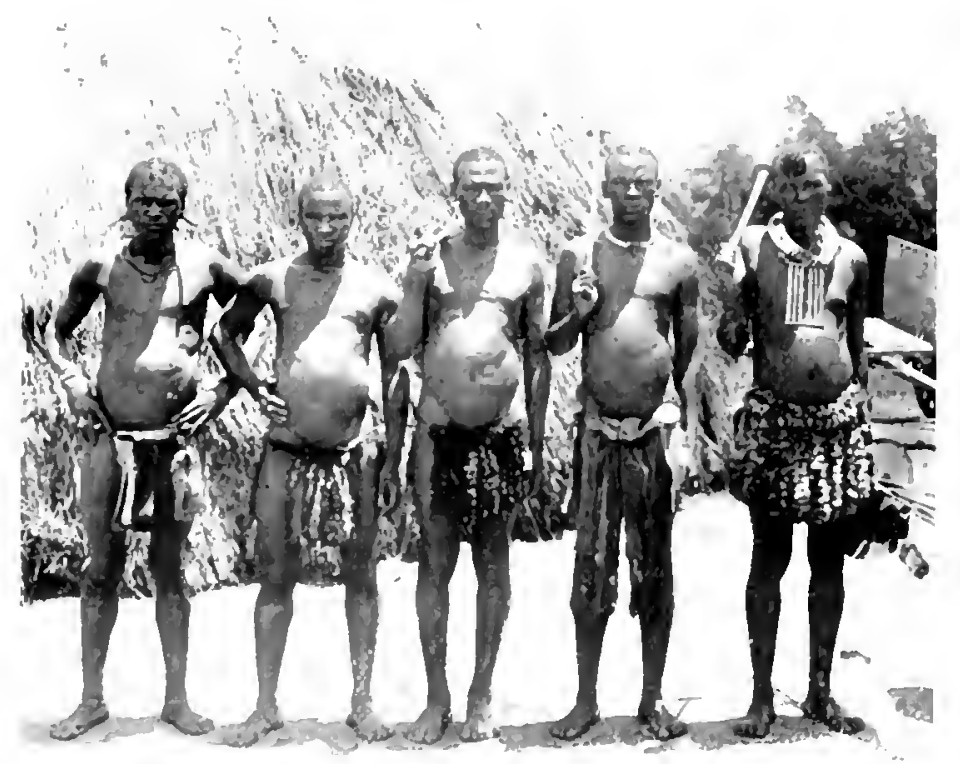




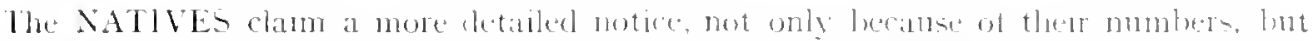

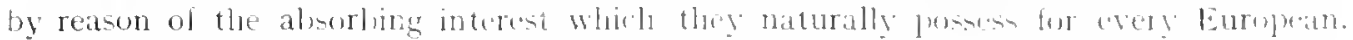

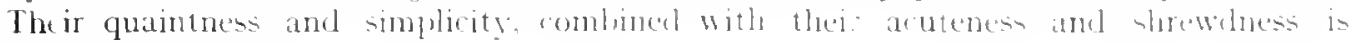
most remarkible.

The student of human chareter whll find wh their good nature. curious customs and methods of thonght, a theme of the mont protomed interes. In them lu will disconer

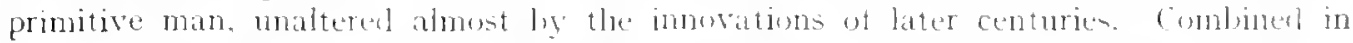

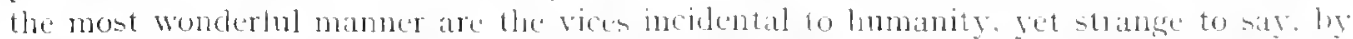
codes of their omn. With which the white mian has had nothing whaterer to do, ther bave

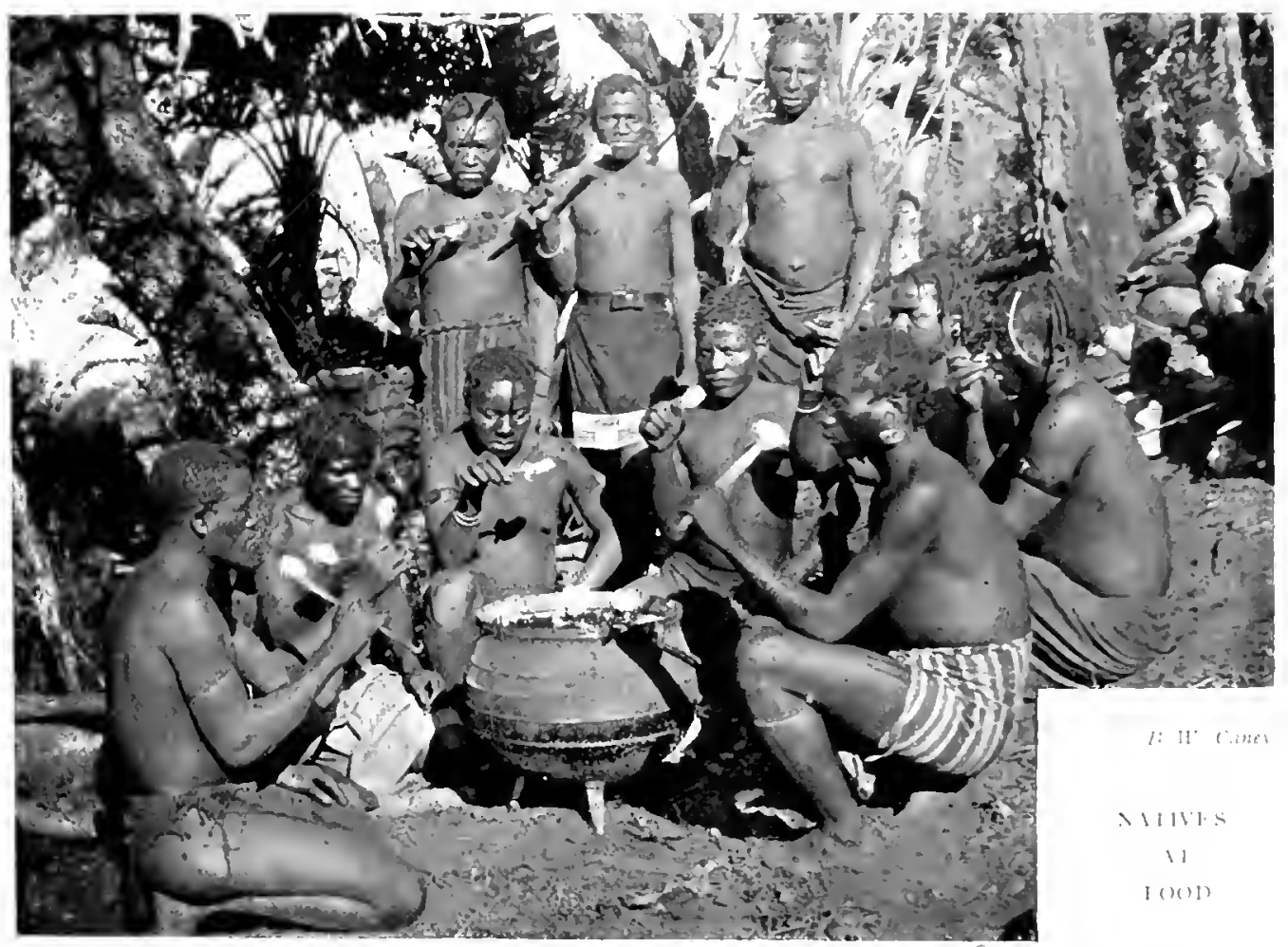

established beneficia! regulations, the wislom of which will be at once alutited lue the rultivated observer

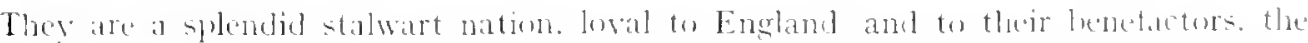

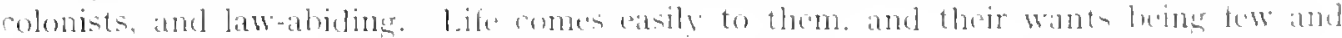
simple. ther toit het little tor their livelilume.

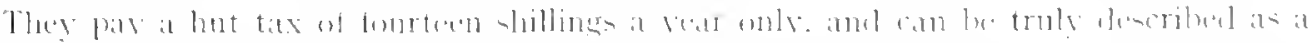

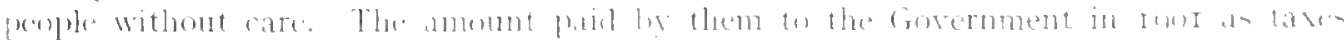

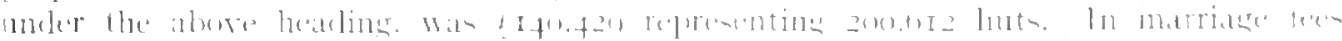

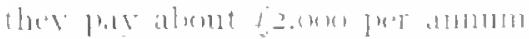

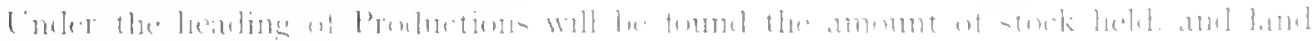
ultivitul he the?]. 


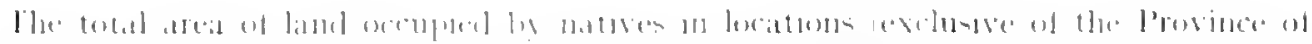

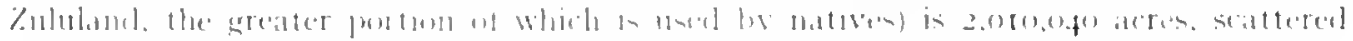

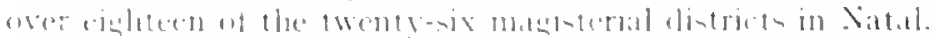

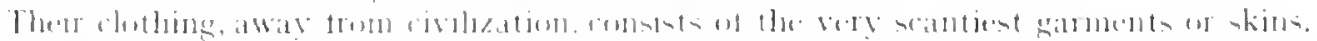

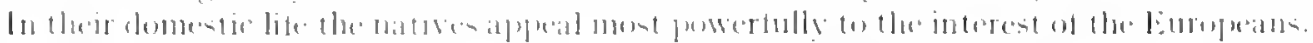

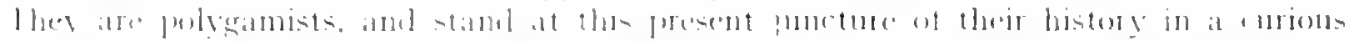

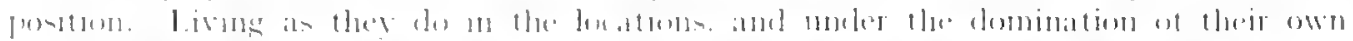

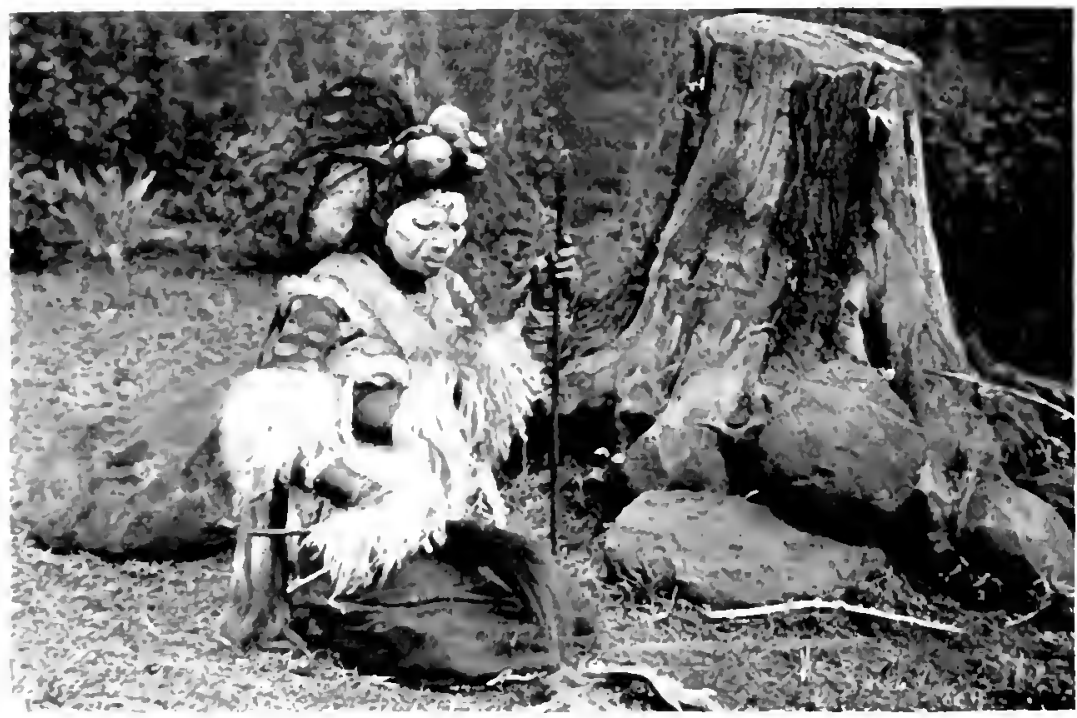

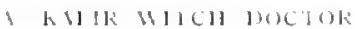

II II Cane?

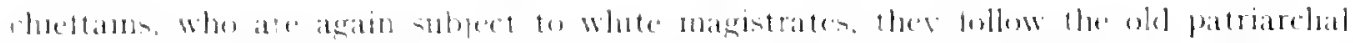

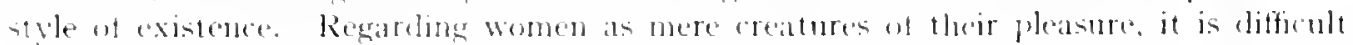

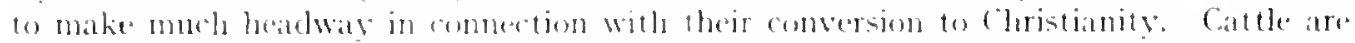

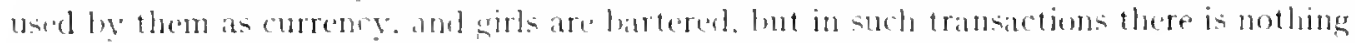
revolting, nother is the hibets of the -nblect materially interfered with. The transactions

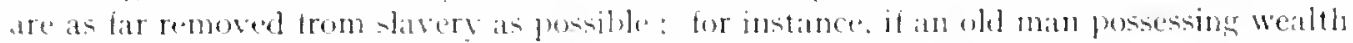

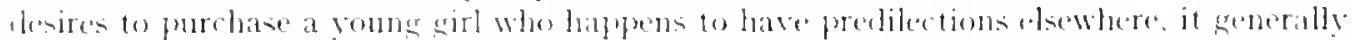

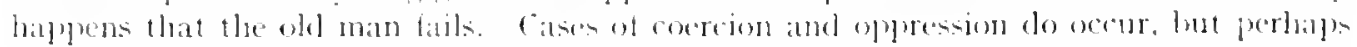
not more frequently than amonget European communities. The amount of rattle given

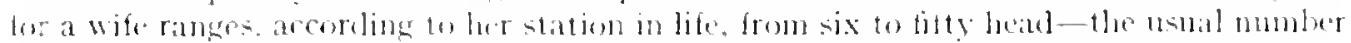
loing from ten to filterert.

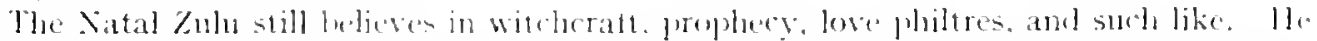

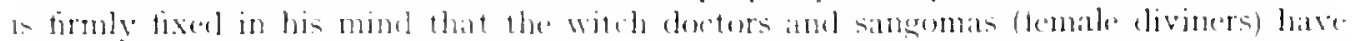
power to bring rain. to trace sulls of witcheralt. to heal hy incantation, and to perform -undry other wonders and mirates. In his mythelogy he has as curioms a collection of

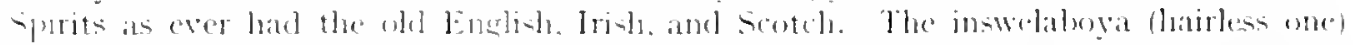

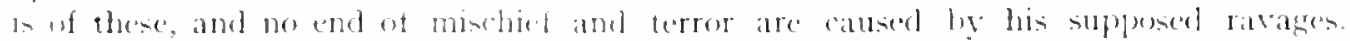

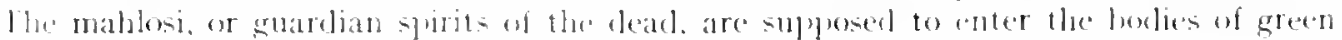
mambas a kind ot snake). These reptiles take refuge in the weedegrown fences of the 
kraals or villages, and are regarded as sacred. Now and again sacrifices of flesh are offered to the reputed guardians. At harvest times. he natives have a feast of first truits, (somewhat analagous to the ancient trivival of "Ceres") when numbers of maidens decked with flowers, cast offerings into the river, dedicating them to the Inkosizana (chieftainess). Their marriages are made occasions for rejoicing, bererdrinking, and a general gathering together. Oft-times the teasts terminate in tribal brawts and boken heads. Hany other instances of the customs and superstitions of the natives might be given, but enough has been outlined to indicate the interest of the sulject. The natives dwell in bee-hive huts, built in circles, the central portion of each kraal or village being occupied by their cattle. They are not great as workers of metal, but show an instinctive talent for wire-working, bead stringing, wod and hone carving, mat making, tanning and pottery. Some of their necessary household utensils display considerable artistic merit. They make good soldiers and policemern, hating a keen sense of the necessity of discipline. During the Zulu War they were on more than one occasion distinguished for bravery in battle, when they ranged themselves with the whites against their own kinsmen.

The language of the natives is a beantiful and musical one, with the peculiarity that every word either begins or ends with it rowel, the penultimate syllable heing invariably accentuated. The result is euphonious, and the language may be regarded as the parent aboriginal one of South. East, and Central Africa.

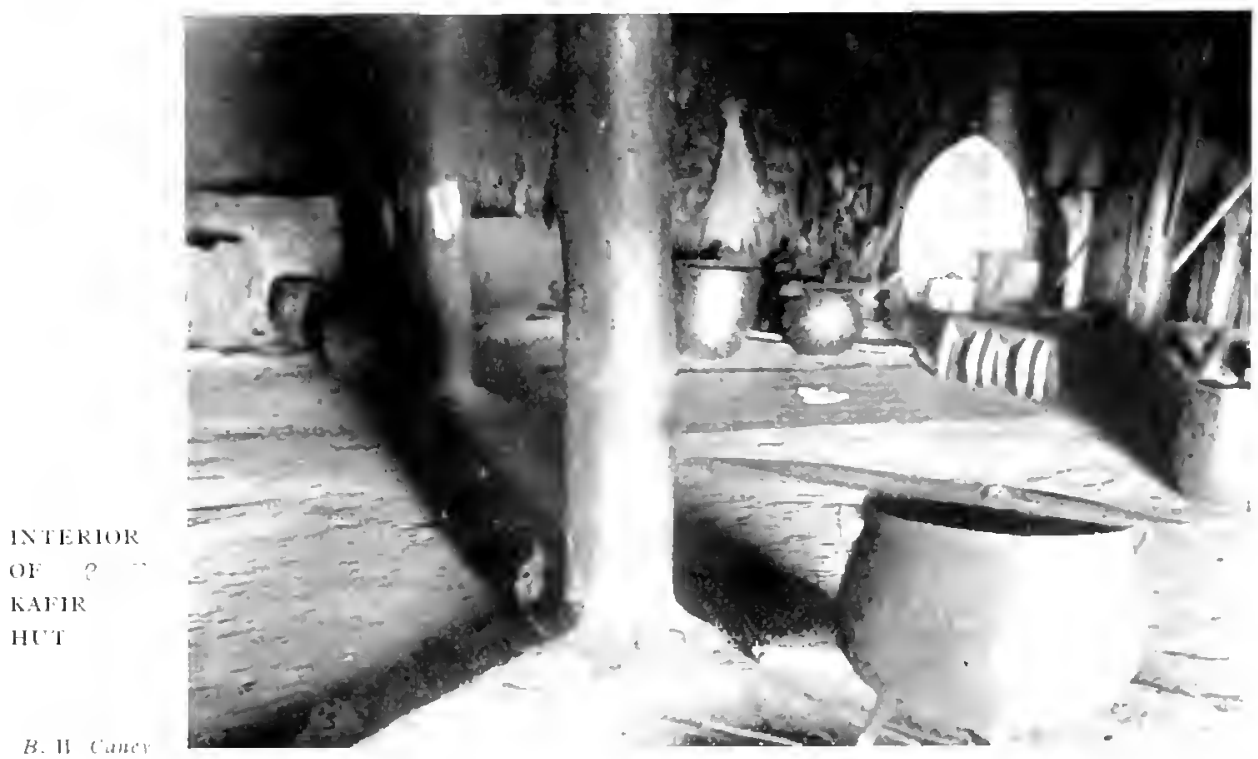

NATAL is dirided into eight connties, namely, fou on the Coast bel-ALFRED,

COUNILS,
TOWNS, V'LLAGES,
AND
MEANS OF ACCESS

ALEXANIRA, DLRLAN, and VICTORIA: three in the llidhnds-PIETERHARITZBLRG, WEENEN. and LMVTI: and one in the north of the ColonyKIl1' RIVER County, All vary in climate according to situation and elevation above sea level. The counties are again divided into districts, each district being presided over hy a Iragistrate. 


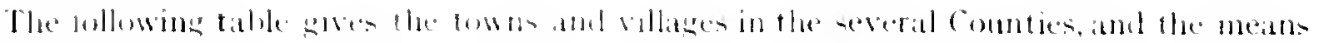
of arcess ilectequ:

\begin{tabular}{|c|c|c|c|c|}
\hline $1+2 \times[11: 3$. & & $1113 \times 211692$ & SII I MiJs. & 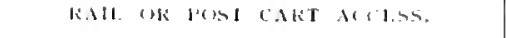 \\
\hline Mltreil & . & Ni. & 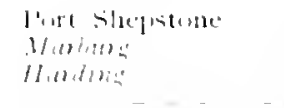 & 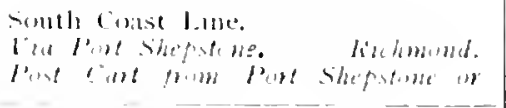 \\
\hline Nesimelrit & - & Sil. & 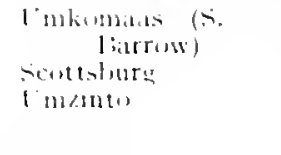 & 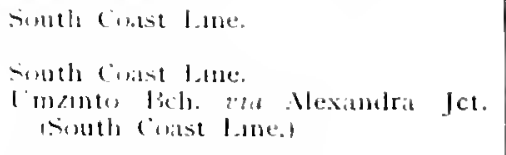 \\
\hline l)urlsum & . & Jurlath (seaphert) & 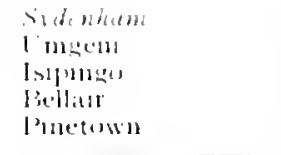 & 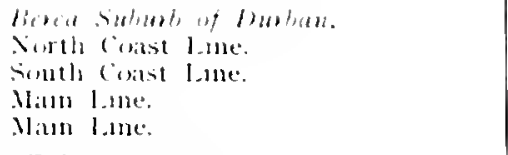 \\
\hline Victuria & - & Verulan & 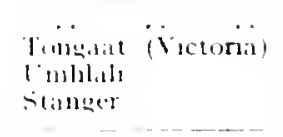 & $\begin{array}{l}\text { North Cinst line. } \\
\text { North Coist line. } \\
\text { North Cinst Line. } \\
\text { North Coatst Line. }\end{array}$ \\
\hline I'petermaritalures & & P.X.bure (Citutal) & 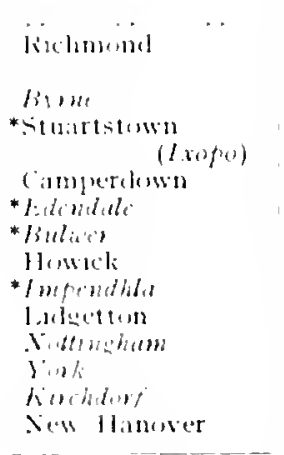 & 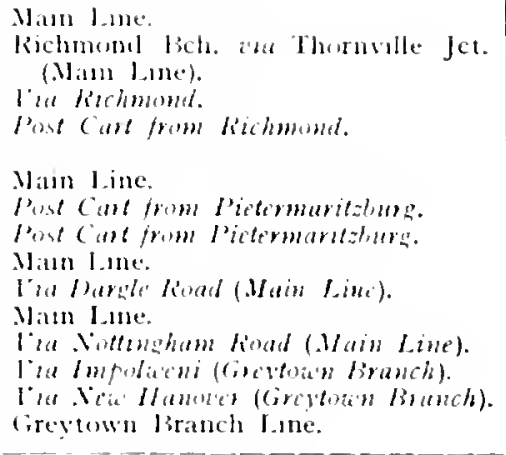 \\
\hline Khp liser & & $\begin{array}{l}\text { Jaulymuth } \\
\text { Jewcaste } \\
\text { Jumber }\end{array}$ & 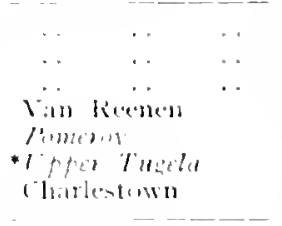 & 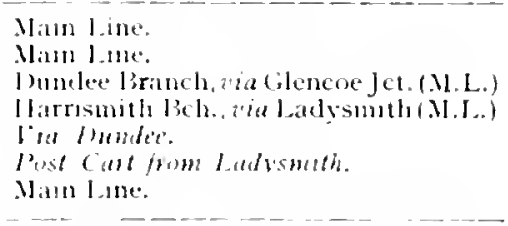 \\
\hline I'mbits & & Arevacus & 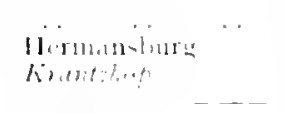 & 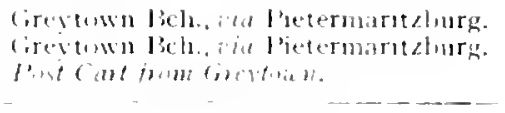 \\
\hline M(n) (n) & . & $\backslash 11$ & 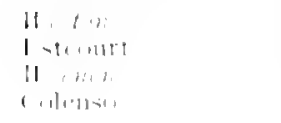 & 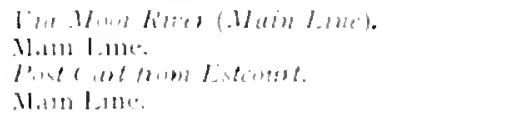 \\
\hline
\end{tabular}

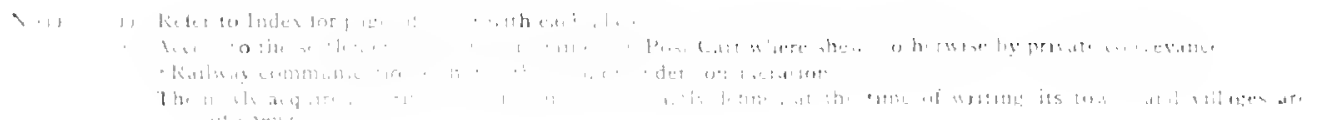


Zululand is not includerl in the foregome. This Province is divided ante the tollowing Magisterial Dintrict: : ESHOIIE. EMTONJANENI. NQUTL, MAHLA-

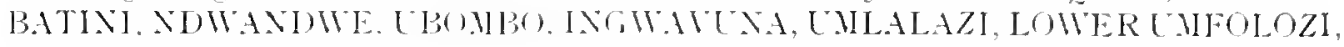
H.ALISA. anI XKANIHL.A. Eshowe is the principal town, and the only other villages

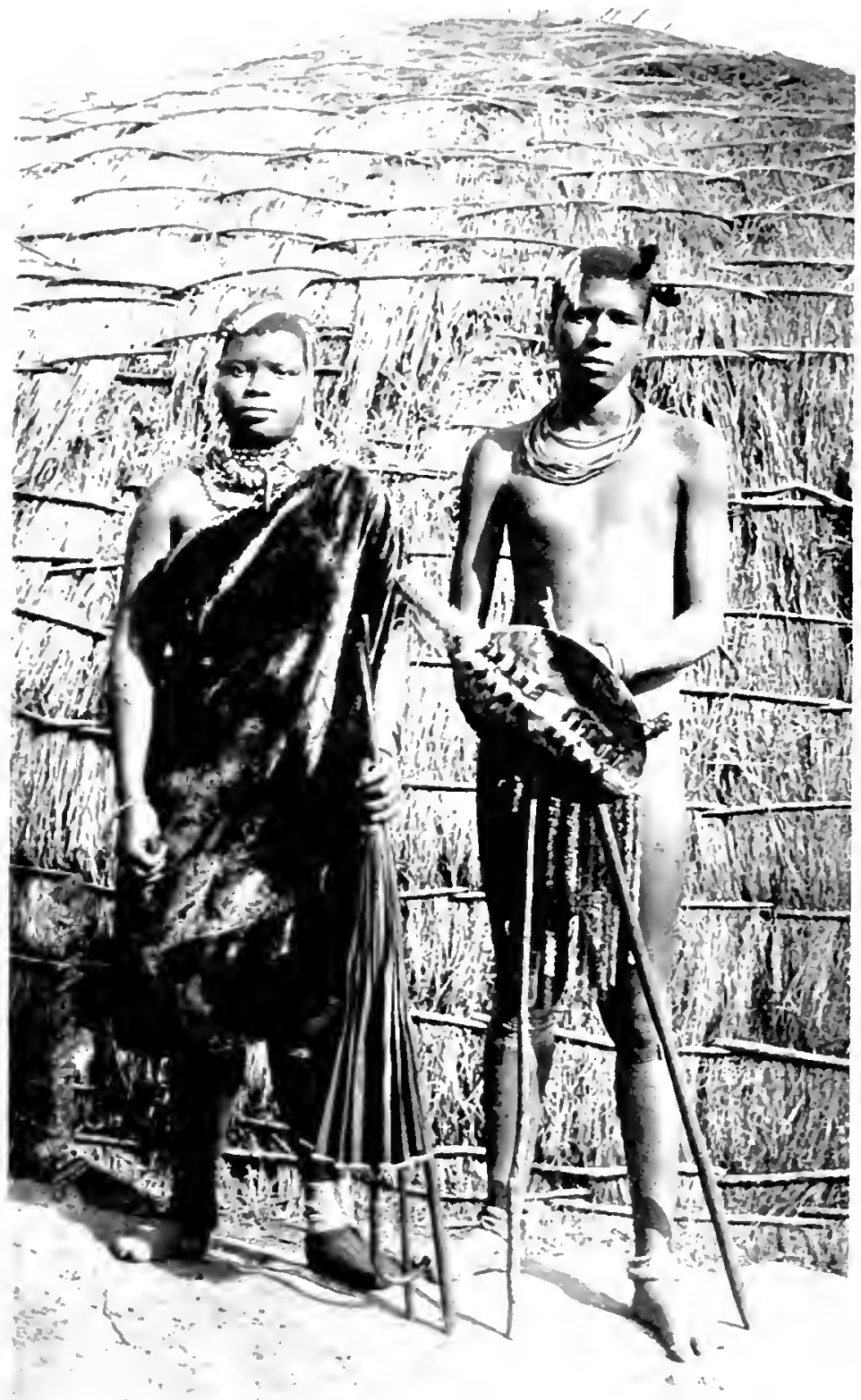

I PAIR OF IOSERS are lleimoth and Nond.

weni. Tlue first two places are reached bi l'ost cart from Gingirsbuever North Coast liranch Lint, see page I settlement, via Inndee.

GONERNHENT

(1) the zoth July Inis. Natal was con. stituted a self-governing colony, with Lpyer and Lower Houses of Parliament. The legislative Council. as the Lpper lonse is termed, consists of twelve members chosen by the Governo: in Council. Five of the members must helong to Durban, Victoria. Alexandra, and Alfred Counties: three to Pietermaritzhure and Imroti Counties, three to Weenen and Klip River Counties. and one to the I'rosince of Zululani. Not more than two members may be chosen trom the same county. The Governor appoints one of the twelve members as President ot the Commeil The Lower Hombes. legislative Assembly. consists of thirty-nine members. dhisen ly election of the jerople. Any person who is at 


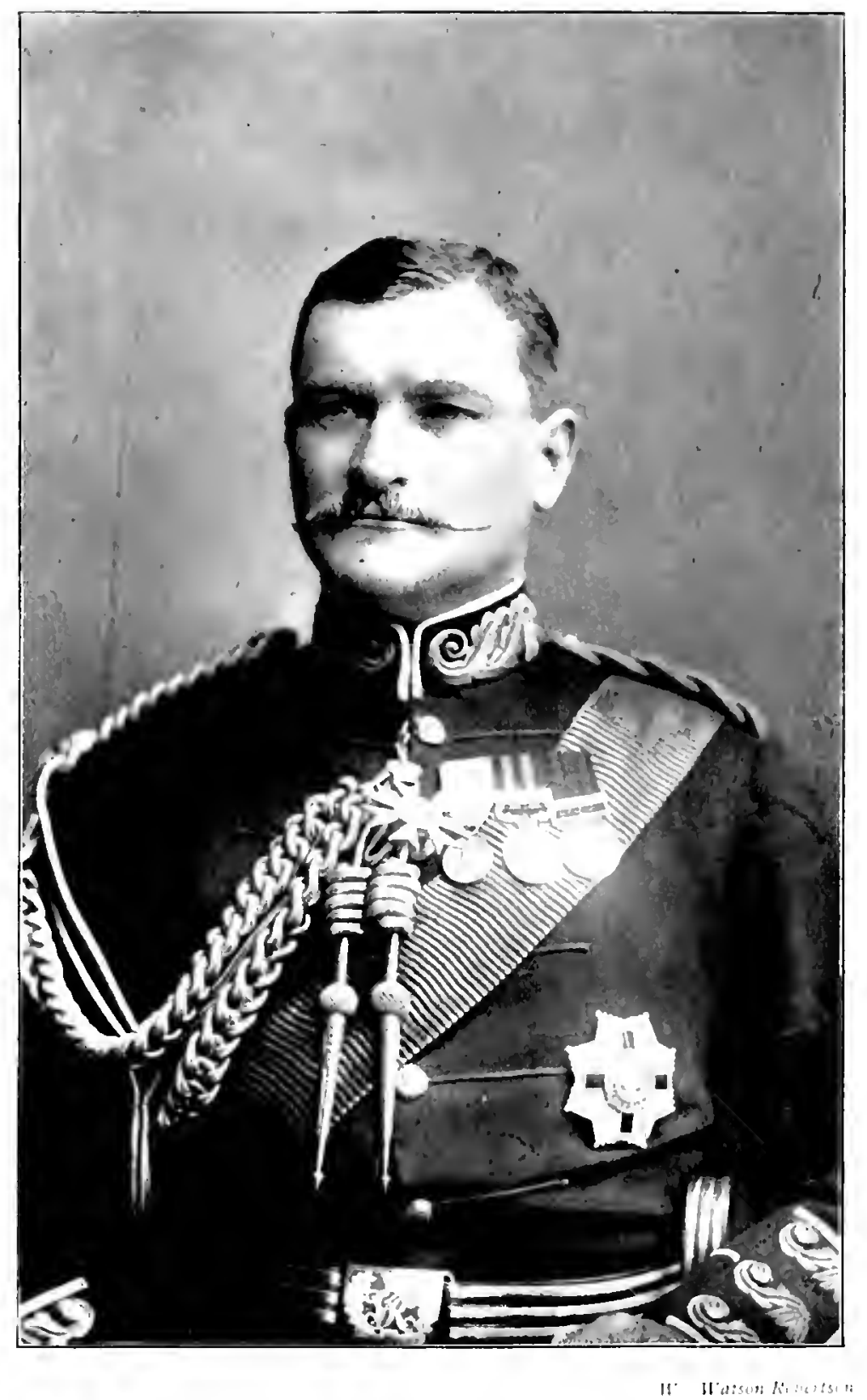

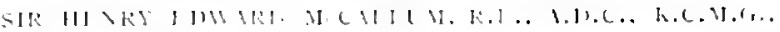

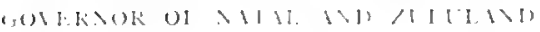



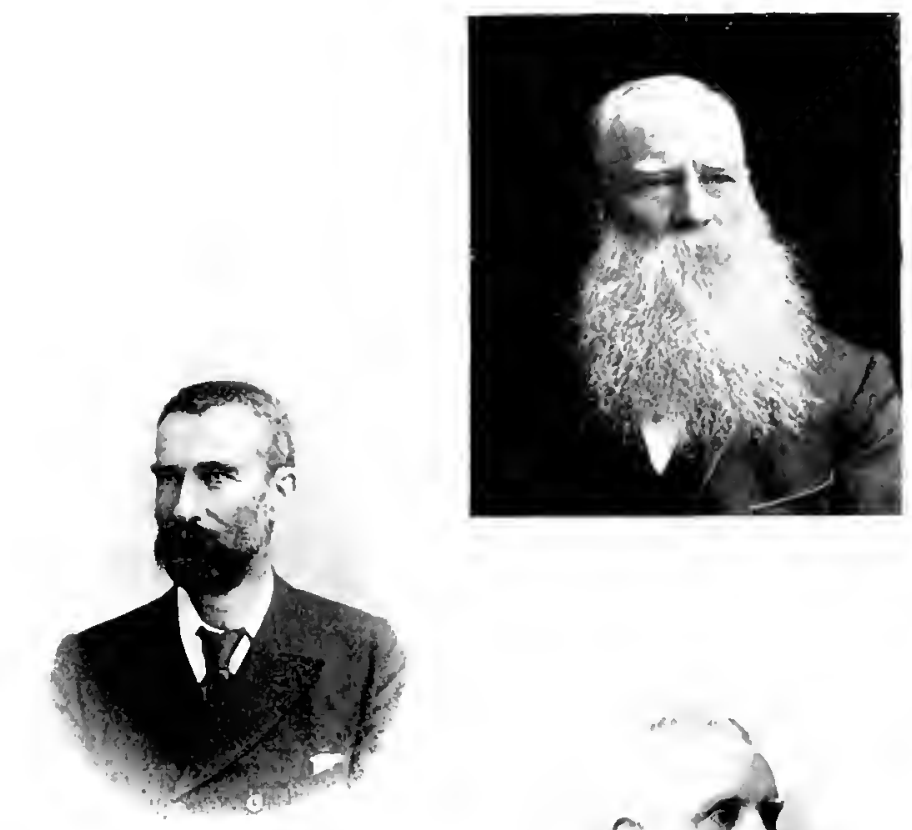

IHE NATAL MINISTRY YEAR 100)!
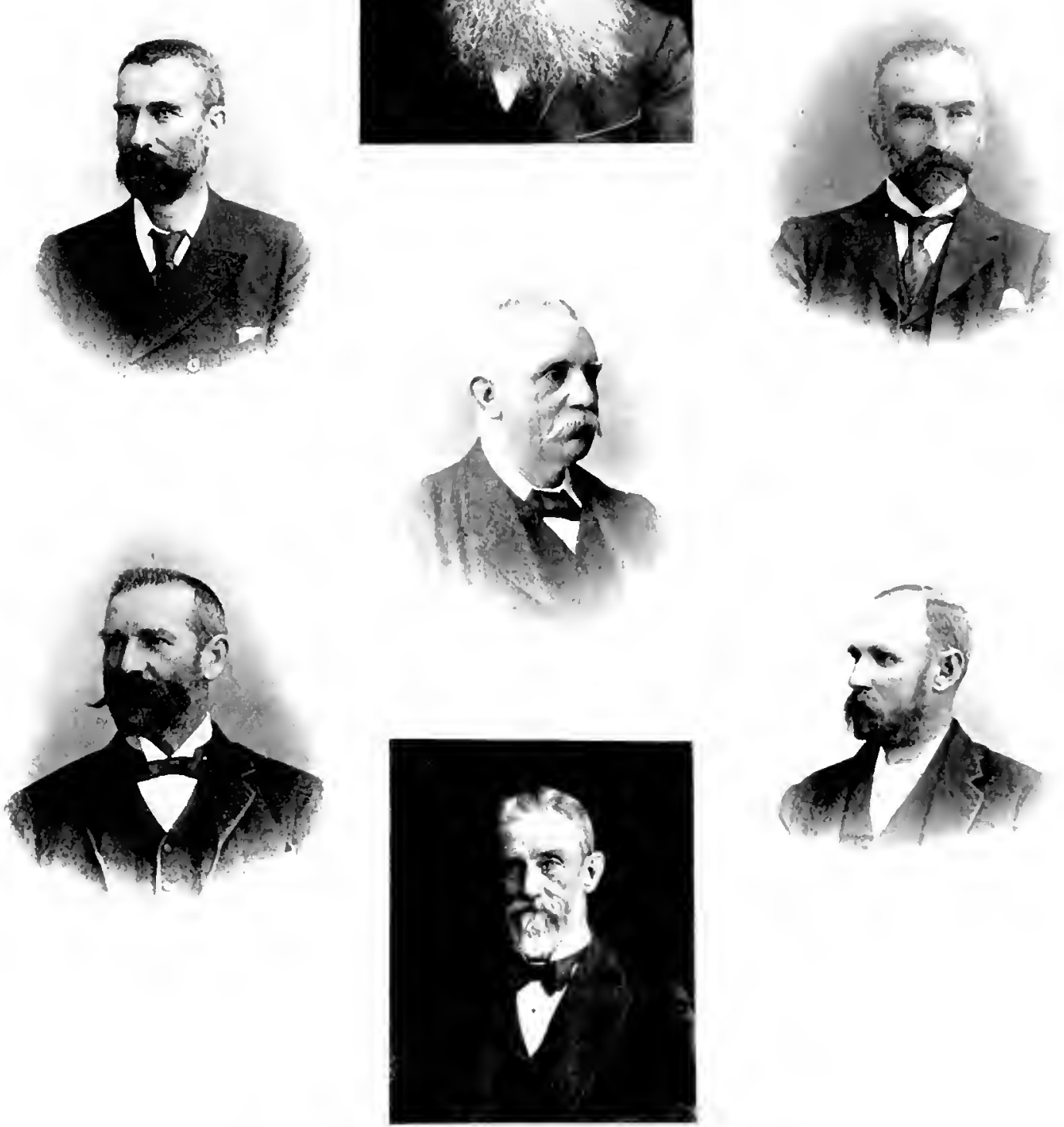

THL HoN C. J. SMT THE Colonial Secretary and Minister of Education. THF HON. H. D. WINTEK, Minister of A ricullure.

THE HON SIR W ARBUCKLE, l'resideat of Legislative Council THE RT, HoY, SIR ALBERT HIME, Prenier and Minister of Iands and Works THE HON. SIR J. LIEGE HULETT, J.P. Speater of Legislative Assembly
THE HWS. GEO. PAYXE. Colonial Treasurer.

The HON. F. K MOOR. Secretary for Native iffairs. 


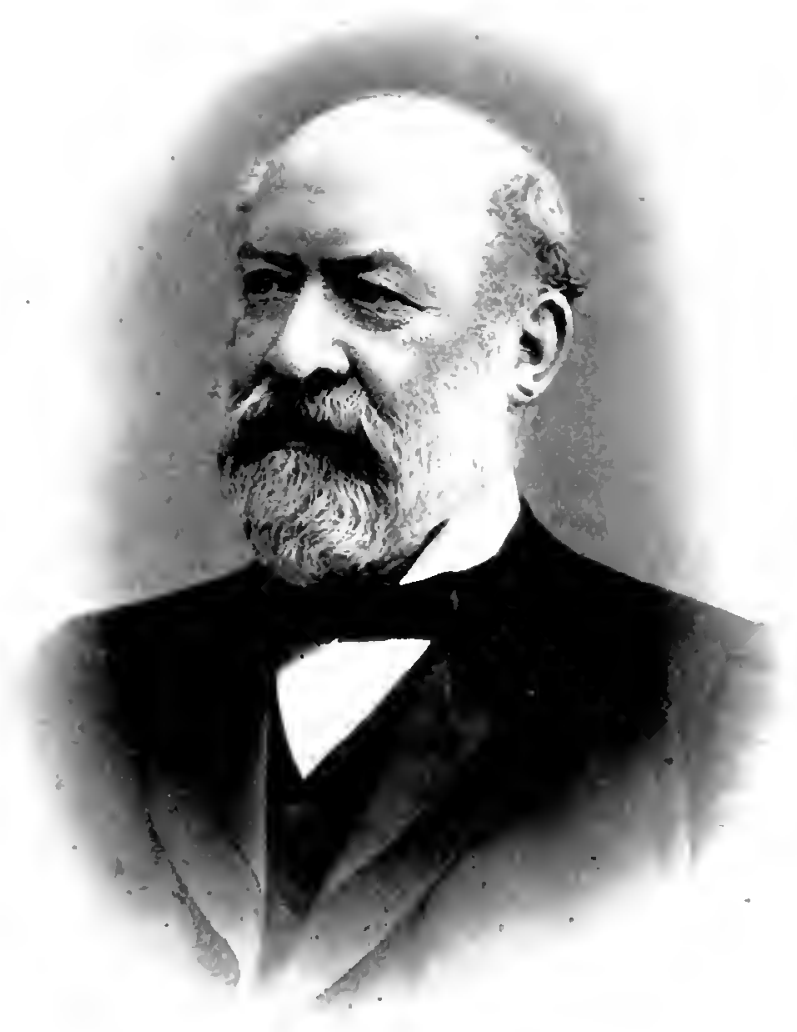

kussell a sons

SIK WALIEK I'EACL, K.C.MGG.AGEAT-GIAERAL FUR NAIAL 


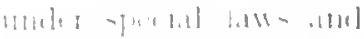

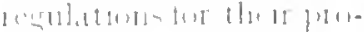

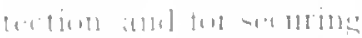

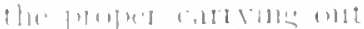

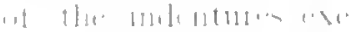

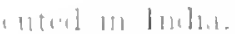

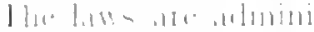

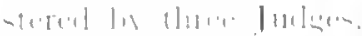

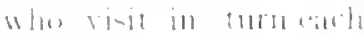
circuit al lla" cilotes.

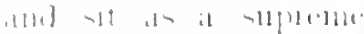
findrt at - lated intel vals. I lor Inlorind (1,11ts

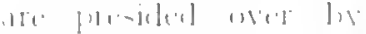

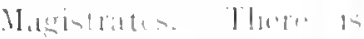

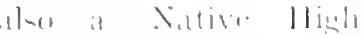
(1) 1111 (1)

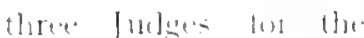
alministation at funtiae amotiset nattivis.

$1: 111(1110)$

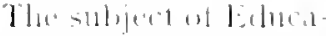
turs hase rearivent rent

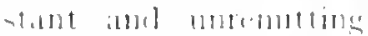

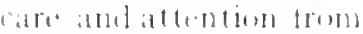
Cimentment. Intil the

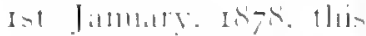
importint heportument

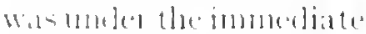

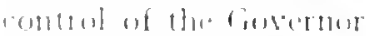

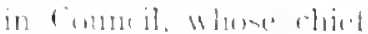

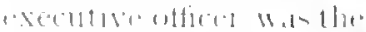

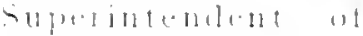

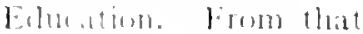

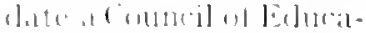

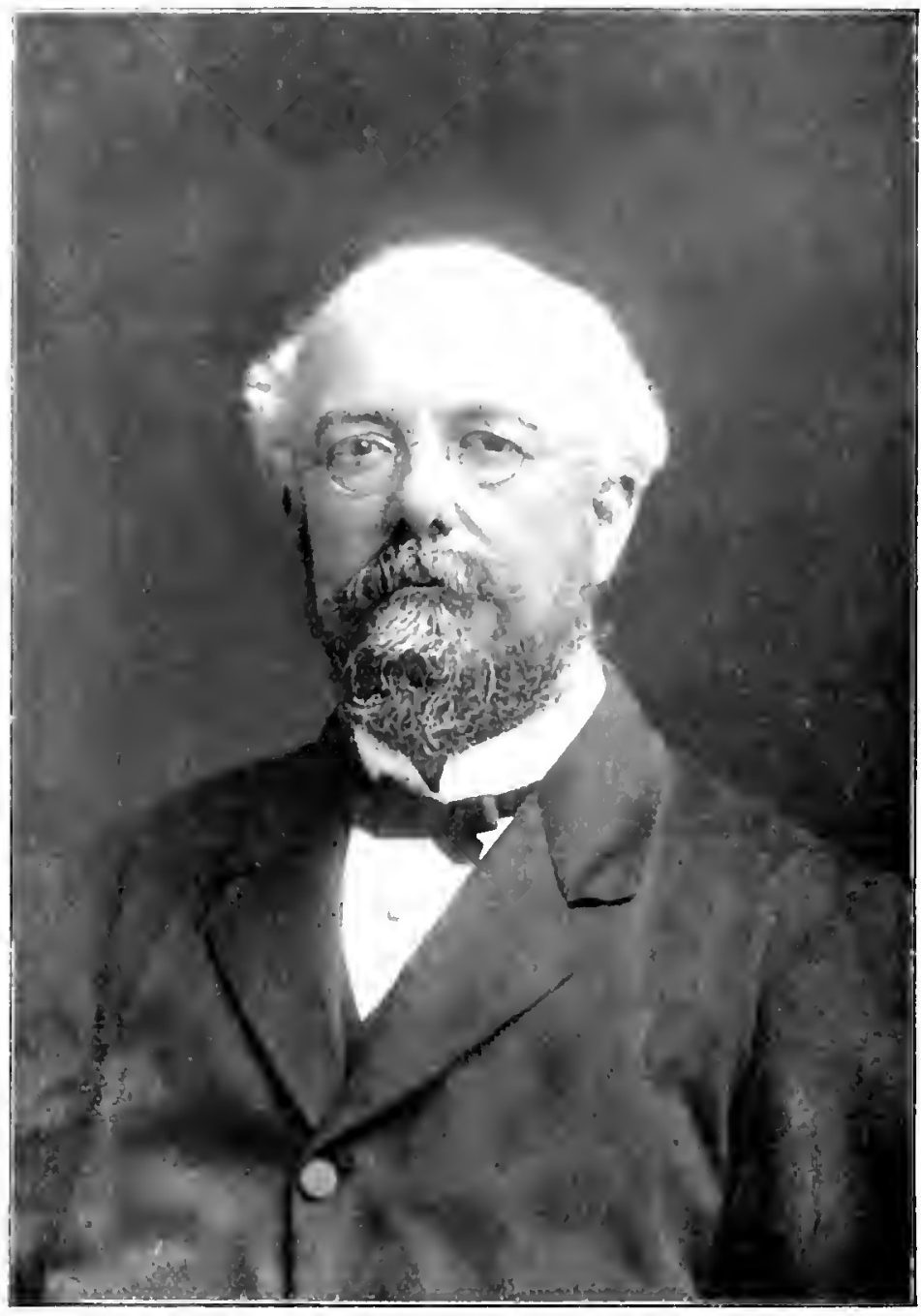

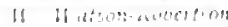

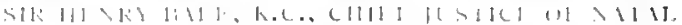

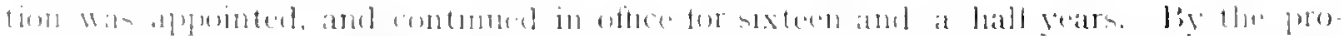

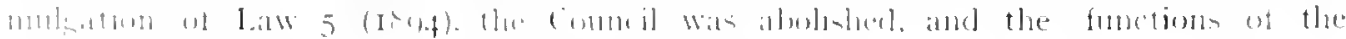

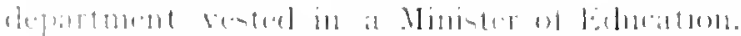

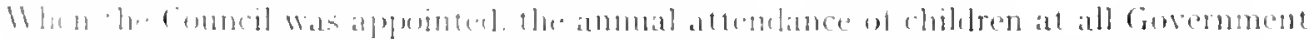

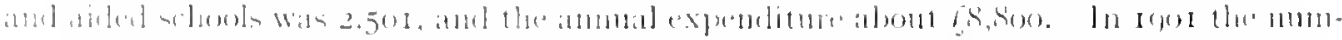

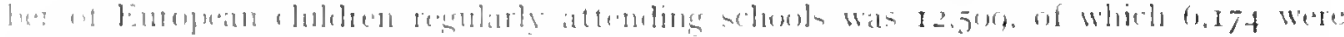

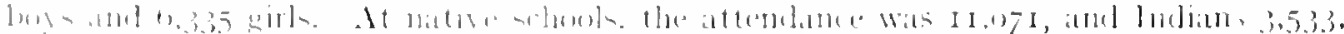

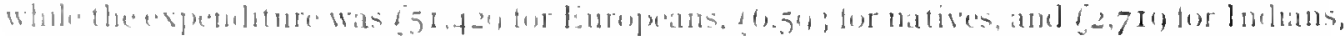
mathing at lotal ot $100.7+1$.

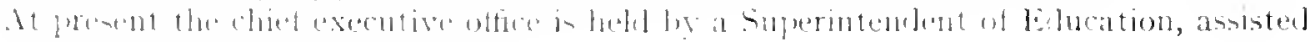

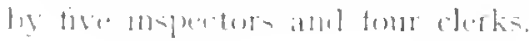


A scheme for aiding farm-house schouls was entablinhed in Isis. In the following vear there was only one examination centre. In Isso there were thirteen fentren woll a total

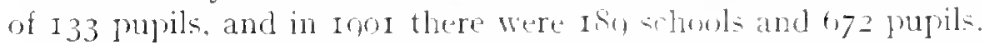

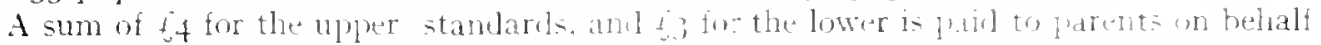

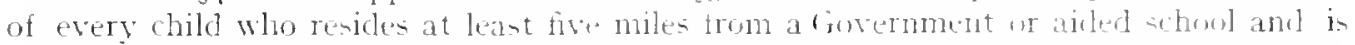
found on examination to have been properly tauglet during the greeceling twelye months. Examination centres are formed at any place where no tewer than ten clisldren can be got together. The Superintendent of Education reports that the srstem is working well.

In the Colony there are altogether $2 \mathrm{~s}$ Eurugran schools, and rot tor natives. The former comprise 33 Gosernment schooln. 5 fixed aided schools. anel Iso firm-house schools. The grants to the native schools during the rear Imo amounted to 6.353 . The natives themselves spent on the scluols a turther sum of i.I 1 b.

As shown elsewhere throughout this volume. there are numerous high-classerlucational institutions, such as the colleges at Maritzhurg. Bulgowan. Weston. Hilton. and elsewhere. while in the two main centres, Naritzbure and Durban. Young Ladies' Collegiate schools. Academies, Government High. Nodel. and Primary schools and many other surh establish ments, most amply provide for the scholastic reruirements of the Colony.

Railways pierce the Colony in all directions, and represent a total length of about 680 miles. Direct connections are afforded to all the other South

RAll,WAYS African Colonies. The quikest and most picturesue route to the Rand, and other portions of the Trunsiad, is wit Pitul. The Part levoted to the Review of the Railways from earliest times. will he found of especlal interest. (See page 274).

British Garrisons are estallished at Pietermaritzlurg, Ladysmith. Jundee, and New

GARRISONS, VOLUN-
TEERS, MOUNTED
POLICE
castle. in Natal: and Eshowe, in Zululand. In addition to these, the defence of the country is ably supplemented by the Natal Volunteer and .llounter Police Forces.

Natal's Volunteers have a stirring and interesting history. They were the first on record throughout the Empire to take part as regularly appointed troops against an enemy. On several occasions, and never more conspictonsly than during the recent Boer War, they have gained distinction, and are markedly efficient in all particulars, alike as regards drill, marksmanship, and every soldierly requirement. Brigadier-General Sir John G. Dartnell, K.C.B., was for a considerable time the Commandant, and much of the success which has attended the career of the Force is to be attributed to his tact and skill.

After twelse months' excellent service in the frekl. the Volunteers were demobilized on the gth October. Inoo. but a composite Regiment of some zoo officers. non-commissioned officers, and men remained in the field. at first under the command of the late lieutenant. Colonel R. W. Erans. and atterwardsuf Lientenant-Colonel Bede Cromptom. The Hounted Regiments and the Xatal Field Artillery were again called upon for survice on the i 8 th Septemher, Inor, owing to a threatened invasion of the Colony by the Boers under Commandant-General lonis botha. The threatened raid. however, proving unsuccesful, the Volunteers were again lemolilized. on the roth October, Igni.

In April, Igo2, the Volunterer Comprite Regrment. heing still in the held. Wats considerably augmented. and a second reginent of similar character was raised. under the name of the Natal Mounted Intantry. the commanel being entrusted to l.telitenant-Colonel F. Idelison, V.1). 
The totalstromgthot the loblunted foreres

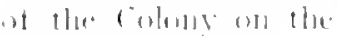

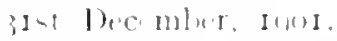
way I,75\% marle 11p at

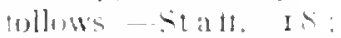
Saral bolunterels. 135 . Homentod liblen. ifs; linelel . Irtillery. ar Intante y +55 Medual statt lorps. at Voterinall (a) $\therefore$ : Renerve, 47 .

Tla. “ Xattal Vulun. tee" Reen d" olstain.

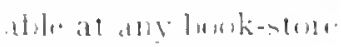
in Xitial. a ream-

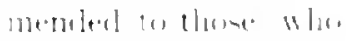

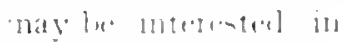
He Volumater Forres. and the - phentiel juat platyed his them, apectlly ilurante the reorent wat

sime lla extablislo-

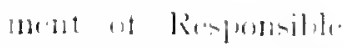

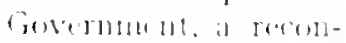

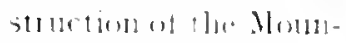

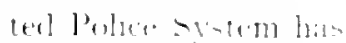

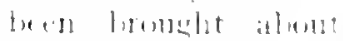
thasughesut the coloms by the com-sidation at 'lar sarmone berrese

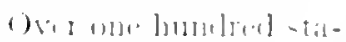

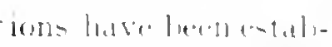

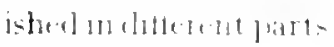

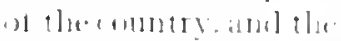

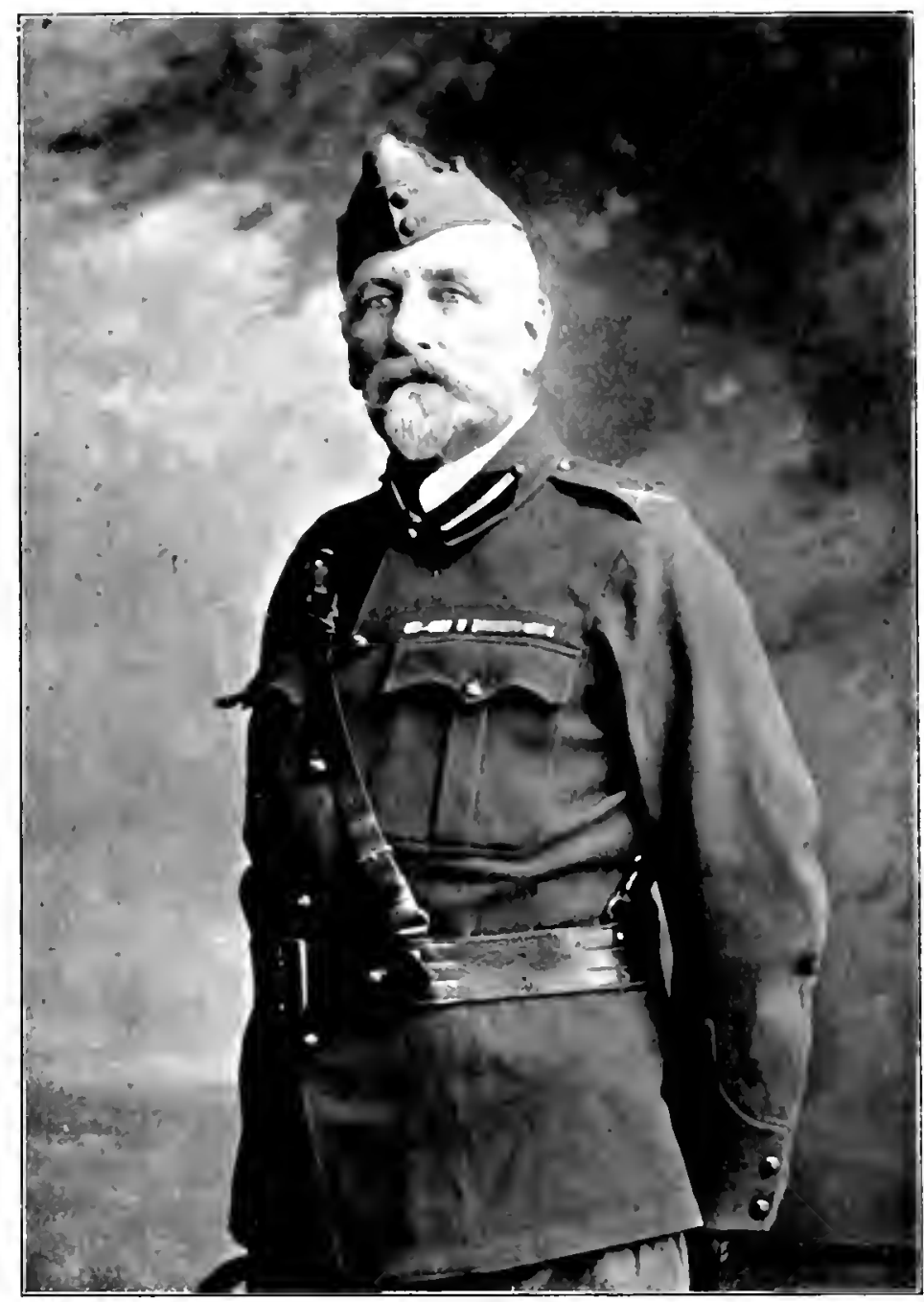

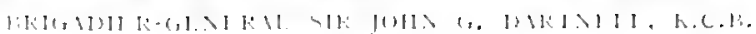

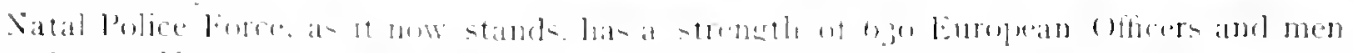

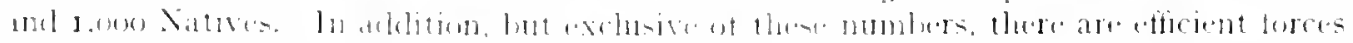

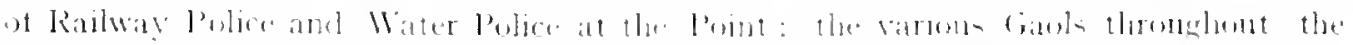

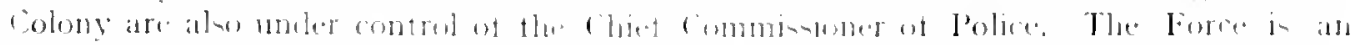

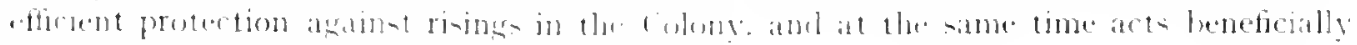

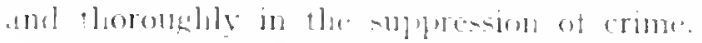

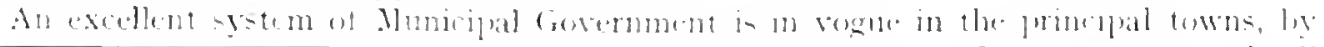

IILNICIPAL SISTEU

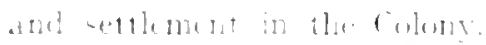

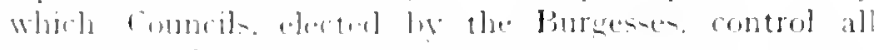
mattiter al linal (a)

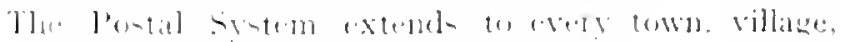

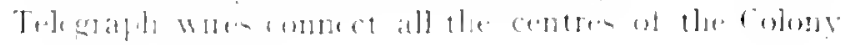


POSTAL AND

TELEGRAPH SYSTEMS

with each other, and with the rest of South Africa. "The total length of line and wire in the Colony at the end of Igor was I,512 and 3,794 miles respectively. Four Submarinc Cables afford the means of communication with the outside workl-two from Cape Town via West Coast, and two from Durban. one via the East Coast and one via Mauritius and Cocos Islands to Austral:a.

The Inland Letter Rate in Natal, and between Natal and the Cape Colonv, Transraal and Orange River Colony, is It. for every half ounce, or fraction therent.

The Telegraph Rate is one penny per word, with a minimum of one shilling; cypher or code telegrams are charged 50 per cent. above ordinary rates. Cablegrams to Europe via East or Wrest Coast Routes are charged for at 3s. per word, and to Australasia from 2s. 3d. to 3s. 8d. per word.

Natal is well supplied with newspapers. Durban and Pietermaritzburg each issue

PRESS dailies, both morning and aftemoon, the "Natal llercury" and the "Natal Advertiser" in the former town, and the "Natal Witness" and the "Times of Natal" in the City. In addition weekly mail editions of several of the daily papers are jrinted for Colonial and Home circulation. The Natal Press is kept in touch, by telegraph and cable, with all incidents of local. home, and foreign importance or interest, both Reuter's and Special News Agencies heing employed. Independently of the foregoing, Durban produces one weekly journal, "The Prince," and Pietermaritzhurg a Dutch bi-weekly, the "Natal Afrikaner." The "Dundee and District Advertiser" and the "Newcastle Alvertiser" are published weekly in the towns trom which they take their respective names.

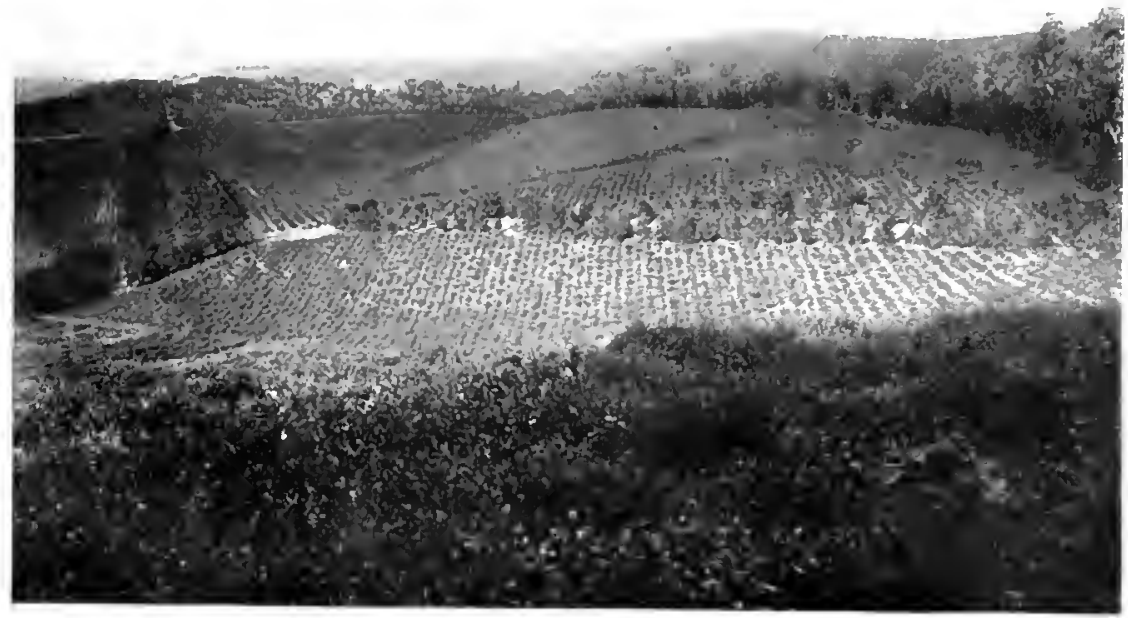

These are exceedingly good, and, whikt. the "class" distinctions are not so txintme SOCIAL
CONDITIONS as in the llothent? comtry, yet there is a due anlo proper regart for those traditions which have produced the tone and culture that are the teatures of English Society to-day. It might also be added that the utmost religious libery prevails, and adherents of all clemuminations wifl have no difficulty in finding congenial church or thapel society ihroughout the colony. 


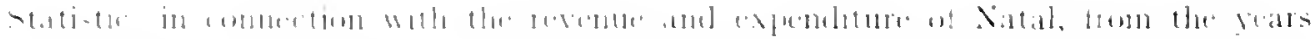

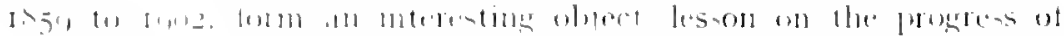

$11 \backslash 1.1 \%$

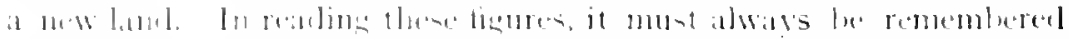

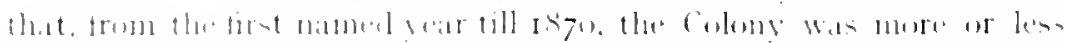

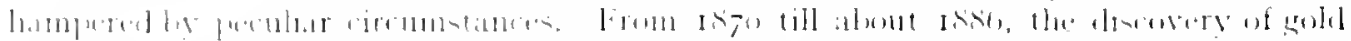

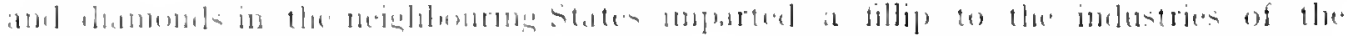

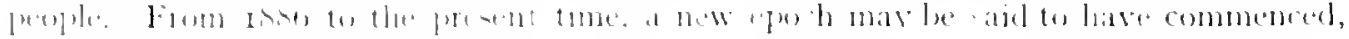

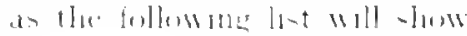

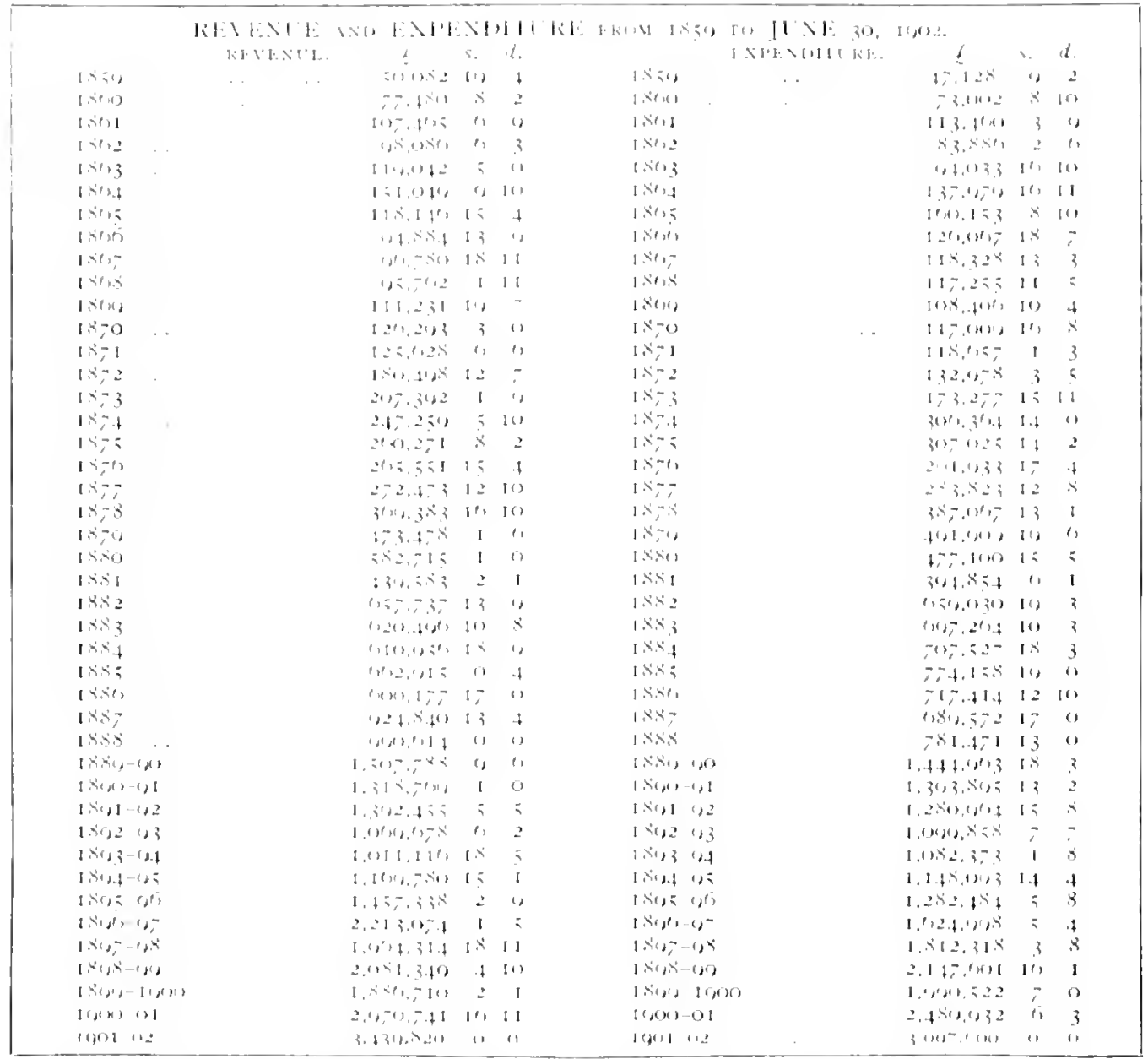

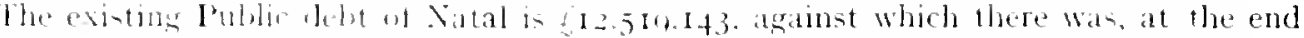

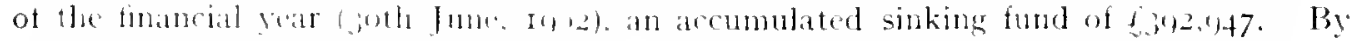

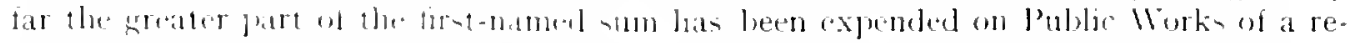

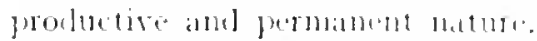

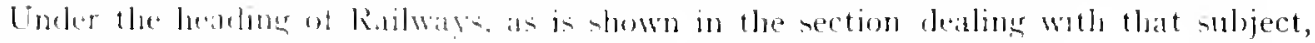

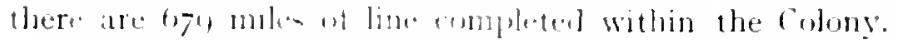

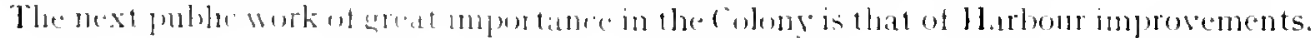


These have tormest the theme for mucl controser-s, hut the fact remain that a comparison of the condition of the llarhour as it is to-daty. with its tacilities ten veare acro. will reveal a rast advance. The Colony is now provided with a service ut tuss, thedgers, wharfage, and other accommatation of a mont efforent eferciption.

Of Roals, Bridges, and Public liuldings. it ran be sald with truth that the Colony is in no respect betind hand. Considering the size of the comntry and it population,

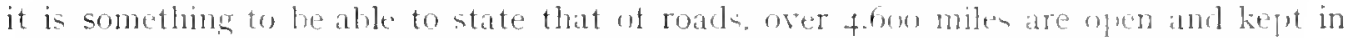
repair. This, in a lilly and mountainous land, is a guod record.

Nearly all the injortint rivers are well and strongly bridged, hoth for roul and rail traffic.

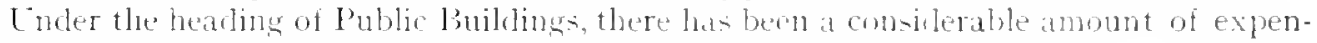

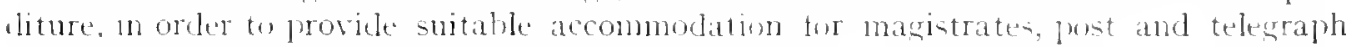
offices, and sther necesary Government hildings.

Crown lands amomnting to alout $1,500,000$ acres in Natal. and $0.000,000$ in Zululand,

NATIVE AND CRONN L.ANIS valued at Ios. fere acre, still remain unsolel. This raluation may, however, be under the mark, as the lands sold recently have realised an aberage price of I 2 s. 6d. per acese. Location and Mission Reserve Lands representing large areas of the Colony, alienated Irom the foremment. are rested in trusts for the natives.

In addition to the above, many other important assets, either directly productive or indirectly bearing on the revenue, might be mentioned, lut enough has been outlined to indicate the solid position of the Colony from a financial point of riew.

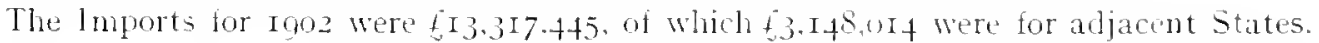
The Exports including goods to the value of 15.783 .578 . sent

COMMERCE Orerland, amounted to $f 0,156,368$, Colonial products alcounting for ${ }_{2} 1.476 .600$.

The re-opening of trade with the Transwal was shown by the fact that gools valued at 6.5.36.064. were sent to that Colony during the year rooz. During the vear isos, the last complete rear under the Boer Government in which trade was uninterrujed. the exports of the Colong to the South-African Republic reached the sum of if I 22,783 .

TABLE OF SHLPIST; IND TRIDL OF THE COLONY.

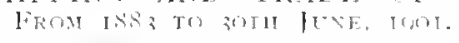

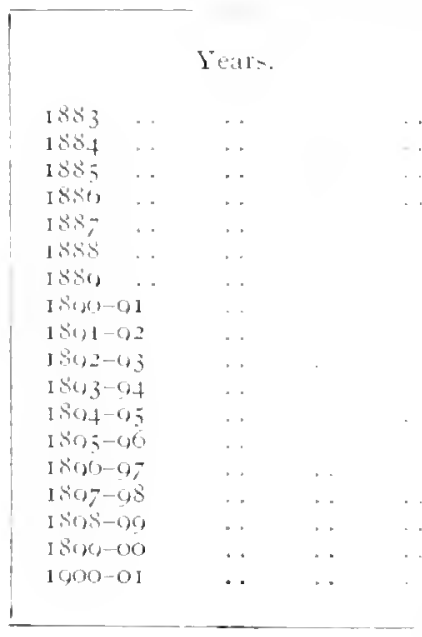

slingling in lom.

\begin{tabular}{|c|c|}
\hline Inwatris. & Outwards. \\
\hline $232,00 \%$ & 331.402 \\
\hline $2\left[0,1 S_{1}\right.$ & $212,(x)_{4}$ \\
\hline $11,5,200$ & 10,5143 \\
\hline Iritis, 151 & 14,183 \\
\hline 235.455 & $231,30 \mathrm{~m}$ \\
\hline 314.420 & 302.235 \\
\hline+311.110 & 431,219 \\
\hline+10.310 & $404.14^{3}$ \\
\hline $5115+424$ & $30,3,1,-\infty)$ \\
\hline $5(1,1), 2,2$ & $503+30$ \\
\hline intefor & i) $54+14$ \\
\hline-22.200$\rangle$ & $-30,1,25$ \\
\hline$S(x) .301$ & 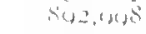 \\
\hline $1,224.1+1$ & $1,2001,583$ \\
\hline 1.2In,NIt & $1,22 m_{1}, 4$ \\
\hline $1.330,355$ & $1,341,1=2$ \\
\hline $1+4+5 i 1$, & I, $35 \times 1,1,0$ \\
\hline 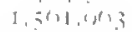 & $1, ; 23,113$ \\
\hline
\end{tabular}

\begin{tabular}{|c|c|c|}
\hline Villute & (Custems & Value \\
\hline f Improts: & levenute. & ut Exports. \\
\hline $1,-31,11 \%$ & $422104 t$ & Disi.suo \\
\hline $1,1,-5, S=13$ & In $1,4,0$ & $\therefore 31,7+4$ \\
\hline $1.51 \div .53$ & $1 ; 0,0(x)$ & $45,-213$ \\
\hline 1.331 .115 & $1+0.4111$ & $(x), 200$ \\
\hline $2.28 \div 3.1200$ & $231.4 \mathrm{II}$ & $1,11=0,0500$ \\
\hline $2, \delta(x), f^{\prime \prime}, x^{\prime}$ & $200,0)+4$ & $1+1 ;-1-1$ \\
\hline$t_{15}: 2,0,015$ & $3(x), q^{n}, 1$ & $1,6=31,318$ \\
\hline $3,020,3010$ & $2-3,024$ & $1.21 \%, 413$ \\
\hline $3,00,-34$ & 300.1113 & 1.3\%, イ゚゙ \\
\hline 2,451$), 5112$ & $21: 1,1$ & $1,3,0,3.35$ \\
\hline $21, I, I, 322$ & $100,5+2$ & $1.25+1350$ \\
\hline $3,3,-0,0,22$ & $1.20,6,30$ & $1,2[1,+3.30$ \\
\hline $3.550,1=5$ & $203,3,-1$, & 1.531 .358 \\
\hline $4,415,24 x$ & $+13,3(11)$ & 1. $-204,2+0$ \\
\hline $5,2,1,-57$ & 30,513 & $1,1,-2,3010$ \\
\hline $5,5(x), 12+3$ & $+30.12=$ & 3.204 .310 \\
\hline $5.31,-7,31$ & 500.415 & $1,3,3,6,8$ \\
\hline - Is-., & $-\left(7^{-}+41 \mathrm{I}\right.$ & ${ }^{x} 2,211455$ \\
\hline
\end{tabular}


Natal, considering her area amb pephlatuon, stamb laurly well in these resprects. At

INI STRItS,

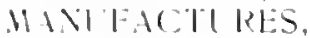
.HIXI:S, Si. the time of writhe there were thirty-six sugar mill, ten dis. tilleries, forty-six grist mill- thirty-one saw mills, thirty-five aterated water factories. thee rectifiers and compounders, two methrlated-spirit makers. forty-two wagon-making establishments, ten weod-turning machines, sixty-nine brick and tile work, one brewery, one arrowroot-mill, three tanneries, eighteen confectionery and preserve factories, eighteen wattle hark-cutting mahines. fourteen tea and coffee mills, ten bone-crushing machines, on woolhn lactorv, twentr-seven iron works, seventeen coal-mines, three lime works twentyefuarries. wo wool-wasling mils, fourteen sausage factories, one ham and hacon-ruring lactory (not now working). fitteen ice and refrigerating establishments. eleven -tome-cutting, polishing. and monumental works,

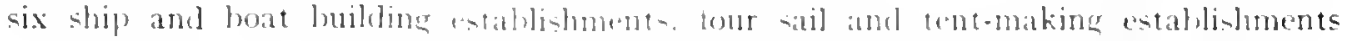

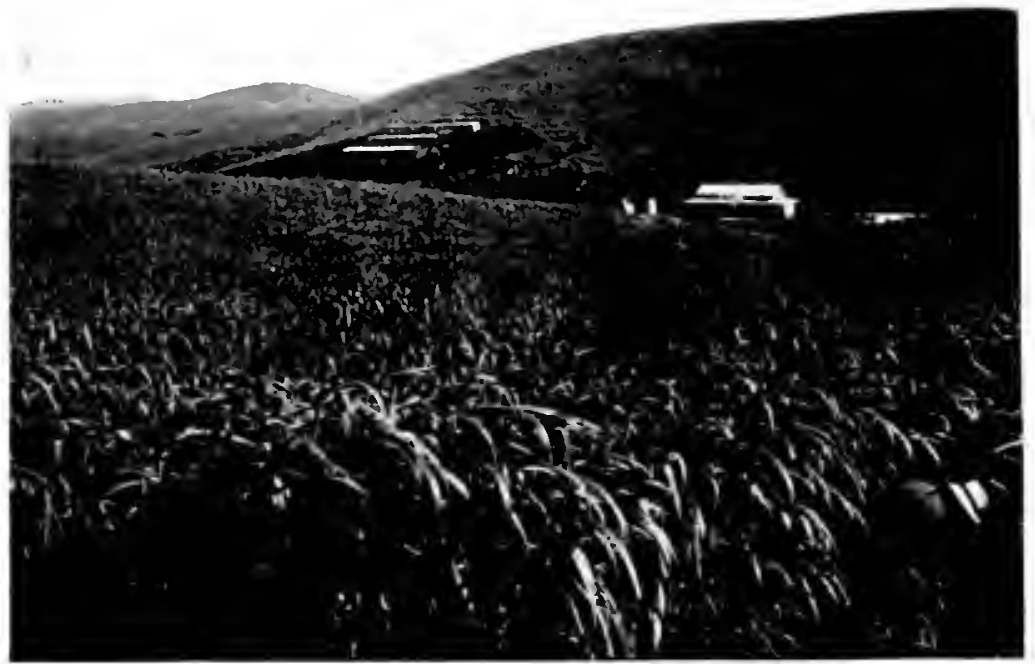

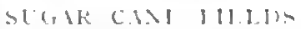

eighteen turniture and bedding factores. nmoteen printung and lookbinding establishments. three lithographing and die-sinking entabishments.nineteen saddlery and hamess-making establishments, ten "lectric light works, eleren cucle works, one hilliard-table factory, three dye-works, one explosives factory. three match tactorics, two soap and candle and one Venetian-blind works. five atablishments for manufacturing jewellery, one fibre factory, and thirty-two small boats and cen steam-trawlers engaged in the fishing industr: The foregroing fisures include Zululand.

The total amount of land under tillage in the colony has been calculated, as nearly

PROHUCTIOXS and systematic manner. I07.35, acres. While tle natwes are roughly estimated to till, in at desultory and spasmodic tashion. about for.tyd ares. the most of which is under 
mealies and kafir corn 216.526 acres heing deroted to the former, and 177.372 to the latter crop. Some $4 \mathrm{I}, 5 \mathrm{I} 2$ acres are cultivated by Indians.

The total production of mealies for the colong in IgoI was I, 35 I,045 muids, and of kafir corn 702,153 muids.

Sugar cane ranks next as a leading crop $2 \$ .4+$ acres being aproximately the amount under it, of which 26,935 acres are cultivated by Europeans, 255 acres by natives, and I,290 by Indians. The cane grown hy natives is not cruslied for sugar. The yield of sugar per acre (Europeans) averages 1.32 ton, and Indians 0.7 ton. The price, of course tluctuates, but fin per ton may be taken as a fair average.

Tea follows, with an acreage of 4,027 by Europeans, and so by Indians. The return for the year Igor wa; I,7IO, I jo lbs. by Europeanc, and Io.000 by Indians, valued at gd. per 16.

A very large area of land has recently been planted with wattle trees, and in Igor the yield of bark (principally exported) was I 4,132 tons, valued at about 170,000 . Follow. ing these, tobacco, cereals, vegetables and other minor products are in evidence.

Owing to the Boer War, the export of wool was very low, only amounting to $2,522,34$ I lbs., as compared with $24,292,777$ lbs. in 1898 .

With regard to coal, the total output during Inor was 560,200 tons, valued at the pit-montl at $\$ 549.439$. Of this, 247,166 tons were bunkered. 57.622 tons exported (including $\mathbf{I}, 4+0$ tons to the Orange River Colony and +25 to the Transvaal), and $1+6,234$ tons were consumed by the Natal Government Railways, leaving i I8, I 8 tons for local use. In I 902 the total output was 592.752 tons.

Hides, skins, and Angora hair constitute fluctuating hut yet important items.

Sub-tropical fruits are extensively cultivated near the coast. Bananas appear to be the staple product. and it is estimated that there are from I. 200 to I,500 acres under them. The Rand aftords a large market, and a good over sea export trade is done. A very considerable traffic in pineaplyes is also carried on. The Malvern district is the chief cultivating centre in the Colony for these fruits. Niartjes and oranges flourish luxuriantly' in many parts of the country, but the culture of other citrus fruits, such as lemons, shaddocks, and limes, has not been systematically undertaken.

Many other productions might be mentioned. but enough has heen set down to indicate something of the scope and nature of the Colony's capabilities. To skilled handicrattsmen and workers, large possibilities are offered in fibre and silk-culture alone. Oving to the altitudinal and climatic conditions of Natal. there are scores of other items of use and lusury, which might, and doubtless will, be developed with adrantage in the coming years.

The subject of Colonial productions alone would he sufficient to warrant the complation

GENERAL REMARKS AS TO COLONIAL PRODUCTIONS teresting as vital, it is necessary to point out the heary disabilities arising from the inhabitation by savages of frontier states, and the great disruptions of war, which have had either to be removed or lived down before the resources of the land could be grasped and utilised commercially. These have stagnated in a great measure 


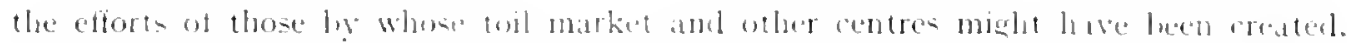

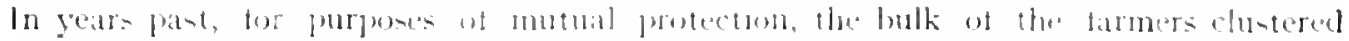

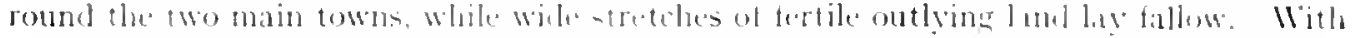

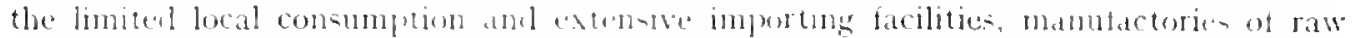

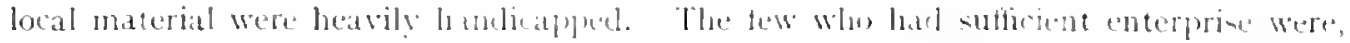

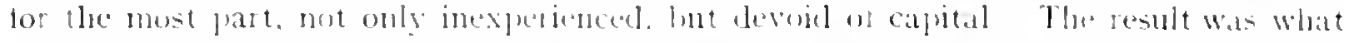
might have been expected. One hy one induntries were taken up am abantoned from

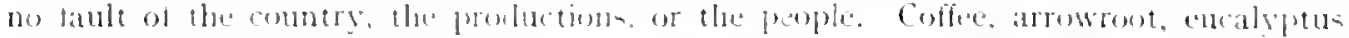

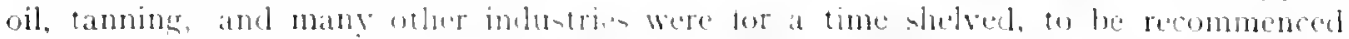

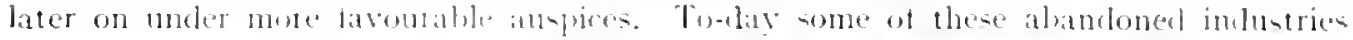

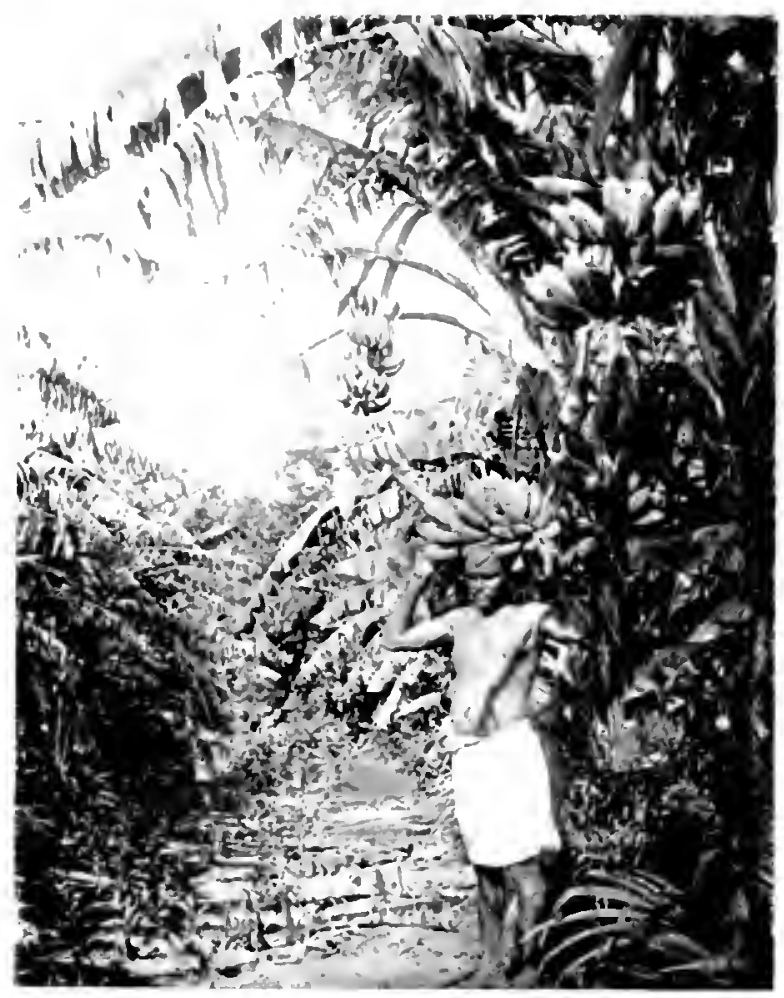

M.1. M.1.1 $111 \mathrm{NC1}$

13. II'. e. ancl

are in tull swing, lut with what a difference Skilled habour. ufwernt machinery, increaced purchasing power. a peacealily settled country, and a wider field of operations, combined with rapid mean of communication provided by the Railway s!stem, place sucess within the grasp of those who have sufficient energy to attain it.

ln connetion with steck. it is smewhat cliffeult to give more than an approximate

sioch number. Acoording to the Bhe-books, the burogean and Afrikanders of Natal own of horned cattle. 2 I 4.777 ; Angora goits, 58.654 ; ordinary

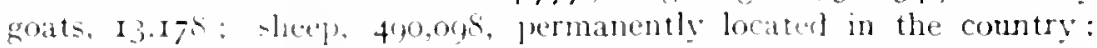
horses, 27, resic; pigs, 16.564; mules. 1.638. The natives of Natal are estimated to own

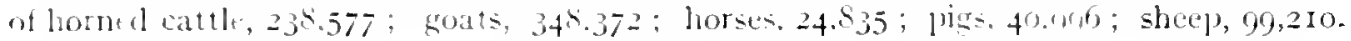


Being an agricultural and pastoral race, whose principal articles of diet are maize, kafis corn, milk and beet, they have a considerahle annual production to curer local consumption.

The lotal figures for the Colony (Europeans, Natives, and Indiand are: Cattle, 456,003 ; donkeys, 1,460 ; guats. 432,936; horses, 53,702; mules, I th3; ostriches, I,071; pigs, 59.047 : sheep, 589.572.

In ISog the figures tor horned cattle reached 7.39 .732 hut rinderpest. cluring I8r, reduced the total to 339.520 . which includes the province of Zululand, annexed to Natal on the zoth of becemher, I 897 . In I \&gs and Isgo, the figures were respectivety 278,558 and $28 \mathrm{I}, 594$.

The interests of agriculture are well represented in the Legislative Asscunhly and a

DEPARTMENT OF AGRICLLTLRE permanent head of the Agricultural Department has recently been appointerl, under the title of Director of Agriculture. This Official (Mr. A. X. Pearson) has had considerable experince inall branches of agricultura! development, and it is hoped that, under his guidance, the Colony will arlvance. as har as agriculture is concerned, at a much quicker pace than has been the case in the past.

Steps are being taken for the establishment of Government Experimntal Farm. In the neighbourhood of Maritzburg and on the Coast; and a scheme of afforestation is also under consideration. A Pomologist, too, will shortly be appointed tor the purpose of assisting in the development of the fruit industry, with a view o the creation of an export trade. Assistance is also rendered to fruit growers desirous of fumigating their trees, and for this purpose fumigating apparatus is kept in stock by the Goremment.

The Dairy Industry is in charge of an expert, who has but lately completed a tour through America and Denmark, as well as Great Britain, with a view to making himelf acquainted with the latest details of working dairit: and tactories in those portions of the world.

The Government Entomologist has been able to runder great assistance to the farmers and fruit growers of the Colony, in checking and coping with the pest incidental to agriculture, as well as in keeping down the houst plague, concerning which. no loubt, united action will be taken before long by all the South Alrican Colonie- and State-

Analyses of soils and experiments with manures are undertaken by the Department.

Irrigation works are being carricd out. hoth by the Natal Sative Tuust, and by the Department, that undertaken by the latter heing in the neighbourhoud of Weenen, where some 20.000 acres are being rendered capable of irrigation.

Communication with the agricultural community, not only of Natal, but of other Colonies and countries, is kept up hy the "Agricultural Journal," a fortnightly publication run under the auspices of the Department.

Seeds are obtained by the Agricultural Department for trial from all prortions of the world, and distributed free to farmers: and, during the last sea=on or two, a local rustresisting vasiety of oats has been successfully distributed all over the Colony.

Experiments connected with the cause and cure of Disease in Stock of all kinds, and investigation work generally, are being undertaken at the Laboratory, Allerton, near Pietermaritzburg, hy the Government Bacteriologist and Director of the Veterinary Department. The principal attention of the Government Bacteriologist is at present being given to Rinderpest, Horse-sickness, Bhe-tongue n sheep, and Lungsiknes inrestigation. 


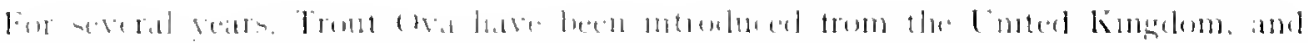

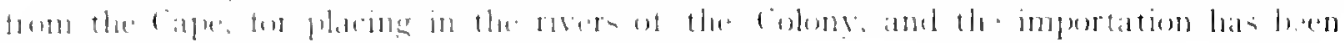

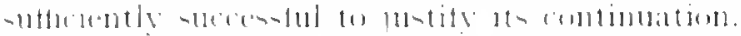

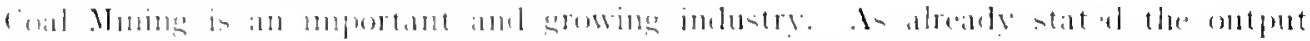

IIEPARTIII:I ( ) $1.111 \times 1: 5$

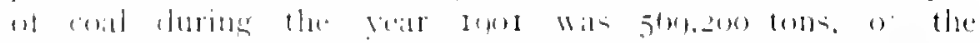

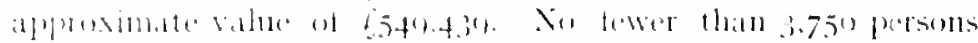

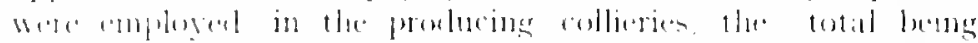

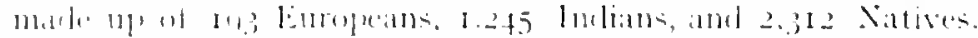

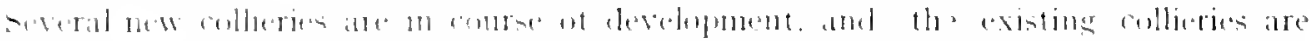

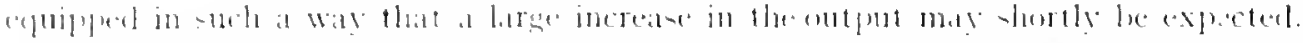

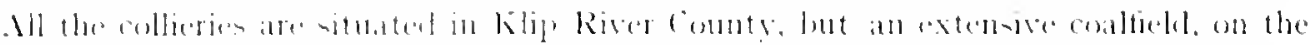

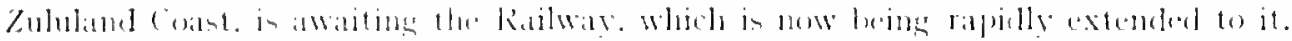

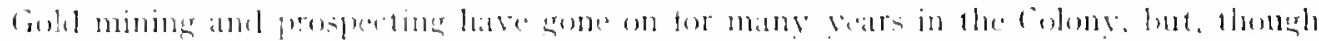

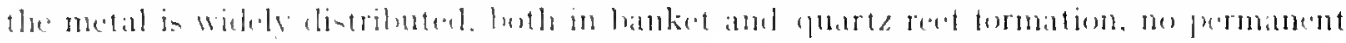

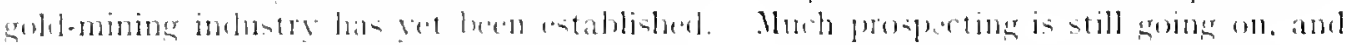
me small mine is bemer worked.

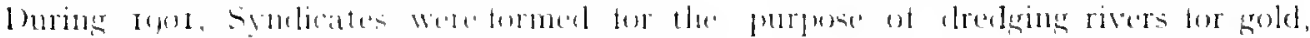

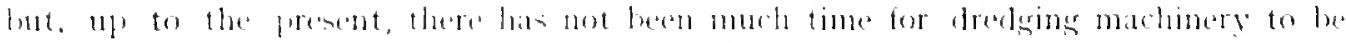
(rectedis.

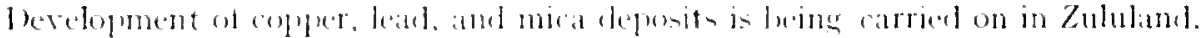

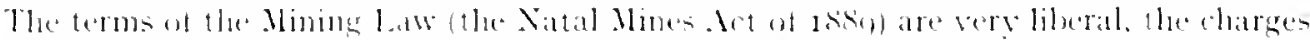

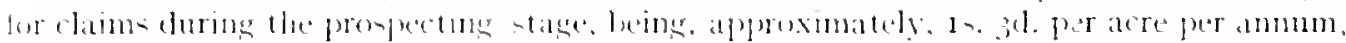

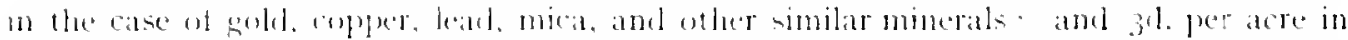

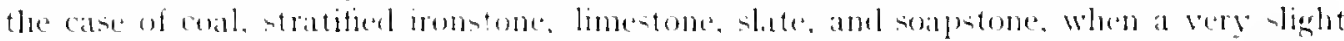

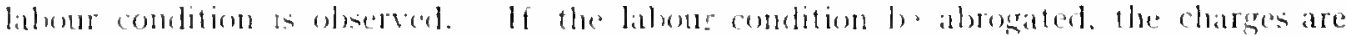

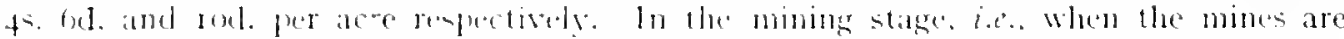

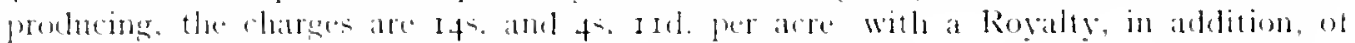
It pere cont. on the value of the mineral at the mine.

The Nines lepartment constets of a Commisioner of Mines (Mr. C. J. Cray) and

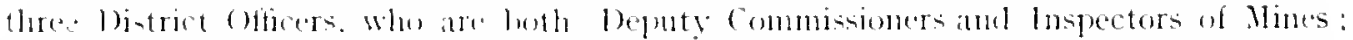
six Drill Superintenkents; and the necsiry staff ot elerks. The Department, in adelition

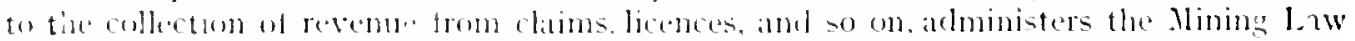
and arries on drilling operation, for minerals and water. Moit of the drilling work is done at pratically cos puce for private persone or syndicate. The plant at preient

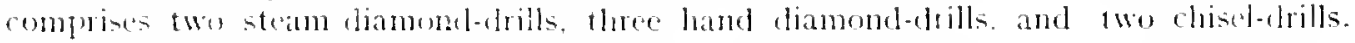
An increased number is contempliated.

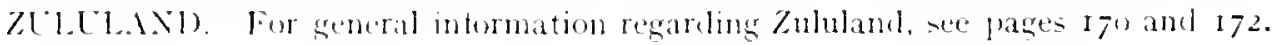




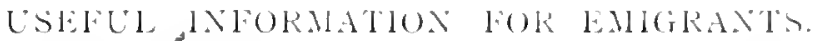

AGHAT GESERAL IX LUSDUN.

Sir Walter Peace. K.C.M.G., a colonist of many vears standing, is the Agent-lueneral tor Natal. His office is at 26 , Victuria Street, Westminster, Lomdon. Those who contemplate sattling in the Colong and desire any information or a lice, wr general anisation particulars, would do well to communicate with him.

\section{()CEAN LINES OF STEAMERS.}

The steamship services with Natal, via the West Coast of Alrica, are trequent and quick.

The Union Castle Line runs a weekly service, the tares ranging from 2 to 20 guineas third class: 26 to 33 sumeas second: ant it to 5 i guineas first class. acrording to description of bott and quality of accommo lation.

The "Natal" (ling and Sons) and "Aberdeen" (Remme and Sons) lines of direct Steamers have fortnightly saitings, the fares being 33 guineas first, and 20 guineats second class.

The German East African Line of Steamers run via the East am the West Coast. The pasiage rates by the West Coast route are from fir Ios. third, f 265 s. second; and t.3 35 . first class. An aldition of tit to $t 5$ is made by the East Coast route.

There are abo constant sailings either direct, or via Cape Town, to and from India, Australasia. America, and other parts of the Globe.

\section{Cestoms, leggage, Conveyances, Hotel Accommontion, de.} (Derbax. Port Natal.)

Personal luggage is admitted lree. Other articles are dutiable according to taritf.

Passengers shoult huve each package legibly addressed in order to facilitate the passing of the same by Customs' Officers

Those wishing to lorward their luggage. Sc. by rail. shonld make application to the Station Uaster or a representative, who will he in attendance on arrival of the vessel, or tencler, at the wharf.

Trollies to take luegage from the Point to the Town of Durban are provided by a number of firms.

Trama run at frequent intervals hetween the Point and Durban, and a train leares Point at 5 p.m. daily, evcept Siturdars and Sundars.

A plentifut supply of rahs and jinrickshas will also be found at the Point.

The plan of Durban at page $I 7$ gives a list of some of the principal hotels in the Town. There are alsn a number of other qood Hotels and Boarding-houses. The daily tariff at the former varies from $S=61$. to $12 \mathrm{~s}$. per das. and the rate at the latter may be put down at between $f_{2} 6$ and $f_{s}$ per month. At the best class of hotels and boarding establishments the cost of living is of murse somewhat hisher. 


\title{
THE RAILWAYS OF NATAL.
}

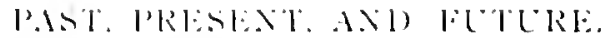

I

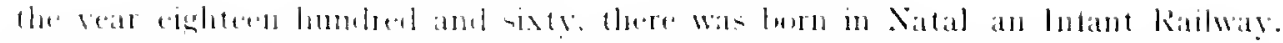

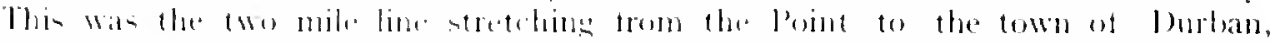

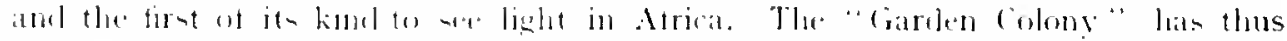

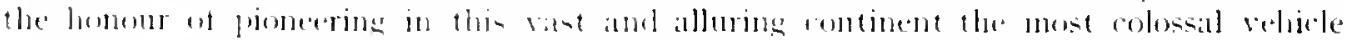

THI: INFINT I.INE

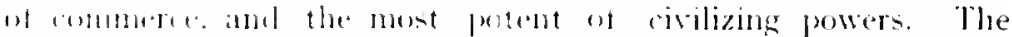

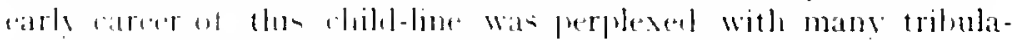

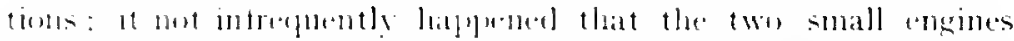

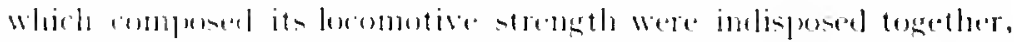

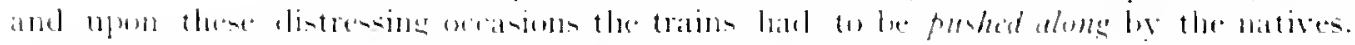

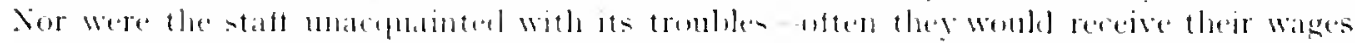

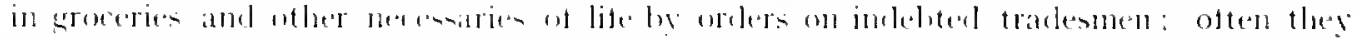

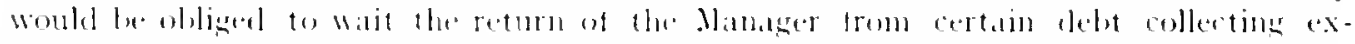

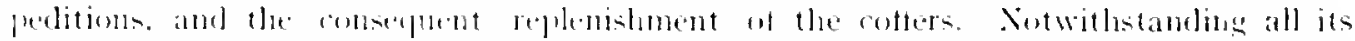

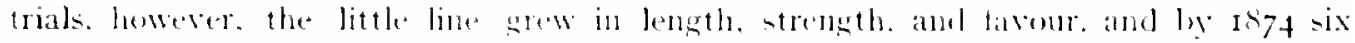
miles were in existence. an athlitional four miles having heen labl along the forth loast trom burbin to lomerent.

So materially did the Ratway pouligy develen the trade of the colong. increase in popularity ant prosper to it prommters' sitistation. that whereas the revenue for the

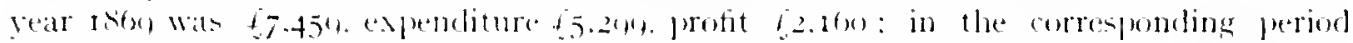

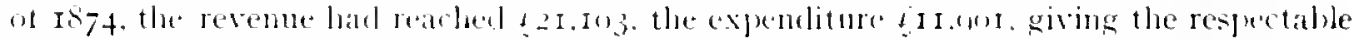

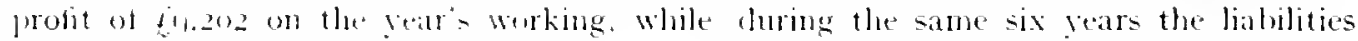

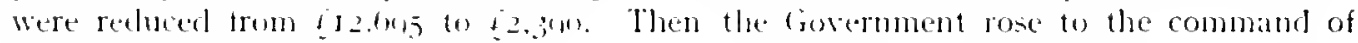
the enterprise.

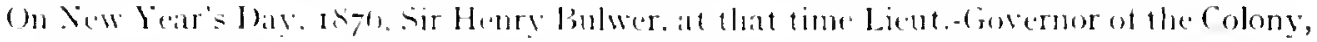

(i) NERTIII:NT Sisti:ll tumed the tirst and of the Geremment sistem of Railways. A tew reatr later the chilel-lime was furchatsed by the cowernment for the sum of forenos. The change in ownership led rapully to an improvement in its comblition anel character.

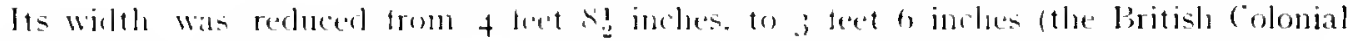
gange), it was furnishel with nell stock. and wa run on a more orthodox and husinem-like hasis.

This is the biget histery of the intant: the chronicles of the adult are naturally more ixtensive.

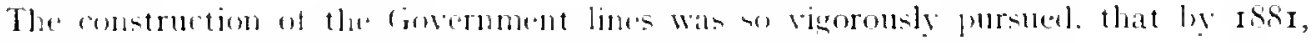

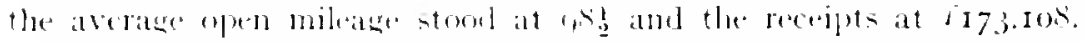

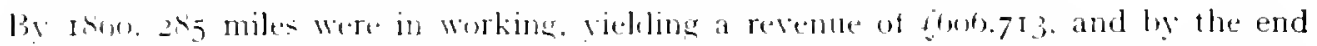

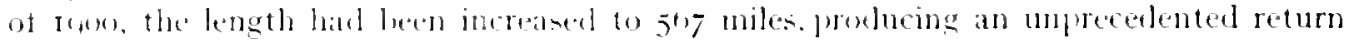

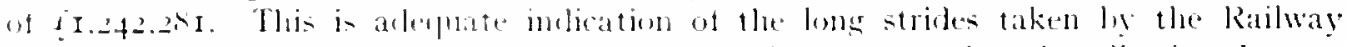
to meet the constant and increasme demame upon its resources. Hut the following alostract of they early working. and the tabe showing the grow and present proportions of the line. digestively arranged, are deserving of examination. 

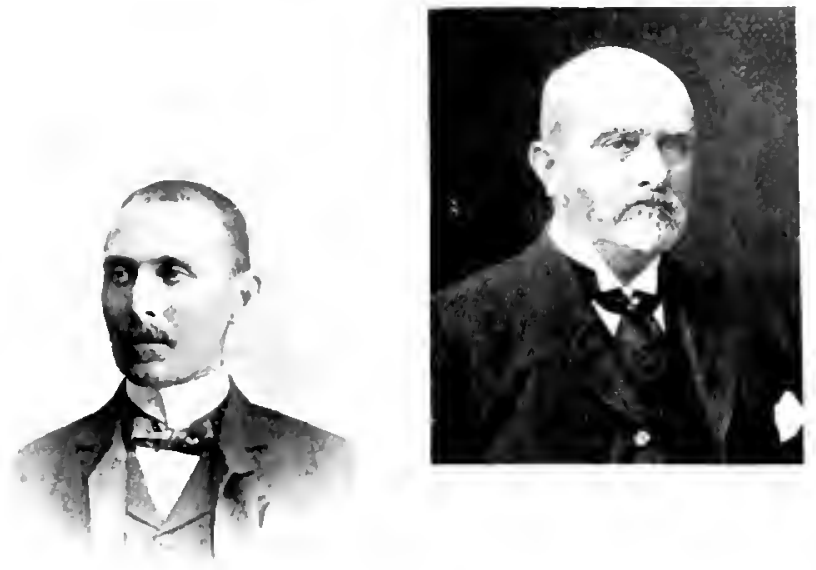

PRINCIPAL OFFICERS.

DATAL GONERNMENT

RAllWAYS.
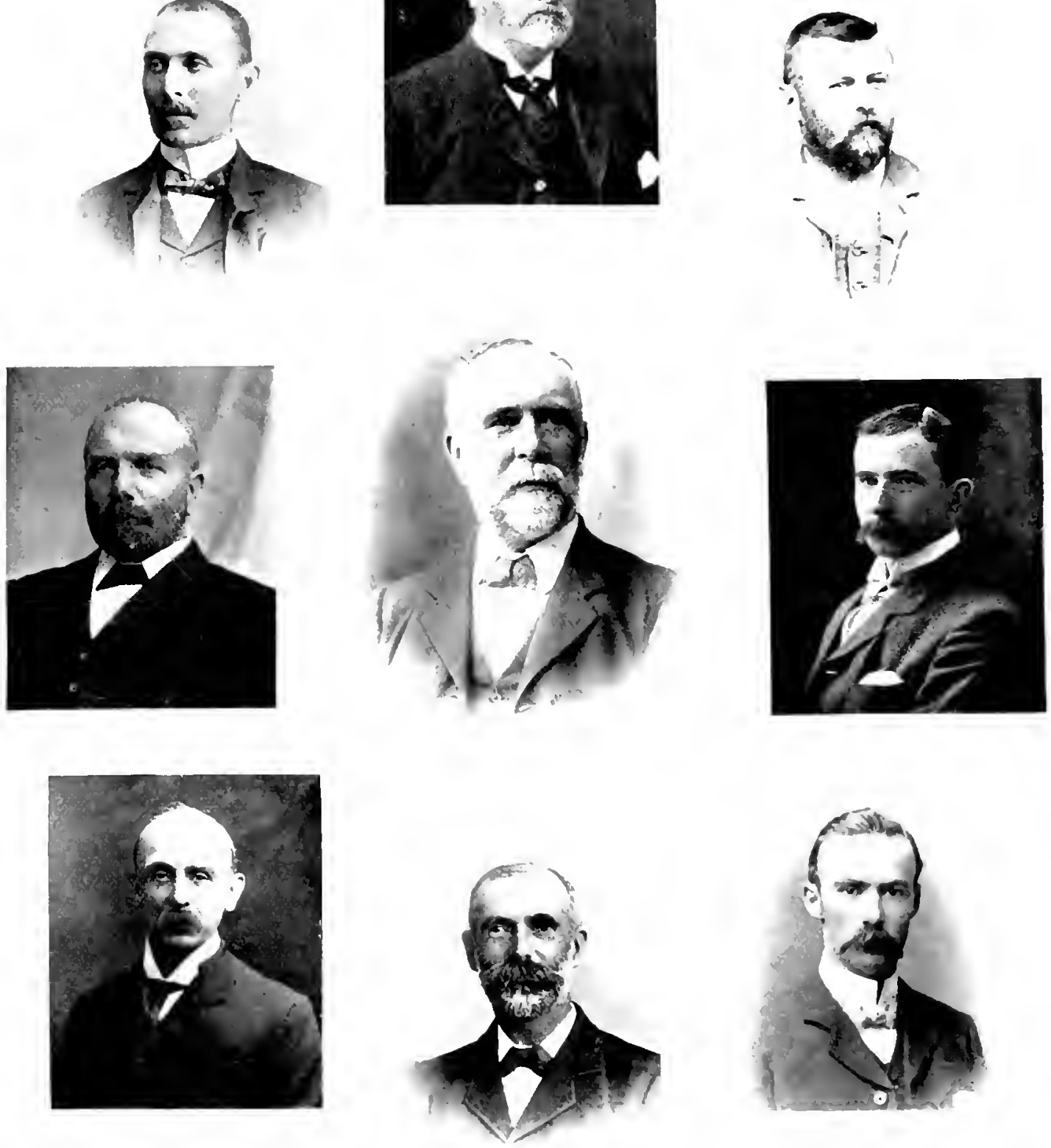

1V. H. COBLEY

(Supt. Eingineer Construction.)

G. IV RIII\}

JOHN W. SHOKI:S, C.MG. [Bumber all Chief.

SIK DAVID HLX゙TER. KC.MG (Cienctal inumets

J.A.YIS M. HUXIER

dissistant cicheral Manaser 


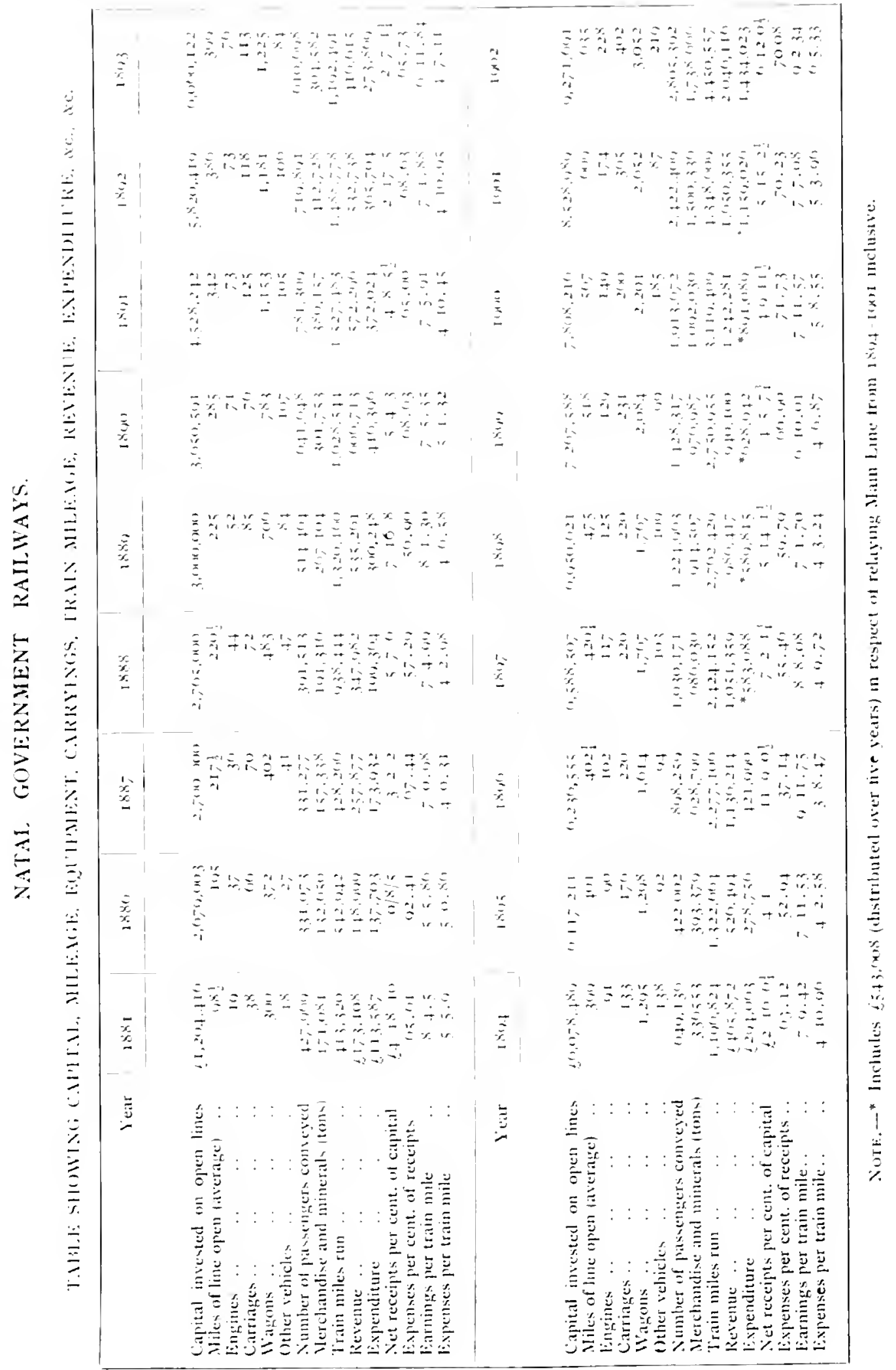




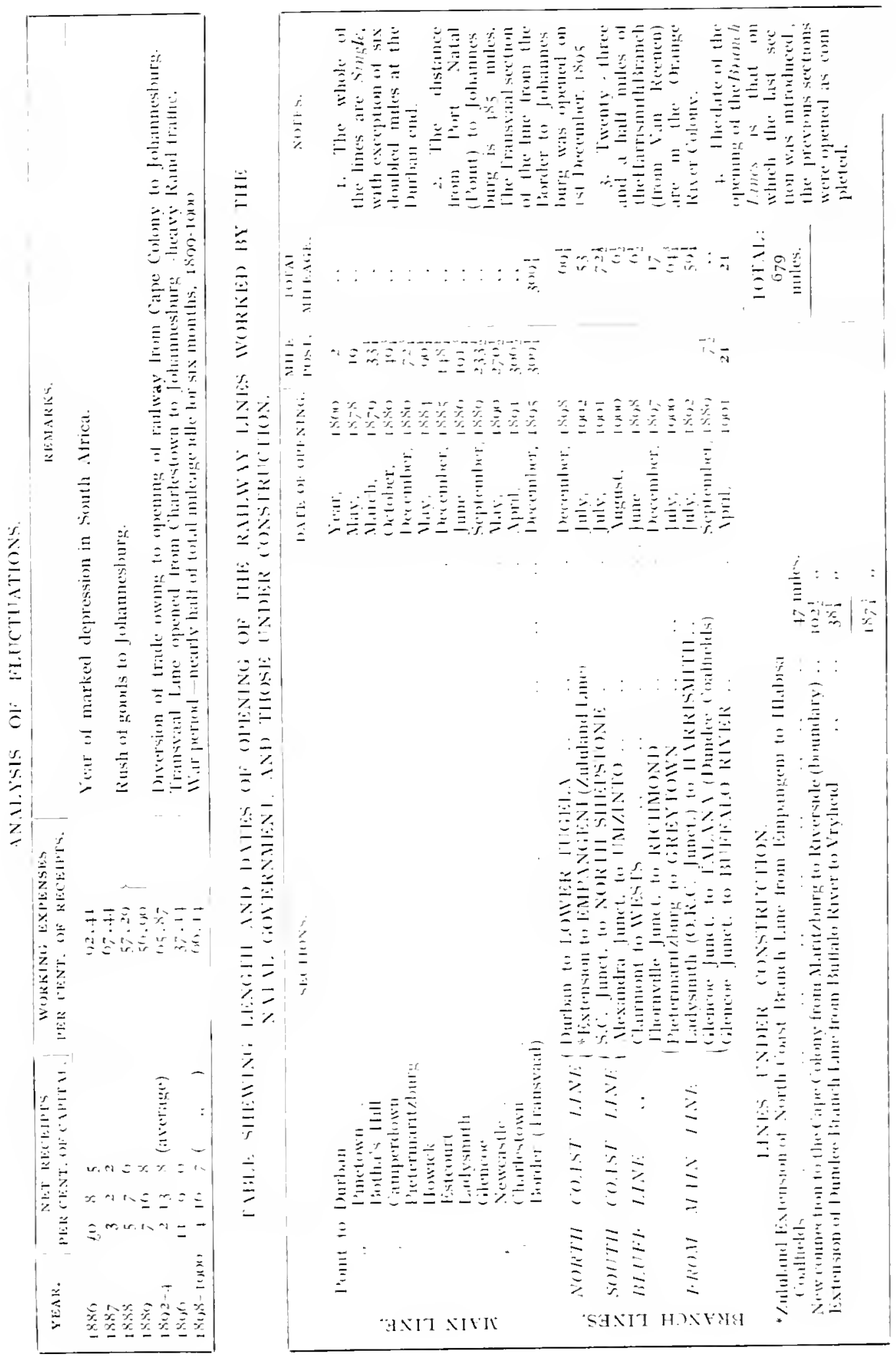




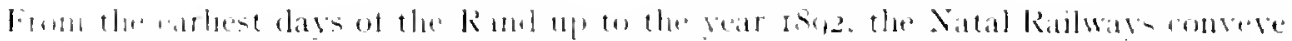

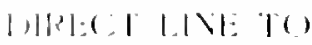
$1: 11: \mid 1+1.51+11$.

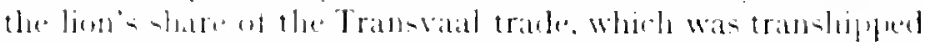

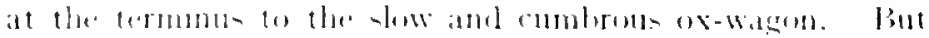

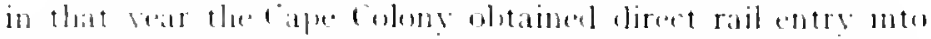

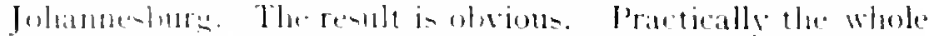

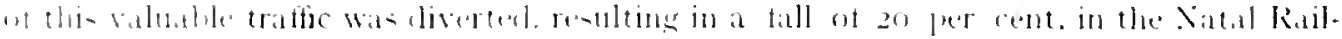

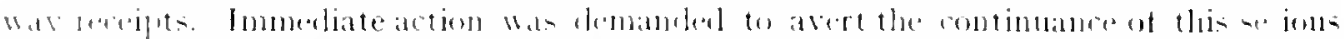

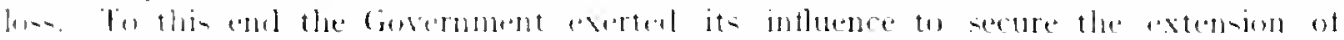

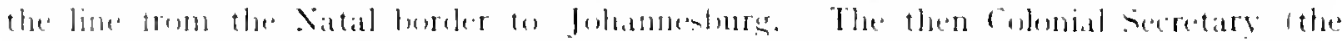

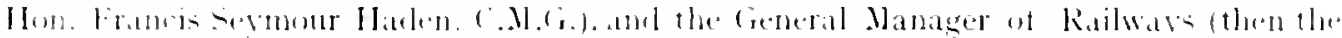

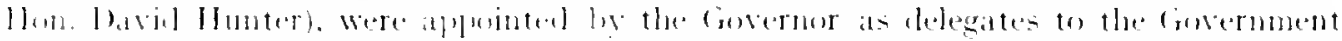

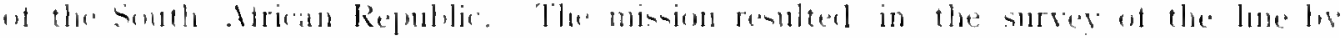

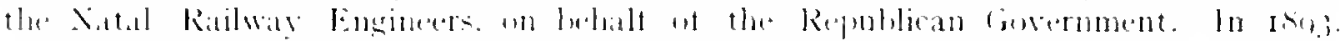

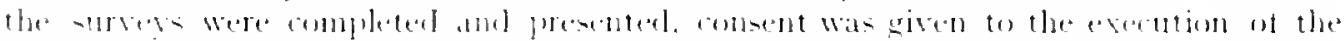

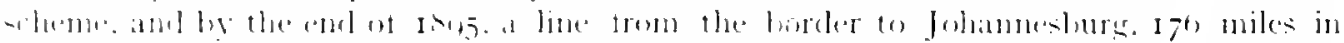

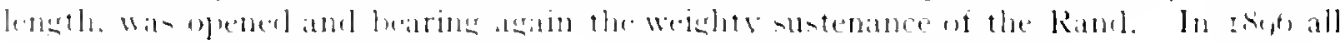

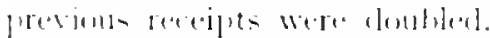

The fre-eminent advantages of the $\mathrm{N}_{\text {atal }}$ route to the Transval are well kmum. Its

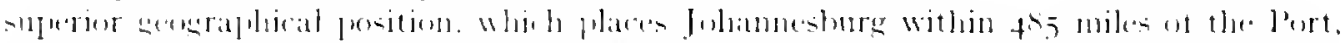

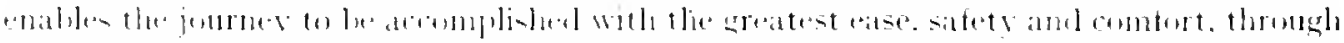

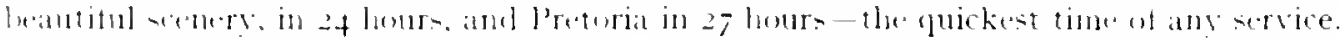

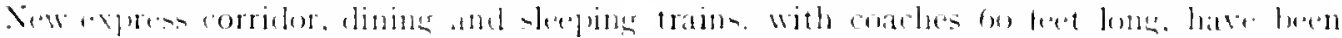

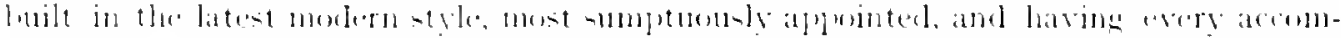

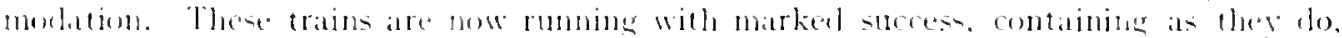

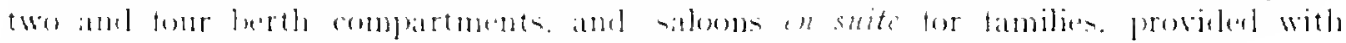

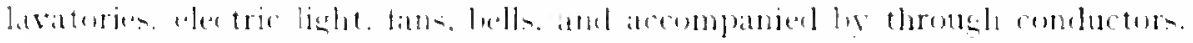

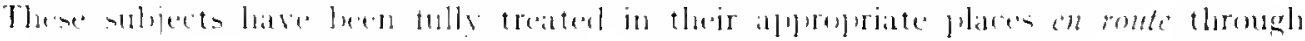

S(S.NERY AN!)

1T1R.ACIONS the coloms. Int it maly le briefly stated luere that the Cittal sintem traterses comstantly rlanginer pansoramas

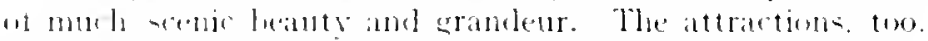

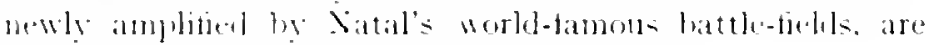
numerons and varjed. interenting alike to the settler and th the tomrist.

The latge complement of rolling stokk. upon which is hestowed the must skilul care

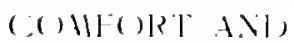
$S A 1: 1 \%$ Y OF PASSIENGERS and attention. Woth in erection and in mantaining it in tatultles number oreler. caters for the requirement is at first. secombl. and thind ches travellers, although the latter class is almost entirely momonolised by the coloured eommunity.

(b) all fosenger trains there are lavatury and toilet conveniences attached to the

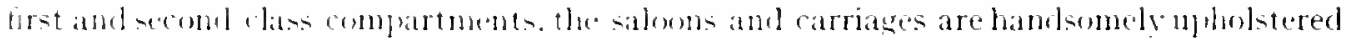

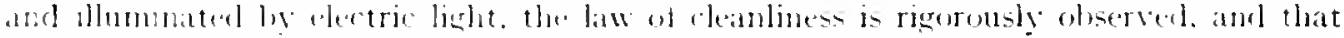

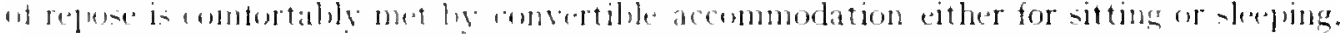

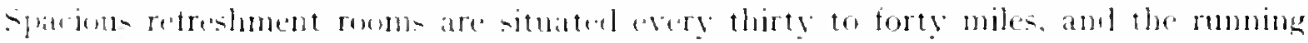
tume of trains are as nearly as josible arranged to allow pasengers ample marein to take the ir meals at the rustomary homb. These roms are under the personal management if the entractor. Mr. C. W. Pomkins. Which is a suarantee of the excellence ut the

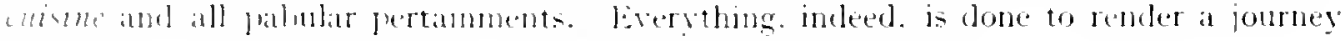

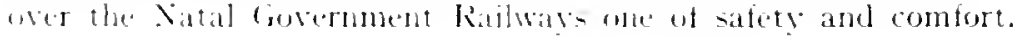




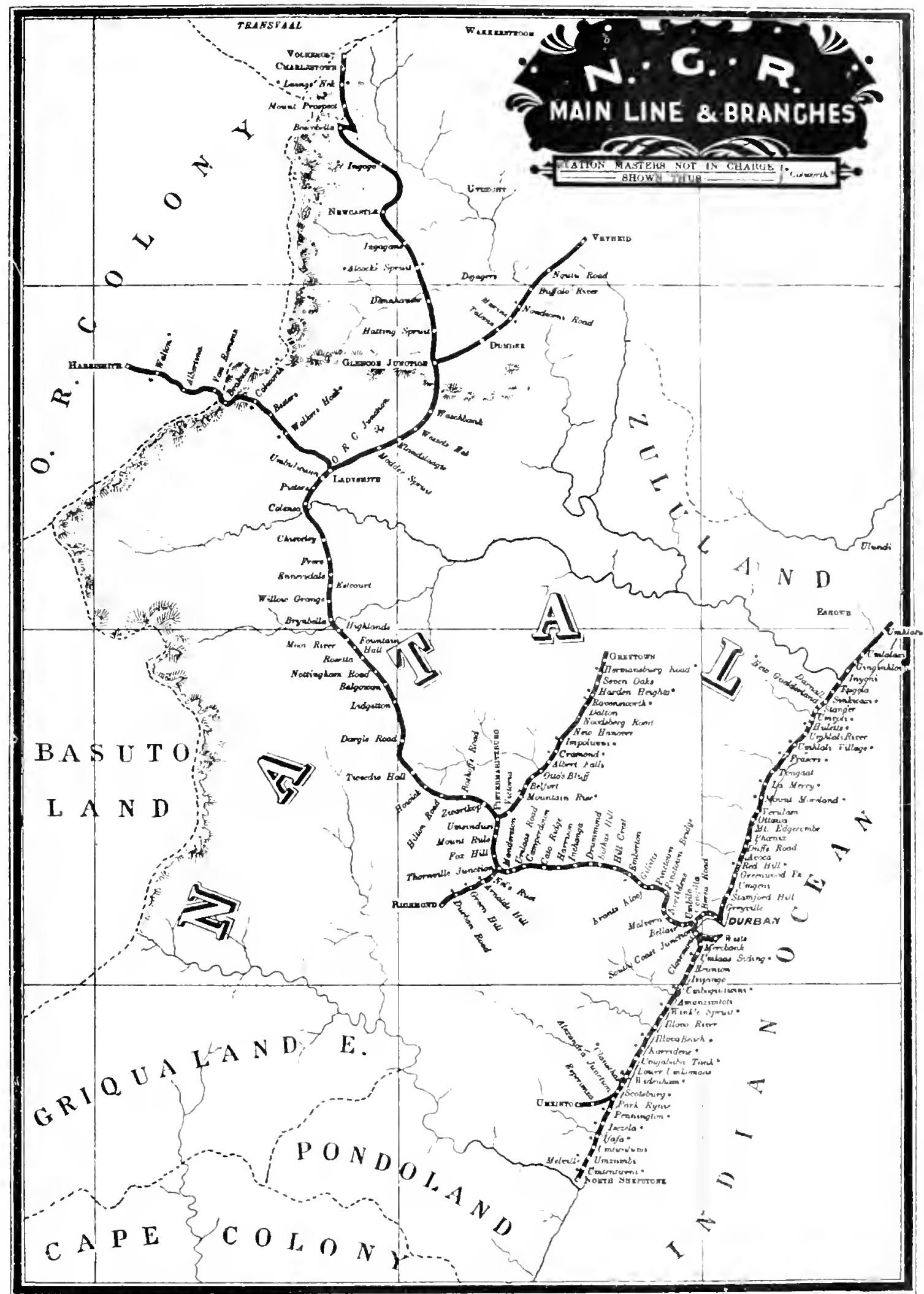




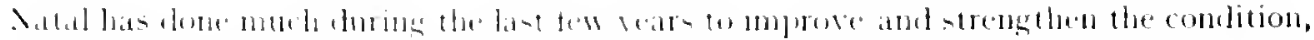

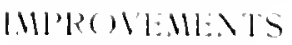

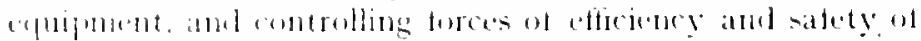

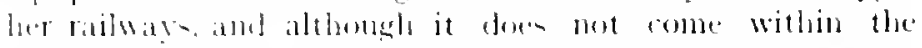
provence of the work to detail the ace acomplishments, get

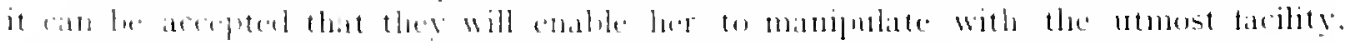

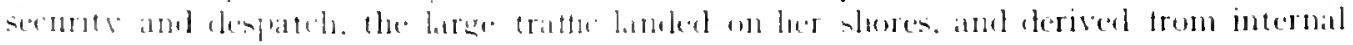
sintricis.

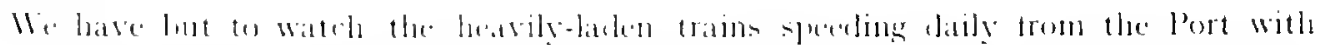

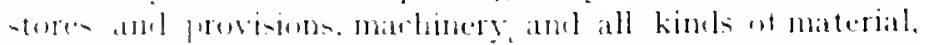

MIMSTRIIS MN1

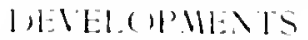

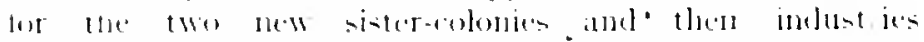
and develogments. to be ascured o. the realization (1) the promenumerment that "the termination of the

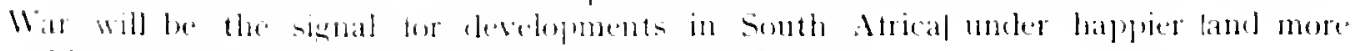
stable conditions than hare arer previously arinted."

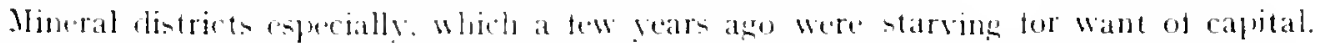
and whers whose known wealth coufl nether be wooed nor won. will eventually le developed and other businenes and industrie dependent and indegendent of the Mining

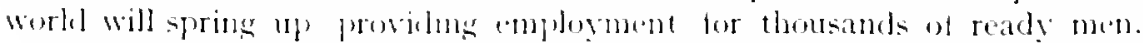

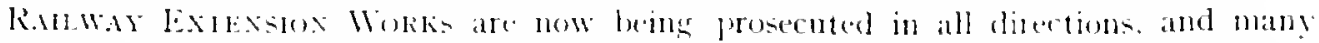

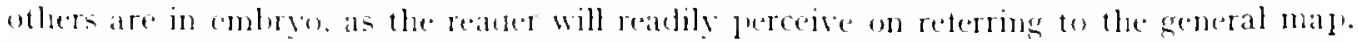

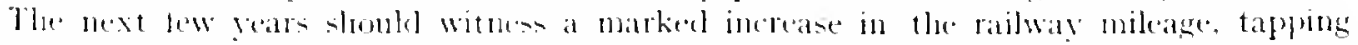

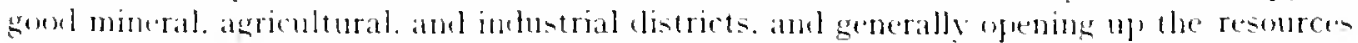
of rich and extensive territories. not only an Xatal. hut in these of her near neighbours.

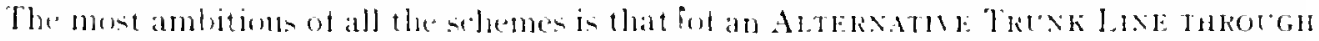

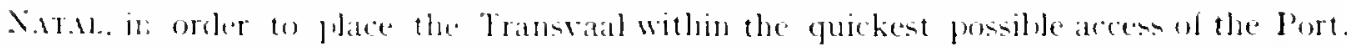

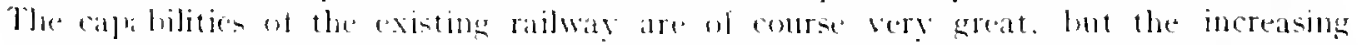
uperomtry and llinterlanel trate and the larger roal-mining operations are factors Which have to lue grajpleel with. and though there is no present tear of this trattic

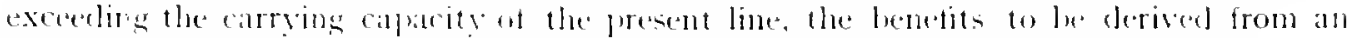

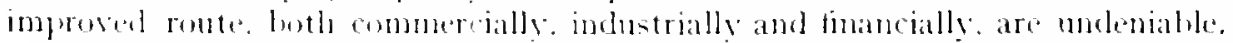

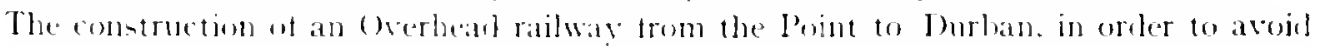
the street level crosings- which are an covbent sonree of danger where edectric trams

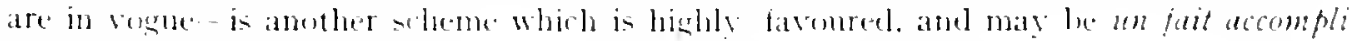
ledore many vars are biat.

The extensions wheh have taken practical shape, or received the necestary sanction, and which, when completed. will operate mont leneficially in the derefoping of new settements and lands. and in more closely uniting and tostering the commeriat interests

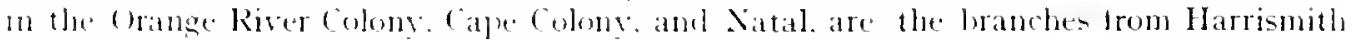
to Bethehem, Bhemtontem, and posibly kimberley in the one direction, and the Xew Capecomnertion- leaving the Natal trunk line at Pietermartalurg and effecting a junction at kiversede on the caje londer-in the other: this batter will shorten the existing route comilerally.

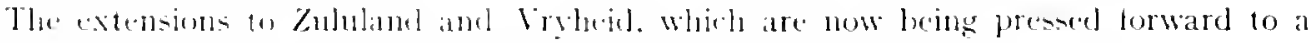
point of completion. Will alon open up new and valuable territories.

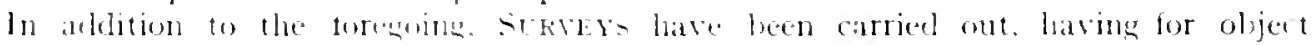
the posilite constrution in the tuture of lime-to the llid-llloro and liprer Tugeta

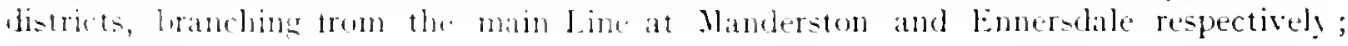




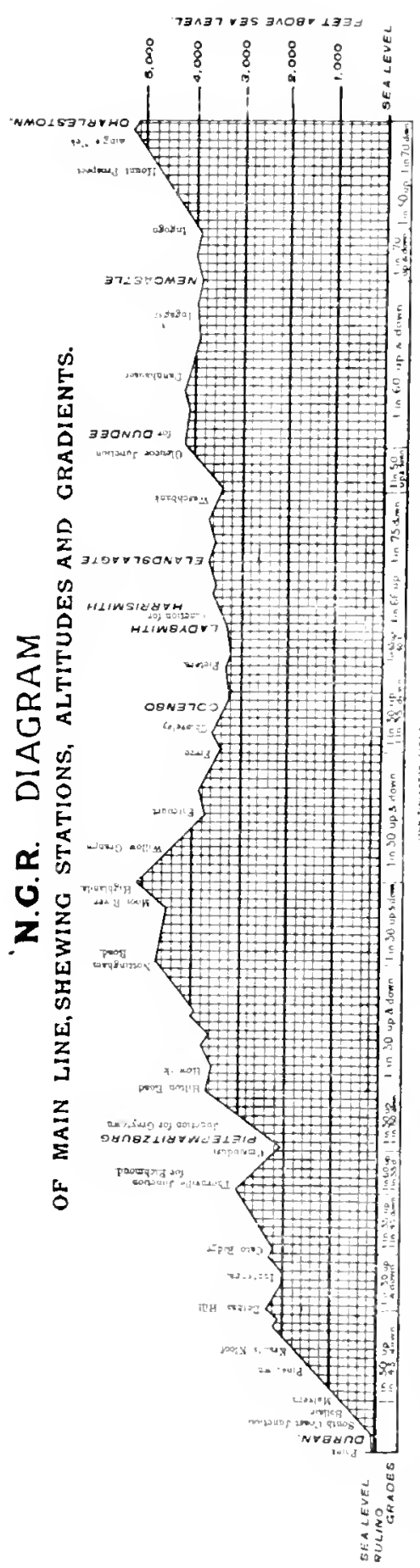

to the Impendhla. Ipolela. and lxopo divisions radiating rom the Natal-Cape line; and througly Altred County as a continuation of the Soutly (uast Branch. while the surveys of the Trunk line to ancratain whether a second line can be run along. or near to. the route of the existing one, as an altemative scherne to the suggested in. dependent line, are engaging attention.

\section{PRACTICAL WORKIXi}

Ix these days of a-mile-a-ninute travelling upon pancake-like tracks in other landa. the duration of the fourne s. and the shortness of the trains on the Natal lines r.th strike the vistor as singularly

\section{SOME LIFFICL'TIES} -trange until he be ands acquainted with the extreme irreg. nlarity of the country. He will them appresiate the many physical difficulties which have to he surmounted. Natal is so mountainous in formation throughout its fength and breadth that the serrated course of the railuays is inevitable. and so trequent and extreme are the risings, twistings. and tallings of the Main line between the Port and the Porder. that it can be likened to a long and writhing switchlack. Looking at the gradient profile-an excellent outline study of the Drakensherg indeed - it will not be difficult to comprelend that every person and every parcel carried letween Durban and Charlestown has to ascend in the ageregate over I 2.600 teet erfual to nearly two. and-a-lalt miles of a vertical devation-crosing a)titudes in sections of two. three. four. and even tive thousand teet above the sea. which when gained are often lost again. and have to be recorered. The branches are all more or les similar, the Harrismith line the more nearly approaching the Hain line in its acute formation. except that it rises for thirty-six miles to Van keeren withont a tall. In the vicinitr of this station the higlest rail eleration in Natal is attained -5.520 fiet alow the sid Taking the total length of the lines in Natal-ore. b-o miles of a single track: a serious obstacte to quick working in itselt-not a tenth of it is on the level. The rutug gradient and curvature letween Durban and Lady. smith are "xeptionaliy seres". vi\%, I in 30, and 300 teet radiun respectively, and these are requendy found in combination. The Mitin line north of Lardy.

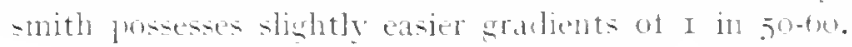
It will theretere be aplarent that such conditions 
of workme not only mimmos the arerase speet, mostre the frepuent alteration of

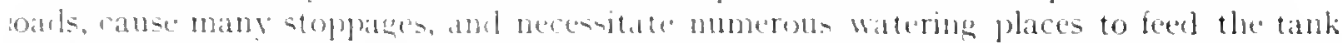

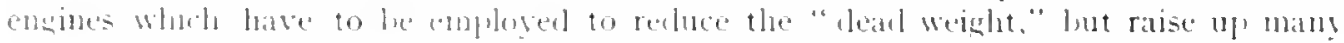
onter hombraneen net commonly experienced in railwaly working.

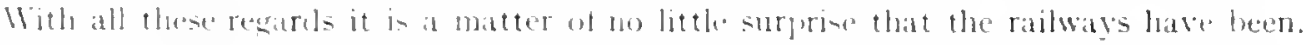

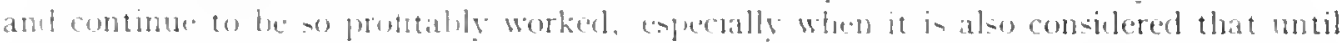

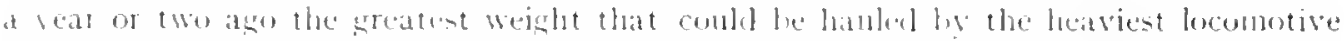

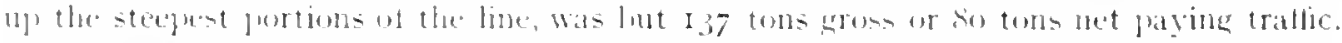

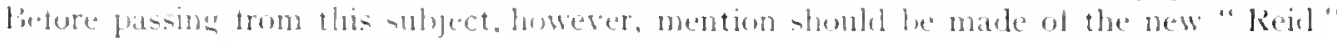
cogrine, complimentally named alter its designer. the late lonemotive lingineer. This

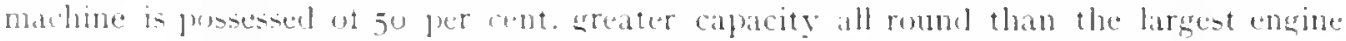
previously in use.

The grates and curses are atho beine improsed and ardelitional crosing stations

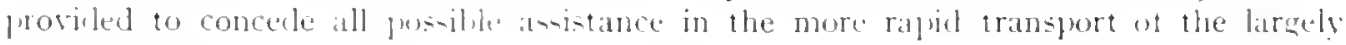
increating tratfic.

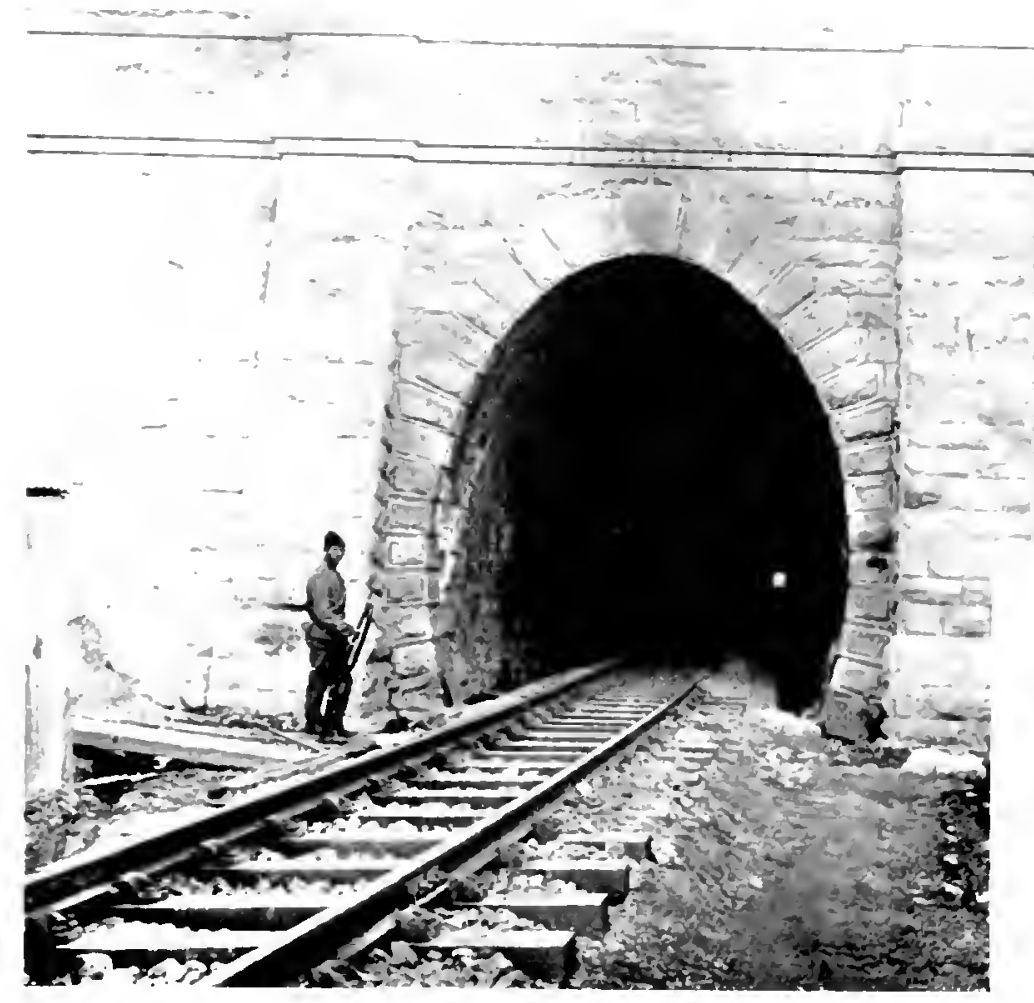

PRINCIPAI. BIIIIIIVIS. WORKS. DEPARTMINTS. \&C.
Department, are
THy seat of the I)rkpix, and as at naturat interpuetice, the controlling stalf and works excepting alone the linginering yecesary to say that lle llorke hoth architecturally and industrially, are impong pillars of the town. Wuch might he
the increased activity with the gresent edifices.

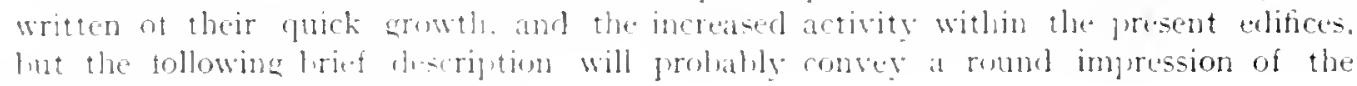
aeneral capacitr and operitions. 


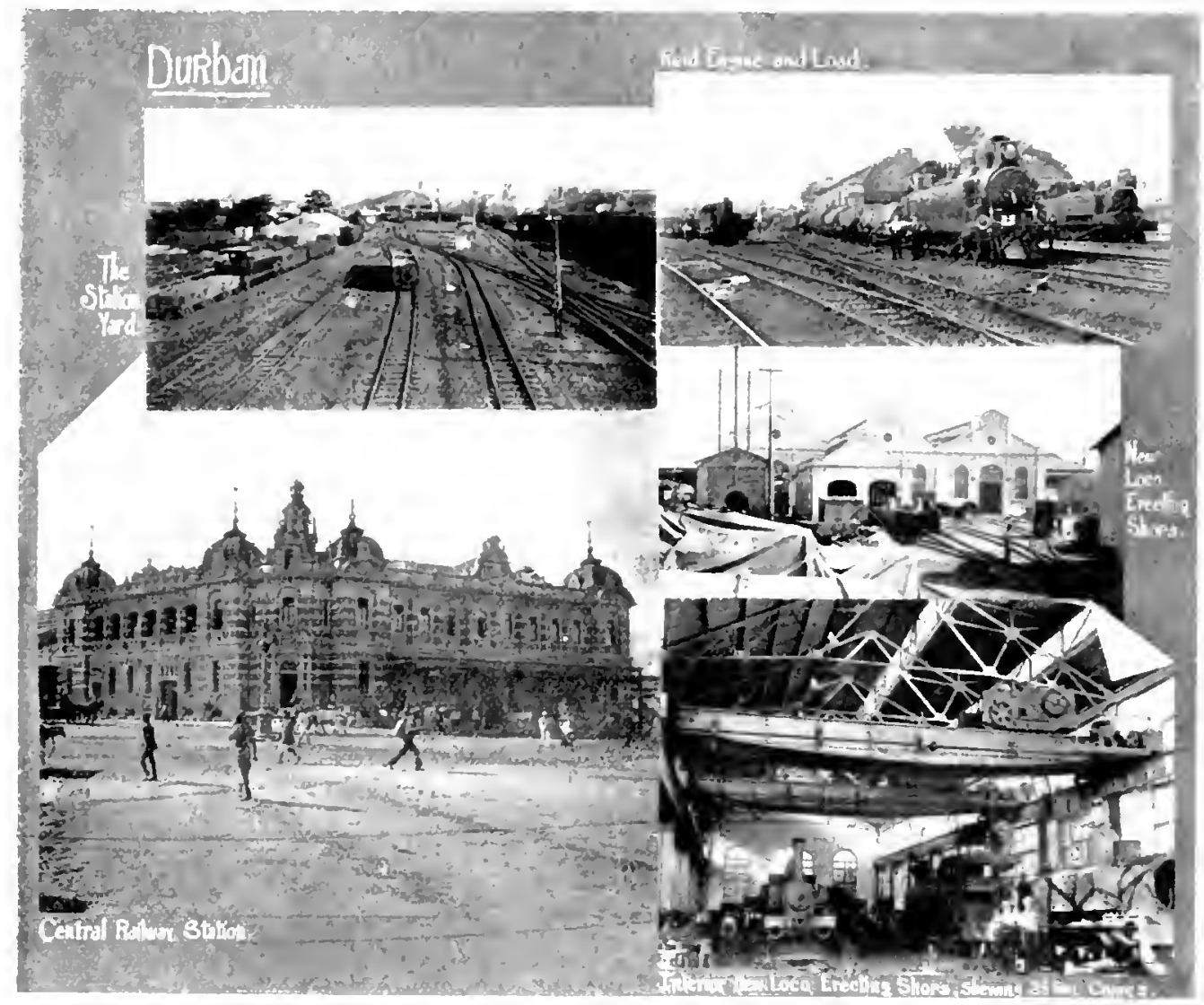

The Exterior will shortly present a handsome treble-storeved. triangukar structure.

WURBAX CENTRAL.

STITION BLILIHNGS

with a tromtatre of ir feet to Pine Street, and I 27 leet to Railway street. The main entrance is from the former. and the exit into the latter street. The upler flows are assigned to the principal depart.

mental offices. Interior: The Booking office taces the principal entrance, and the restibule leads in a direct line to the main plattorms, flanked liy the refreshment bar. dining. waiting, retiring and ckati rems. lavatories, station-officials' offices, and houkstalls. all most conveniently amideser and equipledel.

The Passenger Station proper is arched le a roof supported an brick side-walls 20

THE PASSENGER STATION leet hiubl. havine a clear span ot 105 ket. a length of zo feet. and at rentre beisht ot 5 b text. There are two asplideded peninsula-like platfoms. 350 lect long and 25

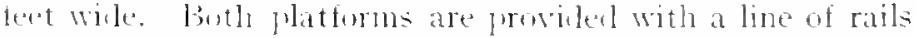

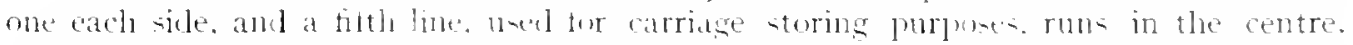

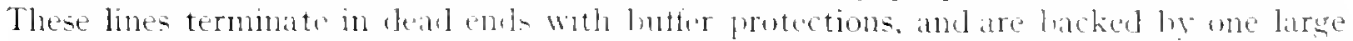

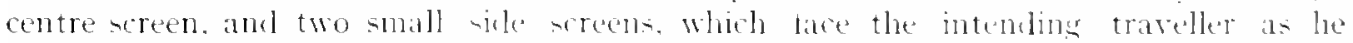

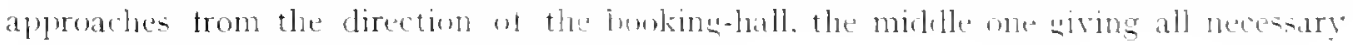
information with regarel to the trains. 
"There workshope ale situated on the right hand sule of the line, opposite the soods

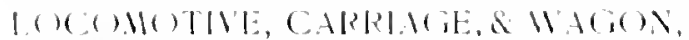

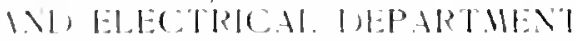

lepot, a liftle way lack from the main station. As mas he imagined. they coser at consilerable areat. and

comprise every tepartment necessary tor the construction. repair, and remewal of the

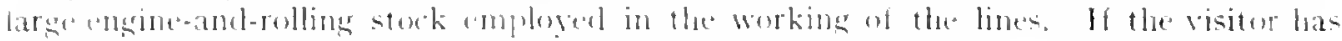
time and inclination. an hour or two may le protitally spent in at tour thromgl the

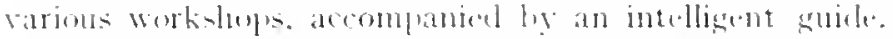

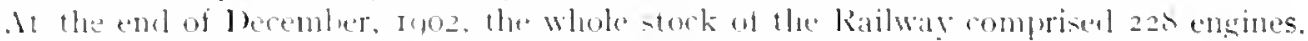

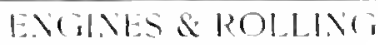
sTOCh f02 rarriages. 3052 wagons, and 21 y other vehicles, while 30 engines ftr carriages and Ithz wagons were moler oreter or construetion.

The heatriest engine, the "Revil," weighe on tons and

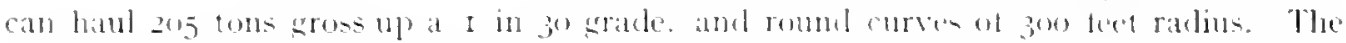
largest carriage is $(x)$ teet hong. Weighs 30 tom. ame can alcommodate zz through

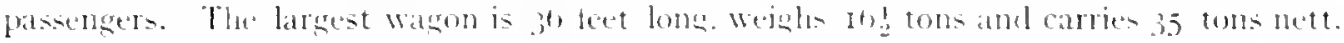

The operations of the Electrical lepartment are tat reabing. Searly all the principal

\section{EI.LCTRIC I.ICHT} A. I) POWER

to the utilized in drivius matchiners and also in many other directions. It is now heing used tor the working of powertul cranes. each with a lifting calpacity of 35 tons. and two of which are able to pict 1 p hodily the hearient focomotises.

A fow facts ame figrure relative to this important branch of the Railwaly service may not be witli. out interest.

\section{A FEW FACIS (N) FlCil'RES}

In all the works and wh. gines Nital conl is used. This is found to be be tar the most ecomomical. Xim ambl extensive "Rumning" shets in which all engines atre prepared tor the jo jourmets. and attencled to on therr return, have recenty hen erceder at Greprille atrel l'ieternarizhurs. gard. stations, offices shops. and trains on the line are thus lighted at night. Eleretrie power is shortly

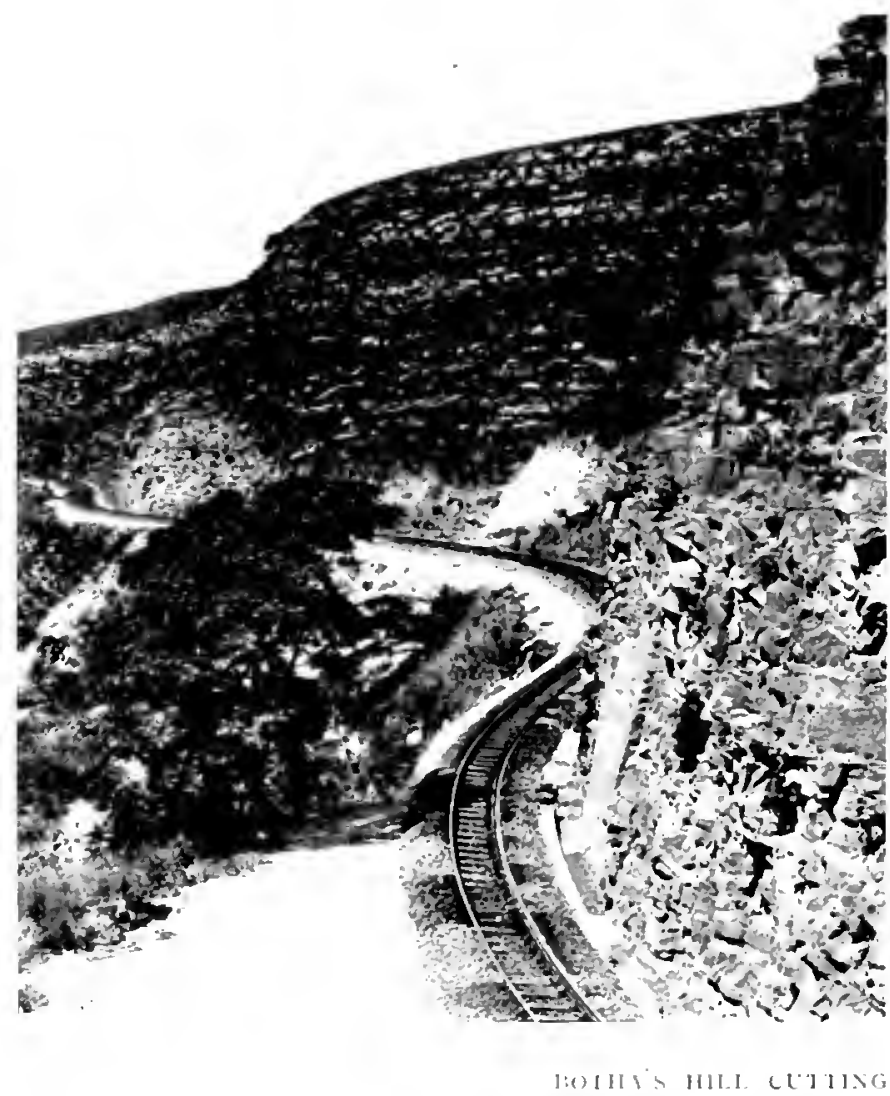




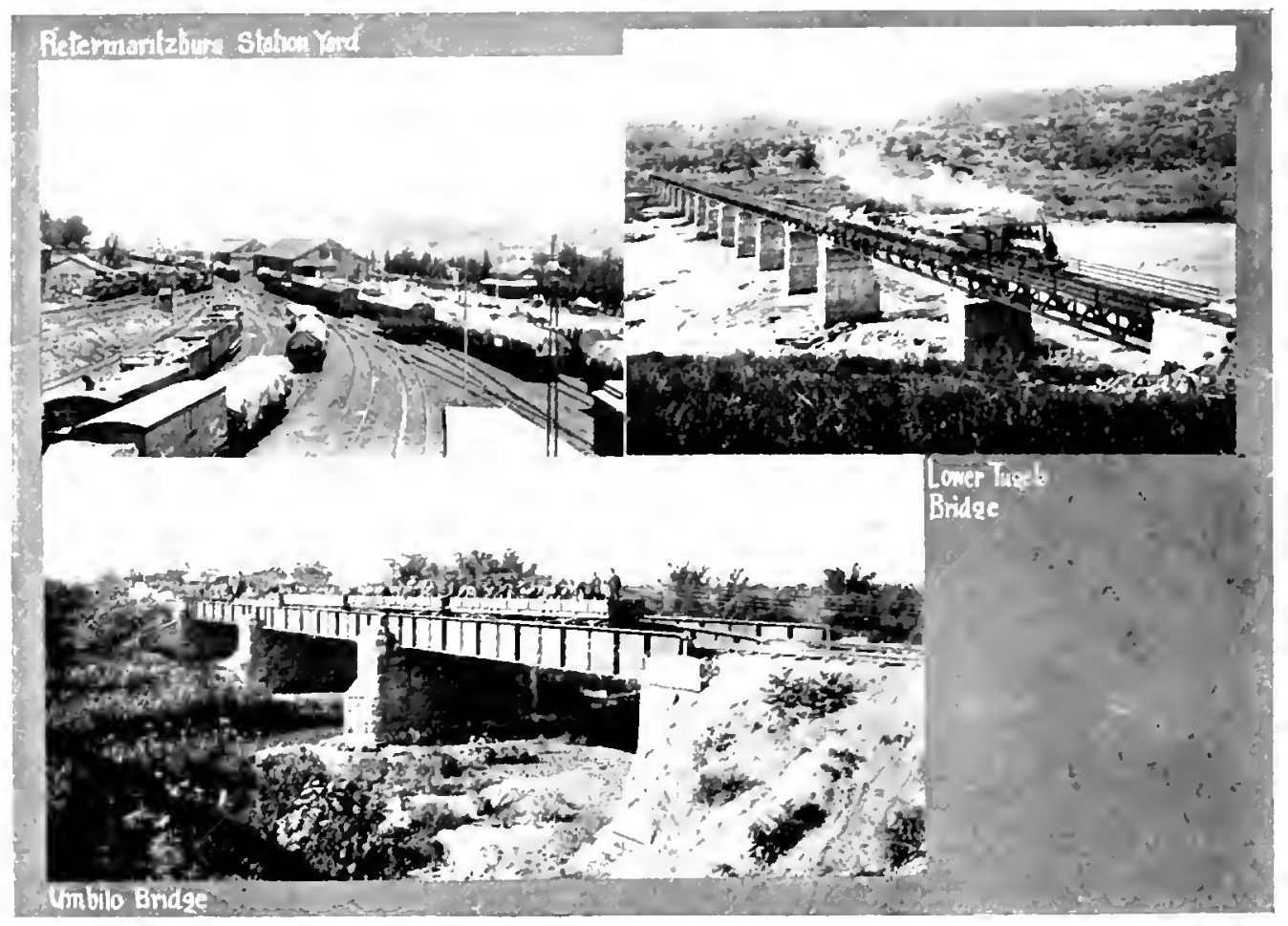

The Locomotive and Carriage and Wagon Works maintain the largest number of skilled employes in Natal. The training ohtained therein is unquestionably the best in the Colonv, and much in request hy the sons of the working classes. The average is one apprentice to three journeymen. and the period of apprenticeship is five rears. The hours of working are $8 \frac{1}{2}$ per ordinary day and 5.12 on Saturdays or f hours per week.

The total number of European men and boys employed in the locomotive. carriage, wagon. and electrical departments is r.765: Indians. 545: Kafirs. 679 : while in adkition no tewer than 713 Europeans are employed in running locomotive engines.

This large portion of the raihwy anatomy comprises so many works of various kinds

ENGINEERING DEPARTIIENT and purjoses. that it is only possible to enumerate the more important of the skilful achievements in sumounting the physical peculiarities which obtain in every part of Xital: e.g. the precision and solidity of the jermanent way at all points: the difficult cuttings through the massive rocks at Botha's Hill and on the Berg: the fine river bridges at Cimbilo. Estcourt. Colenso, Ladymith, Wisehhank, Ingagane, on the main line. the Lmkomaas and Ifafa hridges on the south coast line, and the largest and newest of all. the magnificent britge across the river at Lower Tugela: the ingenious "reversing "stations by which the trains elimb in zigzags the Ingogo Heights and that portion of the Drakensherg which interects the Harrismith line: and, not least of all. the lang's Xek tumnel. 2.2I s teet long. The sale and efficient maintenance of the line also receives the greatest sulicitule at the hands of this department. 


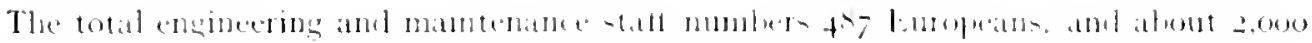

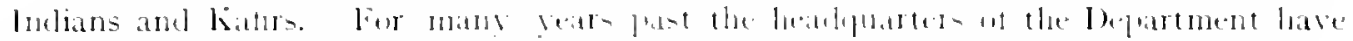

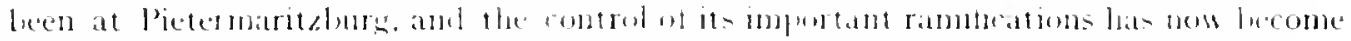

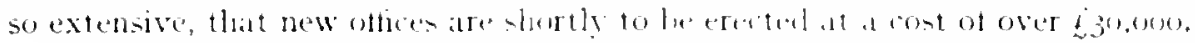

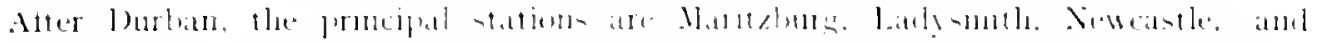

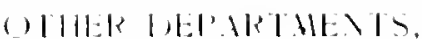

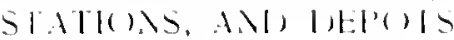

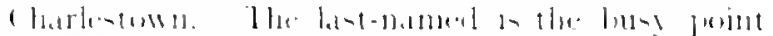

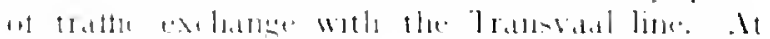

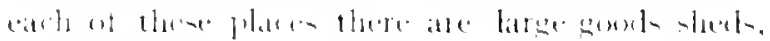

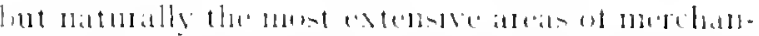

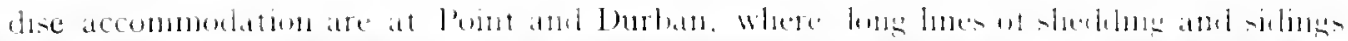

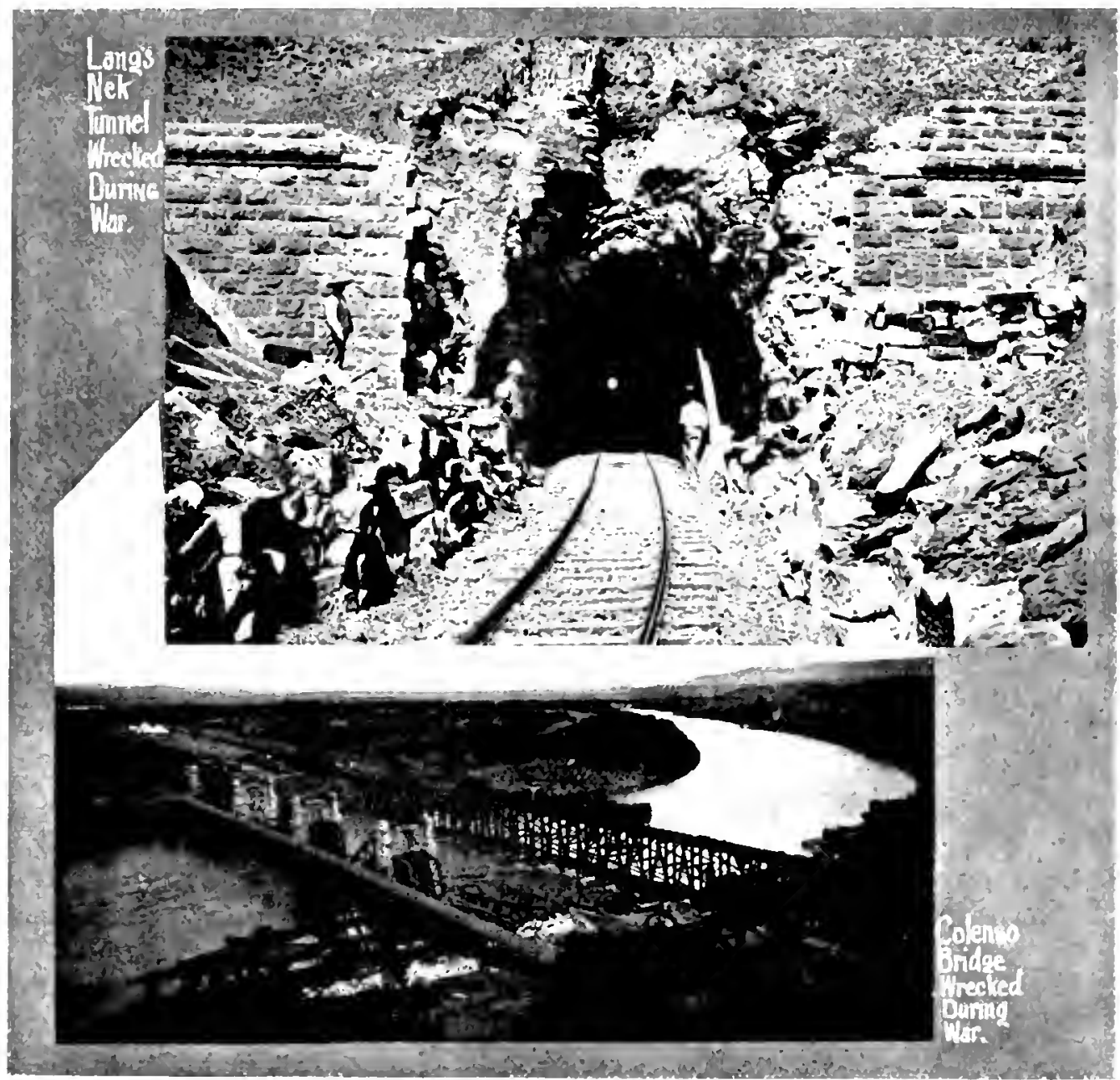

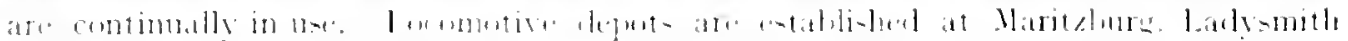

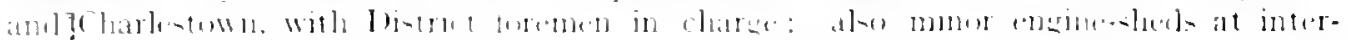
int diate juints. 
An efficient European and Coloured Police Staff is distributerl throughout the line for the maintenance of order, and the detection of any crime.

The Stores and Accountant's Departments are also big factors in the Railway Service.

The General Hanager is assisted by an Assistant General Manager. Assistant Traffic Mlanager, and a loyal and energetic staff.

GENERAL MANAGEMENT ANI, DISTRICT SUPERVISION which has assumed large proportions within the last decade. To secure the best working of the trafic and the most satisfactory main-

tenance of the line, the Railway is divided into four districts. the centre of each being Durban, Maritzburg. Ladrinith, and Newcastle respectively. At these places District Traffic Superintendents are located. While Inspectors of the Permanent Way are stationed at these and a number of other points in addition.

There exist a number of excellent institutions for the promotion of seciability, instruction,

SOCIAL INSTITLTIONS. SC.

Savings Bank. etc. have large memherships. and it is a pleasure to record that all? classes of the Jepartment's employes mix together on the triendliest terms.

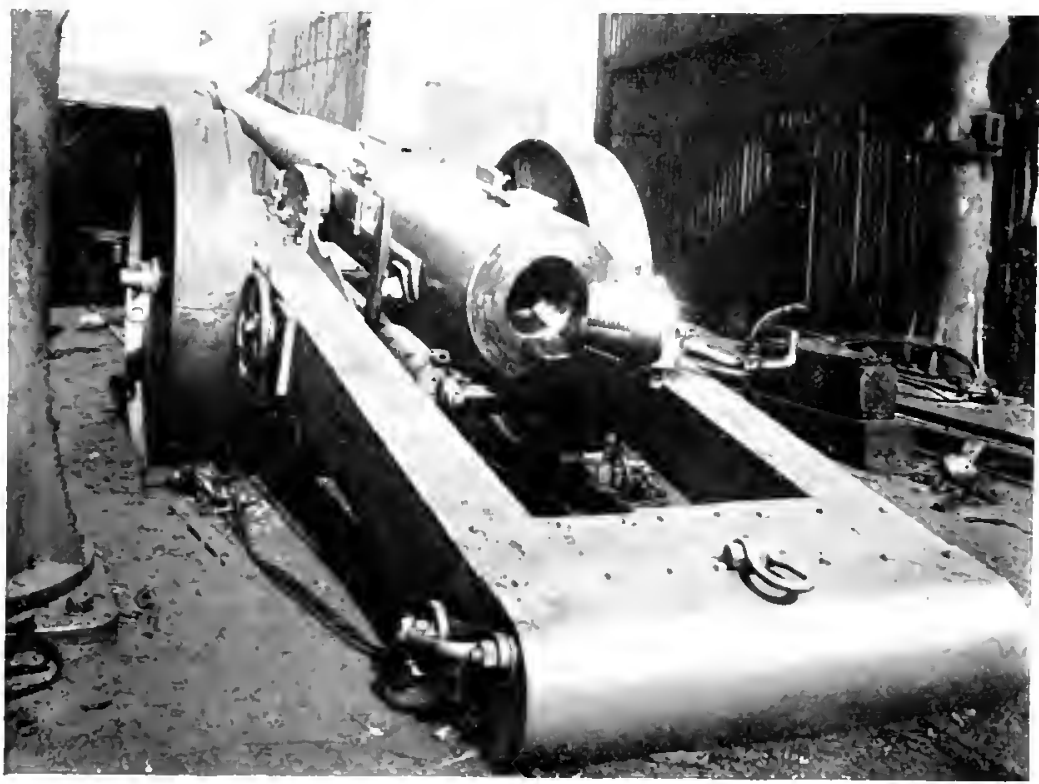

C. IKRI I $, 1:$ W ] $00-11 \%, 6[x$ CONSIRLCTED I.) $D .(, . \mathrm{K}$. LOC(). SHO

\section{THE WAR PERIOD.}

Gor nearly three years the energies of the Natal Railways were continuonsh aborthed - by the necessities of the great boer War. The assistance remelerel by these lines during the atreme crisis of the first twelve months has already- been recorded in other publications, and although it is only possible to retail here fragmentary 


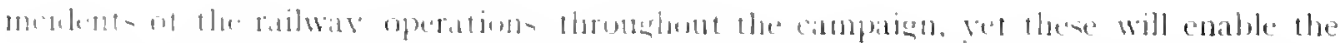

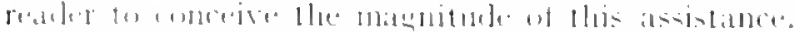

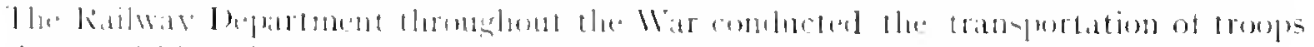

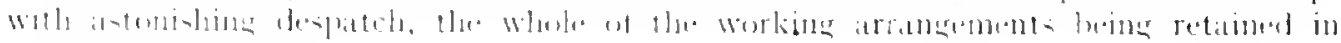
it - आжи h.tukl.

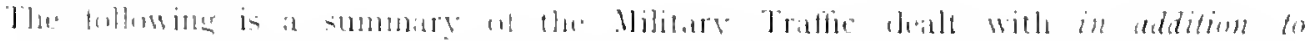

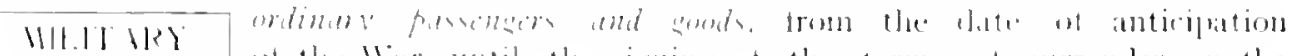

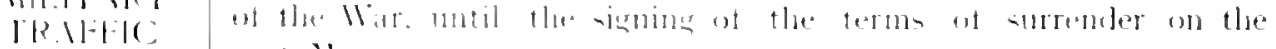

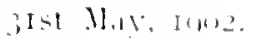

\begin{tabular}{|c|c|c|}
\hline \multicolumn{3}{|c|}{ 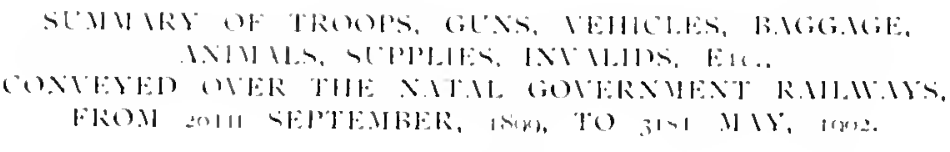 } \\
\hline 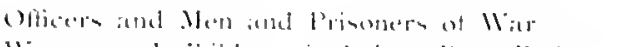 & . & 1 \\
\hline 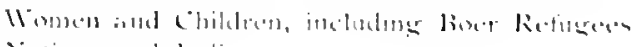 & . & 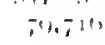 \\
\hline 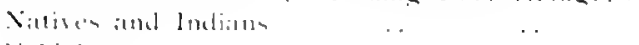 & . & $\quad 40.327$ \\
\hline Virhiclene $\quad$. & . & 0.6 .31 \\
\hline $\lim n \quad \cdots \quad n$ & . & 4.54 \\
\hline Dommition thoses) & . & $12 .-2+1$ \\
\hline 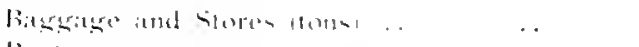 & .. & $1,1,4 i$ \\
\hline Pintom n a & .. & th \\
\hline Tratedion linginde and citrriagen & . & 34 \\
\hline supplinen noment .. & . & $1,1,2.2+3$ \\
\hline llaty and Foratere $10 \mathrm{~cm}$ - & .. & 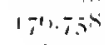 \\
\hline 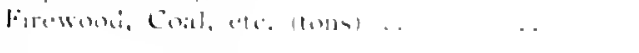 & .. & $5+10.44$ \\
\hline Lis. stowk therald.. & . & . $34,(3)$ \\
\hline 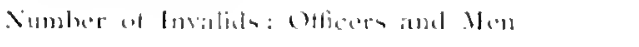 & . & $(x+1)$ \\
\hline
\end{tabular}

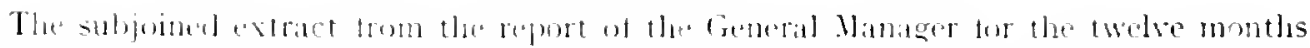

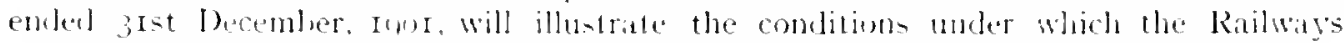
were worked fluring that rat and previously:

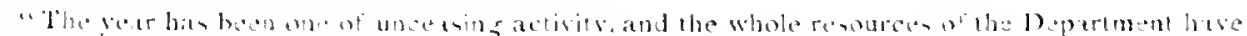

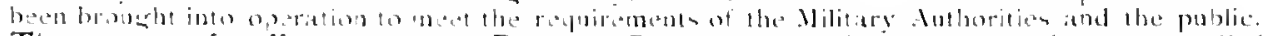
Thz tonnag of traffe losdzd up at Point and Durban during the iwalve months 1931 equalled 515.7) or an 11:r:as: 11pan th: work don? for the tw: ve months anterior to the War of

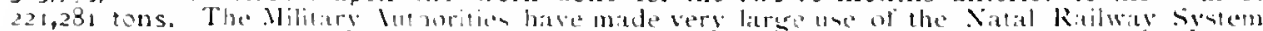

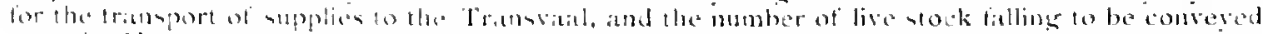

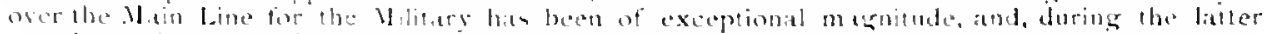

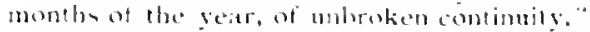

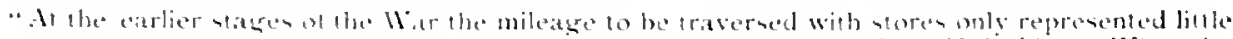

THE EARLIER ST AGES OF THE WAR

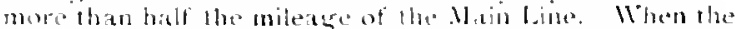

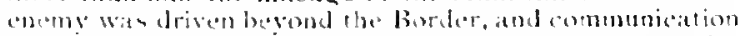

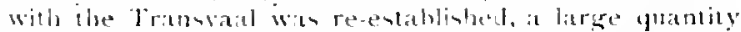

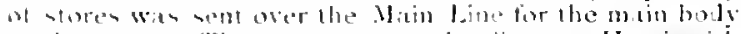

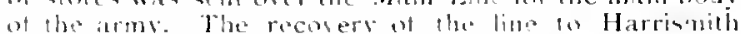

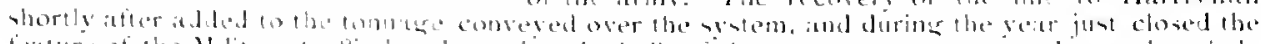

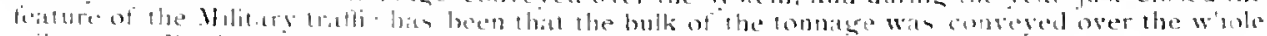

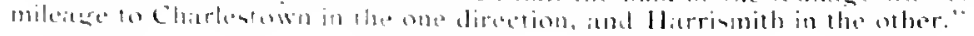




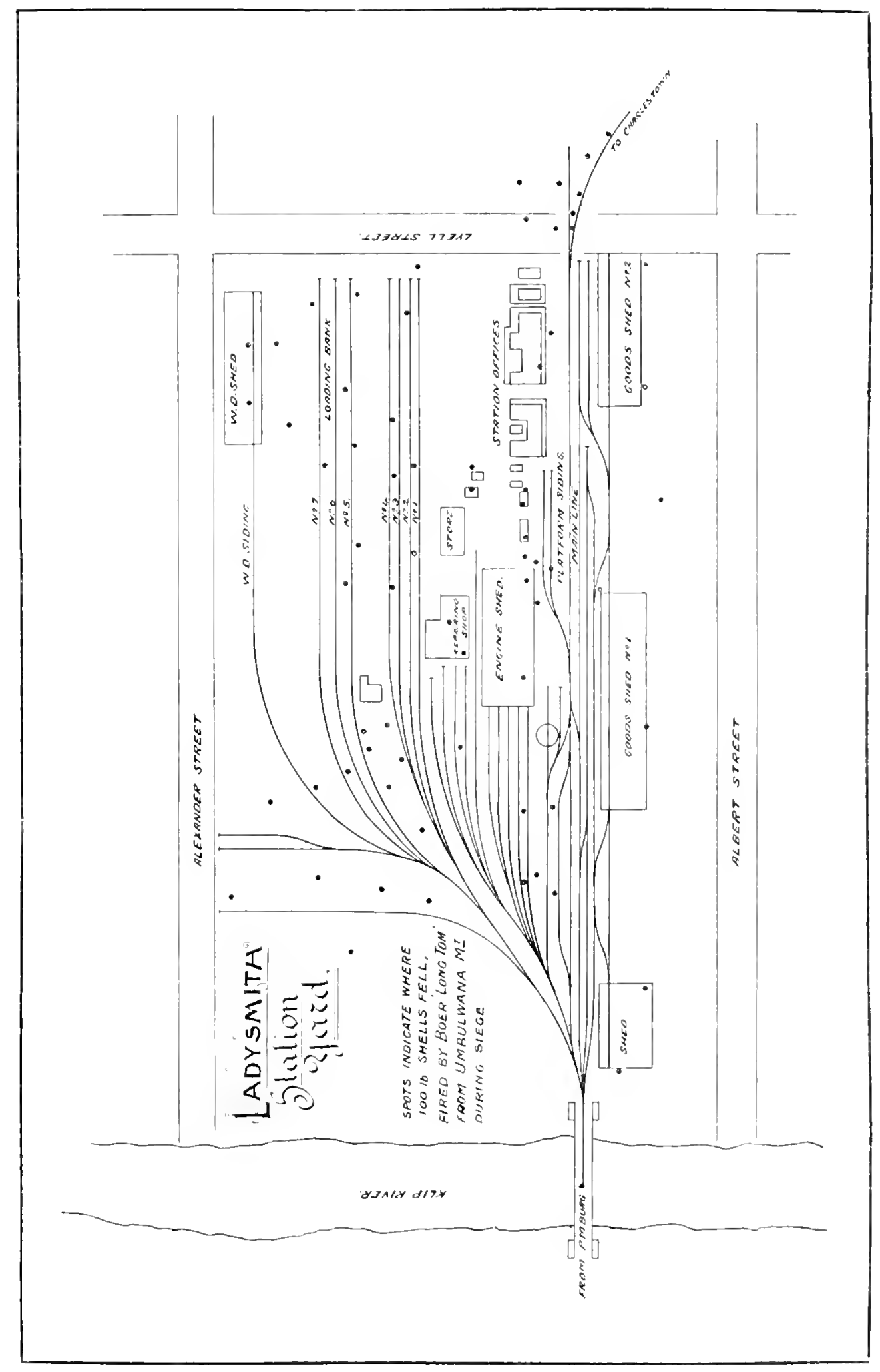


In conmertion with the actual operations of the Har, the Department adapted six

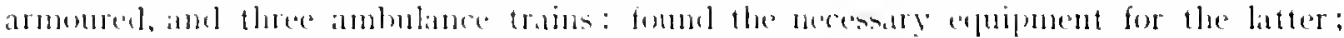

SERIICIS OH TIIL RAIL.WAY ISEPARTIII:NT "reeted the "I'rineess Choistim" hospital train: wired and lampuel the luspitals at hur different centres, and supplien them with electric ourrent, as well as that

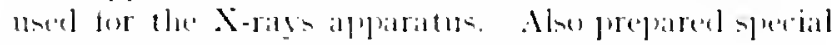

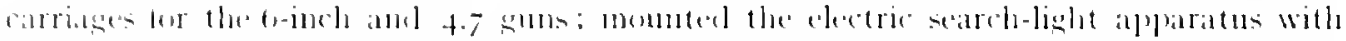

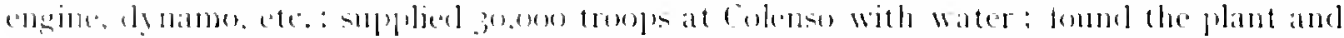

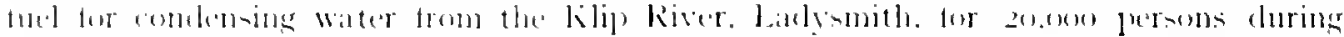

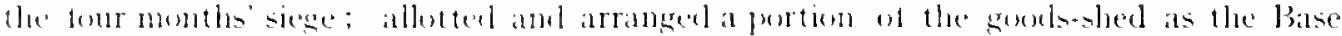

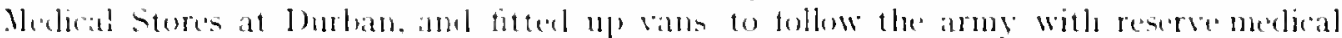

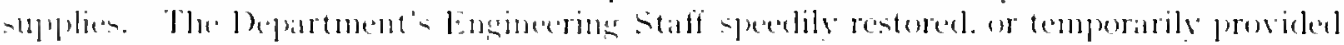
- nut only on the Patal lines. lut tor over an miles on the Transiatal system after

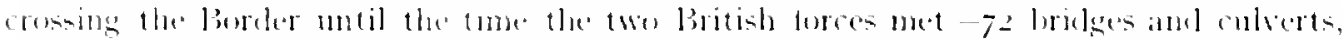

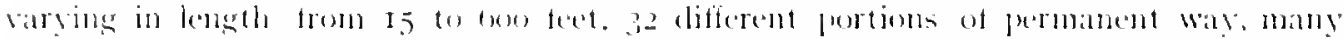
water-tanks, ete.: effected a charance throngh the lang's Xek Tunnd and constructed

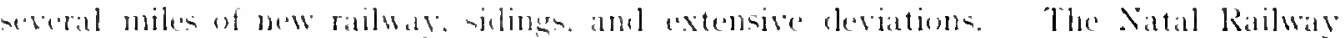

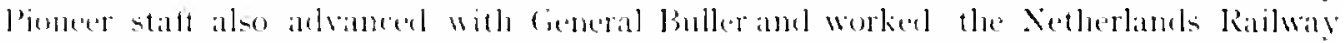

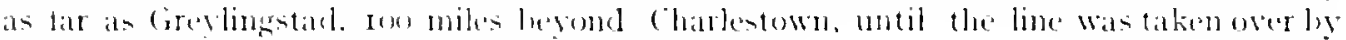
the lmpertal atuthoritices in the I sth . Angust. It)ou.

for marly six monthe mp to the reliet of latysmith-the Natal lines were robbed

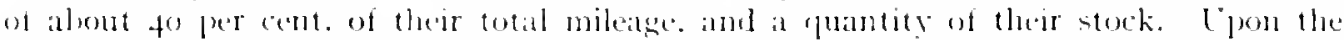

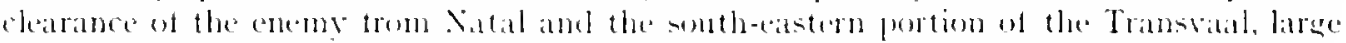

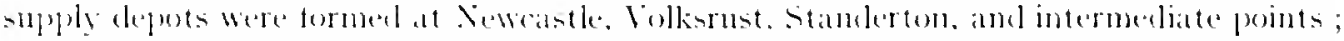
and, on the joinings of the two main portions of the British Army at Hedelbers. the sreater proportion of the stores for the forees in the Transial Wats comsered atid Natil. anel this continned moceasingly mutit the termination of hestilities. The engines and

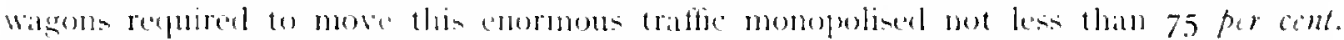

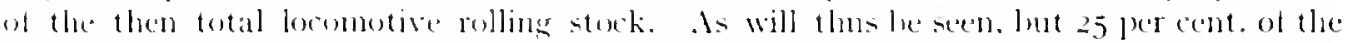
begatment's strength wan avalable for civilian traffec and it is a pleasurable retlection that the public endured the ineritable with praireworthy loyalty. lt should also be recorded that fully a fuarter of the most servecalsle carriage stoek was withelrawn from regular tratte and converted inte the three ambulance trains at the beginning of the war.

This was anesteer of the earlier drawheks against which the railway has to contend.

The inestimable aid remelered by the Railways of Natal received the testimony

\section{SIRTICI:S ()F THE} $5 \mathrm{TAF}$ of the sereral commanders-in-chiet, as well as the heartiest miversal appreciation. The yeoman, and in not a few cases, the leeroic services of the Department's taithful servants have been frecly commenderl, and the cowning recognition of the king in conferring the honour of knighthout upon the fiemeral Ilanager. may als, be interpreted as conveying His llajesty's gracions remembance of the dewoted labenrs of the Staff.

IPINIS. 
Firis:

A

Aconmodation and Equipment, lort Inurban

loton Homes tecesesto

doditimal Iccommodation. Port durlon

Bency for liatal. London - $\quad 273$

Aericularal lepartment - $\quad 27$

Albert Jominal - - $\quad 271$

Albert Falls _ _ + $\quad 207$

Alberina - - $\quad 217$

Alcock's Spruit - I 120

Alexandra Junction $\quad$ 1hro

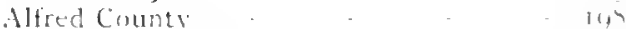

Aliwal Shoal - a this

Alleman's Nek light - 132, 130

Hltitudes

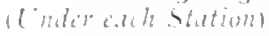

Amanzim:oti

$$
\begin{array}{ll}
. . & \text { livel } \\
. & \text { llicsion Station }
\end{array}
$$

Amajulia

Amatiliuler kiver

Amatonesaland

Animals if Natal

Antelupes...

Trea of llhat Sheda. Hort l)urban

$$
\text { .. Jand. Natives }
$$

Armoured Irain Jisaster. J'rere

trnold's llill is.t.

Arrangements. Port lourban

Attractions. South Const I ine

Ava, Earl-Cirate of

-191
$-\quad 131$
132

Avoca

131.13 .3 .11

173

172

2 jis

2 ;n

[11

254

237

4

213

273

177

II S

I 51 )

B

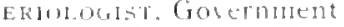

$27 \mathrm{I}$

Balgowan

banks. Tugela River. (Colensul

bar Jepths. I'srt Durban

Bar, Large lessels acrous the

bakstion Hill

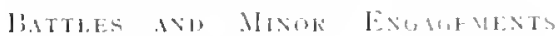

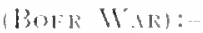

- Mllemants Xek

Ciestat"s Camp

Colenso

Iland 's laagte

(iun) Jill

llart's Hill

IteIpmakaal II ill

Xicholson's Xek ())semation I Hill

['jeter's IJil]

kailway Hill

kietontein, linta inmoil

Surprise ]lill

Sion Kop Intalomnyamal

Talana [l)undee

laal hrant/

II arom Hill

Villow (irange (beacon Hill,

Buy. Il Ie I)tran

litacon Hill

Betore Coltenso

Belfort

Bellair

Bell's (ruay

Berea Rodd

Bester's

.. Jiam

bicreativluers. "1he

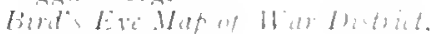

Birds. Nata!

Blatuw kiants kince

blinkwater libl

Msmument

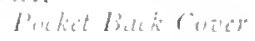

blond liver

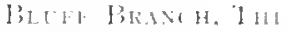

bitutt, Jhe

Boer bridse. Colenan

limer Mal liattles

liner War. limlis of keference -

$$
\text { . Cause uf - } 125
$$

.. Movementsatter ladymith - 832

lioksluere o iti

linshott's Road (S.L.1 - b3

beoston . - $2 \geq 1$

Bothats Hill - . th

. J'ass - . - 132

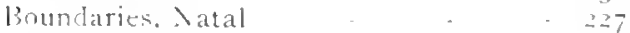

briktuntein - . . I17

Brakwal . 213

lik 1 , H L I,Nis:

bluti

Hundee and liryeid

Grevown -

llarrismith - 212

Xurth Coast. 153

kichmond 201

South Cinat - 17

('mintu

Brealiwaters. Dusban hathum t

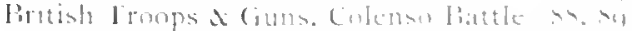

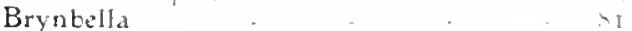

listalokiver $\quad 134.13 ; .235$ 


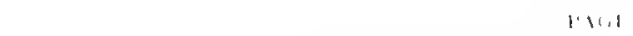

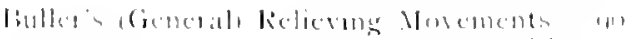

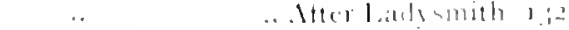
li:14:1'

fiustanan linces

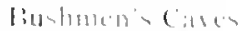

liatte1 1910. >.11,1]

lintme. .. Itterlatismith 1,2 $2 \therefore 1.2 \therefore 2511$

4.215

$2+1:$

$\therefore 1, \cdots+11$

C

$-11 \times C(a m p$

Camperdown

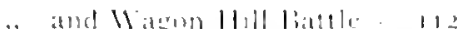

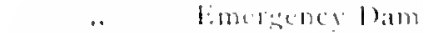

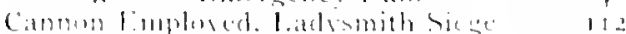

(itpe lillall line

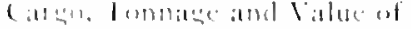
$215,2 \div 3$

Cathula Vative Misum, litutt

Cato Ridge

Calle nit linel II:it

Caversham

Calle. liublument

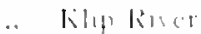

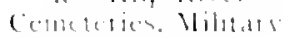

Cicials

Chakis's Kral .. I Illaw.

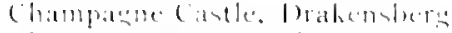

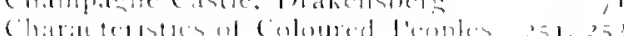

Charlestown

Cheveley .. (iatmp .. Vhltalleceneters

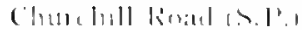

('ingulat ll ll

(i.muthat , . l'.1

\section{Clarmont}

Clastome liuplory

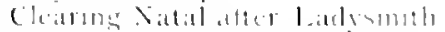

Climalt, Viltal

Clmatreete Comblams

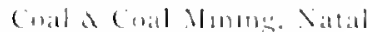

Coalfelds Taland"

(nibling. l'nel loulian

(in) (1) (1)put

Colinso

$$
\text { .. liatlletichl }
$$

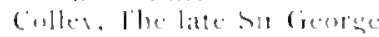

(c)loumed lecoples -

(a)burth is.l't.

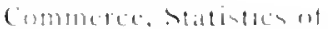

Commisenomed of Vines

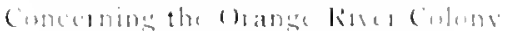

$$
\text { .. } \quad . \quad \text { Iratrintal Cillony }
$$$$
\text { .. Cublimed }
$$

Cimberence Genetal liullet and linghat

Congellat

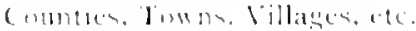

(intle and l.an

Cimbie $>11$ ll

Ci.tmand is.t'.)

(ianes. lint f)urlath

55.11

$\therefore 1$

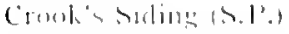

(romedisom

(rounand Dative lande

(untom Ilowes, l'oint

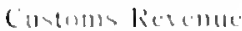

$1 \cdot 16.1$

intis

$\therefore 3$.

217

21,7

Diki Induan

271

Dalton

lian. Klip Rivel

Danubauser

1)atrele and Inpendhla l)inale is

Dargle Road

Darnall

W.lu. Viltal Jululit

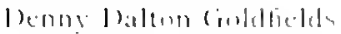

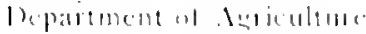
IIine

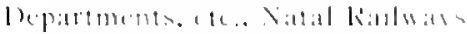

lepth on liar, Pont lomban . at Whatries

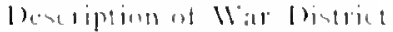

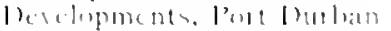

1) wetrop Ralnat

$2 \cdots 7$

I11

121

(ii)

(II)

Ifi.

211,

$1 \div 4$

271

$\therefore 72$

$\therefore 1$

3

11

71

12

$2, i$

1) 1uivulu (hict

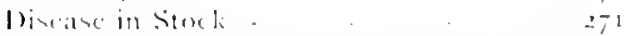

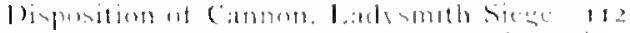

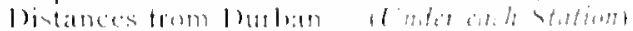

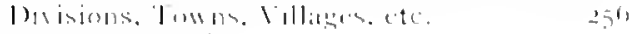

linchs. lone withe

boorotuntein

11

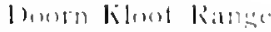

$1 .+2$

15

$15:$

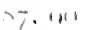

in

17

$1 ; \div$

$-11 .+11$

2,11,

Mraliensture Mentutains

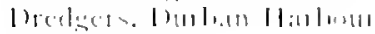

37.111 .117

71.212 .227

Dronk lie.s

Drummond

Dulf's Road

205

in

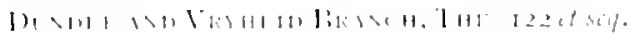

Dundec

litiatiand

liattle ticld | dalatual

$122 i t$ sig.

lituilemes

climate

clulue ete.

linels

Pupulattiun

Durban

Bllent J'ath

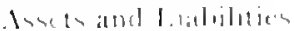

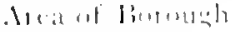

liantus. cle'.

linth liate

Pulanis ratulens

Pindelinges

come:cre reser

(c)let.

122

120

122

$12 ;$

$12:$

126

122

Climate

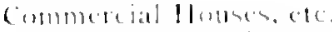

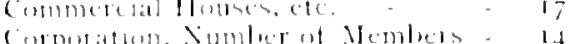

.. I.and

$1 ;$ it $18 \%$ :

111,$2 ;$

i.t

13

17

$1 ;$

if

11

25

3

1.;

It 
Death liate

Entertainments and kecreations

Escombe Statue

Foundation

Giencral Post Office

Government Laboratories

Hotels. etc.

institutions and Associations

" Jubilece" Irountain

"Juads"

Iunicipal Facts

Newspapers

Observatory.

().al. The Albert l'ark

Parlis

Paces of Worship

I'lan of Durbun

Police lorce and lire brigade

Population

Public Gardens

.. Library and lieading Room

.. Market House

. Muscum and Art Giallery

.. Swimming Jaths

Queen Victoria Statue

Racecourse

Railway Station (Central)

Rateable Value of Properties

kates

Revenue and bxpenditure

sichools

Sewerage System

Societies and Clubs

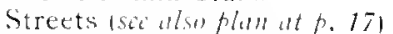

lheatre koyal

lown Hall

Iram Service, ete. (sei plan

Vasco da Gama Jonument

Volunter Corps

IVater Supply.

Durlan-kound l'our :

FROM THE POIXI

Point lioad

VIest Street

Gardiner Street

Bay Limbankment

St. Indrew's Street

Allert Park

Parli Stretet

berea Road

Iluserave linad

Florida koad

First dienue

Lmeni load and

Railway Strect to the

CEXTRAL RALWM STATION.

Durlban lioad (S.l'.) l'in

7.3

15. 16

$\therefore$

13

$\therefore 230$

26

1. 17

15

20

30

It

15

27.28

I 6

If

15

(1) 17

15

I3

20

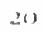

$\therefore 230$

211

20

$2 \mathrm{I}$

30

22,30

$1+$

$1+$

$1+$

15

15

15

$1+$

25

20

I +17

17

(i)

15

\section{Education}

Edward's Falls

Elandstinntein Junction

Elands Laagte

$$
\text { .. } \quad . . \quad \text { liattleficld }
$$$$
\text { . Vines }
$$

lituds River

Electric I ighting Station. Jurlat

Emberton (S.l'.)

Emigrants. Ciseful Intormation .

Emtonjaneni - 172

Enginecring lept. Xatal Railuats 245

Ennersdale . . . . .

Entomolosical - 247

Entomologist, Government - $\quad 27 \mathrm{I}$

Entrance into Ladrsmith. Lord I undonald's it

Epitome of Cause of liner llar - I 25

Equefa listrict - mo

Equipment. ctc.. l'ort l)urhan - ro

Eshome - - - 170

Esidumbent Misson Station - ibs

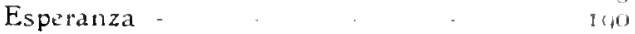

Esplanade. Durtian Pial . . . 22

Estcourt

.. Town and listrict

lixpenditure and hevenut

Exports and lmports

Extensiuns, Railway

240

217

270

F

DES, lont I Huldan

5. 4. 10

I*alls, Colenso

in

Fares. Ocean I,ines of Steamers

27.5

Fares. kalway (from I)urban!

Farquhar's Farm Fisht

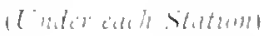

liauna

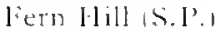

lierns

Iilite

Field's Hill (S. P'.)

Final Attack. Kelievinu Colum

Final Wovements, Relieving Column

linance statiotic

liirst liocer Ittacl

Jish, Satal

1010 1 20

234

Iiora, ..

liorests, ..

lint . Imicl

.. lurntord

.. Itillal

.. Moirnezux

.. licarson

.. IIvlie

Fox $\mathrm{H}_{1}$ ll

l'ratier"s Siding (S. I'.

203
Frere 
1N11:X inntinued

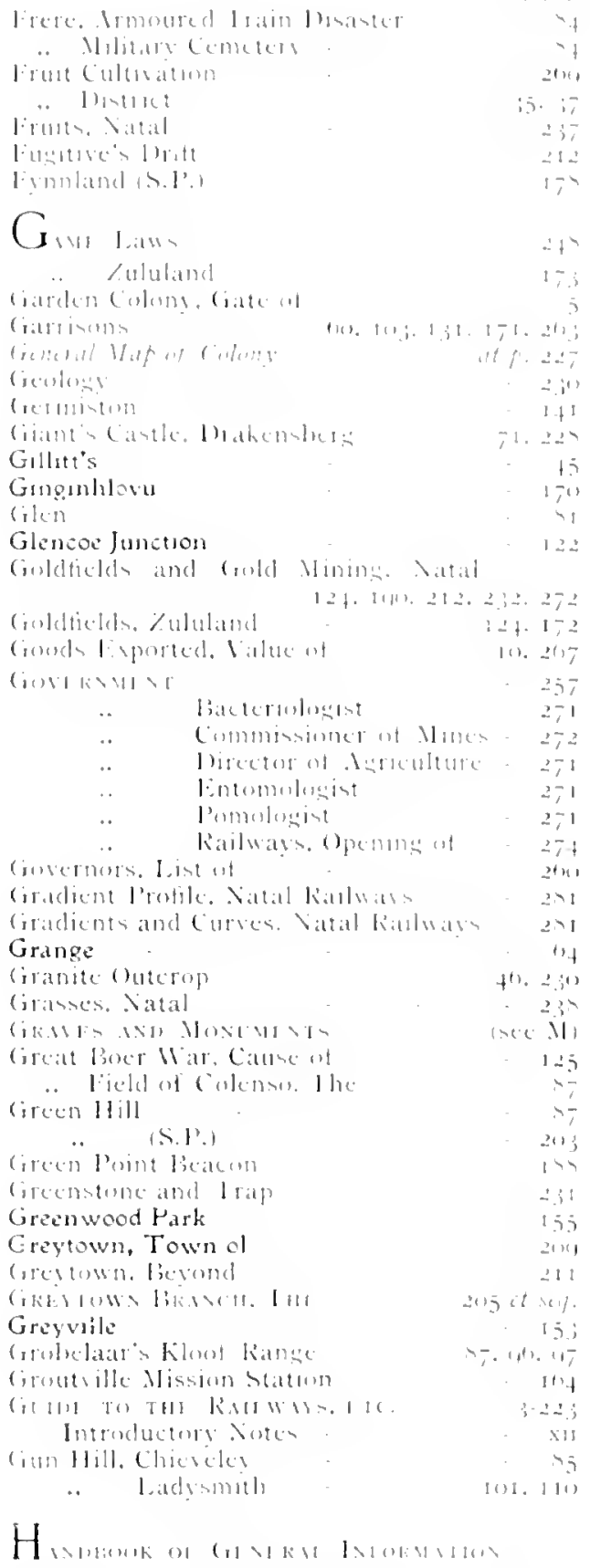

li.11

libul lashthoune

lireahwaters

1) bitis

Signal Station

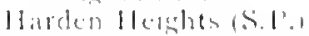

11:adins

Ilatromith and the llat

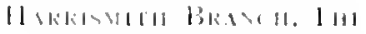

$$
\text { listrict }
$$

Harrismuth Town

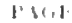

\section{Harrison}

llatrelicest

Hart's

.. I Iill

Hatting Spruit

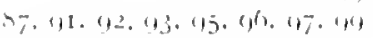

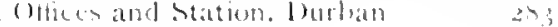

Heidelberg

llelpmakater Hill . Ittach

Hermatuluere koad (S.l".)

Highlands

Hilton Road

$$
1+4
$$

110

$20(9.250$

l|mul|l]c

llint to lourists, South Coast lane

$\rightarrow 1$

(if,

232

llintug of Natal kailwals - 274

Hiatisat and Coalficlds 172

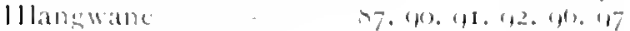

Illatikusit

121. 221

\section{Hospital Siding}

llotel Iccommodation. J)rban

1,7

llouses of Parliament

Ilon S. S. Antelope. Key os

357.213

llorse sickness, ete. Inventisation

\section{Howlik}

Howlek lalls

Ilulets's 1.8.1?

llussat llill

II lut lax. Nittises

$2+3$

2,1

197

l. Mis ist.

Illovo River

Jlleser lionch is. I',

lmperelhla

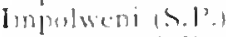

III

Imponts and Expots

Importations of Indiats.

Injerements. L'ort kinilway

Inanda $1 /$ ountains and $\mathrm{Vl}$ ission station Inchanga.

Indians. Concerning the - 251

Indigen .

Indumeni Mountain - I 21

Industries. sios

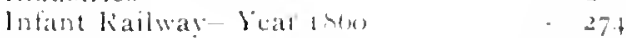

Ingagane - 120

Inecli . Wountains. I(p). 22

Ingogo 131

Inetgen-liarly lisent $\quad$ isi 133

Inswaruma

Inkwelo Vuuntain 131

Inkweloane Mnuntain - 
INIDEX-continuted

Insects. Natal

Insu $<$ Goldfields

Intabmnyama Spion Kopl Battle

Intombi (Indomlia) Cemetery and Camp

Introductory Notes, First Book

101, 104. I I1)

Second..

Introduction to $\ddot{W}$ ar District

lpolela District

lron-ure

Irrigation llork

lsandhlwana

Isezela (S.P.)

Isipingo

lxoper istuartstown

Jun $\operatorname{sen}$

"Jacob's Ladder," South Coast function 30 Jeppestown

Johannesburg

Attractions, etc.

De Kaap Valley

biscovery of Giold

Giold Output

l]istory

Population

I'ress.

Railway liares, tetc.

Sanitation, etc.

Social life

Streets and lsuildings

Jonunos: Kop It et sie

K

AFIK Corn Crop, 1901

liahtskop lunnel

liar kiloof falls

$$
\text { - Range }
$$

liearsney- lea listates and Railway

key to Intelope llorns

klip River Dam

ling. lichard

King"s Rest (S.P.).

Kingston .

Kirchdorf.

kinuckles. The

kiokstad

\section{Krantz Kloof}

krantz kö Gorge and Kloots

\section{ADYSMITH}

101 it.$c^{n} 1$. .

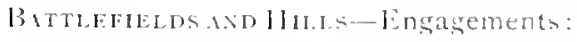

Ciesar"s Camp)

Farquhar's larm (Lombard's lion) - Iol

Gun Hill

llelpmakaar Hill

Nicholson's Nek

Olservation Hill livetiontein I Inta Insomi

Spion kiop intabmntama

Surprise Hill

Vaal kirantz

llagon llill

$.11,1$

$: 1,1$,

115

111

117

31

MISIORIC HIILS

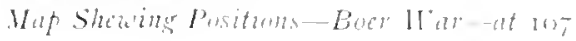

SIEGE-

Bombardment

Cannon employed

I1')

Casualtic:

Ilistoric hills dee mat. 1071 103 wh

lonses

Intomli

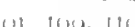

()ccupants

l'rices ol edibles. etc

Scale of rations

Pribute, 1)uke iol York"

Troops and runs

Where shells fell. Railway Jard

lin:

Cemetery

Hotels. ete.

Population

Post Cart Services

Rates -

Situation

Strets. ete.

Iin Iown

Town Hall

Value of l'roperties

La Mercy (S.P.)

Land under tillage, Iatal

Lands, Native, Crown, and Mlission

Langerwachte Spruit

Lane's Jek (s. P.) -

$$
\text { bridis }
$$

arie lessels berthed

Law and Courts

I. aws, Game

Lidgetton

l,ighters and Tugs. l'ort I burtian

lighthouse. biuft

." Scottshurg

fight Railway. Kearsney

Iimenstones, Natal

Iindley Mission Station

l,ion"s kiver lalls

l.ive Sitock. Natal

l,ocomotive l)epartment. X.(i.K.

1.ombard's liop Finht

Long. Col, rGuns, Colensol

119

Iin 3

in:

103

Iuा

I0I

102

10 . I 19

IU2. 1111

in

Ii)

215

211

1,1

(i)

32. 133.135

$1,52.1311$

11

2(16)

$2+4$

(x)

(1)

4

In

‥ I

150

7

2,0

34

I(i)

a)

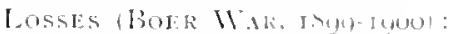

Vlleman's Nek

Colenso ( lirst liattlet

Dundee (Talana) 


\section{IXI:D continued}

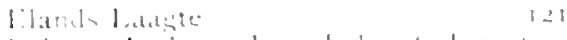

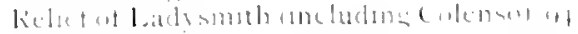

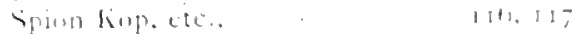

lhoushout Xatal Campaist $1 ;$;

11 ingun 11,11

Lower Tregla

"Unkomaas .

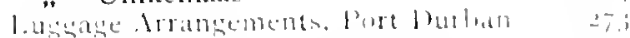

l.undy's 11111

l.ang Sickness, ete. Investisation $\quad 37$

Lynedoch

M

Mahudga Mentation

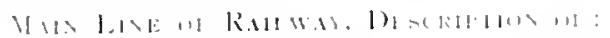

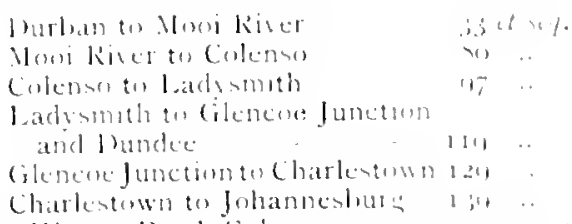

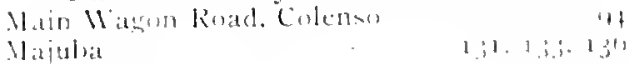

Malvern

Wanaterentent, Railway

Manderston

Maneutacioricen

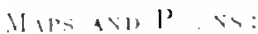

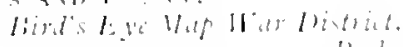

l'uket linklintere

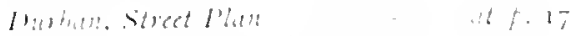

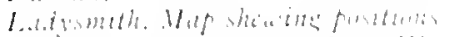

(line) II:H, . 167

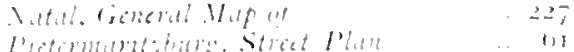

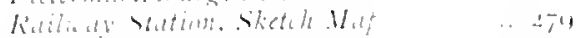

Mations

Mariannhill Momantery

Mariannhill Momantery

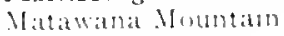

Nealie Crop loges

115.2511

Melmoth

Velrille $1,5.1 \%$

Vembets, lecislative Chamlers

Merebank

Metermaterical

Meinal lloure Collese

Military Camp Siding

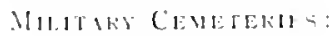

Chieveley

Fort Nipier

lirere

Latromith antombir

Janir's Vek

bation biatele llills

Mlitary Irathe

Mimosa

Minerak
Nine- Hepartment ot

ris.

.. lumber

. Dimble

272

123

21,4

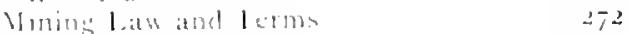

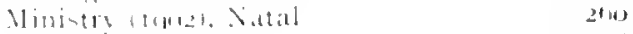

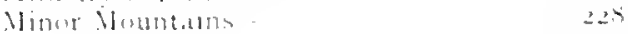

.. Profinctions

.. liners 239

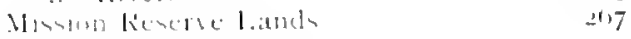

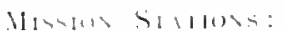

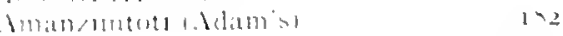

liluti

I: encinde

1. hrowe

1.-idumlen

(iinutiolle

l.melley lnamcial 159

Ilarianhill

Modder Sprut $\quad 120$

Vont itux Sombers

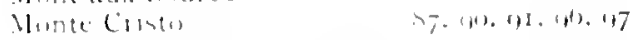

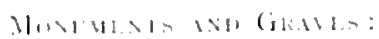

Clackeley 75

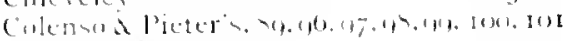

Pundec 1 lalanat - 127

r.ands labigte 121

liere. it

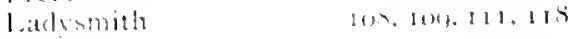

lanes vieli 133

Malinilat

Sion hisp 116

Mool River 73.40

Monj kiver. Datack on

.. liall

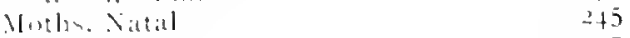

Nenent Nice 115.117

Monut Edgecombe 150

Yount lidecentule Susar Mill

.. Moteland th.t'.

Notelind th.P.1 150

Mount Prospect 1. Tatah 1,35

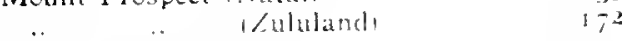

Mount Rule ty

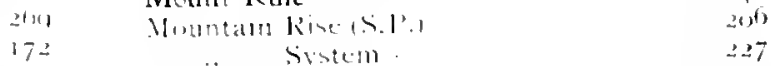

Bominted prifice. 203

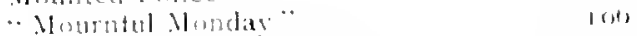

buenents. lielieviner Column an Xatal lomy. Ifter ladyomith 132
115

Muncipal system. $\quad 264$

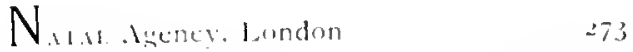

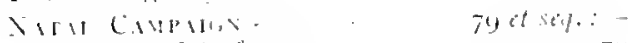
boutis of licterence - 7y

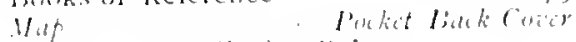
dlovements. Kelieving Column go Atter l,adsinith 132

Natal Capeline - 205.223

Satal Central Sugar listate and Mill I5 


\section{INI)}

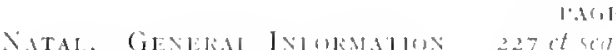

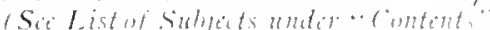
ant . Mup at p. 2371

Native. Crown, and Jission J ande 2ty , Edecation, Zululand - 17\%

Xatues. Cuncerring the

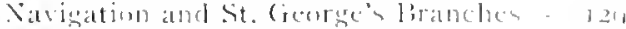

Ndwandwe . 172

Nel's Rust - _ 2 - 201

Velonn'skon - 213

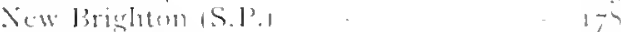

Newcastle: - - - 1, - 1

ditractions - $1 ; 0$

Churches.etc. I it

Industries - Ino

I'inulation _ I 30

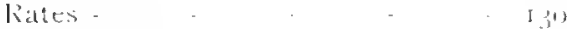

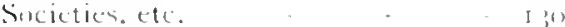

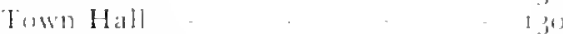

Value of l'ropertices.

llar l'erind.

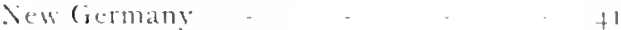

(suckderland IS.l'.) - n - ith

New Hanover

"Xew Repulslic" I2t

Nicholson"s Nel: - no

Niandhla. - I - Iz

Nondweni Goldficlds $\quad 12+$

Nondweni Road - 124

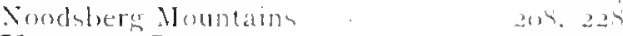

Noodsberg Road . - 2117

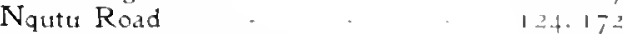

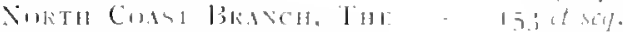

Northdene

Ninwegian Minsinn Sitation a 1-1

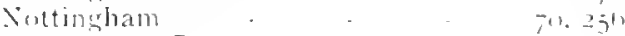

Nottingham Road

?in

$\mathrm{O}$

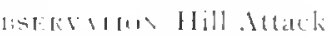

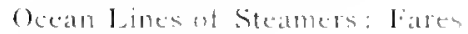

Ordethrouk Sprut

O'veil's larm

Orange River Colony Junction

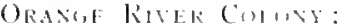

Arear

1)istriegs

Harriomith

Jintors

I'hisicald ficatures

Situation

Ores. Irom and Cinpere

Ottawa

Otto's Bluff

111), I I I

27.3

11. 117

135

212

3211

2211

21,2114

2211

$2+1$

230

231.232

154

207

$P_{A 1311 !}$

l'alm4. Nallal

Park Ryale

$+2$

3,5

I, in

Parliancent. Heuses of - 257

l'ant. l'resent. and Inuture. Ratluats - 3it

Pattont Slip, l'ut l)urlian l'aul's Whalf. Prot lowban

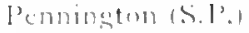

[. 36.9

Peoples, ocoupations, cte. of - 251

lepwoth"s Hill - 121)

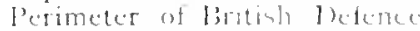

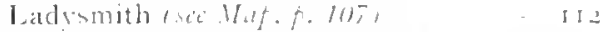

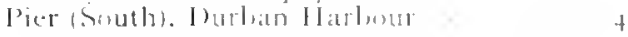

Pietermaritzburg - - $\quad-51$ it if :-

Alexandra l'ark and Recreation (irrunds

Area of Biroush

Assets and lobliblitice

lianky

bisth katce

Isotancal ciarderon

Cillis.te.

Clmate

J)ath Ratc

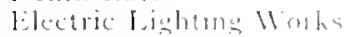

Entertanments

Exhilitions

Extrace from specech H.K.H. I buke int lonk

Fonnation of Cits

Font Sitpier

Firundation

Gitrion

Gicheral bltractions

Holida contres and l'ichiching l'laces

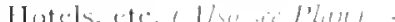

Industriest

Dilitary Cemetery

Menicipal Matters

Satal Sncicty

New Paileding

Newspapers

Places if l'ulide keseme

$$
\text { .. . Mirship }
$$

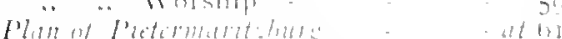

police lingece and fire lirigade - 5: C. Natial Meruntedl _. im

Population

Prost Caut Serrices: lidendale. IBul wer, and bimtum

Pullic Buildines

Railway Facilitues

literble Value ot lournugh

Rates -

Resenue and lispenditure

kitle Insociatmo

Sanitation

Sehomls

Situation

Sucictics. Institutions. and Clule

Situtulir. exte.

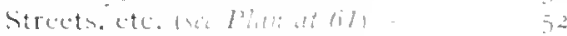

Sulurbs - 111

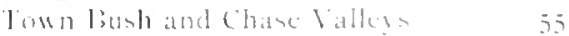

Iown Ilall .

linun I ands. Value ot $5=$

Voluntecess ins 


\section{INIIEX}

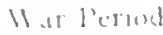 \\ II ater Supply \\ 11 atolumbin}

Pleters

l'eler's Hill and liattle

Punetowa

Pinetown Bridge

Phonesx

l'hycical cieontaphy. Dittal

H'min and Mups

Point, Port Durtan:

$$
\begin{aligned}
& \text { the lowetis } \\
& \text {.. Jeety }
\end{aligned}
$$

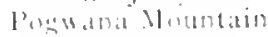

lestedal buntrut

linlice. Ilounted

l'umeros:

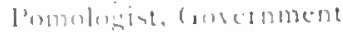

lism-lim liardere

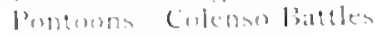

limpulation. Nattal

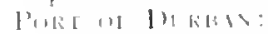

1)

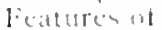

Mijtaty l ratic

() thicials

Irade ete. Statistats

\section{Port Shepstone}

Ittractionst

Civation of l'out

lintrance and liat

Marble () natries

Natulut:

l'molnilition

lint Cart Service

kiser l moimhula

st. Helen in kets

liakl.

Villate and limiroms

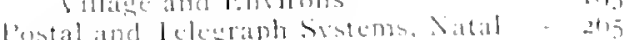

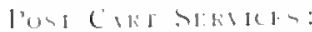

le lingtan

.. liuluer

.. lourh Vlei

.. likndale.

.. 1. vionuce

.. Haroing

.. Kolubal

. Situatistiman 1 dxopon

.. Cincimitulu

. Virheid

. II exenen

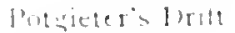

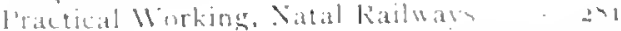

J'ress

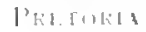

liublinster.

Capital, the

biamund Wining

Hinturs

Indiaticics

l'spulaten (i) $11012 \times 4$

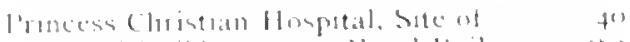

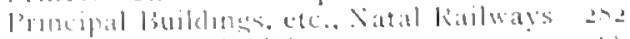

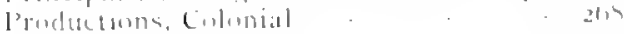

Puble l) lut. Natal

.. Whath lount

21,

. IInhs.

$21,21,7$

$\mathrm{R}$

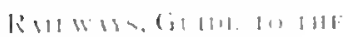

20

$1-2 \geq 3$

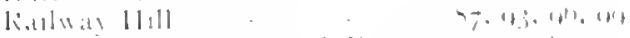

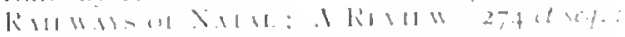

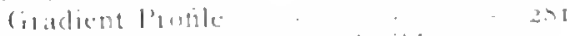

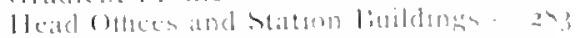

length on lence

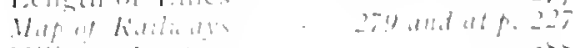

Wilitat l tattic

l'atst. libent and liuture 274

l'hucill liatures, ete. 2hI

pacteat Miskins. 231

"licid" lingine - 242

Sititivice - 271

Wiar l'elund. Ithe

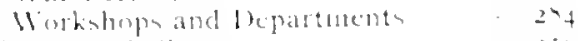

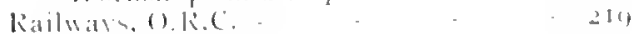

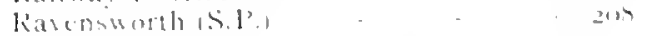

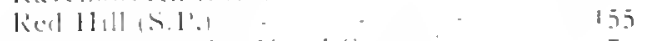

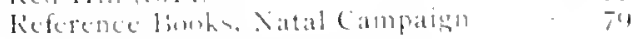

kenlel le 75.211

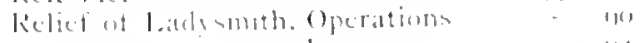

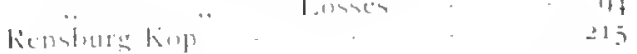

lieptiles. \ittal 230

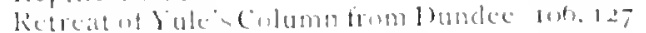

Retwion - 17il

liesenue and lixpenditure. Natal - zho

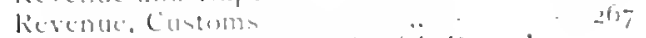

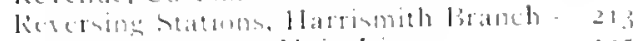

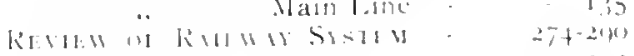

Richmond - 203

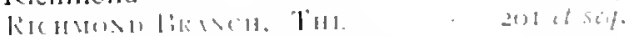

kiclomend listrict - sot

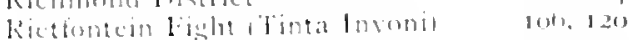

kinderpest.ele. Insestivation - 273

kivers. \ittal - $\quad 2 \geq 1$

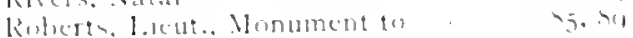

kindents. vattil - 234

kimilint - 1211

kintic bitt 124.212

Rosetta - 72

Sinr lacia lay . . 173

Salislum lsland. Durloan - I2

Sanderies. Satal - 230

Scenery. Ilarrimith branch - 212

I.th

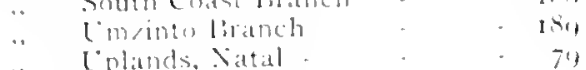

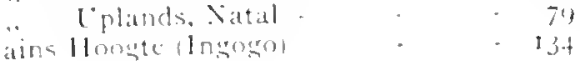




\section{INLEX-continued}

Schools, Natal

Scott-Chisholm. Col.. Grave of

Scottslure (S. P.)

$$
\text { Lightlaruse }
$$

Seaport I m n of Jurban. The

Seasons. Matal

\section{Sea View}

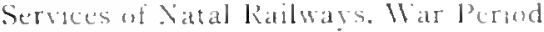

\section{Seven Oaks}

\section{Shepstone, Port}

Shipping lonnage Statistics

Ships lintered Port louran

Siese. Ladysmith.

Signal Station. Durlan Harlour

Silver. Niatal

Situation of Natal

Slip at Poin:

Social Conditions. Natal.

South Arrican comstabulary Remont beprit

South Coast Junttion

Sulth COAsT BRANCH. I HE

Spearman's farm.

Spion Kop. liattle of

Spitz kop

Sipots where Shells tell. Ladismith

Station latd

Springticld ] bistrict

\section{Stamford Hill}

\section{Standerton}

\section{Stanger}

Sratisics: Commerce

$$
\text { .. Finance }
$$

.. Militars lrattio

.. Rathats

.. Irade. Shipping. cte.

Steamers and I ares, Oean line

Siecrens. (r. II.. Grate of

Sterk Spluit

Stock in Tatal

Stuartstown (lxopo)

Sub-tropical liruits

Sugar Mills. Jrincipal

.. l'roduction of

.. Refinery, South Coast function

Sunday"s River"

Sulprise llill. Solte

Swan : Crossing (S. I'.।

Sweet Waters

Sidenham. Iccess to

$\mathrm{T}$

lalile dlountain

labbles, Meteorolusical

Statintical.

Ialana. Battle of

Talana Coallields Hills

Tea Inistrict, lhe

.. Production of

lelesraph and Pustal Systems
[' 46,1

26,2

is

init)

Int

13

$2+1$,

in

277

209

(sei P.)

24,7

[il

(16) L.

$+$

232

237

II)

215

\section{nt}

$+5$

$3^{11}$

17 it seif.

- IIj

115

132

29,

+. II?

153

ifu

[1)

$24 \div$

20n

10. 24

$\therefore 70,377$

10. 207

- 27

II

207

$2115 \cdot 250$

237.200

I 50. It

24

36

121

110

11'

24. 250

$-4$

$+55$

250

( icis.

1213

125

12 ;

Itio

योiा

245
Jerraces (1)hyscal cieography.

Terrace Hill i Hart's

lerritory of Zululand

Ierritory kecently Acquired

Therns. The L'moti

Thornville Junction

"Three Sisters." Ihe

lhree lree litil

H.MT

227

ic H.l

172

227

211

$+$

215

115

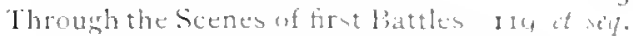

$$
\begin{gathered}
. . \\
\text { nestures }
\end{gathered}
$$

Tiger"s Kingt

$$
\text { Nar Jintrict }
$$

lim]er. Aatal

Tinata lntoni lijeht

Tin Iown Camp, Ladysmith

Iintwa Pass

Tongaat

$$
\text { .. kiver }
$$

.. Sugar Vill

lonsaland (Amatorgaland)

Tongage. Ships and Carso

Tour of Durban.

$$
\text { .. The Docks, Point }
$$

"Towers." The Lrakensheren

Town and l'ort of l Murlian

$$
\text { .. Cemetery. Iadymith }
$$

Towns, Villacres, and access thereto

Trade, etc.. Statistics. Port l)urban

Tratic Hotel (1)rummond

Trains. ctc.. Point. Durtian

linasian. The

Climate.

Districts

luture

Johannesbuts

Physical Features

Situation

Pretoria

I rappist llonastery

Trenches at Colenso. etc.

Trichardt"s 1)rift

Tronps. etc.. throush Jurlian

Trout Ora

Tugela. I.nwer

Tusela River. Colenson

.. .. Sourcent.

Tušla, $\ddot{\text { Ipper }}$

Tugs and lighters. lont l)ubloan

Tweedle Hall

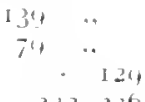

232. 236

I(it). 120

11) 3.1 I9

2 I

- 1112

Itis

$1+13$

172

I0

17

6

$-2$

3

II

251

IO

$+6$

273

$1+1.150$

150

$1+4$

150

Ineid J.1

$1+9$

- $1+0$

1.:

+1. +2

o. 14

115

I0. 34

272

- I0

$67 .(11) \cdot 17)$

2211

$103.25^{11}$

IO

U

llundi

Lombile kiver

Fills

Lmberintuni is.P".

Umbulwana

Lmbulwana Meunture

cmelosi.

$$
\text { kise }
$$

('nusabaloa (S.J.)
17

172

35.40

40

190

IUI

I0) $1, I(x)$

1,2

173

I. 
INII:X combumed

Ungen

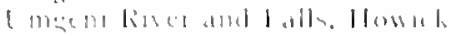

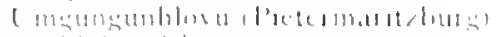

[ mbhildar livet

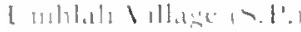

lomblamed kines

labhlaturankise

l mblat liser

['mblumburet i.l'.)

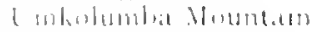

Umkoman, Lowat

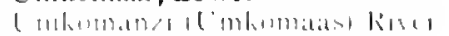

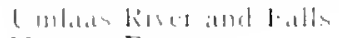

Umians Roud

I mblital

C'mpoubaryoni kiser

Umsinduss

I malmatas lines lialls

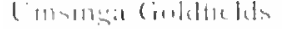

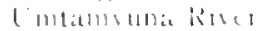

L mentucis is.l'.)

Untw.4!nm

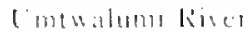

(mi)tl kilel

$$
\text { .. 1.t.'.1 }
$$

$$
\text { . I Jutrom }
$$

l'msitare lised

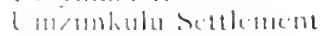

$$
\text { .. liner. }
$$

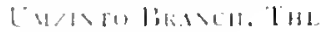

Cmanto linel

Uinzinto Village

I melmatl kive and falls

\section{Unzumb1}

CPper lugelat l'une Cam

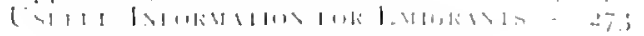

$\mathrm{V}$

Wil lirant,

- kise's

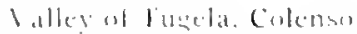

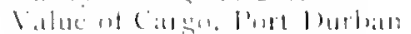

(inade lisported

Van Reenen

I. an licenen l'an

. IIsh's Ilill

linctialies.

Verutam

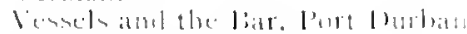

$$
\text { .. lintered at }
$$

beternats! Depatanent

Vieturia j:splunate

Victora Rod

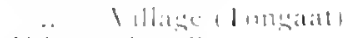

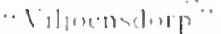

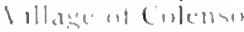

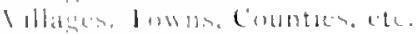

Volksrust

Sishuntees

Inheset

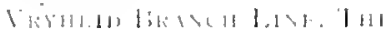

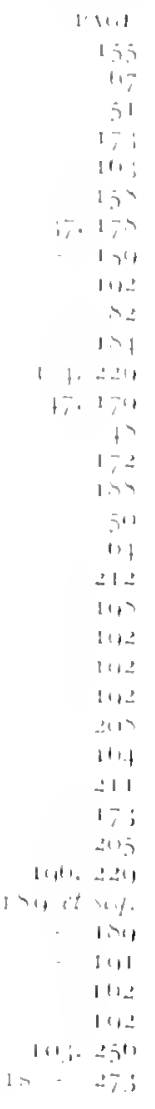

20

117
171

11.5111

id

(1)

215

215

$1 ; 2$

$\therefore i 7$

! 识

11

ic)

$2-1$
W
I.11,
(1)

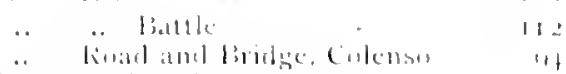

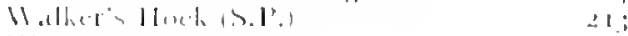

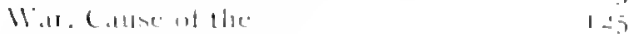

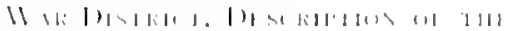

ind 4019

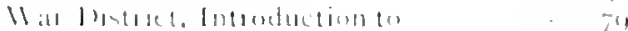

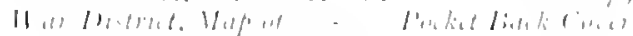

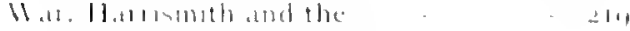

.. Dithal lialluabe and lla

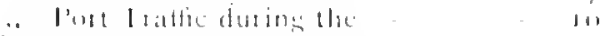

Waschbank 121

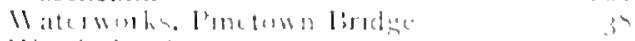

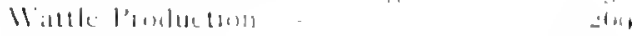

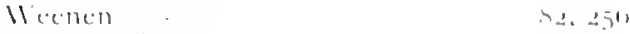

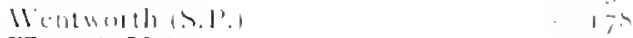

Wessel's Nik 1 121

11 intur $73.23^{11}$

Wests |Blufl-sidel

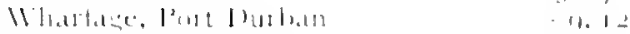

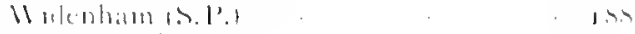

Milectoratein 231

Wile link 217

Whllow Grange

Millow arame löicht

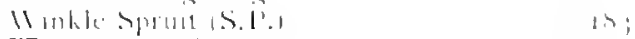

Wunter's Kloof

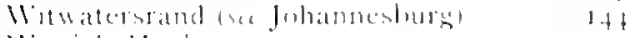

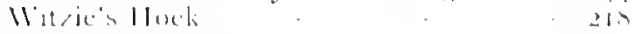

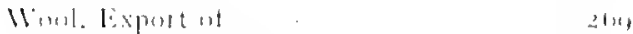

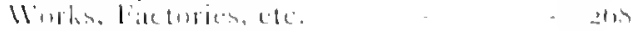

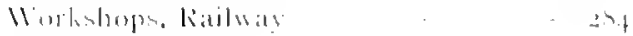

Winke, luble the

Wyabank

$1=$

Y.ik

207.2511

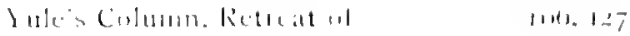

Zinin:

Areal

Cultisations tis

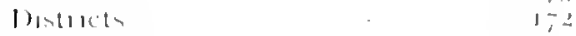

lishome 1711

lint ltald I

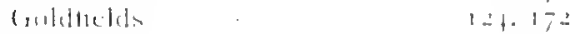

Illabiand - 172

Webmath 172

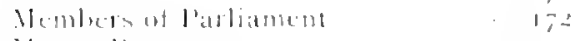

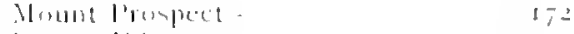

Dilue liducatoun

Population - 172

líntis 178

linals

st. lucia lat! - 17s

lownhips - 172

Clundi 172

Villates $\quad 172$

Zwaartkop

l. watrliup Ilill

115.117 
.60 


\section{MPSB LIBRARY}

University of California

SOUTHERN REGIONAL LIBRARY FACILITY

305 De Neve Drive - Parking Lot 17 - Box 951388

LOS ANGELES. CALIFORNIA 90095-1388

Refurn this material to the library from which it was borrowed. 


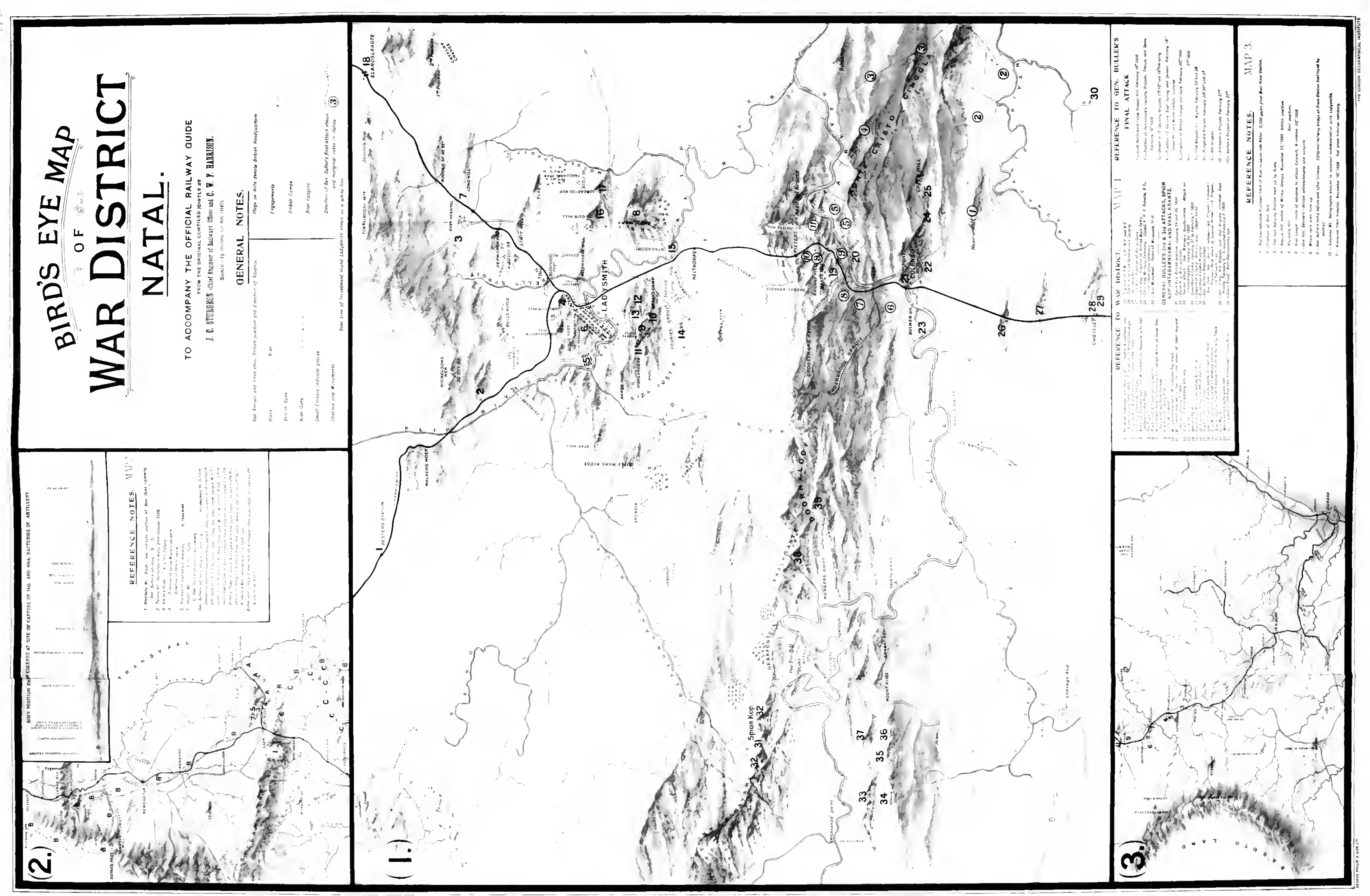




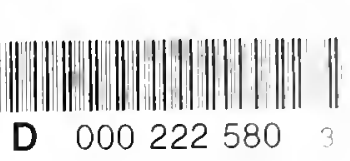




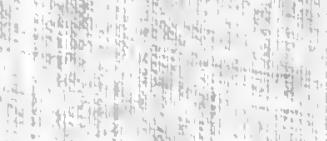

-
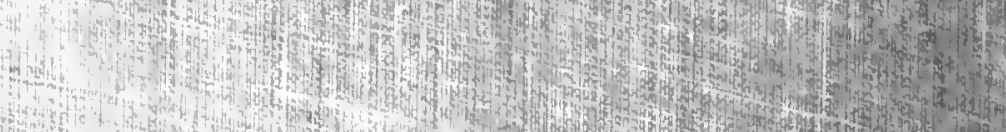

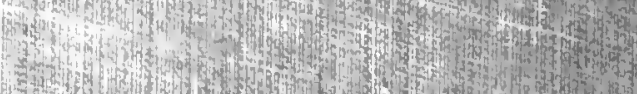

v.7.

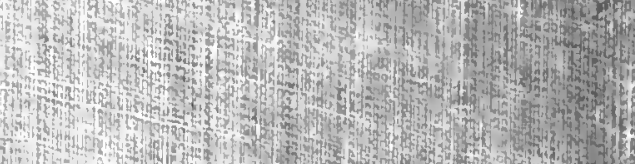
1.

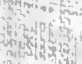

3.t. 5.

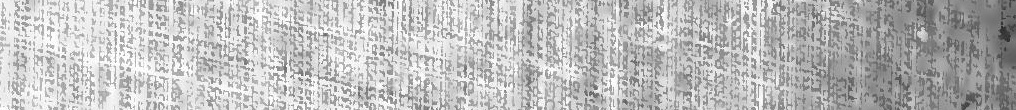

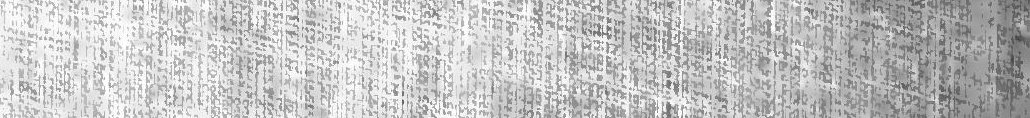
H. 6.7. H. 9. 1. aty

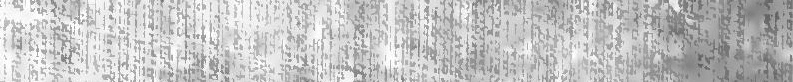

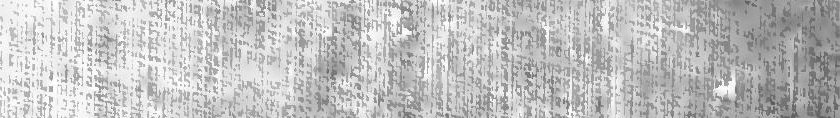
W 